UNIVERSIDADE DE SÃO PAULO

INSTITUTO DE GEOCIENCIAS

DEDALUS - Acervo - IGC

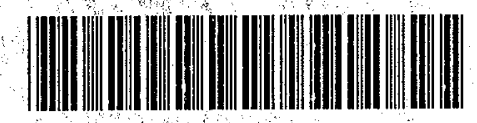

30900017630

\title{
EVOLUÇÃO E DINÂMICA ATUAL DO SISTEMA CÁRSTICO DO ALTO VALE DO RIO RIBEIRA DE IGUAPE, SUDESTE DO ESTADO DE SÃO PAULO
}

Ivo Karmann

Orientador: Prof. Dr. Georg Robert Sadowski

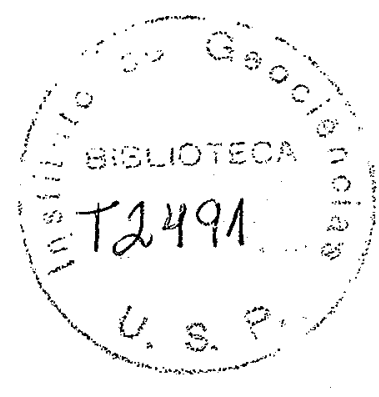

TESE DE DOUTORAMENTO

COMISSÃO JULGADORA

nome

Presidente :

Examinadores:

\begin{tabular}{l} 
Dr.G.R.Sadowski \\
\hline Dra M.Szikszay \\
\hline Dr. R.Hypólito \\
\hline Dr.W.L.Ponçano \\
\hline Dr.C.L.Maciel Filho \\
\hline
\end{tabular}

ass.

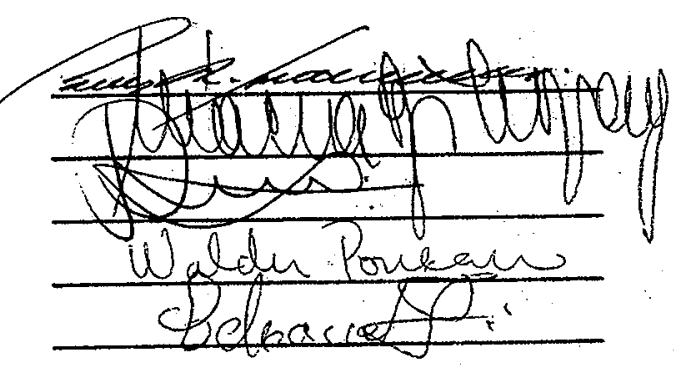


"Cavernous limestone karst ... is the terrain type whose geomorphological understanding becomes an art, matured only through experience, and then applied sensitively and individually at each new site assessment."

(Waltham, 1981) 


\section{Evolução e dinâmica atual do Sistema Cárstico do Alto Vale do Rio Ribeira de Iguape, sudeste do Estado de São Paulo}

\section{SUMÁRIO}

Índice de figuras

página

Índice de tabelas

iv

Índice de fotografias

$\mathrm{xi}$

Lista de anexos

xiii

Resumo

xiv

Abstract

$\mathrm{XV}$

Agradecimentos

Xviii

CAPÍTULO 1 -

Introdução

1.1 Apresentação do tema de trabalho 1

1.2 Seleção da área estudada 2

1.3 Objetivos da pesquisa e organização da tese 5

1.4 Métodos e técnicas

CAPÍTULO 2 -

Fisiografia e geologia da região de estudo

2.1 Contexto geológico regional e local da área estudada $\quad 7$

2.2 Situação geomorfológica da área de estudo 13

2.3 Hidrografia e ambiente atual $\quad 14$

2.4 As rochas carbonáticas do Alto Ribeira 15

\section{CAPÍTULO 3 -}

Drenagem superficial e formas de relevo do Carste do Alto Ribeira

3.1 Arcabouço geológico e aspectos gerais da morfologia cárstica

Área carbonática Furnas Santana

Área carbonática Lageado Bombas

3.2 Zoneamento morfológico das áreas de amostragem 24

3.2.1 Zona fluvial $\quad 25$

3.2.2 Zona de contato $\quad 28$

3.2.3 Zona fluviocárstica 30

3.2.4 Zona de depressões poligonais e a transição de fluviocarste para carste poligonal

3.2.4.1 Depressões poligonais e a paleodrenagem fluvial 45

3.3 Morfometria das áreas de amostragem $\quad 50$

Densidade de depressões $\quad 53$

Índice de dolinamento $\quad 53$

Razão de dolinamento $\quad 54$

Densidade de sumidouros autogênicos $\quad 54$

Índice de sumidouros autogênicos $\quad 55$

Profundidade das depressões $\quad 55$

$\begin{array}{ll}\text { Área e perímetro de depressões } & 57\end{array}$

3.4 Condicionamento estrutural e hidrológico do relevo 60

3.4.1 Geologia estrutural das áreas de estudo 61

Definição da superficie dobrada

Sistema de fraturamento. Medidas de juntas e falhas 62

3.4.2 Expressão fisiográfica de estruturas planares $\quad 70$ 


\section{CAPÍTULO 4 -}

\section{A drenagem subterrânea e a evolução de sistemas de cavernas}

4.1 Introdução

4.2 Distribuição e características fisicas gerais dos sistemas de cavernas nas áfeas investigadas

4.2.1 Distribuição de sistemas de cavernas

4.2.2 Áreas de captação dos sistemas de cavernas 85

4.2.3 Gradiente hidráulico dos sistemas de cavernas $\quad 86$

4.2.4 Extensão de cavernas acessiveis ao longo dos sistemas 86

4.3 Modelo espeleogenético para o carste do Alto Ribeira 87

4.3.1 Aspectos teóricos da espeleogênese $\quad 87$

4.3.2 Morfologia e características lito-estruturais das cavernas estudadas 90

$\begin{array}{ll}\text { 4.3.2.1 Geometria planimétrica } & 90\end{array}$

Cavernas curvilíneas e sinuosas $\quad$. 90

Cavernas retilíneas e angulosas $\quad 92$

Galerias e salões de abatimento $\quad 92$

Relação entre sinuosidade e largura de fluxo 93

4.3.2.2 Geometria em seções longitudinais e transversais 94

$\begin{array}{ll}\text { Entalhamentos vadosos } & 94\end{array}$

$\begin{array}{ll}\text { Alargamento freático } & 103\end{array}$

$\begin{array}{ll}\text { Formas geradas pela incasão } & 103\end{array}$

$\begin{array}{ll}\text { Níveis de cavernas } & 104\end{array}$

4.3.2.3 Condicionamento estrutural e hidráulico da morfologia subterrânea $\quad 107$

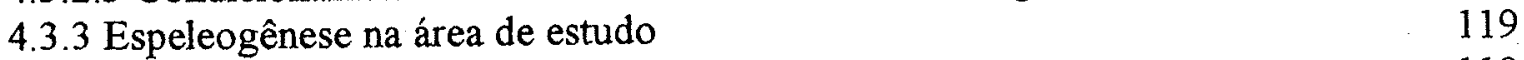

4.3.3.1 Fase de pré-iniciação 119

4.3.3.2 Fase de iniciação 119

$\begin{array}{ll}\text { 4.3.3.3 Fase de desenvolvimento } & 128\end{array}$

4.3.3.4 Rebaixamento do nível de base e desenvolvimento da espeleogênese $\quad 136$

4.4 Cronologia da evolução de condutos 137

$\begin{array}{ll}\text { 4.4.1 Introdução } & 137\end{array}$

4.4.2 Taxas de entalhamento subterrâneo e a idade do sistema cárstico estudado 138

4.4.2.1 Localização e descrição dos pontos amostrados 139

4.4.2.2 Resultados obtidos $\quad$. 145

$\begin{array}{ll}\text { Taxas de entalhamento fluvial subterrâneo } & 148\end{array}$

Estimativa da idade de condutos e dos vales adjacentes ao sistema de cavernas Pérolas-Santana $\quad 150$

4.5 Evolução do sistema cárstico num quadro geomorfológico regional 152

$\begin{array}{ll}4.7 \text { Conclusões } & 157\end{array}$

\section{CAPÍtulo 5 -}

\section{Dinâmica moderna do sistema cárstico do Alto Ribeira}

5.1 Introdução

5.2 Hidrologia cárstica do sistema Pérolas-Santana 160

5.2.1 Medição de vazão 160

Métodos utilizados $\quad 160$

Resultados obtidos $\quad 163$

5.2.2 Análise do fluviograma da ressurgência do sistema Pérolas-Santana 165

5.2.3 Balanço hídrico e área de captação do sistema Pérolas-Santana 171

$\begin{array}{ll}\text { Volume de precipitação } & 172\end{array}$

Volume de água escoada pelo sistema e sua área de captação 172 
Balanço hídrico da bacia do sistema Pérolas-Santana 173

Área de captação e recarga do sistema 174 ,

5.3 Hidroquímica do carste do Alto Ribeira 175

5.3.1 Amostragem e parâmetros hidroquímicos medidos 176

$\begin{array}{ll}\text { 5.3.2 Parâmetros hidroquímicos derivados } & 177\end{array}$

Dureza total

Condutrividade específica corrigida para $20^{\circ} \mathrm{C} \quad 177$

Condutividade especifica e dureza total 178

Razão molar cálcio/magnésio 179

Índices de saturação em calcita $\left(S I_{c}\right)$ e dolomita $\left(S I_{d}\right) \quad 179$

Pressão parcial de $\mathrm{CO}_{2} \quad 179$

$\begin{array}{ll}\text { Erro de balanço iônico (IBE) } & 180\end{array}$

5.3.3 Fácies hidroquímicas do carste estudado $\quad 180$

$\begin{array}{ll}\text { Escoamento superficial alogênico } & 181\end{array}$

Escoamento superficial autogênico $\quad 182$

Escoamento superficial fluviocárstico 182

Percolação autogênica vadosa em fissuras 183

Percolação autogênica vadosa em condutos $\quad 183$

Circulação freática em condutos profundos 183

Ressurgências cársticas 185

5.3.4 Evolução geoquímica das águas do sistema cárstico estudado 186

5.4 Dinâmica corrosiva do sistema cárstico Pérolas-Santana 195

5.4.1 Taxa de saturação de águas alogênicas 195

5.4.2 Variação sazonal dos índices de saturação em calcita e dolomita de águas cársticas 196

5.4.3 Taxa de denudação química da bacia do sistema Pérolas-Santana $\quad 200$

5.5 Conclusões 208

CAPÍTULO 6 -

Considerações finais $\quad 212$

REFERÊNCIAS 215 


\section{ÍNDICE DE FIGURAS}

Figura 1.1 - Localização, acesso e demarcação da área estudada. Os terrenos cársticos

delimitam-se pelos sumidouros.

Pág.

Figura 2.1 - Contexto geológico regional da área estudada, ressaltando a ocorrência de rochas carbonáticas:

Figura 2.2 - Contexto geológico local das áreas carbonáticas estudadas.

Figura 2.3 - Seção geológica simplificada do Subgnupo Lageado na região estudada. Adaptada de Campanha (1991). Legenda das unidades litológicas e localização da seção indicadas na figura 2.2 .

Figura 2.4 - Classificação química das rochas carbonáticas do sudeste paulista, com base no diagrama de Martinet e Sougy (1961). Análises químicas de $\mathrm{CaO}$ e $\mathrm{MgO}$ obtidas em: Souza (1990). faixa carbonática Itaiacoca: Barbieri (1993), faixa carbonática Lajeado e MMAJ/JCA (1983), faixa carbonática André Lopes.

Figura 3.1 - Delimitação e denominação das áreas carbonáticas estudadas. *1- Bairro Furnas, *2- Caverna Santana, *3- Bairro Lajeado, *4- Bairro Bombas.

Figura 3.2 - Seções da área Furnas-Santana. 1-1', seção longitudinal, sem exagero vertical. 2-2' e 3-3', seções transtersais, com exagero vertical de $2 \times$. Localização indicada na fig 3.1

Figura 3.3 - Seções da área Lajeado-Bombas. 4-4'- seção longitudinal, sem exagero vertical. 5-5'- seção transversal com $2 \times$ de exagero vertical. Localização das seções indicada na fig 3.1

Figura 3.4 - O abismo Ponta de Flecha no contexto da inversão de relevo causada pela retração das encostas do vale do rio Betari, bairro da Serra, área LajeadoBombas.

Figura 3.5 - Perfis compostos de vales cegos. Gradiente médio indicado à esquerda

Figura 3.6 - Seção da caverna Lage dos Macaquinhos, representando um salão de desmoronamento associado a um paleo-sumidouro. Borda NE da área Lageado Bombas.

Figura 3.7 - Evolução esquemática de poljes de contato. A- Fase inicial de exposição dos calcários, escoamento superficial (R) predominante. B- Desenvolvimento de condutos subterrâneos e infiltração (I) crescente. C- Condutos integrados, rebaixamento do N.A. e absorção total de $R$ através de sumidouros, com instalação de vales cegos. D- Incisão mais profunda de vales cegos, entalhamento vadoso sobre condutos subterrâneos e retração da encosta calcária por colapso de cavernas. E- Desenvolvimento de planície aluvialcoluvial sobre os calcários. caracterizando o polje de contato

Figura 3.8 - Exemplo de polje de contato, junto ao sumidouro principal do sistema de cavernas Água Suja. Topografia extraída da carta U12, 1:10.000, DAEE, 1957.

Figura 3.9 - Exemplo do padrão planimétrico de depressões poligonais simples da região Furnas-Santana. P- profundidade da depressão. Contornos extraídos da folha V12, 1:10.000, DAEE, 1957. 
Figura 3.10 - Depressão composta (uvala) das Areias, região do Lajeado. A ressurgência e sumidouro marcados nò centro, correspondem ao fundo da dolina de abatimento que dá acesso ao sistema de cavernas Areias. Extraído da folha W12, 1:10.000, DAEE, 1957.

Figura 3.11 - Representação esquemática dos tipos fundamentais de formas de absorção do escoamento superficial em fundos de depressões poligonais na região estudada. A- infiltração difusa ao longo de fraturas alargadas por dissolựão e colmatadas com material residual. B- infiltração concentrada ao longo de condutos verticais abertos (abismos). C- absorção direta do escoamento por condutos de sistemas de cavernas.

Figura 3.12 - Seção esquemática representando a ssociação de formas de absorção do escoamento superficial em depressões poligonais. 1- Dolina de dissolução associada a rota de drenagem subterrânea eficiente. 2- Atual caverna vertical (abismo) representando antigo fundo de depressão com taxa de ampliação menor. 3- Fendas de dissolução na zona epicárstica. 4- Rota de infiltração vertical concentrada sobre descontinuidades. 5- Linhas de fluxo geradas pelo cone de rebaixamento do lençol freático. 6- Condutos associados à rede de drenagem subterrânea. 7- Superficie da rocha entalhada por sulcos de dissolução (karren cobertos). 8- Infiltração vadosa difusa na zona epicárstica. 9- Solo

Figura 3.13 - Representação esquemática da evolução de um conjunto de depressões poligonais, através do modelo de competição e coalescência, gerando depressões compostas a as associações de dolinas de dissolução e abismos, com inversão de relevo. A a $E$, seções e $A^{\prime}$ a $E^{\prime}$, vista em planta.

A. Situação pré-carstificação.

B- Inicio de carstificação e aumento de permeabilidade secundária.

C. Instalação de um cone maior de rebaixamento do lençol freático sobre a rota preferencial de drenagem subterrânea. X marca a depressão com taxa de ampliação maior, devido a sua conexão com a drenagem subterrânea.

D- Englobamento de depressões menores pela depressão com taxa de ampliação maior (formação de depressões compostas).

E- Erosão de solo e detritos acumulados ao longo das rotas de infiltração de depressões menores inseridas no raio do cone de rebaixamento do lençol associado à depressão maior. Iniciação de dolinas secundárias (S) devido ao rebaixamento do lençol e conexão de rotas de infiltração com condutos subterrâneos. Inversâo de relevo (I), com a localização de antigos fundos de dolinas nas encostas de depressões maiores.

Figura 3.14 - Seções longitudinais dos abismos do Fóssil (A) e dos Caramujos (B), localizados na área carbonática Lajeado-Bombas. Adaptados de Gusso, et. al. (1979) e Collet et. al. (1970). As entradas destas cavernas verticais representam antigos fundos de depressões.

Figura 3.15 - Fluxograma do processo de desenvolvimento e ampliação de depressões poligonais através do fenômeno de realimentação. $1,2,3=$ linhas de realimentação positiva. Adaptado de Williams (1985).

Figura 3.16 - Depressões secundárias (linha tracejada) contornando a depressão principal. Exemplo extraido do mapa morfológico da área Lajeado Bombas 
Figura 3.17 - Sequência evolutiva de depressões poligonais a partir da drenagem fluvial

A- Fase inicial de exposição dos metacalcários. Drenagem superficial ativa e lençol freático raso.

B- Drenagem superficial parcialmente ativa. Instalação de pontos de absorção do escoamento superficial. Rebaixamento do lençol freático sobre estes pontos.

C- Drenagem superficial segmentada. Instalaçâo de dolinas de dissolução.

Desenvolvimento de divisores entre sumidouros.

D- Ampliação dos divisores entre sumidouros e estabelecimento de bacias poligonais fechadas.

Figura 3.18 - Interpretação do traçado da paleodrenagem fluvial da área Furnas-Santana. 1Ressurgência do córrego Grande. 2- Ressurgência do córrego do Grilo. 3Ressurgência do córrego Roncador (caverna Santana). 4- Ressurgência do córrego Água Suja. 5- Ressurgência do córrego do Couto.

Figura 3.19 - Interpretação do traçado da paleodrenagem da área carbonática LajeadoBombas. 1- Ressurgência da córrego seco. 2- Ressurgência do córrego Ouro Grosso. 3- Ressurgência do córrego Alambari. 4- Ressurgência do Lago do Bairro da Serra. 5- Ressurgência do córrego das Águas Quentes (sistema Areias).

Figura 3.20 - Variação do gradiente médio $(G)$ em função do comprimento de vales cegos $(\Delta L) .21$ medidas.

Figura 3.21 - Distribuição das profundidades de depressões poligonais do carste do Alto Ribeira. A- área Lajeado-Bombas, 83 medidas. B- área Furnas-Santana, 23 medidas. C- total das medidas de ambas as áreas. Curvas de distribuição exponencial e normal obtidas através do programa Statgraphics.

Figura 3.22 - Histogramas de frequêencia e curvas de distribuição da área (A) e perímetro (B) das depressões poligonais da área carbonática Lajeado-Bombas.

Figura 3.23 - Área versus perímetro das depressões poligonais da região Lajeado-Bombas, 351 pontos, obtidos na escala 1:25.000.

Figura 3.24 - Projeção estereográfica das medidas de descontinuidades da área carbonática Furnas-Santana. Os círculos máximos em $\mathrm{B}$ a $\mathrm{F}$ indicam as atitudes predominantes.

Figura 3.25 - Projeçâo estereográfica das medidas de descontinuidades da área carbonática Lajeado-Bombas. Os círculos máximos em B a F indicam as atitudes predominantes.

Figura 3.26 - Representação esquemática da geometria em planta do sistema de fraturamento das áreas carbonáticas estudadas, com interpretação da posição do esforço de compressão máxima ( $\sigma 1)$ em relação ao dobramento.

Figura 3.27 - Histogramas do comprimento de fotolineamentos acumulados em função da direção.

Figura 3.28 - Interpretação do condicionamento estrutural dos principais alinhamentos de sumidouros autogênicos nas áreas Furnas Santana e Lajeado Bombas. Alinhamentos extraídos dos mapas morfológicos. AC- acamamento, FR- junta simples longa, FL- falha, DP- contorno aproximado de depressão poligonal. Ddique básico.

Figura 3.29 - Localização da zona de concentração de condutos cársticos com relação à topografia. Corte transversal a área Furnas-Santana, setor sul. A- Zona de carste poligonal B-Zona de transição de fluviocarste para carste poligonal. 
Figura 4.1 - Interpretação do condicionamento hidrológico da distribuição preferencial de sistemas de cavernas ao longo do contato SE dos metacalcários.

Figura 4.2 - Padrões em planta das rotas fluviais subterrâneas das cavernas da área estudada. As setas indicam o sentido do fluxo principal de água e $(-\delta)$ a sinuosidade destas rotas.

Figura 4.3 - Definição dos parâmetros planimétricos extensão e largura da faixa de fluxo.

Figura 4.4 - Sinuosidade em função da largura de fluxo das cavernas estudadas. Coeficiente de correlação 0,97 e $\mathrm{R}^{2}$ de $95 \%$, com modelo linear de correlação, sem considerar a caverna Santana.

Figura 4.5 - Classificação geométrica de seções transversais no plano vertical. L, largura; $\mathrm{H}_{\text {s }}$ altura e $\mathrm{F}$, traço de fratura.

Figura 4.6 - Seções transversais da caverna Santana. Traços contornando seções indicam o acamameto. Canyon vadoso, $\mathrm{CV}$; conduto freático, $\mathrm{CF}$, salão de abatimento, $\mathrm{SA}$; conduto retangular. $\mathrm{CR}$ e conduto triangular, $\mathrm{CT}$.

Figura 4.7 - Seções transversais da caverna Laje Branca. Canyon vadoso, CV; conduto freático, $C F$ e salão de abatimento, SA; traço de falha, $f$.

Figura 4.8 - Seções transversais da caverna Areias. Canyon vadoso. CV; conduto freático, CF e salão de abatimento. SA, traço de fratura, F.

Figura 4.9 - Perfil longitudinal simplificado da caverna Santana, indicando a variação do topo do entalhamento radoso.

Figura 4.10 - Exemplos de condutos verticais. A- Caverna Água Suja. B- Caverna Ouro Grosso. C- Caverna Santana.

Figura 4.11 - Formas geradas pela incasão na caverna Água Suja.

Figura 4.12 - Características de sistemas multifásicos observadas no sistema Pérolas Santana.

Figura 4.13 - Controle da sinuosidade de rotas de condutos pela relação angular ( $\alpha$ ) entre a direção do padrão de descontinuidades (fraturas e/ou planos de estratificação) $e$ o gradiente hidráulico. Para simplificação da análise. utilizou-se um padrâo ortogonal de descontinuidades verticais. Conceito adaptado de Worthington (1991).

Figura 4.14 - Geologia estrutural da caverna Santana. A- Planta da carerna. B- Histogranma de direções do desenvokimento da caverna. C e D- Projeção estereográfica de estruturas planares.

Figura 4.15 - Esquema interpretativo do condicionamento estrutural-hidráulico do padrão anguloso de ramos tributários da caverna Santana.

Figura 4.16 - Inflexões agudas na rota de fluxo condicionadas pela intersecção acamamentofalhas, observadas na caverna Santana. Esquemas A e B em planta.

Figura 4.17 - Geologia estrutural da caverna Lage Branca. A- Planta da caverna. B e CDiagramas de projeção estereográfica. D- Histograma de direções do desenvolvimento total da caverna. 
Figura 4.18 - Geologia estrutural da caverna Areias. A- Planta da caverna. B e D- Projeção estereográfica de estruturas planares. C- Histograma de direções do desenvolvimento total da caverna.

Figura 4.19 - Caráter meandrante da caverna Áreias em torno do gradiente hidráulico seguindo falhas e fraturas longas medidas. Segmento $a-b$ indicado na figura 4.18A. Vide comentário no texto.

Figura 4.20 - Características morfológicas e estruturais de proto-cavernas observadas na caverna Santana.

A- seção transversal indicando os pontos de observação, localizada a cerca de $300 \mathrm{~m}$ a montante da ressurgência.

B- vista em planta da geometria de condutos de iniciação e canalículos de anastomose, observados no teto de conduto freático parcialmente preservado.

C- esquema tridimensional da relação entre proto-caverna, canalículos de anastomose e cone de dissolução, preservados no teto do ponto observado. As setas indicam o fluxo de água de percolação ao longo de descontinuidades.

- Profundidade de condutos da caverna Santana em relaçâo à superfície.(Seções localizadas na planta da caverna no lado inferior direito)

Figura 4.22 - Diagrama da corrosão de mistura aplicado às águas do sistema Pérolas Santana. Acompanhar explicação no texto. Adaptado de Dretbrodt (1981b).

Figura 4.23 - Linhas de fluxo condicionadas pelo mergulho da superficie de acamamento (adaptado de Worthington, 1991).

A- Iniciação de condutos condicionada somente pelo plano de acamamento.

B- Iniciação de condutos condicionada pelas intersecções acamamento fraturas, gerando rotas côncavas escalonadas de condutos.

Dx- profundidade máxima de condutos.

Lx- extensão da área de captação

I- pontos de injeção. R- ponto de ressurgência.

Lf- largura da rota de fluxo.

L- linha de fluxo da água subterrânea

$\theta$ - mergulho do plano de acamamento

Figura 4.24 - Profundidade média de fluxo (Dm) em função da extensão da área de captação do aqüifero $(\mathrm{Lx})$ e mergulho da estratificação $(\theta) .{ }^{*}$ medidas da caverna Santana. Demais pontos extraidos de Worthington (1991).

Figura 4.25 - Representação esquemática da morfologia em seção transrersal resultante da fase de desenvolvimento. (1) abaixo do lençol freático, gerando tubos freáticos e (2), com rebaixamento do lençol, acompanhando a ampliação do conduto, gerando a seção típica, popularmente denominada de "buraco de fechadura". 
Figura 4.26 - Esquema simplificado da evolução de condutos associados ao sistema de cavernas Pérolas Santana, em perfil longitudinal. Escala aproximada.

$A$ - Fase de Iniciação. Implantação de proto-condutos ao longo de uma rota de fluxo côncava escalonada, a uma profundidade média de $200 \mathrm{~m}^{z}$, na zona freática (ZF).

$B$ - Fase de desenvolvimento. Conexão de uma rota preferencial de condutos freáticos entre a insurgência (I) e ressurgência (R), com coseqüente ampliação da zona vadosa $(\mathrm{ZV})$.

C- Ampliação de condutos freáticos e progressivo rebaixamento do NA. Entalhamento vadoso (EV) nos segmentos convexos (ascendentes) de condutos freáticos expostos acima do N.A. Desenvolvimento de invasões vadosas (IV). Iniciação de proto-condutos em niveis freáticos abaixo do conduto principal.

$D$ - Fase avançada de desenvolvimento da espeleogênese. Conexão das invasões vadosas com o sistema de cavernas desenvolvido. Ampliação das invasões vadosas, gerando condutos verticais (CV). Instabilização mecânica no maciço carbonático, causando modificação dos condutos acima do N.A., através de incasão (IN). Implantação de novas rotas de condutos profundos. Paleoressurgência (PR) localizada em cotas acima da ressurgência ativa.

Figura 4.27 - Esquema da interpretação da variação vertical (sinuosidade vertical) de condutos freáticos em função da variação de altura do canyon vadoso ao longo do conduto principal da caverna Santana. No ponto B ocorre a transição de canyon vadoso para conduto freático ativo.

Figura 4.28 - Tipos de ampliações freáticas observadas nas cavernas estudadas.

a- alargamento freático preferencial sobre plano de fratura ou falha

b- alargamento freático preferencial sobre plano de acamamento

c- alargamento homogêneo

d- alargamento freático com dissolução preferencial de estratos mais solúveis, produzindo seção irregular

e- seção freática irregular produzida pela corrosão de mistura gerando cones de dissolução.

Figura 4.29 - Interpretação do rebaixamento do nivel de água associado ao desenvolvimento de redes afluentes ao conduto principal da caverna Santana. No sistema tributário de condutos, a morfologia freática foi parcialmente preservada, enquanto que no conduto principal, ocorreu o entalhamento vadoso do canyon.

Figura 4.30 - Seções transversais da caverna Pescaria indicando os pontos amostrados para geocronologia de calcita secundária.

Figura 4.31 - Seção transversal à galeria do rio, junto ao ponto de amostragem $\mathrm{C} 1$, na caverna Santana, cerca de $200 \mathrm{~m}$ da entrada.

Figura 4.32 - Seção transversal mostrando a situação morfológica do ponto de amostragem C2, caverna Santana, entroncamento dos caminhos para o salão São Paulo e galeria dos "Vulcões".

Figura 4.33 - Seção transversal no ponto de coleta CA3, caverna Alambari de Baixo.

Figura 4.34 - Seção morfológica da caverna Morro Preto, junto ao ponto de coleta C11.

Figura 4.35 - Altura sobre o leito fluvial atual versus a idade das amostras datadas, com indicaçâo das barras de erro. A inclinação das retas ajustadas fornece as taxas. de entalhamento fluvial para as cavernas estudadas. 
Figura 4.36 - Quadro demonstrativo da cronologia de eventos geomórficos cenozóicos na região do Alto Ribeira. Subdivisão do Cenozóico adaptada de Van Eysinga (1975).

1- Entalhamento vadoso de sistemas de cavernas.

2- Fase de iniciação de condutos freáticos.

3- Dissecação da superfície de aplainamento Japi (entalhamento do vale do rio Betari).

4- Desenvolvimento da superficie Japi, segundo proposta deste trabalho.

5- Desenvolvimento da superficie Japi, segundo Almeida (1976).

6- Desenvolvimento da superficie Japi, segundo Almeida (1964).

Indicação da idade máxima e minima em relação à média.

Figura 4.37 - Representação esquemática da agradação do vale do rio Betari (no Bairro da Serra) e re-dissolução de estalagmites formadas sobre o leito fluvial de afluentes subterrâneos do rio Betari, interpretados como sendo produto da variação eustática do nível de base na área, durante a última fase glacial.

Figura 5.1 - Demarcação pelos divisores topográficos das áreas de captação referentes às bacias hidrográficas dos sistemas cársticos Pérolas-Santana e Grilo, com localização dos pontos de amostragem hidroquímica e de instalação dos limnógrafos.

Figura 5.2 - Relação entre altura do rio e vazão para a ressurgência do sistema PérolasSantana e sumidouro principal do sistema, caverna Pérolas.

Figura 5.3 - Hidrograma da ressurgência do sistema de cavernas Pérolas-Santana para o periodo de 11 de junho de 1990 a 16 de março de 1992.

Figura 5.4 - Hidrogramas de deflúvio com indicação dos coeficientes de recessão $(\alpha)$ da ressurgência da caverna Santana para os períodos de março a junho de $1991 \mathrm{e}$ junho a agosto de 1991 .

Figura 5.5 - Totais mensais de chuva medidos no posto pluviométrico Serra dos Motas (bairro da Serra, Iporanga)

Figura 5.6 - Geometria da conexão subterrânea entre os sistemas Pérolas-Santana e Grilo interpretada em função do balanço hídrico da bacia Pérolas-Santana e o padrão de condutos da área.

Figura 5.7 - Condutividade específica em função da dureza total das águas coletadas.

Figura 5.8 - Representação gráfica da variação dos principais parâmetros hidroquímicos das fácies hidroquimicas identificadas.

Figura 5.9 - Perfil esquemático de um sistema cárstico com a localização das fácies hidroquímicas identificadas na área de estudo.

Figura 5.10 - Variação do indice de saturação em calcita em relação à pressão parcial de $\mathrm{CO}_{2}$ nas fácies hidroquímicas identificadas. 1- Fácies de escoamento alogênico, 2-Fácies de escoamento fluviocárstico, 3-Fácies de escoamento autogênico, 4- Fácies de percolação vadosa em fissuras, 5- Fácies de percoalção vadosa em condutos, 6- Fácies de circulação freática profunda e 7Fácies de ressurgência cárstica.

Figura 5.11 - Variação da dureza total em relação à pressão parcial de $\mathrm{CO}_{2}$ nas fácies hidroquímicas identificadas.

Figura 5.12 - Variação da alcalinidade em relação ao $\mathrm{pH}$ nas fácies hidroquimicas identificadas na área de estudo. 
Figura 5.13 - Alcalinidade em função do $\mathrm{pH}$ das amostras do rio Roncador na caverna Pérolas (A), do escoamento fluviocárstico na planicie do polje junto ao sumidouro da cav. Pérolas (B) e da ressurgência na cav. Santana.

Figura 5.14 - Seção esquemática da superficie dos metacalcários nas encostas de bacias poligonais fechadas mostrando a morfologia da zona epicárstica (seğundo definição de Williams, 1985). R1- escoamento superficial direto, R2escoamento lateral na porosidade do solo, R3- escoamento lateral na zona epicárstica. Velocidade de $\mathrm{R} 1>\mathrm{R} 1>\mathrm{R} 3$. I- infiltração vertical, I>i, condicionando lençol freático temporário.

Figura 5.15 - Alcalinidade em função do pH das águas de percolação vadosa em fissuras.

Figura 5.16 - Variação dos índices de saturação em calcita e dolomita ao longo da drenagem do sitema Pérolas-Santana, entre o contato com metapelitos e a ressurgência do sistema. P1- sobre o contato, P2 e P3 - sobre a planície do polje de contato, P4no inicio da caverna Pérolas e PS- na ressurgência do sistema, proximidades da entrada da caverna Santana.

Figura 5.17 : Variação sazonal do índice de saturação em calcita das águas da ressurgência da caverna de Santana e de percolação vadosa em fissuras em função da vazão do sistema de cavernas Pérolas-Santana.

Figura 5.18 - Relação entre dureza total e vazão da reșsurgência do sistema Pérolas-Santana. Coeficiente de correlação $-0,83$. Envoltórias de 90 e $95 \%$ de probabilidade.

Figura 5.19 - Distribuição de freqüência das análises de dureza total (mg/l equivalentes a $\mathrm{CaCO}_{3}$ ) da ressurgência da caverna Santana para o período de junho de 1990 a julho de 1991. Total de 23 amostras, média $=97,34 \mathrm{mg} /$, coeficiente de variação $=8,8 \%$. Os três grupos de freqüência correspondem aos regimes de vazão alta, média e baixa, respectivamente, da esquerda para direita.

Figura 5.20 - Taxas de denudação cárstica $(D)$ em função da precipitação efetiva ou escoamento da bacia $(P-E v)$, segundo White (1984). Os pontos plotados foram extraidos de 1- Ártico canadense, Smith (1962); 2 e 3-Polônia, Glazek e Markovicz-Lohinovicz (1973); 4- West Virginia, EUA. Ogden (1982); 5Irlanda, Williams (1963); 6- Bulgaria, Markovicz, et. al. (1972); 7-Montanhas Tatra, Polônia, Glazek e Markovicz-Lohinivicz (1973); 8- Nova Zelândia, Williams e Dowling (1979); 9- Nova Zelândia, Gunn (1981b); 10-Belize, Miller (1982); 11-Gunung Mulu, Malásia, Sweeting (1979) e R-Alto Ribeira, Brasil, ponto calculado no presente trabalho.

Figura 5.21 - Variação da dureza total em função da vazão na ressurgência da caverna Santana para o periodo de $29 / 6 / 90$ a $18 / 6 / 91$. Coeficiente de correlação de 0,88 e $\mathrm{R}^{2}=76,8 \%$.

Figura 5.22 - Fluxo de massa equivalente a $\mathrm{g} / \mathrm{s}$ de $\mathrm{CaCO}_{3}$ em função da vazão na ressurgência da caverna Santana. Coeficiente de correlação de 0,99 e $\mathrm{R}^{2}=$ $98,9 \%$.

\section{ÍNDICE DE TABELAS}

Tabela 3.1

Distribuição quantitativa das zonas morfológicas nas áreas estudadas. FS, área Furnas-Santana; LB, área Lajeado-Bombas.

Tabela 3.2 - Parâmetros morfométricos dos vales cegos

Tabela 3.3

- Índices morfométricos de sumidouros alogênicos e ressurgências das áreas estudadas. 
Tabela 3.4 - Parâmetros morfométricos do carste poligonal do Alto Ribeira num quadro comparativo com outras áreas cársticas. * valôres calculados com os dados publicados pelos autores citados.

Tabela 3.5 - Atitudes médias dos principais conjuntos de descontinuidades das áreas de estudo. Medidas extraídas dos estereogramas correspondentes das figuras 3.24 e 3.25. Número de medidas em parênteses

Tabela 4.1 - Características morfométricas dos principais sistemas de cavernas das áreas Furnas Santana (A) e Lajeado Bombas (B).

* parte do desenvolvimento de cavernas extraídos de Martim, Chrysostomo e Rodrigues, 1989.

Altitude em metros sobre o nivel do mar.

Extensão é a distância horizontal em linha reta entre sumidouro e ressurgência.

Desnivel é a distância vertical entre sumidouro e ressurgência.

Comprimento de condutos é a somatória do desenvolvimento de cavernas mapeadas. Desenvolvimento é a somatória do comprimento de galerias e eixos maiores de salões, medidos em planta.

$\mathrm{C} / \Delta \mathrm{L}$ é o grau de carernamento do sistema, ou seja, a tazão entre o comprimento de condutos acessiveis e a extensão.

a, b, c são índices referentes à diferentes tributários do sistema.

Tabela 4.2 - Áreas de captação de escoamento superficial na região investigada.

* Áreas aflorantes de metacalcário menos as zonas fluviais.

Tabela 4.3 - Fração de condutos acessiveis ao longo da extensão ( $\Delta \mathrm{L}$ ) dos sistemas nas áreas estudadas.

Tabela 4.4 - Parâmetros morfométricos planimétricos das principais cavernas da área estudada. Medidas obtidas sobre mapas 1:500 a 1:1000 das cavernas.

Tabela 4.5 - Variação do acamamento nas cavernas de Santana e Areias (de cima e de baixo). Entre parênteses são indicados os números de medidas.

Tabela 4.6 - Profundidades de condưtos de iniciação e extensões de rotas completas sistemas de cavernas. Medidas 1 a 16 foram extraidas de Worthington (1991).

Tabela 4.7 - Resultados das análises de datação $\mathrm{Th} / \mathrm{U}$, realizadas no laboratório de geocronologia dos Deparamentos de Geografia e Geologia da McMaster University, Hamilton, Canadá. ( ${ }^{*}$ Porcentagem de erro indicada entre parênteses.

Tabela 4.8 - Taxas de entalhamento radoso vertical para as carvernas amostradas no Alto Ribeira.

Tabela 4.9 - Quadro comparativo entre taxas de entalhamento fluvial subterrâneo de diferentes regiões cársticas.

Tabela 5.1 - Vazões medidas na ressurgência da caverna Santana e na caverna Pérolas (respectivamente, ressurgência e sumidouro principal do sistema de cavernas Pérolas - Santana). * sazös medidas sonente com o mécido de diluição de sal. Altura do rio medida sobre a régua de referência instalada para cada limnógrafo.

Tabela 5.2

- Parâmetros hidrológicos de vazão do sistema Pérolas-Santana. As vazões e volumes calculados envolvem um erro de até $12 \%$ devido à incerteza desta ordem de grandezạ nas medições de vazão. 
Tabela 5.3 - Classificação de nascentes cársticas em função das características da vazão (adaptado de Worthington, 1991).

Tabela 5.4 - Coeficientes de recessão calculados para a ressurgência da caverna Santana.

Tabela 5.5 - Parâmetros físico-químicos medidos e calculados para as fácies hidroquímica identificadas no sistema cárstico estudado. * - valores do coeficiente de variação não calculados

Tabela 5.6 - Classificação química das rochas carbonáticas da área carbonática Furna Santana. Análises químicas extraida de Barbieri (1993). * Composição média de 3 análises. $\bar{X}=$ valor médio, $\mathrm{CV}=$ coeficiente de variação, $\Delta=$ variação. ( ) número de análises. $\mathrm{CaO}$ e $\mathrm{MgO}$ em \% em peso na rocha.

Tabela 5.7 - Relação do fluxo de sólidos dissolvidos ( $\mathrm{g} / \mathrm{s}$ equivalente $\mathrm{CaCO}_{3}$ ) em função do regime de vazão da ressurgência do sistema Pérolas-Santana.

Tabela 5.8

Relação dos períodos com vazâo alta, média e baixa e os totais correspondentes em volume escoado ( $V$ ) e massa equivalente a $\mathrm{CaCO}_{3}$ remorida em solução $(V$.

T) pelo sistemä Pérolas-Santana durante o periodo monitorado.

Tabela 5.9

- Quadro resumido das taxas de denudação química calculadas segundo métodos diferentes para a bacia do sistema Pérolas-Santana

\section{ÍNDICE DE FOTOGRAFLAS}

Foto 3.1

Foto 3.2

- Estratificação ritmica de camadas carbonáticas, pelitico-carbonáticas e pelíticas, típicas da área Furnas-Santana. Vista da parede lateral da galeria principal da caverna Laje Branca.

- Paredões calcários associados a vales cegos, característicos do contato entre metapelitos e metacalcários. Vale cego da caverna Laje Branca, contato SE da área Furnas-Santana.

Foto 3.3

- Exemplo de cone cárstico. Área Furnas-Santana, vista da estrada Apiaí Iporanga, do mirante da serra da Boa Vista.

Foto 3.4 - Dolinas de subsidência em fundos de depressões poligonais. Sudeste da área Lajeado-Bombas.

Foto 3.5 - Vista típica de cones cársticos que delimitam depressôes poligonais. Área Lajeado-Bombas, local denominado Sítio Novo.

Foto 4.1 - Espeleotema tipo "pata de elefante", ponto P3 da caverna Pescaria.

Foto 4.2 - Ponto de amostragem Cl, caverna Santana, local conhecido como Pata de Elefante

Foto 4.3 - Bloco abatido de escorrimento calcítico de onde se extraiu a amostra C2.

Foto 4.4

- Vista do escorrimento calcítico suspenso, ponto CA3, indicado pela seta, caverna Alambari de Baixo.

Foto 4.5

- Aspecto do nivelamento de cristas na área estudada, correlacionado à superficie Japi. Vista do vale do rio Betari do mirante da Serra da Boa Vista, estrada Apiá - Iporanga. 
Foto 5.1

- Vista do limnógrafo instalado na ressurgência do sistema Pérolas-Santana, a cerca de $100 \mathrm{~m}$ da entrada da caverna Santana. A esquerda do limnógrafo oberva-se a régua de referência.

\section{LISTA DE ANEXOS}

Anexo 3.1 - Mapa estrutural da área Furnas-Santana.

Anexo 3.2 - Mapa estrutural da área Lajeado-Bombas

Anexo 3.3

- Mapa morfológico da área carbonática Furnas-Santana.

Anexo 3.4

- Mapa morfológico da área carbonática Lajeado-Bombas.

Anexo 3.5

- Zoneamento morfológico das áreas carbonáticas Furnas-Santana e Lajeado-Bombas.

Anexo 3.6 - Perfil longitudinal composto do rio Betari.

Anexo 4.1 - Mapa geoespeleológico da caverna Laje Branca

Anexo 4.2 - Distribuição de sistemas de cavernas nas áreas carbonáticas Furnas-Santana e LajeadoBombas.

Anexo 5.1

- Registro de variação do nível do rio na tessurgència da caverna Santana.

Anexo 5.2

- Exemplo de cálculo de vazão pelo método de diluição de sal através do programa elaborado por Karmann (1989) em Turbo Pascal 6.0 (profissional).

Anexo 5.3

- Listagem das análises químicas das amostras de água coletadas e de seus principais parâmetros calculados. $\mathrm{SI}_{c}=$ índice de saturação em calcita, $\mathrm{SI}_{\mathrm{d}}=$ índice de saturação em dolomita, $\mathrm{SAT}_{\mathrm{c}}$ e $\mathrm{SAT}_{\mathrm{d}}=$ porcentagem de saturação em calcita e dolomita, $\mathrm{BBE}=$ erro de balanço iônico.

Anexo 5.4

- Listagem da dureza total ( $\mathrm{mg} / \mathrm{l}$ equivalentes a $\mathrm{CaCO}_{3}$ ), condutividade corrigida para $20^{\circ} \mathrm{C}$ e razão molar $\mathrm{Ca} / \mathrm{Mg}$ das amostras de água coletadas. 


\section{RESUMO}

Estudou-se do ponto de vista geomorfológico, geoespeleológico, hidrológico e hidrogeológico, uma área com terrenos cársticos desenvolvidos sobre metacalcários, metacalcários dolomíticos e magnesianos, de idade proterozóica média, pertencentes ao Grupo Açungui. A área localiza-se no alto vale do rio Ribeira de Iguape, entre os municípios de Apiaí e Iporanga, sudeste do Estado de São Paulo.

O mapeamento geomorfológico permitiu identificar uma seqüência evolutiva da paisagem cárstica, a qual inicia-se com um sistema fluvial, onde os vales da drenagem superficial são gradativamente segmentados com o tempo, através da implantação de bacias de drenagem fechada, cujo desenvolvimento levou à formação de carste poligonal. Esta transição da paisagem fluvial para a cárstica levou à definição das zonas morfológicas fluviocárstica, de transição (com bacias poligonais compostas) e a de carste poligonal (com bacias poligonais simples).

O relevo cárstico é estruturalmente condicionado, onde os sumidouros (fundos de depressões poligonais) instalaram-se preferencialmente na interseç̧ão entre planos de estratificação, juntas e falhas. Estes pontos de absorção do escoamento autogênico alinhamse preferencialmente sobre traços de acamamento, em situações de mergulho alto deste e, predominantemente sobre traços de fraturas longas e falhas, no caso de mergulho moderado a baixo do acamamento.

Propõe-se a evolução do conjunto de depressões poligonais através do processo de competição e coalescência entre estas (taxas de ampliação diferenciadas), o qual gera inversões de relevo, onde antigos fundos de depressões fechadas hoje localizam-sé em ${ }^{\gamma}$ cristas. Este processo é acompanhado pelo mecanismo de geração múltipla, onde depressões maiores com drenagem subterrânea mais eficiente, deflagram a instalação de depressões menores, vizinhas e sobre a maior.

A morfometria do relevo levou à conclusão de que o carste estudado é semelhante ao carste poligonal da Nova Guiné e Jamaica, com zonas de alto grau de carstificação, apesar das condições climáticas distintas do Alto Ribeira, em comparação com aquelas áreas.

$\mathrm{Na}$ área carbonática encaixante do sistema de cavernas Pérolas-Santana, a zona de carste poligonal mais desenvolvida é associada à concentração de condutos em profundidade nas proximidades da linha de contato SE da faixa carbonática.

$\mathrm{O}$ mapeamento geológico de cavernas evidenciou que entre o grande número e variedade de descontinuidades presentes na rocha metacarbonática, as estruturas mais favoráveis para instalação de condutos são os planos de estratificação, fraturas simples longas e falhas.

A morfologia planimétrica dos sistemas de cavernas reflete o estilo estrutural do metacalcário encaixante. Cavernas com padrão planimétrico retilíneo e anguloso (p. ex, cav. Santana), associam-se à mergulhos altos do acamamento, enquanto que o padrão sinuoso e curvilíneo (p. ex., cav. Areias) refletem mergulhos moderados a baixos da estratificação. O 
grau de sinuosidade de condutos subterrâneos é controlado pelo ângulo agudo entre a direção do gradiente hidráulico e a deseontinuidade favorável para instalação do conduto. Quanto maior for este ângulo, tanto mais sinuosa será a rota de condutos da água subterrânea.

A iniciação de proto-cavernas acompanha linhas de intersecção entre o acamamento e fraturas simples longas e falhas. O sistema de cavernas Pérolas-Santana segue o modelo de Worthington (1991), o qual prevê que a profundidade média $(D m)$ de iniciação de condutos freáticos (abaixo do N.A.) segue uma função exponencial, onde a base desta função é o produto entre o seno do ângulo de mergulho da estratificação(sen $\theta)$ e a distância $(L x)$ entre o ponto de insurgência e ressurgência da rota de condutos em iniciação (obtevese a função $\left.D m=(L x \operatorname{sen} \theta)^{0.82}\right)$.

A fase de desenvolvimento da espeleogênese na área estudada produziu canyons vadosòs com até $50 \mathrm{~m}$ de entalhamento vertical. Este entalhamento é interpretado como produto de uma taxa moderada de rebaixamento do nível de base dos sistemas de cavernas, o que por sua vez, seria reflexo de um soerguimento tectônico moderado da área. Com base nas idades preliminares $\mathrm{Th} / \mathrm{U}$ de calcita secundária sobre depósitos fluviais subterrâneos, estimou-se uma taxa máxima média de entalhamento vadoso subterrâneo de $0,0042 \mathrm{~cm} /$ ano (42mm/ka). Aplicando esta taxa de entalhamento vadoso aos canyons subterrâneos observados na área, concluiu-se que os sistemas de cavernas da região encontram-se na fase de desenvolvimento por aproximadamente 1,7 Ma. A idade mínima do sistema PérolasSantana, incluindo a estimativa teórica de duração da fase de iniciação, é em torno de $2 \mathrm{Ma}$. A correlação deste entalhamento fluvial subterrâneo com o rebaixamento do canal fluvial externo do rio Betari, sobre metacalcários, permitiu estimar uma idade mínima de $6,4_{-3,}^{+\pi, 4}$ Ma. para o entalhamento do vale do rio Betari na área de estudo.

A ressurgência do sistema de cavernas Pérolas-Santana é do tipo fluxo total permanente (classificação de Worthington, 1991), com razão entre vazão máxima e mínima de 19,7 para o ano hidrológico de 1990-1991. Os coeficientes de recessão do deflúvio do escoamento básico desta ressurgência refletem um aqüífero cárstico com alto grau de fissuramento interconectado, segundo classificação de Milanovic (1976).

Com base no cálculo do balanço hídrico do sistema Pérolas-Santana, comprovou-se que a área de captação da bacia associada ao sistema, definida inicialmente pelo traçado dos divisores topográficos $\left(14,8 \mathrm{~km}^{2}\right)$ é insuficiente para alimentar o volume de água escoado pela ressurgência, por um ano hidrológico. Ajustando o balanço hídrico, definiu-se uma área de captação de $25,4 \mathrm{~km}^{2}$ para esta bacia. Comprovou-se assim, uma conexão subterrânea entre sistemas vizinhos de drenagem subterrânea, os quais, através de uma análise convencional da rede de drenagem superficial, seriam independentes,

Definiu-se as seguintes fácies hidroquímicas para o sistema cárstico estudado: escoamento superficial alogênico, escoamento superficial fluviocárstico, percolação autogênica vadosa em fissuras, percolação autogênica vadosa em condutos, circulação freática em condutos profundos e escoamento de ressurgências cársticas. A evolução geoquímica das águas no sistema cárstico é controlada principalmente pela ação de água 
meteórica enriquecida em ácido carbônico. Ao longo de rotas de circulação profunda e localmente no zona vadosa, a carstificação pelo ácido carbônico é provavelmente somada à ação de ácido sulfúrico produzido pela oxidação de sulfetos.

A dinâmica erosiva atual do terreno cárstico estudado é expressa pela taxa de saturação em calcita e dolomita de águas alogênicas que invadem o sistema cárstico, pela sazonalidade dos índices de saturação em calcita e dolomita das principais fácies hidroquímicas que circulam pelo sistema e pela taxa de rebaixamento da superficie epicárstica por dissolução (denudação química). Para esta última, obteve-se uma média de $31,1 \pm 6 \mathrm{~mm} / \mathrm{ka}$. 


\section{ABSTRACT}

The geomorphology and the conduit aquifer, and associated cave systems, of a karst area $\left(74 \mathrm{~km}^{2}\right)$ in dolomitic and calcitic. metalimestones of the Middle Proterozoic Açungui Group have been studied in the Upper Ribeira river valley, between Apiai and Iporanga, southeastern São Paulo, Brazil.

The transition between fluvial and karst landforms was recognized through detailed aerial photointerpretation and field observations. The fluvial system has been gradually disrupted by the growth of closed drainage basins with a polygonal pattern. Based on this transition, a morphological zonation has been defined over the limestones. Three main landform categories are recognized in the limestone: the fluviokarst zone (with dominant surface runoff), the transitional zone (characterized by large composite closed depressions) and the polygonal karst zone (with simple closed depressions).

The karst topography exhibits strong structural control. Autogenic swallets occur mainly at the intersections of bedding planes, fractures and faults. These inlet points for autogenic recharge are preferentially aligned on bedding traces where dip is high. In areas where the dip is low to moderate, swallets preferentially follow long fracture and fault traces of steep dip.

The observed population of closed depressions is interpreted as resulting from competition and coalescence processes between depressions in response to different rates of depression enlargement, as well as by the multiple generation process described by Kemmerly. In this model, larger depressions, connected by efficient underground drainage routes, trigger the initiation of other depressions over and in the vicinity of the larger depressions. The competition between depression enlargement rates leads to topographic inversions, where ancient depression bottoms now occupy hill crests.

Morphometric analysis of the karst topography of the Upper Ribeira polygonal karst shows similarities to New Guinean and Jamaican polygonal karst landscapes.

Within the limestone area above the Perolas-Santana cave system, the best developed polygonal carst is related to conduits in depth, close to the southeastern contact of limestone with metapelites.

Among the variety and large number of discontinuities present in the metamorphic limestone, the most favorable structures for cave development are bedding planes, long simple fractures and faults.

The planimetric patterns of cave systems are controlled by the structural style of the limestone. Rectilinear and angular cave map patterns are related to steeply dipping strata, whereas sinuous and curvilinear patterns reflect low-dipping, folded limestone. The simuosity of conduits is mainly controlled by the angle between the direction of the general hydraulic gradient and the strike of the favorable subvertical discontimuities for conduit development. The greater this angle is, the higher the sinuosity, confirming Worthington's (1991) model. 
The initiation of proto-conduits mainly follows the intersections between bedding planes and simple long fractures and faults. Worthington's model for prediction of mean conduit depth is confirmed by the Pérolas-Santana cave system. The mean depth of 200 to $300 \mathrm{~m}$ beneath the watertable for the initiation conduits of this 5 stem agrees well with the prediction of the exponential equation which is based on the stratal dip and the horizontal length (catchment length) between the main insurgence and the ressurgence of the cave system.

Vadose canyons with up to $50 \mathrm{~m}$ of vertical entrenchment were produced during the speleogenetic development phase, as the result of moderate rates of base level lowering, which itself was due to moderate rates of regional tectonic uplift. Based on preliminary Th $U$ ages of secondary calcite covering ancient fluvial deposits in vadose cave canyons, an average maximum rate of $0.0042 \mathrm{~cm} /$ year $(42 \mathrm{~mm} / \mathrm{ky})$ is proposed for the vadose entrenchment within the studied caves. This rate gives a minimum age of 1.7 My for the development phase in the Santana cave. Including the theoretical time span of the initiation phase, the total age of the Pérolas-Santana cave system is around $2 \mathrm{My}$.

The correlation between the cave river entrenchment rate and the external river channel lowering over the limestone, close to the cave system, allows an age estimation of $16.4_{-3.1}^{+7.4}$ My for the Betari valley in the studied area.

The calculated baseflow recession coeficients, tsuggest that he karst aquifer of the Pérolas-Santana system has a high degree of interconnected fissures.

The initial analysis of the surface drainage systems, using concepts of topographic divides, indicates the presence of two separate drainage basins over the Furnas-Santana limestone area, each related to a cave system. The hydrological balance of the PerolasSantana cave system suggests, however, that the catchment area must be larger $\left(25,4 \mathrm{~km}^{2}\right)$ than indicated by this initial interpretation. It is therefore suggested that two adjacent cave systems (Perolas-Santana and Grilo systems) are connected at depth, in order to balance the annual discharge measured at the Santana cave ressurgence.

The following hydrochemical facies have been defined: allogenic surface runoff, fluviokarstic runoff, vadose autogenic fissure seepage, vadose autogenic conduit flow, deep phreatic conduit flow and karst ressurgence flow. The hydrochemistry indicates that the carstification is basically controlled by meteoric water enriched in carbonic acid. Minor dissolution of carbonate by sulphuric acid produced by oxidation of pyrite disseminated in impure limestone is thought to occur in deep flow routes.

The modern erosive dynamics of the studied karst has been quantified according to the following parameters: saturation rate in calcite and dolomite of allogenic rivers entering the limestone surface, the seasonality of the saturation index of the main hydrochemical facies and the rate of limestone surface lowering through dissolution (chemical denudation). The calculated mean chemical denudation rate for the PerolasSantana basin is $31.1 \pm 6 \mathrm{~mm} / \mathrm{ky}$. 


\section{AGRADECIMENTOS}

A realização desta tese não teria sido possível sem a colaboração de um grande número de pessoas e de várias instituições.

Entre as instituições ressaltaram-se o Department of Geology e o Deparment of Geography, ambos da McMaster University (Hamilton, Canadá), o Instituto de Geociências da Universidade de São Paulo, a Fundação de Amparo à Pesquisa do Estado de São Paulo (FAPESP), o Conselho Nacional de Desenvolvimento Científico e Tecnológico (CNPq), o Instituto de Pesquisas Tecnológicas do Estado de São Paulo, e o Instituto Florestal da Secretaria do Meio Ambiente do Estado de São Paulo.

O desenvolvimento desta pesquisa, assim como seu sucesso, são atribuídos principalmente ao grande incentivo e aos valiosos ensinamentos recebidos do Prof. Dr. Derek Ford. Agradeço especialmente ao Prof. Derek Ford, pela sua dedicação e atenção dispensados a mim e ao projeto de pesquisa, durante a minha estadia como aluno de pósgraduação junto ao Departamento de Geologia da McMaster University, onde me foi proporcionada a oportunidade de tomar conhecimento das diversas técnicas e pesquisas atuais desenvolvidas em terrenos cársticos.

Ao Prof. Dr. Georg Robert Sadowski agradeço pelo apoio e encorajamento, desde a concepção desta tese, até os preparativos finais desta e as muitas discussões sobre a abordagem geológica do fenômeno cárstico.

À Steve Worthington, Marcus Buck, Joyce Lundberg, Jane Mulkevitch, Karen Gooder, Nicky Keizer, Sue Vajoczki, Wang Xing Lee e Fereydown Shazbhan, agradeço pelas valiosas contribuições na minha formação teórica e prática em geoespeleologia e hidrologia cárstica, obtidas através de discussões acadêmicas, trabalhos de laboratório e de viagens a campo nas cavernas e áreas cársticas do sudeste do Canadá e nordeste dos Estados Unidos.

Ao Prof. Dr. Henry Schwarcz, na época chefe do Department of Geology da McMaster University, e à todo corpo docente deste departamento, agradeço a agradável acolhida, amizade e prestatividade durante minha estadia em Hamilton.

Ao Professor e amigo Dr. Aldo da Cunha Rebouças, expresso minha gratidão, pela confiança em meu trabalho, o que possibilitou a obtenção de recursos junto à FAPESP e CNPq para execução dos trabalhos de campo.

Os quase $30 \mathrm{~km}$ de mapeamento topográfico e geológico de cavernas, produto de exaustivos trabalhos de campo e de gabinete, assim como as fases de coleta de água e medições de vazão na região do Alto Vale do Ribeira, foram desenvolvidos em grupo, onde no período de 1987 a 1993, estiveram envolvidos os seguintes colegas e amigos: Alex Barbieri, Nelson Luis Nogueira Batisttuci, Paulo César Boggiani, Marcos Philadelphi, Maurício de Alcântara Marinho, Rinaldo Ademar Campanha, José Carlos Sicoli Sedane, Richard Lepine, Martim Afonso de Souza, Arnaldo Alcover Neto, Anderson Moraes, Andrea Yida de Matos, Edilson Pissato, Alberto Carlos Kaminsky, Armando Torquato, Adriano Gambarini, Ana Lúcia Dezensi Gesicky, Maria Cândida Barbosa do Nascimento, 
Eduardo Shinohara, Mauro Carrari Chamani, William Salum Filho, Oduvaldo Viana Jr., Ricardo Fraga Teixeira e Luís Guilherme Teixeira. :Agradeço à todos pela valiosa colaboração.

Aos colegas do Departamento de Geologia Geral, Coriolano de Marins e Dias Neto (que em muito contribuiu nesta tese através de longas e férteis discussões); Rômulo Machado (o qual pacientemente revisou a primeira versão deste trabalho), Maria Cristina Motta de Toledo, Ian McReath, Marcos Egydio da Silva e Joel Barbugiani Sígolo, agradeço pela colaboração durante a redação deste trabalho. Ao Professor Thomas Rich Fairchild sou grato pela revisão de textos em inglês.

Especiais agradecimentos devo à Química Sandra Andrade e ao Prof. Dr. Raphael Hypólito, pelo apoio na parte analítica desta pesquisa.

Grande parte das ilustrações deste trabalho devo à equipe de desenho do IGc-USP, Sr. Francisco José Pinheiro de Almeida Filho, Srta. Itacy Krohne e Rodrigo Vascon, aos quais agradeço muito. Agradeço também, ao setor gráfico deste Instituto, chefiado pelo Sr. Dalton.

Sou profundamente grato à Boris Karmann e Monique Therese da Graça Carreiro, cujo apoio e incansável prestatividade na área de informática, foram essenciais, no tratamento estatístico de dados e na elaboração de figuras. $\mathrm{Na}$ área de informática, agradeço, também, ao Sr. Geraldo Carlos Lino Freitas.

À Srta. Maria Aparecida Bezerra agradeço pela detalhada revisão da listagem de referências.

À população do Bairro da Serra e funcionários do PETAR em geral e, em especial, à Vandir de Andrade e Joaquim Justino, agradeço a hospitalidade e cooperação durante os trabalhos de campo.

À Maria Cândida Barbosa do Nascimento, agradeço o incentivo moral e carinho, que foram essenciais, para cumprir esta etapa de trabalho.

À Heinz Karmann e Valerie Karmann, meus pais, agradeço toda formação e inesgotável apoio até hoje recebidos. 


\section{CAPÍTULO 1 \\ INTRODUÇÃO}

\subsection{Apresentação do tema de trabalho}

Rochas carbonáticas, principais hospedeiras das paisagens cársticas e sistemas de cavernas, ocupam cerca de $12 \%$ das áreas continentais sem cobertura glacial. A fração deste total de terrenos carbonáticos, com significativa circulação de água subterrânea através de aqüíferos cársticos, é estimada, entre 7 a 10\%. Áreas cársticas, tornam-se ainda mais relevantes, quando se considera a estimativa, de que no mínimo, $25 \%$ da população mundial é abastecida através ou depende, em grande parte, de recursos hídricos extraídos de aqüíferos cársticos (Ford e Williams, 1989).

Entende-se por terrenos cársticos, as regiões sobre rochas, as quais sofreram importantes processos de dissolução, tanto por águas superficiais, como também, pelas águas subterrâneas. Estes processos de dissolução, são responsáveis, pela geração de feições características, como solos típicos (às vezes escassos), depressões fechadas, dolinas, sistemas de cavernas associados à drenagem subterrânea e, ausência quase total, de sistemas fluviais de superficie. Terrenos cársticos podem ser apropriados para implantação de projetos de mineração, geração de energia e de abastecimento de água, levando-se em consideração, as devidas precauções técnicas, devido ao fato destes terrenos, representarem ambientes extremamente frágeis e que, freqüentemente, respondem às pressões ambientais de uma forma mais rápida e mais dramática do que outros tipos de terrenos (Back e Arenas, 1989).

Devido aos fatos acima apontados, o estudo da dinâmica atual e evolução de paisagens cársticas, incluindo o entendimento da origem e desenvolvimento de sistemas de cavernas, deixou de ser somente uma curiosidade científica de alguns naturalistas abnegados, tornando-se um fator cada vez mais importante, no planejamento de uso e ocupação de terrenos carbonáticos, e na exploração e conservação de recursos hídricos destas áreas (Waltham, 1981).

Estima-se atualmente, que há no minímo $8.000 \mathrm{~km}$ de condutos subterrâneos mapeados no mundo (Waltham, op cit.), definidos como cavidades naturais, com dimensões suficientes para permitir a passagem do homem. O sistema Flint - Mammoth (EUA), com até $530 \mathrm{~km}$ de desenvolvimento em planta, representa o sistema de cavernas mais longo da atualidade, enquanto o sistema Jean Bernard (França), com 1535m de desnível, é o mais profundo explorado até o presente (Courbon, et. al., 1989). Constantemente, o mundo recebe notícias de novas descobertas de grandes sistemas de cavernas, em regiões sub-árticas até tropicais. A exploração e mapeamento sistemático de cavernas, tem sido a fonte de um enorme conjunto de dados, os quais fundamentaram a formulação de vários modelos espeleogenéticos durante as últimas cinco décadas (Watson e White, 1985 e Lowe, 1992).

O Brasil, com seus $8.500 .000 \mathrm{~km}^{2}$ de território, conta com extensas áreas cársticas, as quais, numa estimativa preliminar, representam cerca de 5 a $7 \%$ do total de sua área. A 
regionalização preliminar de terrenos cársticos do Brasil (Karmann e Sánchez, 1986), evidenciou o enorme potencial espeleológico destas áreas. Entre as mais extensas e contínuas, ressaltam-se os terrenos cársticos associados à cobertura carbonática plataformal do Grupo Bambuí, na região central do País; aos metacalcários e dolomitos do Grupo Corumbá, na serra da Bodoquena, Mato Grosso do Sul e à seqüência carbonática do Grupo Araras, na bacia do alto rio Paraguai, Mato Grosso. Na região sudeste, apesar de possuirem expressão em área muito inferior às regiões carbonáticas acima citadas, os terrenos cársticos concentram-se sobre os metacalcários e metadolomitos do Grupo Açunguí e correlatos.

A atuação de grupos de exploração de cavernas, durante as últimas três décadas, vem reunindo, um grande conjunto de dados, sobre a localização e características físicas de sistemas de drenagem subterrânea no Brasil, o qual, conta atualmente, com no mínimo 411 $\mathrm{km}$ de condutos subterrâneos topografados em seus traços gerais (Martim, Chrysostomo e Rodrigues, 1989). Neste quadro, ressalta-se a Toca da Boa Vista (município de Campo Formoso, BA), com 50,2 km de passagens topografadas até o momento, representando a mais longa caverna conhecida na América do Sul (Auler e Rubbioli, 1993).

A descoberta e exploração de cavernas cársticas, em território brasileiro, alcançou um adiantado estágio de desenvolvimento, enquanto a pesquisa científica, sob o ponto de vista dos processos geológicos, hidrológicos e geomórficos, envolvidos na evolução e dinâmica destas cavernas e seus terrenos cársticos associados, encontra-se ainda em fase incipiente. Este fato é evidenciado pela restrita bibliografia técnico-científica nacional disponível sobre este tema, conforme ressaltado em Sánchez (1986) e confirmado pela pesquisa bibliográfica realizada para o presente trabalho. Entre os estudos acadêmicos, que enfocam o sistema cárstico, na área das geociências, ressaltam-se os trabalhos de Coutard, Kohler e Journaux (1978) e Kohler (1989), sobre o relevo da região de Pedro Leopoldo e Lagoa Santa $(\mathrm{MG})$; as análises morfoestruturais e hidrogeológicas de regiões cársticas sobre o Grupo Bambuí no norte de Minas Gerais (Silva, 1984) e Bahia (Silva, 1973 e Guerra, 1986) e, mais recentemente, o estudo realizado por Barbieri (1993), sobre a variedade de formas de calcita secundária, apresentando um esboço preliminar dos contrôles físico-químicos e mecanismos de deposição de espeleotemas nas cavernas do alto vale do rio Ribeira de Iguape (SP).

Neste quadro, de grande potencial científico e com pouca pesquisa específica realizada, o presente trabalho pretende contribuir na abertura e estabelecimento de uma linha de pesquisa geocientífica sobre terrenos cársticos brasileiros, a partir do estudo geomorfológico, geológico e hidrológico, de uma área de amostragem da região cárstica do alto vale do rio Ribeira de Iguape ( sudeste do Estado de São Paulo).

\subsection{Seleção da área estudada}

As cavernas da região cárstica do alto vale do Ribeira de Iguape vem despertando a atenção de naturalistas e exploradores, desde o início deste século, época em que foram realizados os primeiros levantamentos geográficos da região. Como exemplos, citam-se o 
relato antropológico de Krone (1914) e o primeiro levantamento de cavernas da área entre Apiaí e Iporanga, realizado por Krone em 1909 e posteriormente publicado em 1950. Com o objetivo de localizar sítios paleontológicos e arqueológicos, Krone procurou as cavernas, onde encontrou restos da megafauna pleistocênica e apresentou a primeira descrição das cavernas e de seu relevo associado. Neste relato, ressalta a presença de importantes cavernas com rios subterrâneos, como o rio Roncador, na época impenetrável para o pesquisador, mas estimada por este, como sendo uma caverna com cerca de $15 \mathrm{~km}$ de extensão.

A partir de 1962, até o presente, a região iniciou a ser constantemente visitada por grupos de exploração espeleológica. Um histórico desta atividade pode ser encontrada em Marinho (1989). Estas explorações confirmaram as espectativas de Krone, revelando a existência de mais de uma centena de cavernas. A caverna do rio Roncador, atualmente denominada de caverna Santana, mostrou ser ưm đos treçhos àcešsíveis mais exteñ̄̃os dos sistemas de drenagem subterrânea da região. Os resultados iniciais desta exploração sistemática de cavernas, foram publicados por Le Bret (1966), constituindo-se ainda hoje, uma das mais detalhadas e completas descrições de cavernas desta região.

Uma grande quantidade de dados relativos à localização e topografia de cavernas tem sido acumulada sobre a região. Este acervo está parcialmente disponível nos arquivos da Sociedade Brasileira de Espeleologia. Segundo o cadastro de cavernas desta sociedade (Martim, Chrysotomo e Rodrigues, 1989), os terrenos cársticos delimitados pelos municípios de Apiaí, Iporanga e Guapiara (fig 1.1), abrigam cerca de $80 \mathrm{~km}$ de cavernas, parcialmente exploradas e topografadas.

Segundo a regionalização de áreas cársticas apresentada por Karmann e Sánchez (1986), o alto vale do Ribeira, apresenta um dos maiores graus de conhecimento disponível, quanto à presença e distribuição de cavernas, em comparação com as demais regiões carbonáticas do Brasil.

Como estratégia do presente estudo, selecionou-se portanto, o Alto Ribeira, dentre as várias regiões cársticas do Brasil, pois desta se dispunha de um conhecimento prévio maior, a respeito da distribuição e das características físicas principais de sistemas de drenagem subterrânea, associados a um relevo característico e variado de terrenos cársticos, até o presente, não estudados, do ponto de vista geológico.

Como um dos objetivos desta tese era o monitoramento hidrológico de um sistema de cavernas, o que exigiu visitas a campo, no mínimo mensais, durante 18 meses, a facilidade de acesso associada a uma situação apropriada para monitoramento, foram fatores fundamentais na demarcação da área de estudo, indicada na figura 1.1 .

Outro fator importante na escolha da área de estudo foi o fato da bacia hidrográfica monitorada se encontrar numa área de preservação ambiental (Parque Estadual Turístico do Alto Ribeira), pois desta maneira, teve-se a oportunidade, de analisar a dinâmica hidroquímica original desta bacia, sem efeitos antrópicos superpostos.

Selecionou-se, portanto, a bacia hidrográfica do rio Roncador para o monitoramento hidrológico e hidroquímico, pois a mesma, possui somente uma ressurgência (fator 


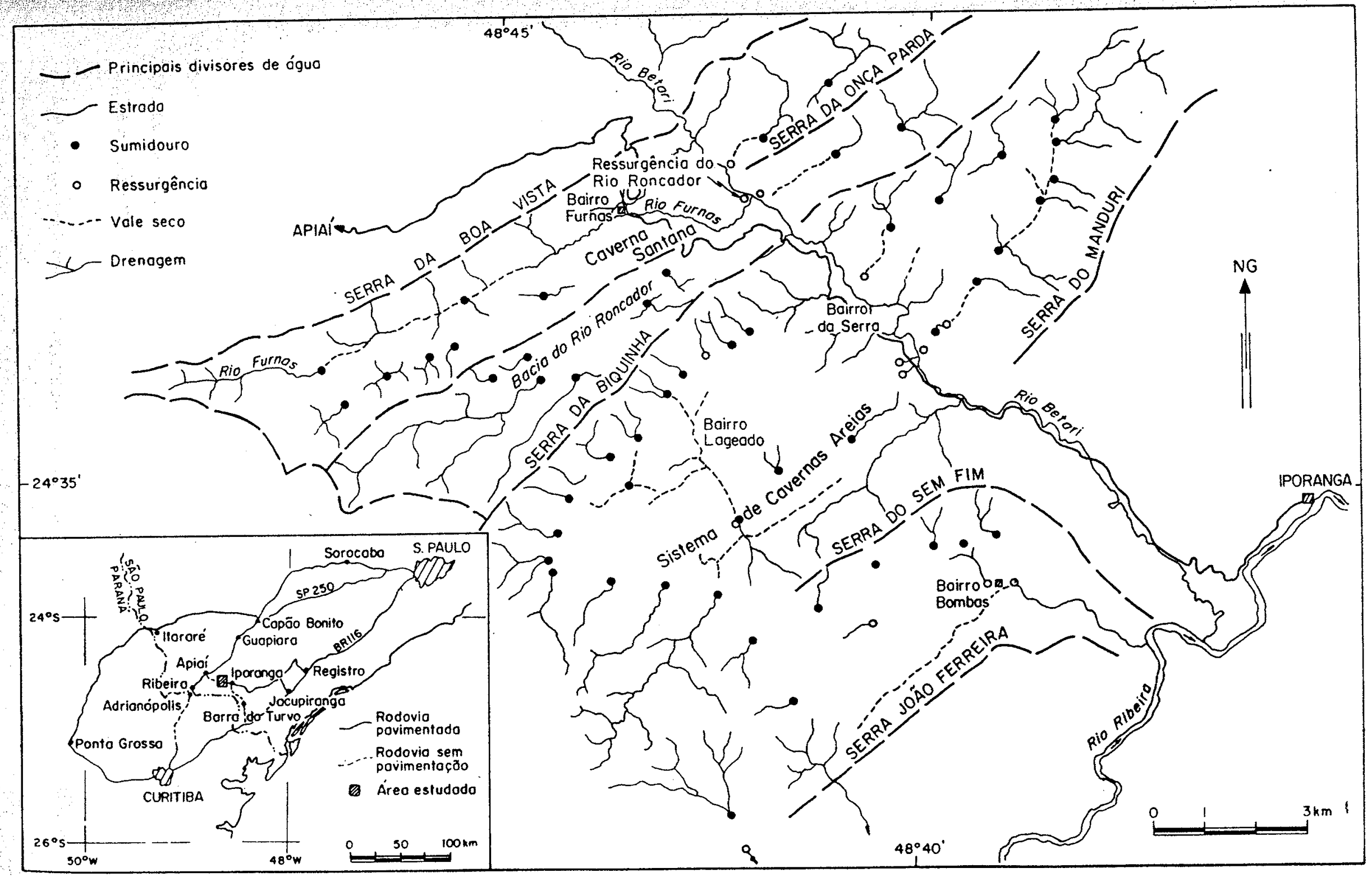

Figura 1.1 - Localização, acesso e demarcação da área estudada. Os terrenos cársticos delimitam-se pelos sumidouros. 
esssencial para o estudo), sendo de fácil acesso (fig 1.1). Para a análise de relevo e de sistemas de cavernas, optou-se pelo corpo calcário associado à bącia do rio Roncador e a sinforma calcária encaixante do sistema de cavernas Areias. Esta duas áreas calcárias, constituem uma amostra representativa, da diversidade morfológica do carste superficial e subterrâneo do Alto Ribeira.

\subsection{Objetivos da pesquisa e organização da tese}

Os objetivos deste trabalho, consistiram em pesquisar os aspectos abaixo, sobre uma área tipo, de carste subtropical úmido:

- Identificar, descrever, estabelecer parâmetros morfométricos e determinar os fatores condicionantes (estruturais e hidráulicos) das formas de relevo cárstico. Com estas informações, esboçar a gênese destas formas (tema do capítulo 3).

- Obter um quadro da distribuição, identificar os padrões morfológicos e determinar os fatores condicionantes desta distribuição e morfologia de sistemas de cavernas. Integrar estes dados num modelo espeleogenético da área, obtendo uma história evolutiva do desenvolvimento de sistemas de circulação cárstica, da área estudada, propondo uma cronologia deste processo. Através da elaboração do modelo espeleogenético, contribuir na previsibilidade da ocorrência de sistemas de cavernas, tornando estes estudos aplicáveis em planos de uso e ocupação de áreas cársticas.

- Associar a evolução de sistemas de cavernas com o desenvolvimento da paisagem superficial e, através da obtenção da taxa de entalhamento fluvial subterrâneo, estimar a idade do relevo associado ao sistema cárstico.

- Determinar os parâmetros hidrológicos e hidroquímicos atuais de uma bacia hidrográfica cárstica, representativa da região do Alto Ribeira. Com estas informações, esboçar o mecanismo de corrosão atuante no sistema e estimar a taxa de denudação química desta bacia.

Como objetivo geral deste trabalho, pretendeu-se adaptar e desenvolver, os métodò atuais utilizados em estudos geológicos e hidrológicos de sistemas cársticos, prática ainda pouco usual no campo geocientífico nacional.

\subsection{Métodos e técnicas}

Os métodos e técnicas utilizados neste trabalho são detalhados nos itens pertinentes. Apresenta-se, em seguida, uma listagem resumida destes.

1. Fotointerpretação de detalhe, em escala 1:25.000, das áreas demarcadas para este estudo, traçando os divisores de água e a rede de drenagem, identificando sumidouros e ressurgências, o que resultou nos mapas morfológicos destas áreas (anexos 3.3 e3.4), base para os estudos morfométricos.

2. Medição de parâmetros morfométricos seguindo as recomendações de Williams (1972a e 1972b). 
3. Identificação, em campo, das características de relevo reconhecidas na fotointerpretação.

4. Mapeamento topográfico e geológico das principais cavernas da área de estudo. Mapeou-se cerca de $15 \mathrm{~km}$ de condutos subterrâneos. Foram utilizados os métodos de topografia subterrânea e mapeamento geoespeleológico desenvolvidos com este trabalho, detalhados em Battistucci (1988), assim como, as recomendações de Thompson e Taylor (1991), para medição do espaço subterrâneo.

5. A obtenção de parâmetros hidrológicos envolveu os seguintes procedimentos: instalação de limnógrafos na ressurgência e no sumidouro principal do sistema de cavernas monitorado; medição de vazão nestes pontos, em diferentes alturas do nível do rio subterrâneo. Para medição da vazão, utilizou-se tanto um molinete fluviométrico, assim como, adaptou-se a técnica de diluição de sal, conforme a recomendação de Church e Kellerhals (1970). Executou-se o monitoramento do sistema de cavernas Santana-Pérolas pelo periodo de um ano hidrológico.

6. A obtenção de dados hidroquímicos, exigiu a coleta sistemática de amostras de água nos diferentes pontos do sistema de circulação cárstica monitorado. A coleta seguiu as recomendações expressas em Ford e Williams (1989). Os teores dos principais cátions, presentes nestas amostras, foram obtidos através de análises por absorção atômica, seguindo-se os cuidados necessários para conservação das amostras até sua análise. Os principais ânions foram analisados através de um cromatógrafo de íons.

7. Para determinar taxas de entalhamento fluvial subterrâneo, foram coletadas amostras apropriadas de calcita secundária nas cavernas, em pontos favoráveis, após o mapeamento destas. Durante a amostragem, foram tomados cuidados especiais, para não afetar a estética dos depósitos de calcita nestas cavernas. Estas amostras, foram datadas pelo método Th/U, utilizando contagem alfa. Com o objetivo de familiarizar-se com esta técnica, as amostras foram processadas pelo autor, sob orientação do Prof. Dr. Derek Ford, junto ao laboratório de geocronologia dos Departamentos de Geografia e Geologia da McMaster University. 


\section{CAPÍTULO 2 \\ FISIOGRAFIA E GEOLOGIA DA ÁREA DE ESTUDO}

\subsection{Contexto geológico regional e local da área estudada}

O sudeste paulista está inserido na Faixa Dobrada Apiaí (Hasui e Oliveira, 1984), a qual, compõe o segmento sudoeste do Cinturão Ribeira (Cordani e Brito Neves, 1982). A Faixa Apiaí caracteriza-se por um conjunto de rochas supracrustais vulcano-sedimentares, de grau metamórfico fraco a médio, denominadas genericamente de Grupo Açungui, cujo embasamento, é formado por rochas gnássico-migmatíticas, localmente charnockíticas e com intercalações metassedimentares com grau metamófico médio a alto. Este embasamento, de posição estratigráfica ainda controvertida, domina o leste paranaense, enquanto as supracrustais, ocupam predominantemente, o sudeste paulista (Campanha, 1991).

A estrutura regional é constituída por uma série de intrusões granitóides, do Proterozóico Médio a Superior, as quais, afetam tanto a seqüência supracrustal, como também o embasamento: Sobre este quadro, ressalta-se um sistema anastomosado de zonas de cisalhamento transcorrentes; verticalizadas a subhorizontais, de caráter dúctil a dúctilrúptil, de movimentação na direção NE-SW, e rejeitos quilométricos. Este sistema de cisalhamento imprime uma compartimentação da região em blocos tectônicos, cujas formas são lenticularizadas, com alongamentos maiores na direção genérica NE-SW. Esta fragmentação tectônica dificulta as correlações lito-estratigráficas entre blocos crustais distintos (Campanha, Bistrichi e Almeida, 1987 e Campanha, 1991).;

Os terrenos cársticos estudados inserem-se no Bloco Lajeado, definido por Campanha (1991). Delimita-se a sul pelo Lineamento da Figueira, e a norte pelo Lineamento Quarenta Oitavas, localmente definido pela falha do Espírito Santo (figuras 2.1 e 2.2)

Seguindo Campanha (1991), a norte do Lineamento Quarenta Oitavas ocorre o Bloco Apiaí, composto por xistos (granada micaxistos, quartzo micaxistos e micaxistos) e mármores calcíticos, localmente sulfetados. $\mathrm{O}$ autor acima propõe que estas rochas são uma extensão da Seqüência do Lajeado, em condições de metamorfismo e deformação mais intensos. A sul do Lineamento da Figueira, encontra-se o Bloco Ribeira, composto principalmente por filitos e metassiltitos laminados e rochas metabásicas, com intercalações de metaconglomerados, metarenitos e mármores.

O Bloco Lajeado é constituído pela seqüência metassedimentar de grau metamórfico baixo (zona da clorita) do Subgrupo Lajeado, incluindo no topo o Gabro de Apiaí (fig 2:2). Este subgrupo foi originalmente definido por Hasui, Cremonini e Born (1985) e redefinido por Campanha et. al. (1985).

Sua estrutura geral é formada por sinclinais e anticlinais, localmente falhados, com eixos de direção NE-SW e planos axiais subyerticais a fortemente inclinados para NW (fig 2.3), indicando vergência para SE. De acordo com Campanha (1991), o grau de deformação na zona central do Bloco, sobre o Anticlinal do Sem Fim, Sinclinal do Bairro 


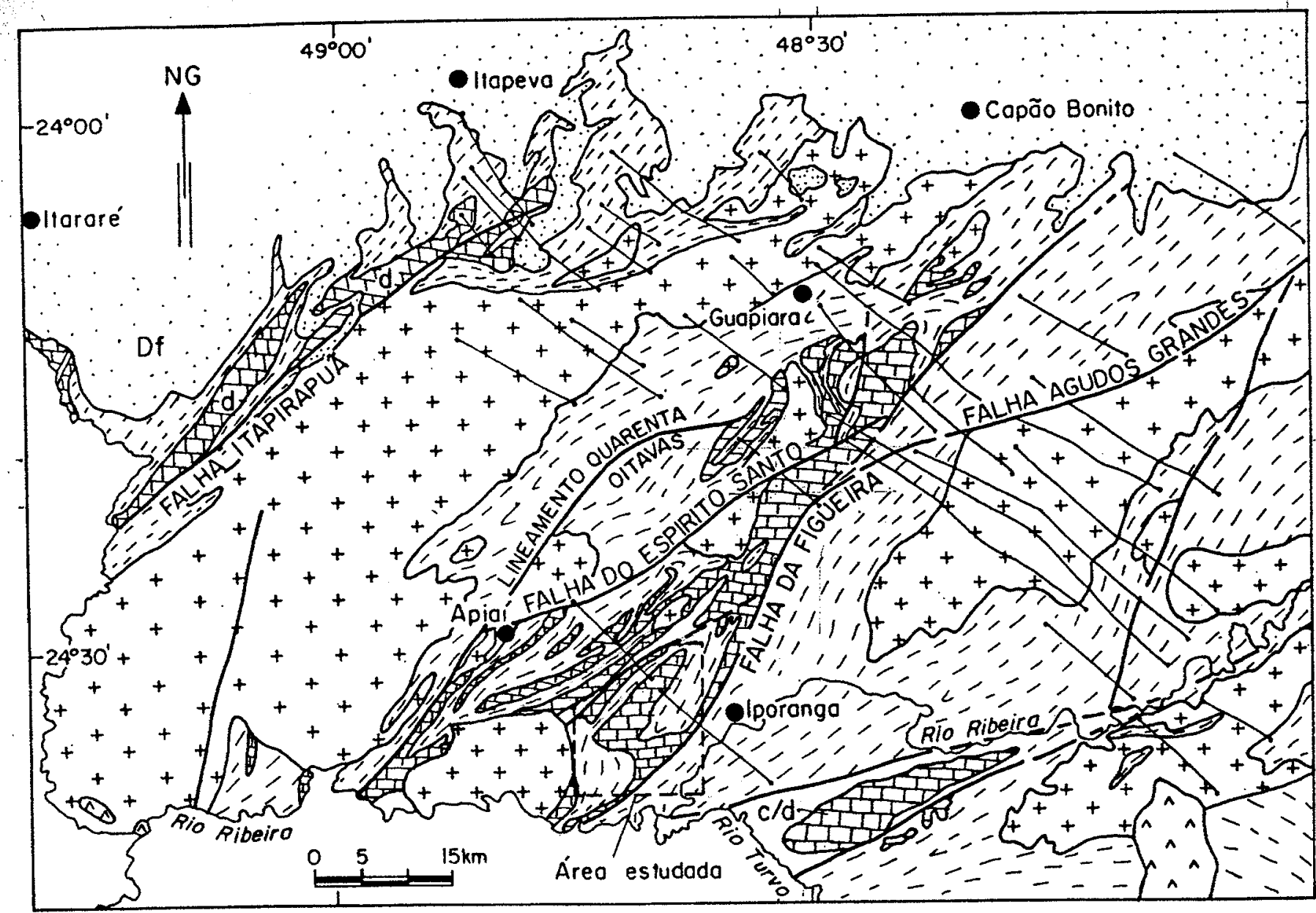

FANEROZÓICO

$\wedge \hat{n}$ Inirusões alcalinas

$>$ Diques bósicos

$\because \therefore$ Formoçäo Furnas e llaroré (Bacia do Parana)

PROTEROZÓICO MÉDIO A SUPERIOR

+++
++
sin-e postectónicas

$\infty$

Grupo Açungui (Faixo Dobrada Apiaí)

$1 / 247^{1-M e t a s s e d i m e n t o s ~ p e l i t o-p s o m i-~}$

, 位 cos e metabósicas

i1 II 2-Rochos metacorbonáticas

iv 2 -calcíticas $d$-dolomíticas

Zonas de cisalhamento

Adaplado de IPT, 1981

Figura 2.1 - Contexto geológico regional da área estudada, ressaltando a ocorrência de rochas carbonáticas. 


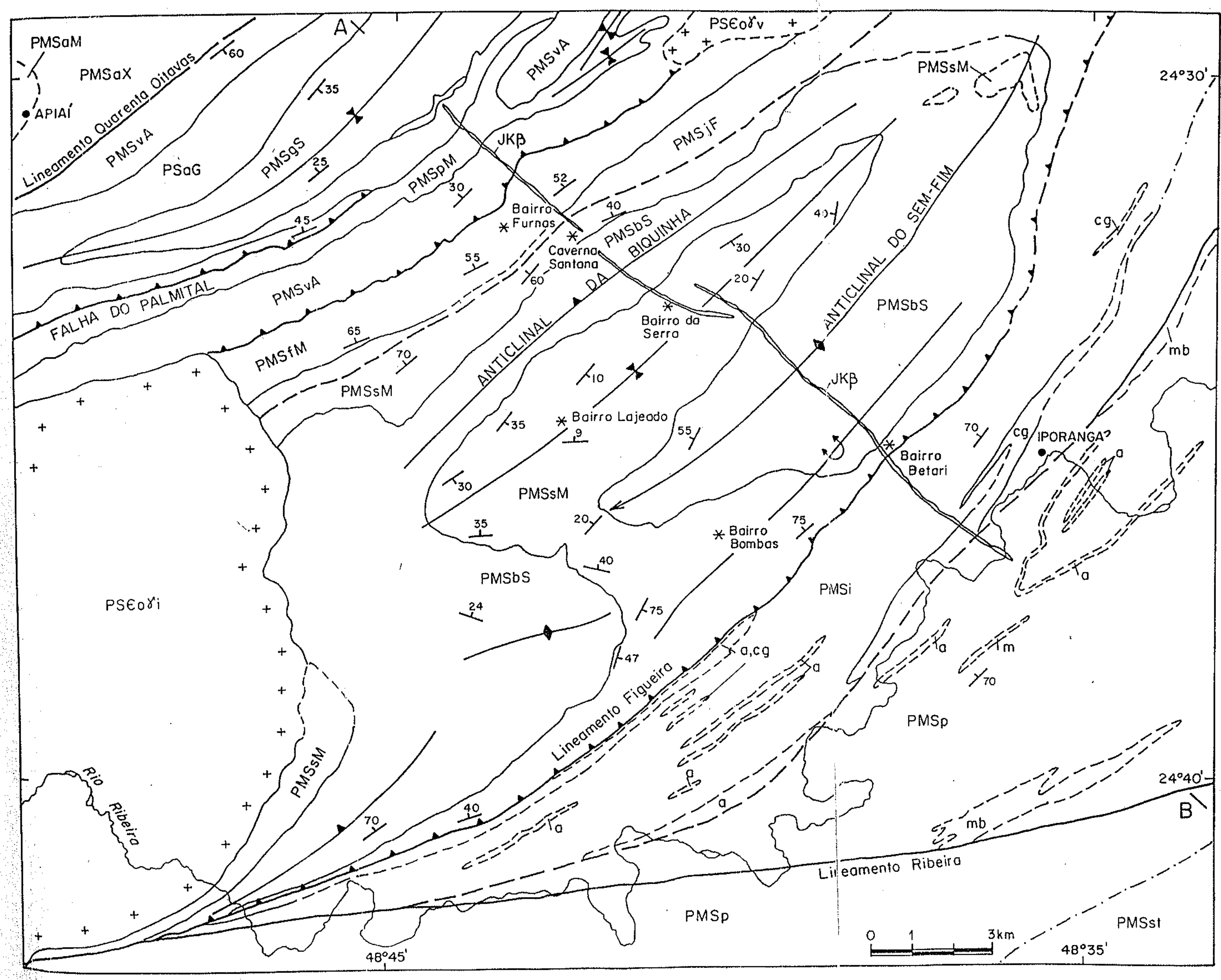

UNIDADES LITOESTRATIGRÁFICAS (Depósitos de cobertura não representados) JURÁSSICI-CRETÁCEO

JKB Diques bósicos

PROTEROZÓICO SUPERIOR A EOPALEOZÓICO

PSEOd. Granitóides pós- tectônicos i:llaóco v: Vargem Grande PPROTEROZÓICO SUPERIOR

PSoG Gabro de Apiá

PROTEROZÓICO MÉDIO A SUPERIOR

PMSa Xistos (X) e Mórmores (M) Apioí

FORMAÇÕESS LITOLOGIA

1 PMSgS Gorutuba-Metarritmitos pelito-carbonáticos

PMSPM Passa Vinte - Metocolcários dolomíticos e calcíticos

PMSvA Serra da Boa Vista-Metarenitos

PMSfM Mina de Furnas-Metacalcórios colcíticos bandados

PMS jF Água Suja - Filitos e metassiltitos

PMSSM Bairro da Serra - Metacalcários calcíticos

PMSbS Betari-Metossititos e filitos

PMSi Iporanga-Metossiltitos, metargilitos e metarenitos

PMSP Perau-Filitos, xistos verdes, metassiltitos

PMSst Setuva -Xistos, filitos e quartzitos

CONVENCẼ̃ES

- Anticlinal Anclinal
- Atitude de acamamento
- Fona de cisalhamento definida e provável

* Localidades

Adaplado de Campanha, 1991

Figura 2.2 -

Conte xto geológico local das áreas carbonáticas estudadas. 


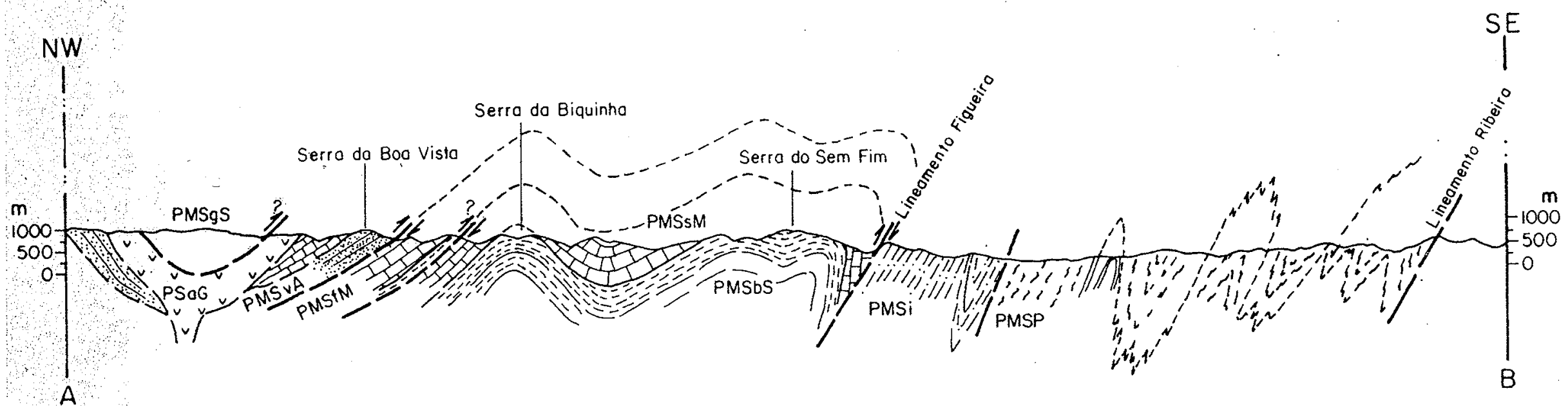

5

Figura 2.3 - Seção geológica simplificada do Subgrupo Lageado na região estudada. Adaptada de Campanha (1991). Legenda das unidades litológicas e localização da seção indicadas na figura 2.2 . 
da Serra e Anticlinal da Biquinha, é baixo, onde estruturas primárias, como gradações normais, estratificações cruzadas e onduladas, foram perfeitamente preservadas. Na faixa de influência da Zona de Cisalhamento da Figueira, a deformação é intensa, afetando parte do flanco invertido SE do Anticlinal do Sem Fim. Esta falha exibe comportamento dúctil e movimento inverso. O flanco sul do Sinclinal do Calabouço, ou flanco norte do Anticlinal da Biquinha (fig 2.2 e 2.3), caracteriza-se por deformação moderada, e uma série de cisalhamentos com movimento inverso, responsáveis por repetições tectônicas da litologia. O Sinclinal do Calabouço, no limite norte deste bloco tectônico, exibe deformação fraca, semelhante à zona central. Por último, a zona de contorno do Granito Itaóca, caracteriza-se por deformação e metamorfismo mais intensos, relacionados àquela intrusão.

Fora das zonas de influência dos cisalhamentos, o estilo de dobramento é de dobras abertas a fechadas, nos metapelitos, e abertas nos metacarbonatos e metabásicas. Predominam dobras simétricas nas zonas de charneira dos grandes anticlinais e dobras fortemente assimétricas nos flancos.

Associado ao metamorfismo fraco destas rochas, predomina a foliação plano axial do tipo clivagem ardosiana (com sericita e moscovita), freqüentemente com clivagem de crenulação superimposta, nos filitos e metassiltitos, e clivagem de fratura nos metacalcários.

- A litoestratigrafia do Subgrupo Lajeado, apreśentada abaixo, da base para o topo, segue a proposição e descrição de Campanha (1991):

Formação Betari - Esta unidade basal do Subgrupo Lajeado é constituída por dois membros. O membro basal é formado por metarenitos arcoseanos e 'micáceos, com níveis e lentes de metaconglomerados oligomíticos micáceos, com espessuras decimétricas. Estes metapsamitos passam gradativamente para o menbro superior, composto por metarritmitos síltico-arenosos e metapelitos laminados, onde se ressalta o caráter gradacional da estratificação. O contato desta formação com a unidade sobrejacente é brusco e concordante no flanco norte do Anticlinal do Sem Fim e transicional no flanco norte do Anticlinal da Biquinha. No flanco sul do Anticlinal do Sem Fim, o contato provavelmente é discordante (fig 2.2).

Formação Bairro da Serra - Esta é a unidade carbonática do Subgrupo Lajeado, com maior expressão em área, sendo formada por dois corpos distintos: a faixa carbonática homoclinal da caverna Santana, que representa o flanco norte do Anticlinal da Biquinha, e outro, de forma irregular, estruturado pelo sinclinal do Bairro da Serra, Anticlinal do Sem Fim e o flanco invertido do anticlinal do Bairro Betari (fig 2.2).

É composta por metacalcarenitos e metacalcilutitos impuros e margosos, predominantemente calcíticos e localmente dolomíticos, de coloração cinza escuro. Sua estratificação caracteriza-se pela alternância de estratos mais ou menos impuros, com freqüentes intercalações de metassiltitos carbonáticos e filitos. São marcados por pirita disseminada, assim como, concentrada em alguns dos leitos mais impuros. Estratificações cruzadas, onduladas e gradacionais são freqüentes, com textura clástica dos grãos parcialmente preservada. 
Formação Água Suja - Constitui uma faixa metapelitica intercalada provavelmente tectonicamente sobre os metacalcários da Formação Baỉro dă Serra (fig 2.2) e, em contato normal sob a Formação Mina de Furnas. Sua espessura varpàmuito, sendo provavelmente interrommpida na parte central, devido à adelgaçamento tectônêe. formada por filitos cinza escuros, com lâminas de metassiltito e filito carbonático.

Formação Mina de Furnas - É formada por metacalcarenitos cinza escuros, semelhantes à Formação Bairro da Serra. Distingue-se da faixa carbonática da caverna Santana, pela ritmicidade menor da alternância de estratos puros e impuros e camadas pelito-carbonáticas. Nas proximidades da vila residencial da Mina de Furnas, ocorre uma intercalação de filitos e metassiltitos laminados, cuja continuidade ao longo de todo pacote carbonático é controvertida.

Encontra-se sotoposta aos metarenitos da serra da Boa Vista, através de contato tectônico (fig 2.2).

Formação Serra da Boa Vista - Esta formação marca o contorno estrutural do sinclinório do Calabouço (fig 2.2). E formada por metarenitos mal selecionados, de granulação desde muito fina até grossa, localmente com niveis conglomeráticos, arenitos micáceos e arcoseanos, metassiltitos e filitos. O grau de deformação desta unidade é crescente no sentido $\mathrm{NW}$, com metarenitos quase indeformados no flanco sudeste do sinclinal, enquanto no flanco noroeste, ocorrem quartzo xistos e quartzo milonitos. Junto ao Granito Itaóca, quartzo-mica hornfels, com biotita, moscovita e andaluzita, atestam o metamorfismo de contato.

Formação Passa Vinte - Representa outra unidade carbonática, formada por metacalcários de coloração cinza escuro, cinza claro e branco, bandados. As camadas cinza escuro a claro, são predominantemente calcíticas e os estratos brancos, dolomíticos, conforme reconhecido neste trabalho.

O contato com os metarenitos Boa Vista, sotopostos, admite duas interpretações, pelo fato de apresentar intercalações decimétricas de metarenito boudinado dentro dos metacalcários. A primeira, é que este contato é concordante e gradativo, com interdigitação sinsedimentar de arenito e calcário. A segunda admite contato por cisalhamento, onde a interdigitação acima é de origem tectônica. O contato superior, com a Formação Gorutuba é através de uma zona de cisalhamento de baixo ângulo, denominado por Campanha (1991), de Falha do Palmital.

Formação Gorutuba - Caracteriza-se por metarritmitos laminados; com alternância de metassiltitos e metargilitos, além de rochas calcissilicáticas e mármores, sempre exibindo ritmicidade da estratificação. As rochas calcissilicáticas (conhecidas informalmente como gorutubitos), segundo Campanha (op. cit.), correspondem a hornfels metassomático, gerado pela intrusão do Gabro de Apiaí e do Granito Itaóca.

Gabro de Apiaí - Trata-se de uma rocha escura, isótropa, de granulação média e textura ofitica a subofitica. Sua mineralogia principal é composta de plagioclásio, augita e hiperstênio. Campanha (1991) observou um local, onde estas exibem relação de contato discordante com a Formação Gorutuba, além do generalizado metamorfismo de contato 
causado pelo gabro sobre esta formação. Segundo este mesmo autor, os gabros distinguemse dos diques de diabásio mesozóicos, somente pela presença de hiperstênio, nos primeiros.

Finalmente, convém ressaltar a opinião de Campanha (op. cit.), de que várias das unidades acima da Formação Bairro da Serra podem representar repetições tectônicas de um número menor de formações, mas que, devido à falta de critérios precisos de correlação lateral entre estas, é preferivel manter as denominações litoestratigráficas formalizadas anteriormente.

Ambiente deposicional - Os metassedimentos do Subgrupo Lajeado, devido ao seu caráter rítmico da recorrência litológica e presença de estruturas primárias, como estratificação gradacional, foram interpretados por Pires (1988 e 1989), como representantes de uma sucessão de sistemas turbidíticos, com leques submarinos, depositados na transição entre uma plataforma continental e talude, sob condições de tectônica ativa, durante o Proterozóco Médio a Superior.

Eventos Mesozóicos e Cenozóicos - A região de estudo encontra-se sobre o flanco nordeste do Arco de Ponta Grossa, o qual representa uma estrutura crustal positiva, em ascenção tectônica desde o Triássico (Asmus, 1981), ou talvez, desde o Devoniano, conforme a interpretação de Ferreira et. al. (1981). Neste processo de domeamento e sob esforços trativos, sofreu a intrusão de um grande número de diques básicos, datados do Jurássico-Cretáceo, orientados segundo a direção NW-SE (fig 2.1 e 2.2).

Durante o Cenozóico, até a atualidade, a região continuou sendo dominada pelo soerguimento e denudação, com exceção de algumas zonas, as quais sofreram subsidência e acúmulo de sedimentos, através da instalação de prováveis bacias tectônicas. Estas foram interpretadas por Melo et. al. (1990), no baixo vale do Ribeira, sobre o Alinhamento Tectônico de Guapiara, como é o caso do Gráben de Sete Barras, com sedimentos fluviais, cuja base foi atribuída preliminarmente ao Terciário Inferior.

\subsection{Situação geomorfológica da área de estudo}

1 A região estudada encontra-se sobre o flanco sudoeste da serra de Paranapiacaba, a qual, representa um relevo montanhoso, com amplitudes topográficas de até $700 \mathrm{~m}$, entre fundọs de vales e topos de cristas. Esta área serrana constitui a zona de transição entre o Planalto Atlântico, a noroeste da área de estudo, e a Baixada Costeira, a leste-sudeste, caracterizada por vastas planícies aluviais entre agrupamentos de morros arredondados.o

Na classificação geomorfológica do relevo paulista de Almeida (1964), adotada com pequenas modificaç̃̃es e algumas complementações no mapa geomorfológico do Estado de São Paulo (IPT, 1981a), esta faixa de transição entre o Planalto Atlântico e a Baixada Litorânea, constitui a Sub-Zona da Serrania do Ribeira, da Zona da Serrania Costeira da Província Geomorfológica Costeira. Neste quadro, a serra de Paranapiacaba, constitui o ramo sul da Zona da Serrania Costeira (genericamente conhecida como Serra do Mar), recuado para o interior, abrindo espaço para a vasta planície costeira, a leste da serra.

Embutidos na Serrania do Ribeira, ocorrem planaltos parcialmente dissecados, adjacentes a vales profundamente entalhados. Estas superficies foram classificadas como 
Planaltos Interiores (IPT, 1981a). As áreas carbonáticas estudadas fazem parte de um destes planaltos, denominado de Planalto do Lajeado (IPT, op. cit.). Este é cortado transversalmente pelo rio Betari, o qual representa o nível de base local deste planalto.

A Serrania do Ribeira, nos arredores da área de estudo, apresenta cristas niveladas entre 900 e 1.100 metros, alinhadas segundo a direção geral NE-SW, com encostas de declividade alta a média. As cotas mais elevadas correspondem a metarenitos e as intermediárias a metapelitos. O Planalto do Lajeado, constituído essencialmente por metacalcários, exibe topos nivelados em torno de $700 \mathrm{~m}$, tendo seus limites demarcados por sumidouros. A amplitude de relevo, entre as cristas das serras alongadas e os fundos de vales, encaixados no planalto, varia entre 690 e $450 \mathrm{~m}$.

No quadro de serras alongadas da. Serrania Costeira e do Ribeira, ressalta-se o subnivelamento dos topos de cristas de rochas mais resistentes à degradação (foto 4.6), o qual foi correlacionado por Almeida (1964) à superficie Japi, definida pelo mesmo autor, como sendo um testemunho de uma antiga superficie de aplainamento, pós-cretácea, característica do sudeste paulista.

\subsection{Hidrografia e ambiente atual}

A região estudada é drenada pela bacia hidrográfica do rio Betari, afluente da margem esquerda do rio Ribeira de Iguape, o qual, neste trecho, apresenta-se na transição entre seu alto e médio curso.

$\mathrm{O}$ rio Betari possui suas nascentes na borda do Planalto Atlântico (localmente denominado de Planalto de Guapiara), nas cotas entre 900 e $1100 \mathrm{~m}$, atingindo o rio Ribeira na cota de $80 \mathrm{~m}$, próximo à cidade de Iporanga. Pelo fato desta bacia drenar a Serrania do Ribeira, o rio Betari e seus principais afluentes, apresentam vales encaixados e perfis longitudinais de alto a médio gradiente, localmente encachoeirados. Com exceção de trechos sobre o Planalto do Lageado, este rio possui característica fortemente erosiva, com intenso entalhamento vertical. Nas áreas carbonáticas deste planalto, o rio assume baixos gradientes, com feições de agradação, evidenciadas pelos vales alargados, de fundo plano a suavemente ondulado, preenchidos por alúvios e colúvios.

O segmento principal do rio Betari apresenta um padrão retilíneo, segundo a direção NW-SE, com seus afluentes principais ortogonais a esta direção, formando um padrão de drenagem geral do tipo treliça.

A bacia do rio Ribeira de Iguape, localiza-se inteiramente no domínio do sistema climático sub-tropical, mais precisamente, na zona de transição entre os domínios do ar tropical e das invasões dos fluxos polares, com variações anuais de temperaturas médias mínimas e máximas, controladas principalmente pela altitude e, secundariamente, pela latitude (Monteiro, 1969 e Gutjahr, 1993).

De uma forma genérica, o clima do vale do Ribeira é classificado como sub-tropical úmido (Gutjahr, op cit.). 
A região de Apiaí, borda do Planalto de Guapiara, apresenta pluviosidade média anual de $1480 \mathrm{~mm}$ (média dos últimos 32 anos), com máxima anual de $2200 \mathrm{~mm}$ e mínima de $980 \mathrm{~mm}$, neste período. A temperatura média é de $18^{\circ} \mathrm{C}$ (DAEE, 1991).

O Bairro da Serra (área de estudo), inserido na Serrania do Ribeira, transição Planalto-Baixada Costeira, apresenta pluviosidade média dos últimos 19 anos de $1604 \mathrm{~mm}$, com máxima anual de 1860 e mínima de $1069 \mathrm{~mm}$, registradas neste período. O trimestre menos chuvoso concentra-se nos meses de junho, julho e agosto e o mais úmido em janeiro, fevereiro, março. A temperatura média anual é de $20^{\circ} \mathrm{C}$, com média mínima de $14^{\circ} \mathrm{C}$ e máxima de $27^{\circ} \mathrm{C}$ (DAEE, 1992).

A região do baixo vale do Ribeira, em contraste com as áreas serranas interioranas, possui pluviosidade média entre 2000 e $3000 \mathrm{~mm} /$ ano, conforme a altitude (zona da Baixada Costeira ou altos da Serra do Mar), com temperaturas médias mínimas e máximas de 20 e $27^{\circ} \mathrm{C}$.

A pluviosidade e umidade elevadas são bem distribuídas durante o ano, mantendo uma cobertura vegetal densa, popularmente conhecida como Mata Atlântica, típica ao longo de toda bacia do Ribeira, e ainda parcialmente preservada nas áreas serranas. A região estudada encontra-se no domínio da Floresta Sub-Tropical Úmida, característica da Serrania do Ribeira e Baixada Costeira. Esta mata perenifolia higrófila, é substituída em direção ao planalto Atlântico, a partir da Serrania Costeira, pelo domínio da Floresta Subtropical Subcaducifolia, marcada pela presença do Pinheiro do Paraná (Araucaria angustifolia).

Os terrenos cársticos estudados, assim como grande parte das áreas de captação dos sistemas de cavernas investigados, encontram-se nos limites do Parque Estadual do Alto Ribeira (PETAR), unidade de conservação criada por Decreto Estadual em 1958, com o objetivo de preservar uma amostra significativa do meio biótico e fisico da Serrania do Ribeira (Karmann, 1983 e Sánchez, 1984).

\subsection{As rochas carbonáticas do Alto Ribeira}

A região sudeste do Estado de São Paulo, apresenta três faixas de rochas carbonáticas, inseridas na seqüência metassedimentar supracrustal da Faixa de Dobramento Apiaí, esboçada no item 2.1.

Cruzando a Faixa Apiai (fig 2.1), partindo do noroeste em direção sudeste, identifica-se as faixas carbonáticas associadas ao Grupo Itaiacoca (Souza, 1990), ao Subgrupo Lajeado e à Seqüência Serra das Andorinhas (Campanha, et. al., 1985).

A faixa carbonática Itaiacoca limita-se a noroeste pela cobertura sedimentar da Bacia do Paraná e a sudeste pelo Lineamento Itapirapuã (fig 2.1). As rochas carbonáticas do Grupo Itaiacoca são predominantemente metadolomitos maciços e secundariamente metadolomitos calcários laminados (fig 2.4), Souza (1990), com intercalações locais de metacalcários magnesianos. Nas proximidades da zona de cisalhamento Itapirapuã, exibem intensa recristalização, com texturas de mármore. Nas porções internas, esta recristalização 
é fraca, o que possibilitou a preservação de um variado conjunto de estruturas sedimentares primárias.

A superficie cárstica é predominantemente rebaixada em relação às rochas menos solúveis adjacentes, caracterizando um carste alogênico. Numa classificação preliminar, a paisagem desta área carbonática enquadra-se na categoria de carste alogênico, em grande parte coberto com "ilhas" de carste poligonal e cones cársticos desenvolvidos, e zonas de fluviocarste. A cobertura é formada tanto por restos de arenitos devonianos, como por sedimentos detríticos, colúvio-aluvionares, provavelmente terciários (Souza, 1990). A presença da cobertura devoniana, sobre uma superficie préviamente carstificada, indica um caráter paleocárstico desta paisagem. Apesar do escasso sistema de drenagem superficial, e importantes sumidouros, o aqüifero cárstico apresenta sistemas de cavernas acessíveis pouco desenvolvidos (ou talvez desconhecidos), ponto interessante a ser esclarecido através de pesquisas futuras.

A faixa carbonática Lajeado, da qual uma área de amostragem é tema do presente trabalho, representa o alinhamento NE-SW de rochas carbonáticas situadas na parte central da Faixa Dobrada Apiaí (fig 2.1). Limita-se, a noroeste, pelo Lineamento Quarenta Oitavas e, à sudeste, pelo Lineamento da Figueira. Esta faixa carbonática é composta por metacalcários dolomíticos, metacalcários magnesianos e metacalcários (fig 2.4). Caracterizam-se por fraca recristalização, estruturas primárias de fluxo turbidítico preservadas e estratificação plano-paralela rítmica, marcada pela alternância de estratos carbonato-pelítcos e puramente carbonáticos, além de freqüentes intercalações pelíticocarbonáticas, de espessura decimétrica.

A superficie carbonática é rebaixada em relação às rochas não carbonáticas, condicionando importante injeção alogênica no sistema cárstico. A paisagem cárstica apresenta-se bem desenvolvida, com variadas formas de carste poligonal e trechos fluviocársticos. O aqüífero cárstico possui importante entalhamento subterrâneo, com sistemas integrados de cavernas acessíveis, conforme será detalhado ao longo deste trabalho.

A faixa carbonática André Lopes, localizada na região sudeste da Faixa Apiaí (fig 2.1), pertence à Seqüência metassedimentar Serra das Andorinhas, do Complexo Setuva (Campanha et. al., 1985). Estas rochas carbonáticas foram denominadas de André Lopes devido ao fato destas formarem a serra homônima, importante acidente topográfico da área. Predominam metadolomitos calcários e secundariamente metacalcários dolomíticos (fig 2.4), com recristalização moderada a intensa, devido ao metamorfismo de grau médio (Campanha, op. cit.). São principalmente maciços, sem estruturas reliquiares preservadas.

Distingue-se das demais faixas carbonáticas descritas, justamente pelo fato de constituir um relevo positivo em relação às rochas metapelíticas encaixantes, o que torna o sistema cárstico, desta faixa, de natureza principalmente autogênica, o que é uma exceção na região descrita. Pouco se conhece da distribuição de sistemas de cavernas e das características morfológicas e geológicas do aqüífero associado, apesar, desta área abrigar 
uma das cavernas turísticas mais conhecidas do Estado de São Paulo (cav. da Tapagem, ou do Diabo, denominação turística da mesma).

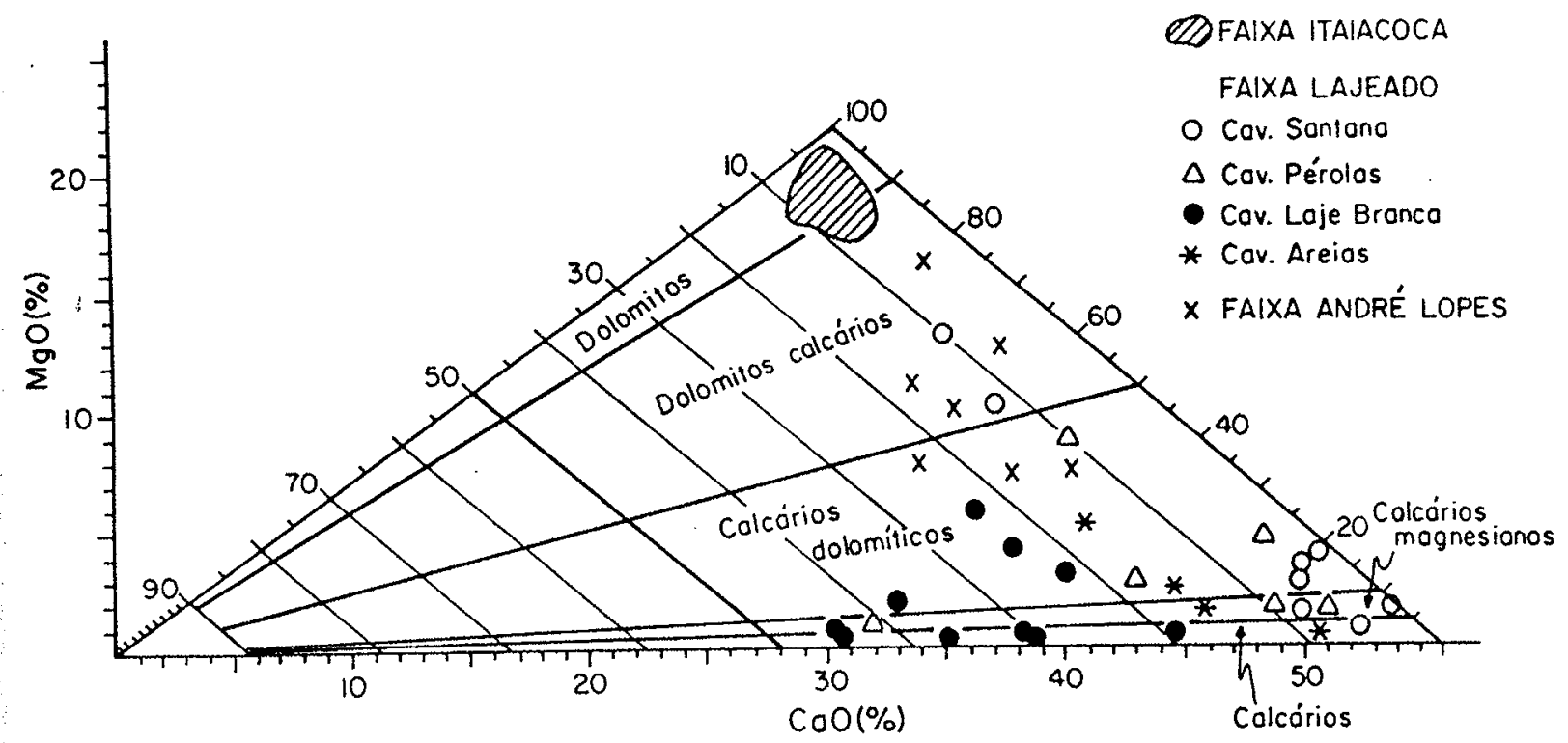

Figura 2.4 - Classificação química das rochas carbonáticas do sudeste paulista, com base no diagrama de Martinet e Sougy (1961). Análises químicas de $\mathrm{CaO}$ e $\mathrm{MgO}$ obtidas em: Souza (1990), faixa carbonática Itaiacoca; Barbieri (1993), faixa carbonática Lajeado e MMAJ/JCA (1983), faixa carbonática André Lopes. 


\section{CAPÍTULO 3 \\ DRENAGEM SUPERFICIAL E FORMAS DE RELEVO DO CARSTE DO ALTO RIBEIRA}

\subsection{Arcabouço geológico e aspectos gerais da morfologia cárstica}

Duas áreas carbonáticas foram selecionadas na região do Alto Ribeira, sobre as quais, procedeu-se um estudo morfológico da rede de drenagem e das formas de relevo. Esta seleção baseou-se na área exposta de rochas carbonáticas, sua estrutura geológica (estilo e grau de deformação e fraturamento), presença de sistemas de cavernas mapeados e a variedade de feições cársticas, tanto em superficie como em subsuperficie. Com isto em mente, considera-se que as áreas carbonáticas, denominadas aqui de Furnas-Santana e Lajeado-Bombas (fig 3.1), compreendem uma amostra representativa da morfologia do carste do Alto Ribeira

\section{Área carbonática Furnas-Santana}

Esta área carbonática forma uma faixa metassedimentar de direção NE-SW, representando uma estrutura geral homoclinal, com direção NE do acamamento $\mathrm{e}$ mergulhos moderados a altos para NW. Dobras menores, métricas a decamétricas, assimétricas, caracterizam esta estrutura com vergência para sudeste. Estes metacalcários exibem uma alternância rítmica de estratos carbonáticos e pelíticos, onde os primeiros possuem espessura entre alguns centímetros até 2 a 3 metros (foto 3.1).

Estruturas primárias, como estratificações cruzadas, gradacionais e onduladas, estão preservadas em função da fraca recristalização dos grãos carbonáticos, associada a um metamorfismo incipiente. Estas rochas são classificadas como calcilutitos impuros e calcarenitos finos a médios. A fração insolúvel, formada por argilo-minerais e micas finas (sericita e moscovita) atinge ate $20 \%$ em alguns estratos carbonáticos. Os estratos pelíticos possuem espessura bastante variável, entre alguns milímetros a $30 \mathrm{~cm}$, contendo até $20 \%$ de grãos calcíticos. Constituem metassiltitos e filitos carbonáticos, com níveis arenosos. A espessura total desta unidade, incluindo a intercalação metapelítica maior, atinge $600 \mathrm{~m}$.

Ao longo do contato noroeste, uma importante falha inversa proterozóica colocou os metarenitos da Serra da Boa Vista sobre os metacalcários (Campanha, 1991). O limite sudeste da faixa carbonática é um contato normal com rochas metapelíticas e psamíticas, as quais mergulham sob os calcários. Na direção sudoeste, os carbonatos são limitados por uma intrusão granítica de idade proterozóica superior (fig 2.2).

Três expressivos conjuntos de fraturas, com direções gerais N, NE e NW foram mapeados ao longo dos metacalcários, como também observados em fotografias aéreas (anexo 3.1 ) As fraturas $\mathrm{NE}$ e $\mathrm{N}$ são atribuídas ao evento compressivo proterozóico responsável pelo dobramento e falhamento inverso, acima citado. $\mathrm{O}$ conjunto $\mathrm{NW}$ é associado ao soerguimento e arqueamento crustal jurássico-cretácico, responsável pela intrusão de diques basálticos (Campanha, 1991 e Melo, 1990).

As rochas metacarbonáticas Furnas-Santana formam uma faixa topograficamente deprimida, com area de exposição em planta de $27,5 \mathrm{~km}^{2}$, sendo cortada pelo rio Betari, o qual representa a única saída do escoamento superficial desta área. Com uma vazão média 


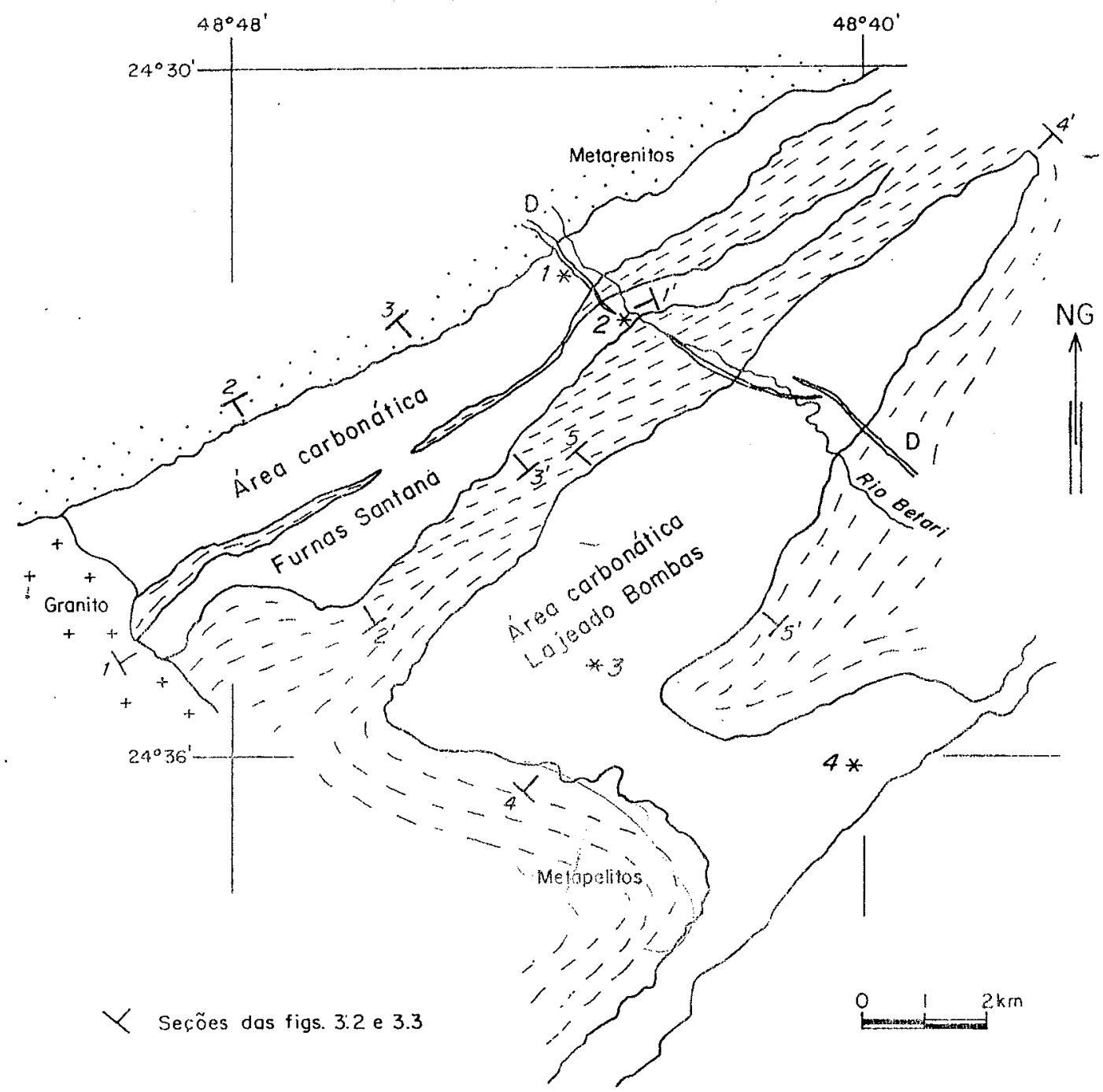

Figura 3.1 - Delimitação e denominação das áreas carbonáticas estudadas. *1- Bairro Furnas, *2- Caverna Santana, *3- Bairro Lajeado, *4- Bairro Bombas.

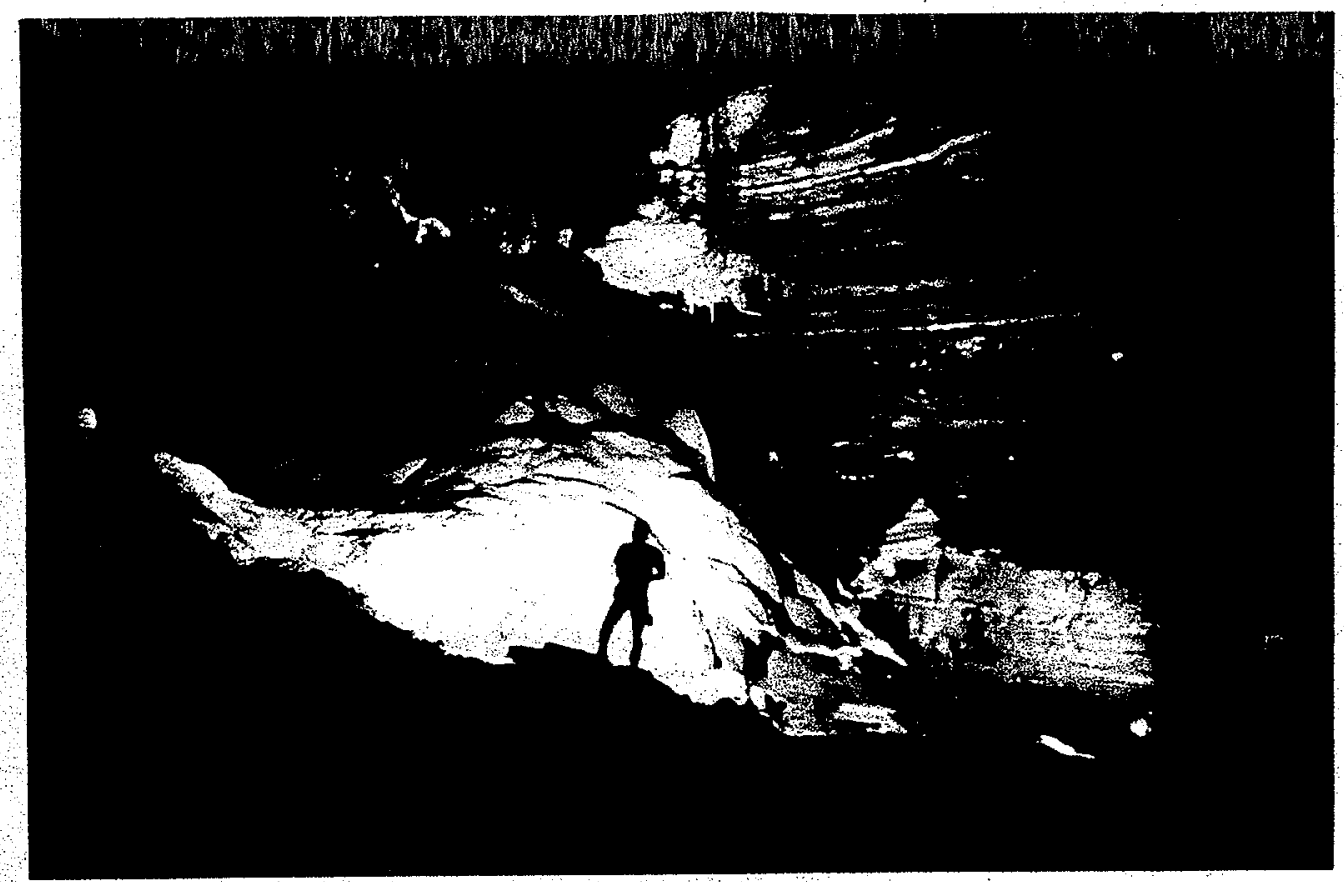

Foto 3.1 - Estratificação rímica de camadas carbonáticas, pelítico-carbonáticas e pelíticas, típicas da área Furnas-Santana Vista da parede lateral da galeria principal da caverna Laje Branca. 
de cerca de $2 \mathrm{~m}^{3} / \mathrm{s}$, o vale do Betari foi entalhado principalmente sobre fraturas NW, correndo ortogonalmente à estratificação, sem desenvolvimento de cavernas ou condutos. Ao contrário, o intenso entalhamento fluvial interceptou os carbonatos e seus condutos subterrâneos orientados a NE-SW, formando uma série de nascentes cársticas alinhadas, que representam os principais tributários do rio Betari, ao longo dos calcários. $\mathrm{O}$ entalhamento da direção NW produziu um vale com escarpas escalonadas e encostas de alto ângulo, que chegam a somar desníveis totais de até $80 \mathrm{~m}$.
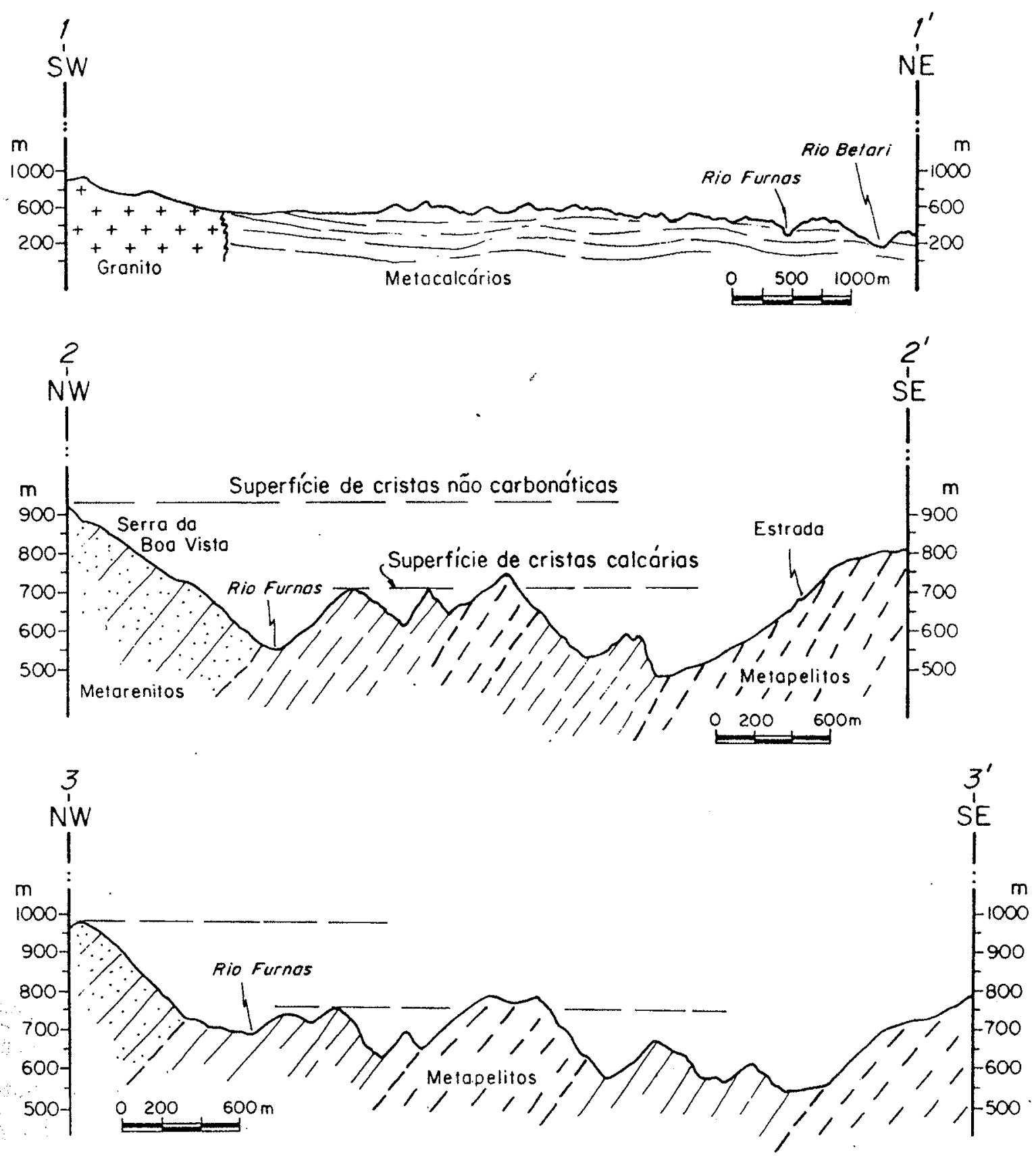

Figura 3.2 - Seções da área Furnas-Santana. 1-1', seção longitudinal, sem exagero vertical. 2-2' e 3-3', seções transversais, com exagero vertical de $2 \times$ Localização indicada na fig 3.1 
A partir de uma altitude de 600 a $630 \mathrm{~m}$ s.n.m. no contato sudoeste, junto aos granitos, e de $650 \mathrm{~m}$ ao longo da borda nordeste, a superficie geral dos topos de cristas dos calcários mergulha centripetamente para o vale do Betari, para a cota de 260 a $280 \mathrm{~m}$. Esta superficie geral de cristas possui inclinação paralela ao traço do acamamento, mergulhando de $3^{\circ}$ a $4^{\circ}$ no setor sudoeste (seção $1-1^{\prime}$, fig 3.2 ) e $5^{\circ}$ a $6^{\circ}$ no trecho nordeste, em direção ao Betari. As cristas e picos carbonáticos atingem entre 650 e $750 \mathrm{~m}$ de altitude, contrastando com os altos de 900 e $1000 \mathrm{~m}$ das rochas insolúveis adjacentes (fig 3.2).

Devido à presença de vales fluviais ativos sobre o calcário e injeção significativa de rios alogênicos, esta paisagem pode ser classificada como sendo um fluviocarste, parcialmente segmentado, seguindo a definição de Jennings (1985) e White (1988). Esta segmentação parcial da rede de drenagem superficial, resultando num alinhamento de depressões fechadas compostas (seguindo a definição de Day, 1976) ocorre na faixa noroeste da área Furnas-Santana, assim como, ao longo da faixa sudeste, mas com uma segmentação mais avançada, vales fluviais pouco preservados, depressões fechadas menores e um grande número de dolinas de colapso e sumidouros. Ao longo do contato litológico, praticamente toda drenagem alogênica é absorvida por vales cegos, às vezes com grandes pórticos de cavernas e paredões rochosos (foto 3.2). Planícies cársticas e poljes de contato caracterizam tanto as extremidades nordeste e sudoeste desta área. Sistemas de drenagem subterrânea, com cavernas verticais e horizontais estão bem desenvolvidos, comforme será mostrado no capítulo 4.

A morfologia geral dos morros e morrotes é de cones cársticos assimétricos, estruturalmente condicionados, alinhados pela direção do acamamento e truncados por juntas transversais (foto 3.3). Corredores cársticos são freqüentes entre estes cones, assim como, às, vezes, sobre estes, refletindo um alargamento e entalhamento de fraturas por dissolução.

Finalmente, uma característica importante desta área, é a superficie extremamente irregular dos calcários, os quais afloram pouco, devido à exuberante cobertura vegetal associada a um manto espesso de solo residual.

\section{Área carbonática Lajeado-Bombas}

Com no mínimo $47 \mathrm{~km}^{2}$ (em mapa) de rochas carbonáticas continuamente expostas, esta é uma das maiores áreas carbonáticas do carste do alto Ribeira (fig 2.1). Esta região consiste predominantemente de metacalcarenitos cinza escuros, de granulação fina a grossa, com estratos maciços, de espessura entre alguns decímetros a $5 \mathrm{~m}$. Intercalações de metacalcarenitos impuros, argilosos e micáceos, assim como de metassiltitos puros e carbonáticos, além de filitos carbonáticos são freqüentes. A espessura destas intercalações é da ordem de 10 a $40 \mathrm{~cm}$. A litologia predominante desta área, com exceção da característica maciça e espessura maior dos estratos calcários, é muito semelhante à seqüência carbonática da região Furnas-Santana.

Dois domínios estruturais são identificados nesta área (anexo 3.2). O primeiro é representado por um sinclinal, ligeiramente assimétrico, com direção geral NE-SW do acamamento e mergulhos entre 10 e $50^{\circ}$ para SE e NW Seus flancos possuem dobras 


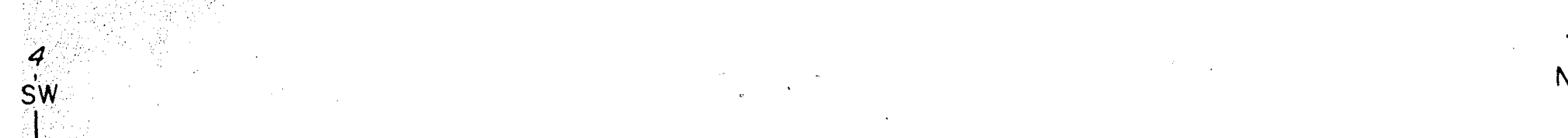

,

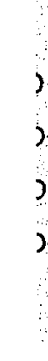

Superfície de cristas não carbonáticas

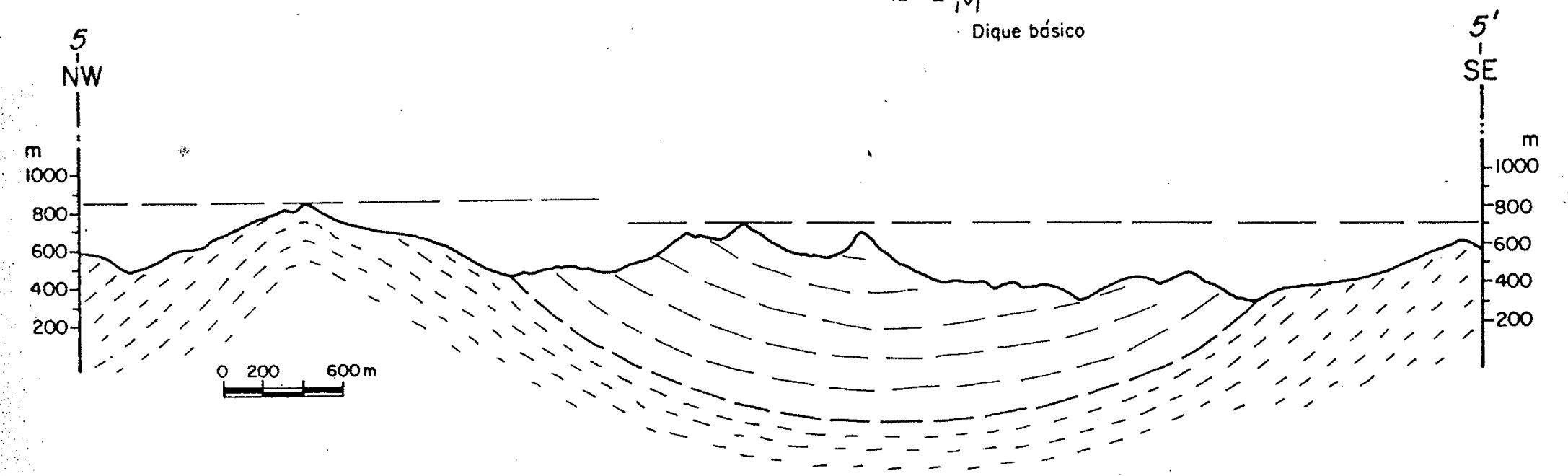

Figura 3.3 - Seções da área Lajeado-Bombas. 4-4'- seção longitudinal, sem exagero vertical. 5-5'- seção transversal com $2 \times$ de exagero vertical. Localização das seções indicada na fig 3.1 


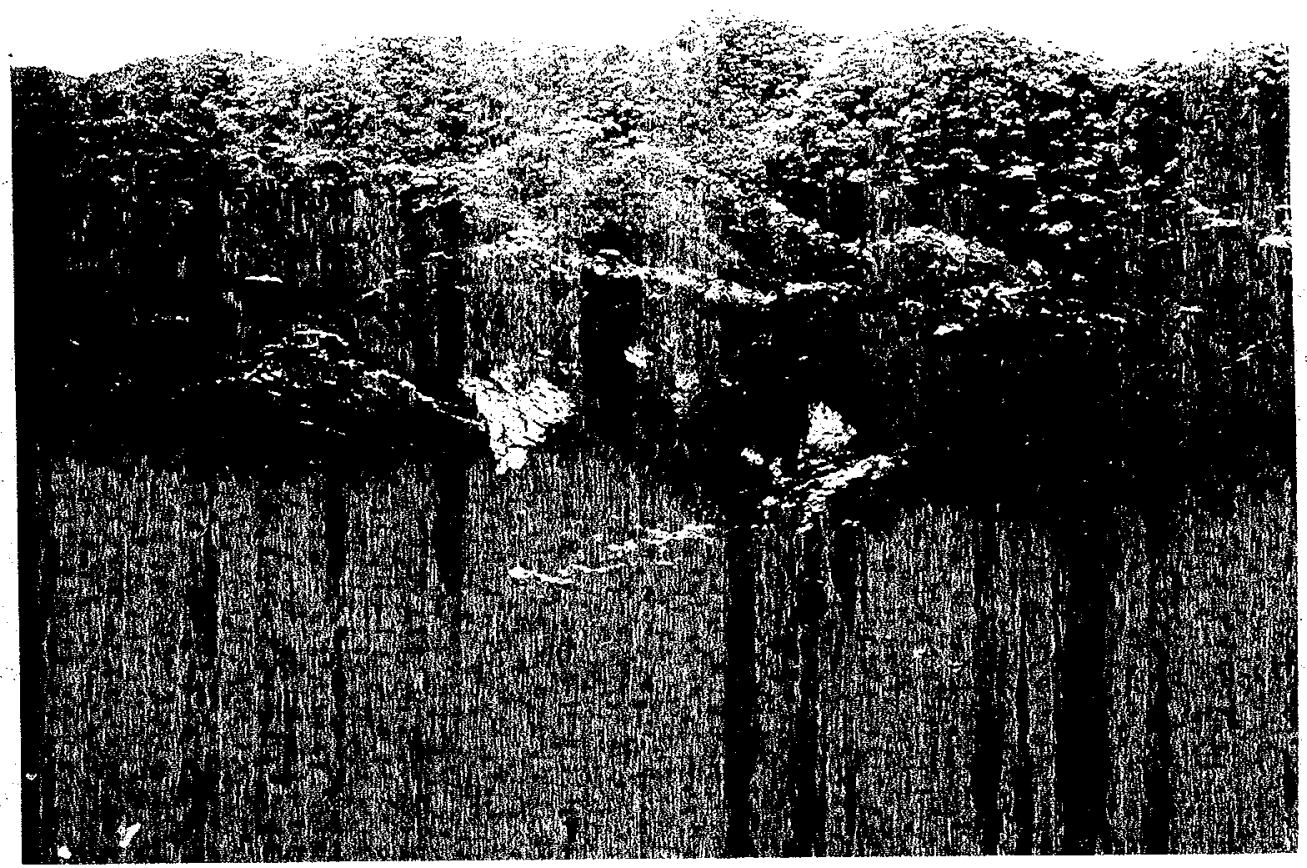

Foto 3.2 - Paredões calcários associados a vales cegos, característicos do contato entre metapelitos e metacalcários. Vale cego da caveraa Laje Branca, contato SE da área FurnasSantana.

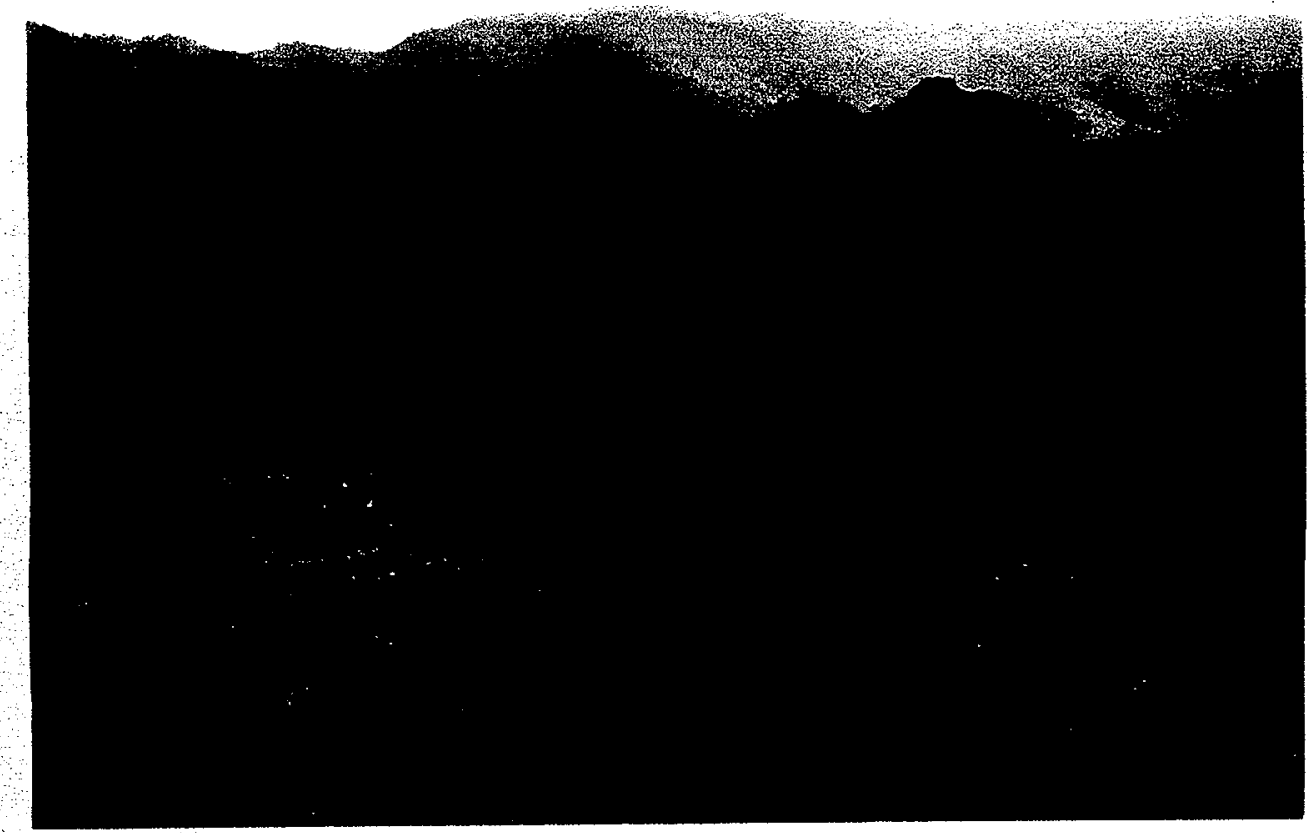

Foto 3.3 - Exemplo de cone cárstico. Área Furnas-Santana, vista da estrada Apiaí Iporanga, do mirante da serra da Boa Vista. 
menores abertas, que ondulam a superficie do acamamento. O flanco sudeste deste sinclinal passa para uma estrutura homoclinal, com direções paralelas, porém com mergulhos altos, de até $80^{\circ}$, dominantemente para NW. Este setor homoclinal perfaz o segundo domínio estrutural, interpretado por Campanha (1991) como sendo um anticlinal com flanco SE invertido junto a um importante falhamento reverso (falha da Figueira). Juntas e falhas subverticais são freqüentes, com direções predominantes N20-30E, N50-70E e N60-70W (anexo 3.2).

Esta área carbonática, quando comparada com a região Furnas-Santana, distingue-se desta, por exibir um relevo mais homogêneo e um padrão de depressões poligonais mais desenvolvido, conforme será detalhado adiante. Circundada por metapelitos e metapsamitos finos, a água de injeção alogênica nasce em cotas de 800 a $900 \mathrm{~m}$, atingindo os calcários entre 450 a 500 m.s.n.m. (fig 3.3). Com exceção do rio Betari, toda água coletada sobre $37,14 \mathrm{~km}^{2}$ de rochas insolúveis é injetada nos metacarbonatos, o que condiciona formas de absorção de água alogênica, como poljes de contato, grandes vales cegos e sumidouros, ao longo do contato litológico. O rio Betari, ao contrário, cruza os carbonatos formando um vale tipicamente fluvial, representando o nível de base local relativo à drenagem subterrânea. De modo similar à área Furnas Santana, a drenagem superficial sobre os calcários denota uma paleodrenagem fluviocárstica, mas com um grau de segmentação mais alto. Vales secos, hoje pouco ativos, mas com testemunhos de depósitos fluviais, encontram-se interrompidos por sumidouros. A paleodrenagem pode ser parcialmente traçada, seguindo o alinhamento de depressões fechadas. Muito pouco escoamento superficial ocorre presentemente. Pequenos córregos autogênicos seguem somente algumas dezenas de metros em superficie, pois são rapidamente absorvidos por sumidouros. Alguns destes dão acesso à cavernas verticais com desníveis de até $80 \mathrm{~m}$.

A morfologia geral da superficie carbonática é de morros arredondados, com encostas suavemente convexas e fortemente inclinadas. Apresentam freqüente alongamento maior em direções preferenciais (NE e NW) paralelas à juntas ou traços de acamamento, formando cristas. Entre estes altos ocorrem vales, de contorno muito irregular, representando o fundo de depressões fechadas poligonais. Estes vales, quando colmatados por depósitos residuais (colúvios), possuem fundos planos ou ondulados com dolinas de subsidência (foto 3.4). Exposições da rocha limitam-se à encostas subverticais, onde formam escarpas rochosas. Estas ocorrem principalmente ao longo das bordas de poljes de contato, vales cegos e corredores cársticos. Quando exposta, a superficie calcária é entalhada com caneluras de dissolução (rillenkarren), abertas ao longo de fraturas e planos de acamamento.

Ainda em contraste com a região anterior, esta possui menor incidência de estruturas de colapso.

\subsection{Zoneamento morfológico das áreas de amostragem}

Com o objetivo de avaliar a distribuição espacial das formas de relevo, suas propriedades planimétricas e relação com $o$ sistema de drenagem, foi realizada a 
fotointerpretação detalhada em escala 1:25.000 da região em estudo. Atenção especial foi dada, sob magnificação, ao traçado dos divisores topográficos, sumidouros e canais de drenagem ativos e inativos. O método de Williams (1972a e 1972b) foi parcialmente seguido.

Com base nos mapas morfológicos obtidos (anexos 3.3 e 3.4), observações de campo e cartas topográficas 1:10.000, as seguintes zonas morfológicas foram individualizadas (anexo 3.5);

\subsubsection{Zona fluvial}

A paisagem sobre calcários, modelada principalmente pela água de escoamento superficial e processos fluviais normais, é classificada aqui, como sendo uma zona fluvial, o que sobre rochas carbonáticas extensivas, constitui exceção. O vale do Betari, cruzando as áreas carbonáticas Furnas-Santana e Lajeado-Bombas, como também, parte do vale do rio Furnas, são os principais exemplos (anexos 3.3, 3.4 e 3.5).

Nos carbonatos Furnas-Santana o rio Betari formou um vale fluvial entrincheirado, com encostas fortemente inclinadas, do tipo through valley, segundo a classificação de Ford e Williams (1989). Com uma vazão média de aproximadamente 1,2 a $2 \mathrm{~m}^{3} / \mathrm{s}$ junto à borda do calcário, o Betari nunca foi absorvido por condutos subterrâneos. Isto é interpretado, como sendo conseqüência de um favorecimento ao entalhamento superficial em competição com a taxa de abertura de condutos subterrâneos. A causa deste favorecimento é a combinação dos seguintes fatores: alta descarga fluvial $\left(2 \mathrm{~m}^{3} / \mathrm{s}\right)$, situação estrutural desfavorável para injeção de água, (sentido do gradiente hidráulico contrário ao do mergulho da estratificação, anexo 3.6) e a presença de fraturas extensivas subverticais, com traço NW, paralelas à direção regional de entrincheiramento do rio Betari. A combinação dos controles hidrológico e estrutural acima e suas conseqüências morfológicas, é muito semelhante à situação descrita por Mills (1981), para o carste do norte de Vancouver, Canadá.

Deve-se lembrar também, a implicação geomórfica do transporte de sedimento fluvial. O Betari nasce no planalto, em torno da cota de $1000 \mathrm{~m}$, atingindo o calcário a $285 \mathrm{~m}$ (anexo 3.6). Este rio, e seus principais tributários, apresentam um gradiente hidráulico (variação de altitude, $\Delta \mathrm{h}$, sobre a distância horizontal correspondente, $\Delta \mathrm{l}$ ) médio de 0.208 $(20,8 \%)$, à montante do calcário. A declividade relativamente alta, aliada à morfologia entalhada, indicam alta capacidade erosiva e de transporte desta drenagem. Após a transição entre o planalto e a borda da planície do rio Ribeira, o gradiente do rio Betari decresce para 0.03-0.04 (3 a 4\%). Esta brusca redução de inclinação ocorre a cerca de $1,5 \mathrm{~km}$ antes do ro atingir os carbonatos Furnas-Santana. Isto implica numa importante redução de velocidade e capacidade de transporte da carga detrítica pelo rio, o que causa a deposição de cascalho e areia grossa. Estes depósitos fluviais, isolam parcialmente o leito fluvial carbonático, protegendo-o da abrasão e corrosão. Durante eventos de alta vazão, a carga de fundo, préviamente depositada, é arrastada ao longo do canal, erodindo e rebaixando o talvegue Muito pouco sedimento é observado no leito do setor de alto gradiente. Com 
exceção de armadilhas locais preenchidas com cascalho e areia, predominam seixos, calhaus e matacões. A quantidade de sedimento depositądo aumenta à jusante, atingindo o máximo, quando o rio Betari intercepta os calcários Lajeado-Bombas, junto ao Bairro da Serra. Neste trecho, o rio exibe a paisagem fluvial mais desenvolvida, sobre carbonatos, atingindo o gradiente mais baixo, com $0.0092(0.9 \%)$ de declividade. Em contraste com os calcários Furnas-Santana, onde o vale possui encostas fortemente inclinadas e talvegue estreito, a zona fluvial Lajeado-Bombas é caracterizada por um talvegue largo, aliado a uma cobertura aluvial mais expressiva, onde o rio apresenta padrão meandrante (sinuosidade $=1,49$ ) com uma planície de inundação bem desenvolvida.

Devido à abertura do vale e a redução brusca de gradiente, instalou-se uma situação de leque aluvial (segundo a definição de Rust; 1979); na chegada do nio na planície do Bairro da Serra. Os depósitos fluviais, com espessura muito variável, atingem cerca de 12m no máximo, sendo compostos por cascalheiras sustentadas por clastos, grossas a finas, com calhaus e blocos; cascalheiras mal selecionadas sustentadas por matriz arenosa, assim como cordões de areia e depósitos síltico-argilosos. Ocorre uma importante contribuição de partículas finas nestes aluviões. Esta fração fina, em grande parte, é proveniente da lavagem das encostas íngremes e intensamente intemperizadas que circundam o vale.

Embora com situação estrutural favorável (mergulho da estratificação concordante com a direção do gradiente hidráulico), o rio Betari não foi capaz de ser absorvido por condutos nesta área carbonática. Isto é explicado, através da ação protetora da cobertura sedimentar contra o processo de injeção de água nas descontinuidades do calcário. Principalmente as partículas finas, que colmatam parte dos proto-condutos em iniciação, reduzindo o fluxo de água e corrosão ao longo destes, o que, por sua vez, causa redução na taxa de abertura de condutos e, conseqüentemente, um aumento relativo da taxa de entalhamento superficial.

Comparando a morfologia dos vales fluviais das rochas psamíticas e pelíticas, com a de rochas carbonáticas, ao longo do rio Betari (anexo 3.6), nota-se que nestas últimas os talvegues são da ordem de 5 a 30 vezes mais largos que nos primeiros. Este fato também está relacionado à dinâmica fluvial. Sobre os calcários, o gradiente fluvial é sistematicamente inferior do que nas seções não carbonáticas, o que condiciona acumulação maior de sedimentos sobre os primeiros, conforme foi observado. Graças a esta cobertura, o talvegue carbonático é mais protegido da incisão vertical, o que causa uma eficiência relativa maior da erosão e corrosão lateral, alargando mais os vales carbonáticos, em relação aos não carbonáticos.

$O$ rio Betari representa, atualmente, o nível de base local dos sistemas de drenagem das áreas carbonáticas em estudo. $O$ entalhamento e alargamento do vale do Betari nestas áreas, interceptou a drenagem subterrânea, formando ressurgências, as quais formam os principais tributários deste rio ao longo dos carbonatos. Estas nascentes cársticas dão acesso à sistemas de cavernas e rios subterrâneos, com exceção de ressurgências mais profundas, como o lago do Barro da Serra e o córrego Seco. O desenvolvimento desta circulação cárstica será discutida no capítulo 4 . 
A retração das encostas do vale do Betari na área Lajeado-Bombas, em função da erosão remontante causada pelo escoamento superficial ao longo destas, invadiu a superficie de depressões poligonais, iniciando a remoção de cristas adjacentes a-fundos de depressões. A evolução deste entalhamento remontante está causando uma inversão de relevo, onde os fundos de antigas depressões fechadas localizam-se atualmente em cristas. Um exemplo deste processo é o abismo Ponta de Flecha (fig 3.4), cuja entrada hoje está sobre uma crista, mas que no passado, representou o fundo de uma depressão poligonal, conforme é evidenciado também, pelos depósitos clásticos, ricos em ossadas da fauna pleistocênica, preservados em patamares desta caverna vertical (Karmann, 1982 e Barros Barreto, et. al., 1982). Esta inversão de relevo é, portanto, consequeência da concorrência entre a evolução da superficie de depressões poligonais e o entalhamento e alargamento fluvial do vale do Betari, onde este último processo, tem ocorrido com taxas superiores.
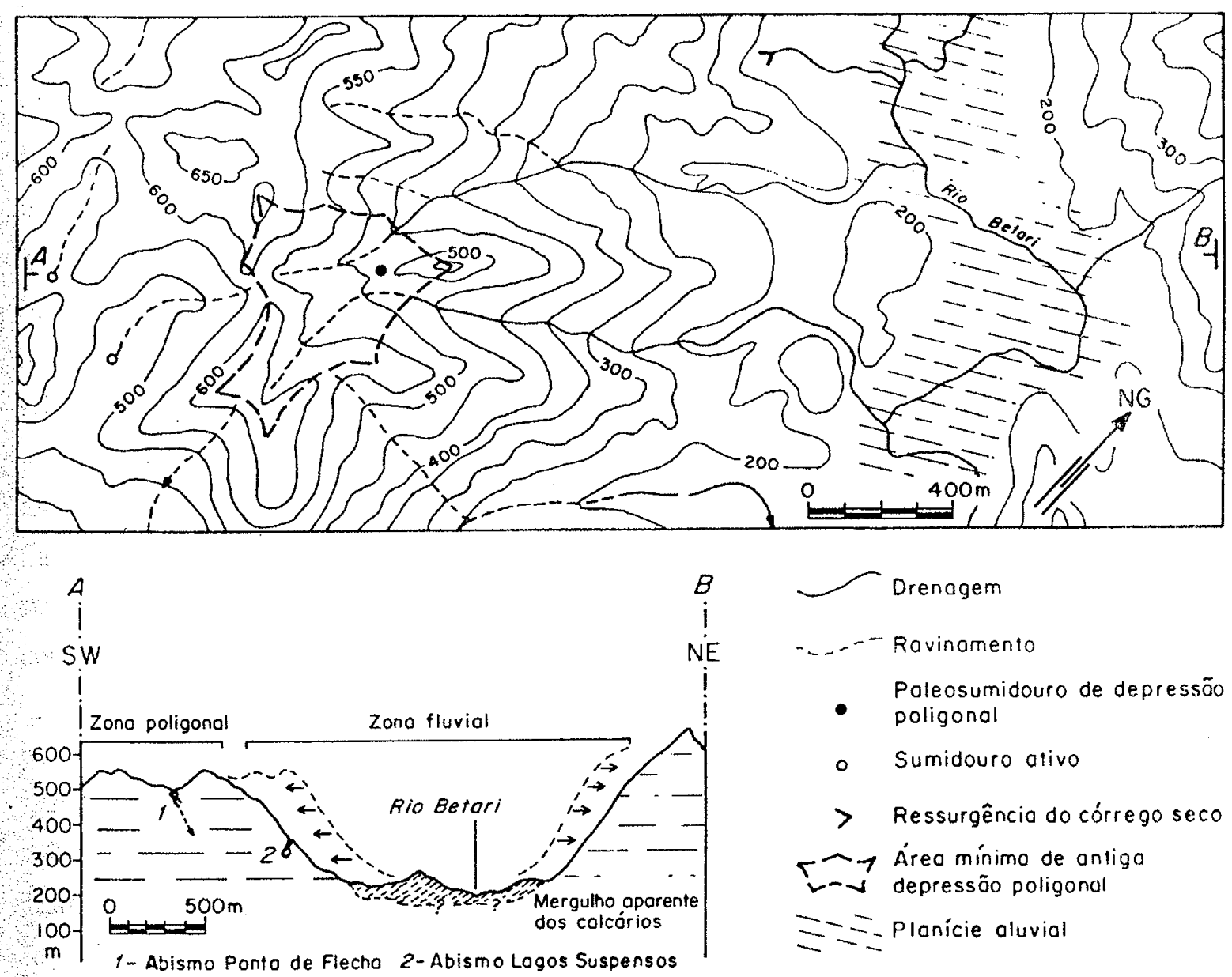

$$
\begin{aligned}
& \text { Drenagem } \\
& \text {.... Ravinamento } \\
& \text { - Poleosumidouro de depressõo } \\
& \text { - poliganal } \\
& \text { - Sumidouro ativo } \\
& >\text { Ressurgêncio do córrego seco } \\
& \checkmark \sim \text { Área minimo de antiga } \\
& \checkmark-v \text { depressõo poligonal } \\
& z=- \text { Planície aluvial }
\end{aligned}
$$

Figura 3.4 - $O$ abismo Ponta de Flecha no contexto da inversão de relevo causada pela retração das encostas do vale do rio Betari, bairro da Serra, área Lajeado-Bombas.

O segundo domínio fluvial sobre calcários da área de estudo é parte da bacia do rio Furnas, entre a vila homônima e sua junção ao rio Betari (anexos 3.33 .5 e 3.6). Três segmentos morfológicos constituem a bacia do rio Furnas. O primeiro setor, com direção NE-SW, acompanhando a borda nordeste dos calcários, forma um alinhamento de depressões fechadas, compostas, com sumidouros e um canal segmentado, ao longo do qual 
pouca água corre atualmente, com uma inclinação média de $0.14(14 \%)$ e desvio padrão de 0.21 (anexos 3.3 e 3.6). Esta paisagem é uma transição entre a morfologia fluvial e a morfologia cárstica superimposta. $\mathrm{O}$ segmento verdadeiramente fluvial, inicia-se onde o rio inflete para a direção NW-SE. Neste trecho, o gradiente do talvegue aumenta para 0.17 (desvio padrão de 0.23 ), sendo escalonado com cachoeiras. O vale torna-se fechado com encostas abruptas. A vazão atual do rio Furnas é decorrente quase que exclusivamente $\left(\sim 0,15 \mathrm{~m}^{3} / \mathrm{s}\right)$ da caverna do Grilo, que é uma nascente cárstica localizada no início deste trecho do rio Furnas. Seguindo com características puramente fluviais, o terceiro segmento inicia-se quando o rio atinge o contato SE do calcário. O canal assume declividade média uniforme de 0.11 (desvio padrão de 0.03). O vale abre-se bruscamente e a quantidade de sedimentos aumenta em função da redução brusca de gradiente. O talvegue alargado está coberto por depósitos aluviais e coluviais interdigitados.

Uma feição interessante, a ser discutida adiante, é a caverna Santana, a qual cruza por baixo do segundo setor do rio Furnas e ainda não foi interceptada pela incisão deste.

Resta ainda a questão do não desenvolvimento de condutos ao longo do segmento NW-SE do rio Furnas. Similar ao rio Betari, a situação estrutural é desfavorável à injeção de água nos planos de acamamento. Outro fator notado, é a natureza principalmente autogênica da água do rio Furnas (índice médio de saturação em $\mathrm{CaCO}_{3}=0,28$ ), o que a torna pouquíssimo agressiva, favorecendo portanto, a capacidade de abrasão mecânica deste escoamento superficial em detrimento da abertura de condutos.

\subsubsection{Zona de contato}

Esta é a unidade morfológica dominada por feições de injeção de água alogênica, formando uma faixa ao longo do contato dos metacalcários (anexos 3.3, 3.4 e 3.5). Caracteriza-se por vales cegos, poljes de contato e sumidouros, os quais absorvem o escoamento superficial das rochas insolúveis que contornam os metacalcários. A nomenclatura destes têrmos segue Gams (1978), Jennings (1985) e Ford e Williams (1989).

De modo geral, o contato entre metapelitos-psamitos e metacalcários é marcado por um vale assimétrico, cujo flanco sobre os calcários é formado por uma superficie suavemente ondulada, de largura variável, parcialmente coberta por depósitos aluviocoluviais e marcada com sumidouros e afundamentos de terreno. Esta superficie termina junto a encostas íngremes de calcário (fig 3.5).

Vales cegos são melhor representados ao longo do contato sudeste da área FurnasSantana (anexo 3.3) e contornando grande parte do contato dos calcários Lajeado-Bombas (anexo 3.4). Estes vales possuem morfologia fluvial normal, com gradientes entre $0.12 \mathrm{e}$ 0.33 sobre os metapelitos (fig 3.5). Esta drenagem adentra-se sobre os carbonatos entre 50 a $400 \mathrm{~m}$, com uma inclinação média de 0,04 . Os vales cegos com maior penetração nos calcários, ocorrem na borda sudeste da área do Lajeado, associando-se às maiores bacias de captação alogênica e aos mais desenvolvidos sistemas de cavernas. Estas incisões no calcario formam anfiteatros, que em mapa apresentam padrão semi-circular a triangular com encostas fortemente inclinadas e paredões rochosos. $O$ fundo destes anfiteatros é coberto 


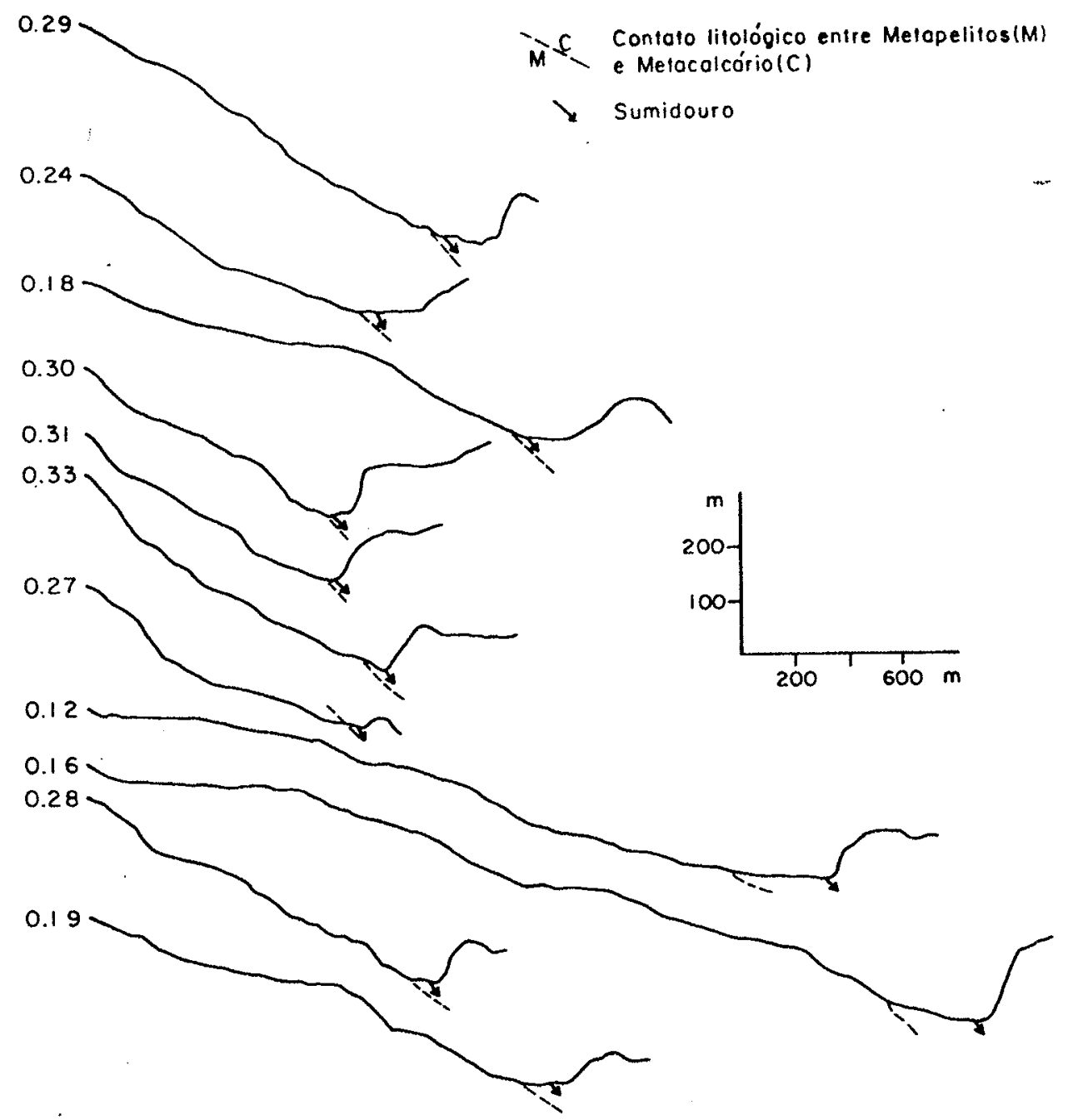

Figura 3.5 - Perfis compostos de vales cegos. Gradiente médio indicado à esquerdas.

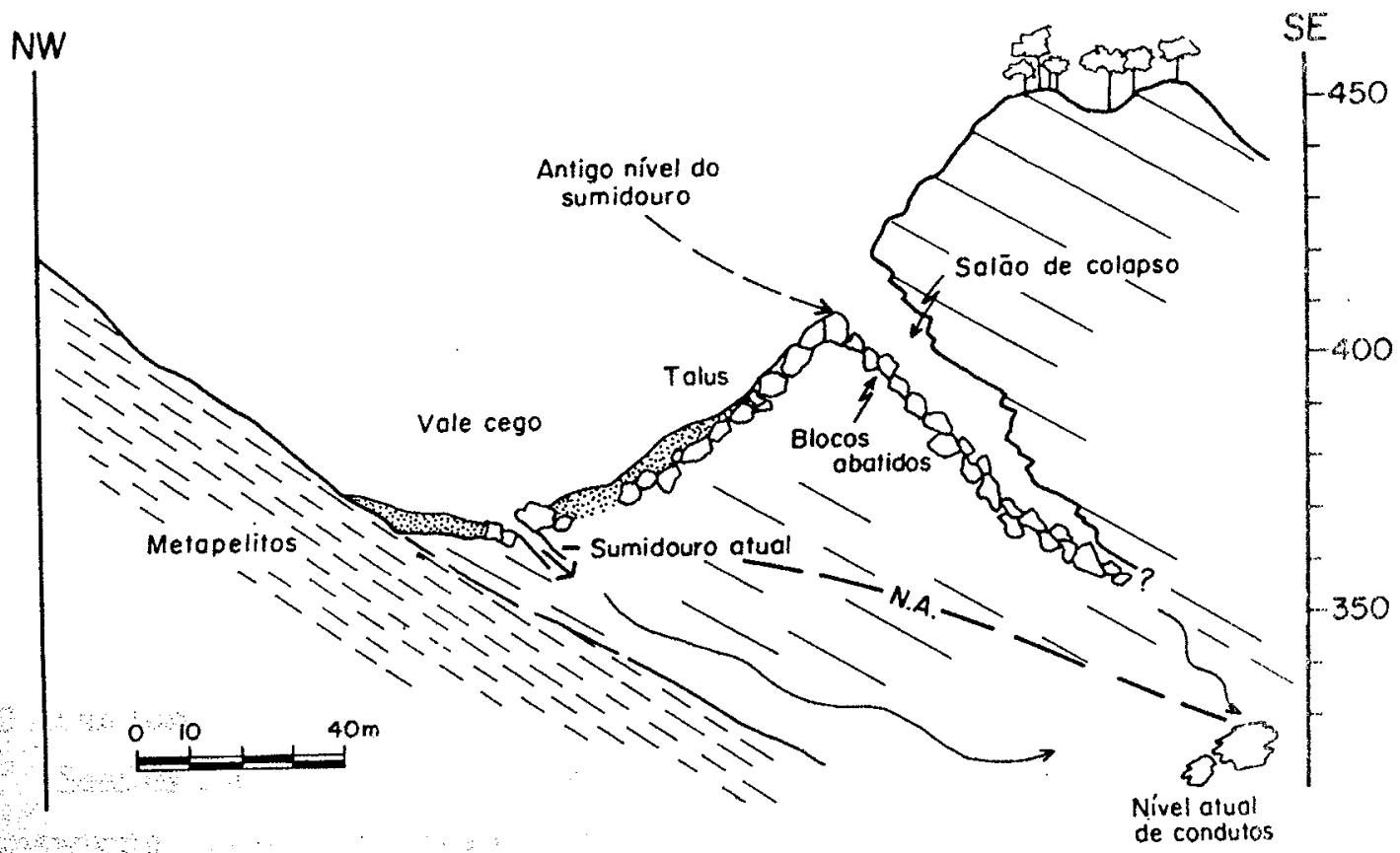

Figura 3.6 - Seção da caverna Laje dos Macaquinhos, representando um salão de desmoronamento associado a um paleo-sumidouro Borda NE da área Lajeado-Bombas. 
por depósitos residuais e de tálus dos calcários, com blocos e matacões, além de cascalheiras e calhaus fluviais. A maioria destes vales cegos apresenta salões de abatimento, cujas entradas localizam-se cerca de $40 \mathrm{~m}$, em desnível, acima dos sumidouros atuais, como por exemplo, a caverna Lage dos Macaquinhos (fig 3.6), que ocorre no contato NW dárea Lajeado-Bombas. Estas cavernas de abatimento, são interpretadas como sendo testemunhos de um antigo nivel superior de sumidouros.

Poljes de contato foram identificados no setor sudeste e nordeste da região FurnasSantana (anexo 3.5) e na extremidade nordeste e sul-sudoeste do corpo carbonático Lajeado-Bombas (anexo 3.5). Similar aos vales cegos mais entalhados, estes poljes associam-se aos rios alogênicos que desenvolveram importantes sistemas de drenagem subterrânea, com cavernas. De fato, os poljes de contato diferem dos vales cegos, somente pela maior área da superficie plana coluvio-aluvial presente nos primeiros. Isto sugete uma transição entre vales cegos e poljes, onde certos vales cegos, dada uma drenagem subterrânea eficiente, por um período de tempo maior, podem evoluir para poljes, coñforme interpretação esquematizada na fig 3.7.

Os poljes de contato são caracterizados por córregos de baixo gradiente associados a uma superficie suavemente ondulada e coberta por material aluvial e coluvial (fig 3.8). Esta cobertura detrítica possui espessura irregular, atingindo vários metros. É composta por material terrígeno síltico-arenoso com cascalheiras e blocos, refletindo a composiçấo dos metassedimentos vizinhos. $O$ fundo calcário aparece somente em raros pontos, na forma de elevações arredondadas cobertas por solo residual. Grandes blocos basculados de caicário são freqüentes, às vezes, com restos de cavidades e espeleotemas, sugerindo remanescentes de cavernas em escarpas colapsadas. Esta planície é delimitada por encostas calcárias abruptas ou pelo próprio contato litológico, com quebra na declividade. Salōes de abatimento ou abrigos rochosos ocorrem ao longo destas escarpas e o sumidouro principal é normalmente entre blocos na base ou próximo da escarpa calcária.

Onde não ocorrem poljes, nem vales cegos, a zona de contato é caracterizada por uma estreita planície ondulada por depressões rasas, desenvolvidas sobre material residual insolúvel dos carbonatos, que grada lateralmente para depósitos de encosta e aluviôes dos metapelitos adjacentes. Algumas destas depressões encontram-se conectadas por córregos intermitentes, ativos somente durante épocas de alta pluviosidade. Afloramentos cálcarios são escassos, restringindo-se à matacões e blocos imersos em solo residual. As bacias de captação destes setores são relativamente pequenas, quando comparadas às dos vales cegos. A descrição de semi-vale cego de Jennings (1985) é similar a esta feição, a qual é bem representada na borda centro-sul da região do Lajeado (anexos 3.4 e 3.5).

\subsubsection{Zona fluviocárstica}

Setores das áreas carbonáticas estudadas, onde a drenagem superficial ainda é predominante, apesar de importante infiltração, juntamente com feições cársticas conspicuas, são classificadas aqui como zonas fluviocársticas (figuras 3.4 e 3.5). A seguinte morfologia caracteriza esta paisagem 


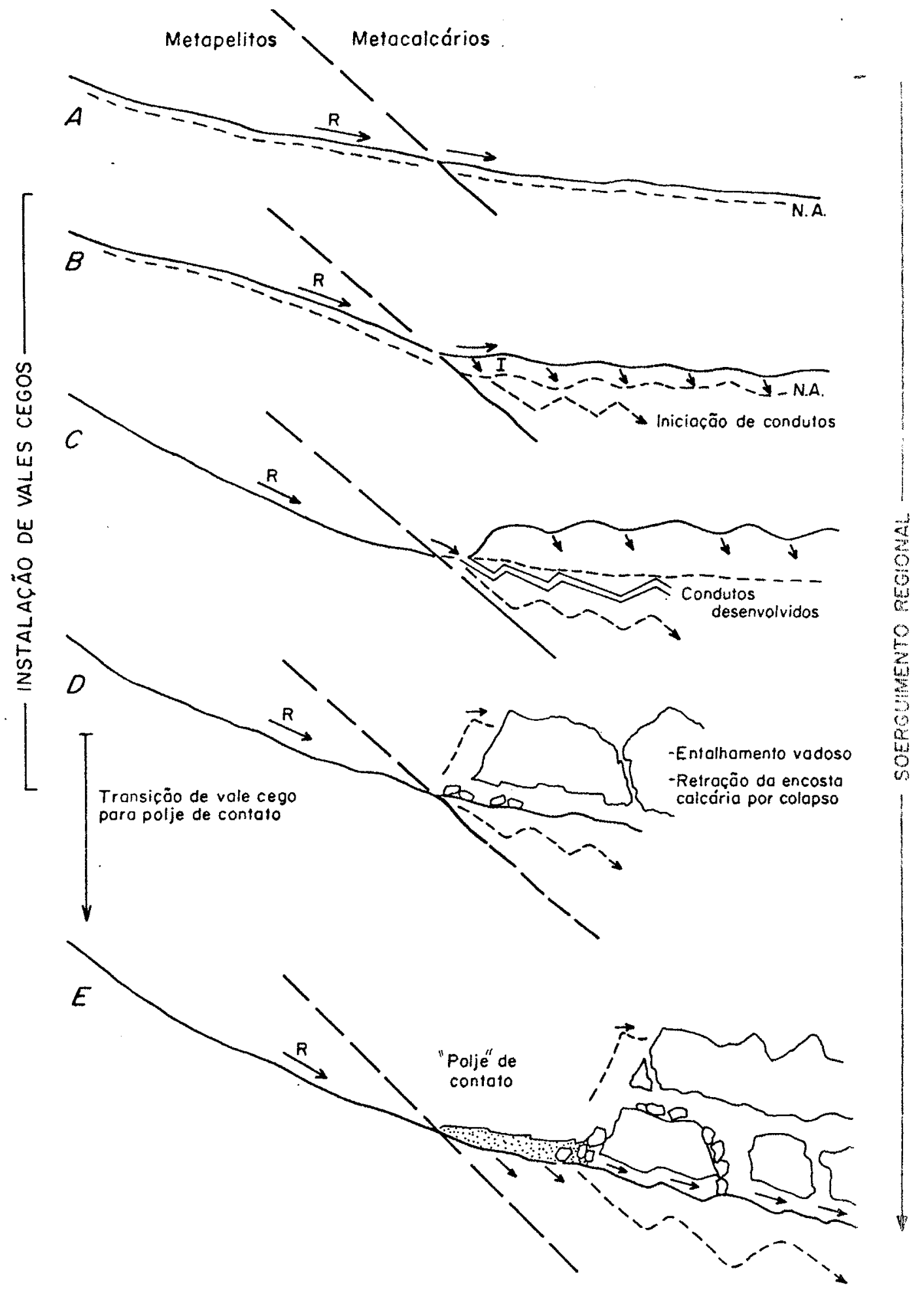

Figura 3.7 - Evolução esquemática de poljes de contato. A- Fase inicial de exposição dos calcários, escoamento superficial $(R)$ predominante. B- Desenvolvimento de condutos subterrâneos e infiltração (I) crescente. C- Condutos integrados, rebaixamento do N. A e absorção total de $\mathbf{R}$ através de sumidouros, com instalação de vales cegos. D- Incisấo mais profunda de vales cegos, entalhamento vadoso sobre condutos subterrâneos e retração da encosta calcária por colapso de cavernas. E- Desenvolvimento de planície aluvial-coluvial sobre os calcários, caracterizando o polje de contato 
- Drenagem superficial parcialmente ativa com escoamento superficial reduzido. Córregos alogênicos seguem seu curso sobre o calcário, mas, perdem gradativamente sua vazão. Às vezes exibem vales entalhados, hoje praticamente inativos, como por exernplo, na área de captação do sistema Àgua Suja, noroeste da região Furnas-Santana.

- Vales secos podem ser traçados facilmente sobre fotos aéreas 1:25.000. Quando observados em campo, apresentam canais com sedimentos fluviais alóctones, interrompidos por depressões rasas.

- Divisores de água entre sumidouros, ao longo dos vales, são pouco desenvolvidos, sendo dificilmente reconhecíveis em escala 1:25.000.

Zonas fluviocársticas foram delimitadas no sudoeste e nordeste da área carbonática Furnas-Santana e ao longo da faixa sudeste e extremidade nordeste da área liajeadoBombas (anexo 3.5).
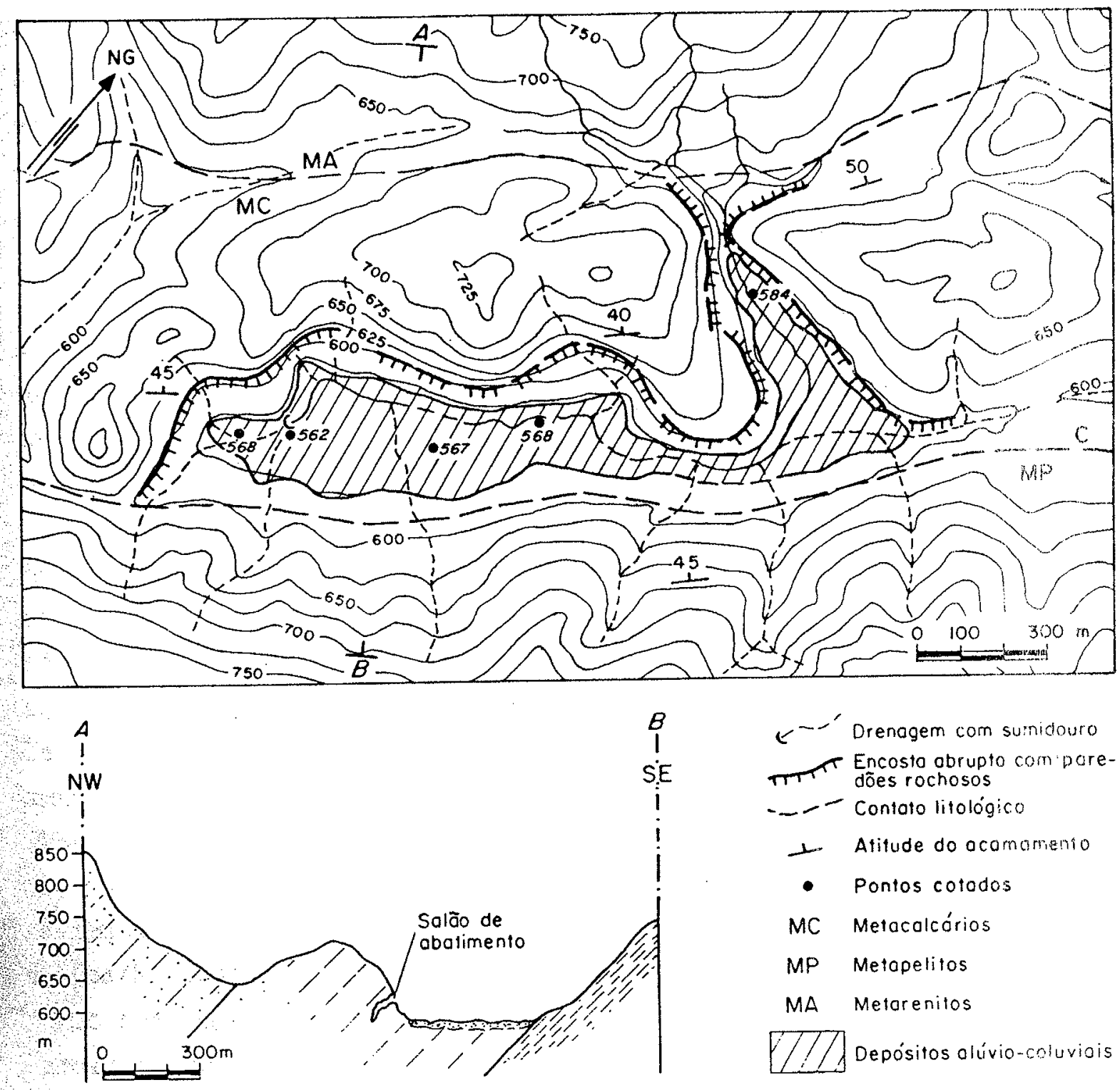

Figura 3.8 - Exemplo de polje de contato, junto ao sumidouro principal do sistema de cavernas Água Suja. Topografia extraída da carta U12, 1.10.000, DAEE, 1957. 
A presença de sedimentos fluviais alóctones por longas distâncias adentro dos calcários, indica que um importante sistema fluvial precedeu os vales atualmente quase secos. Isto pode ser observado no setor sudoeste da área Furnas-Santana, onde a bacia de drenagem reliquiar do rio Furnas exibe canais com cascalho e areias, incompatíveis com as descargas máximas atuais. A diminuição gradativa da vazão à jusante, não somente concentrada em sumidouros pontuais, indica uma infiltração dispersa, que por sua vez, sugere condutos cársticos (permeabilidade secundária) pouco desenvolvidos, em grande parte desta zona.

A topografia geral da zona fluviocástica é de morrotes suaves e aredondados, com cones cársticos isolados entre vales fluviais parcialmente inativos.

\subsubsection{Zona de depressões poligonais e a transição de fluviocarste para carste poligonal}

Esta é a paisagem sobre rochas carbonáticas, onde o escoamento superficial, de natureza essencialmente autogênica, é totalmente absorvido por sumidouros (insurgências) localizados nos fundos de depressões, as quais são delimitadas por divisores de água, formando um padrão planimétrico celular de polígonos irregulares (anexos 3.3 e 3.4). $\mathrm{O}$ termo depressão poligonal, ou fechada, utilizado aqui, segue a definição de Williams (1972b) e Day (1976), como sendo uma depressão de dissolução, a qual é drenada para um ou vários sumidouros internos, através de uma rede de drenagem incipiente e centrípeta.

Estas depressões foram demarcadas sobre fotografias aéreas 1:25.000. Devido à presença de mata densa sobre grande parte dos calcários, a localização exata de alguns sumidouros e divisores foi dificultada, induzindo um certo erro e distorção neste traçado, somente detectável após sua demarcação em campo. Mas, o padrão geral dos polígonos, compativel com a escala 1:25.000, está bem expresso nos mapas morfológicos, conforme verificação realizada em campo.

$\mathrm{Na}$ área carbonática Furnas Santana, as depressões poligonais concentram-se em faixas de direção NE-SW, principalmente entre o contato sudeste dos calcários e a intercalação pelítica central, acompanhando o alinhamento geral da estratificação (anexo 3.5). No corpo carbonático Lajeado-Bombas (anexo 3.5), a zona poligonal é mais expressiva em área, formando manchas irregulares, principalmente ao sul do vale do Betari. De modo geral, esta unidade morfológica é caracterizada por uma superficie intensamente ondulada, com cristas nas cotas de 600 a $700 \mathrm{~m}$ e fundos de vales fechados entre 420 e $550 \mathrm{~m}$, produzindo uma variação altimétrica (relevo relativo) de até $130 \mathrm{~m}$ (fig 3.3 ).

Depressões fechadas, com dimensões moderadas (entre algumas dezenas à centenas de metros de diâmetro), são consideradas como sendo a unidade essencial do relevo cárstico (Sweeting, 1972 apud Gunn, 1981a). Segundo Gunn (1981a), a similaridade entre a função hidrológica de depressões fechadas na paisagem cárstica e a de vales fluviais normais, foi primeiramente reconhecida por Grund (1914) e quantificada pelos estudos morfométricos de Williams (1971, 1972b) e Day (1976), os quais demonstraram que muitas depressôes fechadas exibem características muito semelhantes às de pequenas bacias de drenagem superficial Considerando que a bacia hidrográfica é a unidade basica para 


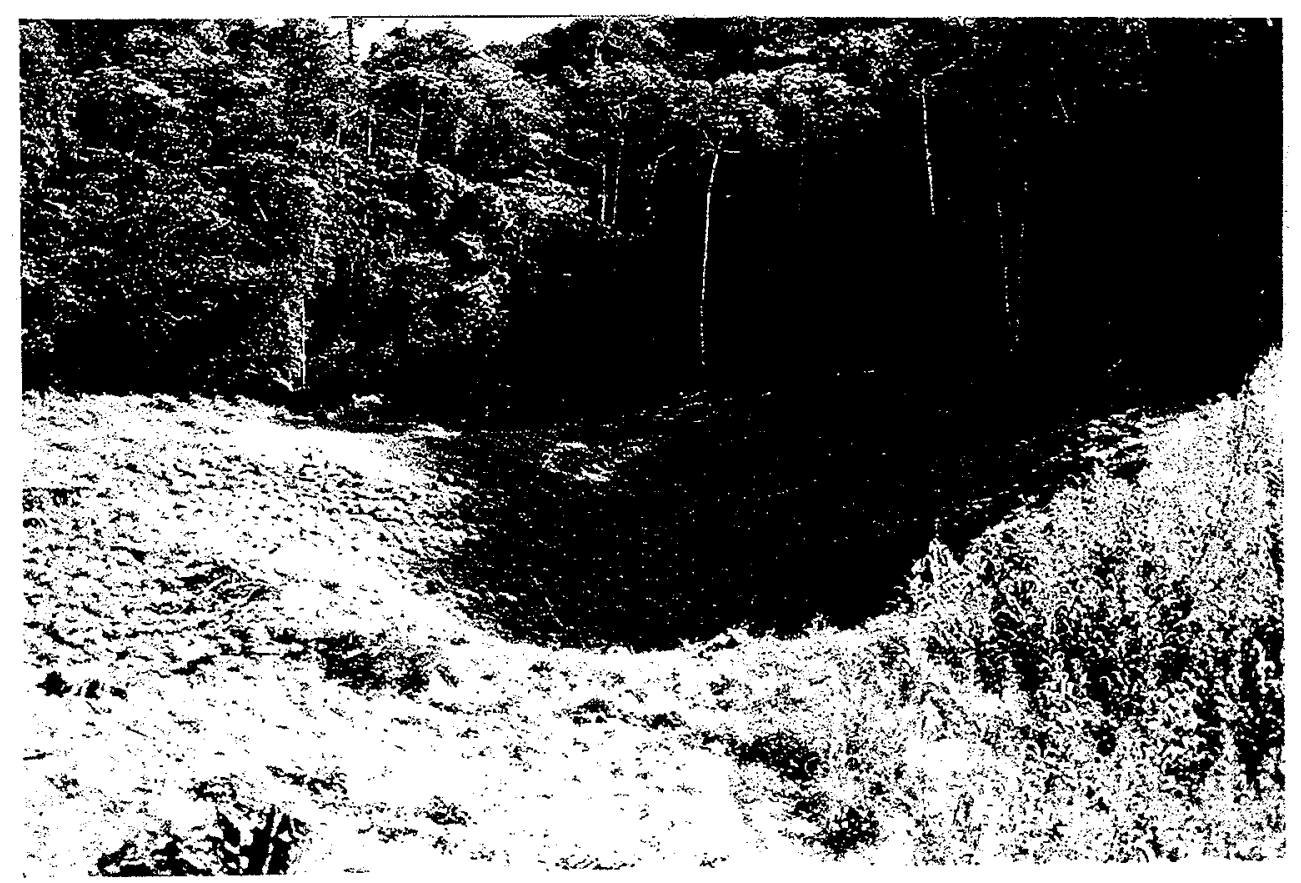

Foto 3.4 - Dolinas de subsidência em fundos de depressões poligonais. Sudeste da área Lajeado-Bombas.

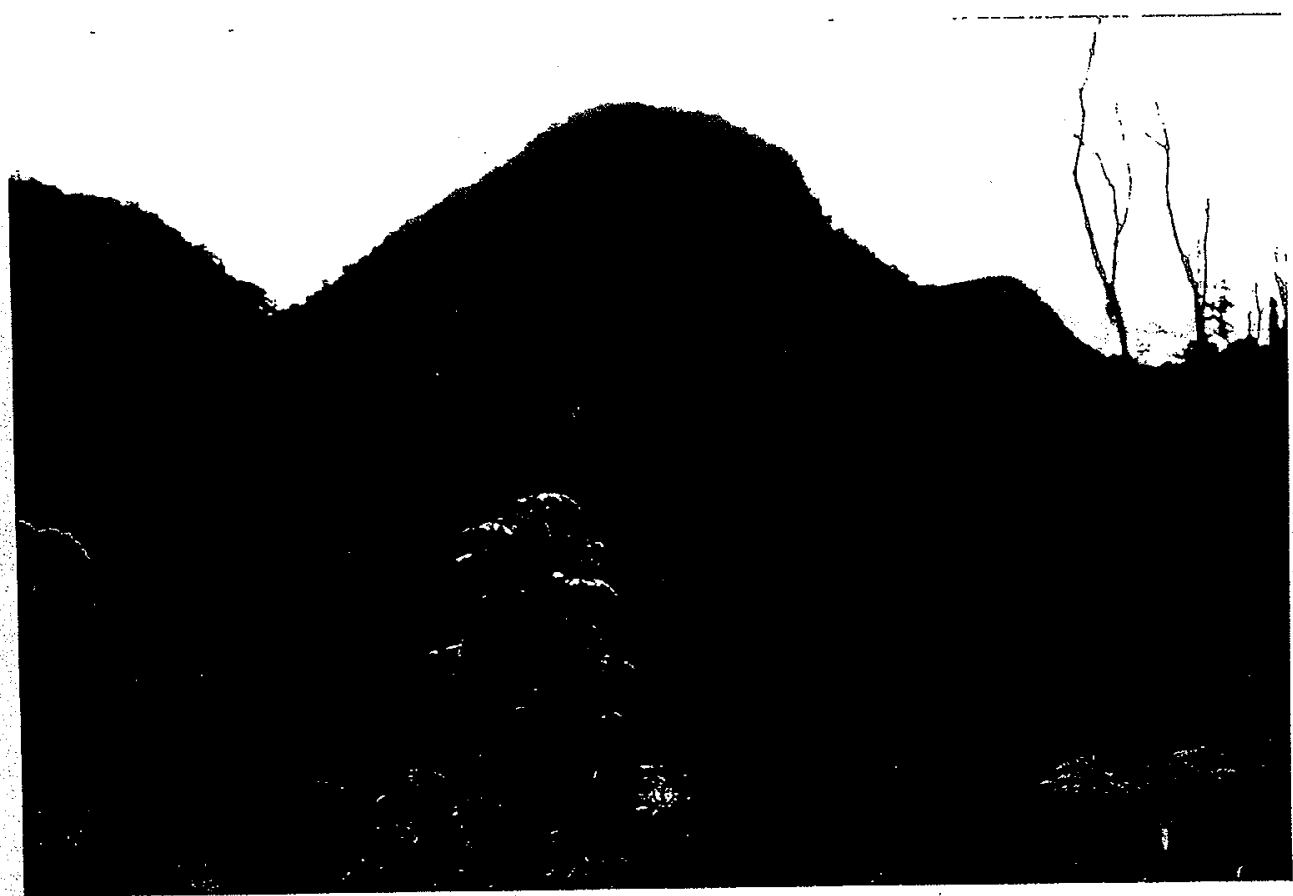

Foto 3.5 - Vista típica de cones cársticos que delimitam depressões poligonais. Área Lajeado-Bombas, local denominado Sítio Novo. 
investigações geomórficas e hidrológicas do relevo, Gunn (1981a) confere às depressões fechadas a mesma posição na hidrologia de sistemas cársticos autogênicos, ou seja, para caracterizar o escoamento superficial de terrenos cársticos e os mecanismos de recarga dos aquíferos associados, é fundamental a demarcação e caracterização morfológica destas bacias poligonais.

Com o objetivo de integrar o processo de desenvolvimento das formas de relevo com a evolução do aqüífero cárstico (tema do cap.4), procedeu-se a identificação dos tipos de depressões fechadas presentes nas áreas de estudo. Dois tipos fundamentais foram reconhecidos, em função de seu tamanho (área em planta) e padrão de drenagem interna, observados em fotografias aéreas 1:25.000, mapas topográficos 1:10.000 e, quando possível, em campo. A área das depressões foi medida sobre os mapas morfológicos, utilizando o programa Autocad 11 (detalhes são apresentados no item 3.3). O padrão de drenagem, foto-restituído, foi classificado conforme as ordens de Strahler (1964) para redes de drenagem superficial.

Depressões simples são aquelas com área planimétrica menor (entre 0,003 e 0,05 $\mathrm{km}^{2}$ ) e somente um sumidouro principal. A drenagem interna é pouco desenvolvida, sendo formada por ravinas e canais incipientes, predominantemente de segunda ordem. Suas profundidades (desnivel entre o sumidouro e a crista de divisor mais próximo, em cota, fig. 39) variam entre 5 e $30 \mathrm{~m}$. O contorno destas depressões é bastante irregular, tendendo a formas planimétricas poligonais (triangulares a hexagonais) ou, às vezes, subcirculares a elípticas, conforme se nota nos mapas morfológicos e no exemplo da fig 3.9. O eixo maior destas figuras varia de 50 a $600 \mathrm{~m}$, com alguns casos extremos, de até $900 \mathrm{~m}$. As encostas e fundo apresentam-se cobertas por solo residual argiloso escuro (rico em matéria orgânica). Exposições rochosas são raras, limitando-se à pequenas escarpas, ao longo das encostas, ou lajedos próximos aos sumidouros. A água coletada pela superficie destas bacias é transmitida para subsuperficie através de infiltração difusa ou concentrada ao longo de um conduto vertical (shaft), conforme será discutido adiante.

Depressões compostas caracterizam-se pela área maior (aproximadamente entre 0,05 e $0,8 \mathrm{~km}^{2}$ ), contorno mais irregular, quando comparadas com as depressões simples e uma rede de drenagem interna mais complexa, com múltiplos sumidouros (fig.3.10). A rede de drenagem interna é formada por canais desenvolvidos, freqüentemente de terceira ordem, apresentando-se interrompidos por sumidouros. A superficie interna é ondulada, possuindo vários pontos baixos, os quais podem, ou não, estar associados à sumidouros. Na escala 1:25.000 não é possível individualizar os divisores destes pontos baixos. Sua profundidade é muito variável, oscilando entre 10 e $80 \mathrm{~m}$, com um valor excepcional de $130 \mathrm{~m}$. O eixo maior destas figuras atinge máximos de até $2,7 \mathrm{~km}$. Detalhes morfométricos são apresentados no item 3.3. O padrão geral destas depressões é de uma superficie ondulada, com inclinação geral centrípeta, demarcada por divisores topográficos bem desenvolvidos.

Tanto as depressões simples, como as compostas, são delimitadas por morros agudos, às vezes triangulares, e cristas com encostas suavemente concavas e fortemente 


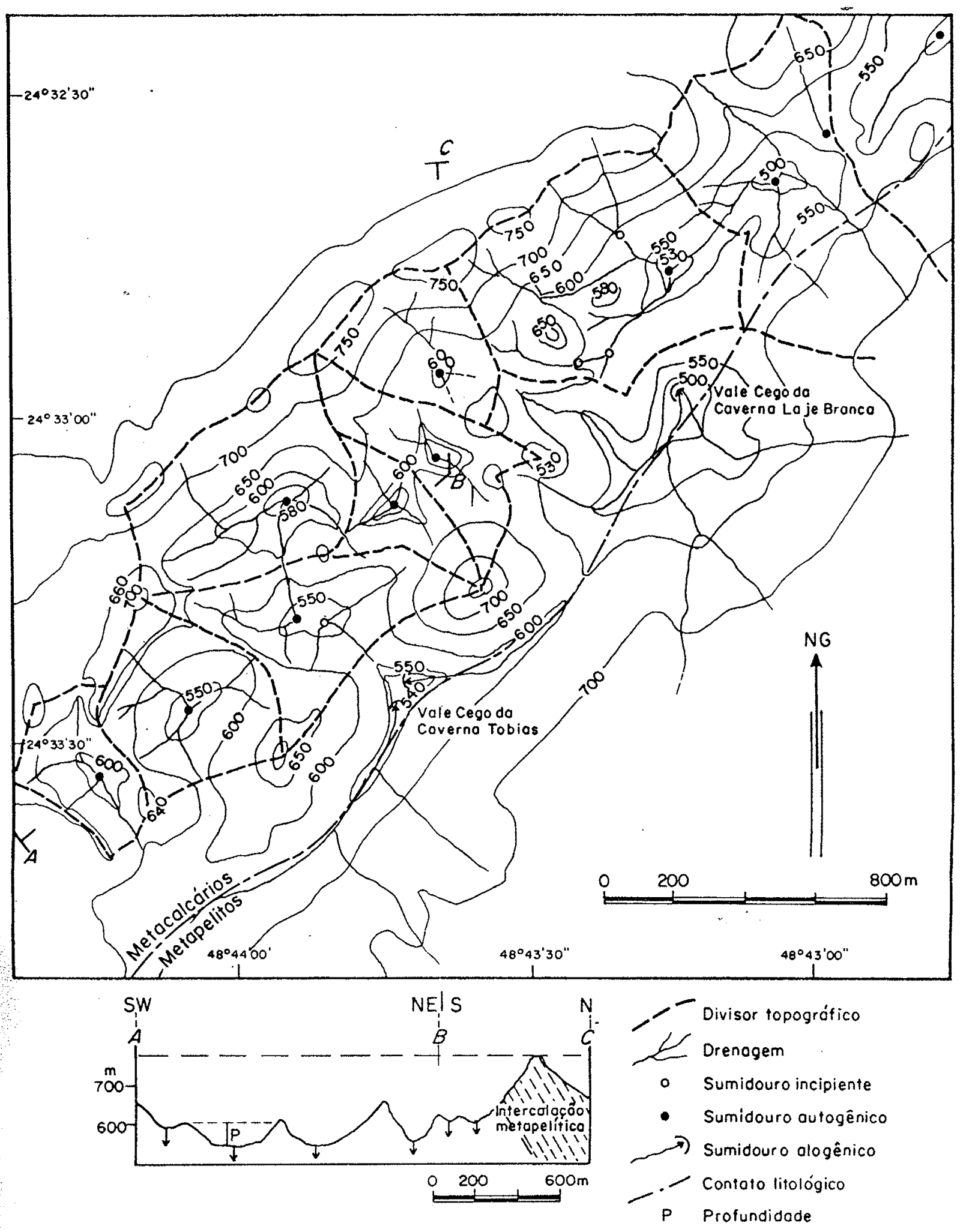

Figura 3.9 - Exemplo do padrão planimétrico de depressões poligonais simples da região Furnas-Santana. P- profundidade da depressão. Contornos extraídos da folha V12, 1:10.000, DAEE, 1957. 


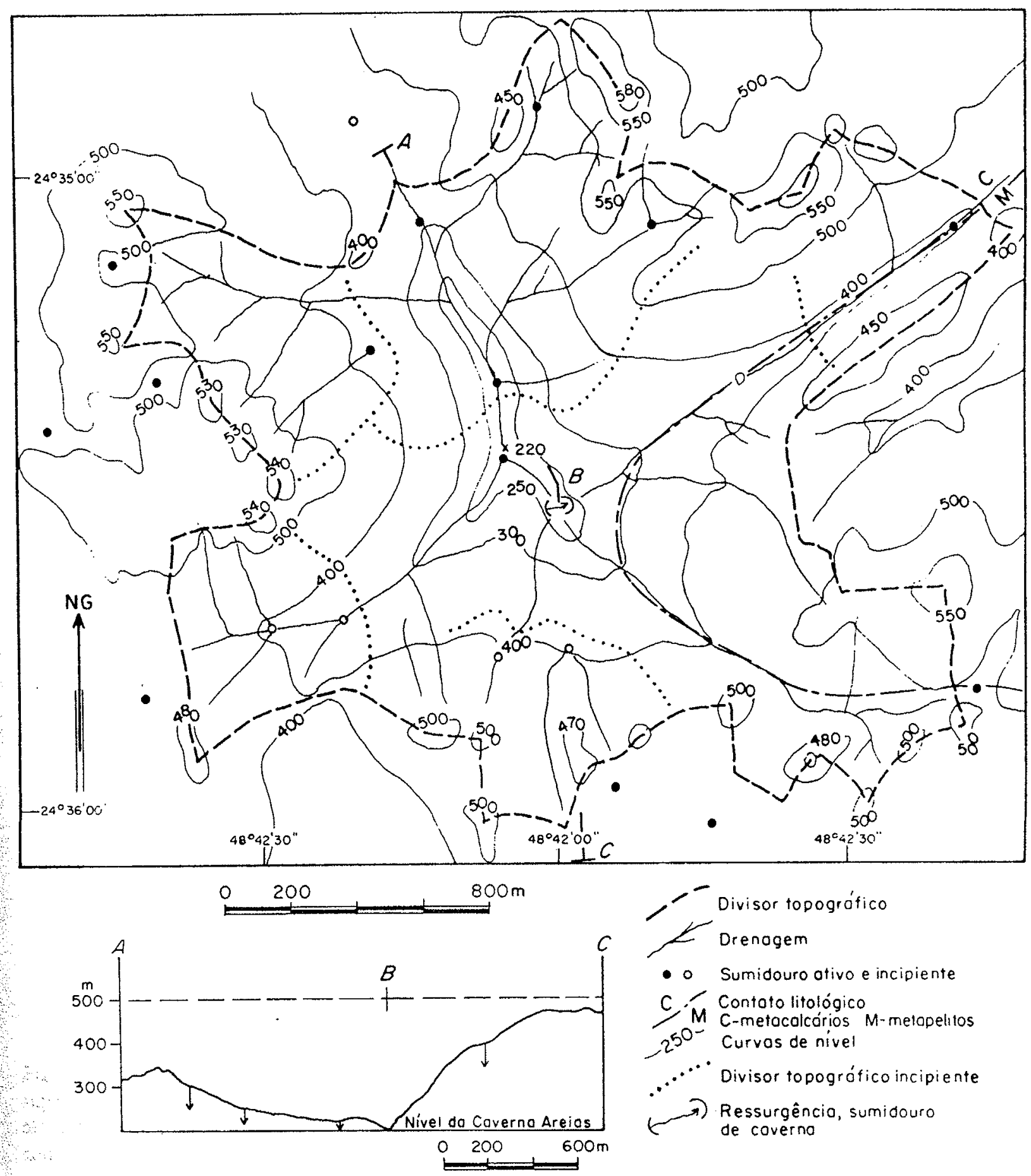

Figura 3.10 - Depressão composta (uvala) das Areias, região do Lajeado. A ressurgência e sumidouro marcados no centro, correspondem ao fundo da dolina de abatimento que dá acesso ao sistema de cavernas Areias. Extraído da folha W12, 1:10.000, DAEE, 1957. 
inclinadas, as quais convergem internamente para uma zona rebaixada (figuras 3.2 e 3.3 e foto 3.5 ).

As depressões simples identificam-se com cockpits, definidos por Sweeting (1958) para o carste da Jamaica, enquanto que as compostas enquadram-se na categoria de uvalas, pelo fato de possuírem múltiplos pontos de infiltração (Terzaghi, 1958, apud White, 1988), apesar das uvalas originalmente descritas, não apresentarem uma amplitude de relevo, tal qual, as depressões compostas aqui descritas.

$A$

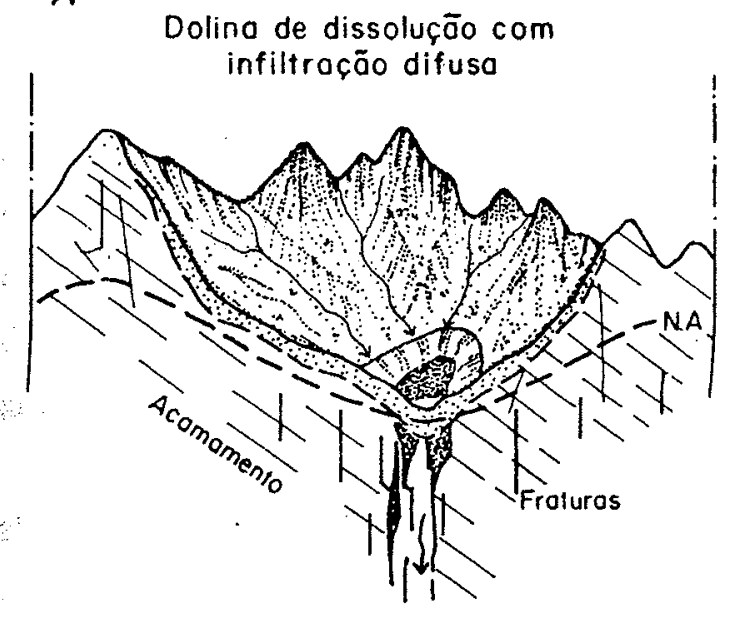

$C$

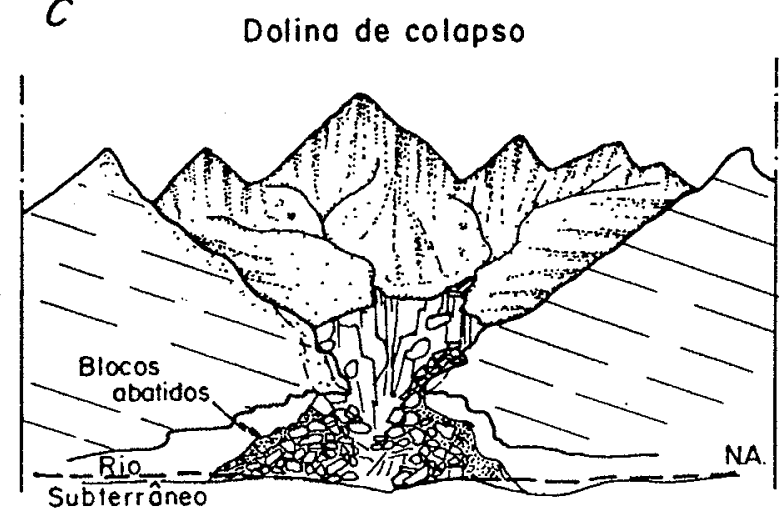

$B$

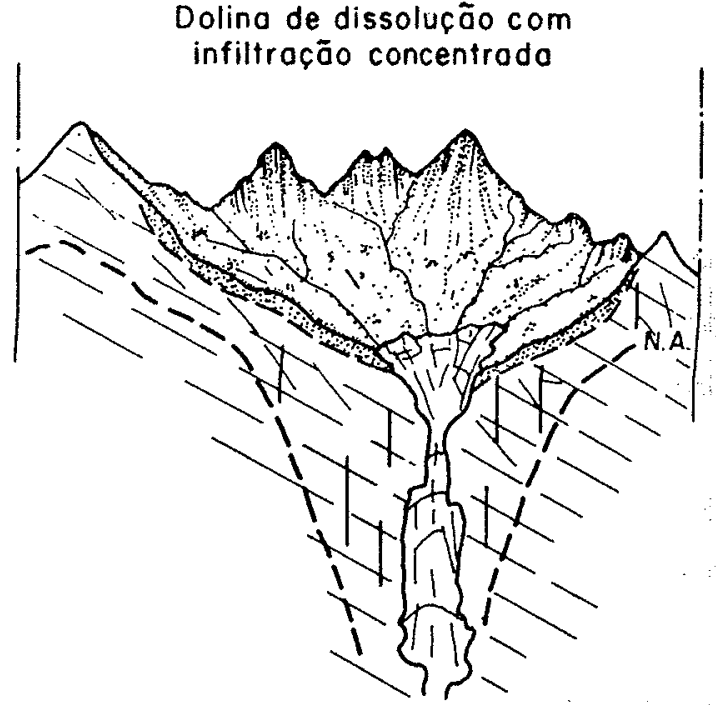


intensa, formam alagamentos, que na época seca transformam-se em zonas de solo argiloso escuro e úmido. Esta morfologia é típica de dolinas de dissoluçãe, associadas à infiltração vertical difusa da água meteórica ao longo de fraturas e juntas alargadas, conforme os modelos de Gunn (1983) e Williams (1985). O segundo tipo, menos freqüente que o acima descrito, é constituido pelos sumidouros pontuais e abertos, muitas vezes associados à cavernas verticais (fig 3.11a). A entrada destes condutos verticais localiza-se no vértice de depressões cônicas, com encostas mais íngremes que no caso das dolinas de dissolução. Estas feições são denominadas de poços ou chaminés de dissolução (White, 1988), sendo associados à infiltração vadosa concentrada ao longo das paredes de condutos verticais. Grande parte dos abismos, denominação espeleológica de cavernas verticais, comuns nas áreas em estudo, são exemplos destas feições. O terceiro tipo, e menos comum, são as depressões com paredes rochosas e fundo coberto por bloços, matacões e depósitos finos de encosta, os quais formam um. talus que vai de encontro à salões subterrâneos ou condutos associados a rios subterrâneos (fig 3.11c). Estas feições ocorrem, tanto em fundos de depressões compostas, como simples, resultando do colapso de cavernas, devido à intersecção do rebaixamento da superficie com o nível de condutos e salões subterrâneos.

As formas acima descritas, representam os três tipos extremos (end members) de absorção do escoamento superficial para subsuperficie, devendo-se ressaltar aqui, que ocorrem diversas formas de transição entre elas e, também, associação destas numa mesma depressão poligonal, principalmente nas compostas. $O$ exemplo mais freqüente de associação é a ocorrência de pontos de absorção na forma de condutos vadosos verticais (feiçôes do $2^{\circ}$ tipo) ao longo das encostas de uma depressão poligonal maior, enquanto que, nos pontos mais baixos desta mesma depressão, incidem, mais freqüentemente, dolinas de dissolução (formas do $1^{\circ}$ tipo), conforme esquema da fig. 3.12.

A origem desta associação é interpretada como sendo conseqüência do mecanismo de evolução de um conjunto de depressões de dissolução, onde, com o passar do tempo, ocorre uma taxa de evolução diferenciada e competição entre as mesmas (fig.3.13). Numa primeira fase, considera-se que uma série de pontos de infiltração iniciam seu desenvolvimento, ao mesmo tempo, sobre uma superficie calcária, em função do aumento gradativo de permeabilidade secundária no interior da rocha carbonática. Num certo momento, algumas destas rotas subterrâneas de fluxo vadoso vertical tornam-se mais eficientes, o que causa a remoção de um volume maior de material em solução e suspensão, coletados por estas, nos pontos correspondentes em superficie. A partir deste estágio, as depressões associadas às rotas mais eficientes de escoamento subterrâneo, terão uma taxa de abertura e subsidência maior em comparação com as depressões vizinhas, com drenagem subterrânea menos eficiente. Desta maneira, inicia-se uma competição entre as diferentes taxas de desenvolvimento de depressões, o que pode culminar com o englobamento de várias depressões menores por uma maior, a qual possui velocidade de crescimento maior: Neste processo de coalescência de várias depressões, a erosão remontante das encostas da depressão maior e mais profunda, pode invadir e, eventualmente, remover os divisores de depressóes menores adjacentes, produzindo a associação acima descrita, onde feições de 
absorção de água superficial, típicas de fundos de dolinas, ocorrem, ao contrário, nas encostas e até cristas de depressões maiores, resultando em inversões de relevo.

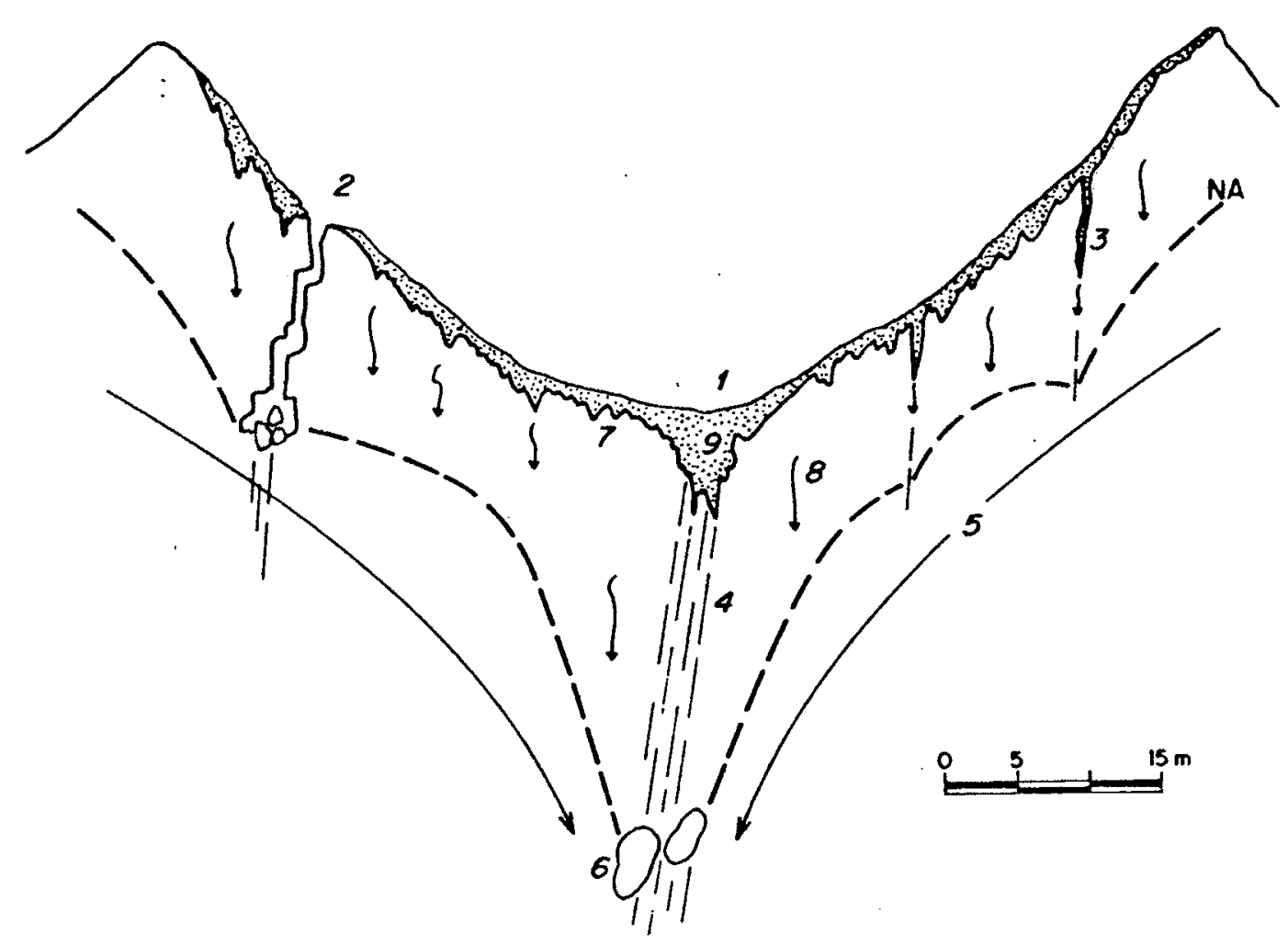

Figura 3.12 - Seção esquemática representando a ssociação de formas de absorção do escoamento superficial em depressões poligonais. 1- Dolina de dissolução associada a rota de drenagem subterrânea eficiente. 2- Atual caverna vertical (abismo) representando antigo fundo de depressão com taxa de ampliação menor. 3- Fendas de dissolução na zona epicárstica. 4- Rota de infiltração vertical concentrada sobre descontinuidades. 5- Linhas de fluxo geradas pelo cone de rebaixamento do lençol freático. 6- Condutos associados à rede de drenagem subterrânea. 7- Superficie da rocha entalhada por sulcos de dissolução (karren cobertos). 8- Infiltração vadosa difusa na zona epicárstica. 9- Solo

Tanto na área Furnas-Santana como Lajeado-Bombas, observa-se a predominância de condutos vadosos verticais (abismos) nesta situação de encosta ou crista e não a de dolinas de dissolução, com infiltração difusa (impenetráveis ao homem). Como exemplos, citam-se os Abismos do Fóssil, Juvenal e dos Caramujos (fig 3.14). A interpretação deste fato, num quadro geral de evolução do carste poligonal, é a de que estas rotas de infiltração concentrada, teriam passado uma fase inicial, onde as fraturas alargadas estariam colmatadas por material residual, como ocorre nos fundos atuais da maioria das depressões observadas. Mas, em função do desenvolvimento lateral de uma zona profunda de permeabilidade maior (abertura de condutos freáticos), responsável pela implantação da depressão maior, ocorre o rebaixamento do lençol freático, formando um cone de rebaixamento do lençol, o que causa o aumento do gradiente hidráulico e a instalação de linhas de fluxo, de forma centripeta, com isopotenciais contornando a zona de maior permeabilidade Se as depressóes menores estiverem inseridas no perímetro deste cone de rebaixamento do lençol, haverá um incremento do gradiente hidráulico e consequentemente, 
PERFIL

$A$
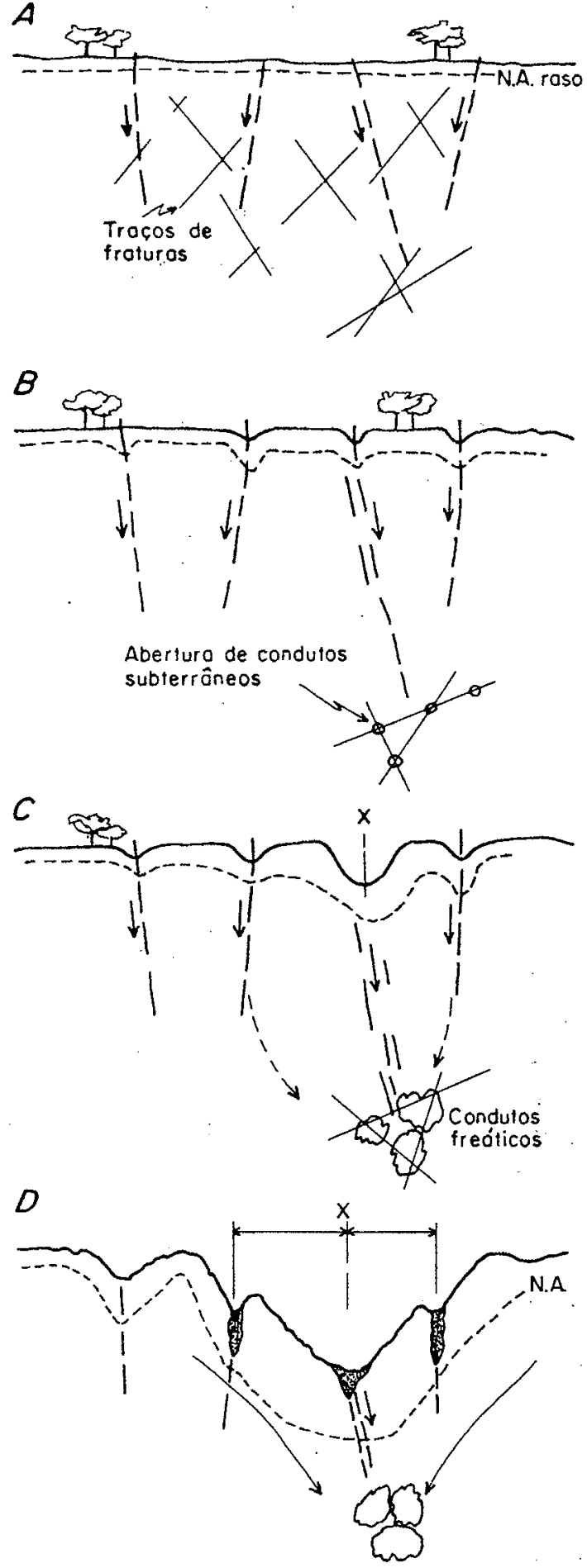

E

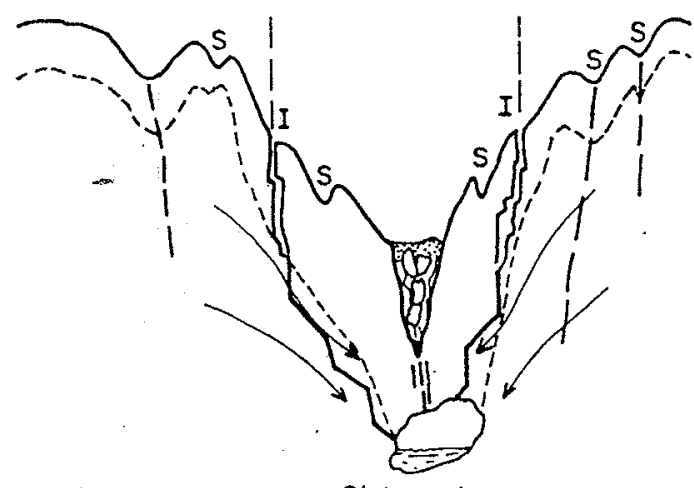

Pl ANTA
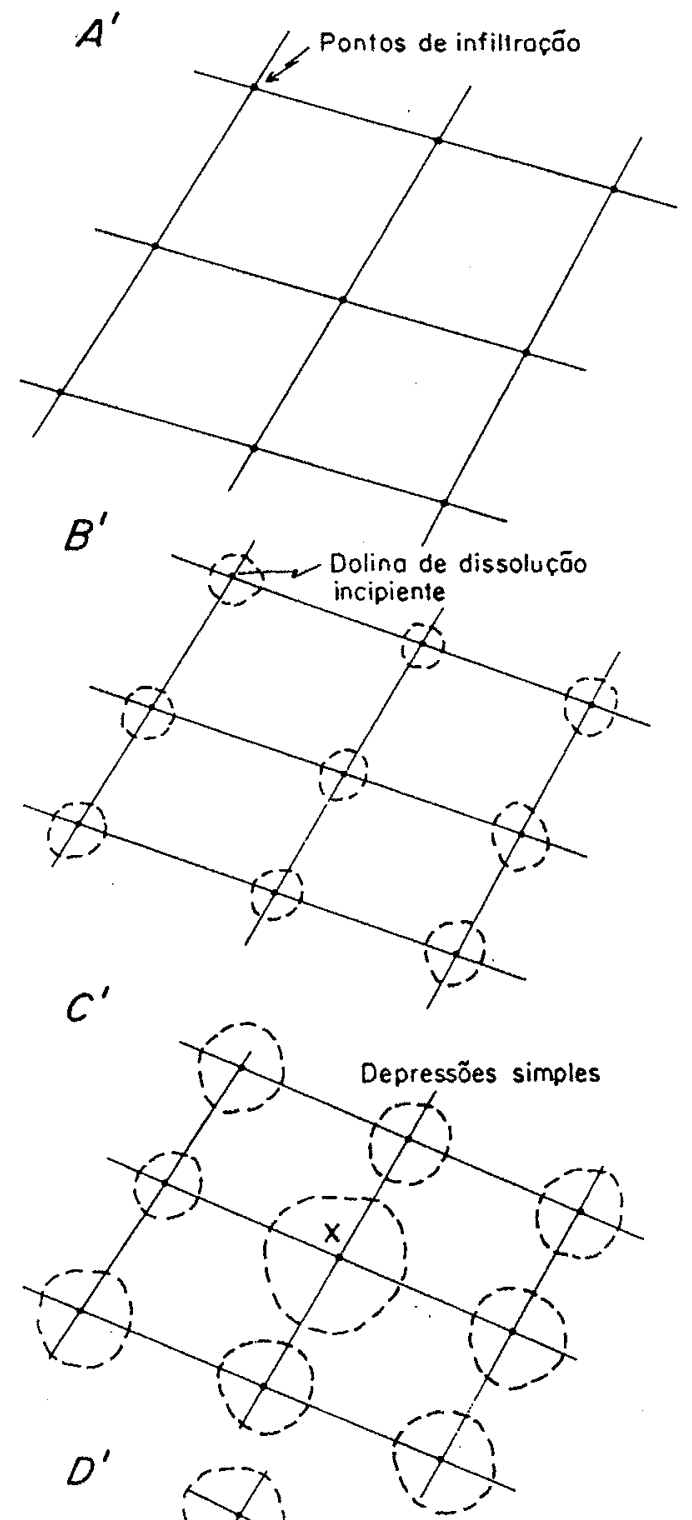

$D$

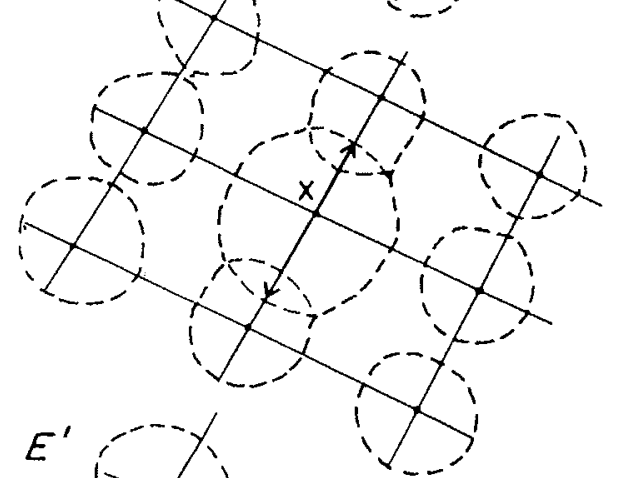

$E^{\prime}$ 
Figura 3.13 (ao lado esquerdo)- Representação esquemática da evolução de um conjunto de depressões poligonais, através do modelo de competição e coalescência, gerando depressões compostas a as associações de dolinas de dissolução e abismos, com inversão de relevo. A a E, seções e $A^{\prime}$ a E', vista em planta.

A- Situação pré-carstificação.

B- Início de carstificação e aumento de permeabilidade secundária.

C- Instalação de um cone maior de rebaixamento do lençol freático sobre a rota preferencial de drenagem subterrânea. X marca a depressão com taxa de ampliação maior, devido a sua conexão com a drenagem subterrânea.

D- Englobamento de depressões menores pela depressão com taxa de ampliação maior (formação de depressões compostas).

E- Erosão de solo e detritos acumulados ao longo das rotas de infiltração de depressões menores inseridas no raio do cone de rebaixamento do lençol associado à depressão maior. Iniciação de dolinas secundárias (S) devido ao rebaixamento do lençol e conexão de rotas de infiltração com condutos subterrâneos. Inversão de relevo (I), com a localização de antigos fundos de dolinas nas encostas de depressões maiores.

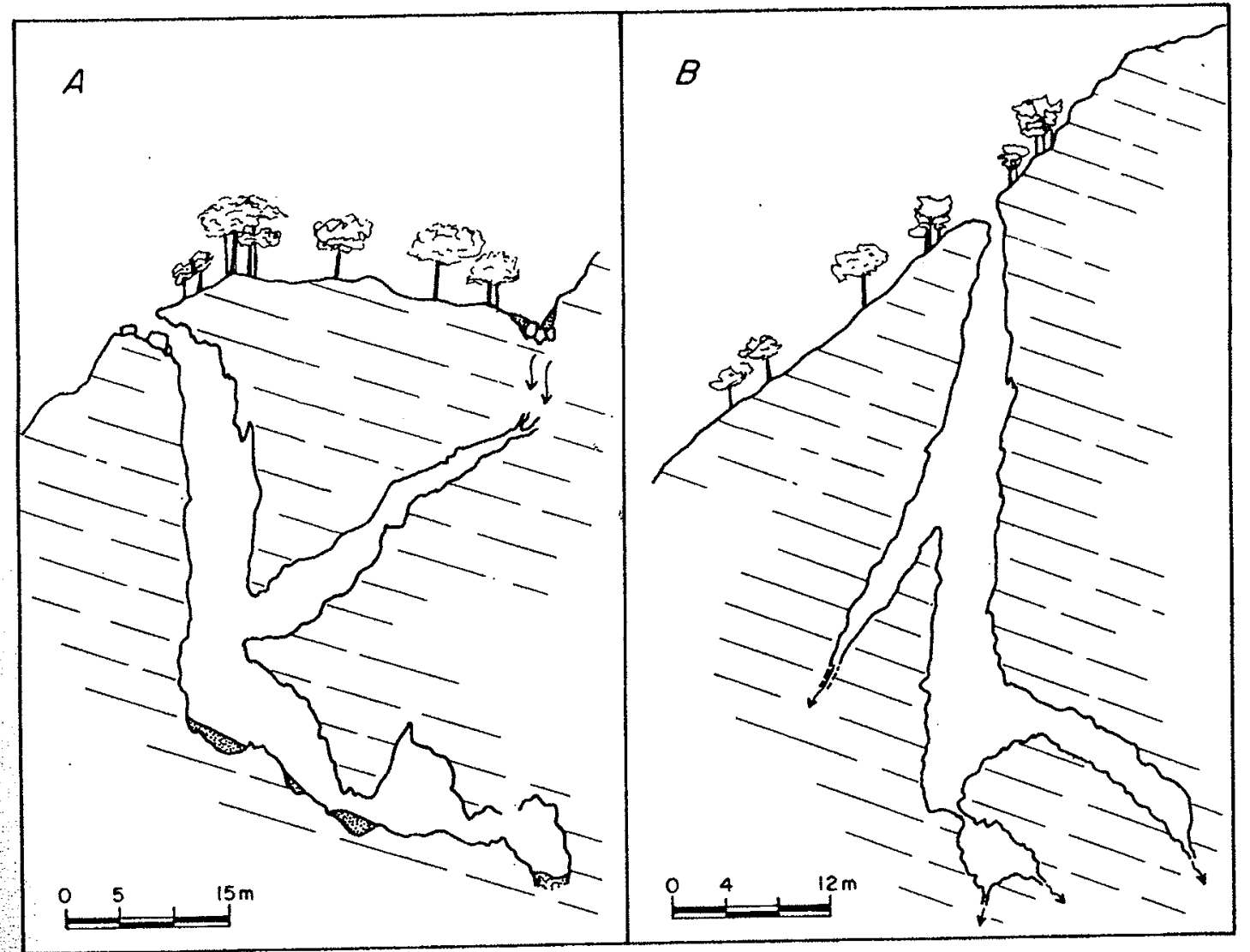

Figura 3.14 - Seções longitudinais dos abismos do Fóssil (A) e dos Caramujos (B), localizados na área carbonática Lajeado-Bombas. Adaptados de Gusso, et. al. (1979) e Collet et al (1970) As entradas destas cavernas verticais representam antigos fundos de depressões. 
da energia de transporte da água de infiltração no fundo da depressão menor lateral. Com o aumento da capacidade erosiva da água de infiltração, aliada à ampliação da zona vadosa ao longo da rota de infiltração, o material residual que colmatava as fraturas ałargadas, acaba sendo erodido e as paredes das fraturas corroidas pelo escoamento do filme de água meteórica sobre a rocha exposta (fig 3.13E). Deve ainda ser salientado, que o volume de material residual coletado por esta depressão, diminui com o tempo, pois sua área de captação é reduzida drasticamente com a remoção de suas encostas devido à ampliação da depressão maior.

Um fenômeno importante, que realça as diferenças entre taxas de ampliação de bacias poligonais, é o processo de realimentação (feedback) hidrológica positiva, definido por Williams (1985). Este processo resulta no aumento da taxa de expansão de dolinas de dissolução, associadas a rotas eficientes de drenagem subterrânea, pois com uma ampliação inicial da área de captação de uma depressão, um volume maior de água meteórica será coletado, o que, por sua vez, reforça o fluxo de água e corrosão ao longo da zona de infiltração, alargando-a, o que acaba voltando a ampliar a superficie de captação da depressão (fig 3.15).

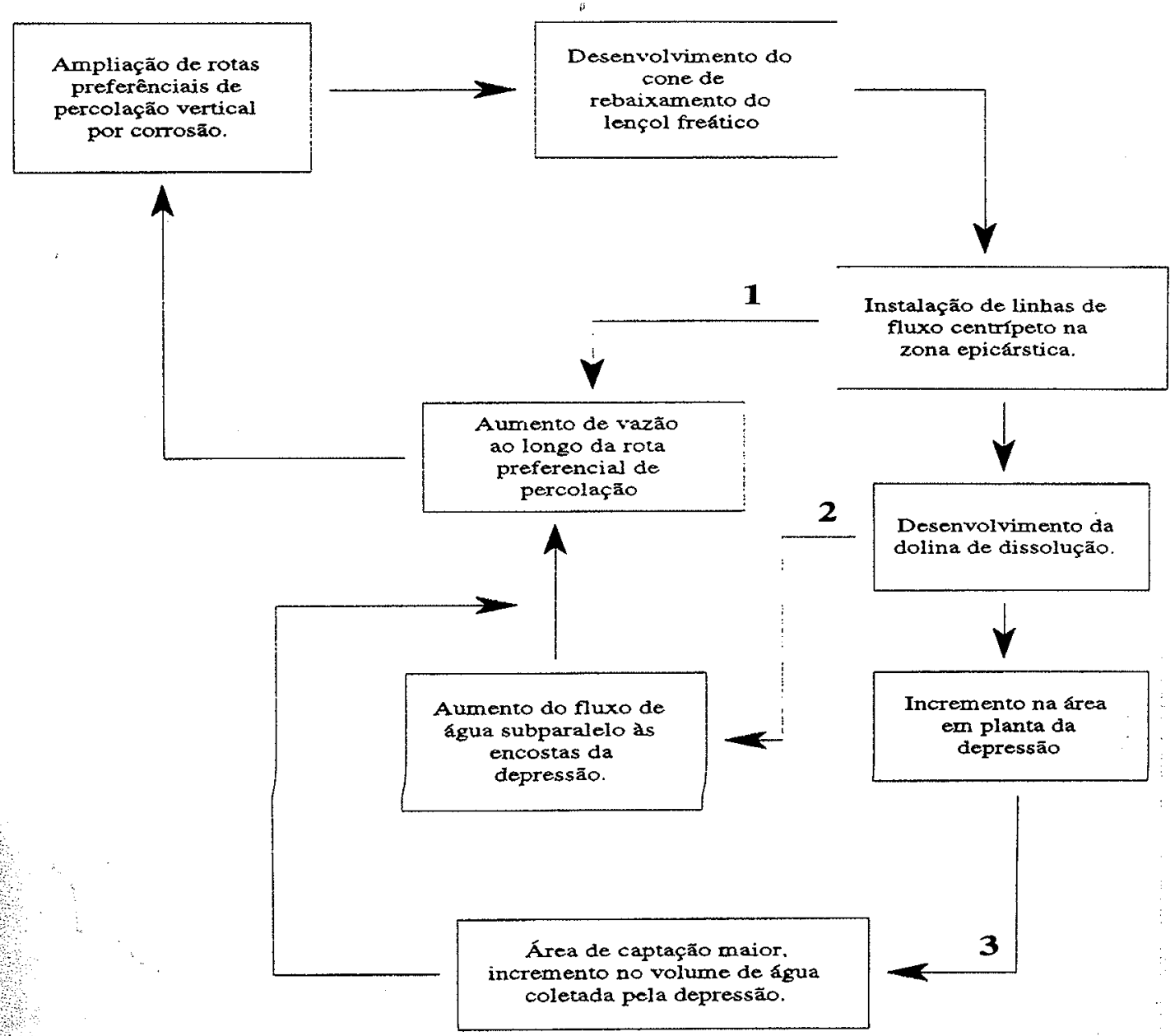

Figura 3.15 - Fluxograma do processo de desenvolvimento e ampliação de depressóes poligonais através do fenómeno de realimentação $1,2,3=$ linhas de realimentação positiva. Adaptado de Williams (1985) 
Nesta morfologia geral de depressões simples e compostas, há ainda, pequenas depressões, somente notáveis em campo. Suas dimensões, variam desde suaves concavidades, com alguns metros de diâmetro, até $1 \mathrm{~m}$ de profundidade, à depresssões mais pronunciadas, que atingem no máximo $15 \mathrm{~m}$ de diâmetro, por 2 a $3 \mathrm{~m}$ de profundidade. Estas pequenas dolinas de dissolução ocorrem tanto ao longo de encostas, como também, sobre os divisores de depressões poligonais. Estas feições são interpretadas como dolinas em início de desenvolvimento, cujo surgimento foi disparado pela evolução das depressões maiores e mais profundas, conforme o modelo de geração múltipla e competitiva (Multigenerational diffusion and competition process model), proposto por Kemmerly (1982), baseado nos trabalhos de LaValle (1967), Ford (1964), Drake e Ford (1972), Williams (1972a) e Palmquist (1979), para explicar a origem e evolução de grandes populações de dolinas. Este modelo prevê que o desenvolvimento e ampliação de uma depressão primária (depressão maior), aumenta, em muito, a probabilidade de surgimento de outras dolinas secundárias nas vizinhanças da primeira, durante o episódio de rebaixamento do lençol freático, criado pela ampliação da dolina primária. $O$ passo fundamental para o sucesso desta iniciação secundária, segundo Kemmerly (op. cit.), é a conexão de micro-canalículos abertos por dissolução, ao longo de planos de acamamento e fraturas, com os condutos maiores responsáveis pelo cone de rebaixamento do lençol.

Com o modelo acima descrito, muitas depressões simples, identificáveis na escala 1:25.000 e que contornam depressões maiores, podem ser interpretadas como sendo dolinas secundárias, ou seja, iniciadas em função da implantação das maiores. Como exemplo, citase a região centro leste da área do Lajeado, conforme é representado na fig 3.16, extraída do mapa morfológico (anexo 3.4).

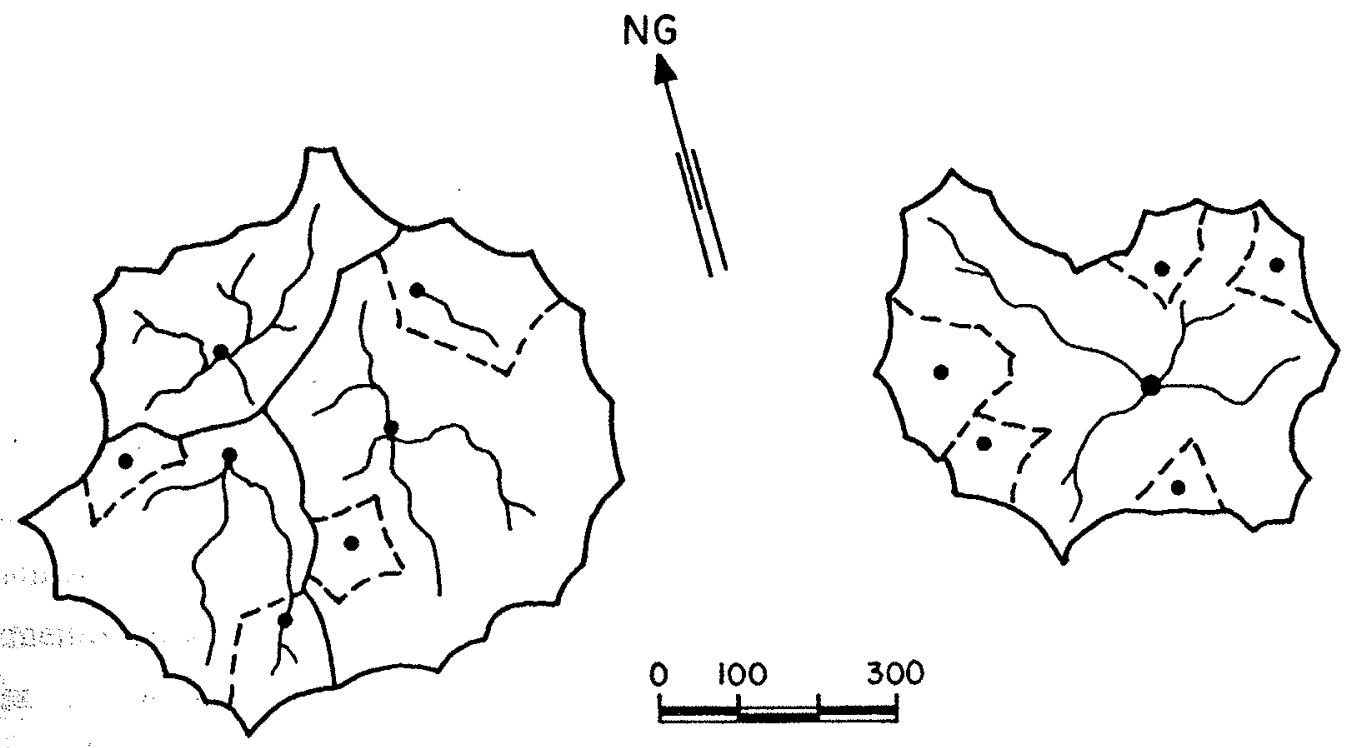

Figura 3.16 - Depressões secundárias (linha tracejada) contornando a depressão principal Exemplo extraído do mapa morfológico da area Lajeado Bombas 


\subsubsection{Depressões poligonais e a paleodrenagem fluvial}

A ocorrência de uma fase fluvial, anterior ao desenvolvimento do relevo cárstico, é considerada na literatura, desde os trabalhos de Penck (1900) e Lehmann (1936)_e Roglic (1960). Com esta idéia em mente, Monroe (1974), Gunn (1978 e 1981a) e Miller (1982), apud Ford e Williams (1989), evidenciaram o processo de transformação da paisagem fluvial para a de bacias poligonais fechadas, através da reconstrução da paleodrenagem superficial sobre o carste de Porto Rico, Nova Zelândia e Belize. Esta transformação é conseqüência do aumento gradativo da capacidade de drenagem subterrânea em rochas carbonáticas (desenvolvimento de permeabilidade secundária) e a evolução de dolinas de dissolução, com respectivas bacias poligonais, sobre os canais e vales fluviais.

Nas áreas carbonáticas em estudo, o alinhamento de sumidouros e respectivas bacias poligonais, assim como, dos talvegues remanescentes entre alguns sumidouros, no interior destes polígonos, sugerem o traço de uma drenagem fluvial anterior, onde um grande número das insurgências observadas, desenvolveram-se sobre estes canais, segmentando-os.

A zona morfológica de transição (anexo 3.5), constituída principalmente por depressões compostas, ilustra o estágio intermediário de desmembramento da rede de drenagem superficial em bacias poligonais fechadas. Estas depressões compostas, freqüentemente exibem vestígios de talvegues, inclusive com testemunhos de sedimentos fluviais, como cascalheiras em pontos isolados. A forma alongada destas depressões, notável principalmente na área Furnas Santana, com divisores em cristas bem realçadas, paralelas ao alinhamento de insurgências sobre uma linha de fundo (antigo talvegue), a qual é segmentada ortogonalmente por divisores menos marcantes, ainda assemelha-se, em muito, à morfologia de vales fluviais encaixados.

Na figura 3.17 apresenta-se um modelo da seqüência de transformação de vales fluviais em bacias poligonais fechadas. Numa fase inicial, em função do soerguimento regional e erosão da cobertura metapelítica dos calcários, cresce a interação entre água meteórica e calcário, o qual, neste período inicial, possui reduzida permeabilidade secundária. Pouca água é, portanto, absorvida pela superficie carbonática, condicionando um lençol freático raso e desenvolvimento de canais de escoamento superficial. Assim, instala-se uma rede fluvial sobre os calcários, concomitantemente à erosão dos metapelitos sobrejacentes. Com o aumento gradativo da permebilidade secundária no pacote calcário e exposição total da sua superficie, surgem rotas de drenagem freática, e o maciço carbonático aumenta sua capacidade de absorção e transmissão de água superficial. Desenvolvem-se, nesta fase, pontos de concentração de infiltração vertical, os quais, instalam-se preferencialmente ao longo dos talvegues fluviais, pois estes, concentram o escoamento superficial. Desta maneira, diminui o volume de escoamento superficial e feições cársticas, como dolinas de dissolução, iniciam a se implantar, imprimindo características fluviocársticas sobre a paisagem. Através do contínuo aumento de drenagem subterrânea e ampliação das rotas preferenciais de percoloção vertical, ampliam-se as dolinas de dissolução, o que resulta no desenvolvimento de drenagens centrípetas e início de segmentação das linhas de escoamento superficial, através da instalação de divisores 
PLANTA

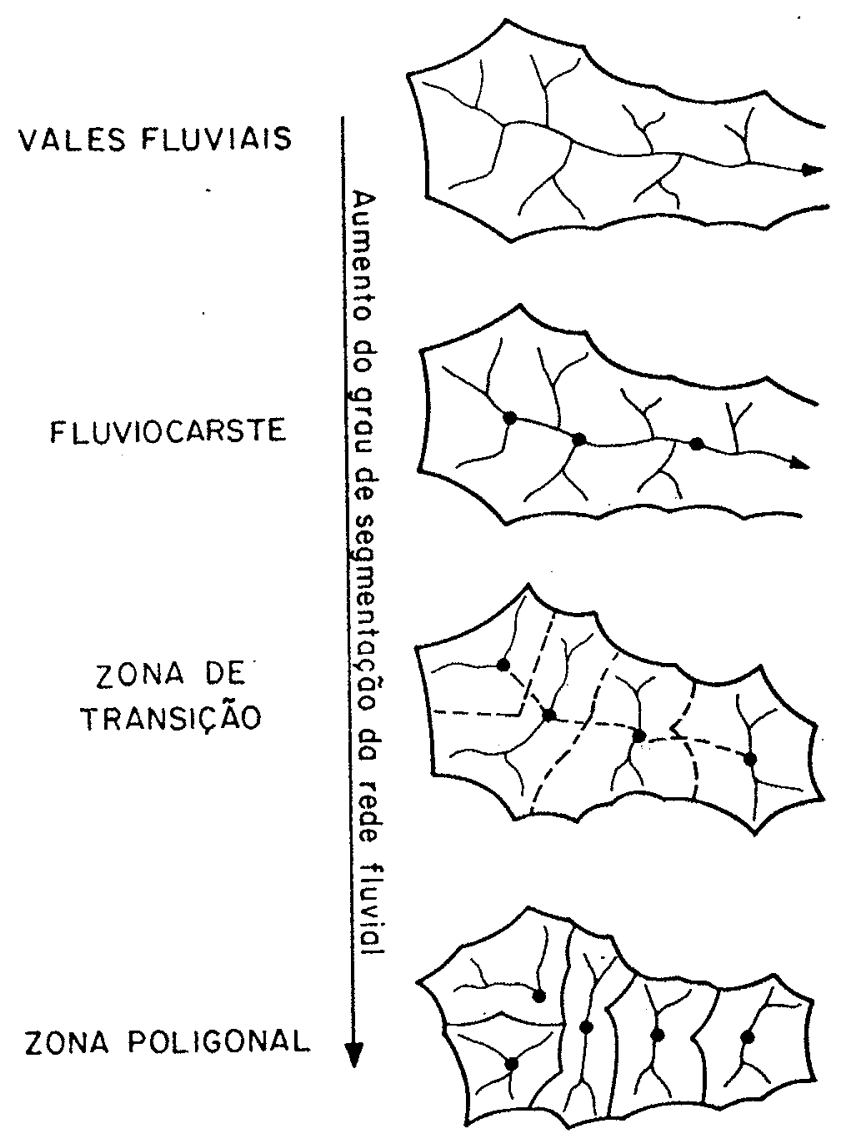

PERFIL

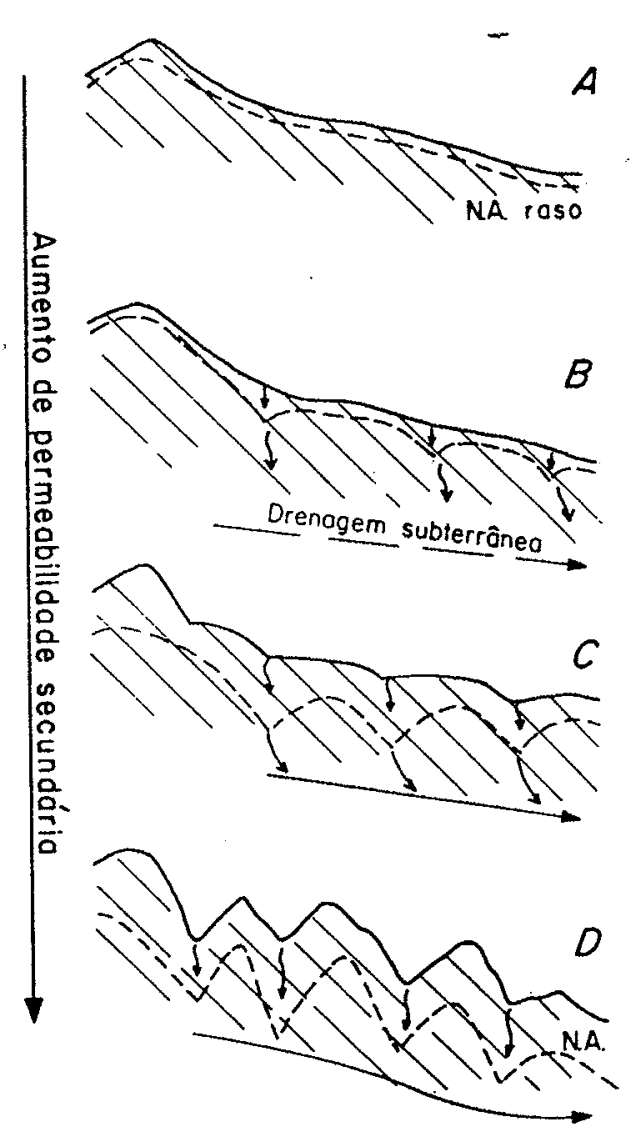

Figura 3.17 - Seqüência evolutiva de depressões poligonais a partir da drenagem fluvial. A- Fase inicial de exposição dos metacalcários. Drenagem superficial ativa e lençol freático raso.

B- Drenagem superficial parcialmente ativa. Instalação de pontos de absorção do escoamento superficial. Rebaixamento do lençol freático sobre estes pontos.

C- Drenagem superficial segmentada. Instalação de dolinas de dissolução. Desenvolvimento de divisores entre sumidouros.

D- Ampliação dos divisores entre sumidouros e estabelecimento de bacias poligonais fechadas.

topográficos entre estas bacias. Neste estágio, o desmembramento da rede fluvial torna-se evidente, e a paisagem fluvial gradativamente dá lugar a de depressões compostas. Com a evolução destas depressões, cresce o grau de segmentação da rede fluvial, através da instalação de novos pontos de absorção vertical (dolinas secundárias), rebaixamento dos fundos de dolinas e desenvolvimento de divisores topográficos entre estas, atingindo a morfologia atualmente observada, com depressões simples e compostas. A tendência evolutiva desta paisagem é a total obliteração de sua história fluvial passada, pois com a dissecação dos antigos interflúvios, pela implantação de dolinas sobre estes, além do processo de inversão de relevo, através da competição entre depressões, as antigas rotas de escoamento superficial acabam sendo substituídas pelo reticulado de bacias poligonais fechadas, conforme é exemplificado por Williams (1972b), sobre o carste da Nova Guiné. 
Uma vez reconhecida a herança fluvial, parcialmente preservada, na zona poligonal, é possível obter o traçado aproximado da antiga rede de drenagem superficial sobre os calcários. Nas figuras 3.18 e 3.19 é apresentada a reconstrução dos antigos padrões de drenagem sobre as áreas carbonáticas Lajeado-Bombas e Furnas-Santana. O critério essencial utilizado para este traçado foi a disposição sub-paralela entre os alinhamentos de cumes de cones cársticos e os fundos de depressões maiores, sobre os mapas morfológicos Os cones cársticos representam testemunhos dos interflúvios, hoje dissecados. Os fundos de dolinas, correspondem, aproximadamente, à superficie rebaixada dos paleo-talvegues do sistema fluvial.

A reconstrução da paleo-drenagem sobre a área carbonática Furnas-Santana (fig. 3.18), exibe um padrão geral em treliça, fortemente guiado pela direção estrutural NE-SW, com o rio Betari sendo o nível de base local. Na margem direita do rio Betari, a paleo-bacia hidrográfica do rio Furnas era responsável pelo escoamento superficial da área carbonática. Esta bacia subdividia-se em três sub-bacias principais: a do rio Pérolas, rio do Grilo e a do próprio rio Furnas. Com o desenvolvimento de bacias poligonais e drenagem subterrânea, estas rotas fluviais acabaram sendo capturadas, respectivamente, pelos sistemas de drenagem subterrânea Santana-Pérolas, do Grilo e do Córrego Grande, que hoje formam nascentes cársticas ao longo da margem direita do rio Betari. Na margem esquerda deste rio, a paleo-drenagem era constituída pelas bacias dos rios Água Suja e Morro Preto-Couto, ambas associadas atualmente à sistemas de drenagem subterrânea, afluentes do Betari Neste setor nordeste, predomina a paisagem fluviocárstica, com vales secos. A zona poligonal é pouco expressiva.

Sobre os carbonatos da área Lajeado-Bombas, a paleo-drenagem exibe um padrão predominantemente dendrítico, no setor sudoeste, e dendrítico a retangular, no setor nordeste (fig. 3.19). É possível individualizar quatro sistemas de drenagem maiores, que eram responsáveis pelo escoamento superficial dos carbonatos: as sub-bacias associadas ao rio Betari, a bacia do córrego Sem Fim, a drenagem do córrego Bombas e o sistema do córrego Cotia de Cima. Na margem esquerda do rio Betari, as paleo-bacias do córrego Ouro Grosso e Alambarí drenavam os fluxos alogênicos, que cruzavam os carbonatos, desaguando no Betari. Hoje representam importantes sistemas de circulação subterrânea, com ressurgências cársticas na borda da planície aluvial do rio Betari. Na sua margem direita, ocorria a paleo-bacia do córrego Macaquinhos, atualmente com suas águas ressurgindo, em parte, no córrego Seco (ressurgência intermitente) e ao longo de nascentes menores junto à borda sul da planície do Betari. $O$ traçado da paleo-drenagem na região sudoeste do Lajeado, sugere que o escoamento superficial, desta área, era coletado pelo córrego Sem Fim, ou um antigo canal, que acompanhava a zona de contato com os metapelitos, até o rio Betari. Com a implantação da drenagem subterrânea associada aos sistemas de cavernas Areias e Córrego Fundo (fig.3.19), esta bacia hidrográfica superficial deixou de existir.

O desenvolvimento da drenagem subterrânea é tema do capítulo 4 , onde sua relação com a drenagem superficial será retomada. 


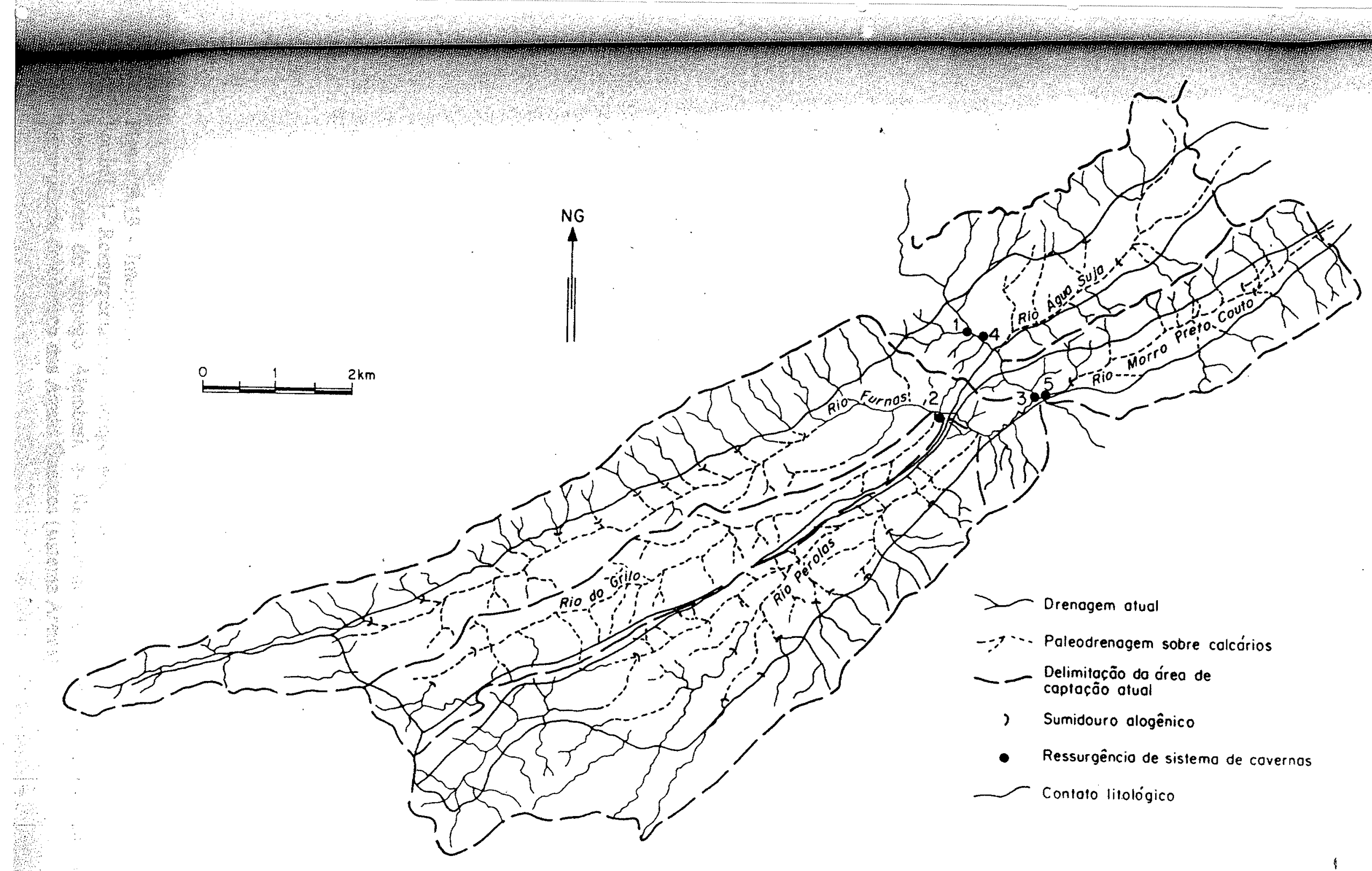

Figura 3.18 - Interpretação do traçado da paleodrenagem fluvial da área Furnas-Santana. 1- Ressurgência do córrego Grande. 2- Ressurgência do córrego do Grilo. 3- Ressurgência do córrego Roncador (caverna Santana). 4- Ressurgência do córrego Água Suja. 5Ressurgência do córrego do Couto. 


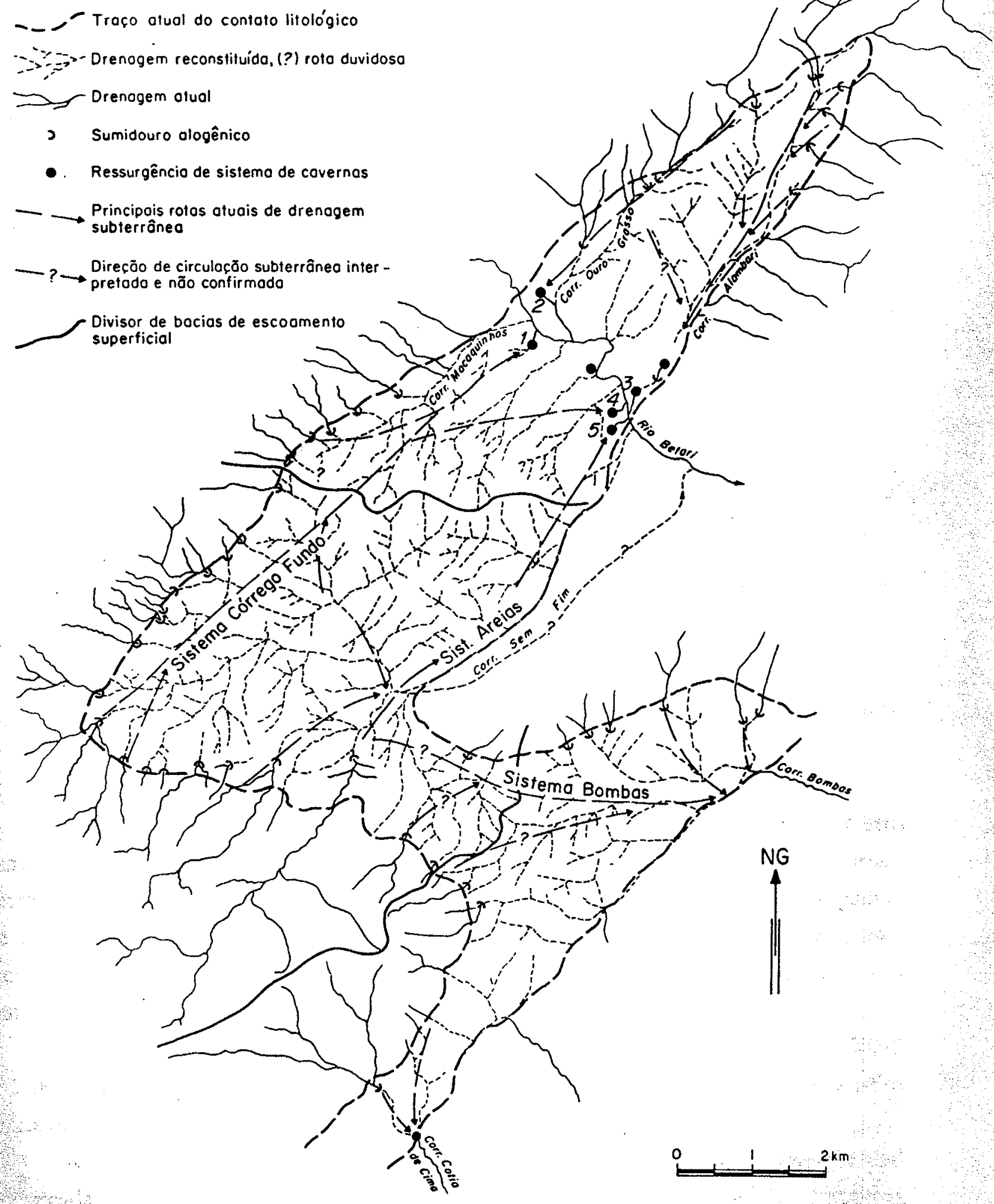

Figura 3.19 - Interpretação do traçado da paleodrenagem da área carbonática LajeadoBombas 1- Ressurgência da córrego seco 2-Ressurgência do córrego Ouro Grosso 3 Ressurgência do córrego Alambari 4 - Ressurgência do Lago do Bairro da Serra 5 Ressurgência do córrego das Águas Quentes (sistema Areias) 


\section{3.: Morfometria das áreas de amostragem}

Com o objetivo de produzir uma descrição quantitativa do relevo cárstico do Alto Riir:eira e abstrair o aspecto subjetivo da classificação qualitativa e genética (Trudgill, 1985), pruızedeu-se à medição de algumas características morfométricas, que expressam valores numericos de fatores de relevo, drenagem, tamanho e forma da paisagem cárstica. Foram seguidas, em grande parte, as recomendações expressas nos trabalhos clássicos de Williams ( $-1,1972$ b), White e White (1979 e 1987) e Troester et. al. (1984), sobre morfometria de ter renos cársticos. Este conjunto de medidas, fornece também, uma base mais precisa para reziizar estudos comparativos entre diferentes áreas, com distintos condicionantes litcestruturais e climáticos do relevo (Williams, 1971).

Na tabela 3.1 é apresentada a proporção ocupada por cada unidade morfológica, em reiáão ao total da área carbonática investigada. As medidas foram obtidas sobre os mapas mcriológicos, o que implica em erro estimado de até $5 \%$.

\begin{tabular}{|c|c|c|c|c|}
\hline \multirow[t]{2}{*}{ Zona Morfológica } & \multicolumn{2}{|c|}{$\begin{array}{l}\text { Área total de } \\
\text { cada zona }\left(\mathbf{K m}^{2}\right)\end{array}$} & \multicolumn{2}{|c|}{$\begin{array}{l}\text { Porcentagem } \\
\text { de cada zona }\end{array}$} \\
\hline & FS & LB & FS & LB \\
\hline Fluvial & 3.64 & 6.1 & 13.2 & 13 \\
\hline Fluviocárstica & 9.11 & 5.68 & 33.1 & 12.1 \\
\hline Contato & 4.34 & 8.39 & 16 & 17.9 \\
\hline Transição & 4.97 & 8.81 & 18.1 & 18.7 \\
\hline Poligonal & 5.39 & 18.02 & 19.6 & 38.3 \\
\hline $\begin{array}{l}\text { Area total de } \\
\text { rocha carbonática }\end{array}$ & 27.5 & 47.1 & & \\
\hline
\end{tabular}

Tabela 3.1- Distribuição quantitativa das zonas morfológicas nas áreas estudadas. FS, área FurnasSantana; LB, área Lajeado-Bombas.

A zona fluvial é caracterizada morfometricamente pelo gradiente $(\Delta \mathrm{H} / \Delta \mathrm{L})$ de seus carizis principais e a amplitude dos talvegues associados. Enquanto os rios Betari e Furnas, scrte metapelitos e metapsamitos, possuem inclinação entre 0,2 e 0,03 , com desvio padrão de - . 1, sobre os metacalcários este valor é de 0,018 e 0,009, com desvio padrão de 0,0047, ricsiando canais mais uniformes e menos inclinados. Quanto aos talvegues, suas amoiitudes variam de 60 a 1100 metros, sobre os carbonatos, e de 20 a $40 \mathrm{~m}$ nos pelitos.

A zona fluviocárstica, em contraste com a fluvial, possui gradientes médios de 0,012 a 005 com desvio padrão de 0,0025 , mostrando pequena variabilidade, característica tirıca de sistemas fluviais senis, associados à planícies.

A zona de contato caracteriza a passagem de rochas insolúveis para solúveis, a qual é marcada por um importante desnível topográfico, que condiciona uma série de drenagens associadas aos vales cegos. Com base em 21 medidas de comprimento e desnível de vales cesss (parte destes representados na fig 3.5), contornando tanto a área Furnas Santana como Lajeado Bombas, obtiveram-se valores morfométricos dos canais principais deste rales, conforme é apresentado na tabela 32 


\begin{tabular}{|c|c|c|c|c|c|}
\hline Parimetro & $\begin{array}{l}\text { Valor } \\
\text { Min. }\end{array}$ & $\begin{array}{l}\text { Valor } \\
\text { Máx. }\end{array}$ & Variagato & Média & Desvio Padrzo \\
\hline Comprimento $(\mathrm{AL})$ & 890 & 5090 & 4200 & 1557.6 & 1003.3 \\
\hline Desnfrel $(\Delta \mathrm{H})$ & 265 & 575 & 310 & 357.7 & $90.4-$ \\
\hline Gradiente $(\Delta H / \Delta L)$ & 0.113 & 0.348 & 0.235 & 0.26 & 0.058 \\
\hline
\end{tabular}

Tabela 3.2- Parâmetros morfométricos dos vales cegos

Relacionando o gradiente médio com o comprimento destes canais, foi obtida uma relação inversamente proporcional, ou seja, quanto maior o comprimento do canal, menor é sua inclinação média. Esta observação coincide com a generalização de que a maioria dos rios possui perfis longitudinais, que seguem uma função exponencial definida (Shulits, 1941 e Hack, 1973, apud White e White, 1983). Para os vales cegos em questão, a melhor curva de regressão obtida do gradiente médio em relação ao comprimento dos canais é a função logaritmica $\ln G=2,574-0,546 \ln \Lambda \mathrm{L}$ (fig 3.22), com coeficiente de correlação $-0,92$ e $\mathrm{R}^{2}$ de $84 \%$.

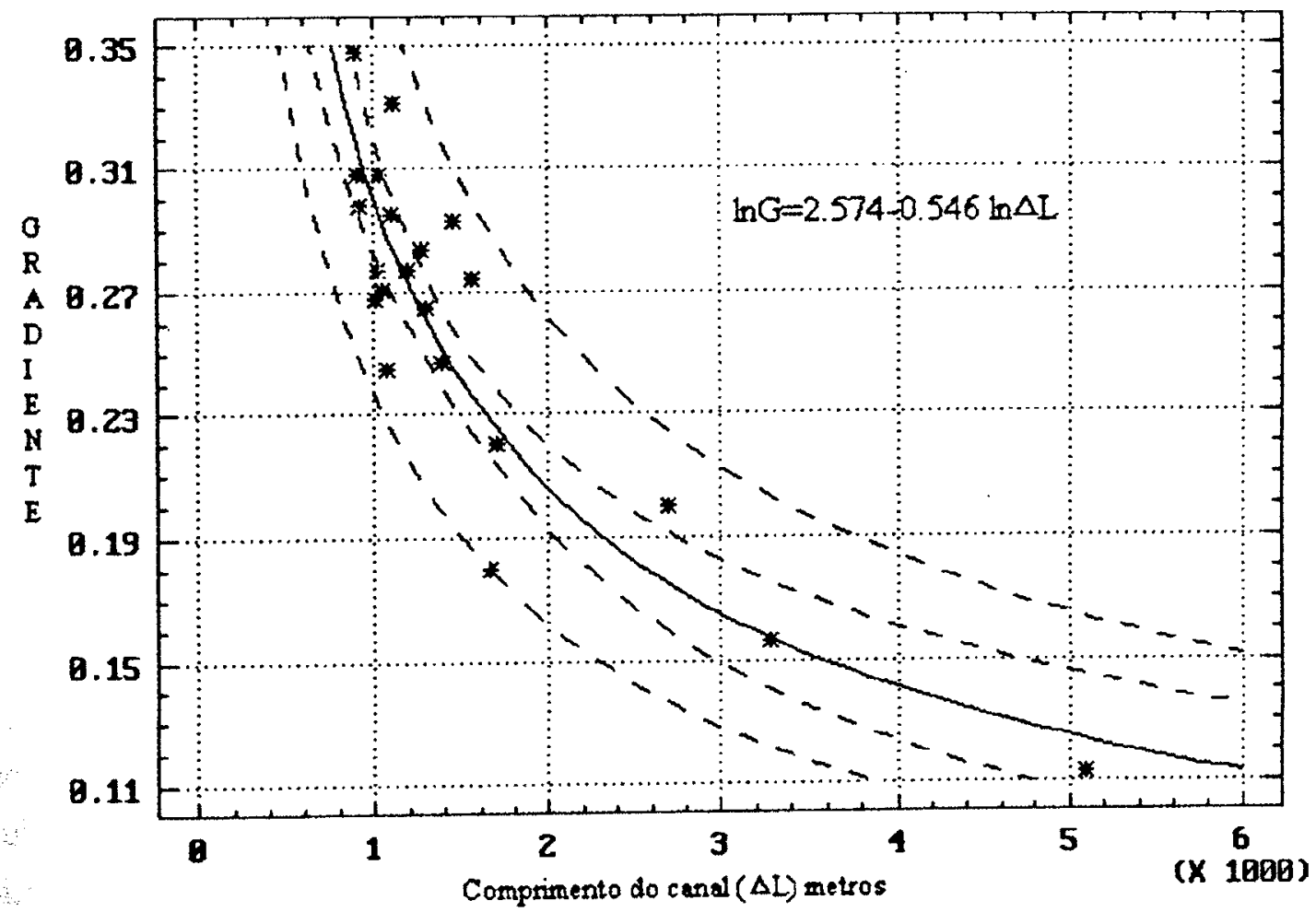

Figura 3.20 - Variação do gradiente médio $(G)$ em função do comprimento de vales cegos ( $\Delta L)$. 21 medidas.

A dispersão dos pontos neste modelo exponencial, pode ser relacionada à características estruturais dos metapelitos adjacentes a calcários. Se o substrato rochoso fosse homogêneo e isótropo, a direção e inclinação dos canais fluviais seria unicamente controlada pela direção do gradiente hidráulico, o que produzinia perfis longitudinais mais constantes, com um ajuste perfeito sobre a curva de gradiente versus comprimento. Mas, como as rochas da área são intensamente estruturadas, com planos de acamamento, foliação 
metamórfica e conjuntos de fraturas, o desenvolvimento dos canais fluviais acaba sendo parcialmente desviado da direção principal do gradiente hidráulico, através de direções secundárias, guiadas por estruturas mais favoráveis ao intemperismo e entalhamento fluvial. Desta maneira, geram-se perfis, cujos comprimentos são maiores do que o esperado teoricamente, em função de seu desnivel, o que reflete uma variação na assinatura exponencial dos vales cegos observados

Um aspecto importante, para relacionar a morfometria do sistema de circulação fluvial com o cárstico, é o número de sumidouros de córregos alogênicos e o de ressurgências cársticas, conforme Smith e Atkinson (1976). Com a medida destes índices, calculou-se a densidade de sumidouros alogênicos e de ressurgências, para ambas as áreas (tab 3.3). A razão entre sumidouros alogênicos e ressurgências (Rsr) expressa o grau de ramificação subterrânea da circulação cárstica (Trudgill, 1985). Sistemas distributivos, como aqueles com baixo gradiente hidráulico ou grandes volumes de água subterrânea, terão razões baixas, próximas ou menores que um. Sistemas integrados, com rotas de drenagem subterrânea pouco ramificadas, assemelhando-se à rios superficiais, terão razões altas, como é o caso das áreas estudadas $(\mathrm{Rsr}=8,6$ e 12,5), onde um grande número de sumidouros é drenado para poucas ressurgências.

\begin{tabular}{|l|c|c|}
\hline Indice morfonétrico & Area Furnas Santana & Area Lajeado Bombas \\
\hline Ärea aflorante de calcário (Ac), $\mathrm{Km}^{2}$ & 27.5 & 47.1 \\
\hline No.de sumidouros alogênicos (Sa) & 43 & 111 \\
\hline No.de ressurgências (R) & 5 & 9 \\
\hline Densidade de sumidouros (Ds = Sa/Ac) & 1.56 no. $/ \mathrm{km}^{2}$ & 2.35 \\
\hline Densidade de ressurgências (Dr = R/Ac) & 0.18 no. $/ \mathrm{km}^{2}$ & 0.19 \\
\hline $\begin{array}{l}\text { Razão sumidouro : ressurgência (Rst } \\
\mathrm{Sa} / \mathrm{R})\end{array}$ & 8.6 & 12.3 \\
\hline
\end{tabular}

Tabela 3.3- Índices morfométricos de sumidouros alogênicos e ressurgèncias das áreas estudadas.

Nota-se uma grande semelhança entre as densidades de ressurgências das duas áreas estudadas, apesar destas apresentarem áreas aflorantes e demais índices bastante contrastantes. Este fato é interpretado como sendo reflexo de um padrão geral da drenagem subterrânea, o qual, também deve ser semelhante nas duas áreas carbonáticas, ou seja, os sistemas integrados de ambas as áreas devem apresentar um grau de ramificação semelhante.

Sobre as zonas poligonal e de transição, ocupadas por depressões simples e compostas, foram medidos os seguintes índices morfométricos: número de depressões poligonais (Nd), número de sumidouros autogênicos associados à depressões (Ns), área ocupada por depressões (Ad), área e perímetro de cada depressão e profundidade de uma amostra de depressões, sobre mapas topográficos 1:10.000.

Com estes resultados, foram obtevidos os parâmetros resumidos na tabela 3.4, discutidos em seguida. 
Densidade de depressões. Expressa a freqüência de ocorrência de depressões por unidade de área. Segundo Day (1976), este parậmetro, aliado à dimensões planialtimétricas, indica o grau de desenvolvimento e intensidade do relevo cárstico.

Propõem-se distinguir a densidade de depressões sobre o total de rocha carbonática aflorante (Ddt), utilizada pela maioria dos trabalhos morfométricos consultados, da densidade de depressões interna a zona poligonal (Ddp). Esta distinção, tem por objetivo, possibilitar a comparação entre densidades de depressões em zonas poligonais diferentes, as quais estão, cada uma, associadas à variadas proporções de unidades morfológicas não poligonais, como é o caso do Alto Ribeira.

As áreas Furnas-Santana e Lajeado-Bombas, com superficies de 27,5 e $47,1 \mathrm{~km}^{2}$, possuem densidades de depressões sobre o total da área calcária (Ddt) de 2,91 e 7,45/km², respectivamente. Por outro lado, as densidades de depressões internas às zonas poligonais destas áreas (Ddp) correspondem a 7,72 e 13,08/ $\mathrm{km}^{2}$

Deve-se ressaltar a forte dependência destes valores da escala de observação, neste caso de 1:25.000, pois, conforme a escala é ampliada, depressões menores tornam-se demarcáveis, obviamente alterando o valor de sua densidade.

O resultado de Ddp obtido para o Alto Ribeira enquadra-se na faixa de valores típicos para áreas tropicais, quando comparado às densidades obtidas para a Jamaica $\mathrm{e}$ Porto Rico, nas escalas de 1:24.000, por Day (1976) e Troester et. al. (1984) e na Nova Guiné, na escala 1:28.000 (Williams, 1972b), conforme a tabela 3.4. Os valores de Ddp do carste da Nova Guiné, obtidos por Williams (1972b), são praticamente iguais à densidade de depressões obtida para a área Lajeado-Bombas, apesar destas áreas apresentarem condições climáticas contrastantes. Os dois locais da Nova Guiné, localizados em latitudes de 5030', experimentam médias pluviométricas anuais de 3698 e $5761 \mathrm{~mm}$, respectivamente, onde o primeiro (Darai Hills) apresenta um clima tropical sub-alpino, com temperaturas médias anuais de 10 a $13^{\circ} \mathrm{C}$ e o segundo (Mt. Kaijende), possui clima tropical úmido, com média anual de 22 a $27^{\circ} \mathrm{C}$. O carste do Alto Ribeira, numa latitude de $24^{\circ} 35^{\prime}$, em contraste, apresenta média pluviométrica de $1690 \mathrm{~mm}$ e clima sub-tropical úmido, com média anual de $19^{\circ} \mathrm{C}$. Isto confirma que um certo padrão morfológico pode ocorrer com o mesmo grau de desenvolvimento, em condições climáticas variadas, reforçando a hipótese de Smith e Atkinson (1976). Portanto, o significado deste parâmetro morfométrico é puramente geométrico, sendo útil para comparar o grau de desenvolvimento de áreas diferentes, mas sem conotações climáticas bem definidas (Troester et. al., 1984)

Indice de dolinamento (ID). Englobando depressões simples e compostas (zona de transição e poligonal), a área total ocupada por depressões, nos calcários Furnas Santana e Lajeado Bombas, é de 10,36 e $26,83 \mathrm{~km}^{2}$, respectivamente, resultando em índices de dolinamento de 2,65 e 1,75, conforme a definição de Williams (1972b), deste índice. Embora estes números possam apresentar uma certa flutuação, em função do refinamento da fotointerpretação e da escala da base utilizada, eles expressam, numericamente, um importante aspecto visual qualitativo do relevo. Observando os mapas morfológicos, ou as 


\begin{tabular}{|c|c|c|c|c|c|c|c|}
\hline \multirow{2}{*}{$\frac{\text { Parâmetro }}{\text { Área de calcário } \mathrm{Ac}, \mathrm{Km}^{2}}$} & \multicolumn{2}{|c|}{$\begin{array}{c}\text { Alto Ribeira } \\
\text { Furnas Lajeado } \\
\text { Santana Bombas } \\
\end{array}$} & \multicolumn{2}{|c|}{$\begin{array}{c}\text { Nore Guiné } \\
\text { Williams, 1972 } \\
\text { Darai Hills M.Kajende }\end{array}$} & \multirow{2}{*}{$\begin{array}{c}\text { Jamaica } \\
\text { Day, } \\
1976 \\
13.0 \\
\end{array}$} & \multicolumn{2}{|c|}{$\begin{array}{l}\text { EUA } \\
\text { Apalaches Porto Rico } \\
\text { Troester, et.al, } 1984 \\
\end{array}$} \\
\hline & 27.45 & 47.1 & 13.84 & 13.18 & & 4134 & -799 \\
\hline No. de depressôes poligonais, $\mathrm{Nd}$ & 80 & 351 & 188 & 172 & 37 & 5160 & 4308 \\
\hline No. de sumidouros autogenicos, $\mathrm{Ns}$ & 173 & 699 & $188^{*}$ & $172^{*}$ & $37 *$ & - & - \\
\hline $\begin{array}{l}\text { Area ocupada por depressões, Ad } \\
\text { (dep.simples + compostas) } \mathrm{Km}^{2}\end{array}$ & 10.36 & 26.83 & 13.84 & 13.18 & 5.41 & - & 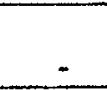 \\
\hline $\begin{array}{l}\text { Profundidade média das depressōes, } \\
\text { metros }\end{array}$ & 20.1 & 15.2 & - & - & 18.4 & 7.8 & 19.0 \\
\hline Perímetro médio das depressōes & & 1.22 & - & - & - & - & - \\
\hline $\begin{array}{l}\text { Densidade de depressóes sobre a á- } \\
\text { rea total Ddt }=\mathrm{Nd} / \mathrm{Ac} \text {, No. } / \mathrm{Km}^{2}\end{array}$ & 2.9 & 7.45 & 13.6 & 13.1 & 2.85 & 1.25 & 5.4 \\
\hline $\begin{array}{l}\text { Densidade de depressões sobre a zo- } \\
\text { na poligonal } \mathrm{Ddp}=\mathrm{Nd} / \mathrm{Ad}\end{array}$ & 7.72 & 13.08 & 13.6 & 13.1 & 6.8 & & \\
\hline $\begin{array}{l}\text { Densidade de sumidouros autogêni- } \\
\cos \mathrm{Da}=\mathrm{Ns} / \mathrm{Ac}, \mathrm{No} . / \mathrm{Km}^{2}\end{array}$ & 6.3 & 14.8 & $13.6^{*}$ & $13.1^{*}$ & $2.85^{*}$ & - & - \\
\hline Indice de dolinamento ID $=\mathrm{Ac} / \mathrm{Ad}$ & 2.65 & 1.75 & 1.0 & 1.0 & 2.40 & - & $=$ \\
\hline Razão de dolinamento $\mathrm{Rd}=\mathrm{Ad} / \mathrm{Ac}$ & 0.376 & 0.57 & 1.0 & 1.0 & 0.416 & - & - \\
\hline $\begin{array}{l}\text { Indice de sumidouros autogênicos } \\
\text { IS }=\mathrm{Ns} / \mathrm{Nd}\end{array}$ & 2.2 & 2.0 & 1.0 & 1.0 & 1.0 & - & - \\
\hline $\begin{array}{l}\text { Area média por depressão } \\
\mathrm{Adm}=\mathrm{AdNd} \mathrm{Km}^{2} / \mathrm{dep}\end{array}$ & 0.13 & 0.076 & 0.07 & 0.08 & 0.15 & - & - \\
\hline
\end{tabular}

Tabela 3.4 - Parâmetros morfométricos do carste poligonal do Alto Ribeira num quadro comparativo com outras áreas cársticas. * valôres calculados com os dados publicados pelos autores citados.

fotos aéreas correspondentes, de ambas as áreas, nota-se que a área Lajeado-Bombas exibe um padrão mais desenvolvido de depressões e uma drenagem superficial mais desorganizada em relação aos carbonatos Furnas-Santana, ou seja, qualitativamente, afirmase que o relevo cárstico poligonal é mais desenvolvido sobre a primeira área. Esta conclusão qualitativa, é confirmada de forma mais concisa, através dos índices de dolinamento, pois, segundo Williams, op. cit., quanto mais próximo a 1 é o valor do índice de dolinamento, tanto mais desenvolvido será o relevo poligonal de uma região cárstica. No caso em estudo, a área Lajeado Bombas, com $\mathrm{D}=1,75$, possui relevo poligonal, cerca de $30 \%$ mais desenvolvido, em relação a área Furnas Santana, com $\mathrm{ID}=2,65$.

Razão de dolinamento (Rd). É o inverso do índice de dolinamento. Expressa a fração da área total do carste ocupada por depressões poligonais. No caso da área FurnasSantana, este parâmetro é 0,376 , o que equivale também a $37,6 \%$ da área total da área carbonática. Nos calcários Lajeado-Bombas, $57 \%$ da área total é ocupada por depressões poligonais, o que resulta na razão de dolinamento de 0,57 . Sua interpretação é semelhante ao índice de dolinamento.

Densidade de sumidouros autogênicos (Da). Indica a freqüência de pontos de absorção do escoamento superficial coletado sobre a superficie carbonática. Este número é relacionado ao grau de desmembramento da rede de drenagem superficial, isto é, quanto maior a densidade de sumidouros, tanto menor é a continuidade dos canais fuviais e, portanto, maior será o grau de segmentação destes. Este parâmetro confirma a segmentação mais avançada da rede de drenagem fluvial da area Lajeado-Bombas $\left(\mathrm{Da}=14,8 / \mathrm{km}^{2}\right)$, em comparação com a área Furnas Santana $\left(\mathrm{Da}=6,3 / \mathrm{km}^{2}\right)$. 
Índice de sumidouros autogênicos (IS). Oservando os mapas morfológicos das áreas estudadas, nota-se que muitas depressões poligonais possuem mais de um sumidouro. $O$ índice de sumidouros expressa a proporção geral de sumidouros autogênicos em relação ao total de depressões. Obteve-se valores de 2,2 e 2,0 , respectivamente, para as áreas Furnas-Santana e Lajeado-Bombas. Assim como a densidade de sumidouros, relaciona-se este índice ao grau de segmentação da drenagem superficial. A situação de máxima segmentação corresponde ao IS = 1 (como é o caso do carste da Nova Guiné, tab.3), isto é, um ponto de insurgência para cada depressão. $O$ fato de haver mais de um ponto por depressão, é resultado, principalmente, da presença de depressões compostas com remanescentes de talvegues fluviais, em processo de segmentação através da instalação de dolinas, como também, do processo de competição e coalescência de depressões.

Profundidade das depressões. Segundo Day (1976), esta é definida pela distância vertical entre o ponto mais baixo do fundo da depressão, normalmente representado por um dos sumidouros, e o ponto de menor cota de seu perímetro, delimitado por uma curva de nível, neste caso, sobre mapas topográficos 1:10.000 da área.

Foram medidas as profundidades de 105 depressões poligonais. Este número reduzido de medidas deve-se ao pouco detalhe expresso nas cartas topográficas da área, o que levou a seleção apenas das depressões bem definidas sobre as cartas.

Obtiveram-se 82 medidas sobre a área Lajeado-Bombas, as quais apresentam valor médio de $15,2 \mathrm{~m}$, desvio padrão de $10,1 \mathrm{~m}$ e valor máximo de $66 \mathrm{~m}$ e minimo de $3 \mathrm{~m}$. A depressão composta das Areias (fig 3.10), com 130 m, é considerada uma exceção. Para a área Furnas-Santana, mediu-se 23 profundidades, com valor médio de $20,2 \mathrm{~m}$, desvio padrão de $13,1 \mathrm{~m}$ e valores máximo e mínimo de 53 e $3 \mathrm{~m}$, respectivamente (tab 3.4).

Segundo White e White (1979) e Troester et. al. (1984), a distribuição de freqüência das profundidades de depressões, segue preferencialmente uma distribuição exponencial. Este comportamento matemático da profundidade de depressões é característico de diversas áreas de carste poligonal, em diferentes situações lito-estruturais e climáticas, sendo utilizada pelos autores acima para expressar numericamente a intensidade de relevo de cada área.

Para a área Lajeado-Bombas, obteve-se uma distribuição exponencial da freqüência de profundidades (fig 3.21a), com valores predominantes entre 3 e10m. Nota-se o caráter excepcional da medida de $130 \mathrm{~m}$.

A distribuição de freqüência para a área Furnas-Santana, ajusta-se melhor a uma curva normal com tendência bimodal (fig 3.21b), bastante irregular, com praticamente 3 subpopulações de medidas, entre 5 e $16 \mathrm{~m}, 20$ e $30 \mathrm{~m}$, predominante, e outra em torno de $50 \mathrm{~m}$. O ajuste não exponencial destas medidas, é interpretado como sendo conseqüência de uma falha de amostragem, pois, nesta área, conforme observado qualitativamente em campo e nas fotos aéreas, ocorre um número maior de profundidades rasas, as quais não foram detectadas sobre os mapas topográficos 1:10.000.

Reunindo as medidas de ambas as áreas, foi obtida uma típica distribuição de frequência exponencial (fig $321 \mathrm{c}$ ), considerada como representativa do carste estudado. 

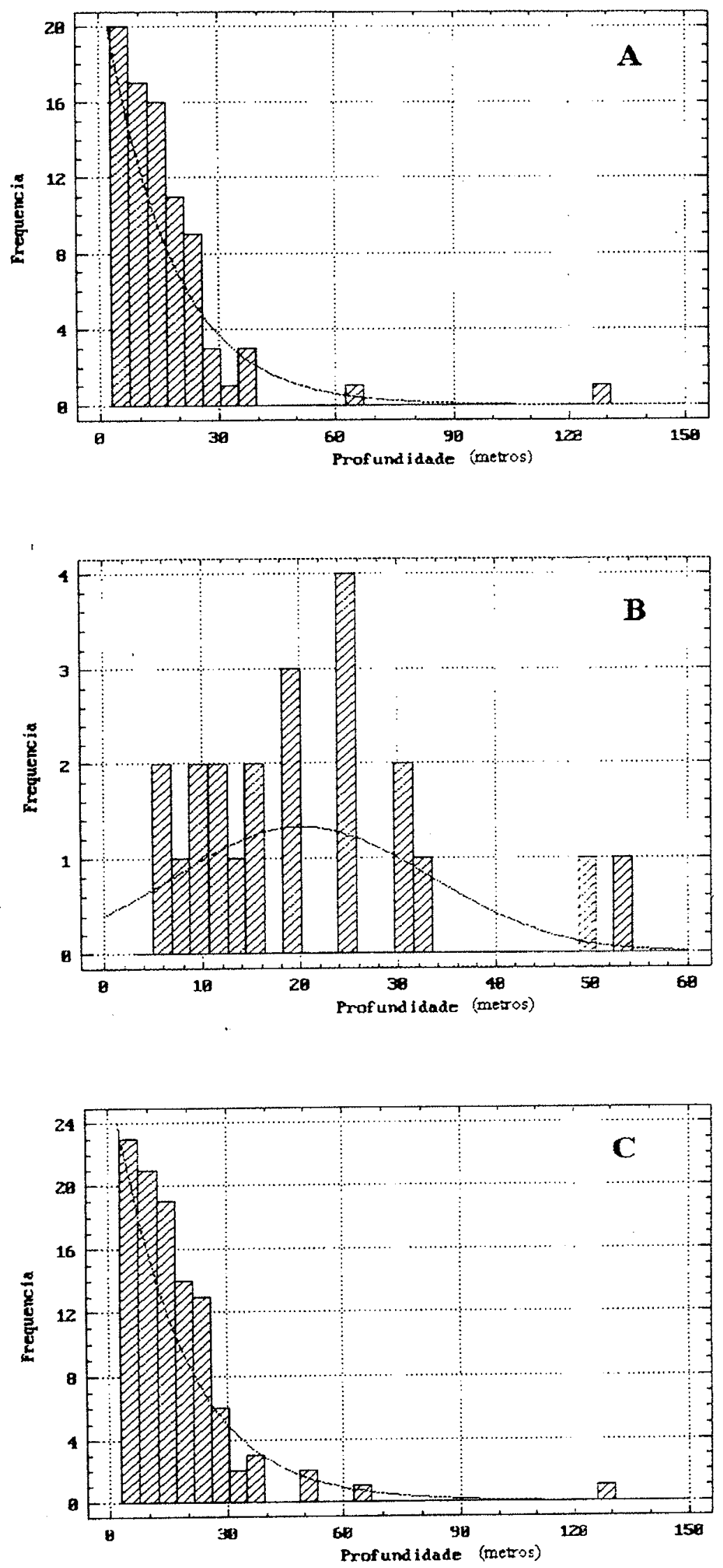

Figura 3.21 - Distribuição das profundidades de depressões poligonais do carste do Alto Ribeira A-área Lajeado-Bombas, 83 medidas. B--área Fumas-Santana, 23 medidas. Ctotal das medidas de ambas as áreas. Curvas de distribuição exponencial e normal obtidas atraves do programa Statgraphics. 
para a população geral de depressões do Alto Ribeira, com profundidades variadas, predominando entre 5 e $10 \mathrm{~m}$, e com casos esporádicos acima de $60 \mathrm{~m}$. Estas depressões mais profundas encontram-se próximas aos alinhamentos de importantes rotas de drenagem subterrânea, sendo que no caso da de $130 \mathrm{~m}$, esta interceptou o nível do rio subterrâneo.

Os resultados obtidos acima, concordam com a generalização proposta por Cramer (1941) e Troester et. al. (1984) de que há uma diferença na intensidade de relevo entre regiões cársticas temperadas e tropicais, expressa pela profundidade de depressões poligonais. A profundidade média em regiões temperadas varia entre 5,4 e $8,3 \mathrm{~m}$, enquanto que em zonas tropicais, estes valores são praticamente triplicados, com médias entre 15 e $23 \mathrm{~m}$ (Troester, op. cit.).

A definição exata deste parâmetro, depende da qualidade (resolução) dos mapas topográficos da área cárstica, ou de um exaustivo levantamento de campo, para obtenção de um número de medidas estatisticamente representativo. No caso estudado, a única base disponível em escala maior, é o levantamento 1:10.000 (DAEE, 1957), deficiente em detalhes. Deverá ser executado, numa etapa futura de trabalho, levantamento de campo para refinar o resultado aqui obtido.

Área e perímetro de depressões. Williams (1972b), demonstrou sobre o carste da Nova Guiné, que a área de depressões poligonais cresce geometricamente com o aumento da ordem de Strahler da drenagem interna às depressões, através da regressão do logarítmo da área em relação a ordem da drenagem interna. Esta relação é similar àquela que expressa a área de bacias de drenagem na morfometria fluvial, o que suporta a idéia de que depressões poligonais cársticas são pequenas bacias de drenagem fluvial. $O$ mesmo autor, considera que esta similaridade, evidencia que as depressões poligonais são geradas principalmente por corrosão superficial pela drenagem e não por colapso de vazios subterrâneos.

White e White (1987) obtiveram para o carste do planalto dos Apalaches uma relação exponencial crescente entre a área de bacias fechadas, drenadas internamente por dolinas, e o número de dolinas no interior destas bacias.

Reams (1992) utilizou a plotagem log versus $\log$, entre área e perímetro de grandes populações de depressões do centro leste dos EUA, para testar o caráter fractal do perímetro destas. Comprovou este comportamento matemático para depressões com áreas superiores a $10.000 \mathrm{~m}^{2}\left(0,01 \mathrm{~km}^{2}\right)$, medidas sobre mapas topográficos $1: 24.000$.

Com o objetivo de testar o comportamento matemático da rede poligonal planimétrica das depressões do Alto Ribeira e obter uma expressão numérica deste, mediuse a área e perímetro da população de depressões da zona poligonal da área Lajeado Bombas. Estas medidas foram digitalizadas sobre o mapa morfológico 1:25.000 (anexo 3.4).

A média aritmética da área de 350 depressões é de $0,072 \mathrm{~km}^{2}$, com desvio padrão de 0,078 e valores mínimo e máximo de 0,00359 e $0,788 \mathrm{~km}^{2}$, respectivamente. O perímetro deste conjunto possui média de $1,22 \mathrm{~km}$, desvio padrão de $0,672 \mathrm{~km}$ e valores mínimo e máximo de 0,279 e $5,562 \mathrm{~km}$. Novamente aparece a depressão das Areias como exceção, 
pois sua área de $2,05 \mathrm{~km}^{2}$ e perímetro de $8,29 \mathrm{~km}$ são muito destoantes do resto da população, além de estar, em parte sobre metapelitos.
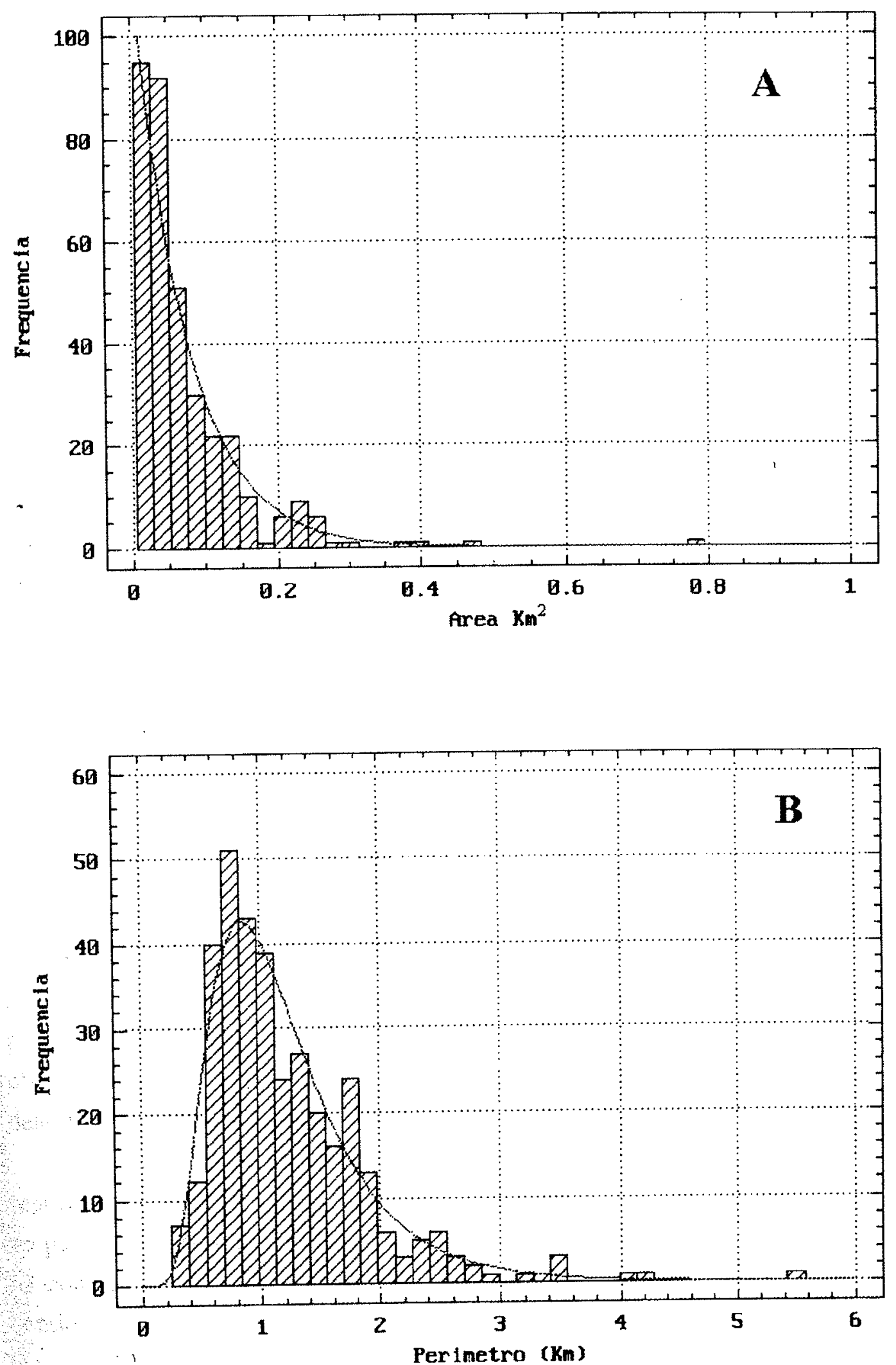

Figura 3.22 - Histogramas de freqüência e curvas de distribuição da área (A) e perímetro (B) das depressões poligonais da área carbonática Lajeado-Bombas. 
A área média por depressão (Adm) resultante do cálculo de $\mathrm{Ad} / \mathrm{Nd}$ (tabela 3.4) para a área Lajeado-Bombas é de $0,076 \mathrm{~km}^{2}$, semelhante à média aritmética das 350 medidas. Já para a área Furnas-Santana, o valor de Adm é $0,13 \mathrm{~km}^{2}$, quase o dobro da área média por depressão da região Lajeado Bombas, reflete a predominância de depressões compostas maiores nesta área. Um fato interessante observado com estas medidas, é a grande semelhança entre as dimensões planimétricas do Alto Ribeira e os valores de outras regiões cársticas (tabela 3.4), o que confirma que há um padrão geral de relevo cárstico, independente de pequenas variações locais.

Testando a distribuição de freqüência das áreas de depressões para a região Lajeado Bombas, obteve-se um ajuste exponencial decrescente da freqüência em função do aumento da área, com predominância de áreas entre 0,0036 e $0,05 \mathrm{~km}^{2}$ (fig 3.22a). Nota-se uma pequena subpopulação, com áreas em torno de 0,2 e $0,25 \mathrm{~km}^{2}$, a qual corresponde às depressões compostas.

O perímetro destas depressões obedece uma distribuição de freqüência lognormal (fig 3.22b), onde o número de ocorrências cresce rápidamente com perímetros entre $0,25 \mathrm{e}$ $0,6 \mathrm{~km}$, atingindo o máximo entre 0,6 e $0,9 \mathrm{~km}$, decrescendo regularmente até perímetros de - $3 \mathrm{~km}$. Notam-se alguns valores de exceção, assim como das áreas correspondentes, que representam depressões compostas ou testemunhos de vales fluviais em início de segmentação por dolinamento.

Conforme esperado, o gráfico das áreas versus seus perímetros, ajusta-se melhor a uma função exponencial. A equação obtida para a área Lajeado-Bombas é Per. $=5,264 \times$ Área ${ }^{0,519}$, com 351 medidas, incluindo a grande depressão das Areias (fig 3.23). O coeficiente de correlação desta relação exponencial é $0,97, \operatorname{com} \mathrm{R}^{2}=94,74 \%$.

A inclinação desta reta logarítmica reflete a taxa de variação do perímetro com o aumento da área das depressões. Ou seja, quanto mais rugoso, ou irregular é o perímetro, maior será seu comprimento, com uma pequena variação na área correspondente. Desta maneira, poderia-se relacionar o coeficiente angular ou a inclinação desta reta com o grau de rugosidade planimétrica das depressões, isto é, quanto mais inclinada a reta, tanto mais rugoso será o padrão poligonal, o que por sua vez, refleteria o número de vértices positivos presentes nos divisores do relevo. Estes vértices correspondem ao número de cones cársticos ou segmentos de cristas, o que é uma característica do relevo condicionada pela densidade de descontinuidades favoráveis ao entalhamento da superficie carbonática.

Gráficos logarítmicos da área versus perímetro de populações poligonais, representam portanto, uma assinatura quantitativa das características físicas planimétricas do padrão poligonal de uma determinada região cárstica, sendo úteis como uma referência na comparação entre diferentes regiões cársticas e seu condicionamento lito-estrutural, considerando a mesma escala de observação.

Devido à falta de cartas topográficas e fotos aéreas em escalas variadas, não se verificou o caráter fractal destes polígonos, conforme a recomendação de Reams (1992), pois para tal, seria obrigatória a obtenção de distribuições de frequência em diferentes 
escalas, para se verificar como varia o número de polígonos em função da escala

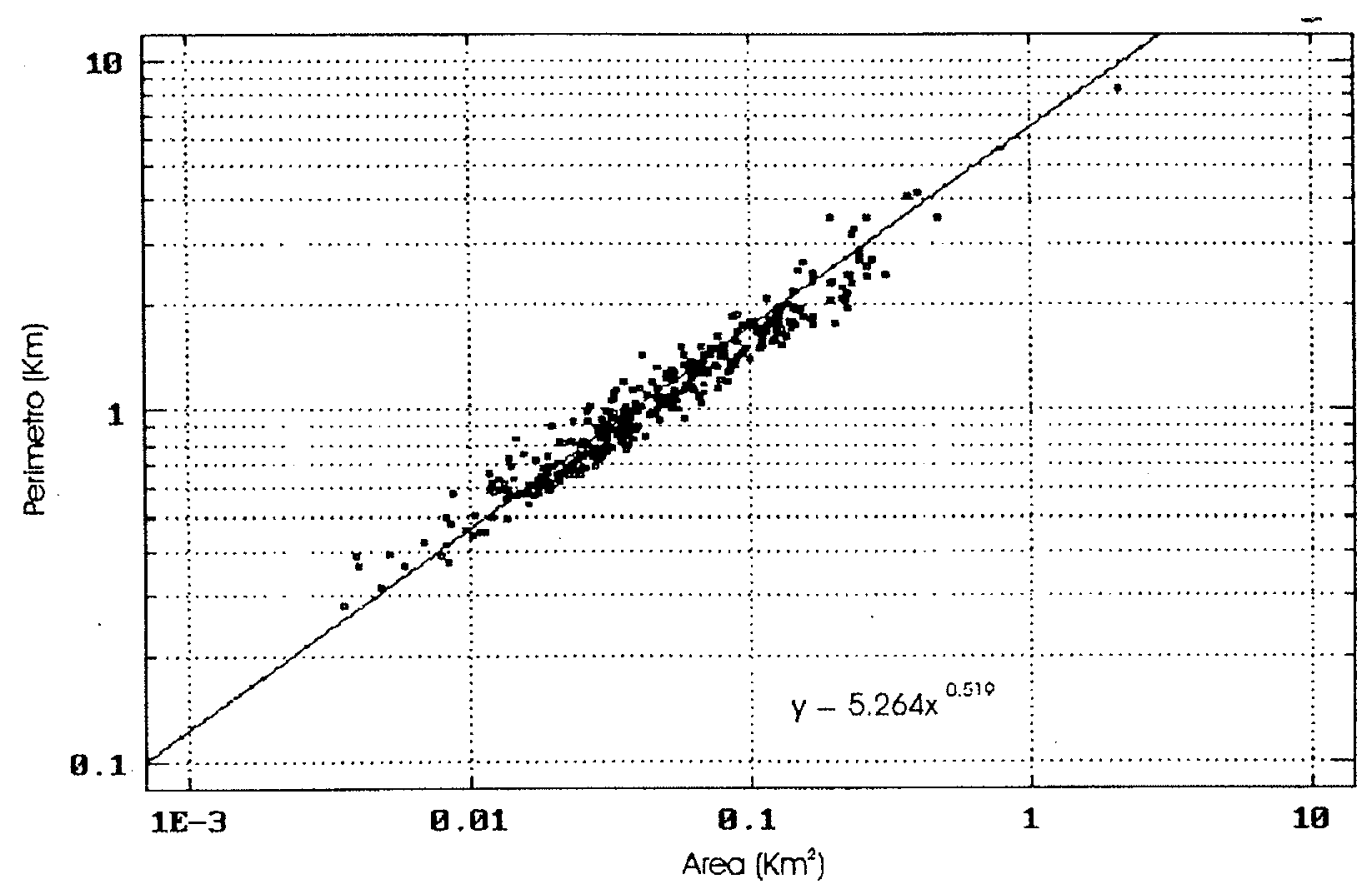

Figura 3.23- Área versus perímetro das depressões poligonais da região Lajeado-Bombas, 351 pontos, obtidos na escala 1:25.000.

de observação, seguindo a definição de Mandelbrot (1983), da dimensão fractal de figuras geométricas. Aliás, a natureza fractal ou euclidiana do carste poligonal ainda não está definida, pois, conforme as referências consultadas (White e White, 1987 e Reams, 1992), a análise em variadas escalas não foi totalmente explorada.

Não é objetivo deste trabalho discutir e testar todas possibilidades morfométricas do relevo e interpretar seu significado geológico-geomórfico, mas sim, pretende-se somente iniciar o estudo de parâmetros morfométricos, devendo aprofundar-se estas análises em trabalhos futuros.

\subsection{Condicionamento estrutural e hidrológico do relevo}

A evolução da paisagem cárstica, sobre rochas carbonáticas sem porosidade primária, é conseqüência da disponibilidade de água em movimento e o desenvolvimento progressivo de permeabilidade secundária ao longo do maciço carbonático (Smith e Atkinson, 1976 e Gunn, 1986). O desenvolvimento de permeabilidade secundária concentra-se sobre descontinuidades presentes na rocha carbonática, através da dissolução e lixiviação de minerais carbonáticos pela água de percolação ao longo destas decontinuidades. Portanto, para estabelecer os fatores condicionantes da permeabilidade secundária e, conseqüentemente, do desenvolvimento da paisagem cárstica, é fundamental conhecer os tipos de descontimuidades presentes, assim como, sua distribuição espacial na rocha soluvel.

No sentido de identificar as descontinuidades e obter um quadro geométrico destas, procedeu-se o levantamento da geologia estrutural dos corpos carbonáticos em estudo. 


\subsubsection{Geologia estrutural das áreas de estudo}

A região carbonática do Alto Ribeira foi alvo de diversos levantamentos geológicos, com ênfase na evolução tectônica, estratigrafia e análise estrutural de sua seqüência metassedimentar, conforme é apresentado no capítulo 2. Pouco detalhamento tem sido feito sobre as estruturas disruptivas, como juntas e falhas desta área.

Neste trabalho, utilizou-se como base geológica, a Folha Iporanga, 1:50.000, da carta geológica do Estado de São Paulo (Campanha, et. al., 1985) e o mapa geológico, na mesma escala, apresentado por Campanha (1991). Deste último, extraíram-se medidas de acamamento de setores das áreas Furnas-Santana e Lajeado-Bombas, não visitados durante esta pesquisa, mas importantes para caracterização da estrutura geral dos metacalcários.

As principais estruturas levantadas no presente estudo, resumem-se às superficies primárias (planos de acamamento) e, secundárias (juntas e falhas) seguindo a nomenclatura de Ramsay e Huber (1987) para estruturas disruptivas em rochas deformadas.

A ênfase dada às juntas, falhas e ao acamamento, deve-se ao fato de que estas estruturas constituem os principais guias da rede de condutos de dissolução do sistema cárstico (Deike, 1969; Ford, 1971b, Milanovic, 1981 e Lauritzen, 1989), rede esta, responsável pela permeabilidade de regiōes carbonáticas.

$\mathrm{O}$ conjunto de medidas apresentado em seguida (figuras $3.24,3.25$ e tabela 3.5 ) foi obtido durante o mapeamento geoespeleológico de cavernas da área, o mapeamento morfológico externo e a prospeç̧ão de cavernas.

\section{Definição da superficie dobrada. Medidas de acamamento.}

Os planos de estratificação das rochas carbonáticas constituem as descontinuidades mais longas e contínuas em ambas as áreas investigadas. Devido à característica rítmica da interestratificação de leitos carbonáticos, pelítico-carbonáticos e pelíticos, com espessuras centimétricas a decimétricas, pouco variáveis ao longo do estrato, o acamamento é uma superficie muito notável, sendo possível de ser seguido por dezenas de metros.

As medidas obtidas na área Furnas-Santana distribuem-se ao longo de uma guirlanda de superficie cilíndrica (fig. 3.24a), com concentração máxima de pólos no quadrante SE, refletindo a estrutura geral homoclinal com dobras parasitas métricas a decamétricas, assimétricas, de flanco NW longo e flanco SE curto, o que é expresso pelo número menor de medidas com mergulho para SE. A direção geral do acamamento é N45-70E, com mergulhos de 40 a $80^{\circ}$ para NW. As dobras parasitas possuem plano axial em torno de N65E $75 \mathrm{NW}$ e eixos S65W/10-20 . Nota-se uma tendência incipiente de espalhamento das medidas de acamamento ao longo de um círculo máximo de direção geral NE-SW, o que reflete um dobramento superposto incipiente, com início de formação de superficies cônicas, fato mais evidente na área Lajeado Bombas.

O acamamento medido na área Lajeado Bombas reflete uma estrutura geral sinformal cilíndrica (fig 3.25a), com eixo em torno de N50E/10-200, direçôes predominantes entre N30-65E e mergulhos de 60SE a 40NW: Esta estrutura sinclinale ondulada por um dobramento superposto aberto, com eixo determinado no estereograma, 


\begin{tabular}{|c|c|c|}
\hline & \multicolumn{2}{|c|}{ Atitudes Predominantes } \\
\hline Tipo de descontinuidade & Área Furnas. Santana & Área Lajeado Bombas \\
\hline Juntas Preenchidas & $\begin{array}{lccc}\text { N8E } & 85 \mathrm{NW} & \text { a } & 85 \mathrm{NE} \\
\mathrm{N} 50 \mathrm{E} & 80 \mathrm{SE} & \text { a } & 80 \mathrm{NW} \\
\mathrm{N} 16 \mathrm{~W} & 75 \mathrm{NE} & \text { a } & 75 \mathrm{NW} \\
\mathrm{N} 70 \mathrm{~W} & 70 \mathrm{SW} & \text { a } & 75 \mathrm{NE} \\
\mathrm{N} 50 \mathrm{E} & 5 & \text { a } & 20 \mathrm{SE} \\
& (126) & & \\
\end{array}$ & $\begin{array}{lccc}\text { N14E } & 70 \mathrm{NW} & \text { a } & 60 \mathrm{SE} \\
\mathrm{N} 50 \mathrm{E} & 70 \mathrm{SE} & \text { a } & 80 \mathrm{NW} \\
\mathrm{N} 10 \mathrm{~W} & 70 \mathrm{NE} & \text { a } & 70 \mathrm{NW} \\
\mathrm{N} 60 \mathrm{~W} & 76 \mathrm{NE} & \text { a } & 80 \mathrm{SW} \\
& (51) & & \end{array}$ \\
\hline Juntas Simples & $\begin{array}{llll}\text { N55E } & 75 \mathrm{NW} & \text { a } & 70 \mathrm{SE} \\
\mathrm{N} 55 \mathrm{~W} & 75 \mathrm{NE} & \text { a } & 80 \mathrm{SW} \\
\mathrm{N} 60 \mathrm{E} & 0 & \text { a } & 20 \mathrm{SE} \\
\mathrm{N} 18 \mathrm{~W} & 80 \mathrm{NE} & \text { a } & \mathrm{SW} \\
& (274) & & \end{array}$ & $\begin{array}{llcc}\text { N45E } & 84 \mathrm{NW} & \text { a } & 84 \mathrm{SE} \\
\mathrm{N} 70 \mathrm{E} & 85 \mathrm{NW} & \text { a } & 85 \mathrm{SE} \\
\mathrm{N} 60 \mathrm{~W} & 70 \mathrm{SW} & \text { a } & 80 \mathrm{NE} \\
\mathrm{N} 20-50 \mathrm{E} & 0 & \text { a } & 15 \mathrm{SE} \\
\mathrm{N} 20 \mathrm{E} & 80 \mathrm{NW} & \text { a } & 80 \mathrm{SE} \\
& (175) & & \\
\end{array}$ \\
\hline Falhas Inversas & $\begin{array}{lc}\text { N30E } & 40-60 N W \\
\text { N54E } & 60-80 S E \\
\text { N75E } & 60-80 \mathrm{SE} \\
\text { N75W } & 40-55 \mathrm{SW} \\
& (30) \\
\end{array}$ & $\begin{array}{ll}\mathrm{N} 20 \mathrm{E} & 40-70 \mathrm{NW} \\
\mathrm{N} 55 \mathrm{E} & 75 \mathrm{SE} \\
\mathrm{N} 20 \mathrm{~W} & 60 \mathrm{NE} \\
& (7)\end{array}$ \\
\hline $\begin{array}{l}\text { Falhamentos direcionais e com } \\
\text { movimento indeterminado. }\end{array}$ & $\begin{array}{ll}\text { NS } & 65-85 W \\
\text { N40E } & 80 \mathrm{SE} \text { a } 80 \mathrm{NW} \\
\text { N75E } & 65-85 \mathrm{SE} \\
\text { N30W } 70 \mathrm{NE} \\
\text { N55W } 80 \mathrm{NE} \text { a } 80 \mathrm{SW} \\
\\
\end{array}$ & $\begin{array}{cc}\mathrm{N} 15-20 \mathrm{E} & 45-80 \mathrm{SE} \\
\mathrm{N} 50-60 \mathrm{E} & 60-70 \mathrm{NW} \\
\text { N40-50W } 50-85 \mathrm{SW} \\
\text { a verticais } \\
\text { (32) }\end{array}$ \\
\hline Juntas de Cisalhamento & \begin{tabular}{ll} 
N10-15E & $80 \mathrm{NW}$ \\
N50-65E & $60-80 \mathrm{NW}$ e SE \\
EW & $70-80 \mathrm{~S}$ \\
N40-45W $60-70 \mathrm{SW}$ \\
\multicolumn{1}{c}{$(25)$} \\
\end{tabular} & $\begin{array}{l}\text { N15 - 20E verticais a } 60 \mathrm{NW} \\
\text { N10 - 20W } 70-80 \mathrm{NE} \\
\text { N50W } 70-80 \mathrm{NE} \text { e SW } \\
(19)\end{array}$ \\
\hline Falhas Normais & $\begin{array}{lc}\mathrm{N} 35 \mathrm{E} & 50 \mathrm{SE} \\
\mathrm{N} 75 \mathrm{E} & 80 \mathrm{NW} \\
\mathrm{N} 55 \mathrm{~W} & 50 \mathrm{SW} \\
& (4) \\
\end{array}$ & $\begin{array}{l}50 S W \\
(6)\end{array}$ \\
\hline Acamamento & $\begin{array}{c}\mathrm{N} 45-70 \mathrm{E} \quad 40-70 \mathrm{NW} \\
(201)\end{array}$ & $\begin{array}{ccccc}\mathrm{N} 30-65 \mathrm{E} & 60 \mathrm{SE} & \text { a } & 40 \mathrm{NW} \\
\mathrm{N} 50-70 \mathrm{~W} & 70 \mathrm{NE} & \text { e } & 60 \mathrm{SW} \\
(232) & & \\
\end{array}$ \\
\hline
\end{tabular}

Tabela 3.5 - Atitudes médias dos principais conjuntos de descontinuidades das áreas de estudo. Medidas extraídas dos estereogramas correspondentes das figuras 3.24 e 3.25. Número de medidas em parênteses

em torno de $\mathrm{S} 50 \mathrm{E} / 20^{\circ}$, produzindo direções do acamamento entre N50-70W e N25-40W, com caimentos entre 30 a $60^{\circ}$ para SW e NE (fig 3.25a). Este padrão de ondulações em domos e bacias ocorre principalmente no setor sudoeste da grande sinforma do Lajeado, onde é nitidamente expresso por camadas argilosas ressaltadas por dissolução diferencial ao longo da caverna das Areias. Nos setores central e nordeste esta superposição de dobramento é pouco notável, predominando a estrutura sinclinal simples. A estrutura homoclinal, junto ao flanco sudeste deste sinclinal, não foi detalhada neste trabalho.

\section{Sistema de fraturamento. Medidas de juntas e falhas.}

As juntas foram descritas em campo quanto a sua dimensão (comprimento), espaçamento, preenchimento e movimento relativo dos blocos adjacentes, seguindo as: recomendações de Badgley (1965) e Blés e Feuga (1986). Com esta descrição qualitativa foi possível classificar o conjunto de medidas em juntas simples ou diáclases, preenchidas ou fendas e de cisalhamento. Esta classificação teve como objetivo permitir uma análise 

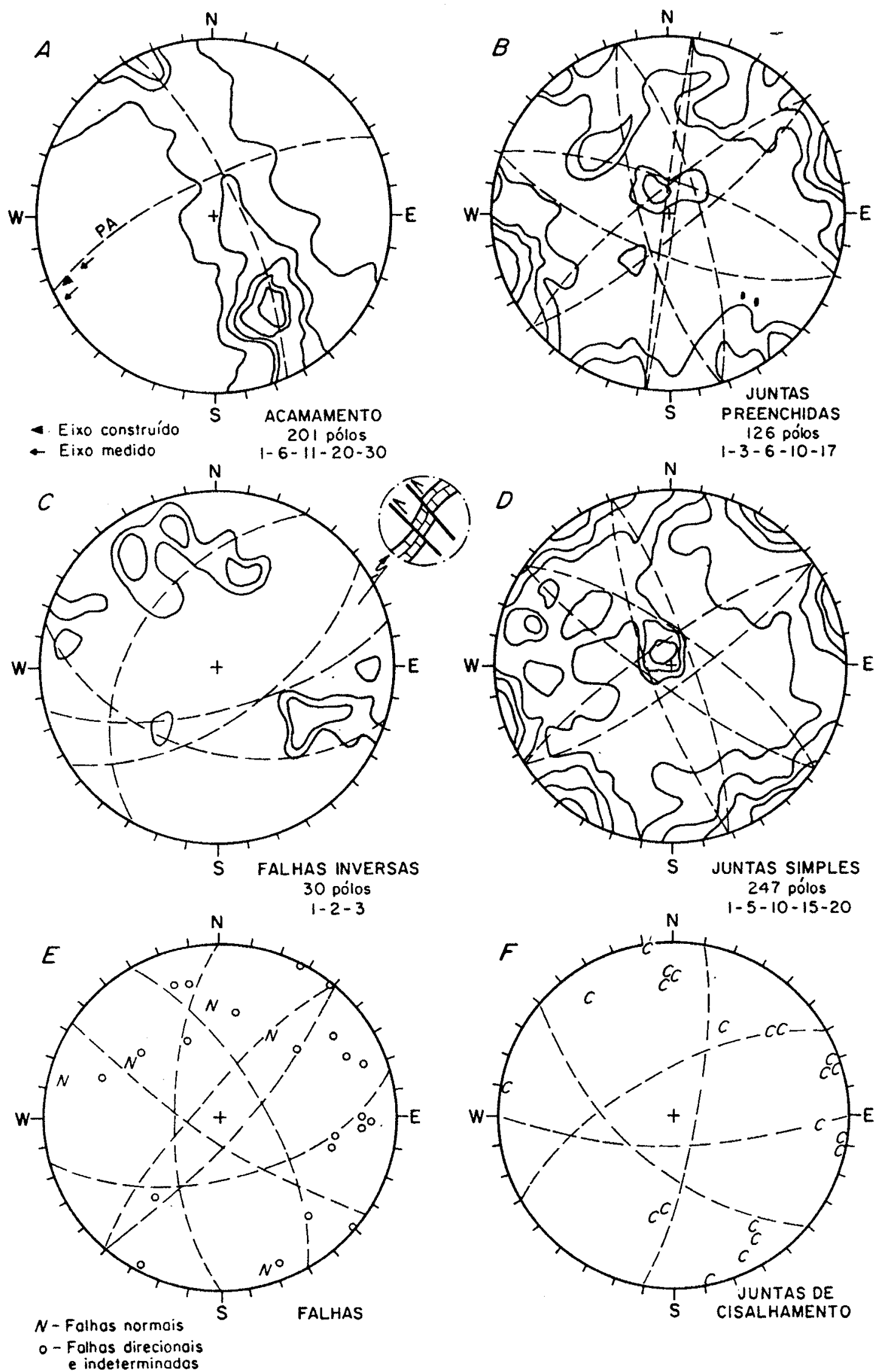

Figura 3.24 - Projeção estereográfica das medidas de descontinuidades da área carbonática Furnas-Santana. Os círculos máximos em B a F indicam as atitudes predominantes. 

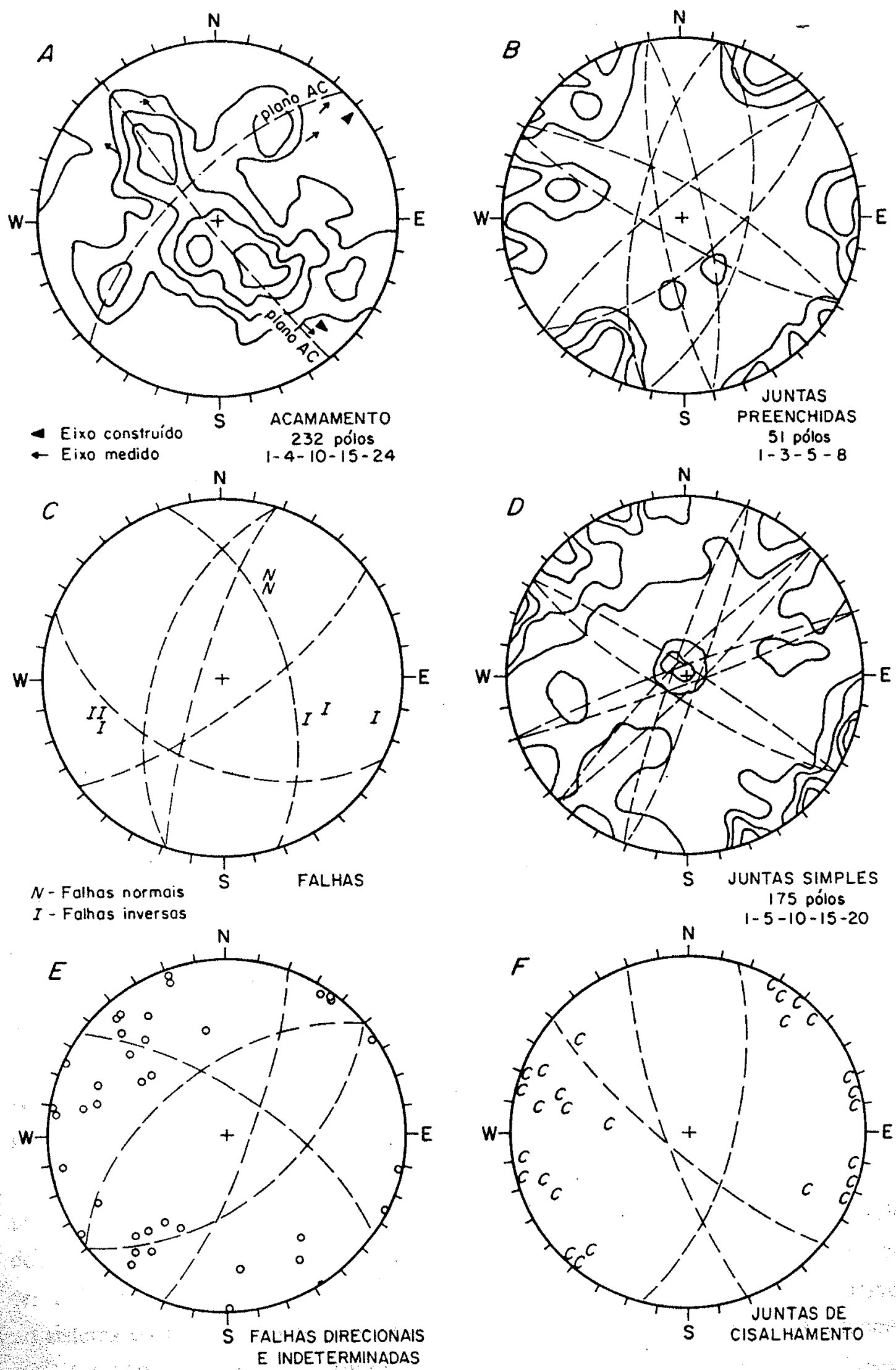

Figura 3.25 - Projeção estereográfica das medidas de descontinuidades da área carbonática Lajeado-Bombas Os círculos máximos em B a F indicam as atitudes predominantes. 
preliminar da origem destas fraturas, relacioná-las ao sistema de esforços responsável pela deformação dos metacalcários em estudo e posteriormente analisar sua função hidrolégica no condicionamento do carste.

As juntas preenchidas são aquelas que ao se formarem sofreram afastamento milimétrico a centimétrico dos seus blocos adjacentes, sem que houvesse deslizamento significativo entre estes, o que criou espaço disponivel para a precipitação de minerais a partir de soluções percolantes, durante o metamorfismo e deformação da seqüência carbonática. Devido ao fato de que nem sempre foi possivel observar se houve deslizamento relativo entre os blocos adjacentes à junta preenchida, é provável que entre os conjuntos de juntas preenchidas obtidos aqui (tabela 3.5 e figs. 3.24B e 3.25B), ocorram algumas juntas de cisalhamento, pois estas, freqüentemente apresentam-se preenchidas. Tanto na área Furnas-Santana como Lajeado-Bombas, as juntas preenchidas apresentam comprimento predominante decimétrico a métrico, com espessura máxima de preenchimento entre alguns milímetros até 3 centímetros, principalmente com calcita e menos freqüentemente com quartzo. Os conjuntos com direção N8E, N16W e N70W, da área Furnas-Santana e os conjuntos N14E, N10W e N60W, da área Lajeado-Bombas (tab. 3.5), formam veios de comprimento decimétrico a métrico, com espaçamento de 5 a $50 \mathrm{~cm}$, concentrando-se ao longo de faixas com larguras métricas a decamétricas. Estas faixas representam zonas de fratura destes conjuntos. As medidas predominantes de ambas as áreas de estudo são semelhantes, levando em consideração a variação de direção de 10 a $20^{\circ}$ destes veios, conforme é visualizado nos estereogramas das figuras 3.24B e 3.25B.

$\mathrm{Na}$ área Furnas-Santana, os conjuntos ao redor do alinhamento NS e N60W, freqüentemente estão subparalelos à falhamentos, tanto direcionais como inversos, assim como, obliquos, respectivamente às falhas N50W e NS, em relação as quais, constituem juntas sigmoidais. As juntas preenchidas N50E, com alto mergulho, são desde decamétricas, com espaçamentos métricos e preenchimento de até $5 \mathrm{~cm}$, até centimétricas a decimétricas, formando veios com espessura milimétrica e espaçamento centimétrico, às vezes na forma de juntas sigmoidais oblíquas às falhas NS. A geometria geral destes conjuntos é representada na figura 3.26 , onde é sugerida uma orientação aproximada da direção de compressão máxima $\left(\sigma_{1}\right)$, em função da superficie dobrada e orientação de juntas e falhas. Neste esquema de esforços para a área Furnas Santana, os veios mais compridos e subverticais, em torno de N16W e N50E, excluindo as juntas sigmoidais, são interpretados como juntas de tração, onde o primeiro conjunto é subparalelo à direção $\sigma_{1}$ e o segundo, perpendicular, representando juntas de tração alinhadas segundo as charneiras NE-SW das dobras parasitas. Os conjuntos em torno de NS e N60-70W, neste regime de tensão, podem ser atribuídos à juntas preenchidas, com tendência à cisalhamento e falhamento, associadas ao sistema conjugado de juntas de cisalhamento em relação à $\sigma_{1}$, conforme o modelo de Riedel (1929 apud Badgley, 1965) para geração de juntas em função da direção de compressão máxima.

Na caverna de Santana notou-se um conjunto de juntas preenchidas e simples, de ocorrência pouco frequente, às vezes com falhamentos associados, gerando zonas 
brechadas, de atitude geral sub-horizontal a N50E 20SE, comprimento decamétrico e preenchimento de até $5 \mathrm{~cm}$ de espessura. Quando estas ocorrem, seu espaçamento é decimétrico a métrico. Estas são interpretadas, segundo o modelo de Blés e Feuga (1986), como juntas de tração, com componentes de cisalhamento, paralelas ao plano $\sigma_{1}-\sigma_{2} \mathrm{e}$ associadas ao movimento reverso, com vergência $\mathrm{SE}$, que gerou a falha inversa do contato NW dos metacalcários.

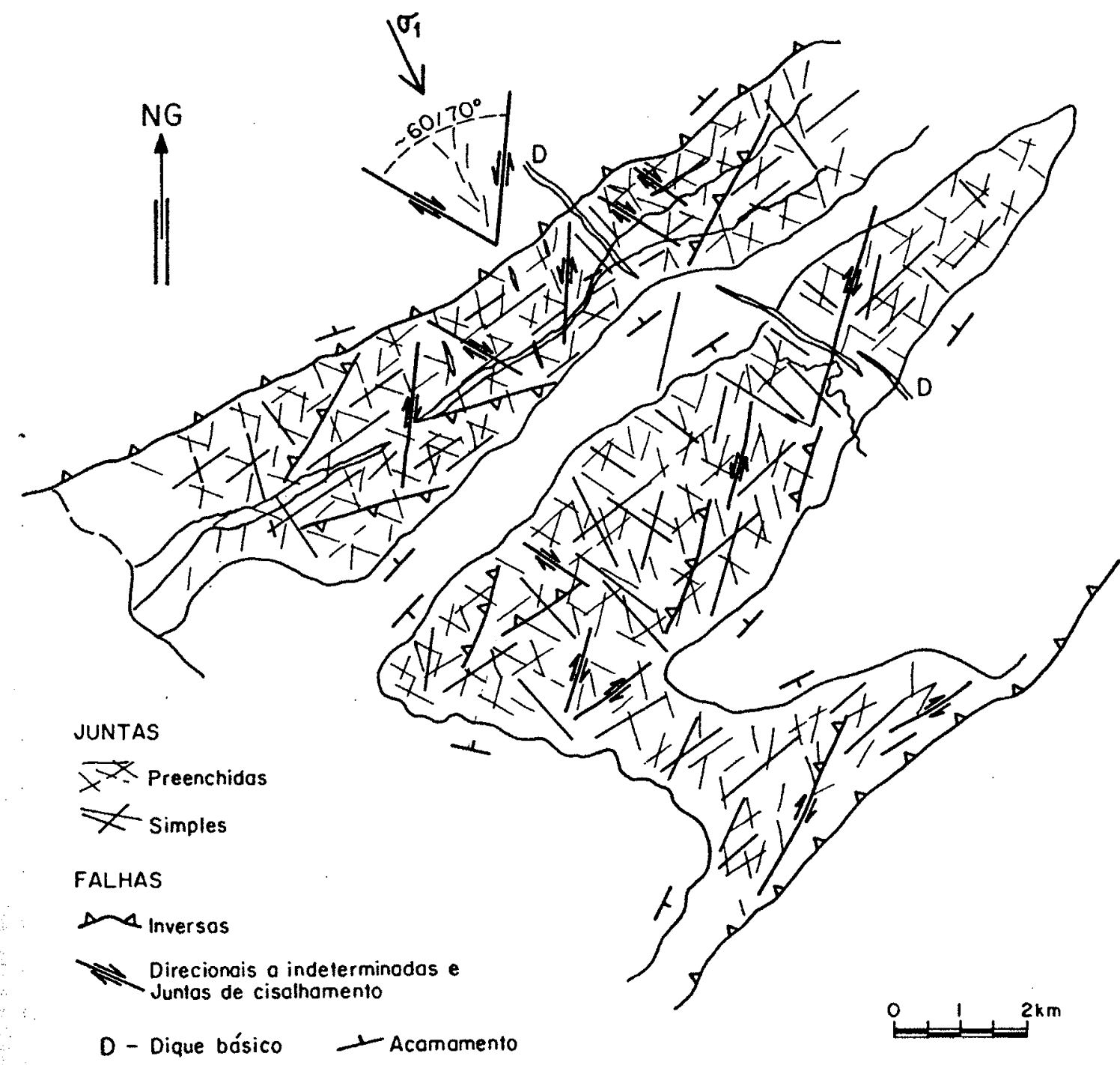

Figura 3.26 - Representação esquemática da geometria em planta do sistema de fraturamento das áreas carbonáticas estudadas, com interpretação da posição do esforço de compressão máxima $(\sigma 1)$ em relação ao dobramento.

$\mathrm{Na}$ área Lajeado-Bombas, a estrutura sinclinal principal indica um esforço de compressão máxima $\left(\sigma_{1}\right)$ também orientado segundo NW-SE. Os conjụntos em torno de N14E e N60W sugerem um sistema conjugado, com cerca de $70^{\circ}$ entre sí, como se fosse um sistema de juntas de cisalhamento com relação à $\sigma_{1}$ a N30W. Em função desta geometria (fig 326 ), estes conjuntos identificados como juntas preenchidas devem incluir untas de cisalhamento, o que é reforçado pela ocorrência de falhas com atitudes próximas a N50-60W, assim como, de juntas de cisalhamento a N15E (tab 3 5). Neste quadro de 
esforços, as juntas N10-20W são atribuídas ao conjunto de tração, subparalelo a $\sigma_{1}$, e o conjunto N50E, ortogonal à compressão máxima, corresponde às juntas de dilatação geradas nas charneiras das ondulações menores do sinclinal, de forma semelhante ao descrito para o homoclinal Furnas-Santana. Estas últimas possuem dimensões maiores, até decamétricas, quando comparadas aos demais conjuntos. Deve-se frizar ainda, que o regime de esforços foi mais complexo, pois a região deve ter passado por um período de compressão, menos intensa, orientada grosseiramente segundo NE-SW, evidenciada pelas ondulações dômicas detectadas na região centro e sudoeste da área do Lajeado, esforço este, que também deve ter gerado estruturas disruptivas superpostas às produzidas com o evento de dobramento principal. Este segundo evento de compressão, pode estar relacionado, com a intrusão do batólito granitóide localizado a SW dos metacalcários, o que também foi proposto por Campanha (1991). Por último, não se deve esquecer, o evento de reativação tectônica do Mesozóico, responsável pela intrusão dos diques básicos e arqueamento crustal, o que sem dúvida contribuiu para a geração de estruturas disruptivas na área, conforme Melo (1990). Com relação a este último evento, é provável que parte dos veios métricos orientados a NW-SE, preenchidos com quartzo e calcita, possam ser atribuídos a este, pois dispõem-se paralelamente ao dique básico NW-SE, que secciona os metacalcários.

Juntas simples ou diacláses, são aquelas, ao longo das quais não houve deslizamento nem afastamento significativo dos blocos adjacentes durante sua formação, produzindo rupturas planares limpas e de grande superficie. Estas juntas são identificadas em campo através de traços com largura milimétrica a sub-milimétrica. Após o soerguimento e exposição do maciço carbonático a níveis próximos à superficie, estas juntas, inicialmente seladas, normalmente sofrem um pequeno afastamento dos seus blocos adjacentes, através da expansão geral da rocha em resposta ao alivio de carga litostática (Badgley, 1965). A abertura sub-milimétrica destas juntas acaba permitindo a infiltração e circulação de água meteórica, em regime capilar, por níveis rasos no maciço rochoso. Isto pode ser observado ao longo das cavernas, onde principalmente este tipo de junta, representa importante rota de percolação de água meteórica, o que é evidenciado pela precipitação de espeleotemas ao longo do traço de intersecção destas juntas com a cavidade.

Devido ao fenômeno de alívio de carga litostática, nem todas descontinuidades sem preenchimento, são de origem tectônica, ou seja, produzidas durante o evento de deformação das rochas. Por exemplo, é comum ocorrer a expansão do maciço rochoso, formando juntas sub-paralelas ao entalhamento de vales profundos, assim como, juntas subparalelas à superficie geral exposta do maciço rochoso (Davis, 1984 e Ford e Williams, 1989). No caso das áreas estudadas, parte das juntas subverticais orientadas a NW-SE, assim como o conjunto sub-horizontal (figuras 3.24D, 3.25D e tabela 3.5) são atribuídas a este fenômeno. Por outro lado, nota-se uma tendência de concordância da orientação dos conjuntos de juntas preenchidas com as atitudes de diáclases, em ambas as áreas estudadas (figura 3.26). Isto sugere que pelo menos parte destas diáclases é de origem tectônica, 
sendo que sua gênese, é relacionada ao mesmo processo compressivo que gerou as juntas preenchidas e falhamentos as\$ociados. Desta forma, interpreta-se as juntas simples subverticais com direção N60-70E, de ambas as áreas, como sendo juntas plano axiais, geradas tanto por tração em charneiras parasitas, como por alívio de tensão, após a cessação dos esforços tectônicos compressivos. É importante notar que estas juntas possuem comprimentos maiores, decamétricos, quando comparadas com os veios paralelos. $\mathrm{O}$ conjunto N50-60W, além da origem atectônica citada acima, é relacionado também, ao evento de tração responsável pela injeção dos diques mesozóicos na direção N50-60W. Este é muito notável na área Furnas Santana, onde possui espaçamento decimétrico e comprimento métrico, formando uma clivagem de fratura ao longo de certas faixas, com atitude geral N50W subvertical. Com a mesma atitude, ocorrem também, juntas simples decamétricas, com espaçamento muito variável, desde métrico a decamétrico, tanto na área Furnas-Santana, como Lajeado-Bombas. Por último, há ainda, as diáclases com atitude N20E subvertical, observadas na área do Lajeado, paralelas ao conjunto de falhas inversas de mesma direção, e portanto, provavelmente associadas a estas.

O comprimento das juntas simples, de modo geral, é predominantemente métrico a decamétrico, com espaçamentos métricos. A densidade destas juntas é bem inferior à das juntas preenchidas, mas seus comprimentos são superiores, fato importante a ser lembrado na discussão do condicionamento estrutural do relevo.

Falhas inversas representam importantes descontinuidades nas áreas estudadas, já notáveis em mapas regionais, onde formam contatos tectônicos. Foram reconhecidas principalmente durante o mapeamento de cavernas, onde foi possível segui-las por até centenas de metros, como nas cavernas Lage Branca (centro-sul da área Furnas-Santana, anexo 4.2) e Ouro Grosso (noroeste da área Lajeado-Bombas, anexo 4.2). Caracterizam-se por comprimentos longos (dezenas a centenas de metros) e zonas de cisalhamento com espessuras entre 10 e $40 \mathrm{~cm}$. Este cisalhamento produziu tanto zonas transpostas, finamente laminadas (milonitos), como também, cataclasitos e microbrechas, o que comprova regime de cisalhamento dominantemente dúctil nas primeiras e rúptil (friável) nas segundas. $O$ movimento reverso foi observado através de dobras de arrasto associadas às faixas de cisalhamento assim como pelo rejeito, de até $2 \mathrm{~m}$, em falhas inversas menores.

Sua geometria é representada nas figuras $3.24 \mathrm{C}$ e $3.25 \mathrm{C}$. As falhas com direção N55-75E e vergência para NW, da área Furnas Santana, são interpretadas como sendo rupturas de flancos e charneiras de dobras paralelas, tendo sido geradas durante e na fase final do desenvolvimento da estrutura geral homoclinal com dobras parasitas e caimento para NW (fig 3.24C). As falhas N30-40E, com vergência para SE, são interpretadas como sendo um conjunto de falhas conjugado ao anterior, decorrente da compressão NW-SE. Estas falhas possuem comprimentos observados de dezenas a centenas de metros. As falhas inversas com atitude geral N75W 50SW indicam esforços alinhados à NNE-SSW, o que permite associá-las tanto ao arqueamento crustal associado aos diques mesozóicos como também aos esforcos gerados pela intrusão dos granitóides a SW dos metacalcários. Na area Lajeado-Bombas, apesar do número menor de falhas inversas observadas, nota-se uma 
geometria semelhante à discutida acima, onde as direções N20E e N55E devem corresponder à falhamentos de flancos de dobras menores associadas à sinforma.

Falhas direcionais são freqüentes em ambas as áreas, sendo carcterizadas por uma zona de cisalhamento tabular, com brechamento da rocha carbonática em diferentes graus de moagem, com espessuras entre alguns centímetros a $0,5 \mathrm{~m}$. Nem sempre foi possível detectar o sentido de movimentação dos blocos adjacentes à zona de cisalhamento, ou até, às vezes, notou-se evidências de movimentos tanto reversos como direcionais ao longo da mesma estrutura de cisalhamento. Como o objetivo principal deste mapeamento não foi o de elucidar a evolução tectônica rúptil da área, mas sim, obter um quadro geométrico e da distribuição de juntas e falhas presentes nas rochas carbonáticas, incluiu-se estas estruturas dúbias, na categoria de falhas com movimento indeterminado, sem perder sua localização e orientação, importantes para testar sua função de condicionante morfológico ou hidrológico.

$\mathrm{Na}$ área Furnas Santana foram identificadas falhas direcionais de alto mergulho com várias direções, conforme listado na tabela 3.5 e representado na figura $3.24 \mathrm{E}$, tanto destrais como sinistrais. Nas direções gerais NS e N30-60W, ocorrem falhas transcorrentes, àlém de indeterminadas, com comprimento mínimo decamétrico (observação limitada à galerias e salões subterrâneos) e zonas brechadas de até $30 \mathrm{~cm}$, as quais devem estar associadas ao sistema conjugado de cisalhamento, em relação à compressão máxima responsável pelo dobramento (fig 3.26). Conforme já citado, é comum ocorrerem juntas preenchidas paralelas a estas, assim como pequenas falhas ou juntas de cisalhamento e juntas sigmoidais transversais. As falhas $\mathrm{N} 40 \mathrm{E}$ a N75E, em grande parte são de movimento indeterminado, de grande comprimento e zona de cisalhamento com brechas e milonitos de até $50 \mathrm{~cm}$ de espessura. Classifica-se estas, como falhas secundárias associadas aos falhamentos maiores, predominantemente reversos.

De maneira semelhante, na área Lajeado-Bombas, atribui-se as falhas direcionais, incluindo as indeterminadas, nas direções médias N20E e N40-50W ao sistema de cisalhamento conjugado gerado durante o processo de formação da sinforma. A direção N50W, além da relação acima, também pode estar associada à falhamentos gerados na ocasião do arqueamento e intrusão do dique básico a NW-SE, em ambas as áreas. Deve-se lembrar aqui, que o contato SE dos carbonatos Lajeado-Bombas ocorre através de uma importante falla regional, principalmente inversa (Falha da Figueira, Campanha, 1991), e que em função desta, é possível que parte das falhas a $\mathrm{N} 20 \mathrm{E}$ e principalmente aquelas segundo N50-60E, possam representar falhas menores e ramos associados a Falha da Figueira.

Juntas de cisalhamento são aquelas com pequeno movimento relativo paralelo aos blocos adjacentes, de comprimento decimétrico a métrico, quase sempre preenchidas com calcita, microbrechas milimétricas e, às vezes, quartzo. A espessura deste preenchimento não ultrapassa $2 \mathrm{~cm}$. Em função de sua pequena extensão e rejeito de no máximo alguns centímetros, não caracterizam falhas, podendo ser consideradas microfalhas. A sua definição em campo é dificultada quando não há estratos de referência para detectar o 
rejeito ou exposição do plano da junta para exibir estriamento. Desta maneira, como citado anteriormente, é provável que entre as demais categorias de juntas definidas, possam ocorrer juntas de cisalhamento.

Apesar das poucas medidas obtidas (figs $3.24 \mathrm{~F}$ e $3.25 \mathrm{~F}$ ) em ambas as áreas, é possível notar-se tendências de orientação preferencial. Na área Furnas-Santana, os conjuntos N10E e N40-45W, aproximam-se ao sistema conjugado de cisalhamento com a direção de $\sigma_{1}$ em torno de $\mathrm{N} 20-30 \mathrm{~W}$, conforme já sugerido pelas juntas preenchidas (fig 3.26. Estes conjuntos, ocorrem em zonas, onde chegam a ter espaçamento decimétrico, muito semelhante às juntas preenchidas descritas anteriormente. $\mathrm{O}$ conjunto $\mathrm{N} 50-60 \mathrm{E}$, de porte maior que as anteriores e paralelo às juntas plano axiais de tração, é associado aqui, tanto às falhas inversas com vergência $\mathrm{SE}$, como também, às rupturas de flancos $\mathrm{e}$ charneiras de dobras paralelas e assimétricas parasitas ao homoclinal Furnas-Santana.

$\mathrm{Na}$ área Lajeado-Bombas, ressaltam-se os conjuntos alinhados a N10-20E e N50W, com juntas métricas, freqüentemente paralelas à falhas com zonas de cisalhamento desenvolvidas.

As falhas normais são as estruturas disruptivas menos freqüentes nas áreas estudadas (tabela 3.5 e figs $3.24 \mathrm{E}$ e $3.2 \mathrm{C}$ ). Caracterizam-se por zonas de falhas com preenchimento, brechamento e pequenas fissuras preenchidas oblíquas. Estas zonas possuem comprimentos decimétricos a métricos, terminando em juntas simples e/ou preenchidas ou dobras. Associa-se as falhas normais N35E e N75E à fraturas de tração, geradas em charneiras de dobras parasitas. A direção N50-60 W pode estar associada ao evento de tração e intrusão do dique básico, sub-paralelo a estas falhas.

\subsubsection{Expressão fisiográfica de estruturas planares. Levantamento de fotolineamentos.}

É senso comum, no estudo de fraturas a nível regional, que as descontinuidades de alto mergulho sejam expressas sobre fotografias aéreas verticais, através de alinhamentos topográficos, principalmente de vales e zonas deprimidas (Wadge e Dixon, 1984). Com o objetivo de verificar a correlação entre as estruturas disruptivas mapeadas em campo e feições de relevo lineares sobre os calcários (vales fluviais e alinhamentos de depressões poligonais e dolinas), confeccionou-se os mapas de fotolineamentos das áreas estudadas (anexos 3.1 e 3.2), assim como, os histogramas dos comprimentos acumulados destes lineamentos, em função de sua direção (fig 3.27). Desta maneira, é possível comparar as direções predominantes obtidas em campo, com aquelas observadas em fotografias aéreas, e assim, sugerir quais estruturas condicionam alinhamentos de feições cársticas.

O histograma do total de fotolineamentos (fig 3.27D) traçados em escala 1:25.000, da área Furnas-Santana, indica predominância das direções N40-80E, com máximo neste quadrante, entre N50-60E, e outro conjunto concentrado entre N30-70W, com máximo em N50-60W. Comparando este resultado com os conjuntos de fraturas obtidos em campo (tab 3.5), nota-se que na direção N50-60E há concentrações de juntas simples, preenchidas, de cisalhamento, falhas inversas e direcionais, estas últimas, mais importantes nas direções N40E e N75E Sobre estas estruturas disruptivas, soma-se ainda, a direção dos 

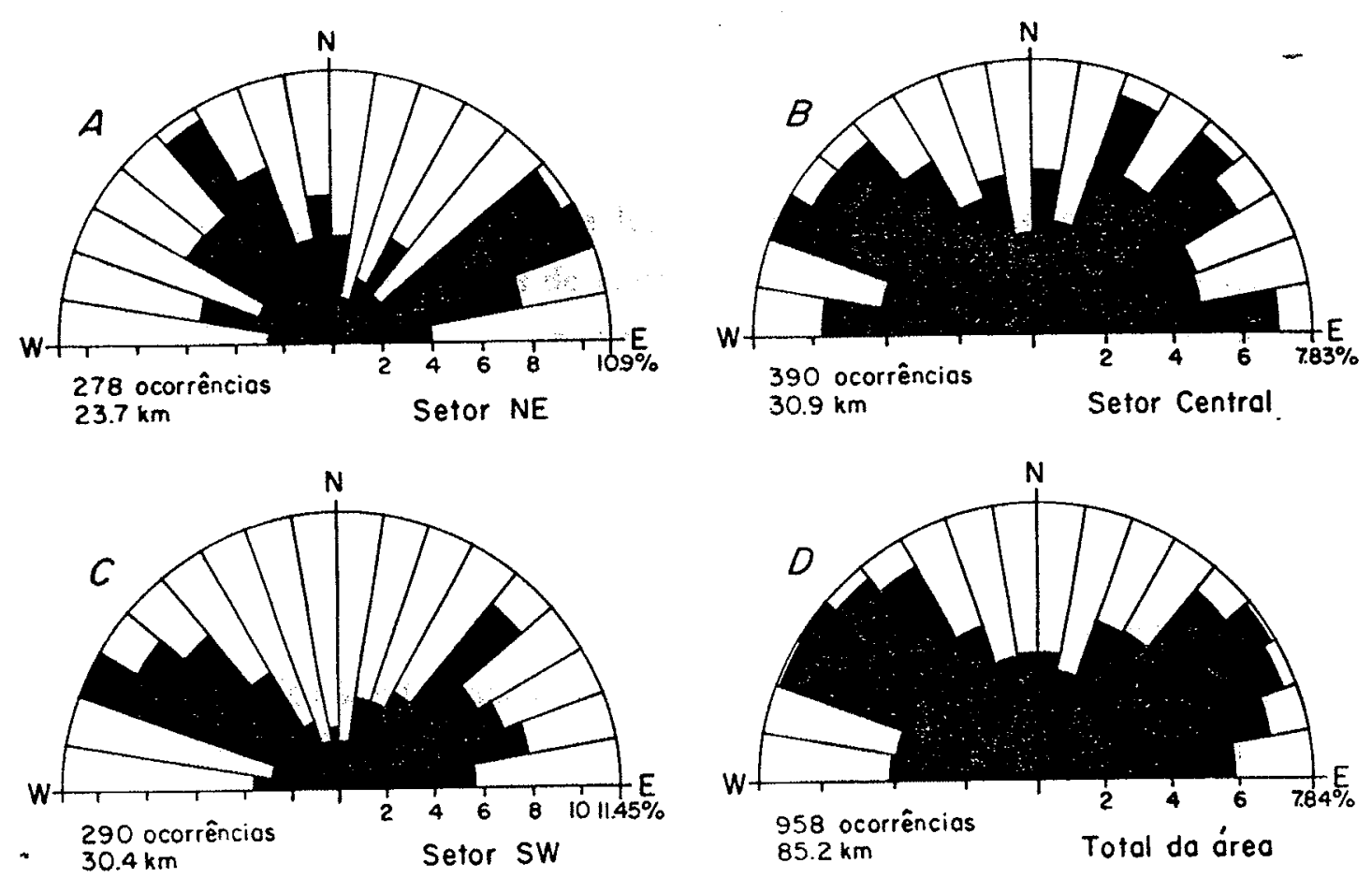

Área Furnas - Sontona
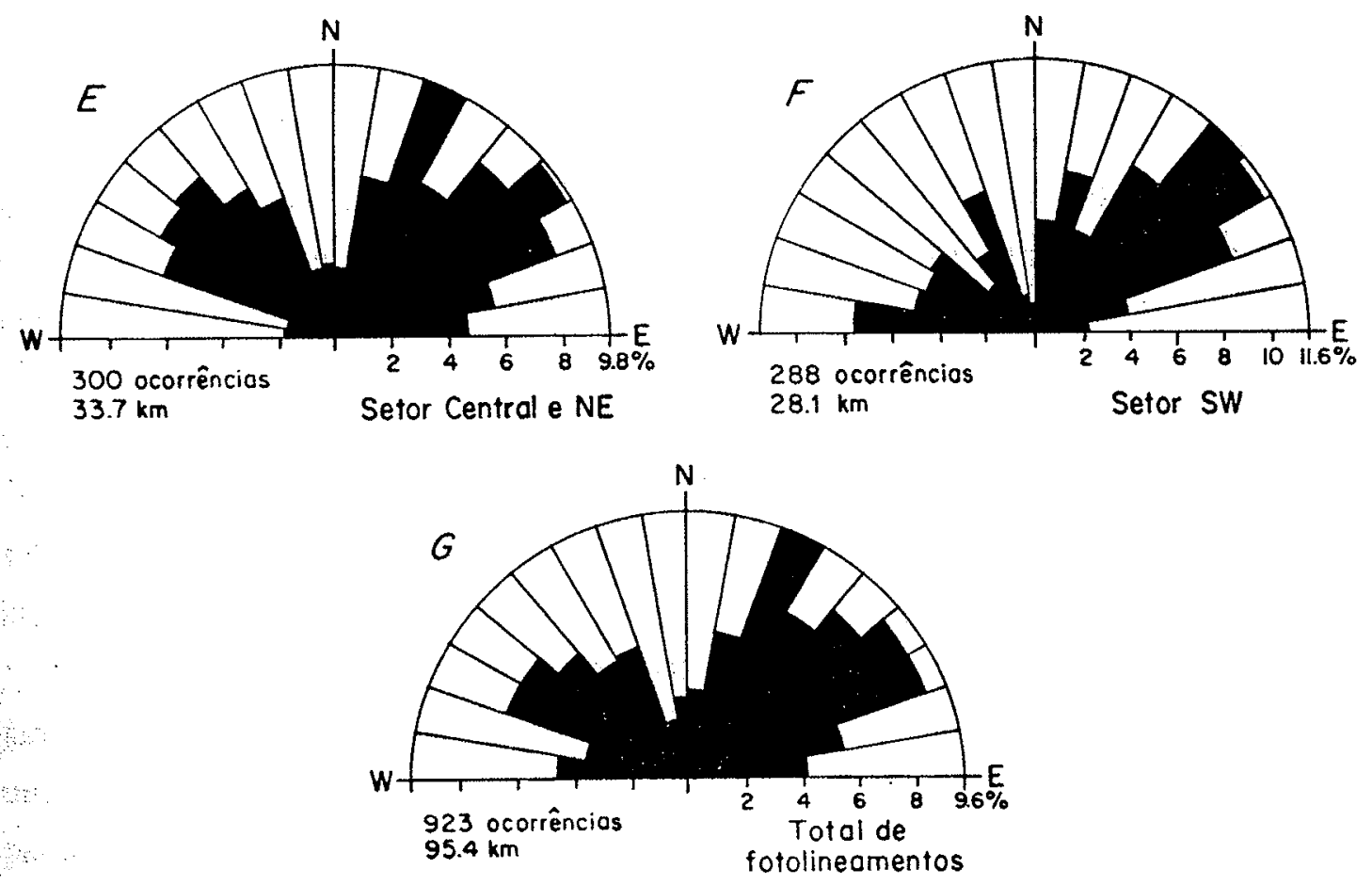

Área Lajeado Bombas

Figura 3.27 - Histogramas do comprimento de fotolineamentos acumulados em função da direção. 
planos de acamamento com alto mergulho, também muito freqüentes e dispersos nas direções N50-70E. No quadrante NW, correlaciona-se o máximo de lineamentos entre N50$60 \mathrm{~W}$, com os conjuntos dominantes, nesta direção, de juntas simples e falhas direcionais a indeterminadas, e a N70W com falhas inversas e juntas preenchidas. A dispersão de lineamentos, tanto nas direções NE como NW, é interpretada como sendo conseqüência da alta freqüência e grande variedade de descontinuidades presentes nas rochas carbonáticas.

Construindo histogramas de lineamentos referentes à setores desta área, obteve-se concentrações de lineamentos menos dispersas (figuras $3.27 \mathrm{~A}, \mathrm{~B}, \mathrm{C}$ ). No setor SW (fig. 3.27C), os conjuntos de falhas direcionais a N40-50E e N50-60W, assim como, as falhas inversas a N75E e N75W, além das juntas preenchidas a $\mathrm{N} 50 \mathrm{E}$ e juntas de cisalhamento a $\mathrm{N} 45 \mathrm{~W}$, coincidem com os picos de freqüência máxima de lineamentos. Passando para a região central da área Furnas-Santana (fig 3.27B), além das correlações já observadas, é realçada uma ocorrência de lineamentos ao redor de NS e outra em torno de EW. A primeira é atribuída aos falhamentos direcionais, juntas preenchidas e de cisalhamento, com direções NS e N1OE e a segunda, corresponde aos lineamentos próximos a EW, produzidos pela falha inversa N75-80E 60-70SE, de comprimento quilométrico, observada ao longo da càverna Lage Branca. Por último, deve-se considerar que a concentração de lineamentos na direção NE é reforçada por traços do acamamento com alto mergulho e grande comprimento.

$\mathrm{Na}$ área Lajeado-Bombas, ocorre também, nítida correlação entre as direções predominantes de fotolineamentos e o sistema de juntas e falhas identificadas em campo. No setor sudoeste da área (fig. 3.27F), a concentração máxima de lineamentos entre N40-60E sobrepõe-se às direções preferenciais de juntas simples, preenchidas, falhas inversas e direcionais e em parte aos planos de acamamento. A concentração EW deste setor é correlacionada, pela falta de importantes fraturas nesta direção, aos planos de acamamento, que neste setor ocorrem próximos a $\mathrm{EW}$, em função do fechamento do sinclinal e também, devido à estrutura em domos e bacias nesta área. Os máximos no quadrante NW, menos expressos no setor SW, ressaltam-se na região central e nordeste da área Lajeado Bombas (fig 3.27E). Neste setor, a predominância de lineamentos entre N40-60W e N20-30E, coincide com dois conjuntos preferenciais de juntas simples, preenchidas, de cisalhamento e falhas. Concentrações menos freqüentes de lineamentos, em torno de NS e N20-30W sobrepõe-se aos demais conjuntos de falhas inversas, juntas de cisalhamento e preenchidas, identificados na área.

Uma vez demonstrado que os fotolineamentos são a expressão morfológica de juntas (incluindo as juntas de estratificação) e falhas presentes nos metacalcários, pode-se utilizar estes lineamentos para calcular a densidade de fraturamento destas áreas, parâmetro proposto em Davis (1984), como sendo a razão entre o comprimento total de fotolineamentos e a área em que estão contidos, neste caso, a área aflorante de metacalcários. No caso de metassedimentos estratificados, propõe-se utilizar o termo densidade de descontinuidades, ao invés de fraturamento, pois traços de planos de acamamento são incluídos no levantamento de fotolineamentos. Este parâmetro, constitui 
um valor quantitativo, para exprimir de forma simplificada e preliminar, o grau de segmentação por descontinuidades de uma área, a partir de fotografias aéreas. Os metacalcários Furnas-Santana, com $27,5 \mathrm{Km}^{2}$ de área e $65,2 \mathrm{~km}$ de lineamentos (subtraindo os lineamentos contidos sobre a intercalação pelítica central), possui densidade de descontinuidades de $2,4 \mathrm{~km}^{-1}$. A área Lajeado Bombas, com $47,5 \mathrm{~km}^{2}$ de calcários expostos e $85,4 \mathrm{~km}$ de lineamentos (subtraindo os trechos de lineamentos que cruzam o contato litológico), apresenta densidade de descontinuidades de $1,8 \mathrm{~km}^{-1}$. Estes valores indicam, respectivamente para as áreas acima, que em $1 \mathrm{~km}^{2}$ de rocha carbonática exposta, ocorrem 2,4 e 1,8 km de lineamentos topográficos estruturalmente guiados, o que leva à conclusão, de que o relevo cárstico destas áreas é fortemente condicionado por estruturas planares, entre as quais, ressaltam-se aquelas alinhadas segundo NE e NW. A densidade maior de descontinuidades na área Furnas-Santana, pode ser interpretada como sendo reflexo da estruturação mais intensa do relevo nesta, em relação a área Lajeado-Bombas. Esta estruturação maior da paisagem sobre a área Furnas-Santana, é atribuída ao fato de que os metacalcários desta área apresentam uma densidade maior de planos de estratificação, em função do caráter fortemente rítmico da alternância de camadas puras e impuras, além dos altos ângulos de mergulho destas.

A identificação de quais estruturas são mais favoráveis ao entalhamento e desenvolvimento de feições cársticas superficiais é apresentada a seguir.

\subsubsection{Fatores condicionantes do relevo cárstico das áreas estudadas}

As bacias poligonais fechadas, células fundamentais do relevo cárstico atual, seguem de modo geral, um padrão de orientação imposto pela paleodrenagem fluvial que antecedeu o carste poligonal nas áreas investigadas. A implantação de uma rede fluvial sobre rochas maciças, é condicionada pela associação entre zonas mais favoráveis ao intemperismo e o gradiente hidráulico (Thornbury, 1969). As zonas mais propícias à desagregação química das rochas são as descontinuidades permeáveis do maciço rochoso solúvel e os estratos carbonáticos mais solúveis em relação àqueles impuros, ricos em pelitos.

$\mathrm{Na}$ área Furnas-Santana, as rotas gerais da paleodrenagem, assim como, grande parte dos eixos maiores de depressões poligonais, seguem a direção N50-70E (anexo 3.1). Esta direção corresponde ao alinhamento dos planos de estratificação, de importantes conjuntos de juntas simples (ou longitudinais em relação ao eixo do dobramento), preenchidas e falhas, todos coincidentes com a direção do gradiente hidráulico sobre os carbonatos. Conclui-se, portanto, que o entalhamento da paleodrenagem seguiu estas estruturas, sendo que, entre estas, mais intensamente os planos de estratificação, falhas e juntas simples (em ordem decrescente), devido à permeabilidade maior destas, em relação às juntas preenchidas. Sugere-se também, que a instalação das linhas preferenciais de drenagem, seguiu a intersecção entre a estratificação N50-70E 40-70NW e os planos de juntas simples e falhas com direções semelhantes e altos mergulhos, pois esta intersecção, produzindo linhas sub-horizontais de concentração de fluxo da água subterrânea aumentou 
a remoção de material em solução ao longo destas rotas, favorecendo assim o entalhamento de vales sobre estas.

$\mathrm{Na}$ área Lajeado-Bombas o condicionamento estrutural da paleodrenagem-também é evidente, mas, seguindo predominantemente o conjunto de juntas e falhas NW-SE, N2030E, N50-60E e localmente planos de estratificação.

Inserido no contexto de que a permeabilidade secundária aumenta com o tempo, causando gradativo incremento na condutividade hidráulica do corpo calcário e rebaixamento do lençol freático sobre as linhas de percolação subterrânea, deve-se discutir, o condicionamento estrutural da instalação de pontos de absorção do escoamento superficial, associados à linhas sub-verticais de maior condutividade hidráulica ao longo da intersecção de descontinuidades de alto mergulho; conforme é ressaltado por Lattman e Parizek (1964), Kiraly et. al. (1971), Parizek (1976) e Williams (1985). Estas rotas verticais de infiltração vão deflagrar o desenvolvimento de dolinas associadas à depressões poligonais. Estes pontos iniciais de absorção, localizam-se, conforme observado nos mapas morfológicos e de reconstrução da paleodrenagem, preferencialmente sobre os canais fluviais, em função da concentração do escoamento superficial sobre estes. Além disto, confirmou-se durante o traçado de fotolineamentos, que a maioria dos fundos de depressões ocorrem na interseç̧ão de lineamentos. Como exemplo, na área Furnas-Santana, os sumidouros autogênicos ocorrem preferencialmente na intersecção de lineamentos de direção geral N50-70W, com o traço do acamamento de mergulho moderado a alto, de direção N40-60E e juntas e falhas paralelas a este, formando alinhamentos preferenciais sobre o acamamento (fig 3.28). Os lineamentos NW-SE representam as juntas de tração paralelas aos diques, assim como, aquelas transversais ao eixo geral do dobramento, todas de alto mergulho a subverticais. $\mathrm{Na}$ área Lajeado-Bombas, nota-se também, o alinhamento de sumidouros. Neste caso o alinhamento predomina sobre traços de fraturas longas e falhas, onde os pontos de infiltração ora correspondem à intersecções destas fraturas proeminentes com traços menores do acamamento ou com outras fraturas (fig 3.28). Conforme observado em campo, as fraturas longas traçadas em fotos aéreas correspondem principalmente aos conjuntos de juntas simples decamétricas e falhas com zonas brechadas associadas.

O alinhamento preferencial ora sobre traços de acamamento, como na área FurnasSantana e, ora sobre linhas de fraturas, como predomina na área Lajeado-Bombas, é atribuído ao ângulo maior de mergulho do plano mais permeável. Isto é, os pontos de infiltração instalam-se nas intersecções, alinhando-se preferencialmente, sobre os planos mais permeáveis e mais inclinados. $\mathrm{Na}$ área Furnas-Santana, esta associação corresponderia aos planos de acamamento e, na área Lajeado Bombas, devido ao baixo mergulho predominante da estratificação, os planos mais inclinados e permeáveis correspondem às juntas simples longas e falhas.

De modo geral, a identificação no terreno do tipo de descontinuidade responsável pelo alinhamento de sumidouros é muito dificil, devido ao espesso solo que cobre a superficie 


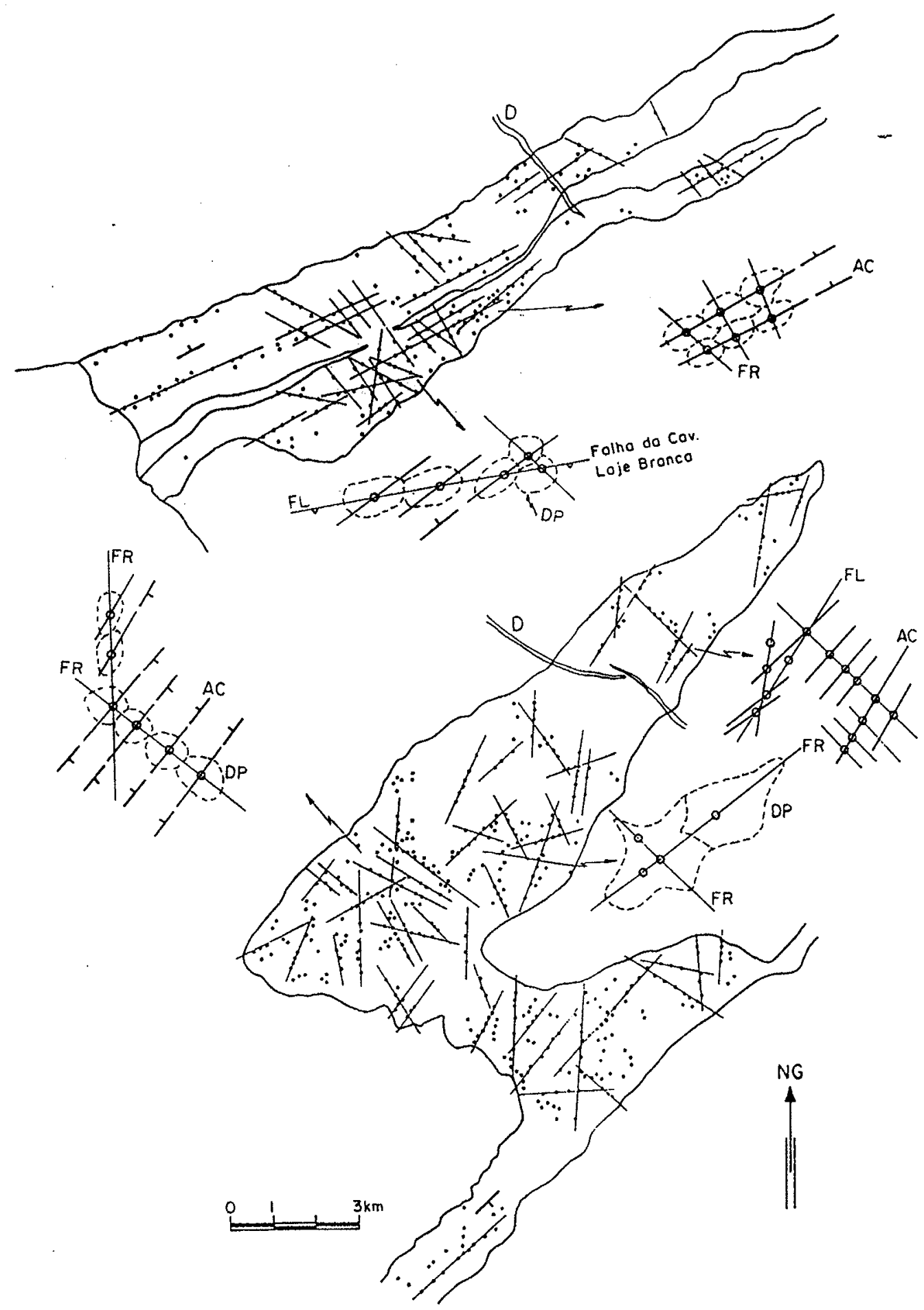

Figura 3.28 - Interpretação do condicionamento estrutural dos principais alinhamentos de sumidouros autogênicos nas áreas Furnas Santana e Lajeado Bombas. Alinhamentos extraídos dos mapas morfológicos. AC- acamamento, FR- junta simples longa, FL- falha, DP- contorno aproximado de depressão poligonal. D- dique básico.

Associado ao alinhamento de sumidouros sobre planos de estratificação e fraturas, muitas depressões poligonais também exibem seu eixo maior, em planta, paralelo a estes lineamentos estruturais. Conforme citado anteriormente, esta é uma herança do condicionamento estrutural da paleodrenagem superficial que posteriormente foi segmentada pela instalação de depressões de drenagem centrípeta. $\mathrm{Na}$ área Furnas-Santana, o eixo maior destas é predominantemente paralelo ao traço da estratificação e de falhas 
inversas como, por exemplo, a falha inversa da Lage Branca (fig 3.28). Já na área LajeadoBombas, o eixo major de depressões e o alinhamento preferencial de sumidouros, segue principalmente estruturas disnuptivas.

Observando a incidência de poljes de contato na área Furnas-Santana, assim como, o entalhamento maior de vales cegos (anexo 3.5), nota-se que ambos estão mais desenvolvidos ao longo do contato SE dos metacalcários. No contato NW, ao contrário, os córregos alogênicos formam trechos fluviais sobre o calcário, antes de atingirem sumidouros. $\mathrm{O}$ número maior de cavernas penetráveis, com pórticos de abatimento junto à sumidouros, também caracteriza a faixa de contato SE desta área. Estes fatos são associados à estrutura geral do homoclinal com mergulho da estratificação para NW, isto é, na situação estrutural onde o mergulho dos planos de acamamento está a favor da direção de injeção de água alogênica, a capacidade de absorção de água pela rocha será maior do que na situação inversa, onde o gradiente hidráulico local é contrário ao sentido de mergulho das camadas (fig 3.29). Havendo capacidade maior de absorção de água, o volume de rocha dissolvida será maior, condicionando assim, um entalhamento mais intenso a favor do mergulho das camadas, produzindo as feições de relevo citadas. Isto evidencia, mais uma veż, o importante papel da estratificação como descontinuidade favorável para percolação de água nos metacarbonatos, condição também observada no carste das montanhas Rochosas por Ford (1971a) e Mills (1981) e no carste da região de Irecê (BA) por Guerra (1986). Este é um exemplo de condicionamento hidrológico e estrutural da paisagem cárstica.

Esta condição de permeabilidade maior de certos planos de estratificação é atribuída ao processo de deslizamento flexural desenvolvido durante o dobramento da seqüência carbonática. Sobre diversas superficies expostas do acamamento foram observadas estrias de atrito e uma fina película de material moído, às vezes cimentado por calcita e quartzo. Estas feições, além de evidenciarem o deslizamento entre camadas, mostram que houve uma pequena abertura entre os estratos, preenchida por material finamente granulado, o que é interpretado como sendo a causa da permeabilidade maior destas superficies, que também possuem grande extensão e continuidade, fator fundamental para condicionarem protocondutos para percolação de água.

A paisagem fluvial dos vales dos rios Furnas e Betari, descrita no item 3.2, também exibe controle estrutural. Com a identificação de lineamentos acima obtida, relaciona-se a direção NW-SE destes vales ao conjunto de juntas simples, de tração, paralelas ao dique basáltico que corta as áreas na mesma direção. Este é outro exemplo de condicionamento hidrólogico e estrutural de relevo, pois -a implantação da paisagem fluvial e persistência desta sobre metacarbonatos, é conseqüência da soma entre a estrutura favorável ao entalhamento superficial e a vazão alta destes rios desde a época de exposição dos metacalcários.

O zoneamento morfológico da área Furnas-Santana (anexo 3.5), mostrou que a zona de carste poligonal, incluindo a concentração de estruturas de colapso em fundos de depressões poligonais, é mais expressiva ao longo de uma faixa NW-SE no setor sudeste da 
área. Isto indica um grau de segmentação maior da paleodrenagem superficial nesta faixa, em relação a zona morfológica de transição, predominante na faixa NW desta área. Conforme Gunn (1986), apesar da aparência de que as formas de relevo do endocarste e exocarste possuem desenvolvimento independente, este cita, que há fortes razões de se considerar, a priori, a evolução mútua e dependente destas formas. Nesta linha, Bull (1980) mostrou que depressões poligonais e dolinas do carste do sul de Gales (Inglaterra) estão relacionadas com condutos subterrâneos localizados até $180 \mathrm{~m}$ abaixo destas dolinas e que o desenvolvimento destas, está envolvido desde as fases primordiais da implantação do sistema de cavernas. Em relação ao carste do Ribeira, esta área maior de zona poligonal, encontra-se exatamente sobre o setor da área Furnas-Santana, onde ocorre, numa profundidade média de $200 \mathrm{~m}$ abaixo da superficie, o maior e mais desenvolvido sistema de cavernas desta área (fig 3.29), conforme detalhes apresentados no capítulo 4 . Isto comprova a evolução dependente entre sistemas de drenagem subterrânea e as feições de relevo superficiais, onde estas últimas, acabam sendo condicionadas, pelo desenvolvimento de sistemas de cavernas.

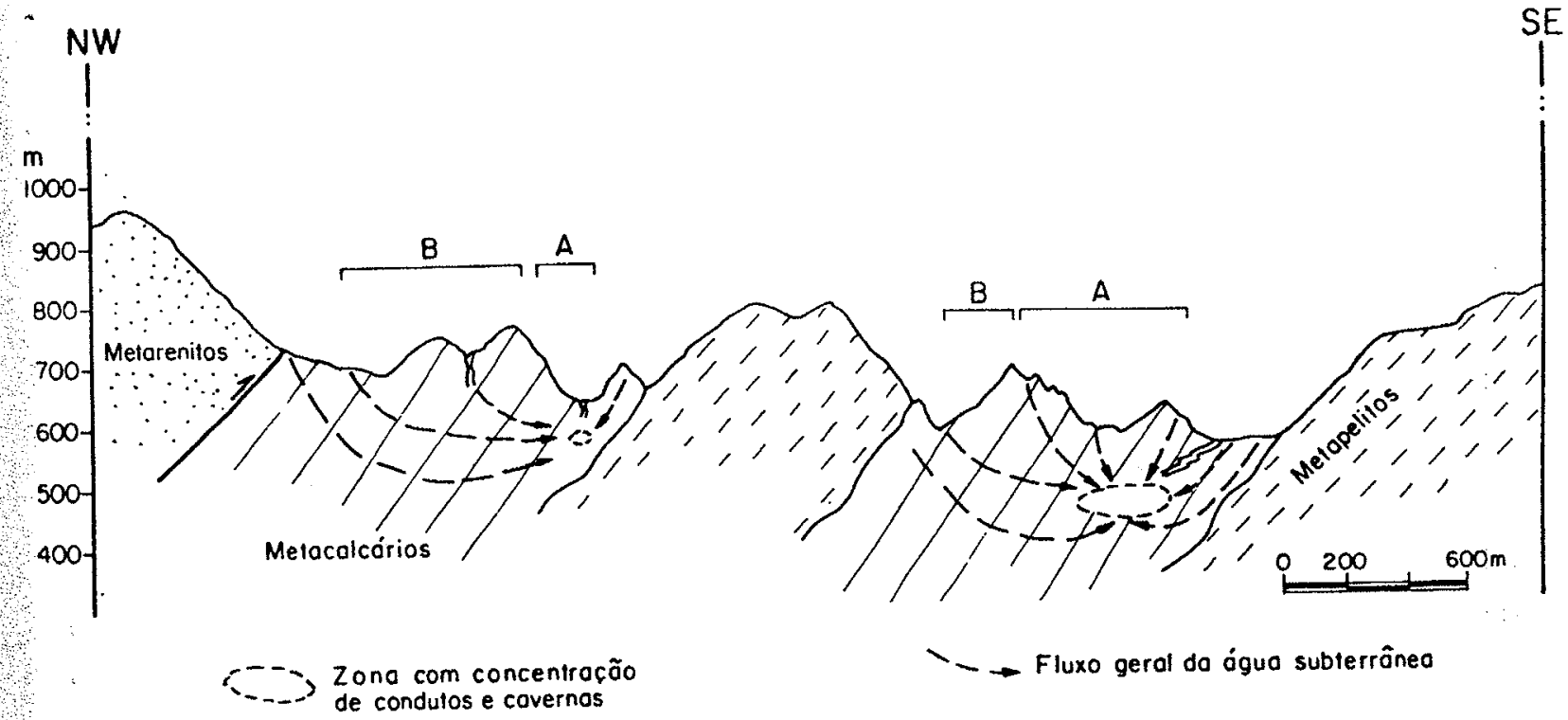

Figura 3.29 - Localização da zona de concentração de condutos cársticos com relação à topografia. Corte transversal a área Furnas-Santana, setor sul. A-Zona de carste poligonal B- Zona de transição de fluviocarste para carste poligonal.

Outro exemplo de condicionamento de formas superficiais por sistemas eficientes de drenagem subterrânea é a grande depressão composta associada à caverna Areias (fig 3.10). Citou-se que esta possui área e profundidade anômalas em relação à população de depressões poligonais das áreas estudadas (item 3.3). Relaciona-se, isto, ao fato desta depressão ter sofrido uma taxa de ampliação maior que as demais, após a conexão direta do seu sistema de drenagem interna à rede de condutos subterrâneos do sistema de cavernas Areias Como conseqüência, após a intersecção da superficie do relevo com 0 nível de condutos subterrâneos, a capacidade de absorção e transmissão do escoamento superficial 
aumentou em muito, o que resultou na realimentação positiva do processo de ampliação desta depressão, conforme modelo da figura 3.15.

\subsection{Conclusões}

O mapeamento morfológico, a medição e cálculo de índices morfométricos sobre as áreas de amostragem, mostraram que, ao contrário da primeira impressão, de que a superficie cárstica exibe um relevo caótico e desorganizado de dolinas, depressões fechadas e sumidouros, o carste do Alto Ribeira possui um padrão de relevo organizado e estruturalmente condicionado.

As unidades morfológicas definidas (zona fluvial, fluviocárstica, de transição e poligonal), permitiram estabelecer diferentes estágios evolutivos do relevo cárstico, partindo de uma paisagem fluvial, a qual é gradativamente segmentada pela implantação de bacias de drenagem fechada, cujo desenvolvimento levou à formação de carste poligonal.

A iniciação de depressões poligonais ocorreu sobre uma paleodrenagem fluvial estruturalmente condicionada, onde os pontos de absorção vertical do escoamento superficial instalaram-se preferencialmente na intersecção entre planos de estratificação e jüntas simples longas e falhas. Sobre o denso reticulado de descontinuidades observadas em ambas as áreas investigadas, na área Furnas-Santana, as depressões alinham-se principalmente sobre traços do acamamento, tendo seus sumidouros definidos pela intersecção de juntas simples e falhas oblíquas aos mesmos. A área Lajeado-Bombas, ao contrário, exibe alinhamento preferencial de sumidouros sobre juntas longas NW-SE, com sumidouros definidos pelas intersecções destas, com traços do acamamento, juntas e falhas. Atribui-se esta diferença ao mergulho mais alto da estratificação na área Furnas-Santana, aliado ao fato, desta apresentar também, densidade maior de planos de estratificação, devido à ritmicidade maior na alternância de estratos carbonato-pelíticos e carbonáticos.

Os poljes de contato estão associados à condição estrutural favorável para injeção de água alogênica (sentido de mergulho da estratificação coincidente com o gradiente hidráulico), assim como filiam-se as maiores bacias de captação de escoamento alogênico.

A evolução da população de depressões ocorreu, e ocorre, através do processo de competição e coalescência entre estas (taxas de abertura diferenciadas), gerando inversões de relevo, assim como pelo mecanismo de geração múltipla, onde a instalação de depressões com drenagem mais eficiente, deflagra a instalação de depressões menores, vizinhas à primeira. Gera-se, desta maneira, uma superficie dinâmica de rebaixamento do relevo, onde se observam feições mais antigas, de fundos de depressões, hoje em cristas, associadas ao lado, ou acima em cota, à pequenas dolinas em iniciação. Neste processo de competição entre taxas de entalhamento do relevo, ressalta-se, na área Lajeado-Bombas, a invasão da superficie de carste poligonal, pelo alargamento do vale do rio Betari adjacente, contribuindo com a inversão de relevo.

As zonas poligonais mais desenvolvidas refletem a presença de condutos subterrâneos e sistemas de cavernas com drenagem eficiente do escoamento superficial, como foi comprovado na área Furnas Santana. $\mathrm{Na}$ área Lajeado-Bombas, esta relação é 
menos evidente, apesar da presença de vários sistemas de cavernas, embora, a maior depressão composta desta área, seja decorrente da conexão direta desta, com um sistema eficiente de drenagem subterrânea.

Pela densidade de depressões, concluiu-se que as zonas poligonais do carste do Alto Ribeira encontram-se em avançado estágio de desenvolvimento, com densidades semelhantes ao carste poligonal da Nova Guiné e Jamaica, considerados altamente desenvolvidos (Williams, 1972b e Troester et. al. 1984). Por outro lado, o carste de forma geral, incluindo as demais zonas morfológicas, possui grau de desenvolvimento menor que as áreas típicas de carste poligonal acima citadas, pelo fato do índice de dolinamento das áreas amostradas estar entre 2,6 e 1,7. Neste contexto, concluiu-se que a área LajeadoBombas, possui relevo poligonal mais desenvolvido que a área Furnas-Santana, sendo que nesta última, predominam características fluviocársticas.

Devido à predominância de fluviocarste sobre a faixa carbonática junto ao contato NE da área Furnas-Santana, interpreta-se baixa permeabilidade secundária nesta faixa, em comparação com a faixa carbonática próxima do contato SE, com alta permeabilidade secundária, evidenciada pelo importante sistema de cavernas neste setor.

A intensidade do relevo poligonal é expressa pelas medidas de profundidade das depressões poligonais. $\mathrm{O}$ carste do Alto Ribeira apresenta profundidades típicas de carste tropical.

Com as medidas de área de depressões poligonais, confirmou-se também a grande semelhança entre o relevo poligonal do Alto Ribeira e aquele da Nova Guiné e Jamaica, apesar das condições climáticas distintas reinantes na Nova Guiné. Isto confirma a conclusão de Smith e Atkinson (1976), de que a ocorrência de carste poligonal é possível numa grande amplitude climática.

Os valores morfométricos semelhantes entre diferentes regiões cársticas (com litologia e história climática diferentes), sugerem que há um padrão geral de relevo poligonal, o qual difere somente em pequenos detalhes, entre áreas distintas. 


\section{CAPÍTULO 4 \\ A DRENAGEM SUBTERRÂNEA E A EVOLUÇÃO DE SISTEMAS DE CAVERNAS}

\subsection{Introdução}

Rochas carbonáticas caracterizam-se por abrigarem aquüferos heterogênēos (Yuan, 1985), compostos por redes contínuas de condutos e aberturas menores, ambos alargados por dissolução da rocha. Estes padrões de condutos interconectados constituem os sistemas de cavernas e proto-cavernas, responsáveis pela drenagem subterrânea de áreas cársticas (Ford e Williams, 1989).

Com o entalhamento da paisagem, níveis de condutos freáticos são progressivamente drenados, tornando-se preenchidos com ar, além de água. Entre estes condutos com ar, alguns são bloqueados por sedimentos, outros possuem dimensões impossiveis de serem penetradas pelo ser humano e a maioria destes condutos, continua inacessível, simplesmente por não terem uma conexão que possa ser percorrida pelo homem. Na grande maioria das áreas cársticas, as cavernas acessíveis representam somente uma pequena fração do total de condutos presentes (White, 1988 e Worthington, 1991). Estas cavernas são definidas, por uma convenção antropomórfica (White, op cit.) reconhecida pela União Internacional de Espeleologia, como sendo cavidades subterrâneas naturais, em rocha, e que possuem dimensões suficientes para permitir a passagem de um ser humano. Desta definição surge uma questão polêmica entre exploradores e topógrafos de cavernas naturais, quanto as dimensões mínimas de uma cavidade para ser registrada como caverna num cadastro ou levantamento de cavernas de uma região cárstica. A maioria das associações espeleológicas convencionam um comprimento mínimo entre 150 e $50 \mathrm{~m}$ em planta, ou $20 \mathrm{~m}$ na vertical e diâmetro mínimo que permite a passagem do explorador. Esta definição de caverna, vai depender, portanto, de quem a convenciona. Mas, independentemente destas convenções, deve-se ressaltar que as cavernas constituem as únicas frações diretamente acessiveis para observação do aqüífero cárstico, o que as torna especialmente importantes no estudo da circulação atual e pretérita de água em rochas solúveis.

Neste sentido, necessita-se definir e classificar os condutos cársticos do ponto de vista geomorfológico e hidrológico, independentemente de sua acessibilidade. Ford e Ewers (1978) definiram cavernas cársticas como sendo condutos de dissolução, ou qualquer abertura na rocha solúvel, que tenham dimensões suficientes para permitir fluxo de água em regime turbulento, apesar de que, este fluxo não necessariamente sempre é turbulento neste estágio. A dimensão mínima para esta condição é de 5 a 15 milímetros de diâmetro ou largura deste conduto ou abertura na rocha (Howard, 1964, apud Ford e Ewers, 1978), sob ação de variados gradientes hidráulicos: Para que ocorra este fluxo, a caverna cárstica necessariamente deve estar conectada a uma rota de injeção e saída da água subterrânea. Por outro lado, cavidades integradas numa rota de circulação subterrânea, mas que possuem dimensões abaixo do limite de fluxo turbulento, são classificadas como cavernas 
em início de formação, ou seja, proto-cavernas. Quando ocorre a situação de um ou vários condutos conectados, continuamente na condição de cavęrna cárstica, ao longo de todo trajeto entre injeção e ressurgência da água subterrânea, caracteriza-se um sistema integrado de cavernas, ou simplesmente, sistema de cavernas cársticas. A maioria das cavernas acessíveis ao homem, são fragmentos destes sistemas de circulação subterrânea, onde estes últimos, além de constituírem o aqüífero cárstico, possuem também, equivalência funcional às redes de drenagem superficial na geomorfologia fluvial

Neste contexto de sistemas de cavernas cársticas, este capítulo tem como objetivo essencial, esboçar uma seqüência evolutiva do aqüifero cárstico e suas feições subterrâneas associadas, através da investigação morfológica e geológica dos principais segmentos acessíveis de alguns dos sistemas de cavernas presentes nas áreas carbonáticas FurnasSantana e Lajeado-Bombas (definidas no cap. 3).

\subsection{Distribuição e características físicas gerais dos sistemas de cavernas nas áreas} investigadas

Para delimitar os sistemas de cavernas e suas bacias de captação de água, foram executadas as seguintes etapas de trabalho: mapeamento geoespeleológico das principais cavernas da área; implantação destes mapas e perfis em cartas topográficas 1:10.000 e no traçado morfológico 1:25.000 da superficie e, verificação em campo e localização em cartas topográficas dos principais sumidouros e ressurgências associadas a cada sistema de cavernas. Estas informações são fundamentais para esboçar a geometria do fluxo de água subterrânea nos metacalcários.

O mapeamento geoespeleológico consiste em obter a representação bidimensional, tanto em planta, como em projeção no plano vertical, do conjunto tridimensional de condutos e salões que compõem a caverna, assim como da estrutura da rocha encaixante. A visualização do espaço subterrâneo é auxiliada através da confecção de seções transversais e longitudinais, nas quais, são enfatizados detalhes morfológicos de trechos da caverna. Sobre estas plantas e seções morfológicas são lançadas as atitudes de estruturas, como planos de acamamento, juntas e falhas. Como exemplo do produto deste mapeamento apresenta-se o mapa da caverna Lage Branca, anexo 4.1. A metodologia de mapeamento geológico de cavernas foi desenvolvida em conjunto com grupos de exploração de cavernas, onde ressaltaram-se o Grupo Pierre Martin de Espeleologia e o Grupo de Espeleologia do IG-USP, este último, com vários trabalhos de iniciação científica (Battistucci, 1988; Marinho, 1989; Philadelphi, 1990; Lepine, 1992 e Afonso de Souza, 1993). Como base metodológica utilizou-se também os estudos geológicos de cavernas nos Apalaches (Jameson, 1985) e as orientações de mapeamento espeleológico de White (1966), Chabert e Watson (1981) e Thomson e Taylor (1991).

\subsubsection{Distribuição de sistemas de cavernas}

Através da inserção, na base topográfica e geológica, dos mapas de cavernas obtidos neste trabalho e aqueles disponíveis no cadastro de cavernas da Sociedade Brasileira de Espeleologia, foi obtida a distribuição de cavernas nas áreas carbonáticas Furnas-Santana e Lajeado-Bombas, conforme o anexo 43 As bacias de captação referentes a cada sistema 
foram demarcadas em fotografias aéreas 1:25.000, durante a confecção dos mapas morfológicos das áreas carbonáticas em estudo.

Associando estas cavernas aos respectivos sumidouros e ressurgências, foram identificados os sistemas de drenagem subterrânea presentes nos metacalcários (ānexo 4.2). Os principais estão listados na tabela 4.1, juntamente com suas características morfométricas. Sua denominação segue os nomes das principais cavernas associadas.

A demarcação das bacias de drenagem subterrânea, conforme apresentada no anexo 4.2 , possui caráter preliminar e qualitativo. Sua definição exata depende da aplicação futura de traçadores (p.ex., corantes), através dos quais, poderá se confirmar, ou readaptar, o quadro aqui proposto, para as linhas de fluxo da água subterrânea, as quais, até o momento, são interpretadas em função da posição de condutos mapeados, sumidouros e ressurgências.

Foram identificados onze sistemas principais de drenagem subterrânea, cinco na área Furnas-Santana e seis na área Lajeado-Bombas (anexo 4.2). Num contexto geral, as cavernas associadas acompanham, em grande parte, a direção dos planos de estratificação, com poucas exceções (caverna Laje Branca), concentrando-se ao longo de faixas, com largura variável, próximas aos traços dos contatos sudeste dos metacalcários. A título de exemplo, na área Furnas-Santana, onde esta caracteristica é mais marcante, foram mapeados cerca de $8700 \mathrm{~m}$ de condutos subterrâneos do sistema de cavernas Pérolas-Santana (cavernas Pérolas, Tobias e Santana), 2985m do sistema Água Suja e $530 \mathrm{~m}$ do sistema do Grilo, os quais $(80,9 \%$ do total de condutos mapeados) estão todos alinhados nas proximidades do contato SE. Em contrapartida, na faixa ao longo do contato NW, apesar da intensa prospecção de cavernas, realizada neste trabalho e anteriormente, por moradores locais e grupos de exploração de cavernas, foram mapeados somente cerca de $1000 \mathrm{~m}$ de cavernas integradas à sistemas de drenagem subterrânea (caverna do Zezo, Abismo Furnas). O mesmo ocorre ao longo da faixa central dos metacalcários, onde ocorrem pequenas cavidades isoladas e várias cavernas verticais, sem conexão transponível com sistemas integrados de drenagem subterrânea. $\mathrm{Na}$ área Lajeado-Bombas, do total de $11860 \mathrm{~m}$ de condutos mapeados, cerca de $5660 \mathrm{~m}(47,7 \%)$ desenvolvem-se nas proximidades do contato SE (cavernas Areias de Baixo, 1600m; Alambari de Cima e de Baixo, 1600 e $890 \mathrm{~m}$; Gurutuva, $100 \mathrm{~m}$ e Jeremias, $1270 \mathrm{~m}$ ), enquanto que, junto ao contato NW ocorrem $1750 \mathrm{~m}$ $(14,7 \%)$ de cavernas mapeadas (caverna Passoca, 546m e Ouro Grosso, $1200 \mathrm{~m}$ ). O restante das cavernas nesta área desenvolve-se a partir da margem sudoeste em direção ao centroleste da sinforma do Lajeado, não exibindo a distribuição preferencial em discussão.

Os sistemas são convergentes ou integrados (Trudgill, 1985), isto é, apresentam seus principais sumidouros associados à córregos alogênicos, os quais são coletados por condutos para uma ressurgência por sistema. Estas ressurgências seguem a tendência de distribuição de cavernas, localizando-se preferencialmente junto aos contatos sudeste dos metacalcários (anexo 4.2).

Considerando que as cavernas acessíveis são conseqüência do desenvolvimento de permeabilidade secundária e sistemas eficientes de drenagem subterrânea (Ford e Ewers, 1978), associa-se a concentração preferencial de cavernas, acima descrita, a um 
desenvolvimento de condutos subterrâneos, relativamente mais intenso, junto ao contato $\mathrm{SE}$, quando comparado às zonas mais internas do metacalcário e ao longo do contato NW.

\begin{tabular}{|c|c|c|c|c|c|c|c|c|c|}
\hline & $\begin{array}{c}\text { Sistema } \\
\text { de } \\
\text { Cavernas }\end{array}$ & $\begin{array}{l}\text { Altitude } \\
\text { do Su- } \\
\text { midouro }\end{array}$ & $\begin{array}{l}\begin{array}{c}\text { Aftitude } \\
\text { da Res- } \\
\text { surgencia }\end{array} \\
\end{array}$ & $\begin{array}{l}\text { Extensão } \\
\text { AL. } \\
\text { metros }\end{array}$ & $\begin{array}{c}\text { Desnivel } \\
\Delta H, \\
\text { metros }\end{array}$ & $\begin{array}{l}\text { Gradiente } \\
\Delta \mathrm{H} / \Delta \mathrm{L}\end{array}$ & $\begin{array}{l}\text { Area de } \\
\text { Captaşão } \\
\text { alogentica }\end{array}$ & $\begin{array}{c}\text { Compri } \\
\text { mapea } \\
\text { condutos }\end{array}$ & $\begin{array}{l}\text { nento } \\
\text { ode } \\
\mathrm{C}(\mathrm{m}) \\
\end{array}$ \\
\hline \multirow{4}{*}{ A } & $\begin{array}{l}\text { Onça Parda- } \\
\text { Morro Preto }\end{array}$ & 460 & 240 & 3090 & 220 & 0.071 & $\begin{array}{l}\mathrm{km}^{2} \\
3.62\end{array}$ & $\begin{array}{c}\mathrm{C} \\
1612\end{array}$ & $\begin{array}{l}\mathrm{C} / \Delta \mathrm{L} \\
0.52\end{array}$ \\
\hline & Ägua Suja & 562 & 265 & 2300 & 297 & 0.129 & 2.96 & 2985 & 1.30 \\
\hline & $\begin{array}{l}\text { Pérolas - } \\
\text { Samana }\end{array}$ & 555 & 251 & 5970 & 304 & 0.051 & 7.02 & 9525 & 1.60 \\
\hline & Grilo ${ }_{b}^{a}$ & $\begin{array}{l}700 \\
670\end{array}$ & 440 & $\begin{array}{l}7820 \\
7150\end{array}$ & $\begin{array}{l}260 \\
230\end{array}$ & $\begin{array}{l}0.033 \\
0.032\end{array}$ & 7.41 & $530^{*}$ & $\begin{array}{l}0.067 \\
0.074 \\
\end{array}$ \\
\hline \multirow{4}{*}{ B } & ${ }^{\text {Areias }^{2}}$ & $\begin{array}{l}305 \\
315\end{array}$ & 160 & $\begin{array}{l}5540 \\
6330\end{array}$ & $\begin{array}{l}145 \\
155\end{array}$ & $\begin{array}{l}0.026 \\
0.024\end{array}$ & 8.08 & $4800^{*}$ & $\begin{array}{l}0.86 \\
0.76\end{array}$ \\
\hline & $\begin{array}{l}\text { Córrego } \\
\text { Fundo }\end{array}$ & 449 & 160 & 8100 & 289 & 0.036 & 8.75 & $2000^{*}$ & 0.25 \\
\hline & Ouro Grosso ${ }^{a}$ & $\begin{array}{l}400 \\
440\end{array}$ & 190 & $\begin{array}{l}950 \\
2070\end{array}$ & $\begin{array}{l}210 \\
250\end{array}$ & $\begin{array}{l}0.221 \\
0.121\end{array}$ & 2.63 & 1200 & $\begin{array}{l}1.26 \\
0.58\end{array}$ \\
\hline & $\begin{aligned} & \text { Alambari } \\
& \\
& b \\
& c\end{aligned}$ & $\begin{array}{l}407 \\
383 \\
370\end{array}$ & 165 & $\begin{array}{l}3800 \\
4420 \\
3920\end{array}$ & $\begin{array}{l}218 \\
205\end{array}$ & $\begin{array}{l}0.063 \\
0.049 \\
0.052\end{array}$ & 9.53 & $2590^{*}$ & $\begin{array}{l}0.68 \\
0.58 \\
0.66\end{array}$ \\
\hline
\end{tabular}

Tabela 4.1 Características morfométricas dos principais sistemas de cavernas das áreas Furnas Santana (A) e Lajeado Bombas (B).

* parte do desenvolvimento de cavernas extraídos de Martim, Chrysostomo e Rodrigues, 1989.

Altitude em metros sobre o nível do mar.

Extensão é a distância horizontal em linha reta entre sumidouro e ressurgência.

Desnivel é a distância vertical entre sumidouro e ressurgência.

Comprimento de condutos é a somatória do desenvolvimento de carernas mapeadas. Desenvolvimento é a somatória do comprimento de galerias e eixos maiores de salões, medidos em planta.

$\mathrm{C} / \Delta \mathrm{L}$ é o grau de cavernamento do sistema, ou seja, a razão entre o comprimento de condutos acessiveis e a extensão.

a, b, c são indices referentes à diferentes tributários do sistema.

Propõe-se o seguinte modelo interpretativo para explicar esta geometria de distribuição de cavernas (fig 4.1). O rio Betari representa o nível de base local para os sistemas de drenagem subterrânea, condicionando um gradiente hidráulico local com caimento de SW para NE e vice versa, em relação ao rio Betari. Por outo lado, o rio Ribeira de Iguape constitui o nível de base regional para toda drenagem da serra de Paranapiacaba, onde se inclui o rio Betari, o que causa um gradiente hidráulico regional, sobre os calcários, dirigido genericamente para SE. Estas duas componentes geram um gradiente hidráulico resultante, com sentido E-SE, de forma oblíqua ao traço geral do acamamento. Em função deste gradiente resultante, a água de infiltração, assim como, as linhas de fluxo da água subterrânea, tendem a fluir para E-SE, seguindo as descontinuidades presentes nos metacalcários. Devido ao contraste de permeabilidade entre o calcário com condutos (condutividade hidráulica alta) e os metapelitos subjacentes (condutividade hidraulica baixa), associado a tendência de fluxo, acima citada, ocorre um efeito de represamento 

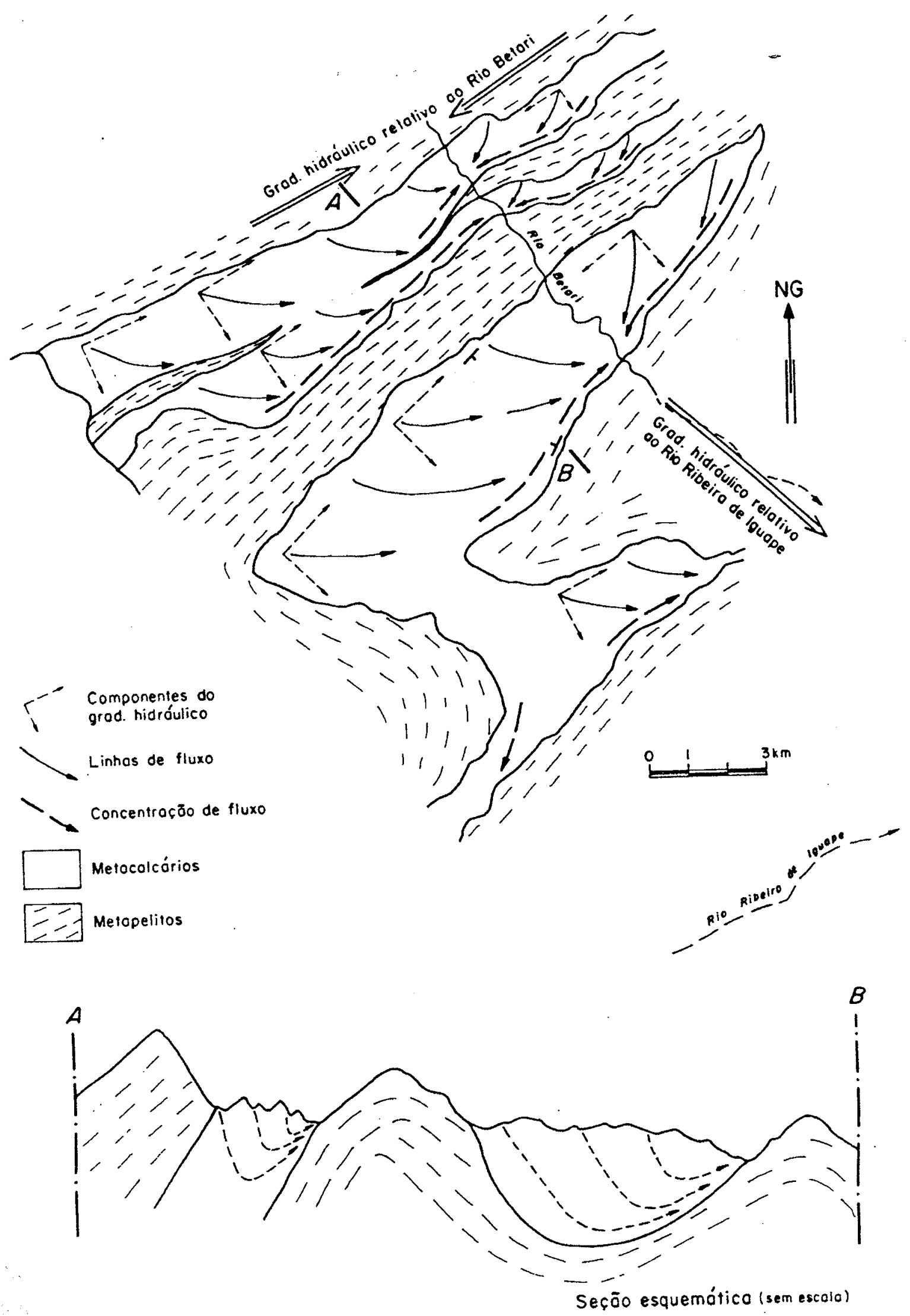

Figura 4.1 - Interpretação do condicionamento hidrológico da distribuição preferencial de sistemas de cavernas ao longo do contato SE dos metacalcários. 
sobre o contato SE (convergência das linhas de fluxo da água subterrânea sobre a interface de permeabilidade menor), o que resulta num volume maior de água subterrânea neste setor. Isto, por sua vez, implica no fluxo mais intenso (velocidade maior de fluxo) e, conseqüentemente, na taxa maior de dissolução e abertura de condutos ao loñgo da faixa de concentração das linhas de fluxo da água subterrânea, conforme o princípio teórico das redes de fluxo e abertura de condutos elaborado por Rhoades e Sinacori (1941).

A partir deste padrão de distribuição de cavernas nas áreas estudadas, seria de se esperar, um importante sistema de cavernas (semelhante ao Pérolas-Santana), acompanhando o contato NW da intercalação pelítica central da área Furnas-Santana. A ressurgência da caverna do Grilo (anexo 4.2) confirma a presença de um sistema de condutos nesta localização. Sua vazão é de cerca da metade daquela do sistema Pérolas Santana, mas, seu grau de cavernamento $(\mathrm{C} / \Delta \mathrm{L}=0.067$, tabela 4.1$)$ é muito inferior, conforme foi observado pelas dimensões da caverna do Grilo e pela falta de continuidade subaérea de condutos no fundo desta. Conclui-se, portanto, que o sistema do Grilo, apesar de se encontrar, hipotéticamente, em situação geológica e hidrológica favorável para um intenso desenvolvimento de condutos, não apresenta um volume de cavernas acessíveis, compativel com os demais sistemas em condições semelhantes.

Levantou-se a seguinte hipótese para explicar esta ausência de cavernas volumosas. Existe a possibilidade da intercalação pelítica central não ser contínua conforme é apresentada pelo mapa geológico de Campanha (1991), adotado neste trabalho. $O$ adelgaçamento e boudinagem, com rompimento de camadas, é observado em pequenos estratos mețapelíticos dispersos nos metacalcários em questão. $O$ mapa geológico apresentado por Pires (1989), para a mesma área, exibe megascopicamente esta característica descontínua das intercalações pelíticas. Neste mapa, a camada pelítica central está interrompida na altura do sumidouro associado à caverna Pérolas, reaparecendo somente nas proximidades do rio Betari, a partir de onde é contínua e mais espessa. $\mathrm{O}$ grau de cavernamento incipiente do sistema do Grilo, acima questionado, seria conseqüência desta interrupção da camada pelítica, pois desta forma, grande parte da água coletada ao longo da faixa a NW do alinhamento desta intercalação, teria condição livre de percolar pelos metacarbonatos, seguindo o gradiente hidráulico dirigido para E-SE, concentrando-se na linha do sistema Pérolas-Santana. No presente trabalho, não foi possivel detalhar a cartografia geológica da área em estudo. A hipótese acima deverá ser testada com trabalhos futuros na área.

\subsection{2 Áreas de captação dos sistemas de cavernas}

A região estudada apresenta sistemas do tipo misto (conforme a classificação de Jakucs, 1977), ou seja, as respectivas bacias de captação do escoamento superficial, estendem-se, tanto sobre rochas não carbonáticas (captação alogênica), como sobre carbonáticas (captação autogênica), (tabela 4.2). As áreas Furnas-Santana e LajeadoBombas, apresentam respectivamente, $46,8 \%$ e $47,5 \%$ de alimentação alogênica, a qual é absorvida, atualmente, por sumidouros pontuais (vales cegos) próximos ao contato entre os metacarbonatos e os metapelitos. Estas aguas alogenicas formam segmentos de rios 
subterrâneos, associados aos sistemas de cavernas, nas proximidades dos sumidouros. A alimentação autogênica é absorvida por fundos de depressões poligonais, através de infiltração difusa ao longo de juntas alargadas por dissolução ou por infiltração concentrada em condutos verticais (invasões vadosas), conforme será detalhado nos ítem 4.3.

\begin{tabular}{|c|c|c|}
\hline Origem da captação & Área Furnas Santana & Área Lajeado Bombas \\
\hline Alogência & $21.01 \mathrm{Km}^{2}, 46.8 \%$ & $37.14 \mathrm{Km}^{2}, 47.5 \%$ \\
\hline Autogênica & $* 23.86 \mathrm{Km}^{2}, 53.2 \%$ & $* 41.0 \mathrm{Km}^{2}, 52.5 \%$ \\
\hline
\end{tabular}

Tabela 4.2 - Áreas de captação de escoamento superficial na região investigada.

* Áreas aflorantes de metacalcário menos as zonas fluviais.

\subsubsection{Gradiente hidráulico dos sistemas de cavernas}

O gradiente hidráulico é um dos requisitos fundamentais no processo de abertura de condutos em rochas carbonáticas, pois é responsável pela movimentação da água subterrânea que carrega o produto de lixiviação da rocha, resultando na ampliação da permeabilidade inicial desta, gerando sistemas de cavernas (Thrailkill, 1968 e Huntoon, 1985). Nas áreas estudadas, o gradiente hidráulico dos sistemas de cavernas é bastante variável, com um valor médio de $65,5 \mathrm{~m} / \mathrm{km}$ e coeficiente de variação de $86,4 \%$. Os gradientes mais elevados ocorrem em sistemas cujos sumidouros localizam-se ao longo do contato NW dos metacalcários (sistemas Água Suja, $129 \mathrm{~m} / \mathrm{km}$ e Ouro Grosso, $221 \mathrm{~m} / \mathrm{km}$, tabela 4.1 e anexo 4.2). Por outro lado, os sistemas com pontos de injeção alogênica localizados ao longo do contato SE, exibem os gradientes mais baixos (p. ex., sistemas Pérolas-Santana, $51 \mathrm{~m} / \mathrm{km}$ e Areias, $25 \mathrm{~m} / \mathrm{km}$ ). Este fato é interpretado como sendo conseqüência do grau de cavernamento e entalhamento subterrâneo maior ao longo de uma faixa nas proximidades do contato SE, conforme comentado anteriormente, o que teria refletido em superficie um rebaixamento relativamente mais intenso dos vales cegos, poljes de contato e sumidouros associados, através do colapso de condutos vadosos. A variação e o papel do gradiente hidráulico no desenvolvimento de cavernas serão especificados adiante, na discussão do modelo espeleogenético.

\subsubsection{Extensão de cavernas acessíveis ao longo dos sistemas}

Outra característica fisica importante dos sistemas de circulação cárstica é a continuidade de condutos acessíveis, atualmente acima da zona saturada, ao longo da extensão entre os pontos de insurgência e ressurgência. Esta continuidade não deve ser confundida com o grau de cavernamento dos sistemas, pois este, inclui níveis superiores de salões e galerias, não integrados na rota atual de circulação de água na zona saturada. Observando a distribuição de cavernas no anexo 4.2 , nota-se que, com exceção do sistema Ouro Grossso, nenhum outro apresenta conexão acessível ao explorador, entre, pelo menos um dos pontos de injeção e a saída da água. As medidas de extensão de cavernas acessíveis em relação à extensão total dos sistemas são apresentados na tabela 4.3 . A maioria das cavernas associadas a estes sistemas, terminam em sifonamentos, tanto no sentido de caminhamento a montante das ressurgéncias, como a jusante dos sumidouros, ou seja, os 
condutos principais iniciam, a partir destes sifonamentos, um percurso abaixo da zona saturada. Tentativas de exploração por mergulhadores do nível freático nos fundos das cavernas Santana e Ressurgência das Águas Quentes, mostraram a continuidade de condutos penetráveis na zona freática. A perfuração de um poço para Sabesp, ño bairro da Serra (vale do Betari, área Furnas Santana, anexo 4.2), atingiu condutos em diversas profundidades, até $150 \mathrm{~m}$. Este poço, com uma vazão de $41 \mathrm{~m}^{3} / \mathrm{h}$ (dados do poço fornecidos pela Politi, S.A.), evidencia a presença de uma importante rede de condutos freáticos, abaixo do nível geral dos rios subterrâneos presentes nas cavernas acessíveis.

\begin{tabular}{|c|c|c|}
\hline Sistema & $\begin{array}{c}\text { Extensão de condutos } \\
\text { acessiveis, Ec, metros }\end{array}$ & $\begin{array}{c}\text { Fração de condutos } \\
\text { acessíveis, Ec } / \Delta \mathbf{L}, \boldsymbol{\%}\end{array}$ \\
\hline Onça Parda-Morro Preto & 320 & 10.4 \\
\hline Água Suja & 1092 & 47.5 \\
\hline Pérolas-Santana & 2516 & 42.1 \\
\hline Grilo & 240 & 3.4 a 3.1 \\
\hline Areias & 3140 & 49.6 \\
\hline Córrego Fundo & 1300 & 16.1 \\
\hline Ouro Grosso & 950 & $100-45.9$ \\
\hline Alambari & 1020 & $26.8-23.1$ \\
\hline
\end{tabular}

Tabela 4.3 - Fração de condutos acessíveis ao longo da extensão $(\Delta \mathrm{L})$ dos sistemas nas áreas estudadas.

Este hiato de continuidade de condutos acima do nível de água nos fundos de cavernas é associado à transição de cavernas vadosas para freáticas, desenvolvidas ao longo das linhas côncavas do fluxo da água subterrânea. Esta concavidade e profundidade das linhas de fluxo é função do gradiente hidráulico, estrutura da rocha carbonática e extensão da linha de captação do sistema (Worthington, 1991), assunto que será explorado no ítem 4.3 , sobre a espeleogênese

\subsection{Modelo espeleogenético para o carste do Alto Ribeira}

\subsubsection{Aspectos teóricos da espeleogênese}

Espeleogênese é o conjunto de processos que afetam a origem e desenvolvimento de cavidades subterrâneas naturais (Bögli, 1978). Os processos fundamentais envolvidos na espeleogênese de sistemas de cavernas, em rochas carbonáticas, são a corrosão (remoção química da rocha), erosão (remoção mecânica) e abatimento (alteração física e movimentos de massa da rocha devido à instabilidades mecânicas do maciço rochoso).

A corrosão de rochas carbonáticas, pela ação de águas meteóricas, é função direta da cinética química do sistema $\mathrm{H}_{2} \mathrm{O}-\mathrm{CO}_{2}-\mathrm{CaCO}_{3}$ (Dreybrodt, 1987, 1988, 1990). A abertura, por dissolução, de condutos profundos no interior de seqüências carbonáticas, é atribuída à três mecanismos químicos principais. $O$ primeiro baseia-se em reações lentas de dissolução de calcita, com cinética de terceira a quarta ordem do sistema acima. Desta maneira, soluções próximas do equilíbrio, são capazes de percolar a rocha por grandes distâncias sem atingir a saturação total em carbonato (Dreybrodt, 1981a e 1990). O segundo mecanismo é o fenômeno da corrosão de mistura, onde duas soluções saturadas em calcita, com concentrações de saturação e pressões parciais de $\mathrm{CO}_{2}$ muito cóntrastantes, 
ao se misturar, formam uma solução agressiva (Bögli, 1964, 1978 e Dreybrodt, 1981b). Por último, modelos atuais de geração de condutos em profundidade, consideram que, a agressividade da água de percolação, causada somente pelo $\mathrm{CO}_{2}$, não seria suficiente para gerar grandes vazios, no tempo disponivel para tal. Atualmente é propostro que a abertura inicial de condutos seja principalmente devida à corrosão da rocha carbonática pelo ácido sulfúrico, gerado pela oxidação de sulfetos, muito freqüentemente disseminados pela rocha calcária (Forti, 1989, Ball e Jones, 1990; Worthington, 1991 e Lowe, 1992).

Alguns aspectos do quimismo atuante no carst do Alto Ribeira serão tratados no capítulo 5, assim como, na discussão da iniciação de condutos.

A erosão mecânica é um importante processo de denudação em fases avançadas da espeleogênese, quando condições fluviais são estabelecidas, principalmente em cavernas cruzadas por rios alogênicos. Newson (1971) determinou que no caso de rios subterrâneos, tabletes de calcário expostos à ação dos rios perdem praticamente a mesma massa, tanto por abrasão mecânica, como por química. $O$ efeito abrasivo do transporte de sedimento clástico alóctone torna-se importante, principalmente durante vazões catastróficas associadas a tempestades.

O abatimento de blocos, desmoronamento ou incasão (do termo incasion, de Bögli, 1969) é o descolamento, ao longo de descontinuidades, e movimentação de fragmentos da rocha encaixante da caverna, resultando, principalmente, na modificação e, às vezes, na ampliacão de salões e condutos subterrâneos. Com o desenvolvimento de vazios por dissolução, e rebaixamento do lençol freático, o campo de tensões no maciço rochoso tende a um novo estado de equilíbrio, o qual é atingido através da redistribuição de massa no maciço, por meio de abatimentos e movimentação de blocos (Ford e Williams, 1989). Conforme ressaltado por Waltham (1981), o processo de colapso de cavidades não forma cavernas, mas sim, ao contrário, devido ao aumento de volume de uma pilha de fragmentos em relação à rocha não fragmentada, este processo tende a preencher o espaço vazio previamente formado, e portanto, deve ser relacionado, somente a um fator de modificação ou rearranjo do espaço, durante o desenvolvimento de cavernas.

Segundo Lowe (1992), a espeleogênese ocorre em tres etapas principais. A primeira corresponde ao período, durante o qual, uma certa rocha carbonática não possue cavernas, mas apresenta um conjunto de descontinuidades planares, potencialmente favorável à penetração e percolação de solventes (permeabilidade primária). É denominada, pelo autor acima de inception phase, aqui traduzido como fase de pré-iniciação Nesta fase, a superficie da zona freática, quando presente, é rasa e a zona vadosa quase inexistente 0 fluxo de água é muito lento, através do sistema de finos capilares ao longo de descontinuidades com aberturas em torno de $0.1 \mathrm{~mm}$. Esta fase de pré-iniciacão passa gradativamente à fase de iniciação, a qual caracteriza-se pela instalação de uma rede de. condutos freáticos interconectados, ao longo das descontinuidades. A dimensão e distribuição destes condutos será condicionada pelos padrões estruturais, características litológicas e composicionais, gradiente hidráulico e disponibilidade de água (Kastning, 1984, apud Lowe, op cit.). Esta fase é marcada pelo início e incremento, com o tempo, da 
permeabilidade secundária. A terceira fase inicia-se com a instalacão de fluxo turbulento ao longo de parte do sistema de condutos, queda rápida do lençol freático e ampliação da zona vadosa. Relaciona-se esta fase à conexão de condutos freáticos com a superficie, ou seja, à intersecção de condutos pelo entalhamento da topografia externa: É denominada de fase de desenvolvimento ou avanço (breakthrough) do sistema de cavernas.

Nas fases de nré-iniciação e iniciação domina o processo de corrosão. Na fase de desenvolvimento, além da dissolução, inicia-se a abrasão mecânica, através da captura de rios alogênicos pelo sistema subterrâneo de drenagem e, no estágio mais avançado de desenvolvimento, com a queda do lençol freático e abandono de níveis superiores de condutos, a incasão inicia um papel importante na modificacão do padrão primário de condutos.

Tendo em mente os processos envolvidos e a evolução seqüencial da espeleogênese, devem ser ainda considerados, os pré-requisitos e controles fundamentais, para que uma região carbonática sofra carstificação e espeleogênese. Ford (1980), McConnell e Horn (1972), Thornbury (1969) e Dreybrodt (1988) apresentam discussão detalhada a respeito A primeira condição é a presença de rocha carbonatica, em superficie ou próxima desta, a qual, após dissolução, deixe o mínimo de resíduos insolúveis, o que manterá os interstícios de dissolução abertos, ponto importante para a iniciação da espeleogênese. Ford (op cit) estabelece uma pureza mínima de 70 a $80 \%$ de $\mathrm{CaCO}_{3}+\mathrm{MgCO}_{3}$, em peso, para esta condição. $O$ segundo requisito refere-se à concentração da dissolução ao longo de rotas pré-estabelecidas por juntas, fraturas e falhas. Em rochas carbonáticas com alta porosidade primária (intergranular), a dissolução será altamente difusa, condicionando um aqǘfero de fluxo difuso, numa escala de centímetros, ou menos. Por outro lado, rochas com alta porosidade secundária, terão o ataque corrosivo concentrado ao longo de descontinuidades, gerando um aqüífero de condutos. $O$ terceiro controle da espeleogênese é a energia necessária para movimentar a infiltração através dos capilares na fase de iniciação. Para que ocorra este fluxo, num ambiente freático inicial, a ȧgua necessita uma alta energia potencial, o que implica, nesta fase, num lençol freático fortemente inclinado, considerando que neste estágio inicial há um lençol freático definido. Portanto, em áreas carbonáticas com altos gradientes hidráulicos, a iniciação de cavernas será favorecida. O último requisito para o pleno desenvolvimento da espeleogênese é uma condição climática úmida. A cinética de dissolução de carbonato de cálcio mostra que a taxa de dissolução é diretamente proporcional à quantidade de água e gás carbônico no sistema. A pressão parcial de $\mathrm{CO}_{2}$, na água de infiltração, também é influenciada pelo clima. Em climas quentes e úmidos, as condições ideais para corrosão de rochas carbonáticas são atingidas, pois nestes, combinamse a disponibilidade de água com alta produção de $\mathrm{CO}_{2}$ biogênico no solo (Ford e Williams, 1989).

A área de amostragem em estudo, representativa do carste do Alto Ribeira, satisfaz plenamente os requisitos acima esboçados, apresentando um variado conjunto de cavernas, conforme será descrito abaixo. 


\subsubsection{Morfologia e características lito-estruturais das cavernas estudadas}

Com o objetivo de recuperar a história de abertura e evolução das cavernas; executou-se o levantamento da morfologia dos condutos e das características litoestruturais da rocha encaixante (a forma do vazio é um testemunho do processo de entalhamento subterrâneo), para um conjunto de cavernas, as quais representam uma amostragem dos diferentes padrões de cavernas da área estudada.

Os sistemas de circulação subterrânea, da área de estudo, apresentam dois tipos básicos de cavernas associadas. Um com desenvolvimento horizontal predominante, e outro, principalmente vertical, denominado genericamnte de conduto vertical (vertical shaft) ou abismo. Formas de transição entre cavernas horizontais e verticais ocorrem, assim como, freqüentemente condutos verticais estão associados aos condutos sub-horizontais, conforme será apresentado adiante.

Selecionou-se as principais cavernas dos sistemas Pérolas-Santana, Agua Suja, Areias e Ouro Grosso, das quais, confeccionou-se os respectivos mapas geoespeleológicos, em escalas de 1:400 ou 1:600. Os condutos verticais associados a estes sistemas também serão analisados.

\subsubsection{Geometria planimétrica}

Na figura 4.2 apresenta-se a projeção horizontal reduzida das cavernas estudadas Nota-se diferentes hábitos morfológicos (geometria) dos condutos e salōes que as compõem. Para quantificar estes hábitos e permitir a comparação não subjetiva entre estes, mediu-se os seguintes parâmetros morfométricos (seguindo recomendações de Worthington, 1991): sinuosidade do conduto principal, largura da faixa de fluxo e largura relativa de fluxo.

Sinuosidade (S) de uma rota de fluxo ao longo de cavernas, é uma propriedade planimétrica, definida como sendo a relação entre o desenvolvimento da caverna percorrido por um rio subterrâneo ativo $(\mathrm{Da})$ e a extensão $(\mathrm{Ec})$, linha reta entre o início e fim, desta rota de fluxo (fig 4.3).

Largura da faixa de fluxo (Lf) é a distância mínima entre as duas retas paralelas à extensão e que envolvem, tangenciando o desenvolvimento do rio subterrâneo ( $\mathrm{Da}$ ). A largura relativa de fluxo ( $\mathrm{Lr}$ ) é a distância Lf sobre a extensão, Ec, (fig 4.3). As medidas estão listadas na tabela 4.4 .

Com estas medidas e a forma em planta do conduto principal do rio subterrâneo, distingue-se os seguintes estilos de cavernas:

\section{Cavernas curvilíneas e sinuosas}

Este é o padrão morfológico dominante na caverna Areias e no segmento à jusante do grande salão de abatimento da caverna Água Suja. Caracteriza-se pelos valores observados mais altos de sinuosidade e largura de fluxo ( $S$ entre 1,20 e 1,40, $\mathrm{Lr}$ entre 0,19 e 0,25 ) e segmentos retilíneos curtos, entre inflexões de direção do conduto principal, as 

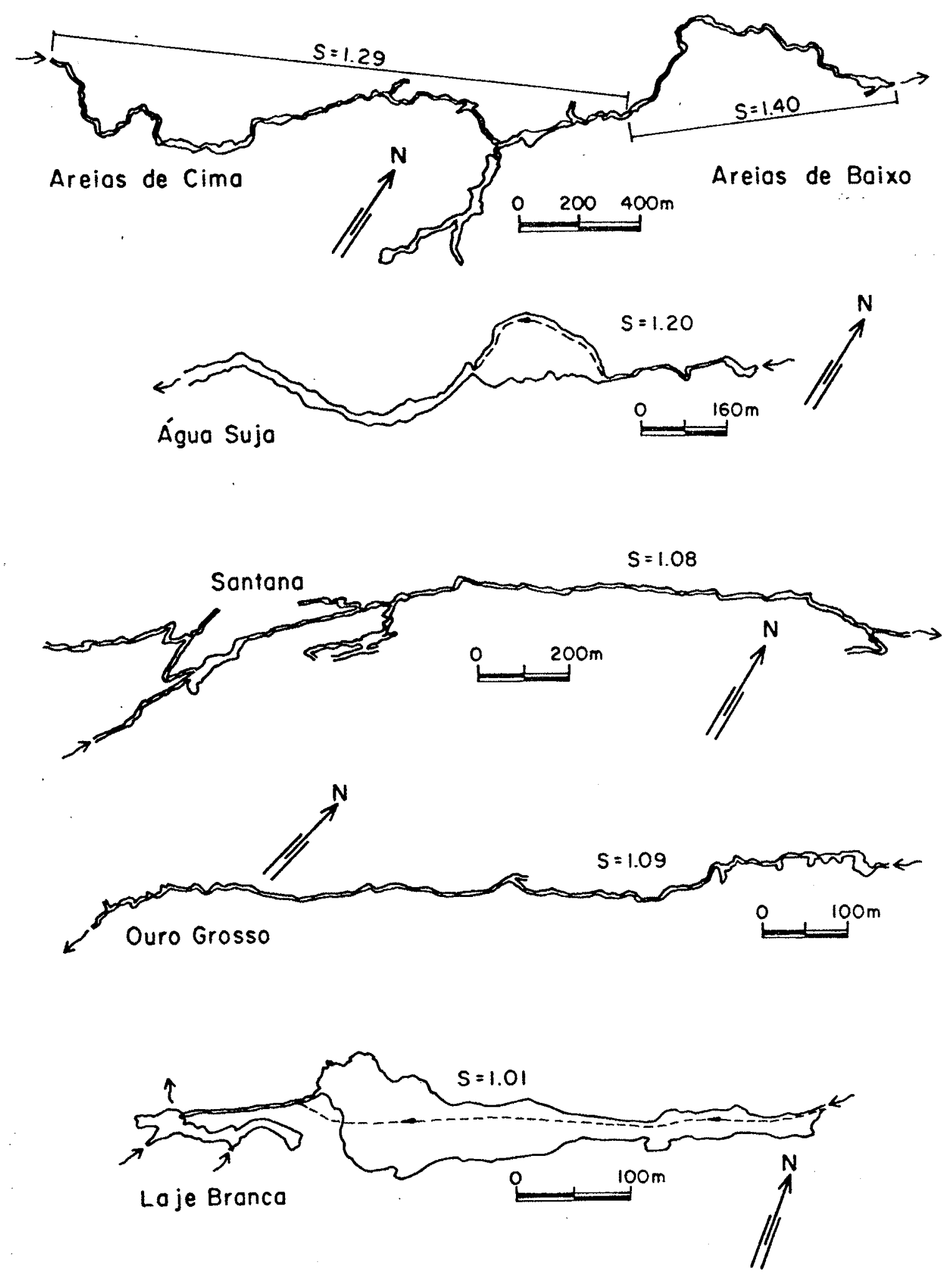

Figura 4.2 - Padrões em planta das rotas fluviais subterrâneas das cavernas da área estudada. As setas indicam o sentido do fluxo principal de água e (S) a sinuosidade destas rotas. 
quais são curvilineas e arredondadas. Estas cavernas enquadram-se no segundo tipo de nãolinearidade, proposto por Deike e White (1969), dominante nos longos sistemas de cavernas Mammoth e Flint Ridge (EUA), onde o condicionamento de galerias por juntas e-fraturas é pouco notável.

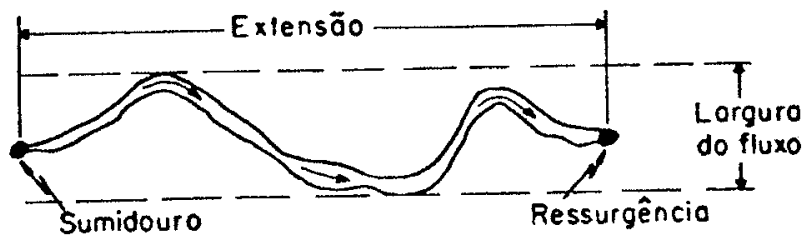

Figura 4.3 - Definição dos parâmetros planimétricos extensão e largura da faixa de fluxo.

\begin{tabular}{|c|c|c|c|c|c|}
\hline $\begin{array}{c}\text { Nome da } \\
\text { Caverna }\end{array}$ & $\begin{array}{c}\text { Extensão } \\
\text { Ec, } \mathbf{m}\end{array}$ & $\begin{array}{c}\text { Desenvol- } \\
\text { vimento de } \\
\text { condutos } \\
\text { ativos, } \\
\text { Da, } \mathbf{m}\end{array}$ & $\begin{array}{c}\text { Sinuosidade } \\
\mathbf{S = ~ D a} / \mathbf{E c}\end{array}$ & $\begin{array}{c}\text { Largura da } \\
\text { faixa de } \\
\text { fluro, Lf, } \mathbf{m}\end{array}$ & $\begin{array}{c}\text { Largura } \\
\text { relativa de } \\
\text { fluxo } \\
\mathbf{L r}=\mathbf{L f} / \mathbf{E c}\end{array}$ \\
\hline Laje Branca & 606 & 612 & 1.01 & 64 & 0,106 \\
\hline Santana & 1746 & 1880 & 1.08 & 232 & 0,133 \\
\hline Agua Suja & 1092 & 1312 & 1.20 & 209 & 0,191 \\
\hline $\begin{array}{c}\text { Areias de } \\
\text { Cima }\end{array}$ & 1764 & 2280 & 1.29 & 258 & 0,146 \\
\hline $\begin{array}{c}\text { Areias de } \\
\text { Bairo }\end{array}$ & 1227 & 1722 & 1.40 & 308 & 0,251 \\
\hline Ouro Grosso & 952 & 1040 & 1.09 & 71 & 0,074 \\
\hline
\end{tabular}

Tabela 4.4 - Parâmetros morfométricos planimétricos das principais cavernas da área estudada. Medidas obtidas sobre mapas 1:500 a 1:1000 das cavernas.

\section{Cavernas retilíneas e angulosas}

As cavernas Santana e Ouro Grosso são os exemplos onde este padrão predomina. Apresentam sinuosidade e largura de fluxo contrastantemente inferiores ao padrão anterior (S entre 1,08 e 1,09, Lr entre 0,07 e 1,33). Caracterizam-se por segmentos retilíneos longos entre inflexões angulosas e agudas. Passagens sinuosas arredondadas são raras. Segundo Deike e White (1969), esta morfologia reflete intenso controle estrutural, típico de áreas dobradas com alto ângulo de mergulho, conforme será detalhado adiante.

\section{Galerias e salões de abatimento (incasão)}

Grande parte das cavernas Laje Branca, Pérolas e o ramo direito da caverna Areias de Baixo são ocupadas por esta morfologia. Trechos isolados de abatimento são freqüentes ao longo de todas cavernas amostradas. Na caverna Água Suja, por exemplo, ressalta-se um 
grande salão de abatimento, notado em planta pelo alargamento anômalo no setor central da caverna. $O$ salão corresponde ao espaço onde a largura é semelhante ao comprimento do segmento da caverna e a galeria de abatimento, ao trecho onde o comprimento suplanta em muito a largura.

Quando a caverna é dominada por este padrão, sua sinuosidade tende a ser reduzida ao máximo, como no caso das cavernas Laje Branca e Pérolas, com $\mathrm{S}$ entre 1,01 e 1,03. A largura de fluxo também tende a ser pequena neste caso, pois, o rio subterrâneo principal concentra-se numa das laterais do conduto de abatimento, seguindo o gradiente local.

Planimetricamente caracterizam-se por áreas maiores, em função da largura maior da passagem, quando comparadas às cavernas com condutos originais (sem abatimento).

\section{Relação entre sinuosidade e largura de fluxo}

Apesar das poucas medidas efetuadas, devido à escassez de mapas completos de cavernas da área, obteve-se uma tendência, diretamente proporcional, da sinuosidade em função da largura de fluxo, com exceção da caverna Santana, a qual, nesta relação, exibe uma sinuosidade inferior à esperada, em função de sua largura de fluxo total (fig 4.4). Esta anomalia é devida ao fato da caverna Santana ser constituída por dois segmentos, onde cada segmento possui largura de fluxo baixa ( 72 e $84 \mathrm{~m}$ ), compatível com a sinuosidade destes ( $~$ $1,08)$, mas os dois segmentos em conjunto, aumentam muito a largura total de fluxo, sem incrementar a sinuosidade final da caverna.

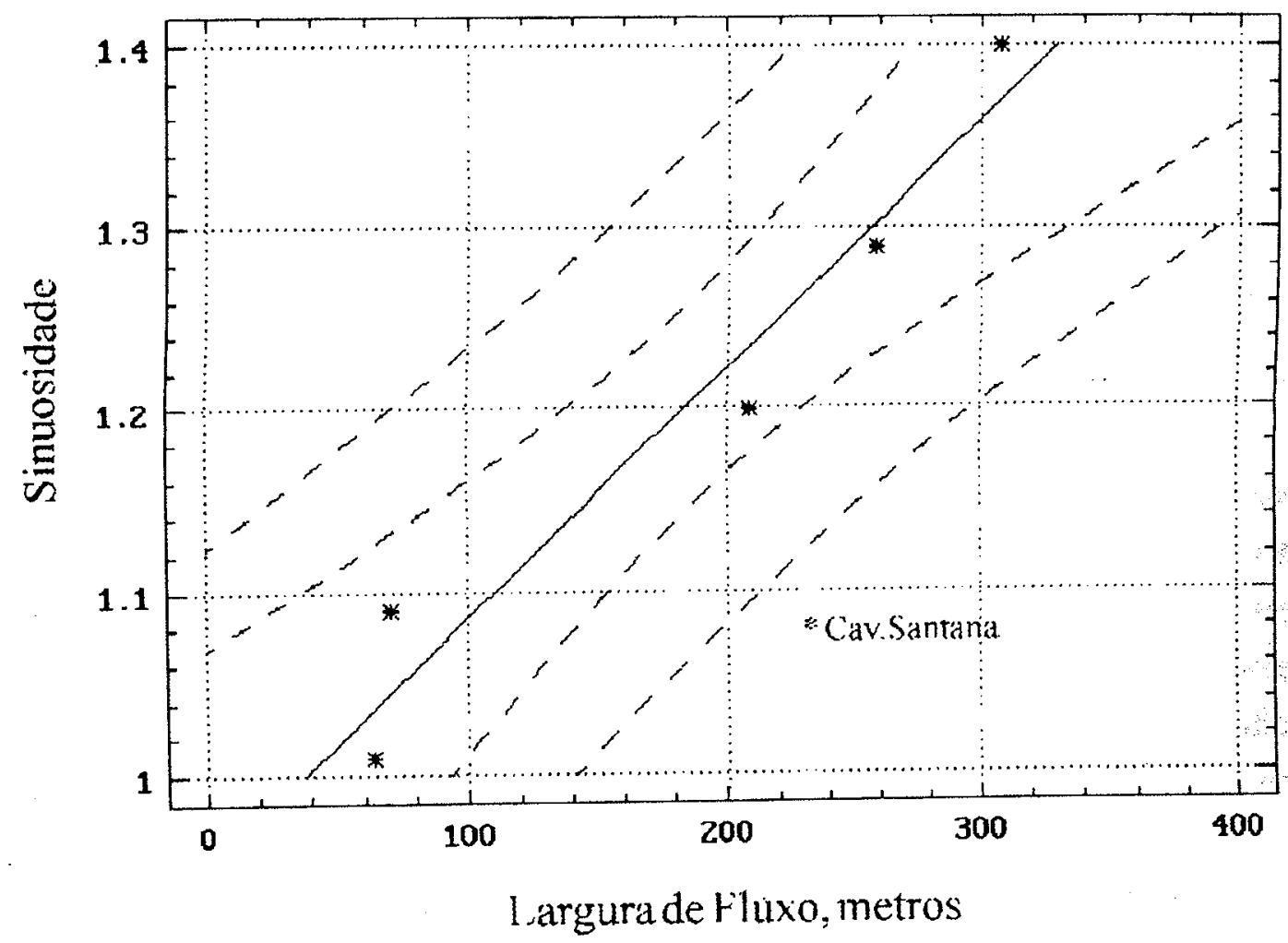

Figura 4.4 - Sinuosidade em função da largura de fluxo das cavernas estudadas Coeficiente de correlação 0,97 e $R^{2}$ de $95 \%$, com modelo linear de correlação, sem considerar a caverna Santana 


\subsubsection{Geometria em seções longitudinais e transversais}

Associadas à geometria em planta, as seções transversais e o perfil longitudinal, fornecem a visualização da terceira dimensão das cavernas, elemento essencial para analisar o entalhamento subterrâneo.

O perfil longitudinal é obtido através da projeção do desenvolvimento da caverna e suas respectivas medidas de altura (desnivel entre o piso e teto da passagem), sobre o plano vertical, paralelo à extensão desta. Fornece parâmetros morfométricos como o desnível do rio subterrâneo, a altura média do entalhamento deste, e a altura relativa entre níveis de passagens. Com o desnivel e a extensão, obtém-se o gradiente médio do rio subterrâneo.

Seções transversais são produzidas a partir de uma série de medidas de altura e largura sobre planos de corte perpendiculares ao desenvolvimento em planta da caverna.

O controle hidráulico (regime de fluxo) tende a gerar duas formas principais de passagens: o entalhamento vadoso (fluxo turbulento com abrasão mecânica, além da dissolução), produzindo entrincheiramentos (canyons) e o alargamento freático (fluxo predominantemente laminar e dissolução), gerando condutos com seções elípticas a circulares (Bögli, 1969, White, 1988 e Palmer, 1991). Formas de transição ocorrem em função da superposição de regimes de fluxo, assim como, formas originais podem ser totalmente obliteradas pelo controle mecânico de rearranjo do vazio subterrâneo através da incasão.

$\mathrm{Na}$ área estudada foram identificadas as seguintes geometrias de passagens subterrâneas no plano vertical:

\section{Entalhamento vadoso}

Entende-se por entalhamento vadoso a abertura ou ampliação de condutos subterrâneos na zona insaturada ou junto da interface zona saturada e insaturada, através da ação de fluxo de água turbulento, onde a corrosão da rocha carbonática alia-se à erosão mecânica devido ao transporte fluvial de detritos abrasivos. As seguintes formas associadas ao entalhamento vadoso foram reconhecidas: canyons, condutos triangulares e retangulares e condutos verticais.

Os canyons representam passagens subterrâneas, com seções transversais, onde a altura é da ordem de 4 a 10 vezes maior que a largura (fig 4.5 e 4.6). Sua base é marcada pelo rio subterrâneo (ou testemunhos deste, em passagens acima do nível de base atual), 0 qual corre sobre leito rochoso ou depósitos fluviais (areias e cascalheiras). Blocos abatidos ocorrem isoladamente. A terminação superior foi pouco observada, devido à dificuldade de acesso. Na caverna Laje Branca é possível percorrer o topo de um canyon subterrâneo por um trecho de 150 metros. Este é formado por um alargamento, onde a seção transversal assume um contorno lenticular a circular, com paredes lisas e eixo maior de 2 a $6 \mathrm{~m}$ (fig 4.7 e anexo 4.1). Segundo Davis (1930), Bretz (1942) e Bögli (1978) estas terminações elípticas no topo de canyons representam a seção de um conduto freático inicial, o aual posteriormente teve seu fundo entrincheirado em ambiente vadoso, através de entallhamento fluvial, originando um canyon vadoso Na caverna Santana, onde a morfologia de canyon é 

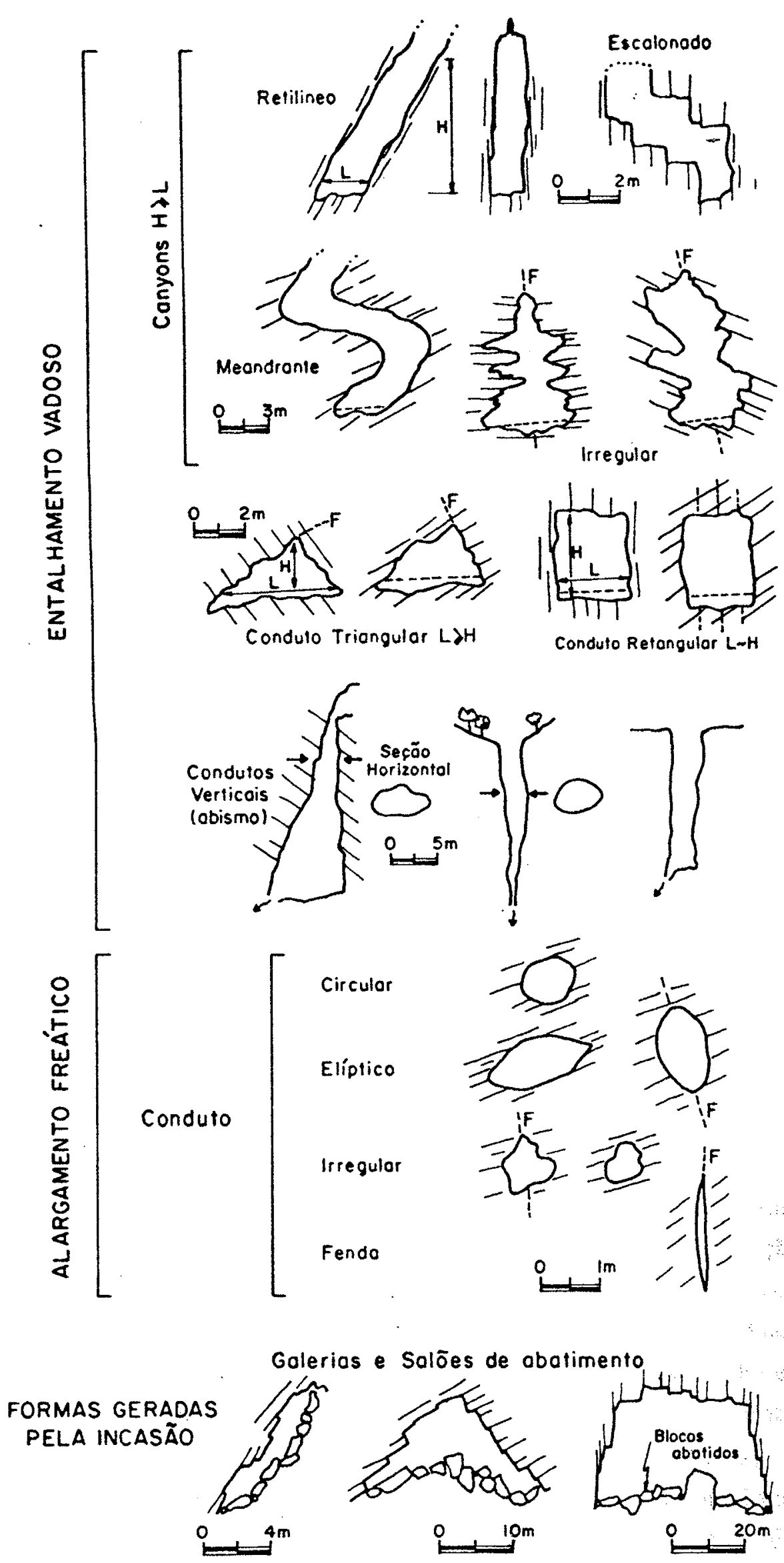

Figura 4.5 - Classificação geométrica de seçôes transversais no plano vertical L, largura, $\mathrm{H}$, altura e $\mathrm{F}$, traço de fratura 
predominante ao longo do rio atual, o acesso ao topo deste requer escaladas. Num dos pontos atingidos (fig 4.6), a terminação do canyon é através de um afunilamento brusco que dá lugar a uma fenda com abertura decimétrica. Interpreta-se esta fenda como sendo um conduto freático inicial, semelhante ao caso da terminação de passagens vadosas menores, descritas adiante. Quando presente, esta iniciação freática imprime um caráter misto a estas seções, onde predomina largamente a feição vadosa, associada neste caso, somente à ampliação da passagem.

Quanto à forma das seções transversais de canyons, distinguem-se quatro padrões principais, denominados de canyons retilíneos, escalonados, meandrantes e irregulares (fig 4.5).

Os canyons retilíneos possuem paredes paralelas retas, com inclinação geral constante. O padrão escalonado é formado por vários segmentos superpostos menores de paredes paralelas e retas, os quais migram lateratmente. Os patamares assim formados correspondem à terraços fluviais subterrâneos. Ambos ocorrem associados à passagens predominantemente retilíneas em planta, como por exemplo, nas cavernas Santana (fig 4.6) e Ouro Grosso, onde o entalhamento fluvial é fortemente guiado pelo acamamento de alto mergulho. O primeiro corresponde ao entalhamento preferencial ao longo de um plano de estratificação e o segundo reflete o entalhamento sucessivo lateral de vários planos de acamamento.

Os canyons meandrantes possuem seção com paredes paralelas e fortemente sinuosas (fig 4.5). Desenvolvem-se em cavernas curvilíneas e com alta sinuosidade, como na caverna Areias (fig 4.8), em função do caráter meandrante do entalhamento fluvial vertical. As seções associadas a estas passagens tomam formas complexas, pois com o avanço à juzante dos meandros, simultaneamente ao entalhamento vertical, o meandro rebaixado estará deslocado em relação ao corte superior; na direção do fluxo fluvial. Estes canyons não evidenciam controle estrutural importante. Conforme Ewers (1972), apud Bögli (1978), canyons meandrantes caracterizam entalhamentos vadosos com mais de $10 \mathrm{~m}$ de profundidade, associados à cavernas de baixo gradiente.

Canyons irregulares são aqueles cujas paredes apresentam contorno em seção transversal com padrão serrilhado e intensamente ondulado, com grande variação da largura ao longo da seção transversal (fig 4.5). O caráter serrilhado ou ondulado corresponde à camadas ressaltadas junto à outras mais entalhadas, devido à dissolução diferencial entre estratos carbonáticos puros e impuros, ricos em partículas insolúveis de silte e argila. Esta forma é freqüente nas cavernas estudadas (fig 4.6 e 4.8 ), onde a estratificação dos metacalcários é marcada por ritmicidade de camadas mais ou menos argilosas:

As alturas de canyons vadosos indicam a profundidade de entalhamento do rio subterrâneo. Nas cavernas estudadas, as alturas variam entre 10 e 50 metros. Estas medidas incluem uma margem de erro, estimada em até 10\%, principalmente nos valores altos, devido à imprecisão nas medidas.

Uma característica notável dos canyons vadosos, principalmente observada nas cavernas Arelas e Santana, é a grande variação de altura na direção do desenvolvimento da 

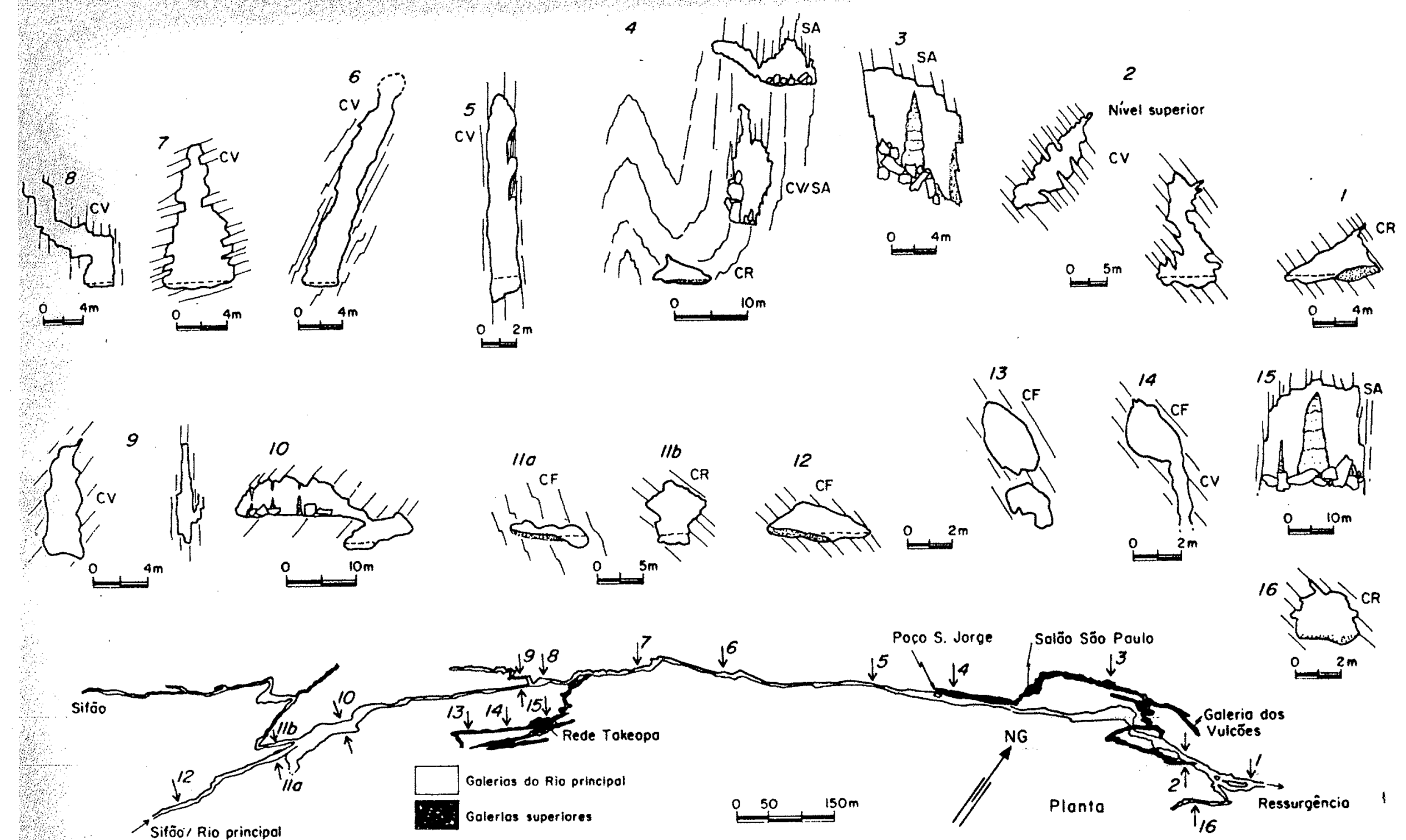

Figura 4.6 - Seções transversais da caverna Santana. Traços contornando seções indicam o acamameto. Canyon vadoso, $\mathrm{CV}$; conduto freático, $\mathrm{CF}$, salăo de abatimento, $\mathrm{SA}$; conduto retangular, $\mathrm{CR}$ e conduto triangular, $\mathrm{CT}$. 

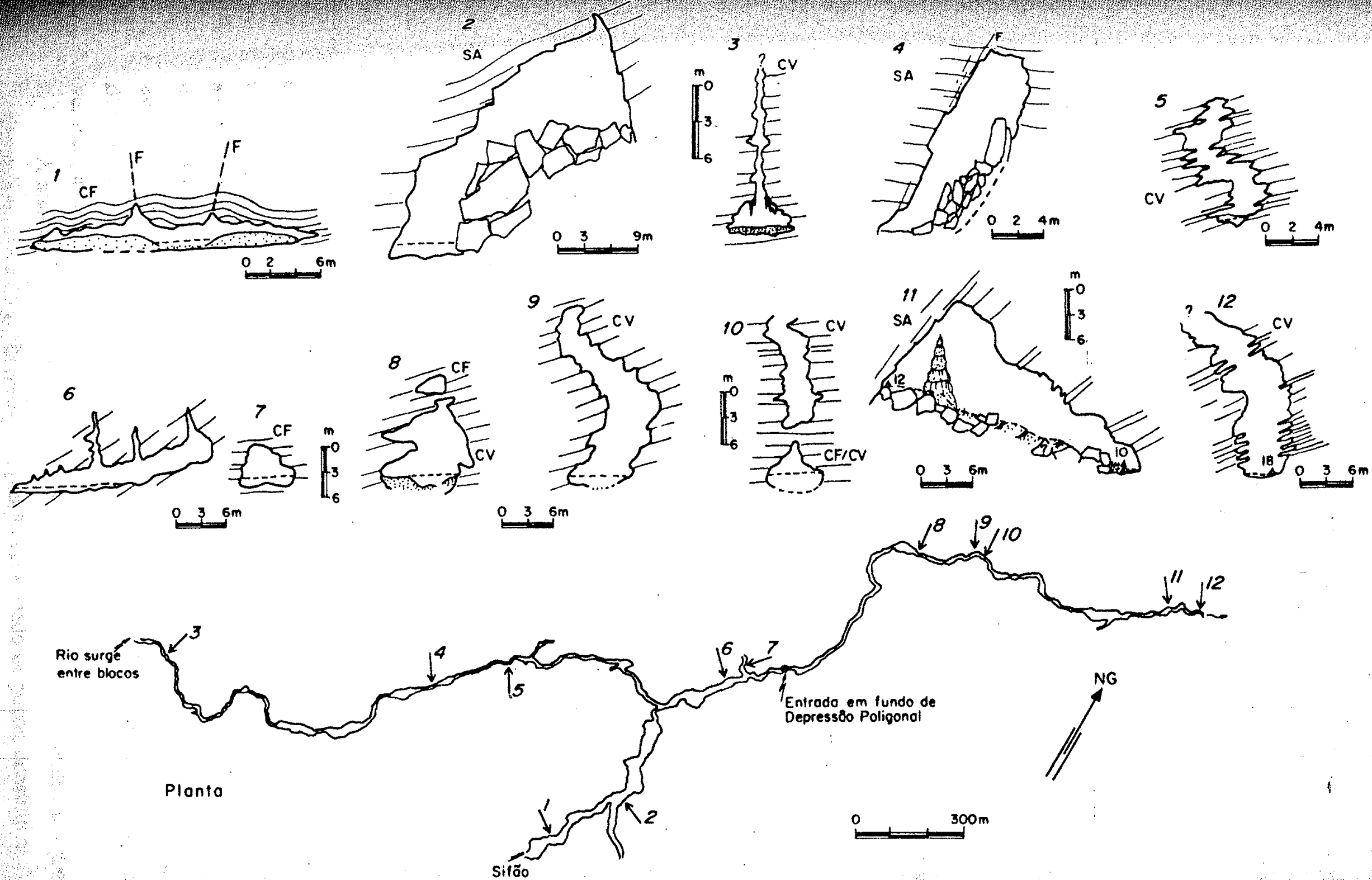

Figura 4.8 - Seções transversais da caverna Areias. Canyon vadoso, CV; conduto freático, CF e salão de abatimento, $\mathrm{SA}$, traço de fratura, F. 
caverna. Como exemplo, acompanhando o perfil longitudinal do rio principal da caverna Santana (fig 4.9), no sentido a jusante, partindo do sifão do fundo da caverna, observou-se que o teto da galeria rapidamente se eleva, de alturas entre 5 e $8 \mathrm{~m}$ para 20 e 30 , atingindo um máximo de $50 \mathrm{~m}$ ao longo do canyon central da caverna. Nas proximidades da entrada, a altura da galeria retorna para 4 a $8 \mathrm{~m}$. A interpretação desta feição é discutida no item referente a fase de desenvolvimento da espeleogênese (página 129).

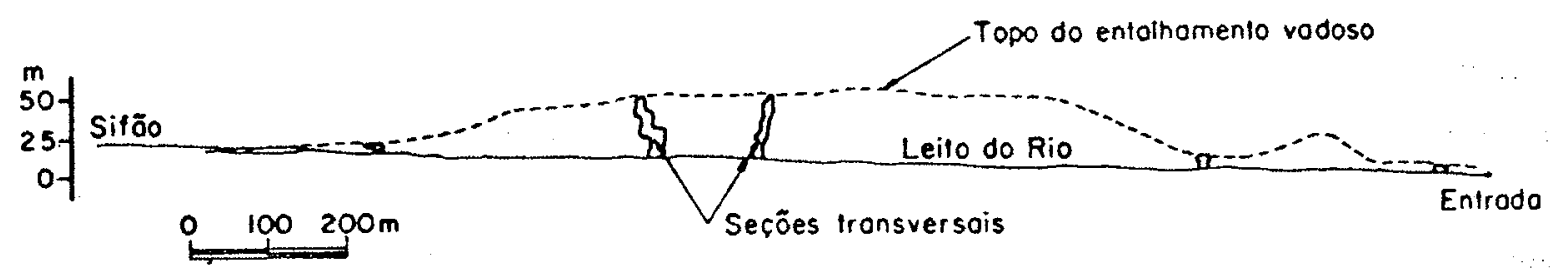

Figura 4.9 - Perfil longitudinal simplificado da caverna Santana, indicando a variação do topo do entalhamento vadoso.

As passagens triangulares e retangulares representam entalhamentos vadosos menos profundos, em comparação com os canyons (fig 4.5). A diminuição de altura em canyons, acima comentada, frequentemente representa a transição destes para passagens do tipo triangular ou retangular (fig 4.9).

As passagens com seção transversal aproximadamente triangular caracterizam-se pela largura igual ou maior que a altura (fig 4.5 e 4.6). Suas paredes divergem a partir de uma linha de intersecção entre um plano de fratura ou falha com a estratificação, ambos com mergulhos moderados. $O$ entalhamento fluvial segue grosseiramente estes planos, 0 que imprime a tendência triangular a estas seções. A iniciação deste tipo de conduto é marcada na intersecção fratura camada, através de um pequeno alargamento (fig 4.5), o qual é atribuído a uma iniciação em ambiente freático, segundo o modelo de Bögli (1969).

As passagens retangulares exibem altura semelhante à largura. Denotam nítido controle estrutural, pois o entalhamento é sempre paralelo ao acamamento, ou à fraturas, ambos de alto mergulho (fig 4.6 e 4.8).

Os condutos verticais caracterizam-se pela geometria geral cilindrica a cônica com eixo vertical (fig 4.5). No plano vertical apresentam seções de paredes divergentes, convergentes ou paralelas, em relação ao ponto superior. Sua projeção em planta é circular a eliptica. Suas dimensões variam de alguns centímetros a dezenas de metros em diâmetro e de alguns metros a centenas de metros em altura. Os exploradores de cavernas denominam estas estruturas genericamente de abismos. Deve-se salientar, que muitas cavernas com desniveis importantes e classificadas pelos exploradores como abismos, não são condutos verticais, mas sim, trechos de canyons vadosos.

A associação de vários condutos verticais superpostos e separados por patamares horizontais ou inclinados, formando um padrão escalonado de poços, constitui as cavernas com o maior desnível da região estudada Como exemplo, cita-se o abismo do Juvenal 
(localizado sobre a rota de fluxo do sistema Pérolas-Santana), com cerca de $250 \mathrm{~m}$ de desnível total e vários condutos verticais superpostos, com alturas entre 15 e $40 \mathrm{~m}$ e diâmetros entre 0.5 e $10 \mathrm{~m}$.

A ocorrência de condutos verticais é vinculada à sistemas eficientes de drenagem subterrânea. Segundo Brucker, Hess e White (1972), os condutos verticais exercem a função de transmitir a água de escoamento superficial ou de aqüíferos suspensos, através da seqüência carbonática em direção ao nível de base do lençol freático. Sua ampliação se dá por meio do fluxo livre de água vadosa, insaturada em carbonato, concentrada sobre as paredes dos condutos.

Ford e Williams (1989) classificam estas cavernas de invasões vadosas, pois, na maioria dos casos, estas se formam pela absorção de rios superficiais pela rocha carbonática previamente drenada por fases anteriores de espeleogênese.

Como exemplos mapeados de condutos verticais citam-se os abismos das cavernas Ouro Grosso, Santana e Água Suja (fig 4.10). Todos representam córregos associados a um nivel superior de cavernas, o qual foi conectado à rota mais profunda de circulação cárstica, através do desenvolvimento de condutos verticalizados que interceptaram os condutos profundos.

Na caverna de Santana, trata-se de um paleo-afluente que corria no nível do salão São Paulo, a cerca de $30 \mathrm{~m}$ acima do rio atual, que interceptou o rio subterrâneo principal, através do popularmente chamado poço São Jorge (fig $4.10 \mathrm{c}$ ), o qual representa a terminação deste antigo afluente superior, através de um conduto vertical.

No sistema Água Suja, os condutos verticais representam a conexão entre o nivel superior de condutos da caverna Vargem Grande e o ramo principal do rio subterrâneo da caverna Água Suja (fig 4.10a). Neste caso, formou-se um conduto vertical com $90 \mathrm{~m}$ de altura

No sistema Ouro Grosso identificaram-se três condutos verticais principais alinhados sobre o conduto inferior do rio (fig 4.10b). Destes, o abismo localizado na extremidade mais à montante da caverna, ainda apresenta um córrego ativo, o qual forma uma cachoeira junto ao abismo. Este alinhamento de abismos coincide com um vale seco em superficie, onde os dois poços mais à jusante representam antigos pontos de absorção deste paleo-rio, hoje restrito a um trecho ativo curto, com o sumidouro principal conectado ao terceiro abismo com cachoeira

Os condutos verticais acima descritos possuem seção típica de paredes divergentes em direção à base, em forma de garrafões. Atribui-se esta forma à característica de fluxo livre em regime supercrítico da lâmina de água agressiva, a qual em queda livre, gera turbilhonamento próximo à base, causando assim, alargamento maior na base.

Outra categoria de condutos verticais é aquela cuja seção no plano vertical exibe paredes convergentes em direção à base. O fundo é normalmente afunilado e intransponível. Caracterizam fundos, e às vezes, encostas de depressões poligonais. Freqüentemente apresentam-se parcialmente revestidos ou preenchidos por material síltico-argiloso, 

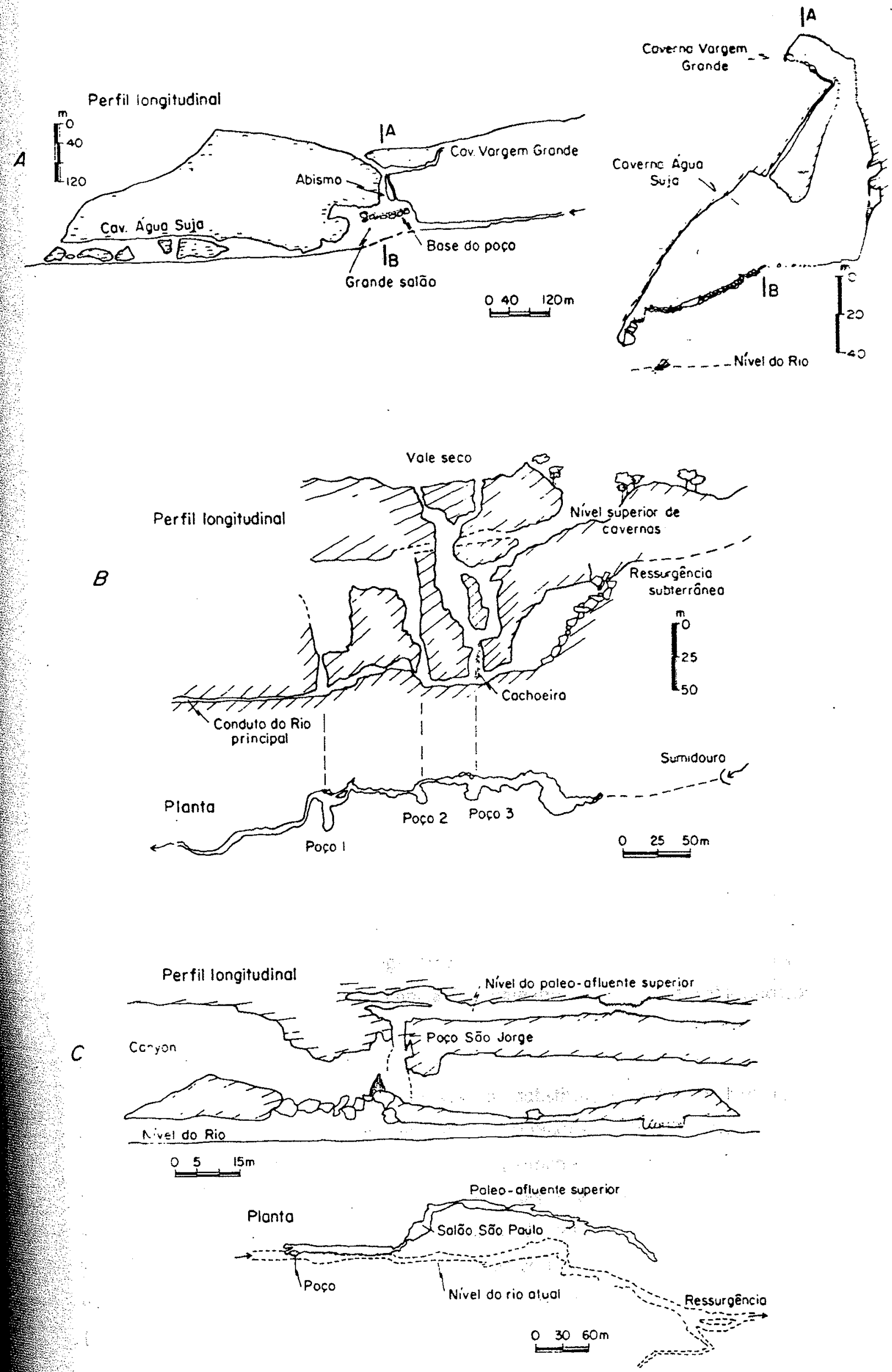

Figura 4.10 - Exemplos de condutos verticais. A- Caverna Água Suja. B- Caverna Ouro Grosso. C- Caverna Santana. 
interpretado como sendo o acúmulo do resíduo insolúvel da dissolução do metacalcário. A presençą deste acúmulo de material residual evidencia uma eficiência menor destas rotas de drenagem vadosa, quando comparadas aos condutos verticais anteriormente descritos. Associa-se, portanto, estes condutos verticais afunilados, a rotas de drenagem vadosa conectadas indiretamente (tributários laterais) aos condutos principais de drenagem cárstica.

\section{Alargamento freático}

Entende-se por alargamento freático a geração de condutos por dissolução na zona saturada. Segundo Bretz (1942), Bögli (1964) e White e Deike (1989), a geometria característica produzida por fluxo de água em condutos de pressão (pipe flow) é de tubos com seções transversais geralmente elípticas e paredes lisas, suavemente onduladas. As dimensões destes condutos freáticos são muito variadas, com diâmetros desde alguns milímetros até 15 metros e comprimentos quilométricos, conforme é descrito por White e Deike (1989).

Nas cavernas estudadas, as formas freáticas estão restritas ao topo de entalhamentos vadosos e a trechos isolados onde condutos freáticos foram preservados do entrincheiramento e da incasão.

Na caverna Santana, ao longo da galeria do Ronco (antigo afluente do flanco direito da caverna) observa-se um trecho parcialmente preservado de conduto freático, por cerca de $80 \mathrm{~m}$ de comprimento (seções 13 e 14, fig 4.6). Possui seção transversal elíptica com eixo maior paralelo ao acamamento. Ao longo do rio atual nota-se condutos elípticos somente onde a altura do teto diminui para 2 a 3 metros, como nas seções 11 a e 12 (fig 4.6). Durante níveis altos do rio, estes trechos ainda hoje passam por períodos freáticos.

Na caverna Laje Branca nota-se um testemunho de conduto freático ao longo do teto de quase todo trecho de abatimento (seção 2, fig 4.7). Acompanhando o brusco estreitamento, logo após o salão de abatimento, observa-se o testemunho mais didático de conduto freático das cavernas estudadas (seções 4 a 7, fig 4.7). Possui seção elíptica com eixo maior predominantemente paralelo a um falhamento inverso.

De modo geral, a morfologia freática é pouco observada nos sistemas de cavernas do Alto Ribeira, devido à predominância de entalhamentos vadosos e abatimentos.

\section{Formas geradas pela incasão}

Incasão é o processo de modificação ou substituição de formas freáticas ou vadosas pela paisagem de colapso subterrâneo (Ford e Williams, 1989). A causa do abatimento de blocos é a ruptura mecânica da rocha, principalmente ao longo de descontinuidades. As formas geradas são salões e galerias com paredes e tetos escalonados e pilhas de blocos angulosos na base (fig 4.5). O caráter escalonado resulta das faces de descolamento dos blocos, ora predominando ao longo de fraturas com os planos de acamamento oblíquos ou vice versa. Os maiores vãos livres e volumes subterrâneos são decorrentes da incasão (Gilli, 1986). 
Nas cavernas estudadas, a paisagem de colapso é bastante freaüente Observou-se que a freqüência de trechos dominados pela incasão é crescente no sentido a montante ao longo dos sistemas de cavernas, ou seja, nas proximidades dos sumidouros, o volume de cavernamento é maior e preponderantemente com formas de abatimento, como por exemplo, na caverna Pérolas. $O$ colapso junto aos sumidouros chega a ser tão intenso, que impede a travessia do explorador entre o final dos condutos preservados e o sumidouro do rio externo.

Notou-se também, que salões de abatimento ocorrem preferencialmente na seguinte geometria de condutos: junção entre tributários (tanto lateralmente como também na invasão de afluentes superiores), presença de condutos superpostos, entalhamento vadoso lateral ou condutos meandrantes.

Os maiores volumes criados por abatimento subterrâneo foram observados nas cavernas Água Suja e Laje Branca, respectivamente com cerca de $280 \times 1.0^{3}$ e $170 \times 10^{3} \mathrm{~m}^{3}$ (medidas obtidas através da integração de seções transversais sobre a planta em escala 1 . 400). No primeiro exemplo, o safão de abatimento está associado a um afluente superior (fig 4.11). A geração do salão é interpretada como sendo consequêencia do desmoronamento das paredes de condutos verticais sobre o canyon vadoso entalhado pelo rio principal $\mathrm{Na}$ caverna Laje Branca, a ampla galeria de abatimento (seções 1 a 3, fig 4.7) é interpretada como sendo produto da instabilização mecânica gerada no calcário em função do intenso entalhamento vadoso lateral.

Como èxemplo de incasão associada à superposição de condutos cita-se o salão Takeopa, na caverna Santana (seção 15 , fig 4.6).

\section{Níveis de cavernas}

Em função de um rebaixamento rápido do nível de base, com o tempo, normalmente ocorre a relocação, para cotas inferiores, dos pontos de insurgência e (ou) ressurgência de sistemas -de cavernas. Os condutos primários associados a estes sistemas, sofrem entalhamento vadoso ou são abandonados pela circulação de água freática, quando são substituídos por condutos gerados junto ou abaixo do nível de base rebaixado (Kastning, 1983 e 1984 e Palmer, 1987). Formam-se, portanto, níveis de cavernas superpostos, os quais evidenciam fases diferentes de abertura de condutos. Sistemas de cavernas com níveis de condutos inativos (drenados) sobre condutos ativos, são classificados de multifásicos, segundo Ford e Ewers (1978).

$\mathrm{Na}$ área estudada, identificaram-se as seguintes evidências de sistemas multifásicos:

- Paleo-sumidouros e paleo-ressurgências em cotas entre 20 e 40 metros acima dos pontos atuais. Como exemplo, cita-se o sistema Pérolas Santana (fig 4.12).

- Condutos inativos a cerca de 20 a 40 metros acima dos condutos associados ao nível de base atual das cavernas. Esta característica é observada em trechos isolados ao longo dos sistemas investigados (fig 4.11, seção A), pois o entalhamento vadoso predomina sobre condutos superpostos preservados 


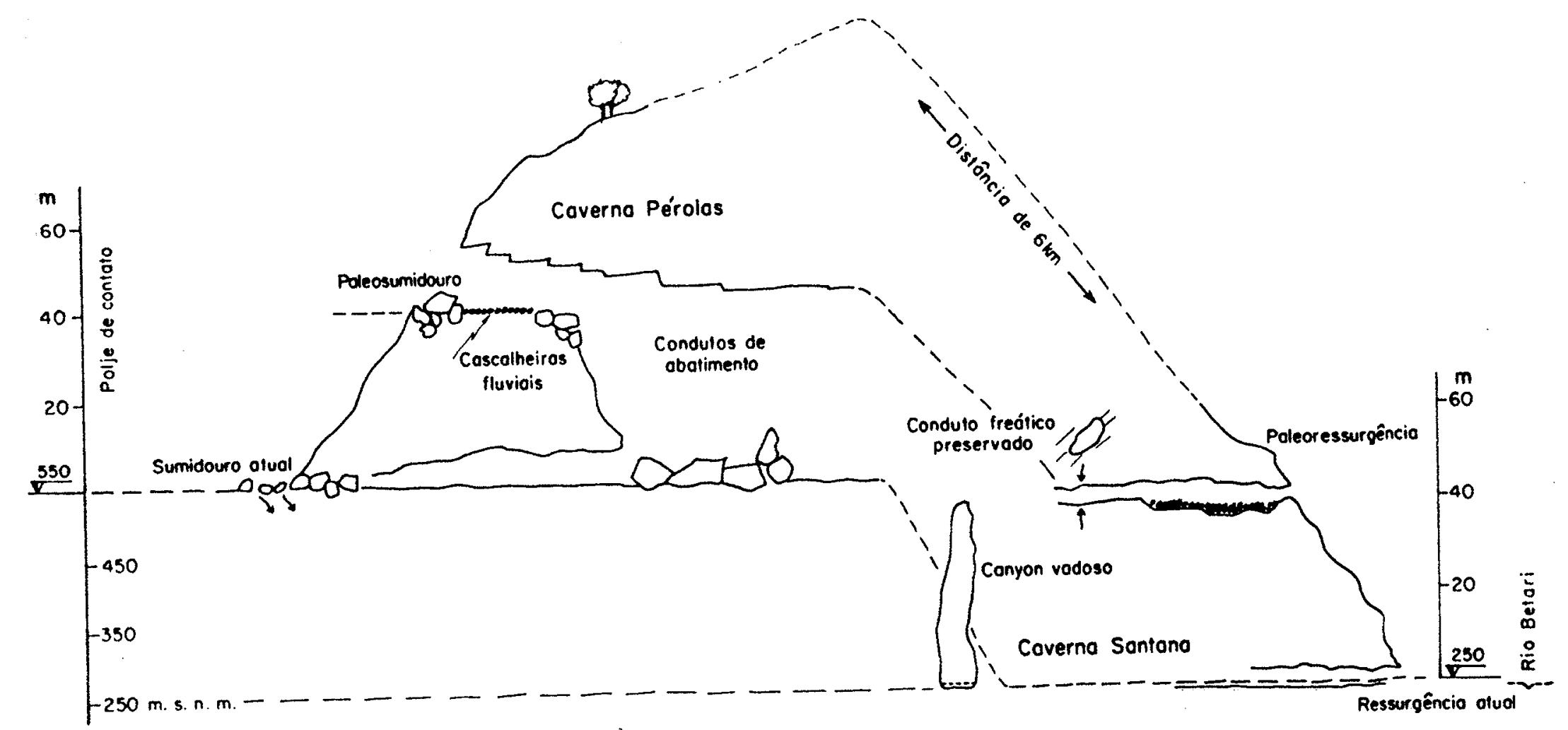

Figura 4.12 - Características de sistemas multifásicos observadas no sistema PérolasSantana. 


\subsubsection{Condicionamento estrutural e hidráulico da morfologia subterrânea}

Estudos detalhados sobre as rotas de fluxo em calcários maciços, estratificados e intensamente carstificados, mostraram que, praticamente todos condutos _observados desenvolveram-se ao longo de estruturas como planos de estratificação, fraturas ou falhas (Worthington, 1991). Os primeiros estudos geológicos de cavernas consideraram cada conduto cárstico como sendo guiado somente por uma única descontinuidade (p.ex., Ford, 1965 e 1971b; Ewers, 1972 e Powell, 1976), mas, posteriormente, a análise estrutural meticulosa sobre sistemas de cavernas, como os trabalhos de Jameson (1981 e 1985), Lauritzen et. al. (1985) e Deike (1989), evidenciaram que os condutos freqüentemente formam-se ao longo da intersecção de descontinuidades.

Deike e White (1969) e Worthington (1991) relacionam a não linearidade e os graus de sinuosidade de passagens fluviais subterrâneas ao padrão estrutural (fraturamento e mergulho da estratificação) da rocha encaixante da caverna. Worthington (1991), examinando o padrão de 53 rotas de fluxo subterrâneo, de diferentes áreas cársticas, mostrou que o grau de sinuosidade é resultante da combinação entre a direção do gradiente hidráulico e a orientação do sistema de fraturamento da rocha. A coincidência entre as direções do padrão de fraturamento e o gradiente hidráulico produz cavernas retilíneas entre os pontos de insurgência e ressurgência da água subterrânea. Quanto maior o ângulo entre as direções do fraturamento e o gradiente hidráulico, maior será a sinuosidade e a largura da rota de fluxo, pois os condutos tenderão a seguir o gradiente hidráulico, meandrando ao longo deste, aproveitando as descontinuidades disponíveis (fig 4.13). Num modelo teórico simplificado de fraturas verticais e ortogonais entre sí, sendo cortadas por um gradiente hidráulico diagonal, Worthington (op cit.), mostrou que a sinuosidade (S) da rota de fluxo é expressa pela equação $S=\cos \alpha+\operatorname{sen} \alpha$, onde $\alpha$ é o ângulo agudo entre a direção do gradiente a as fraturas (fig 4.13).

Nas cavernas estudadas, identificou-se uma nítida correlação entre o estilo planimétrico destas e a estrutura do metacarbonato encaixante. Como exemplos da influência dos padrões de dobramento e fraturamento sobre a geometria de condutos, selecionou-se as cavernas Santana, Laje Branca e Areias, as quais representam uma amostragem da variedade de cavernas da área e das quais obteve-se um levantamento estrutural detalhado.

As cavernas Santana e Laje Branca, componentes do sistema Pérolas-Santana (anexo 4.3), desenvolvem-se na área carbonática Furnas-Santana, caracterizada por um homoclinal de mergulhos altos a moderados para NW, enquanto o sistema Areias insere-se no flanco sudeste da sinforma do Lajeado, área carbonática Lajeado-Bombas (as áreas carbonáticas são descritas no capítulo 3).

O metacarbonato encaixante da caverna Santana possui estratificação com intensa ritmicidade, marcada pela alternância de estratos carbonáticos, carbonato-pelíticos e pelíticos. As espessuras entre camadas diferentes variam de alguns centímetros a decimetros. A espessura de uma mesma camada é pouco variável, formando estratos com comprimentos decamétricos $A$ atitude do acamamento ao longo da caverna possui direção 


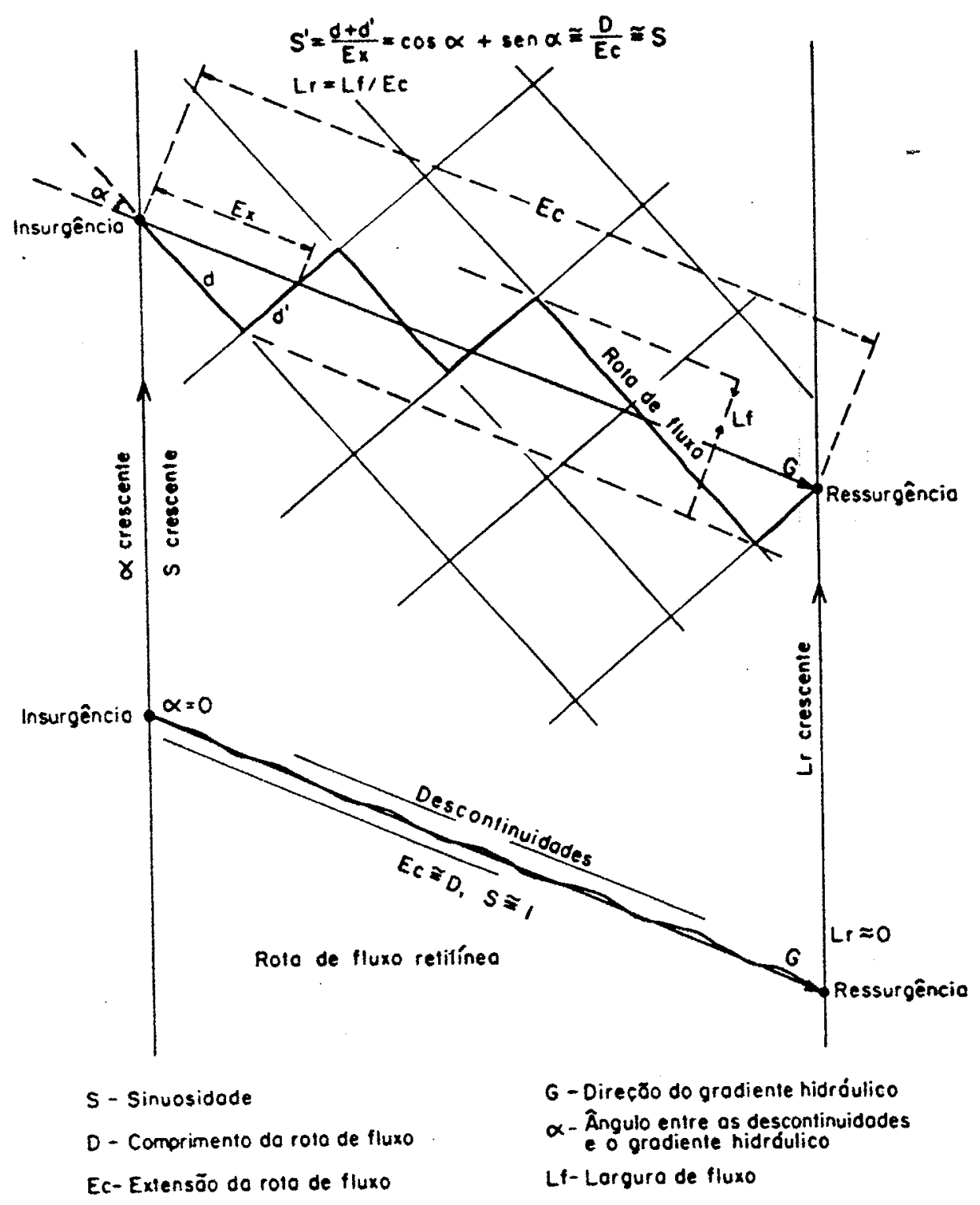

Figura 4.13 - Controle da sinuosidade de rotas de condutos pela relação angular $(\alpha)$ entre a direçáo do padrão de descontinuidades (fraturas e/ou planos de estratificação) e o gradiente hidráulico. Para simplificação da análise, utilizou-se um padrão ortogonal de descontinuidades verticais. Conceito adaptado de Worthington (1991).

e mergulho predominante em torno de N60E 60NW. Mergulhos para SE são locais, em função da presença de dobras menores abertas a fechadas, genericamente coaxiais à direção do homoclinal (fig 4.14a). A variação de atitude é baixa, expressa pelos coeficientes de variação desta (tab 4.5). O fraturamento ao longo da caverna é intenso, com diversos conjuntos de juntas e falhas, tanto subverticais, como de baixo mergulho, transversais e subparalelos ao acamamento, conforme foi descrito na caracterização estrutural da área Furnas-Santana, item 3.4.1, e anexo 3.1.

As direções preferenciais de desenvolvimento da caverna Santana variam entre N40$80 \mathrm{E}$, com concentração máxima de $24 \%$ dos cerca de $6 \mathrm{~km}$ de passagens, entre $\mathrm{N} 50-60 \mathrm{E}$, segundo o histograma de direçōes de condutos (fig 4.14B). A partir deste histograma, do mapa estrutural da caverna (fig 4.14A) e das medidas de estatificação (fig 4.14C), nota-se que esta possui desenvolvimento preferencial grosseiramente concordante ao traço do 
acamamento, com segmentos menores sistematicamente obliquos a este, orientados a N1020E e N50-70W.

\begin{tabular}{|c|c|c|c|c|}
\hline Caverna & \multicolumn{2}{|c|}{$\begin{array}{c}\text { Atitude média do } \\
\text { acamamento }\end{array}$} & \multicolumn{2}{c|}{$\begin{array}{c}\text { Coeficiente de } \\
\text { variação }\end{array}$} \\
\hline & Direção & Mergulho & Direção & Mergulho \\
\hline Santana & N58E (124) & 60 NW & $23 \%$ & $26 \%$ \\
& & & & \\
\hline \multirow{2}{*}{ Areias } & N41E (77) & 38 NE ou SW & $53 \%$ & $49 \%$ \\
& N50W (34) & 33 NE ou SW & $45 \%$ & $53 \%$ \\
\hline
\end{tabular}

Tabela 4.5 - Variação do acamamento nas cavernas de Santana e Areias (de cima e de baixo). Entre parênteses são indicados os números de medidas.

Observando a caverna em maior detalhe, nota-se que os condutos principais são subdivididos em segmentos retilíneos, onde trechos mais longos são paralelos à direção do acamamento e outros, mais curtos, são levemente oblíquos a este, interceptando as camadas contra o sentido de mergulho destas. Esta característica é mais marcante nos condutos tributários, onde os trechos longos, subparalelos ao acamamento, são alternados por segmentos fortemente oblíquos às camadas, inclusive com direções de fluxo contrárias ao gradiente hidráulico geral do sistema de drenagem subterrânea (fig 4.14A). O mapeamento estrutural mostrou que estes segmentos menores, fortemente oblíquos ao acamamento, coincidem com falhas direcionais, juntas de cisalhamento e preenchidas, com direções entre N5-20E e N50-70W e altos mergulhos.

Conclui-se, portanto, que entre o grande número e variedade de descontinuidades presentes (conforme descrito no ítem 3.4.1 e visualizado na fig 4.14D), as estruturas mais favoráveis ao desenvolvimento de permeabilidade secundária, ao longo da rocha encaixante da caverna Santana, são os planos de estratificação com alto mergulho e os conjuntos de juntas de cisalhamento transversais ao acamamento. Estas juntas, incluindo falhas, correspondem ao sistema de juntas de cisalhamento em relação ao esforço máximo de compressão, responsável pelo dobramento da seqüência carbonática-pelítica. A permeabilidade maior do acamamento, é atribuída também, ao fenômeno de deslizamento flexural entre bancos, associado ao dobramento. As evidencias deste processo observadas na área, são o estriamento dos planos de acamamento e a formação de um filme submilimétrico de material moído entre certos estratos, o que acaba aumentando a permeabilidade inicial sobre estas superficies.

Para explicar a baixa sinuosidade e o padrão retilíneo desta caverna, recorreu-se à combinação entre as descontinuidades mais permeáveis e o gradiente hidráulico. Considerando que este foi praticamente constante durante a evolução dos condutos, com sentido geral entre N60-70E, em relação ao nível de base do rio Betari, o ângulo agudo médio $(\alpha)$ entre este e a direção geral do acamamento de alto mergulho é de 5 a $10^{\circ}$, com trechos isolados de até $20^{\circ}$. Utilizando o modelo de condicionamento hidráulico e estrutural de condutos (seg. Worthington, 1991), a sinuosidade calculada por cos $\alpha+\operatorname{sen} \alpha$ é de 


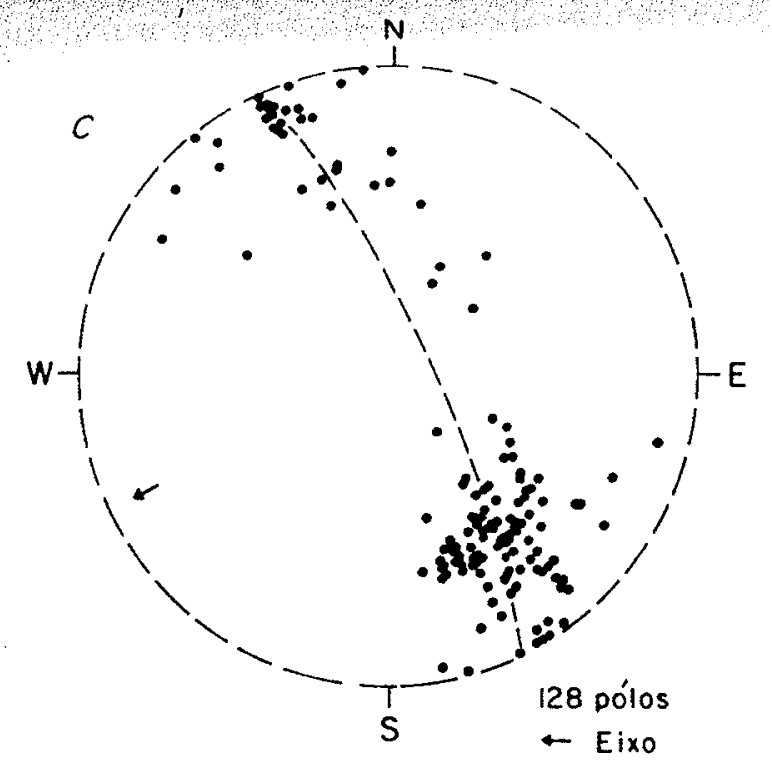

Medidas de ocamamento

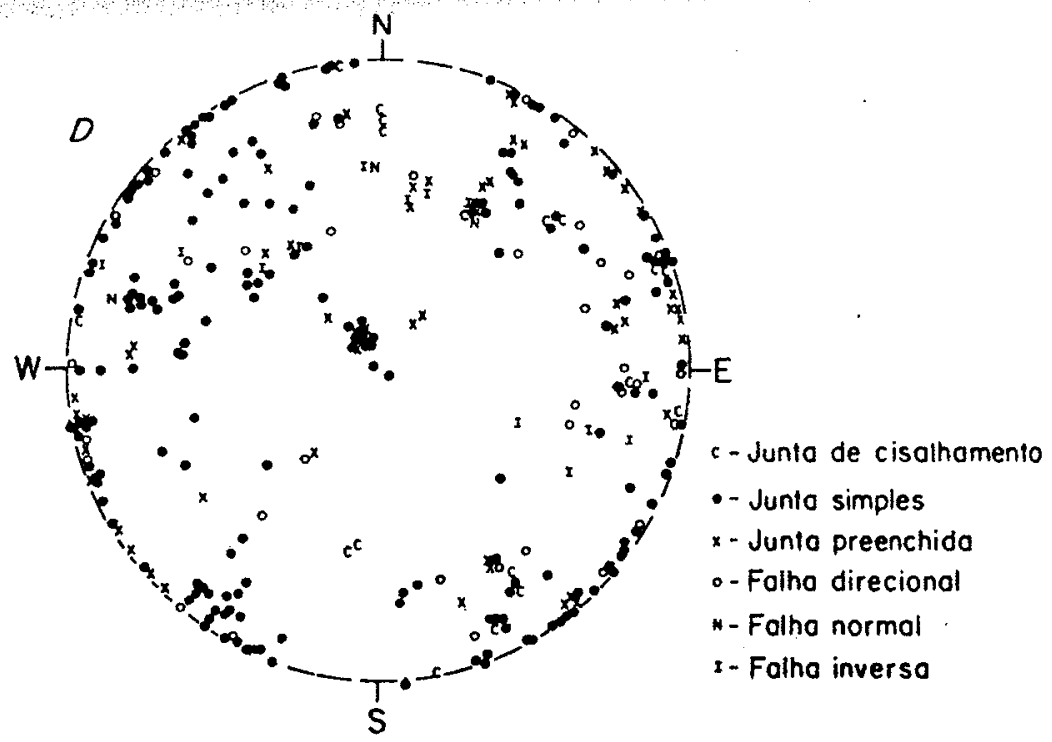

Juntos e Falhas

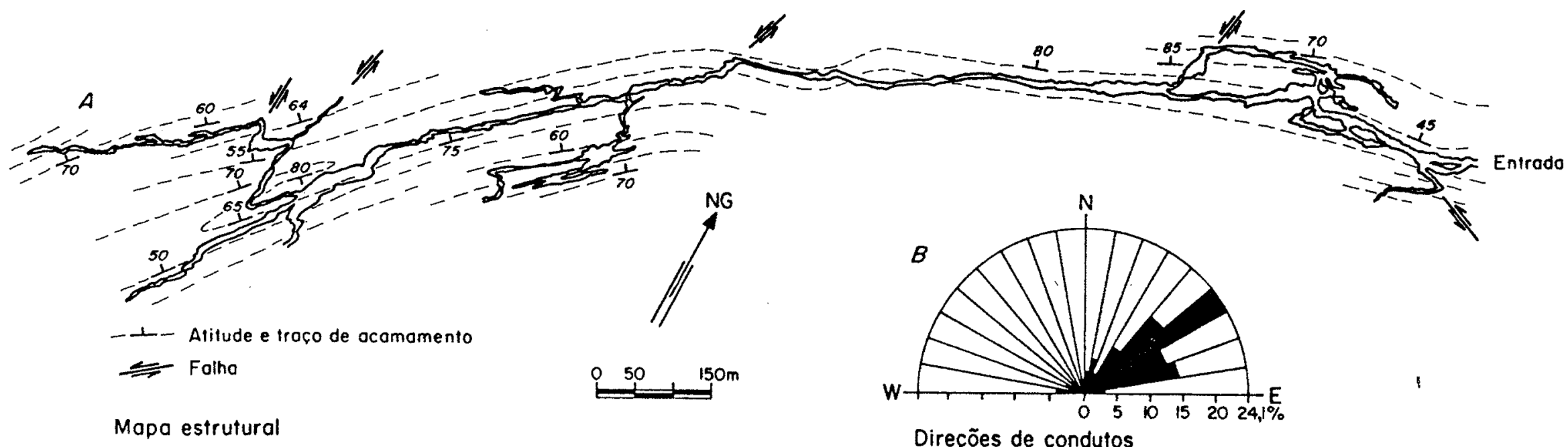

Figura 4.14 - Geologia estrutural da caverna Santana. A- Planta da caverna. B- Histograma de direções do desenvolvimento da caverna. C e D- Projeção estereográfica de estruturas planares. 
$1,08\left(5^{\circ}\right), 1,15\left(10^{\circ}\right)$ e $1,28\left(20^{\circ}\right)$. Com $\alpha$ entre 5 e $10^{\circ}$, os valores calculados são semelhantes à sinuosidade medida, mostrando que a tendência teórica em grande parte é seguida pelo conduto principal da caverna, considerando somente 0 acamamento como descontinuidade principal no condicionamento da caverna. Examinando testemunhos do topo de canyons vadosos, confirmou-se que a abertura inicial de condutos freáticos é condicionada pela interseç̧ão entre o acamamento e juntas simples longas e falhamentos, com direçōes entre N50-70E e mergulos moderados a altos para NW e SE. Define-se portanto, que o padrão retilíneo do conduto principal é condicionado pelo baixo ângulo entre estas linhas de intersecção e o sentido do gradiente hidráulico.

O padrão anguloso, notável principalmente nos condutos tributários, também é uma conseqüência da combinação entre gradiente e estrutura, mas em arranjo diferente. Considerando que os condutos tributários foram gerados após a instalação de um conduto central principal, estes tributários são associados a um gradiente hidráulico local, dirigido diagonalmente e com sentido para o conduto principal, em função do vale de rebaixamento do lençol freático, desenvolvido sobre o conduto principal devido à vazão maior do aquífero sobre a linha de permeabilidade maior, que é o próprio conduto principal (fig 4.15). Com este gradiente local, orientado a NW-SE, a tendência da rota de fluxo será a de sair do acamamento e seguir outras estruturas permeáveis sobre esta direção. Mas, o padrão planimétrico destes afluentes (fig 4.14a e 4.15), mostra que, grande parte dos condutos tributários continua sendo guiada pelo acamamento, e que somente alguns segmentos destes sofrem brusco desvio, entrando em juntas e falhas. Nestes desvios, freqüentemente são estabelecidos padrões de condutos em $\mathrm{Z}$ e S, onde trechos desenvolvem-se à montante do sistema, contrários ao gradiente hidráulico geral (fig 4.15).

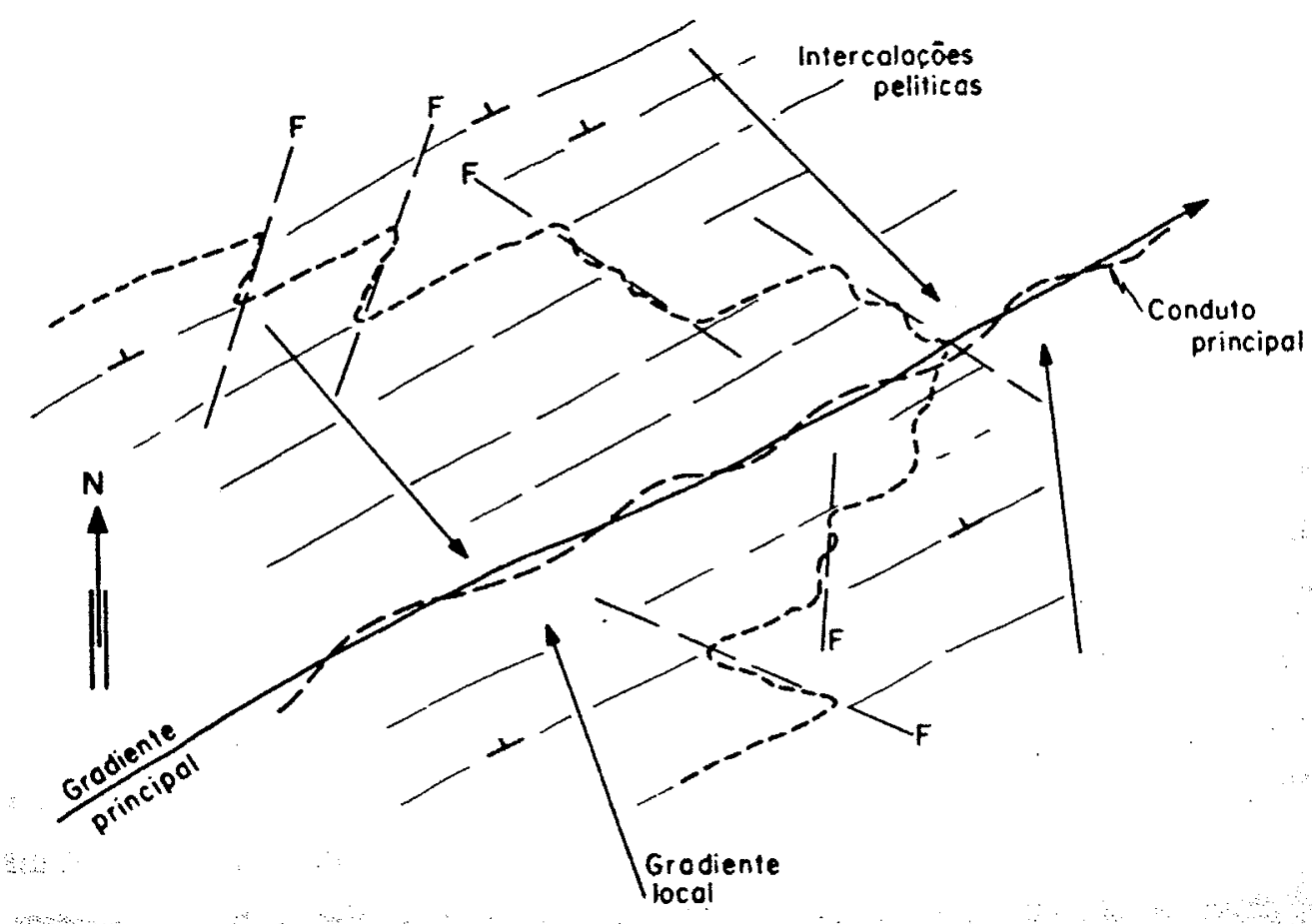

Figura 4.15 - Esquema interpretativo do condicionamento estrutural-hidráulico do padrão anguloso de ramos tributários da caverna Santana. 

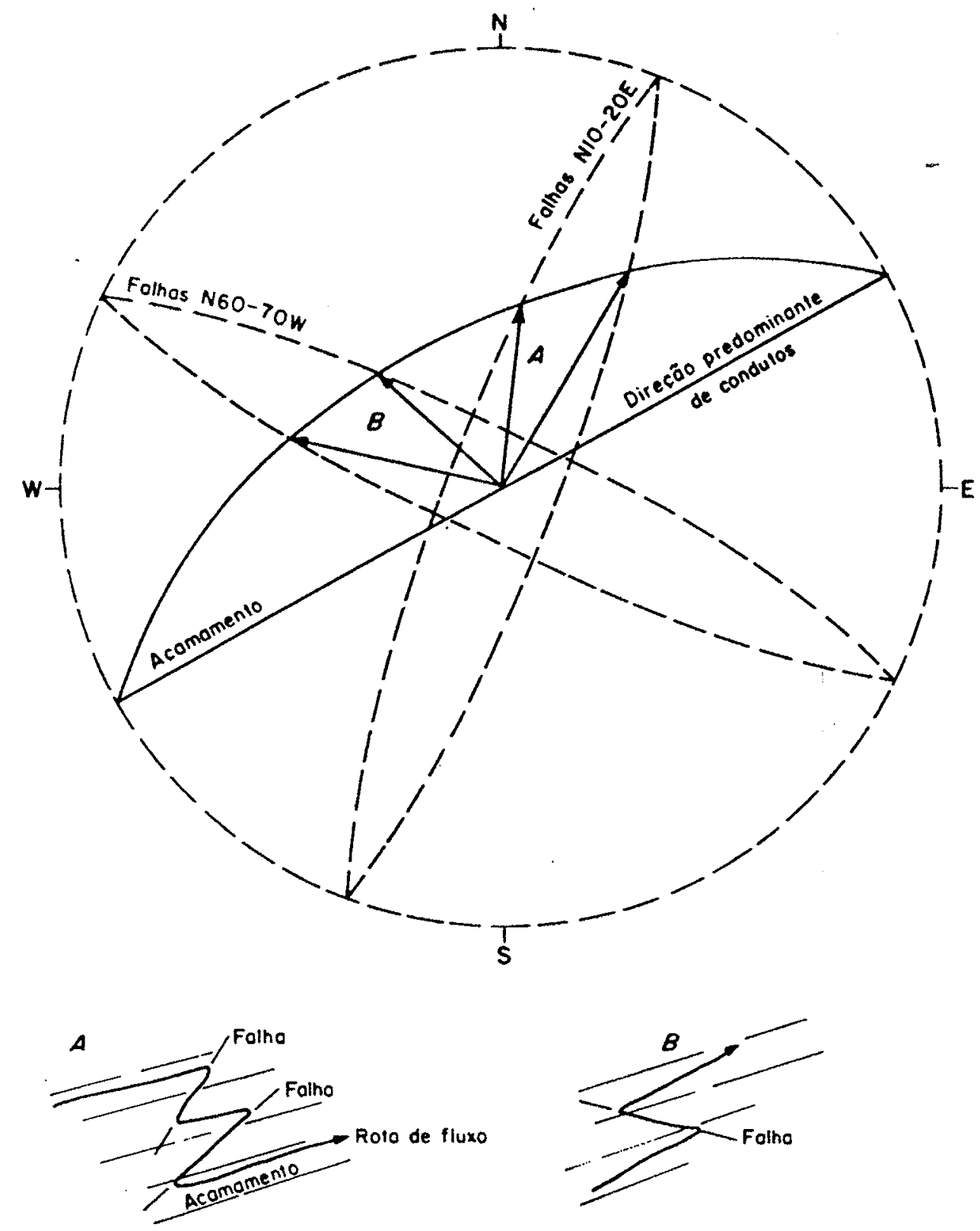

Figura 4.16 - Inflexões agudas na rota de fluxo condicionadas pela interseç̧ão acamamento-falhas, observadas na caverna Santana. Esquemas A e B em planta.

Propõe-se a seguinte interpretação para a geometria acima descrita. Apesar do gradiente local quase ortogonal ao acamamento, parte dos condutos tributários continuam seguindo-o, devido à presença de estratos pelíticos, os quais represam a água de percolação, forçando a abertura de condutos ao longo da interface camada solúvel e insolúvel. Assim que este segmento de represamento é seccionado por uma estrutura permeável (falhamento), a rota de fluxo inicia ou volta à tendência de meandrar pelo gradiente local NW-SE, acompanhando as estruturas disponíveis em estratos solúveis, até atingir uma nova frente impermeável e insolúvel ao longo do acamamento. Desta maneira, geram-se trechos altamente sinuosos e angulosos, onde os condutos alternadamente acompanham falhas e segmentos de acamamento.

A intersecção das falhas e juntas de cisalhamento a N10-20E e N60-70W (observadas na caverna) com o acamamento, gera lineações coincidentes com os segmentos anômalos da caverna, contrários ao sentido geral do fluxo de água (fig 4.16). Interpreta-se 
estes, como sendo condutos, levemente ascendentes, gerados ao longo de linhas de maior permeabilidade inicial (relativamente às descontinuikzdades vizinhas) devido à intersecção entre falhas e planos de estratificação

A caverna Laje Branca representa um tributário do sistema Pérolas-Santana, localizado a sudoeste da caverna Santana (anexo 4.3). Com desenvolvimento de cerca de $900 \mathrm{~m}$, apresenta alinhamento preferencial na direção N70-80E (fig. 4.17A e D). No contexto das direções predominantes entre N40-60E do sistema Pèrolas Santana, a caverna Laje Branca representa um alinhamento de condutos extensos em direção anômala. $\mathrm{O}$ mapeamento geológico, mostrou que, ao contrário da maioria dos demais condutos deste sistema, a caverna Laje Branca não acompanha a direção do acamamento, mas sim, é paralela a uma falha inversa de atitude geral N75E 70-80SE (fig 4.17A). Detectou-se esta falha em vários pontos do teto da ampla galeria de abatimento e ao longo de quase todo conduto freático sobre a fenda vadosa no final da caverna. Caracteriza-se por uma zona de cisalhamento, com até $1 \mathrm{~m}$ de espessura, onde observa-se um bandamento composicional milimétrico (foliação cataclástica). O movimento é expresso por dobras de arrasto do acamamento nas paredes adjacentes a falha.

A intersecção desta zona de cisalhamento com a atitude geral da estratificação, ao longo do conduto freático, preservado sobre o canyon vadoso do final da caverna, produz uma lineação, a qual é coincidente com o eixo longitudinal deste conduto eliptico, conforme é representado na figura $4.17 \mathrm{C}$. Coincide, também, com o alinhamento geral da caverna.

Interpreta-se, portanto, que o padrão retilineo e a baixa sinuosidade (1.01) desta caverna, sejam um produto, do forte condicionamento estrutural da rota de fluxo da água subterrânea, pela intersecção da zona de cisalhamento com o acamamento.

Com relação ao gradiente hidráulico, esta caverna é totalmente contrária ao gradiente geral da área. Mas, por outro lado, há que se considerar. que em função da linha de alta permeabilidade inicial, desenvolveu-se um vale de rebaixamento do lençol freático sobre esta linha, criando um gradiente local, necessáriamente, sub-paralelo à direção da intersecção

A caverna Areias (englobando as cavernas Areias de Cima e de Baixo, separadas por uma dolina de colapso, anexo 4.3) representa o padrão planimétrico mais sinuoso (S entre 1.29 e 1.40) e curvilíneo da área estudada. Está encaixada em metacalcários com estratos carbonáticos de espessura decimétrica a métrica. Localmente ocorrem intercalações, onde a espessura diminui e a quantidade de estratos pelito-carbonáticos aumenta. De forma geral, contrasta com os metacarbonatos Furnas-Santana pela menor freqüência de alternância entre estratos pelíticos e carbonáticos e pela espessura maior dos estratos carbonáticos. A continuidade lateral das camadas também é marcante, podendo ser observada por dezenas de metros

A atitude do acamamento, ao longo da caverna, possui direções predominantes no quadrante NE, com valor médio de N41E e secundariamente no quadrante NW, com valor médio de N50W. Tanto as direções como os mergulhos da estratificação são bastante variáveis, conforme os altos coeficientes de variação destas medidas, expressos na tabela 


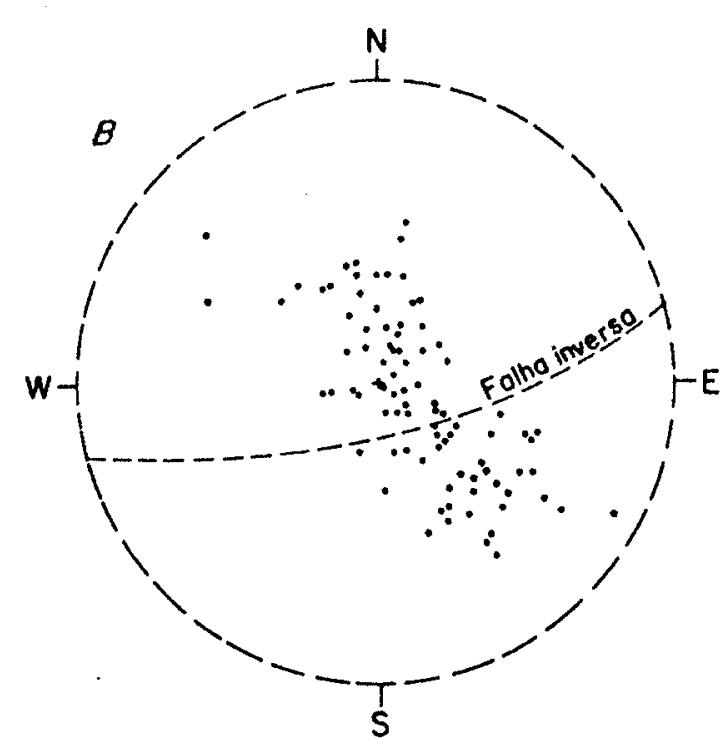

Medidas de ocomamento

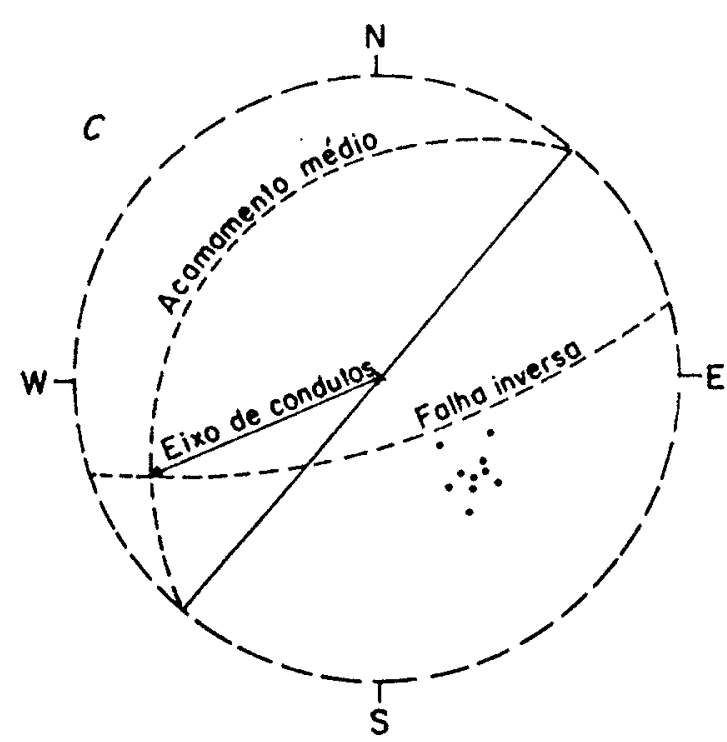

Intersecçõo ocamamento-Falha Medidos no conduto freático

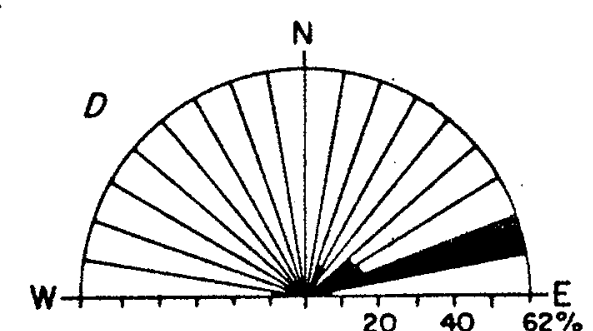

Direçōes de condutos

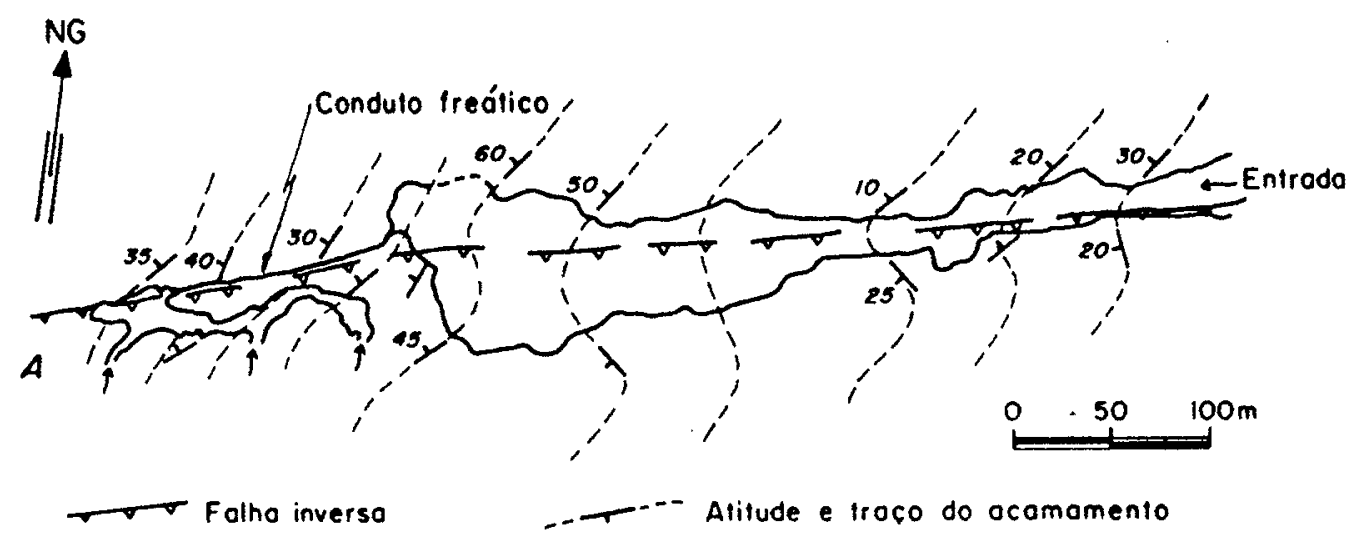

Figura 4.17 - Geologia estrutural da caverna Lage Branca. A- Planta da caverna. B e CDiagramas de projeção estereográfica. D- Histograma de direçóes do desenvolvimento total da caverna. 
4.5. Em contraste com a caverna Santana, o mergulho da rocha encaixante da caverna Areias é moderado (média de 33 a $38^{\circ}$, variando de quadrante). Identificou-se dois domínios estruturais de dobramento do acamamento ao longo da caverna. No setor entre a extremidade a montante da caverna (ponto a, fig 4.18A) e a junção com o ramo direito da caverna Areias de Cima (ponto b), o acamamento apresenta uma série de anticlinais e sinclinais abertos, com eixos de direção aproximada N20W. Do ponto b até a extremidade à jusante, o padrão de dobramento é de um homoclinal com mergulhos moderados e variados para NW e direções suavemente onduladas, indicando um dobramento superposto com eixo genérico a NW.

O fraturamento é intenso e variado, semelhante aos calcários Furnas-Santana, conforme descrição do padrão de fraturamento da área Lajeado-Bombas no item 3.4.1 e o estereograma de juntas e falhas medidas na caverna (fig 4.18D).

A alta sinuosidade desta caverna, é refletida também, pela variedade de direções de condutos ao longo dos seus $4.5 \mathrm{~km}$ de desenvolvimento (fig $4.18 \mathrm{C}$ ). Conforme o histograma de direções da caverna, $13,5 \%$ dos condutos alinham-se entre $\mathrm{N} 30-40 \mathrm{E}$, seguidos por $11,9 \%$ entre N70-80E, $9 \%$ em N10-20E e 7,5\% a N60-70W. Concentrações menores distribuem-se tanto no quadrante NE como NW.

Percorrendo a caverna e observando seu mapa estrutural (fig 4.18A), nota-se que ela pouco acompanha a direção do acamamento. Quantitativamente, cerca de $25 \%$ dos condutos seguem a direção do acamamento. $O$ restante dos condutos é formado por segmentos oblíquos. O mapeamento geológico evidenciou que os segmentos transversais ao acamamento, na sua grande maioria, são subparalelos à traços de falhamentos e juntas simples longas, de alto mergulho. Em vários trechos isolados, onde se teve acesso à condutos freáticos preservados, notou-se que estes acompanham linhas de intersecção entre fraturas e planos de acamamento. O entalhamento vadoso posterior, segue tanto os planos de fratura, como de acamamento, formando camyons escalonados, onde pouca informação é obtida sobre o início de abertura da caverna.

$\mathrm{O}$ alinhamento de condutos a N30-50E é controlado pelos conjuntos de juntas simples N40-45E (subverticais), falhas direcionais a indeterminadas, com atitude $\mathrm{N} 50 \mathrm{E}$, de alto mergulho e, subordinadamente, por planos de acamamento. Um dos segmentos mais longos, em torno desta direção, é observado no trecho mediano da caverna Areias de Cima (entre os pontos c e d, fig 4.18A). É constituído por canyons levemente meandrantes Notase no mapa que possui tendência retilínea e oblíqua aos traços da estratificação. $O$ mapeamento mostrou que é paralelo à juntas simples longas, falhamentos com zonas de cisalhamento centrimétricas e juntas preenchidas. Atribui-se este alinhamento à rotas de maior permeabilidade inicial, com ângulos de 20 a $30^{\circ}$ com a direção geral do gradiente hidráulico do sistema (orientado a N60-70E), condicionadas pela intersecção de juntas simples longas e falhas com o acamamento. Estas intersecções geraram condutos iniciais; grosseiramente retilíneos e subparalelos ao sentido de mergulho das camadas. $O$ segundo maior trecho com direção predominante entre N30-40E, localiza-se no início da caverna Areias de Baixo (b-g, fig 4.18A). Neste setor, os condutos assumem direções subparalelas 


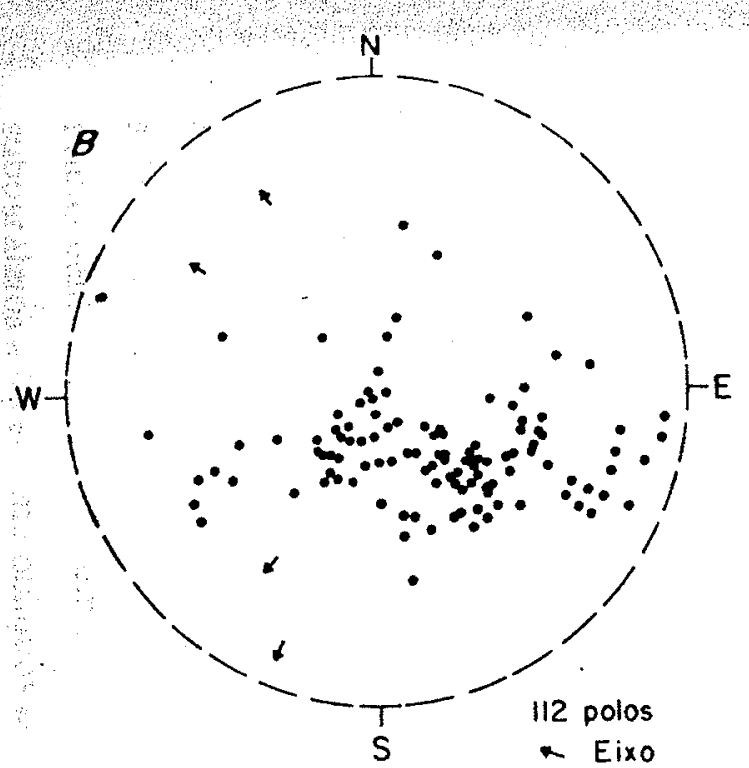

Medidas de ocamamento

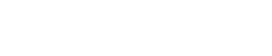

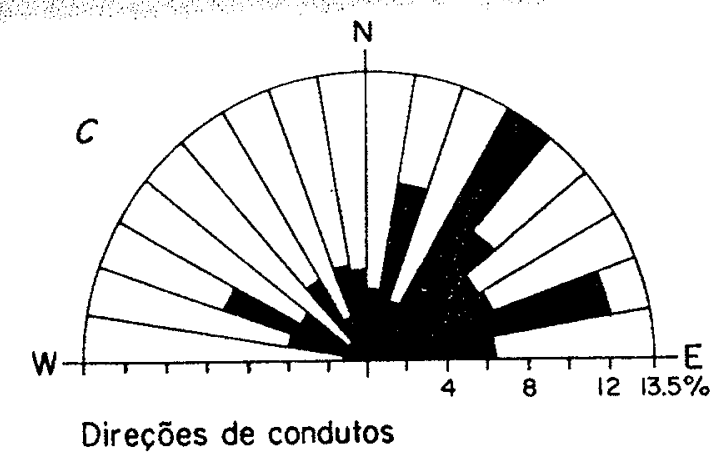
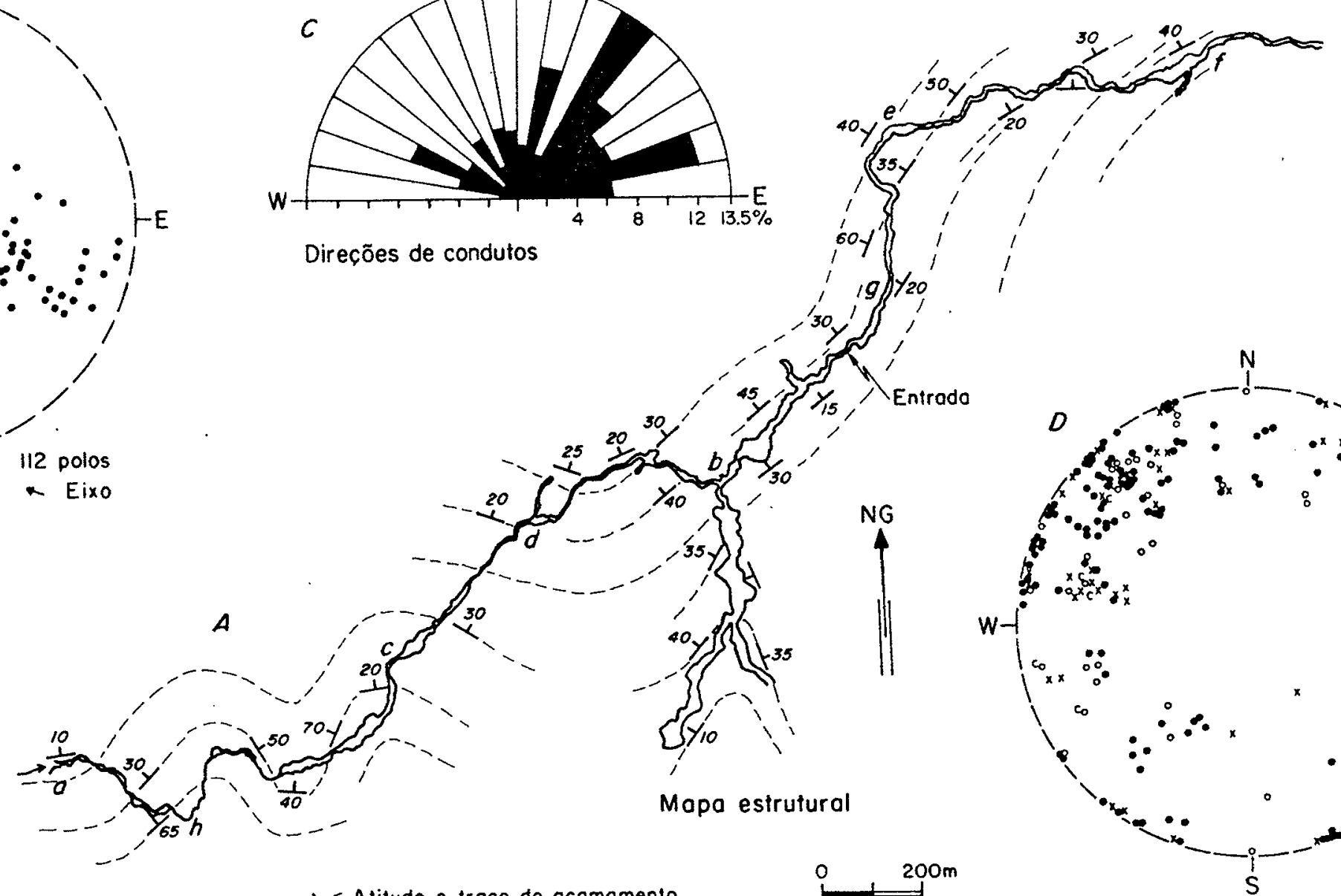

Mapa estrutural

L-Alitude e traço do acomamento
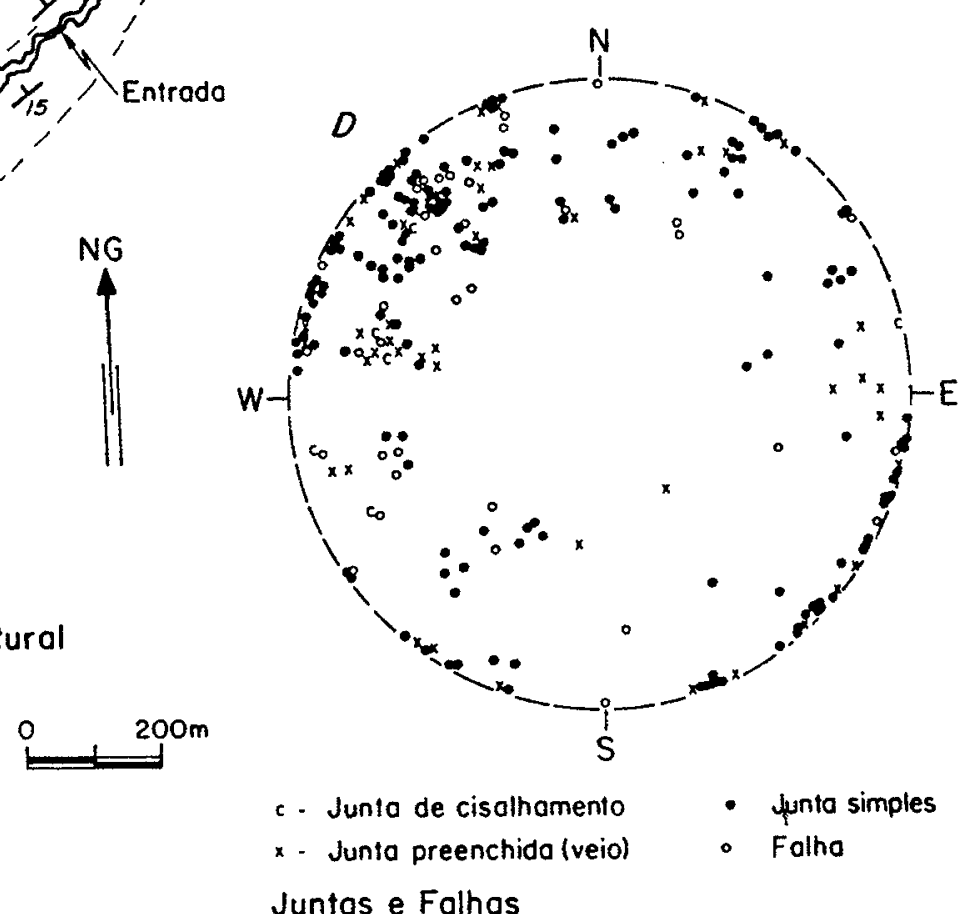

Figura 4.18 - Geologia estrutural da caverna Areias. A- Planta da caverna. B e D- Projeção estereográfica de estruturas planares. C- Histograma de direções do desenvolvimento total da caverna. 
ao traço do acamamento. Interpreta-se que este setor é condicionado por linhas de maior permeabilidade inicial acompanhando traços de intersecção entre o acamamento de baixo mergulho a as juntas longas e falhas subparalelas à direção do acamamento,-mas de alto mergulho.

A segunda orientação preferencial de condutos a N70-80E é predominante no segmento final da caverna, junto à extremidade mais a jusante desta (e-f, fig 4.18A). $\mathrm{O}$ mapeamento mostrou que este setor é principalmente controlado por juntas simples longas a N70E e falhas indeterminadas entre N60-70E. O padrão morfológico dominante é de canyons meandrantes, onde segmentos curtos acompanham grosseiramentê a direção da estratificação e fraturas a N50-60W, alternados por trechos mais longos controlados pelas juntas e falhas a N60-70E. Este é um segmento da caverna, com cerca de $20^{\circ}$ em relação ao gradiente hidráulico geral (N60-70E), onde os condutos tendem a acompanhar as juntas e falhas acima citadas, de baixo ângulo com o gradiente, sendo localmente desviados por rotas de acamamento e juntas do conjunto N50-60W.

A concentração de condutos a N60-70W é associada aos conjuntos de juntas simples N60W e falhas indeterminadas em torno de N50-70W, ambos com mergulhos de 70 a $85^{\circ}$, para NE e SW. Um exemplo de segmento da caverna nesta direção, é observado junto à extremidade mais a montante da caverna Areias de Cima (trecho a-h, fig 4.18a). Neste segmento o desenvolvimento de condutos acompanhou estas juntas e falhas, em posição quase ortogonal ao alinhamento geral do gradiente hidráulico, apesar da disponibilidade de planos de acamamento em posição de baixo ângulo com este. Isto vem evidenciar a alta permeabilidade inicial destas juntas e falhas, a ponto de causar desvios importantes da rota de fluxo, cuja tendência teórica seria de seguir descontinuidades em baixo ângulo com a direção do gradiente hidráulico, como por exemplo, neste caso, os planos de estratificação.

A direção de condutos a N10-20E acompanha falhas inversas e direcionais, assim como, fraturas simples, condicionando rotas oblíquas ao gradiente hidráulico geral, em situação semelhante à descrição e interpretação acima.

Conclui-se, portanto, que a caverna Areias é principalmente guiada pela intersecção entre estruturas disruptivas longas (juntas simples e falhas) e superficies de acamamento. Localmente a rota de fluxo instalou-se em falhas ou planos de acamamento, não havendo evidências claras do condicionamento inicial destas rotas menores por linhas de intersecção

Devido ao baixo mergulho da estratificação e à alta variabilidade das atitudes desta, em comparação com a caverna Santana, as linhas de intersecção de juntas e falhas sobre os planos de acamamento, estabeleceram rotas de fluxo, as quais predominantemente são muito discordantes das direções do acamamento. Na caverna Santana, ao contrário, devido ao alto mergulho do acamamento, as linhas de interseç̧ão de juntas e falhas subverticais sobre o acamamento, produziram rotas de fluxo não muito discordantes da direção do acamamento, imprimindo um padrão planimétrico final dos condutos principais da caverna, subparalelos a levemente oblíquos aos traços do acamamento. 
Analisando a sinuosidade da rota de fluxo principal da caverna Areias, em função da combinação entre a orientação do padrão estrutural dos metacalcários e a direção geral do gradiente hidráulico, obteve-se o seguinte resultado. Considerando que os conjuntos de juntas simples e falhas orientadas a N60-70W, N10-20E, N30-50E e N60-80E são as descontinuidades mais favoráveis ao desenvolvimento de permeabilidade secundária, conforme representado no esquema da fig. 4.19, obtém-se ângulos agudos entre estas linhas e o gradiente hidráulico de $20^{\circ}, 40^{\circ}$ e $60^{\circ}$. As sinuosidades teóricas calculadas com estes ângulos (segundo modelo de Worthington, 1991) são de 1,28, 1,40 e 1,36, respectivamente. Estes valores são muito semelhantes à sinuosidade medida entre 1.29 e 1.40 . O padrão planimétrico sinuoso da caverna Areias, é portanto, condicionado pelo caráter meandrante da rota de fluxo, acompanhando principalmente as juntas e falhas, acima citadas, e tendendo a seguir o sentido $\mathrm{N} 60-70 \mathrm{E}$, estabelecido pelo gradiente hidráulico ao longo deste sistema de cavernas.

Tanto na caverna Santana como Areias, o baixo índice de condutos desenvolvidos a NW-SE, apesar da alta freqüência de juntas neste alinhamento (conforme os estereogramas das figs 3.24 e 3.25 e os histogramas de fotolineamentos, fig 3.27) é atribuído à posição ortogonal destas descontinuidades em relação ao gradiente hidráulico geral destas áreas.

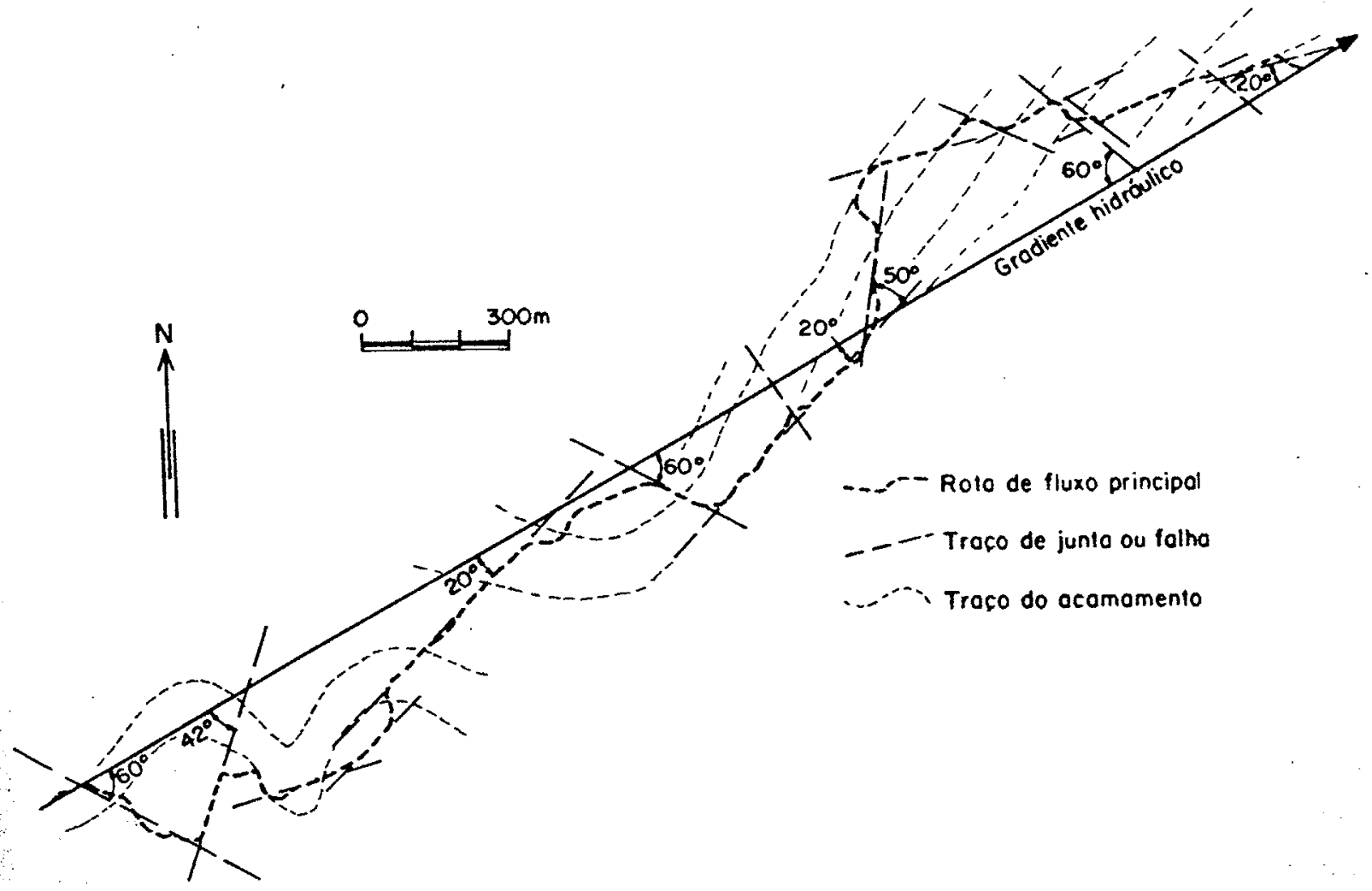

Figura 4.19 - Caráter meandrante da caverna Areias em torno do gradiente hidráulico, seguindo falhas e fraturas longas medidas Segmento a-b indicado na figura $418 \mathrm{~A}$ Vide comentário no texto. 


\subsubsection{Espeleogênese na área de estudo}

Conforme esboçado no item 4.3.1, a espeleogênese consiste das fases de préiniciação, iniciaçãó e desenvolvimento.

\subsubsection{Fase de pré-iniciação}

$\mathrm{Na}$ região estudada, esta fase corresponde à implantação do sistema de fraturamento e falhamento, associado à deformação e metamorfismo da seqüência pelítico-carbonática do Subgrupo Lajeado, durante o ciclo termo-tectônico Brasiliano, do final do Proterozóico Superior (Campanha, 1991). Um segundo evento importante de geração e reativação de descontinuidades corresponde ao arqueamento crustal e injeção de diques de diabásio, durante a reativação tectônica do Mesozóico, conforme detalhado no capítulo 2 .

Com o soerguimento da seqüência metassedimentar e gradativa erosão da pilha de rochas sobrejacente aos metacalcários, estes passam por um processo de expansão em resposta ao alívio de carga litostática. Neste processo, as descontinuidades anteriormente seladas, sofrem uma pequena abertura. Esta abertura inicial é estimada entre $10 \mu \mathrm{m}$ a $0.2 \mathrm{~mm}$ (Dreybrodt, 1981a e Palmer, 1991). Motyka e Wilk (1984), apud Dreybrodt (1981a), mediram aberturas iniciais de fraturas em calcários Triássicos da Polônia até profundidades de $150 \mathrm{~m}$. A abertura mais freqüente encontrada foi de $0.2 \mathrm{~mm}$, com ocorrências raras de até $0.5 \mathrm{~mm}$.

A fase de pré-iniciação culmina com a instalação de um aqüífero fraturado na rocha carbonática, com lençol freático (quando existente) ou nível piezométrico raso. Com a exposição parcial ou total da rocha carbonática, é freqüente o desenvolvimento de sistemas fluviais na superficie, em função da baixa permeabilidade inicial e conseqüente baixa capacidade de absorção e transmissão de água meteórica. A paleodrenagem fluvial, interpretada a partir do alinhamento de depressões poligonais e testemunhos de talvegues, representa este estágio na área estudada.

\subsubsection{Fase de iniciação}

A fase de iniciação instala-se gradativamente com o início da carstificação, expressa subterraneamente pela iniciação de proto-cavernas em ambiente freático (Lowe, 1992). O motor deste processo é o estabelecimento de um potencial hidráulico entre pontos de injeção e saída da água de percolação ao longo de rotas pré-estabelecidas pela trama de descontinuidades (Ford e Ewers, 1978). O potencial hidráulico, por sua vez, é consequência de desníveis formados pelo entalhamento da superficie pela drenagem fluvial. Na área estudada, o potencial hidráulico foi estabelecido pelo entalhamento do rio Betari, o qual representa, até o presente, o nível de base principal em relação à circulação de água pelos metacalcários, conforme ilustrado pela figura 4.1 e anexo 4.2

A fase de iniciação é evidenciada através dos testemunhos de proto-condutos preservados no topo de entalhamentos vadosos. Quando é possível acessar estes pontos como, por exemplo na caverna Santana, conforme é representado na figura 4.20, observouse que os proto-condutos alinham-se segundo intersecções entre juntas simples ou falhas e planos de acamamento. Estes condutos iniciais possuem seções grosseiramente elípticas, com diâmetro mínimo entre 1 a $5 \mathrm{~cm}$ e máximo de $10 \mathrm{~cm}$ O eixo maior das seções 
transversais destes condutos, normalmente é sub-paralelo à superficie de acamamento. $\mathrm{Na}$ caverna Santana, os proto-condutos ocorrem preferencialmente na intersecção do acamamento com juntas simples longas de atitude N50-60E, subverticais e falhas $\mathrm{N} 60-80 \mathrm{E}$ 50-70SE (fig 4.20). Freqüentemente estes proto-condutos são ramificados, onde os segmentos principais ocorrem ao longo das intersecções acima citadas e os ramos secundários, acompanham em parte, a intersecção com juntas oblíquas a ortogonais à direção do acamamento, interconectando os condutos principais, no caso observado, em número de dois, subparalelos (fig 4.20). Os ramos secundários, com diâmetro variável em torno de alguns centímetros, orientam-se aproximadamente segundo a direção de mergulho das camadas. Formam um padrão de canalículos sinuosos e entrelaçados, sobre o plano de acamamento. São classificados como condutos de anastomose, os quais, segundo Ford (1971b) e Ewers (1982), caracterizam condutos subsidiários aos principais, contemporâneos a estes e formados em ambiente freático. Porções dos condutos iniciais principais, também apresentam canalículos anastomosados, paralelos as suas laterais.

Outra feição característica, observada ao longo dos condutos iniciais, é representada por condutos cônicos, com eixo vertical coincidente à intersecção das fraturas subverticais e de alto ângulo, altura entre alguns decímetros até $1 \mathrm{~m}$ e base sobre o conduto inicial principal (fig 4.20). Estas formas, denominadas aqui de cones de dissolução, correspondem à aberturas freáticas do tipo blind pockets de Bretz (1942), Mischungskorrosionkolke, de Bögli (1978) ou solution pockets de Ford e Williams (1989). Cones de dissolução semelhantes a estes, ocorrem também, nas paredes e tetos de condutos freáticos maiores, conforme será descrito na fase de desenvolvimento.

A profundidade das proto-cavernas, acima descritas, em relação à superficie atual dos metacalcários, varia entre 350 e $50 \mathrm{~m}$. As distâncias horizontais, em relação aos pontos de injeção de águas alogênicas, variam entre 500 e $2000 \mathrm{~m}$ (fig 4.21).

Os primeiros estudos quantitativos sobre o mecanismo de dissolução de calcários maciços e fraturados, realizados por Weyl (1958), mostraram que, águas meteóricas, ao percolarem juntas com abertura inicial de $100 \mu \mathrm{m}$, atingem a saturação após alguns centímetros de penetração na rochá. Como explicar então a presença de condutos de dissolução com centenas de metros de profundidade no maciço carbonático?

White (1977) e Dreybrodt (1981a), apud Dreybrodt (1981b), recalcularam: a distância de saturação de águas de percolação para tentar explicar os primeiros estágios de carstificação subterrânea, com base em dados experimentais de Plummer e Wigley (1976) e Plummer et. al. (1978 e 1979) da cinética de dissolução de $\mathrm{CaCO}_{3}$ em sistemas com $\mathrm{CO}_{2} \mathrm{e}$ $\mathrm{H}_{2} \mathrm{O}$. Obtiveram distâncias de somente alguns metros de percolação até a saturação da solução, o que não satisfez a questão acima.

Esta questão clássica da carstificação foi abordada engenhosamente por Bögli (1964 e 1978), Wigley e Plummer (1976) e Dreybrodt (1981b), através do conceito de corrosão de mistura. Segundo Bögli (op. cit.), a geometria de proto-cavernas, acima descrita (fig 4.20), seria uma evidência do fenômeno de corrosão de mistura, pois, além das linhas capilares, formadas pelas intersecçoes fraturas-acamamento proporcionarem rotas de maior 


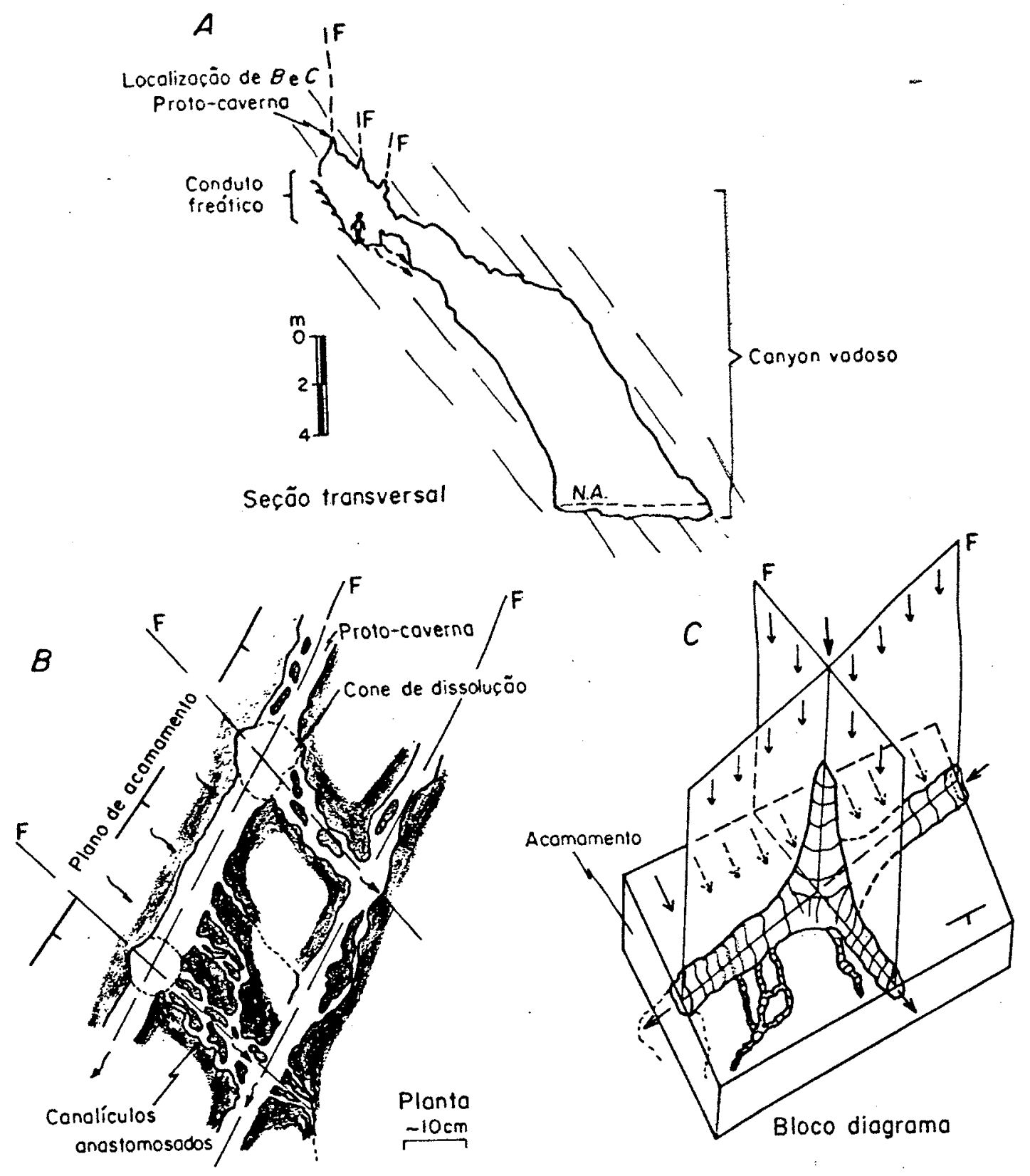

Figura 4.20 - Características morfológicas e estruturais de proto-cavernas observadas na caverna Santana.

A- seção transversal indicando os pontos de observação, localizada a cerca de $300 \mathrm{~m}$ a montante da ressurgência.

B- vista em planta da geometria de condutos de iniciação e canalículos de anastomose, observados no teto de conduto freático parcialmente preservado.

C- esquema tridimensional da relação entre proto-caverna, canalículos de anastomose e cone de dissolução, preservados no teto do ponto observado. As setas indicam o fluxo de água de percolação ao longo de descontinuidades.

eficiência hidráulica (Palmer, 1991), estas também, podem representar linhas de mistura de soluções percolantes com diferentes estados de saturação em calcita.

No exemplo em discussão, como o conduto principal de iniciação desenvolveu-se sobre o acamamento, há que se considerar, que as fraturas subverticais conduziram águas de pecolação de natureza diferente da água conduzida pelo acamamento No encontro 

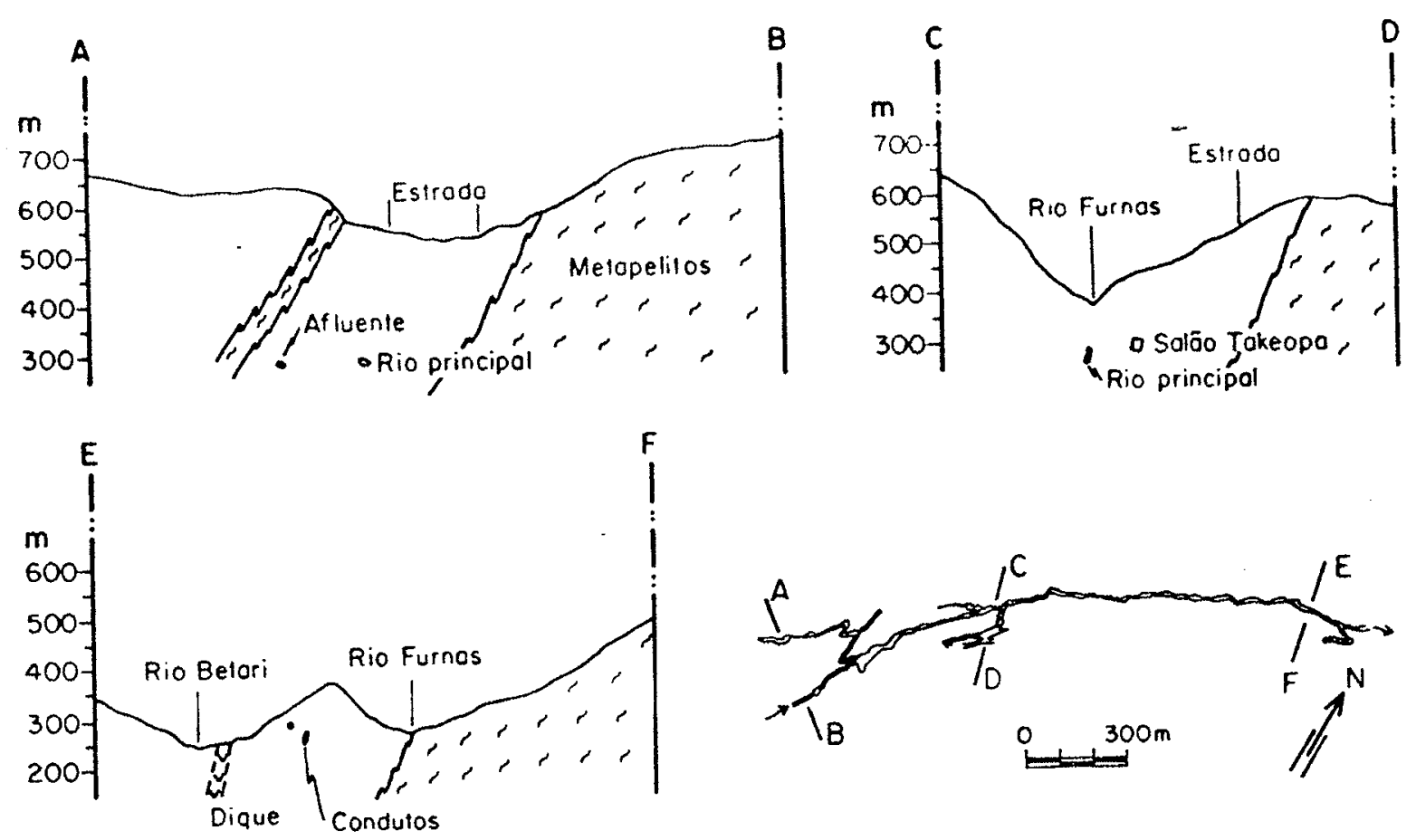

Figura 4.21 - Profundidade de condutos da caverna Santana em relação à superficie.(Seções localizadas na planta da caverna no lado inferior direito)

destas águas, a mistura teria proporcionada uma solução agressiva, a qual alargou o capilar, no sentido de escoamento da água. Os cones de dissolução seriam condicionados pela intersecção de duas fraturas subverticais sobre o plano de acamamento, onde, devido ao encontro de tres descontinuidades, haverá um volume maior de águas em mistura e portanto maior chance de corrosão da rocha, formando o cone sobre esta junção tríplice de planos.

Para testar se as condições hidroquímicas atuais no carste do Alto Ribeira permitem a atuação da corrosão de mistura, utilizou-se o diagrama de equilíbrio de soluções carbonáticas (fig 4.22), elaborado por Dreybrodt (1981b), onde plotou-se um exemplo de águas contrastantes quanto à saturação em $\mathrm{CaCO}_{3}$, coletadas na caverna Santana.

Como exemplo de água com alta concentração de saturação em calcita, utilizou-se a percolação lenta, coletada em gotejamentos de juntas e estalactites (amostras 20, 81, 102, 149 e 166, anexo 5.3). Estas amostras apresentam uma predominância de $75 \mathrm{mg} / 1(1.87 \times$ $10^{-6} \mathrm{~mol} / \mathrm{cm}^{3}$ ) de $\mathrm{Ca}^{++}$em equilibrio com uma média de $0.0065 \mathrm{~atm}$. de $\mathrm{CO}_{2}$, representadas pelo ponto $\mathrm{S} 2$ no diagrama (fig 4.22 ).

Como exemplo de água com baixa concentração de saturação em calcita, selecionou-se o fluxo de condutos do rio subterrâneo da caverna Santana (amostras 1, 2, 3 e 32, anexo 5.3). Esta água possui em média $32 \mathrm{mg} / 1\left(0.80 \times 10^{-6} \mathrm{~mol} / \mathrm{cm}^{3}\right) \mathrm{de} \mathrm{Ca}^{++} \mathrm{com}$ 0.0009 atm. de $\mathrm{CO}_{2}$, ponto $\mathrm{S} 1$ no diagrama.

A área sobre o lado côncavo da curva de equilíbrio de soluções carbonatadas (fig 4.22) representa o campo de soluções insaturadas. Sob o lado convexo estão as soluçôes saturadas em calcita. As retas que unem pontos sobre a curva, representam as misturas de diferentes proporçóes em volume, de duas soluçóes distintas de $\mathrm{Ca}^{++} \mathrm{e} \mathrm{CO}_{2}$, inicialmente 


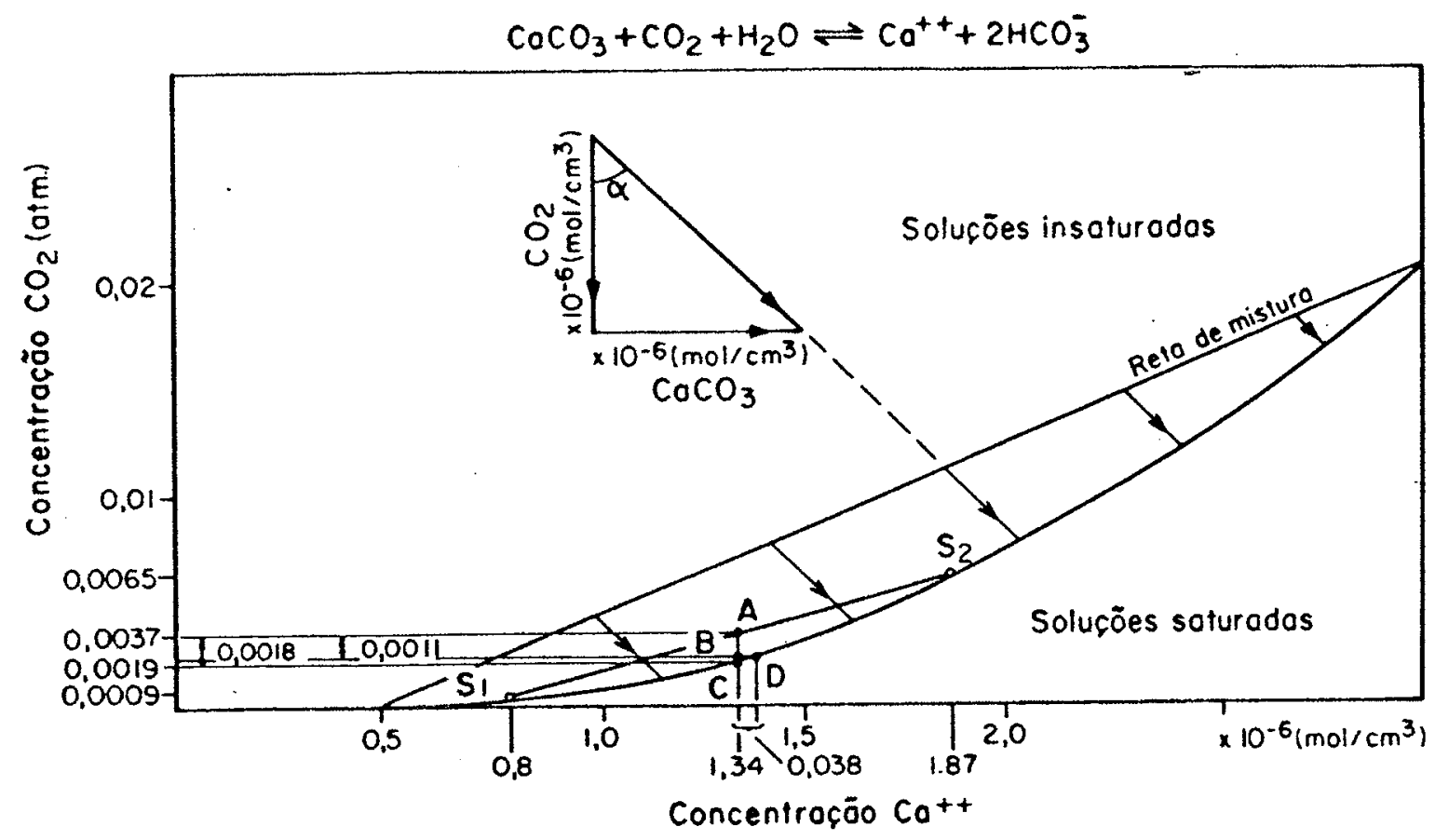

Figura 4.22 - Diagrama da corrosão de mistura aplicado às águas do sistema Pérolas Santana. Acompanhar explicação no texto. Adaptado de Dreybrodt (1981b).

em equilíbrio. Conforme o diagrama, estas misturas necessariamente caem no campo insaturado. Os segmentos de retas transversais às retas de mistura indicam a trajetória das concentrações de $\mathrm{Ca}^{++}$e $\mathrm{CO}_{2}$, de soluções resultantes da mistura de duas soluções com concentrações iniciais diferentes. $O$ ângulo $\alpha$ de inclinação destas linhas é determinado pela reação de decomposição do $\mathrm{CaCO}_{3}$ pelo $\mathrm{H}_{2} \mathrm{CO}_{3}$. Nesta reação, 1 mol de $\mathrm{CaCO}_{3}$ é dissociado por $1 \mathrm{~mol}$ de $\mathrm{CO}_{2}$, o que determina um ângulo de $45^{\circ}$ sobre o gráfico com escalas iguais nos eixos x e y (fig 4.22). $\mathrm{O}$ excesso de $\mathrm{CO}_{2}$ gerado pela mistura de soluçôes saturadas em equilibrio pode ser determinado graficamente com a ajuda da curva de equilibrio (Bögli, 1978), conforme o exemplo a seguir.

A mistura hipotética das soluções $S_{1}$ e S2, numa proporção volumétrica de 1:1, produz uma solução resultante com concentração de $1.34 \times 10^{-6} \mathrm{~mol} / \mathrm{cm}^{3} \mathrm{de} \mathrm{Ca}{ }^{++}$e 0.0037 atm. de $\mathrm{CO}_{2}$ (ponto $\mathrm{A}$, mediano entre $\mathrm{S} 1$ e $\mathrm{S} 2$ devido à proporção $1: 1$ de volumes misturados). Esta solução resultante, insaturada em calcita, somente requer $0.0019 \mathrm{~atm}$ de $\mathrm{CO}_{2}$ para manter $1.34 \times 10^{-6} \mathrm{~mol} / \mathrm{cm}^{3} \mathrm{de} \mathrm{Ca}^{++}$em solução (determinado graficamente pela reta $\mathrm{AC}$ no diagrama, seguindo método de Bögli, 1978). Há, portanto, um excesso de 0.0018 atm. de $\mathrm{CO}_{2}$ em solução. A solução no ponto $\mathrm{A}$, para atingir a saturação, irá percorrer a trajetória $\mathrm{AD}$, consumindo 0.0011 atm de $\mathrm{CO}_{2}$ do excedente de 0.0018 , dissolvendo um adicional de cerca de $0.038 \times 10^{-6} \mathrm{~mol} / \mathrm{cm}^{3}$ de calcita.

Com o resultado obtido acima, comprova-se que atualmente há condiçóes químicas no sistema cárstico do Alto Ribeira, que possibilitam a ocorréncia da corrosão de mistura

Para considerar que a corrosão de mistura operou na fase de iniciação de condutos, a região em estudo deve satisfazer duas premissas fundamentais. A primeira é quanto as 
condições climáticas reinantes durante a iniciação. Isto é, durante a iniciação, o clima deve ter sido semelhante ao atual, ou suficientemente úmido, para sustentar densa vegetação e permitir alta produção de $\mathrm{CO}_{2}$ no solo, fator essencial para gerar água de infiltração autogênica com alta concentração em carbonato. A segunda, refere-se à presença no sistema cárstico de águas com concentrações contrastantes, ou seja, injeções alogênicas com baixa concentração em carbonato e injeções autogênicas com alta concentração. Esta premissa é plenamente satisfeita, pois, devido à origem fluviocárstica da região em estudo, póde-se afirmar, que desde o início da exposição dos metacalcários, houve uma importante área de captação alogênica adjacente a estes. Quanto às condições climáticas, é razoável, considerar que a região apresentou clima úmido e quente, no mínimo durante o último milhão de anos, com períodos intercalados de alguns milhares de anos, com provável menor umidade (clima semelhante ao cerrado atual), correspondentes às fases glaciais pleistocênicas do hemisfério norte ( Ab'Sáber, 1977 e Brown e Ab'Sáber, 1979).

Conclui-se, portanto, que a corrosão de mistura teve condições geológicas e hidroquímicas para contribuir no processo de iniciação de proto-cavernas na área investigada.

Mas, de acordo com os modelos atuais de espeleogênese, como os apresentados por Dreybrodt (1990), Worthingthon (1991), Palmer (1991) e Lowe (1992), a corrosão de mistura é considerada um processo complementar na espeleogênese e não suficiente para explicar a origem de longas redes contínuas de cavernas (da ordem de dezenas de quilômetros), associadas às rotas de fluxo subterrâneo de águas meteóricas em terrenos calcários. Principalmente devido ao fato, de que a solução agressiva resultante da mistura, também atingirá rapidamente (em alguns metros) a saturação em calcita, o que limita a capacidade corrosiva renovada, à regiões próximas do encontro de descontinuidades conduzindo soluções contrastantes. Desta maneira, a geração de cavidades por corrosão de mistura é restrita a pontos isolados no corpo carbonático.

É necessário portanto, invocar outros mecanismos, para explicar a presença de água meteórica agressiva a grandes distâncias no interior do maciço carbonático.

Conforme citado no ítem 4.3.1, o princípio físico-químico, além da corrosão de mistura, utilizado para explicar tal fato, é a variação da cinética da reação de dissolução do $\mathrm{CaCO}_{3}$, conforme as soluções infiltrantes se aproximam da saturação. White $(1977,1984)$, Palmer (1981, 1984 e 1991) e Dreybrodt (1990), desenvolveram uma exaustiva análise teórica sobre a cinética de dissolução de calcita, aplicada à espeleogênese. Uma abordagem qualitativa e simplificada desta questão, pode ser obtida com a análise da equação geral da cinética de dissolução de calcita, seguindo Ford, Palmer e White (1988):

$$
\mathrm{dC} / \mathrm{dt}=\mathrm{k}(1-\mathrm{C} / \mathrm{Cs})^{\mathrm{n}}
$$

onde $\mathrm{dC} / \mathrm{dt}$ é a variação de concentração de soluto com o tempo, $\mathrm{C}$ é a concentração de soluto na água de percolação, Cs é a concentração de saturação de carbonato dissolvido, $k$ é uma constante empírica dependente do comprimento de percolação e sua vazão e n comesponde à ordem de reação. Dados experimentais obtidos por Palmer e Dreybrodt (op. cit.), demonstraram que com o aumento da distância de percolação, a concentração (C) 
tende à saturação e a taxa de dissolução $(\mathrm{dC} / \mathrm{dt})$ decresce. Demonstraram também, que com valores baixos de $\mathrm{C} / \mathrm{Cs}$ (soluções fortemente insaturadas), a ordem de reação (n), inicialmente varia entre 1 e 2.2 . Com valores altos de $\mathrm{C} / \mathrm{Cs}$, ou seja, soluções muito próximas da saturação, a ordem de reação aumenta abruptamente para 4 a 5 . Esta transição ocorre entre 60 a $90 \%$ de saturação (Cs entre 0.6 e 0.9), dependendo da pressão parcial de $\mathrm{CO}_{2}$ e temperatura. Este incremento na ordem de reação, representa uma importante redução na taxa de dissolução de calcita, antes que a solução se torna saturada.

Com este comportamento cinético da dissoluçâo de calcita, as taxas de dissolução na zona epicárstica ou nas proximidades dos pontos de injeção de fluxos alogênicos, são altas, da ordem de $0.1 \mathrm{~cm} /$ ano (Ford, Palmer e White, 1988), mas, diminuem rapidamente com a progressiva saturação e infiltração. Desta maneira, água subterrânea é capaz de penetrar por longas distâncias na rocha carbonática, antes de atingir a saturação e, portanto, dissolve a rocha ao longo das linhas de fluxo da água subterrânea, com taxas muito lentas e uniformes.

A próxima questão sobre a iniciação da espeleogênese, refere-se à profundidade dos condutos de iniciação, em relação ao lençol freático. Isto é, as proto-cavernas desenvolvemse sobre, logo abaixo ou muito abaixo da superficie piezométrica questão esta, ponto de debate histórico no desenvolvimento das teorias e modelos espeleogenéticos, conforme é sintetizado em Watson e White (1985) e Lowe (1992)

A modelagem mais recente e uma das primeiras com abordagem quantitativa, da evolução de aqǘferos cársticos, foi apresentada por Worthington (1991). Com base no estudo da geometria de 16 rotas completas do fluxo de água subterrânea de sistemas cársticos de cavernas, em variadas condições de mergulho da estratificação e fraturamento, o autor acima concluiu, que a profundidade máxima de fluxo de condutos (Dx) é principalmente controlada pelo mergulho da estratificação $(\theta)$ e a extensão da área de captação (Lx), entre o ponto principal de insurgência e a ressurgência da água subterrânea, conforme é esquematizado na fig 4.23. Nesta geometria, considerando que a rede de fluxo desenvolve-se sobre um ou vários planos de maior transmissividade de água, no caso o acamamento, seguindo os traços das interseç̧ões do sistema de fraturas com o acamamento (o que imprime o caráter escalonado às rotas de fluxo), o fluxo mais profundo seria encontrado nas situações de maior mergulho do acamamento, seguindo a expressão abaixo (conforme Worthington, op cit):

$$
\mathrm{Dx}=\mathrm{KLx} \operatorname{sen} \theta \text {, }
$$

onde $\mathrm{K}$ é uma constante de proporcionalidade.

Através da regressão das medidas de profundidade média (Dm) de condutos de iniciação, abaixo do lençol freático, contra Lxsen $\theta$, Worthington obteve o melhor ajuste com a equação:

$$
\mathrm{Dm}=0.11(\mathrm{Lx} \operatorname{sen} \theta)^{0.81}, \operatorname{com} \mathrm{R}^{2}=0.95 \%
$$

Inserindo o sistema de cavernas Pérolas-Santana neste conjunto de medidas (tabela 4.6), obteve-se a relação exponenciâl

$$
\mathrm{Dm}^{\prime}=0.103(\mathrm{Lx} \operatorname{sen} \theta)^{0.82}, \text { com } \mathrm{R}^{2}=95 \% \text { e coef correlação } 0.97
$$


muito semelhante ao resultado de Worthington, conforme é ilustrado pela figura 4.24.
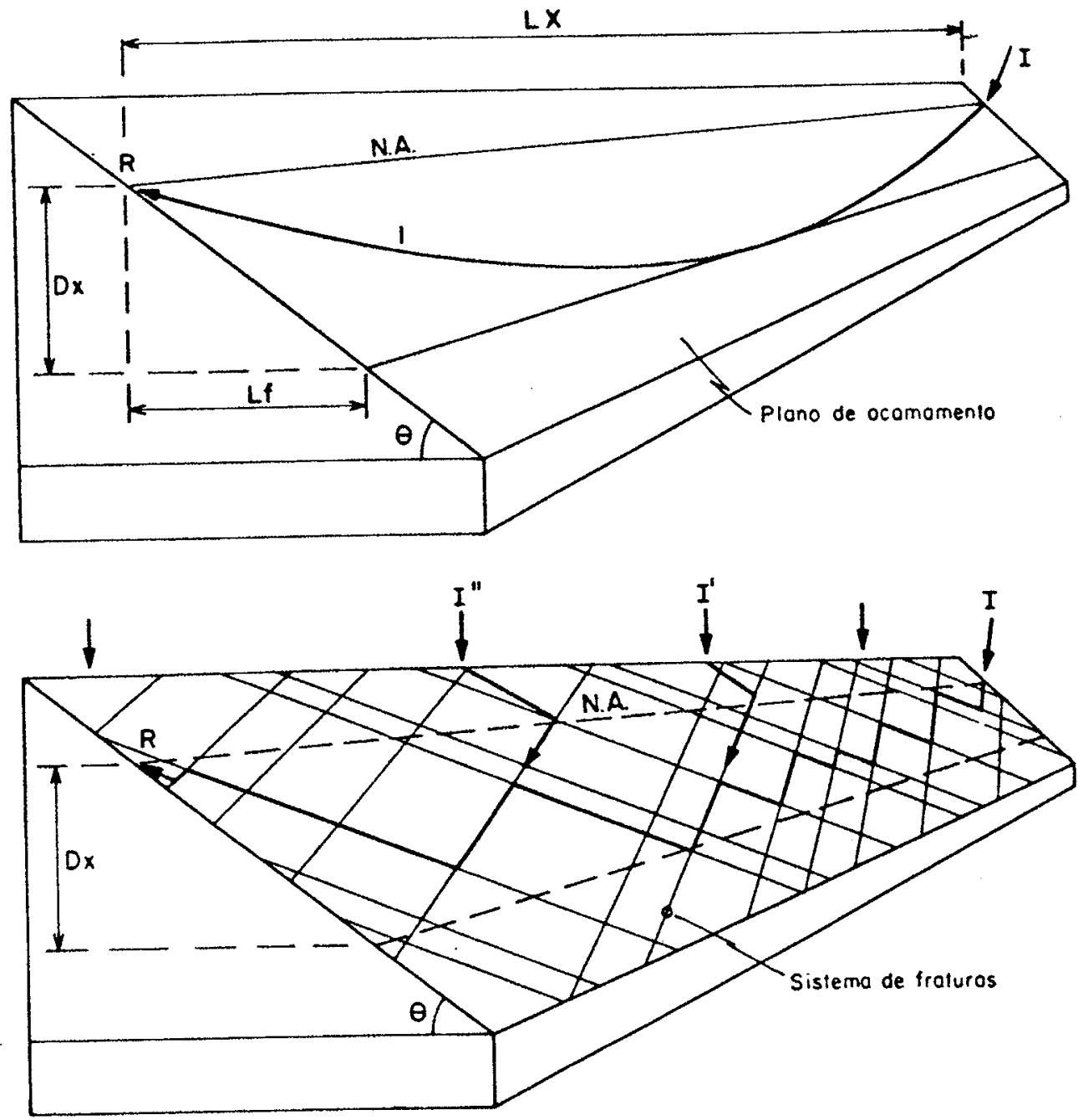

Figura 4.23 - Linhas de fluxo condicionadas pelo mergulho da superficie de acamamento (adaptado de Worthington, 1991).

A- Iniciação de condutos condicionada somente pelo plano de acamamento.

- B-Iniciação de condutos condicionada pelas interseç̧ões acamamento - fraturas, gerando rotas côncavas escalonadas de condutos.

Dx- profundidade máxima de condutos.

Lx- extensão da área de captação

I- pontos de injeção. R- ponto de ressurgência.

Lf- largura da rota de fluxo.

L- linha de fluxo da água subterrânea

$\theta$ - mergulho do plano de acamamento

Considerou-se uma profundidade média de $200 \mathrm{~m}$ (com mínimo de 50 e máximo de $350 \mathrm{~m}$ ) abaixo do lençol freático para os condutos de iniciação observados no topo do entalhamento vadoso da caverna Santana. Esta profundidade foi medida em relação à superficie atual, o que a torna sub-estimada, pois não considera o rebaixamento do relevo, devido à denudação superficial, ocorrido desde a iniciação dos condutos. Esta medida, inclui também, a premissa de que o lençol freático estava próximo da superficie em função da baixa permeabilidade inicial da rocha nesta fase Provavelmente, a profundidade máxima 
de condutos pode ter chegado a cerca de $400 \mathrm{~m}$ abaixo do NA, conforme a estimativa de um rebaixamento da superficie, de no mínimo $50 \mathrm{~m}$, em função da profundidade de depressões poligonais.

\begin{tabular}{|lcccc|}
\hline \multicolumn{1}{|c}{ Caverna } & $\begin{array}{c}\text { Profundidade } \\
\text { Média } \\
(\mathrm{Dm})\end{array}$ & $\begin{array}{c}\text { Profundidade } \\
\text { Máxima } \\
(\mathrm{Dx})\end{array}$ & $\begin{array}{c}\text { Estensão } \\
\text { (Lx) } \\
\mathrm{Km}\end{array}$ & $\begin{array}{c}\text { Mergulho do } \\
\text { acamamento, } \theta\end{array}$ \\
1. Horseshoe Bay, EUA & 6 & 20 & 3 & 0 \\
2. West Kingsdale, Inglaterra & 8 & 30 & 2.7 & 3 \\
3. Jordtulla, Noruega & 9 & 23 & 0.52 & 25 \\
4. Otter Hole, Inglaterra & 10 & 23 & 3.5 & 6 \\
5. Sistema Friars Hole, EUA & 17 & 25 & 11 & 2.2 \\
6. Rio Encantado, Porto Rico & 15 & 25 & 9.5 & 4 \\
7. Guanyan, China & 25 & 100 & 6.5 & 7 \\
8. Swildons-Wookey, Inglaterra & 40 & 90 & 6 & 15 \\
9. Demanova, Checoslovaquia & 23 & 90 & 3.2 & 35 \\
10. Doux de Coly, França & 46 & 56 & 13.7 & 6 \\
11. Hölloch, Suiça & 100 & 190 & 10 & 16 \\
12. Lubang Benarat, Malásia & 105 & 220 & 7 & 45 \\
13. Nettlebed, Nova Zelândia & 120 & 150 & 7 & 50 \\
14. Peña Colorada, México & 120 & 200 & 12 & 40 \\
15. Nelfastla de Nieva, México & 240 & 290 & 7.4 & 70 \\
16. El Abra, México & 800 & 1500 & 150 & 20 \\
17. Sistema Pérolas-Santana, Brasil & 200 & 400 & 6 & 60 \\
\hline
\end{tabular}

Tabela 4.6 - Profundidades de condutos de iniciação e extensões de rotas completas sistemas de cavernas. Medidas 1 a 16 foram extraídas de Worthington (1991).

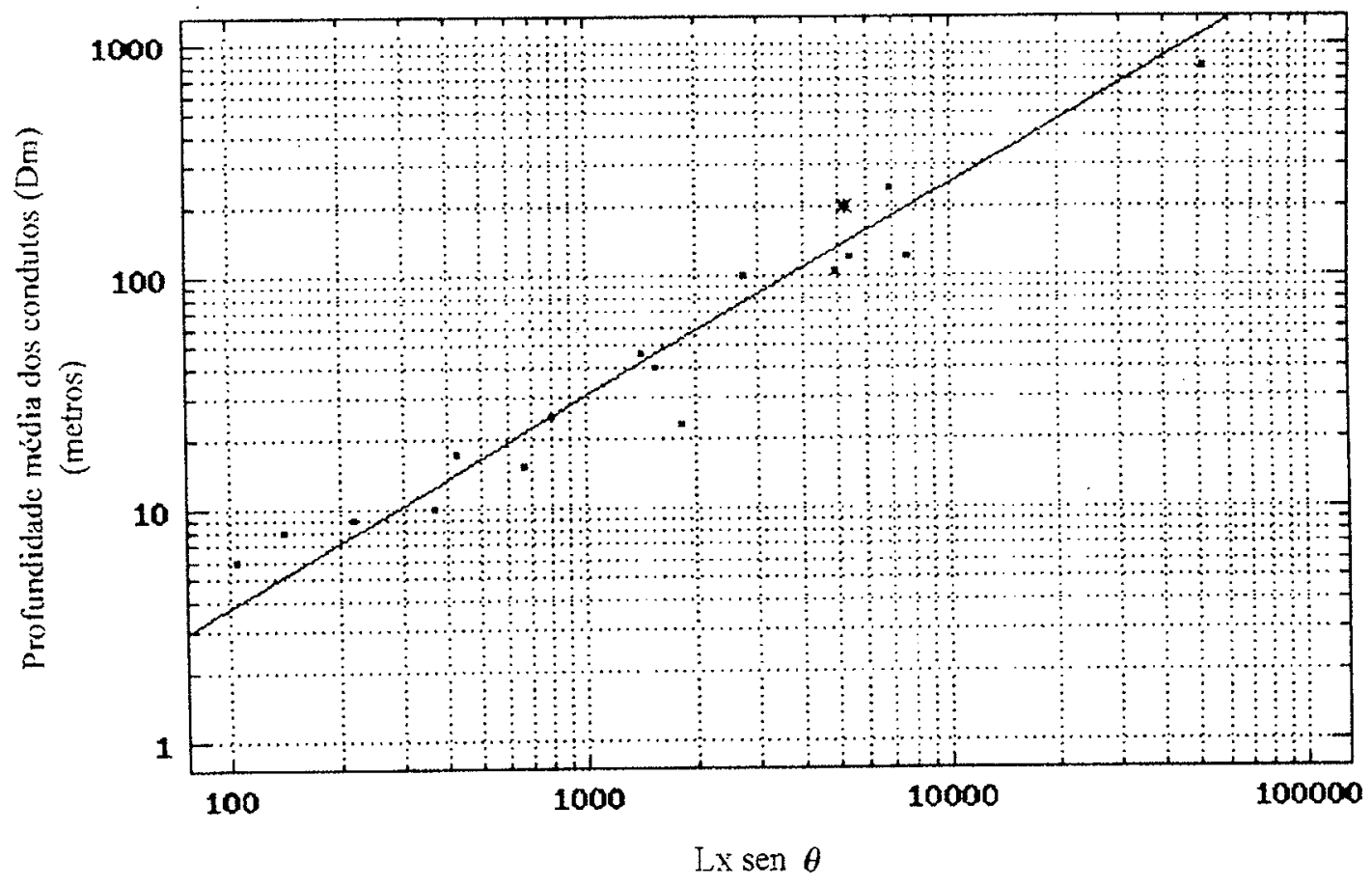

Figura 4.24- Profundidade média de fluxo (Dm) em função da extensão da área de captação do aqüifero (Lx) e mergulho da estratificação $(\theta)$. medidas da caverna Santana. Demais pontos extraídos de Worthington (1991). 
O alinhamento da caverna Santana com os dados de Worthington (fig 4.24), comprova a hipótese sobre a relação existente entre profundidade de condutos de iniciação e o mergulho do acamamento, assim como, confirma também, a forte influência do acamamento sobre a iniciação do sistema Pérolas-Santana

A fase de iniciação, culmina portanto, com a instalação de um sistema interconectado de proto-cavernas, somente observadas diretamente, em testemunhos desta fase, conforme descritos na caverna Santana. Estas proto-cavernas formam-se abaixo do lençol freático, acompanhando as linhas côncavas escalonadas (fig 4.23) da rede de fluxo da água subterrânea, em profundidades conforme o modelo acima apresentado.

Entre os inúmeros canalículos iniciais, somente alguns poucos, evoluem para condutos freáticos maiores. Ocorre um processo de competição entre as taxas de abertura de proto-cavernas. As rotas com maior eficiência hidráulica inicial (maior transmissividade), e portanto, com maior dissolução, terão taxas maiores de alargamento, relativamente aos canalículos vizinhos. Estas proto-cavernas com vazão maior, acabam convergindo para sí, o fluxo de canalículos vizinhos, paralizando o desenvolviménto destes. Este processo de abertura diferencial entre proto-cavernas atinge o máximo quando uma das rotas com ampliação favorecida conecta diretamente as regiões de injeção e saída de água subterrânea (Ford e Williams, 1989). Este momento no processo espeleognético é denominado de breakthrough (Ewers, 1972; Ford e Williams, 1989 e Dreybrodt, 1990), traduzido aqui, como ponto de avanço da espeleogênese.

\subsubsection{Fase de desenvolvimento}

O ponto de avanço marca o início da fase de desenvolvimento do sistema cárstico subterrâneo. Caracteriza-se por um incremento repentino na vazão do conduto vencedor, transição de fluxo laminar para turbulento ao longo deste ("salto" hidráulico, segundo White e Longyear, 1962, apud Worthington, 1991) e pelo aumento de várias ordens de grandeza da taxa de dissolução (até 70 vezes, segundo White e Longyear, op cit). A partir desta transição no regime hidráulico, a dissolução de calcita ao longo do conduto vencedor, procede com cinética de $1^{\mathrm{a}}$ ordem, envolvendo taxas calculadas de retração das paredes, da ordem de 0.003 a $0.1 \mathrm{~cm} /$ ano (Dreybrodt, 1990).

O início da fase de desenvolvimennto, implica também, na aceleração do rebaixamento do lençol freático, o que amplia a zona vadosa acima dos condutos principais.

A morfologia inicial, associada a este estágio de carstificação, vai depender da posição do lençol freático em relação ao conduto vencedor. Se o ambiente freático perdurar, o conduto com dimensões de proto-caverna será ampliado, dando origem a condutos freáticos maiores, com seções sub-circulares a elípticas (conforme descrição no item 4.3.2.2), de diâmetro decimétrico a métrico, raramente decamétricos. No caso da proto-caverna sofrer exposição acima do nível piezométrico, sua base será marcada por entalhamento vadoso (Palmer, 1984 e White e Deike, 1989), figura 4.25.

Com o rebaixamento do nível de base, os primeiros condutos a serem expostos acima do lençol freático, serão as terminações do sistema, junto aos pontos de insurgência 


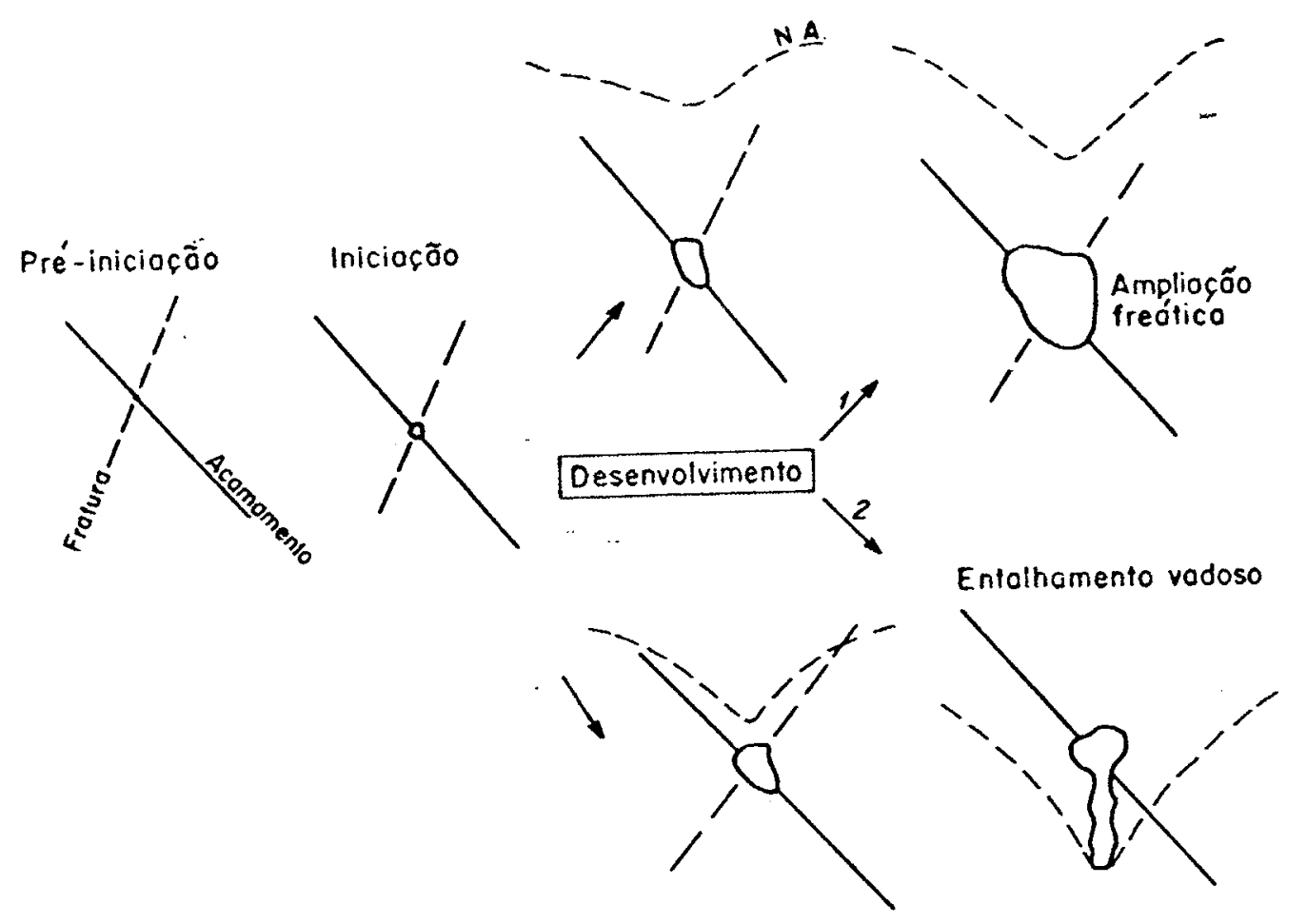

Figura 4.25 - Representação esquemática da morfologia em seção transversal resultante da fase de desenvolvimento. (1) abaixo do lençol freático, gerando tubos freáticos e (2), com rebaixamento do lençol, acompanhando a ampliação do conduto, gerando a seção típica, popularmente denominada de "buraco de fechadura".

e/ou ressurgência do aqüífero (fig 4.26). A partir deste momento, ocorre o desenvolvimento contemporâneo da rede de condutos, tanto em ambiente vadoso como em freático (Palmer, 1991). Devido a este mecanismo, predominam formas vadosas nas proximidades dos sumidouros e ressurgências dos sistemas de cavernas estudados.

A transição de canyon vadoso para conduto freático, muito comum nos sistemas estudados e descrita no item 4.3.2.2 (entalhamentos vadosos, fig 4.9), é interpretada como sendo condicionada pelo padrão escalonado da rota côncava de condutos freáticos. Durante a fase de desenvolvimento, alguns dos segmentos convexos desta rota, serão expostos à condições vadosas, em quanto que, grande parte dos trechos côncavos, continuam no domínio freático (fig 4.26). Nas cristas dos segmentos convexos expostos acima do lençol freático, a água subterrânea inicia a fluir livremente, com fluxo turbulento, causando o entalhamento vadoso destas, segundo o modelo de Ford (1965), apud Ford e Ewers (1978). São gerados, desta forma, canyons vadosos laterais e sincrônicos à ampliações freáticas (Ford, 1965).

$\mathrm{Na}$ caverna Santana, o entalhamento vadoso aumenta gradativamente em altura, a partir do sifão no final do ramo principal, atingindo um máximo de $50 \mathrm{~m}$ (fig 4.9). Interpreta-se, portanto, que a amplitude vertical do escalonamento de condutos ascendentes e descendentes da rota de condutos freáticos, previamente à fase de desenvolvimento, atingia, no mínimo $50 \mathrm{~m}$ (fig 427). Esta estimativa é mínima, porque a exploração do trecho freático, ainda não avançou o suficiente, para demonstrar, até qual profundidade abaixo do nivel niesométrico atual chega o conduto principal do sistema Pérolas-Santana Na caverna 


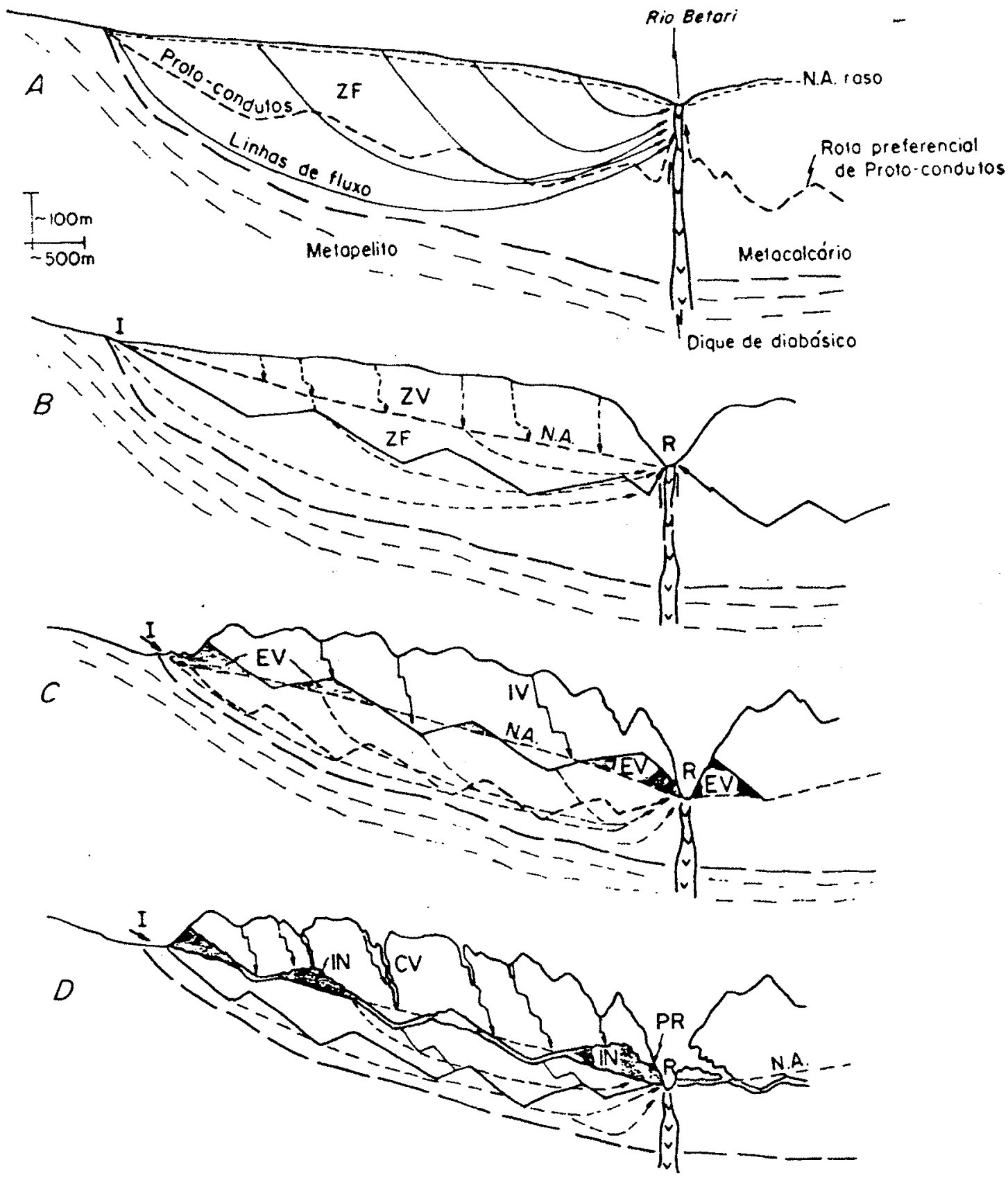

Figura 4.26 - Esquema simplificado da evolução de condutos associados ao sistema de cavernas Pérolas Santana, em perfil longitudinal. Escala aproximada.

$A$ - Fase de Iniciação. Implantação de proto-condutos ao longo de uma rota de fluxo côncava escalonada, a uma profundidade média de $200 \mathrm{~m}$, na zona freática (ZF).

$B$ - Fase de desenvolvimento. Conexão de uma rota preferencial de condutos freáticos entre a insurgência (I) e ressurgência (R), com coseqüente ampliação đa zona vadosa (ZV).

$C$ - Ampliaçăo de condutos freáticos e progressivo rebaixamento do NA. Entalhamento vadoso (EV) nos segmentos convexos (ascendentes) de condutos freáticos expostos acima do N.A. Desenvolvimento de invasões vadosas (IV). Iniciaça de proto-condutos em níveis freáticos abaixo do conduto principal.

$D$ - Fase avançada de desenvolvimento da espeleogênese. Conexão das invasões vadosas com o sistema de cavernas desenvolvido. Ampliação das invasões vadosas, gerando condutos verticais (CV). Instabilização mecânica no maciço carbonático, causando modificação dos condutos acima do N:A, através de incasão (IN) Implantação de novas rotas de condutos profundos. Paleo-ressurgência (PR) localizada em cotas acima da ressurgência ativa. 


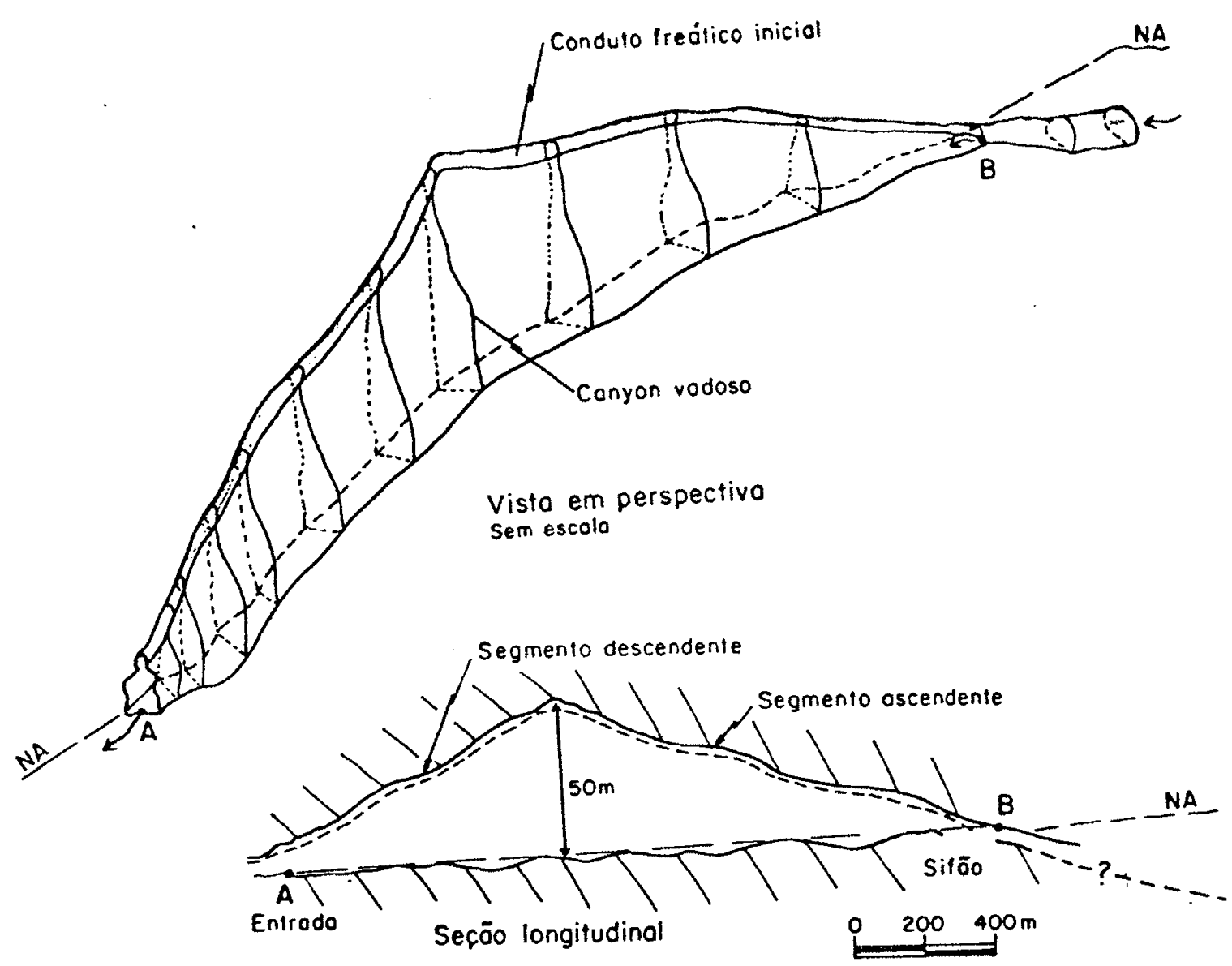

Figura 4.27 - Esquema da interpretação da variação vertical (sinuosidade vertical) de condutos freáticos em função da variação de altura do canyon vadoso ao longo do conduto principal da caverna Santana. No ponto B ocorre a transição de canyon vadoso para conduto freático ativo.

Pérolas, o entalhamento vadoso com cerca de $50 \mathrm{~m}$ nas proximidades da entrada principal, decresce gradativamente em altura até $5 \mathrm{~m}$, ao longo de aproximadamente $400 \mathrm{~m}$ de galeria de abatimento.

Worthington (1991) reconheceu amplitudes de variação vertical de segmentos ascendentes e descendentes entre 5m (sistema Friars Hole, EUA) e 100m (Hölloch, Suiça). Relacionou esta variação ao mergulho da estratificação, ou seja, quanto maior o mergulho, tanto maior a variação vertical do escalonamento de condutos freáticos, nos casos de condutos condicionados pelo acamamento.

A ampliação freática durante a fase de desenvolvimento, nas cavernas estudadas, produziu seções regulares (circulares a elípticas) e irregulares, conforme descrito no item 4.3.2.2 (alargamento freático). As seções elípticas a circulares evidenciam alargamento por dissolução relativamente constante ao longo do perímetro do conduto (fig 4.28), acompanhando preferencialmente a estratificação, falhas ou fraturas. As seções irregulares evidenciam taxas de dissolução diferenciadas ao longo do perímetro, em conseqüência da anisotropia da rocha carbonática (Susteric, 1979), deposição de sedimento e conseqüente isolamento de parte do perímetro do conduto da corrosão (Palmer, 1984) ou corrosão de mistura (Bogli, 1978). Nas cavernas estudadas, atribui-se a irregularidade de seções 
freáticas principalmente à presença de estratos mais e menos solúveis (fig 4.28), devido à intercalação alternada de calcários puros e impuros e à corrosão de mistura, responsável pela formação e ampliação de cones de dissolução (fig 4.28) sobre condutos freáticos.
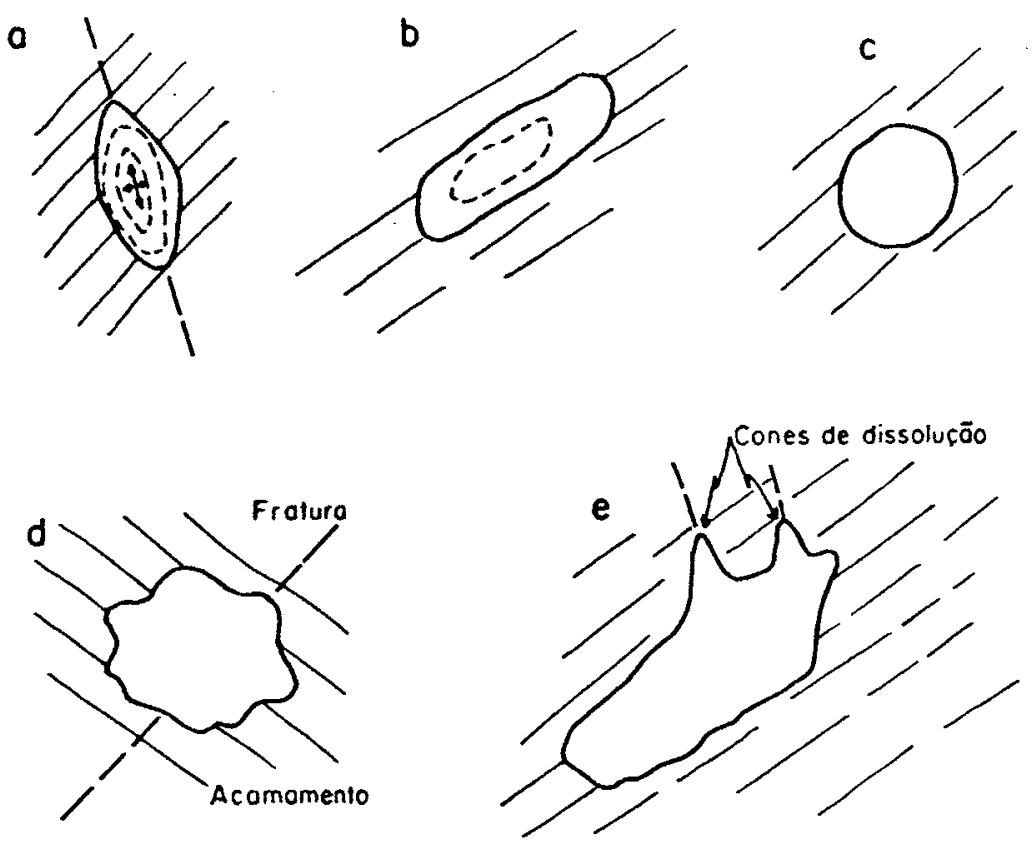

Figura 4.28 - Tipos de ampliações freáticas observadas nas cavernas estudadas.

a- alargamento freático preferencial sobre plano de fratura ou falha

b- alargamento freático preferencial sobre plano de acamamento

c- alargamento homogêneo

d- alargamento freático com dissolução preferencial de estratos mais solúveis, produzindo seção irregular

e- seção freática irregular produzida pela corrosão de mistura gerando cones de dissolução.

No estágio avançado da fase de desenvolvimento dos condutos principais, expresso na área através do intenso entalhamento vadoso destes, o volume de vazios expostos acima do nível de água aumenta, causando a instabilização mecânica do maciço carbonático. Inicia-se, portanto, o processo de incasão, alterando gradativamente a morfologia de entalhamento por dissolução, conforme foi descrito no item 4.3 .2 .2 (formas geradas pela incasão).

O volume maior de abatimento junto aos sumidouros é interpretado como conseqüência destes trechos terem sido os primeiros a serem expostos acima do nível de água, e que portanto, sofreram entalhamento vadoso maior, em relação aos trechos mais internos da rota de condutos.

Com a ampliação da zona vadosa sobre a rota principal de condutos, inicia-se a instalação de invasões vadosas, muito freqüentes na área estudada e representadas pelos condutos verticais (descritos no item 4.3.2.2). Estes constituem cavernas sem uma fase freática inicial (Ford e Williams, 1989). Formaram-se ao longo de rotas subverticais ou escalonadas de maior permeabilidade inicial, como cruzamentos de fraturas longas subverticais e falhas, entre si e com o acamamento. Estas rotas de infiltração, ao se 
ampliarem, acabaram absorvendo o escoamento superficial, num primeiro estágio com contribuição alogênica importante (fase fluvial do exocarst) e posteriormente, escoamento principalmente autogênico, devido à implantação de depressões poligonais. As invasões vadosas conectadas diretamente às rotas principais de condutos da água subterrânea, por possuírem drenagem mais eficiente, sofreram taxas de alargamento maiores que as conectadas indiretamente. Desta forma, os condutos verticais acessiveis à exploração por longas distâncias (até $250 \mathrm{~m}$ na vertical, p. ex., abismo Juvenal), sempre estão associadas diretamente a sistemas de cavernas, fato observado na área estudada.

Outro fenômeno, associado ao rebaixamento do lençol freático sobre o sistema de cavernas, é a captura de cavernas desenvolvidas nas proximidades da rota principal de condutos, formando ramos tributários. Como exemplos, cita-se a rede Takeopa e a galeria entre o salão dos Vulcões e o poço São Jorge, na caverna Santana (fig 4.6). A rede Takeopa, constitui um afluente ativo. Atualmente sua área de captaç̧ão è interpretada como sendo autogênica (depressão poligonal), devido a alta dureza da água. Mas, devido à presença de cascalheiras alóctones aos calcários, parte de sua fase de desenvolvimento é atribuída à injeção alogênica, a qual iniciou o desenvolvimento de um sistema independente de cavernas. Já o ramo entre o salão dos Vulcões e o poço São Jorge, hoje é um paleoafluente, também de origem alogênica, em função de importantes cascalheiras alóctones, hoje cobertas em grande parte por crostas calcíticas. A junção deste ramo com o conduto principal da caverna Santana se deu através de uma invasão vadosa.

Interpreta-se a captura destes afluentes, como sendo condicionada pelo vale de rebaixamento do lençol freático, que se desenvolveu sobre o conduto principal, desde $o$ ponto de avanço da espeleogênese. Com este processo, formou-se um gradiente hidráulico convergente ao conduto principal, responsável pela instalação de condutos neste sentido, os quais acabaram conectando rotas de fluxo e condutos, inicialmente independentes da rota principal.

A partir do ponto de avanço na espeleogênese, inicia-se também, o transporte de um volume significativo de sedimentos detríticos através do sistema de cavernas. Na fase de iniciação, o material detrítico transportado limita-se a partículas na fração silte e argila (Ford e Worley, 1977), principalmente formados por resíduos insolúveis da rocha carbonática. Após a conexão direta de condutos entre a área de captação e a ressurgência, a velocidade de fluxo aumenta em várias ordens de grandeza (Dreybrodt, 1990), o que aumenta a capacidade de transporte deste fluxo. Gale (1984) descreveu o transporte de areia alóctone, com grãos entre $0.1 \mathrm{e} 1 \mathrm{~mm}$, através de condutos freáticos com $67 \mathrm{~cm}$ de diâmetro. Ford e Williams (1989) descrevem evidências de calhaus de calcário denso transportados por redes de condutos freáticos, sendo ejetados no topo de condutos verticais de até $7 \mathrm{~m}$, o que mostra a alta capacidade de transporte de fluxos associados a grandes enchentes.

No caso do Alto Ribeira, um grande volume de sedimentos e transmitido pelos sistemas de cavernas. Estes sedimentos possuem uma importante contribuição aloctone devido às grandes áreas de captação alogênicas associadas aos vales cegos que alimentam 
os sistemas de cavernas. Ao longo dos condutos hoje acessíveis, observam-se depósitos fluviais, desde cascalheiras com calhaus e blocos (compostos principalmente por clastos de filito, metarenito e quartzo), bancos de areia e depósitos finos de silte e argila. A característica de gradação normal (de cascalho na base a argila no topo), muito freqüente em testemunhos de depósitos acima do nivel de fluxo atual e nos depósitos atuais, indica movimentos episósicos de alta vazão no transporte da carga de fundo. Deve-se considerar, portanto, um duplo papel dos depósitos fluviais na espeleogênese, segundo Newson (1971) e Smith e Newson (1974). Durante períodos de vazão normal, esta carga de sedimento age como inibidora da ampliação por corrosão do leito dos condutos. Por outro lado, em eventos esporádicos de alta vazão, a movimentação desta massa detrítica, contribui na ampliação através da abrasão mecânica do leito dos condutos. Esta abrasão é evidenciada através da geração de marmitas de diâmetro decimétrico no canal fluvial. Estes sedimentos agem também como niveladores do leito fluvial, pois preenchem as irregularidades do leito rochoso, tornando os fundos dos entalhamentos vadosos e condutos freáticos planos.

Um último fenômeno, importante na fase de desenvolvimento da espeleogênese, é a geração de uma nova rota de condutos, abaixo do nível de condutos em fase avançada de desenvolvimento, conforme o modelo espeleogenético de Worthington (1991). A profundidade de iniciação desta nova linha de condutos segue os mesmos princípios que condicionaram a rota superior, em função do campo de linhas de fluxo desenvolvido abaixo dos condutos existentes. Isto é, seguem a profundidade Dx e Dm, abaixo do lençol freático, anteriormente discutida.

$\mathrm{Na}$ área estudada, as zonas de vazios detectadas pela perfuração do poço no Bairro da Serra (Politi, relatório de perfuração, 1988), em profundidades entre 60 e $150 \mathrm{~m}$ abaixo do N.A., são interpretadas, como sendo condutos no início da fase de desenvolvimento, contemporâneos ao estágio avançado de desenvolvimento da rota de cavernas superior.

Com o contínuo soerguimento da área e rebaixamento do nível de base, a rota superior de cavernas em desenvolvimento, poderá ser abandonada pelo lençol freático, e o fluxo deste, começa a predominar pela rota inferior de condutos. O momento em que a rota inferior captura o fluxo do nível superior, vai decidir se este é abandonado como um conduto freático ou como entalhamento vadoso (Worthington, 1991), conforme será discutido no item seguinte.

No sistema cárstico estudado, a rota inferior de condutos, não atingiu dimensões suficientes, em tempo hábil, para absorver o volume de água injetado no sistema. Isto associado ao rebaixamento do nível de base (soerguimento tectônico da área), condicionou o intenso entalhamento vadoso do nível superior de condutos freáticos, produzindo $\mathrm{o}$ quadro atual de morfologia subterrânea. Linhas de condutos freáticos superpostos e preservados do entalhamento vadoso, somente são observados em alguns ramos tributários aos condutos principais, como por exemplo, na rede Takeopa, caverna Santana (fig 4.29).

Atribui-se esta preservação da forma freática em ramos tributários, ao volume menor de água injetado nestes condutos. Isto permitiu ao conduto inferior, ampliar em 
tempo hábil e capturar o fluxo do conduto superior, antes que este seja entalhado em ambiente vadoso.

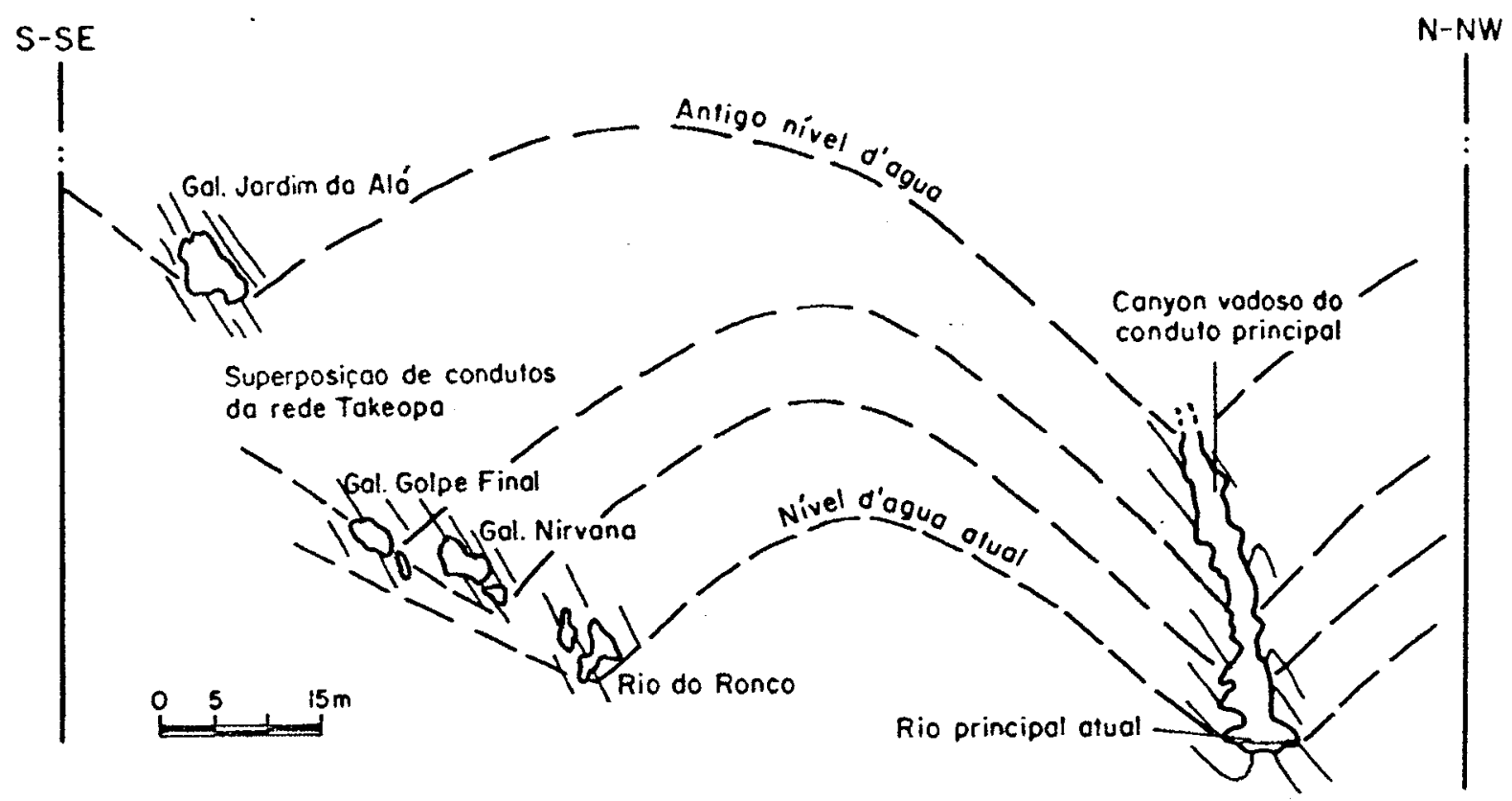

Figura 4.29 - Interpretação do rebaixamento do nível de água associado ao desenvolvimento de redes afluentes ao conduto principal da caverna Santana. No sistema tributário de condutos, a morfologia freática foi parcialmente preservada, enquanto que no conduto principal, ocorreu o entalhamento vadoso do canyon.

Devido à evolução contemporânea do relevo e dos sistemas de cavernas epigênicas, a tendência final será da denudação superficial interceptar o nível de cavernas superior, enquanto o nível inferior entra em fase avançada de desenvolvimento, e um terceiro nível de condutos entre em iniciação. Desta maneira, rotas de cavernas mais antigas são consumidas pela denudação, enquanto novas rotas inferiores são geradas (Palmer, 1991), até a remoção total das rochas carbonáticas, estágio final da evolução do sistema cárstico.

No Alto Ribeira, foi possível detectar dois níveis principais de cavernas. Um superior, em adiantado estado de desenvolvimento e outro, em fase inicial de desenvolvimento, atualmente em ambiente freático, a profundidades observadas entre 50 e $150 \mathrm{~m}$ e máximas estimadas de $400 \mathrm{~m}$.

O estágio atual da denudação superficial interceptou as zonas de insurgência e ressurgência dos principais sistemas, assim como, os fundos de algumas depressões poligonas (p. ex. a depressão composta das Areias), atingiram o topo de entalhamentos vadosos subterrâneos. Neste quadro de conexão entre a dinâmica de entalhamento superficial e desenvolvimento de condutos, citam-se também, as invasões vadosas, que em alguns casos, interceptaram os condutos, inclusive gerando grandes volumes de abatimento subterrâneo. 


\subsubsection{Rebaixamento do nível de base e desenvolvimento da espeleogênese}

A gradativa ampliação do sistema de cavernas na fase de desenvolvimento, implica no aumento da permeabilidade secundária, o que por sua vez, causa a drenagem do aqüifero no maciço carbonático. Neste quadro de dinâmica hidráulica, é fundamental inserir o papel do rebaixamento do nível de base da área durante a espeleogênese

Conforme citado anteriormente, a iniciação da espeleogênese é conseqüência direta do soerguimento tectônico e entalhamento do relevo, responsáveis pelo estabelecimento do gradiente hidráulico entre a zona de insurgência e ressurgência do aqüífero.

A morfologia subterrânea gerada na fase de desenvolvimento, ou seja, canyons vadosos de pequena ou grande profundidade, ou diferentes graus de ampliação de condutos freáticos, é essencialmente, uma resposta da rede de cavernas ao rebaixamento do nível de base relativo ao aqǘfero (Palmer, 1987). Este processo de queda do lençol freático no maciço carbonático, por outro lado, é basicamente controlado pela combinação entre a taxa de soerguimento tectônico da área, variação glacio-eustática do nivel de base, velocidade de ampliação dos condutos e volume de água meteórica injetada no aquüfero.

Considerando pequena variação com o tempo, da taxa de ampliação de protocavernas e do volume de água meteórica coletada pela área de captação do aquífero, devese analisar, como taxas variáveis de queda do nível de base influenciam o produto da espeleogênese.

\section{Rebaixamento muito rápido do nível de base}

$\mathrm{O}$ rebaixamento rápido do nível de base será acompanhado por entalhamento vertical intenso de vales, o que gera elevados gradientes no aqüifero cárstico, entre pontos de insurgência e ressurgência. Esta queda rápida do lençol freático implica em pouco tempo disponível para ampliação de condutos freáticos, os quais acabam sendo expostos acima do NA no início de sua fase de desenvolvimento. Com a sucessiva iniciação de rotas de condutos em ambiente freático e exposição destes acima do lençol, o produto final, numa análise simplificada e qualitativa, serão vários níveis de condutos freáticos pouco desenvolvidos, preservados acima do NA, em rebaixamento.

Associa-se a queda acelerada do nível de base e entalhamento profundo do relevo a um ambiente tectônico com altas taxas de soerguimento, ou, no caso de regiões próximas ao mar, à quedas eustáticas do nível dos oceanos.

\section{Rebaixamento lento do nível de base}

Taxas lentas de rebaixamento do nível de base refletem entalhamento vertical reduzido da topografia, o que induz baixos gradientes entre zonas de insurgência e ressurgência do aqüífero cárstico. Havendo condições mínimas de gradiente hidráulico ( 0,003, segundo Worthington, 1991) para iniciação da espeleogênese, haverá tempo suficiente para ampliação de condutos freáticos, antes que estes sofram exposição na zona vadosa. Nestas condições, geram-se sistemas freáticos de cavernas, com seções transversais de condutos freáticos com eixos maiores métricos a decamétricos com a gradativa 
exposição destes acima do NA e abertura contemporânea de rotas de condutos mais profundos, o.nível superior de condutos acaba sendo abandonado pelo lençol freático antes de soffer importante entalhamento vadoso. O produto final serão amplos condutos freáticos com reduzido entalhamento vadoso na base.

Um exemplo desta situação espeleogenética são os amplos condutos freáticos preservados nos calcários proterozóicos de cobertura cratônica (Grupos Bambuí e Una) do Brasil Central, os quais sofreram carstificação com taxas de sorguimento tectônico lento durante o Cenozóico (Braun, 1971).

\section{Taxas moderadas de rebaixamento do nível de base}

É a situação intermediária entre o rebaixamento lento e o muito rápido do nível de base relativo ao aquífero cárstico. $O$ entalhamento vertical da topografia é expressivo, relativamente menos intenso que no rebaixamento rápido, gerando gradientes hidráulicos moderados, entre a insurgência e ressurgência de sistemas cársticos, onde se desenvolvem condutos freáticos. Mas, o rebaixamento do lençol freático não chega a abandonar totalmente o nivel de condutos em ampliação, ou seja, a ampliação da rota inferior de condutos não é suficiente, para absorver o fluxo de água dos condutos anteriores, e ao mesmo tempo, o rebaixamento do NA não é rápido o suficiente, para abandonar o nível superior de condutos. Ocorre, portanto, uma fase de equilíbrio entre o rebaixamento do NA e o entalhamento vadoso de condutos freáticos. Neste caso, a morfologia resultante é de condutos freáticos de médio a pequeno porte, os quais apresentam sua base entrincheirada por entalhamentos vadosos, característica típica dos sistemas de cavernas da área estudada, conforme descrito anteriormente.

Baseado nestas três situações hipotéticas analisadas acima, interpreta-se portanto, em função da morfologia subterrânea observada, que a espeleogênese na região estudada, ocorreu num regime de rebaixamento do nível de base com taxas moderadas.

\subsection{Cronologia da evolução de condutos}

\subsubsection{Introdução}

Uma das questões críticas no estudo da espelogênese, refere-se às idades de condutos de dissolução e ao tempo envolvido na evolução de aqüiferos cársticos.

Por se tratar de um ambiente dominantemente erosivo, a idade de condutos subterrâneos e da paisagem cárstica superficial, como de qualquer outra feição de relevo, somente é possível de ser estimada, através de métodos indiretos ou correlativos, obtendose idades máximas ou mínimas.

Estudos teóricos da cinética de dissolução do carbonato de cálcio, associados à ensaios de laboratório, envolvendo a simulação de condições reais de dissolução de rochas carbonáticas, como os trabalhos desenvolvidos por Palmer (1984 e 1991); White (1977 e 1984), Dreybrodt (1981a, 1987, 1988 e 1990), produziram equações, as quais demonstram, que sob condições favoráveis, a fase de iniciação da espeleogênese requer no mínimo cerca 
de 10.000 anos. Ford (1980 e 1988), em concordância com White (1984) estabeleceram taxas de desenvolvimento longitudinal (propagação horizontal) de sistemas de protocavernas entre $10^{4}$ e $10^{5}$ anos $/ \mathrm{km}$, com base em estudos cinéticos de laboratório (White, op cit) e de cavernas pós-glaciais, em regiões peri-glaciais (Ford, op. cit).

Mylroie e Carew (1986) obtiveram um periodo máximo de 36.000 anos para o desenvolvimento de um sistema amplo de cavernas, encaixado em calcarenitos eólicos, próximos ao nível do mar, nas ilhas Bahamas. Neste período, sugerem que a ampliação de condutos freáticos com diâmentro de $1 \mathrm{~m}$ ocorreu em cerca de 10.000 anos.

Enquanto a duração da fase de iniciação é bastante especulativa e apoiada fortemente em modelos teóricos de denudação química de rochas carbonáticas, idades relacionadas à fase de desenvolvimento, especialmente ao entalhamento vadoso, são possíveis de serem obtidas, através da geocronologia de calcita secundária depositada no ambiente subterrâneo (Harmon, et. al., 1975, Gascoyne, Schwarcz e Ford, 19.78 e Schwarcz e Blackwell, 1985).

Gascoyne et. al. (1983), com base em idades obtidas através da série de desequilíbrio do urânio e paleomagnetismo em espeleotemas, estabeleceram a evolução cronológica da caverna Castleguard, nas Montanhas Rochosas canadenses. Em função da presença de espeleotemas magneticamente reversos, concluíram que parte da caverna estava sofrendo entalhamento vadoso entre $10^{6}$ e 700.000 anos, e que a maioria dos condutos freáticos iniciaram a ser entalhados por fluxos vadosos há 350.000 anos.

O sistema de cavernas Flint Ridge - Mammoth (Kentucky, EUA), um dos mais longos atualmente conhecidos, foi datado através de correlações geomorfológicas (Miotke e Palmer, 1972), determinações radiométricas de espeleotemas (Hess e Harmon, 1981) e paleomagnetismo de sedimentos finos detríticos (Schmidt, 1982). Estes autores concluíram, que desde a última fase magnética reversa ( 730.000 anos), três níveis superpostos de condutos foram gerados, com condutos freáticos de até $10 \mathrm{~m}$ de diâmetro em cada nível. $\mathrm{O}$ nível superior possui entre 700.000 e 350.000 anos, e o intermediário entre 220 e 180 mil anos.

Utilizando idades radiométricas ${ }^{230} \mathrm{Th} /{ }^{234} \mathrm{U}$ de calcita secundária, Gascoyne (1981) determinou taxas de entalhamento fluvial subterrâneo em quatro cavernas do norte da Inglaterra. Obteve valores entre 0,002 e $0,008 \mathrm{~cm} / \mathrm{ano}$, os quais correlacionou ao rebaixamento de vales fluviais externos. Goede e Harmon (1983), com método semelhante ao de Gascoyne, obtiveram taxas entre 0.0106 e $0.0212 \mathrm{~cm} /$ ano para o entalhamento vertical de rios subterrâneos da Tasmânia.

\subsubsection{Taxas de entalhamento subterrâneo e a idade do sistema cárstico estudado}

Com o objetivo de obter uma estimativa quantitativa da taxa de entalhamento fluvial subterrâneo do carste do Alto Ribeira, aplicou-se o método ${ }^{230} \mathrm{Th} / 234 \mathrm{U}$, da série de desequilíbrio do urânio, para datar depósitos de calcita secundária das cavernas estudadas.

Para abordar esta questão, os pontos ideais para amostragem, correspondem às bases de depósitos calcíticos (escorrimentos calcíticos ou bases de estalagmites), os quais 
cobrem depósitos fluviais. A datação destes pontos, fornece idades mínimas para a posição do nível do rio na época de deposição do sedimento fluvial. Havendo situações deste tipo em diferentes alturas ao longo de um canyon subterrâneo, estas permitem a obtenção de idades mínimas do processo de entalhamento subterrâneo, numa interpretação análoga à de terraços fluviais, em sistemas de drenagem superficiais (Ford, 1973).

Durante o mapeamento das cavernas investigadas, encontraram-se diversos pontos com as características acima descritas. Realizou-se uma primeira etapa de amostragem, para testar a aplicabilidade do método ${ }^{230} \mathrm{Th} / 234 \mathrm{U}$ em espeleotemas da área.

A amostragem seguiu a norma ética de coleta em cavernas, evitando a depredação dos espeleotemas amostrados. Sempre que possível, selecionaram-se pontos pouco notáveis ao visitante, não afetando o aspecto visual da formação. A maioria dos escorrimentos calcíticos e estalagmites foram amostrados com uma sonda portátil, com a qual, extraiu-se testemunhos de zonas mais internas. Os pontos de perfuração foram fotografados e posteriormente selados, restaurando-se a superficie do espeléotema.

\subsubsection{Localização e descrição dos pontos amostrados}

$\mathrm{Na}$ caverna Pescaria encontrou-se uma situação ideal de testemunhos fluviais cobertos por depósitos calcíticos. Esta caverna localiza-se a cerca de $20 \mathrm{~km}$ ao norte da área detalhada neste trabalho, inserindo-se nas mesmas características fisiográficas gerais esboçadas para a área de estudo. Representa a ressurgência de uma bacia de captação alogênica, com cerca da metade da vazão do sistema Pérolas-Santana.

Os pontos amostrados nesta caverna são uma série de escorrimentos calcíticos, em forma de cones, os quais possuem um nivel de cascalho fluvial incrustado em sua base (fig 4.30 e foto 4.1 ). Localizam-se em torno de $300 \mathrm{~m}$ da entrada da caverna. Este tipo de estrutura, popularmente denominado de "pata de elefante", representa uma estalagmite com base mais larga em relação à altura. Com o crescimento vertical, acabou sendo soldada ao teto ou parede lateral do conduto, próximo às margens do leito fluvial subterrâneo.

Através do rebaixamento do canal fluvial, com o tempo, estes cones calcíticos acabaram sendo suspensos, sendo que suas bases, marcam a cota, em que se encontrava 0 nível de deposição do cascalho pelo rio subterrâneo, o que corresponde ao nível de base local do rio, nesta época. A base destes cones deverá fornecer, portanto, a idade mínima de deposição do cascalho, pois a precipitação de calcita sobre o depósito fluvial, pode ter sido iniciada num intervalo de tempo incógnito após a deposição do cascalho e abandono deste pelo fluxo do rio

Na caverna Pescaria teve-se acesso para amostragem aproximadamente central da base de três destes cones (amostras P1, P2 e P3). As alturas entre estes pontos e o leito atual do rio subterranêo foram medidas com trena, obtendo-se, respectivamente $5,8,4,6 \mathrm{e}$ $2,6 \mathrm{~m}$. A espessura atual de cascalho sobre a base rochosa do entalhamento vadoso varia entre alguns centímetros a $40 \mathrm{~cm}$. 


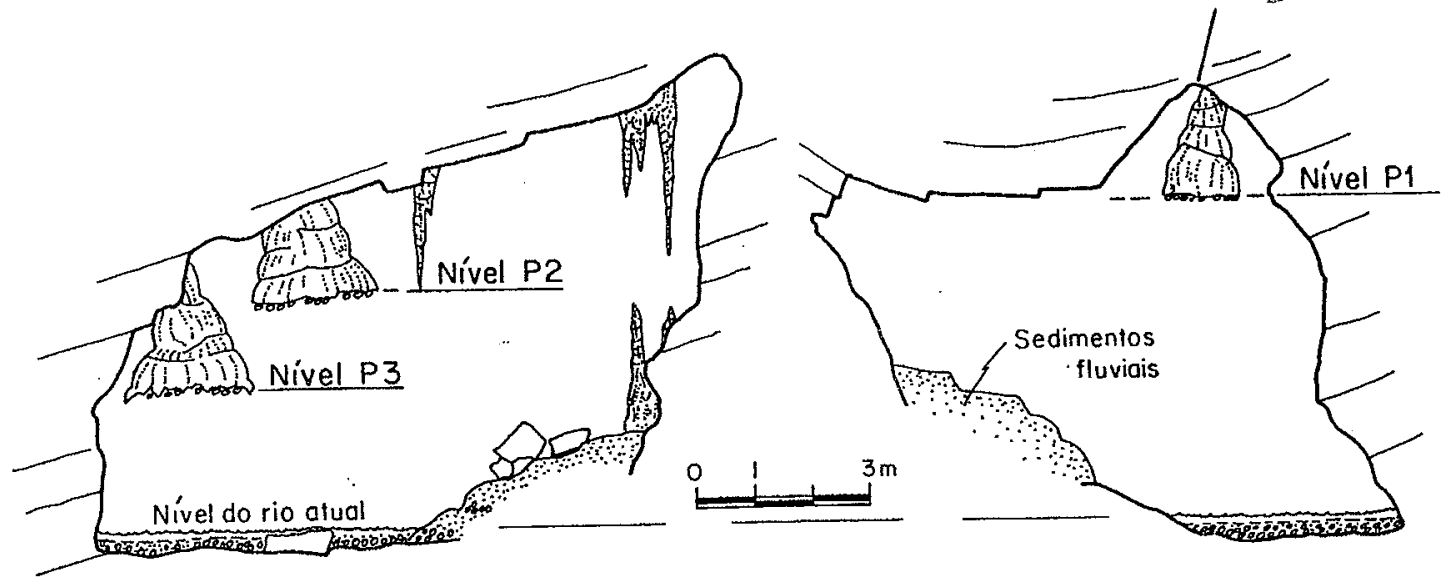

Figura 4.30 - Seções transversais da caverna Pescaria indicando os pontos amostrados para geocronologia de calcita secundária.

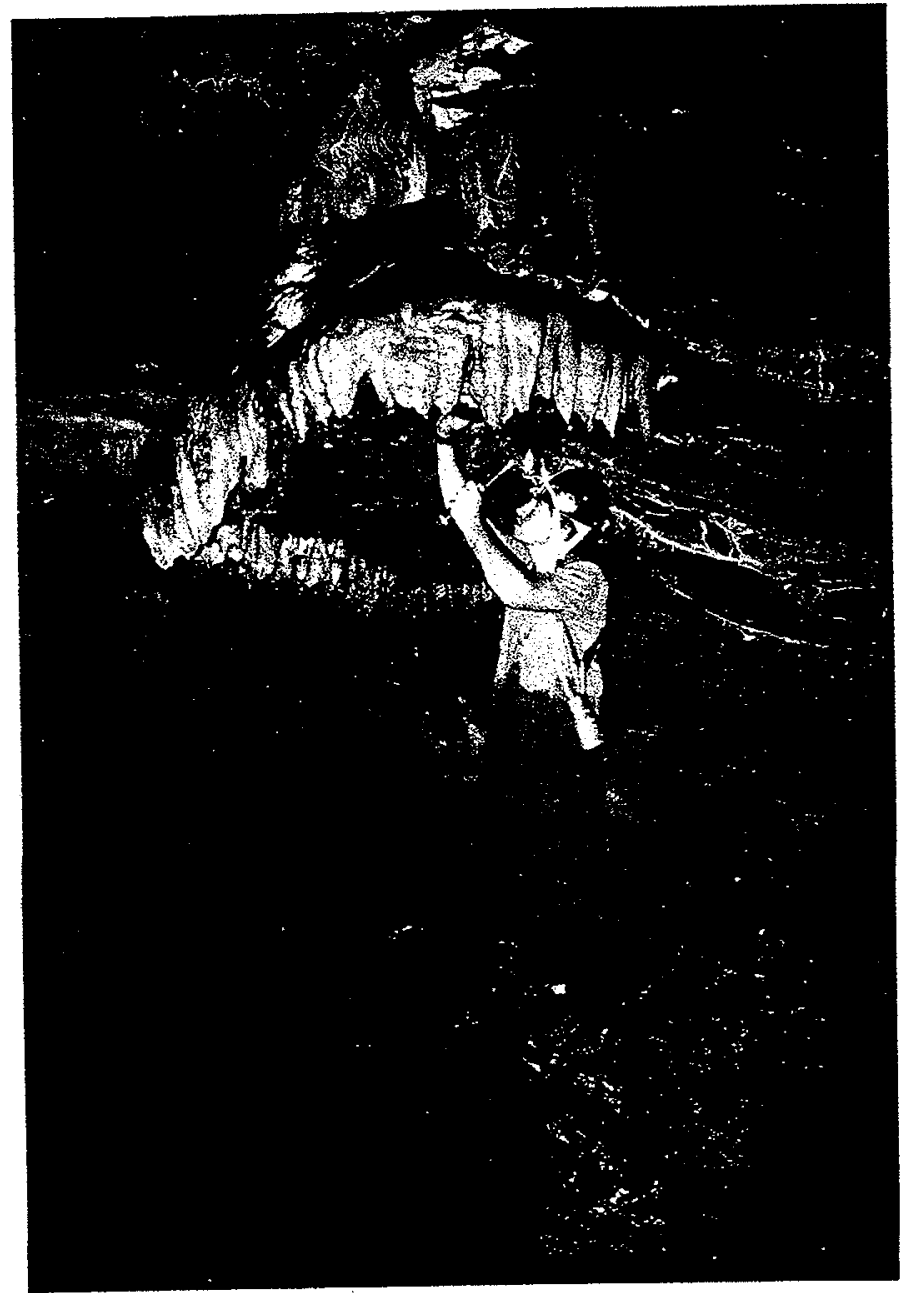

Foto 4.1 - Espeleotema tipo "pata de elefante", ponto P3 da caverna Pescaria. 
Na caverna Santana, amostrou-se o conduto do rio atual e a galeria superior de acesso ao salão São Paulo, interpretada neste trabalho, como sendo um paleo-aflpente do rio principal (fig 4.6).

A amostra $\mathrm{Cl}$ foi obtida na lateral da base de um espeleotema tipo pata de elefante (foto 4.2, fig 4.31), localizado a cerca de $200 \mathrm{~m}$ da entrada da caverna Santana, na margem direita do rio. A base da deposição de calcita sobre cascalho soldado na parte inferior do cone, encontra-se a $1,20 \mathrm{~m}$ de altura em relação ao leito rochoso atual do rio subterrâneo.

$\mathrm{Na}$ galeria de acesso ao salão São Paulo, encontrou-se um bloco abatido de escorrimento calcítico cobrindo seixos fluviais, cuja posição original foi relacionada a um testemunho de cascalheira preservado numa reentrância da parede lateral do conduto (fig 4.32). Devido à dificuldade de acesso deste ponto na parede lateral, amostrou-se a calcita no bloco abatido (amostra C2) imediatamente acima da linha de seixos soldados na base do escorrimento calcítico (foto 4.3), hoje em posição invertida. O desnível entre o topo do testemunho de cascalheira e o antigo leito do canal fluvial, na base do conduto, é de $8 \mathrm{~m}$, com um erro estimado em até $1 \mathrm{~m}$, em função da cobertura parcial da rocha por concrecionamentos calcíticos.

Para obter uma noção da idade de espeleotemas grandes, amostrou-se a parte mais antiga de uma estalactite composta (várias estalactites soldadas entre sí), com cerca de $4 \mathrm{~m}$ de comprimento e $1,5 \mathrm{~m}$ de diâmetro maior (amostra $\mathrm{C5}$ ), localizada no caminho para o salão São Paulo.

Na caverna Alambarí de Baixo, cuja ressurgência se localiza na extremidade sudeste do bairro da Serra (anexo 4.3), ocorrem vários pontos favoráveis para amostragem de testemunhos do entalhamento subterrâneo. Para este trabalho preliminar, coletou-se um fragmento de crosta calcítica suspensa na parede lateral esquerda (sentido jusante), a cerca de $90 \mathrm{~m}$ da ressurgência (amostra $\mathrm{CA} 3$, figura 4.33, foto 4.4). Na parte inferior da crosta há seixos alóctones arredondados incrustrados, evidenciando que a calcita cobria uma cascalheira fluvial. $O$ desnível entre a base da crosta e o leito rochoso do rio atual é de $8,5 \mathrm{~m}$ (fig 4.33).

Na caverna Morro Preto, paleo-ressurgência do sistema de drenagem subterrânea Onça Parda - Morro Preto, afluente da margem esquerda do rio Betari, na borda SE da faixa carbonática Furnas-Santana (anexo 4.3), também se constatou pontos favoráveis para a geocronologia do rebaixamento do nível de base local. Selecionou-se um escorrimento calcítico que cobria um testemunho de cascalheira preservado na parede lateral esquerda (olhando para a entrada) do grande salão central de abatimento (fig 434) Através de sondagem extraiu-se uma amostra de calcita logo acima do cascalho (amostra C11). A altura deste ponto em relação ao nível atual do rio subterrâneo é de $42 \mathrm{~m}$.

Por ultimo, investigou-se a caverna Chapéu, localizada no bairro Caboclos, a norte da área estudada. Representa uma pequena bacia de drenagem subterrânea, com área de captação sobre granitos. Com o objetivo de avaliar o potencial geocronológico de calcita secundária nesta área, coletou-se a extremidade inferior de uma estalactite inativa, em posição original de crescimento, com $40 \mathrm{~cm}$ de comprimento e 15 a $3 \mathrm{~cm}$ de diâmetro Sua 


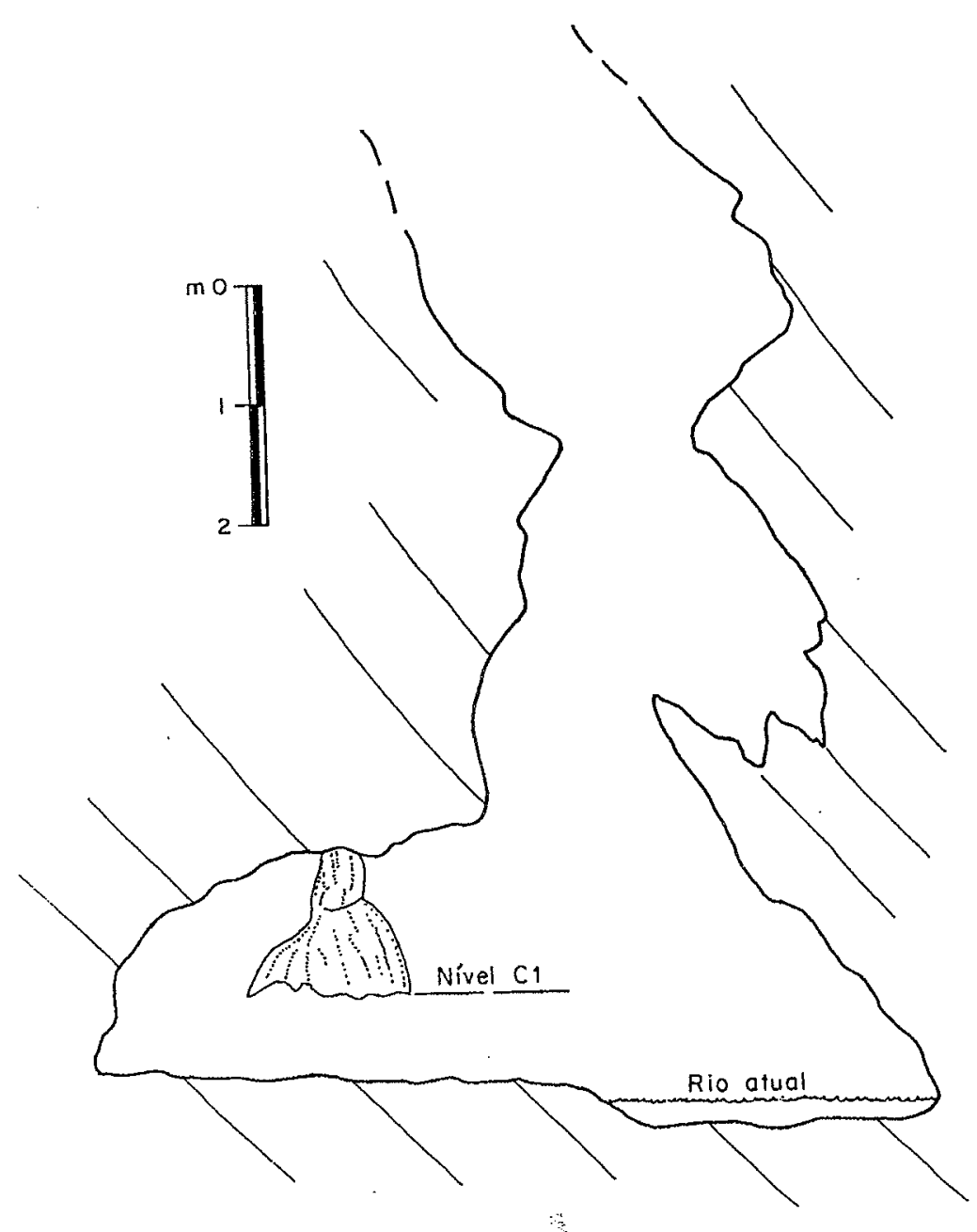

Figura 4.31 - Seção transversal à galeria do rio, junto ao ponto de amostragem $C 1$, na caverna Santana, cerca de $200 \mathrm{~m}$ da entrada.

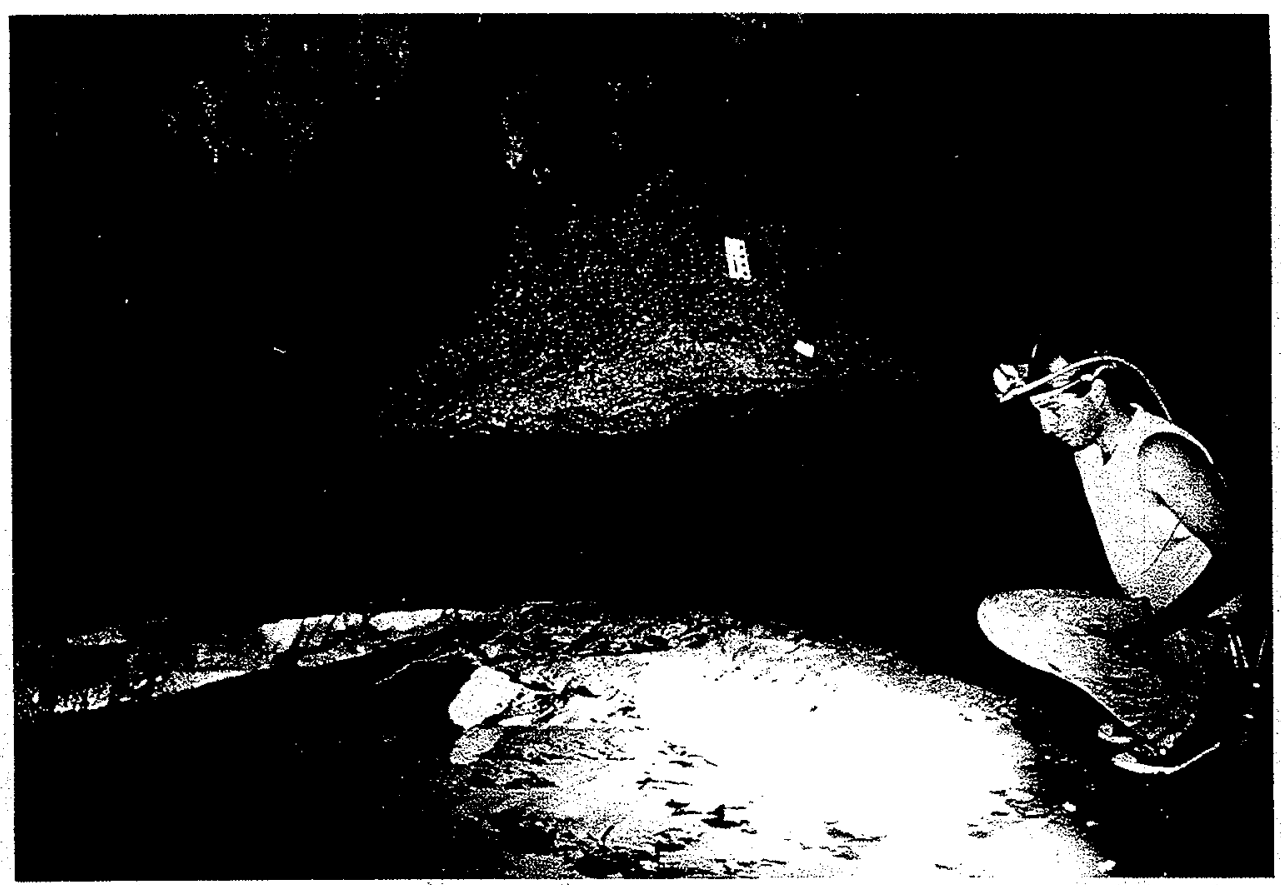

Foto 4.2 - Ponto de amostragem Cl, caverna Santana, local conhecido como Pata de Elefante 


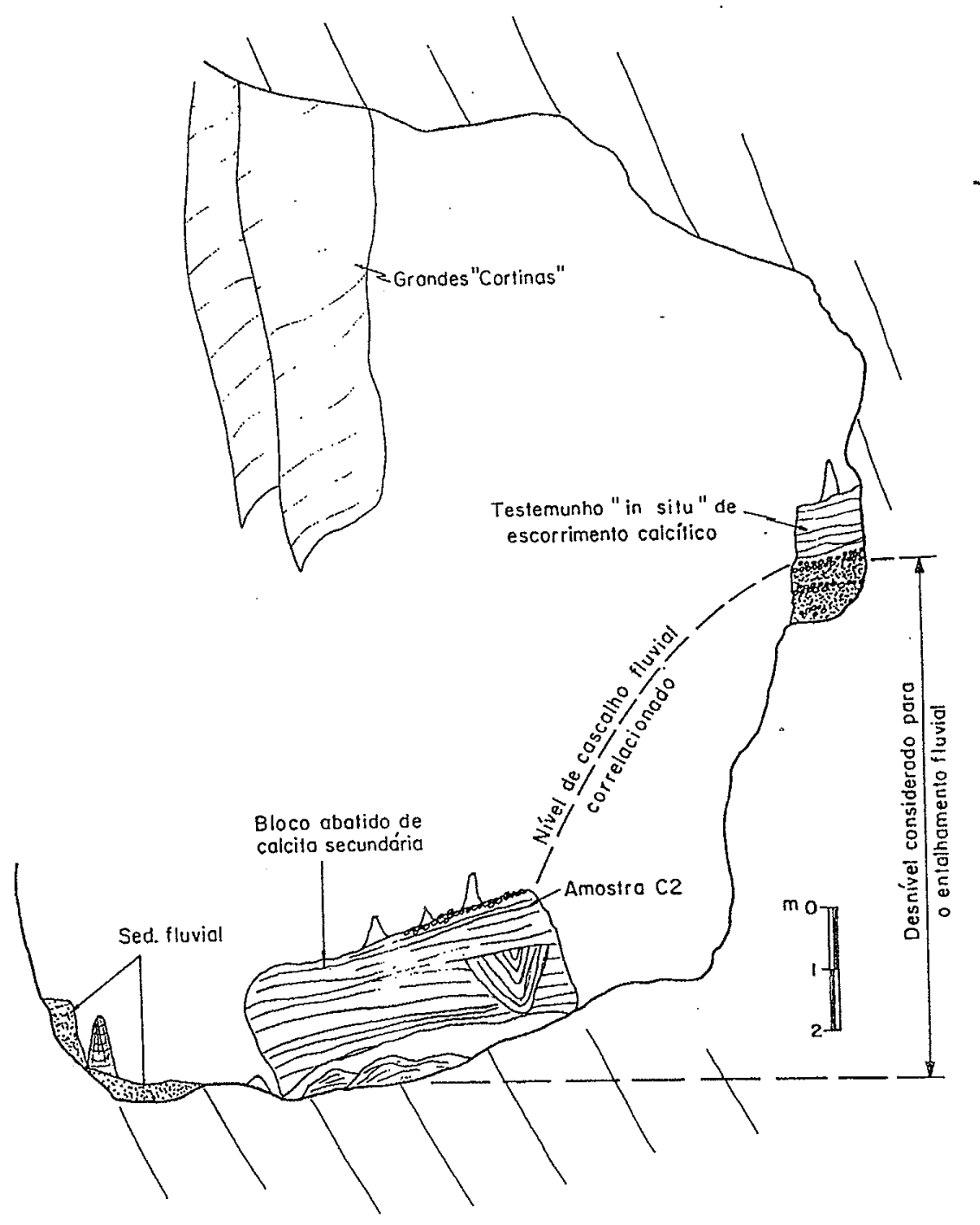

Figura 4.32 - Seção transversal mostrando a situação morfológica do ponto de amostragem C2, caverna Santana, entroncamento dos caminhos para o salão São Paulo e galeria dos "Vulcões".

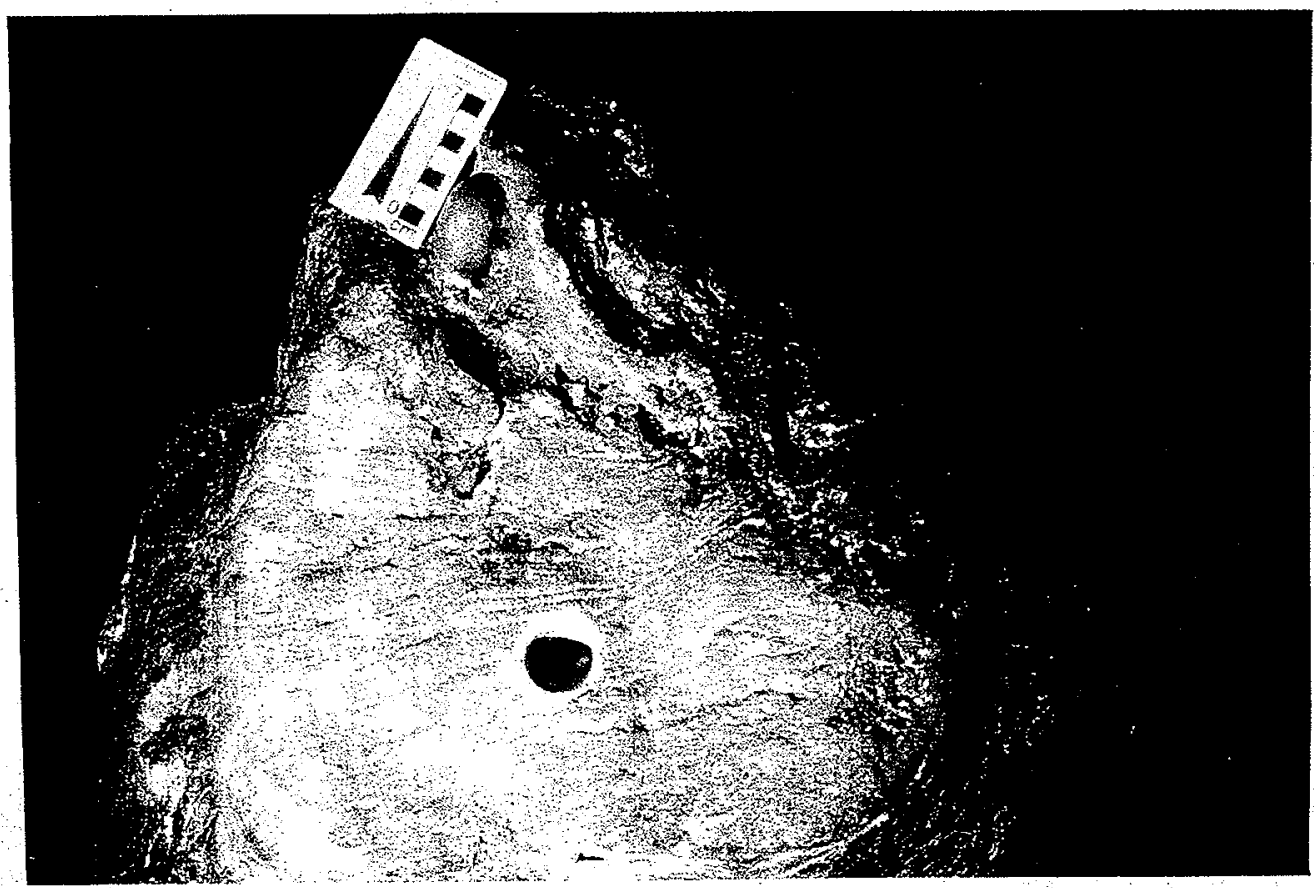

Foto 4.3-Bloco abatido de escorrimento calcítico de onde se extraiu a amostra C2. 


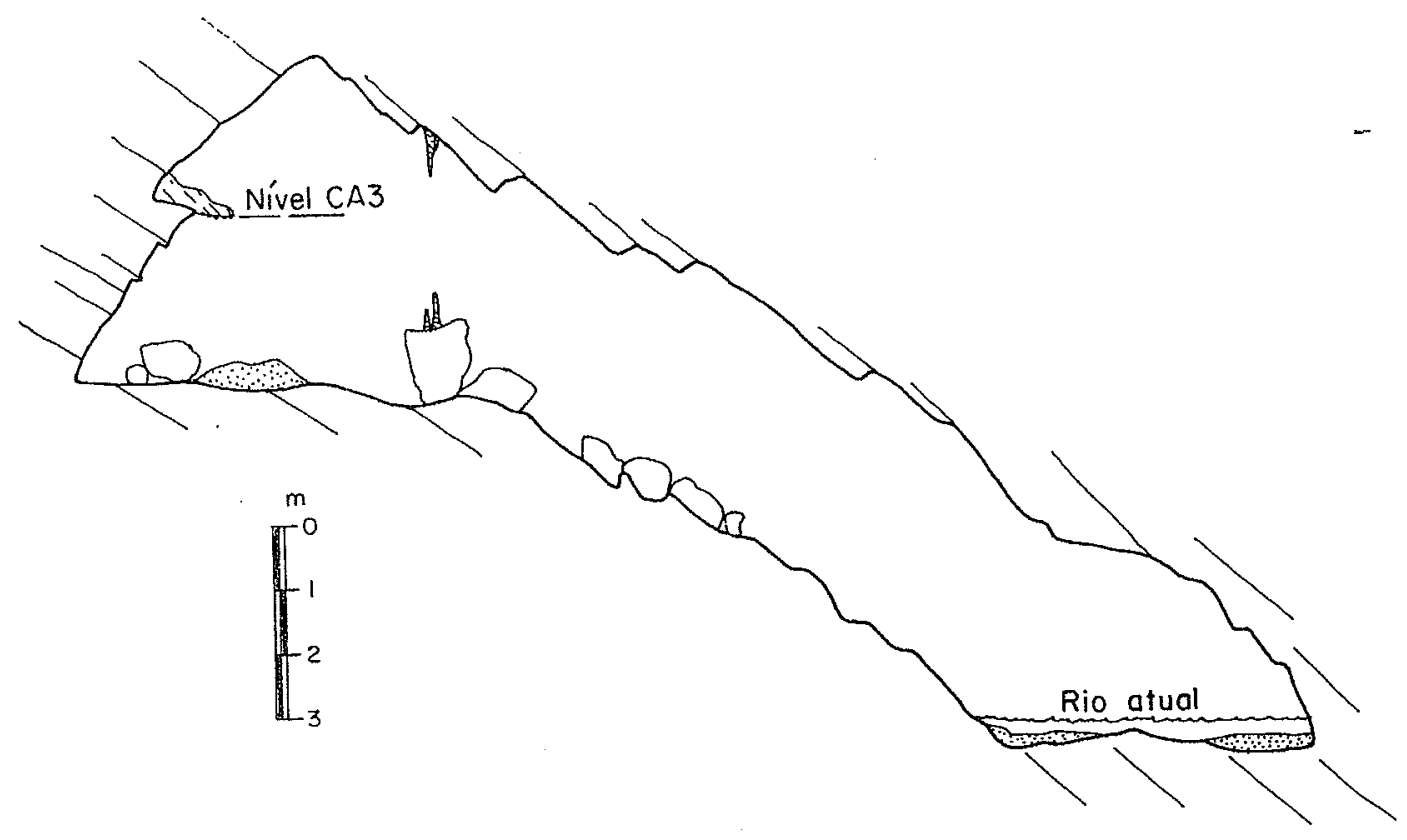

Figura 4.33 - Seção transversal no ponto de coleta CA3, caverna Alambari de Baixo.

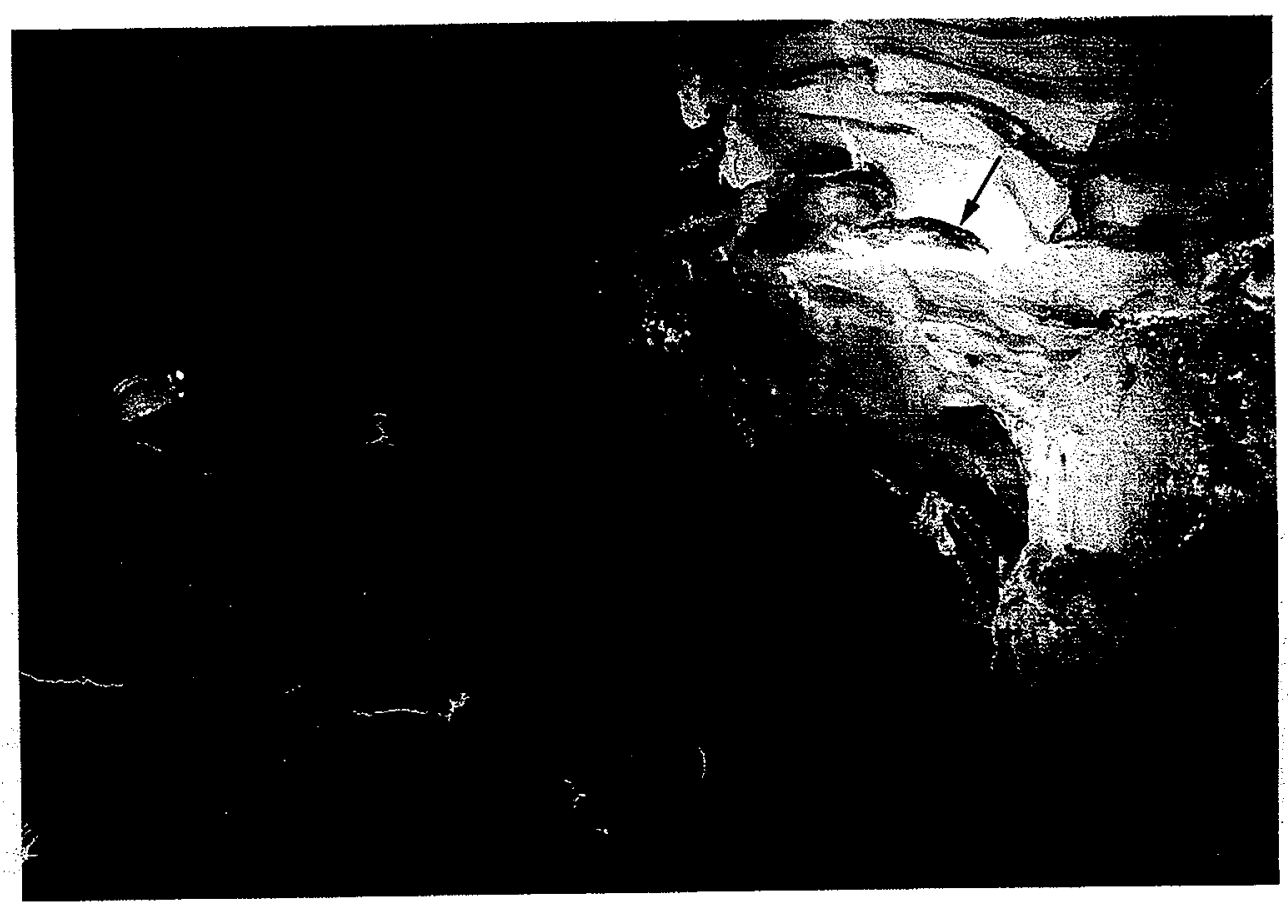

Foto 4.4 - Vista do escorrimento calcítico suspenso, ponto CA3, indicado pela seta, caverna Alambari de Baixo. 


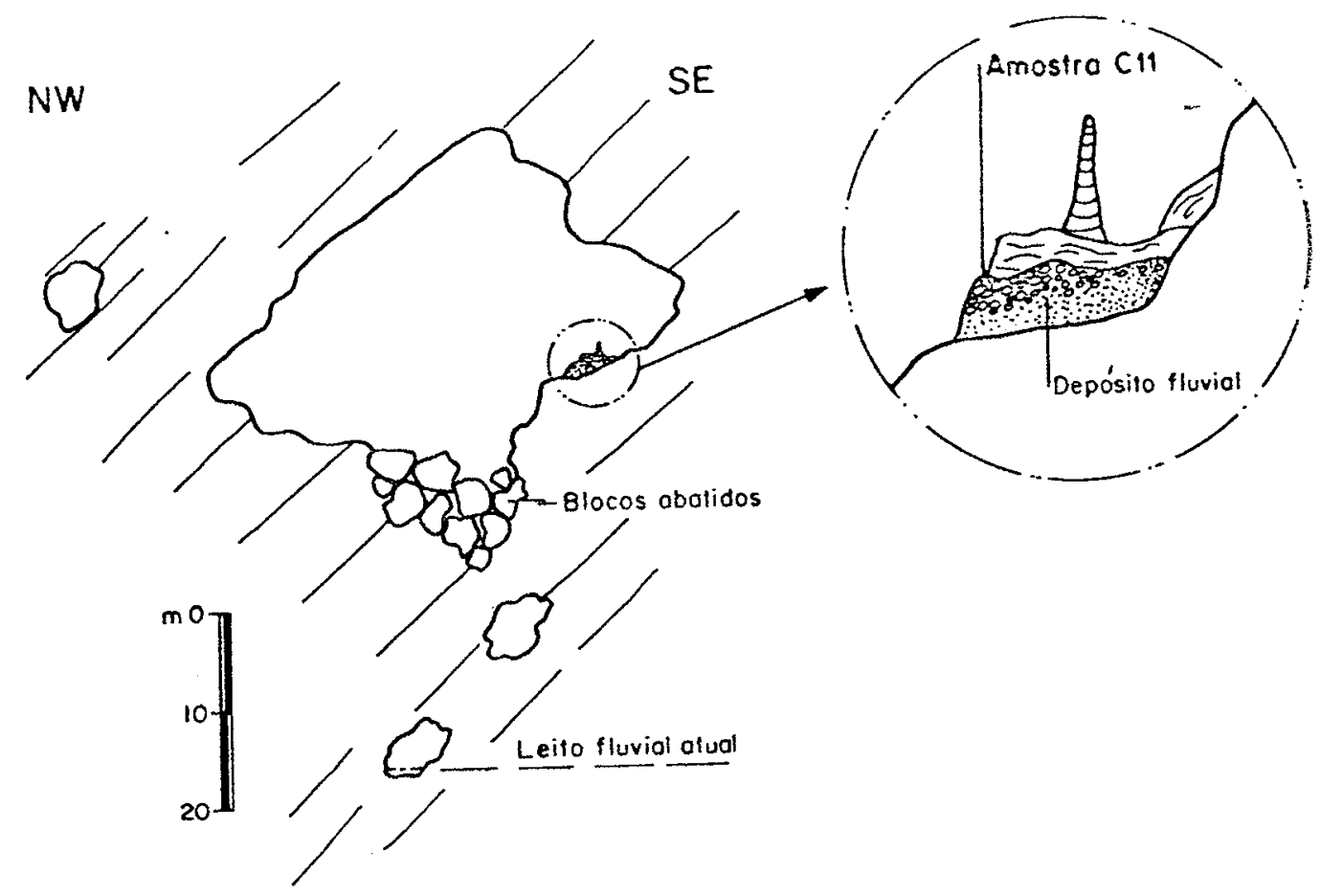

Figura 4.34 - Seção morfológica da caverna Morro Preto, junto ao ponto de coleta C11.

seção transversal é de uma elipse fortemente achatada. Possui linhas de crescimento aflorantes e marcas de entalhamento onduladas do tipo scallops. Estas características morfológicas são típicas de re-dissolução (erosão) desta estalactite por um fluxo dirigido de água agressiva (Gascoyne, et. al., 1983). O córrego subterrâneo está atualmente a 2,5m abaixo desta estalactite (em vazão normal), e o leito rochoso a cerca de $3 \mathrm{~m}$. A identificação da amostra é CC2.

Um fato interessante é que nas proximidades e na mesma altura desta estalactite erodida, ocorrem várias outras, sem marcas de erosão, ou seja, posteriores à erosão da primeira. Atribui-se a re-dissolução desta estalactite a um período de subida do nivel de base, fase esta, responsável também, pelo assoreamento da caverna com sedimentos arenosos fluviais a uma altura de no mínimo $6 \mathrm{~m}$ em relação ao nível atual do rio, conforme foi observado através de testemunhos deste preenchimento, distribuídos pela caverna.

A datação desta estalactite erodida, poderia fornecer portanto, uma idade mínima desta fase de nível de base alto, responsável pela sua erosão.

\subsubsection{Resultados obtidos}

Os resultados analíticos referentes ao método $\mathrm{Th} / \mathrm{U}$ das amostras coletadas estão resumidos na tabela 4.7. O método desenvolvido por Thompson (1974) e Gascoyne (1977) para extração de urânio e tório de espeleotemas foi utilizado, seguindo o procedimento de rotina utilizado no laboratório de geocronologia dos Departamentos de Geologia e Geografia da McMaster University, Hamilton, Canadá. As razōes isotópicas ${ }^{230} \mathrm{Th} /{ }^{234} \mathrm{U}$, ${ }^{234} \mathrm{U} / 238 \mathrm{U}$ e ${ }^{230} \mathrm{Th} / 232 \mathrm{Th}$ foram obtidas através da contagem de partículas alfa, por períodos entre 3 e 7 dias. 
Para avaliar a qualidade das idades $\mathrm{Th} / \mathrm{U}$ de espeleotemas, deve-se considerar os requisitos necessários para obtenção de resultados com precisão aceitável.

O primeiro requisito é a quantidade de urânio presente na amostra. Harmon et. al. (1975) estabeleceram que 0,03 ppm é a concentração mínima necessária para determinação de idades com precisão aceitável, através de contagem alfa. A amostra C5 da caverna Santana está próxima deste limite, o que é um dos fatores no incremento do erro de sua idade calculada. As demais amostras apresentaram teores de $U$ satisfatórios (tab 4.7).

O segundo requisito fundamental é a ausência de contaminação por tório detrítico. Este é freqüentemente incluído na calcita em crescimento através de fragmentos detríticos depositados por enchentes sobre espeleotemas em desenvolvimento na zona de oscilação do nível do rio. Para detectar a presença de ${ }^{230} \mathrm{Th}$ detrítico, utiliza-se o fato do tório detrítico sempre possuir uma fração de ${ }^{232} \mathrm{Th}$, o que não acontece com o tório radiogênico acumulado na calcita a partir do decaimento de ${ }^{234} \mathrm{U}$ e ${ }^{238} \mathrm{U}$. Devido a este comportamento geoquímico do tório, a razão ${ }^{230} \mathrm{Th} / 232 \mathrm{Th}$ é utilizada como um indice de contaminação (Gascoyne, 1980 apud Gascoyne, et. al., 1983). Quando esta razão for menor que 20, a idade calculada deve sofrer uma correção, assumindo razão inicial (tempo zero) de 1,5, para transformá-la na idade corrigida (Gascoyne, op cit).

\begin{tabular}{|c|c|c|c|c|c|c|c|}
\hline $\begin{array}{l}\text { Localização e } \\
\text { código de coleta }\end{array}$ & $\begin{array}{c}\mathrm{U} \\
\mathrm{ppm}\end{array}$ & ${ }^{230} \frac{\mathrm{Th}}{\mathrm{U}}$ & $\frac{{ }^{234} \mathrm{U}}{238 \mathrm{U}}$ & ${ }_{230}^{230 \mathrm{Th}}$ & $\begin{array}{c}\text { Idade } \\
\text { calculada } \\
\times 10^{3} \text { anos } \\
\end{array}$ & $\begin{array}{c}\text { Idade } \\
\text { corrigida } \\
\times 10^{3} \text { anos }\end{array}$ & $\begin{array}{l}\text { Descrição da } \\
\text { amostra }\end{array}$ \\
\hline $\begin{array}{l}\text { Caverna } \\
\text { Pescaria } \\
\text { P1 }\end{array}$ & 0,304 & $\begin{array}{c}0,935 \\
\pm \\
0,47\end{array}$ & $\begin{array}{c}1,1 \\
\pm \\
0,046\end{array}$ & $\begin{array}{c}3.0 \\
\pm \\
0.14\end{array}$ & $\begin{array}{c}+69,6 \\
262,7 \\
-43,0\end{array}$ & $\begin{array}{c}+77,4 \\
200,8(38 \%)^{*} \\
-50,2\end{array}$ & $\begin{array}{l}\text { Calcita de granu- } \\
\text { lação grossa, mar- } \\
\text { rom claro, laminada }\end{array}$ \\
\hline $\begin{array}{c}\text { Caverna } \\
\text { Pescaria } \\
\text { P2 }\end{array}$ & 0,306 & $\begin{array}{c}0,582 \\
\pm \\
0,026\end{array}$ & $\begin{array}{c}1,4 \\
\pm \\
0,033\end{array}$ & $\begin{array}{c}16,3 \\
\pm \\
2\end{array}$ & $\begin{array}{c}+6,2 \\
90,2 \\
-5,9\end{array}$ & $\begin{array}{c}+6,9 \\
84,7(8 \%) \\
-6,6\end{array}$ & Idem a anterior \\
\hline $\begin{array}{c}\text { Caverna } \\
\text { Santana } \\
\text { (Pata do elefante) } \\
\text { Cl } \\
\end{array}$ & 0,06 & $\begin{array}{c}0,651 \\
\pm \\
\pm, 087\end{array}$ & $\begin{array}{c}1,3 \\
\pm \\
0,187\end{array}$ & $\begin{array}{c}1,32 \\
\pm \\
0,81\end{array}$ & $\begin{array}{c}+25,7 \\
107,2 \\
-21,2\end{array}$ & $\begin{array}{c}+6,6 \\
33,1 \\
-10,7\end{array}$ & $\begin{array}{l}\text { Calcita granuląąão } \\
\text { média a fina mar- } \\
\text { rome escuro, lâninas } \\
\text { siltosas }\end{array}$ \\
\hline $\begin{array}{c}\text { Caverna } \\
\text { Santana } \\
\text { Gal. de acesso Salão São } \\
\text { Paulo } \\
\text { C2 }\end{array}$ & 0,085 & $\begin{array}{c}0,913 \\
\pm \\
0,085\end{array}$ & $\begin{array}{c}1,12 \\
\pm \\
0,11\end{array}$ & $\begin{array}{c}48.5 \\
\pm \\
31\end{array}$ & $\begin{array}{c}+121,3 \\
238,2(50 \%) \\
-57,9\end{array}$ & - & $\begin{array}{l}\text { Calcita granulação } \\
\text { média, branco ama- } \\
\text { relada, finamente la- } \\
\text { minada }\end{array}$ \\
\hline $\begin{array}{c}\text { Caverna } \\
\text { Santana } \\
\text { (Salão São Paulo) } \\
\text { C5 } \\
\end{array}$ & 0,04 & $\begin{array}{c}0,716 \\
\pm \\
0,128\end{array}$ & $\begin{array}{c}1,586 \\
\pm \\
0,286\end{array}$ & $\begin{array}{c}23,3 \\
\pm \\
15,6\end{array}$ & $\begin{array}{c}+44,2 \\
122,6 \\
-32,7\end{array}$ & $\begin{array}{c}+47,6 \\
118,3(39 \%) \\
-36,3\end{array}$ & $\begin{array}{l}\text { Granulação grossa a } \\
\text { fina, maciça, marrom } \\
\text { claro a branca }\end{array}$ \\
\hline $\begin{array}{c}\text { Caverna } \\
\text { Chapéu } \\
\text { CC2 }\end{array}$ & 1,374 & $\begin{array}{c}0,808 \\
\pm \\
0,27 \\
\end{array}$ & $\begin{array}{c}2,436 \\
\pm \\
0,031 \\
\end{array}$ & $\begin{array}{c}211,2 \\
\pm \\
27,6 \\
\end{array}$ & $\begin{array}{c}+8,7 \\
142,7 \\
-8,2 \\
\end{array}$ & - & $\begin{array}{c}\text { Granulação fina } \\
\text { branca }\end{array}$ \\
\hline $\begin{array}{c}\text { Caverna } \\
\text { Alambarí de Baixo } \\
\text { CA3 }\end{array}$ & 0,092 & $\begin{array}{c}0,863 \\
\pm \\
0,079 \\
\end{array}$ & $\begin{array}{c}1,555 \\
\pm \\
0,158 \\
\end{array}$ & $\begin{array}{c}11,6 \\
\pm \\
2,1 \\
\end{array}$ & $\begin{array}{c}+41,3 \\
175,8 \\
-31,1 \\
\end{array}$ & $\begin{array}{c}+43,7 \\
165,5(26 \%) \\
-33,8 \\
\end{array}$ & $\begin{array}{l}\text { Granulaçăo media a } \\
\text { fina, marrom claro; } \\
\text { bandada }\end{array}$ \\
\hline $\begin{array}{c}\text { Caverna } \\
\text { Morro Preto } \\
\text { C11 }\end{array}$ & 0,07 & $\begin{array}{c}1,148 \\
\pm \\
0,144\end{array}$ & $\begin{array}{c}1,576 \\
\pm \\
0,208\end{array}$ & $\begin{array}{c}35 \\
\pm \\
16,6\end{array}$ & $>350,0$ & - & $\begin{array}{l}\text { Granulaçäo grossa } \\
\text { marrom escuro ma- } \\
\text { cica }\end{array}$ \\
\hline
\end{tabular}

Tabela 4.7. Resultados das análises de dataçâo $T h / \mathrm{U}$, realizadas no laboratório de geocronologia dos Departamentos de Geografia e Geologia da McMaster University, Hamilton, Canada ( ${ }^{*}$ Porcentagem de erro indicada entre parênteses. 
Nas amostras analisadas (tab 4.7), o índice de contaminação com tório detrítico, de modo geral é alto, forçando a obtenção de idades corrigidas, o que as torna imprecisas. A contaminação destas amostras já era prevista, em função da coloração marrom da calcita, presença freqüente de pequenas palhetas de mica, dificilmente visíveis a olho nú, e argilominerais, notados através do resíduo insolúvel formado após a dissolução das amostras durante a extração do U e Th. Somente as amostras C2 e CC2 apresentaram ausência de contaminação, refletida também, pela sua coloração branca.

Por se tratar de calcita depositada sobre depósitos fluviais, sob influência de enchentes esporádicas no início de seu crescimento, o problema da contaminação sempre será enfrentado nestas amostras. Pretende-se aprimorar no futuro, as datações preliminares obtidas nesta fase, aplicando a técnica recentemente desenvolvida e testada, conforme Przybylowicz, Schwarcz e Latham (1991), para a datação Th/U de calcita contaminada com tório detrítico.

O terceiro pré-requisito é a conservação de um sistema fechado para migração ou adição de nuclídeos após a precipitação da calcita. Deve-se selecionar amostras que não apresentam evidências de lixiviação ou re-dissolução interna. Calcita friável ou com poros internos e canalículos de dissolução devem ser descartadas, pois nestas, a lixiviação de $U$ e Th, ou até a adição destes, pode ter ocorrida. Pelo fato do U sofrer lixiviação preferencial em relação ao Th, modificações pós-deposicionais da composição isotópica da calcita são avaliadas por razões ${ }^{230} \mathrm{Th} /{ }^{234} \mathrm{U}$ anômalas, significativamente maiores que 1.0 (Gascoyne, Schwarcz e Ford, 1978).

Durante a coleta de amostras, foram selecionados pontos sem características visíveis de lixiviação. As razões ${ }^{230} \mathrm{Th} / 234 \mathrm{U}$ obtidas (tab 4.7) confirmam que este pré-requisito foi cumprido, com exceção da amostra $\mathrm{C} 11$, que pode ter sofrido uma leve mobilização de urânio (razão ${ }^{230} \mathrm{Th} /{ }^{234} \mathrm{U}$ maior que 1), o que torna sua idade superestimada.

Considerando os aspectos acima apresentados, as datações mais confiáveis foram obtidas com as amostras C2 e CC2 (tab 4.7), pois apresentam indices de contaminação maiores que 20, por outro lado, a amostra C2 apresenta uma grande margem de erro (cerca de $50 \%$ ) induzida pela imprecisão da razão ${ }^{230} \mathrm{Th} / 232 \mathrm{Th}$, o que a torna pouco significativa.

Entre as demais análises, as amostras $\mathrm{P} 2, \mathrm{C} 5, \mathrm{CA} 3$ e $\mathrm{C} 11$, apresentaram resultados aceitáveis, com consideráveis margens de erro (entre 8 e 39\%), em função das razões de contaminação entre 10 e 20. A amostra C11, devido ao excesso de tório, ultrapassou o limite de datação pelo método $\mathrm{Th} / \mathrm{U}$ com contagem alfa.

As idades obtidas com as amostras P1 e C1, são pouco confiáveis, e provavelmente superestimadas, devido à alta contaminação com tório detrítico.

Os resultados geocronológicos de espeleotemas obtidos neste trabalho possuem um caráter preliminar, confirmando um grande potencial deste tipo de análise para contribuir na quantificação das taxas de evolução do sistema cárstico do Alto Ribeira.

Para tornar estes resultados mais representativos para a região, existe a necessidade de trabalhos específicos de geocronologia de calcita secundária de cavernas, inclusive com a utilização de espectrométria de massa (ao invés da contagem alfa), com o objetivo de 
aumentar a precisão nas determinações de razões isotópicas de $T$ h e $U$, o que não foi possivel realizar neste trabalho. Pretende-se aplicar esta técnica em etapas futuras de pesquisa.

\section{Taxas de entalhamento fluvial subterrâneo}

A altura entre a base de escorrimentos calcíticos ou estalagmites (cobrindo depósitos fluviais) e o leito rochoso do rio subterrâneo, dividida pela idade basal destes espeleotemas, fornece a taxa de erosão ou de entalhamento vertical deste rio.

$\mathrm{Na}$ tabela 4.8 apresenta-se as taxas máximas de entalhamento vertical calculadas para as cavernas amostradas. As taxas são máximas, pois as idades basais obtidas para as alturas dos depósitos fluviais são mínimas.

Plotando as idades contra suas alturas relativas ao leito do rio, obteve-se o gráfico da figura 4.35. A inclinação dos alinhamentos destes pontos representa as taxas de entalhamento. Obteve-se dois alinhamentos extremos. $\mathrm{O}$ primeiro segue os pontos $\mathrm{C} 1, \mathrm{P} 2$ e CA3. Neste alinhamento, a amostra $\mathrm{Cl}$, apesar da pequena margem de erro, é pouco confiável, conforme comentado acima. Já as idades $\mathrm{P} 2$ e CA3 são bastante aceitáveis. A inclinação do alinhamento destes 3 pontos forneceu uma taxa de entalhamento fluvial de $0,005 \mathrm{~cm} /$ ano, o que representa também, o valor médio superior $(0,0052 \mathrm{~cm} /$ ano $)$ das taxas de entalhamento obtidas (tab 4.8). A envoltória inferior, considerando os pontos $\mathrm{P} 1, \mathrm{C} 2$ e a idade máxima do ponto $\mathrm{C} 1$, fornece uma taxa de $0,0029 \mathrm{~cm} /$ ano, valor um pouco abaixo da média das taxas de entalhamento mínimas obtidas $(0,0032 \mathrm{~cm} / \mathrm{ano})$. Neste caso, as amostras P1 e C2, além de uma grande margem de erro, provavelmente são exageradas, o que torna a taxa de entalhamento desta reta subestimada.

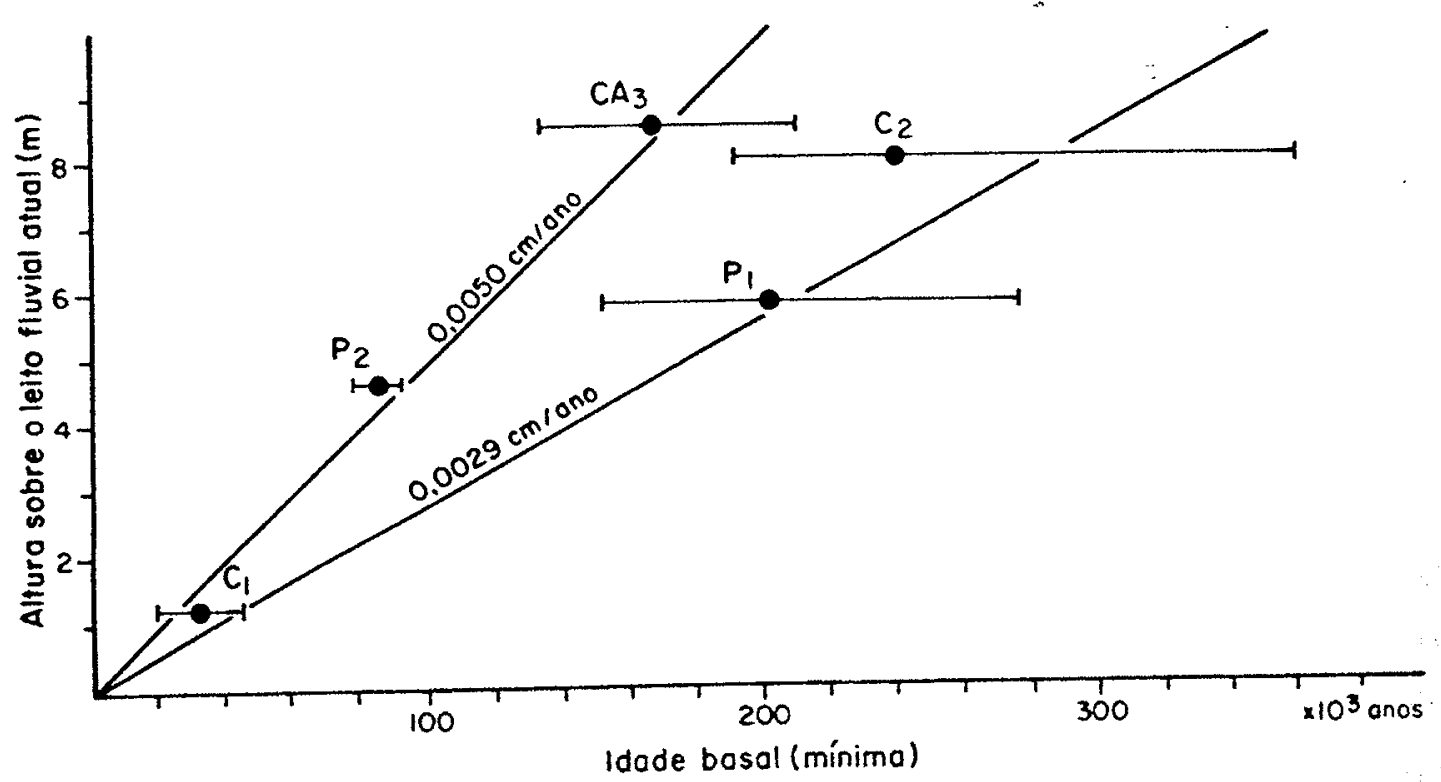

Figura 4.35 - Altura sobre o leito fluvial atual versus a idade das amostras datadas, com indicação das barras de erro $A$ inclinação das retas ajustadas fornece as taxas de entalhamento fluvial para as cavernas estudadas. 


\begin{tabular}{|c|c|c|c|}
\hline Amostra & $\begin{array}{c}\text { Altura sobre o leito } \\
\text { fluvial rochoso } \\
\text { (metros) }\end{array}$ & $\begin{array}{l}\text { Idade mínima } \\
\text { (X 10 }{ }^{3} \text { anos) }\end{array}$ & $\begin{array}{c}\text { Taxa de entalhamento } \\
\text { vertical máxima } \\
\text { (cm / ano) }\end{array}$ \\
\hline $\begin{array}{c}\text { P1 } \\
\text { Caverna Pescaria }\end{array}$ & 5,8 & $\begin{array}{c}200,8^{+77,4} \\
-50,2\end{array}$ & $\begin{array}{c}0,0017 \\
0,0029 \\
0,0039 \\
\end{array}$ \\
\hline $\begin{array}{c}\text { P2 } \\
\text { Caverna Pescaria }\end{array}$ & 4,6 & $\begin{array}{r} \\
84,7 \\
-6,6\end{array}$ & $\begin{array}{c}0,0051 \\
0,0054 \\
0,0059\end{array}$ \\
\hline $\begin{array}{c}\mathrm{Cl} \\
\text { Caverna Santana }\end{array}$ & 1,20 & $\begin{array}{rr} & +6,6 \\
& \\
& -10,7 \\
\end{array}$ & $\begin{array}{c}0,0030 \\
0,0036 \\
0,0054\end{array}$ \\
\hline $\begin{array}{c}\text { C2 } \\
\text { Caverna Santana }\end{array}$ & 8,0 & $\begin{array}{c}238,2^{+121,3} \\
-57,9\end{array}$ & $\begin{array}{c}0,0022 \\
0,0034 \\
0,0044\end{array}$ \\
\hline $\begin{array}{c}\text { CA3 } \\
\text { Caverna Alambarí de } \\
\text { Baixo }\end{array}$ & 8,5 & $\begin{array}{r}+43,7 \\
165,5 \\
-33,8\end{array}$ & $\begin{array}{c}0,0041 \\
0,0051 \\
0,0065 \\
\end{array}$ \\
\hline
\end{tabular}

Tabela 4.8 - Taxas de entalhamento vadoso vertical para as carvernas amostradas no Alto Ribeira.

Conclui-se, portanto, de uma forma preliminar, que a taxa de entalhamento vadoso vertical nas cavernas estudadas, durante os últimos 240 mil anos, foi entre 0,0029 e 0,0052 $\mathrm{cm} / \mathrm{ano}$. Neste intervalo, considera-se que uma taxa mais próxima à $0,005 \mathrm{~cm} /$ ano deve ser mais real, devido ao alinhamento melhor e erro menor destes pontos. Como se trata de uma estimativa preliminar, propõe-se adotar a média entre estes extremos, $0,0042 \mathrm{~cm} /$ ano, com um erro de $+0,001$ e $-0,0013 \mathrm{~cm} /$ ano, aguardando refinamento deste resultado, com pesquisas futuras.

Comparando o resultado obtido neste trabalho com os de outros autores, nota-se que a taxa de entalhamento proposta para o Alto Ribeira, enquadra-se na faixa de variação das taxas obtidas para diversas regiões cársticas, em diferentes condições geomórficas e tectônicas, conforme é apresentado na tabela 4.9 .

O entalhamento fluvial de canyons subterrâneos é conseqüência do rebaixamento do nível de base, que por sua vez, em períodos de centenas de milhares de anos, é controlado principalmente pelo soerguimento tectônico da área.

Com a estimativa quantitativa da taxa máxima de entalhamento na região estudada, observa-se que o valor médio de $0,004 \mathrm{~cm} /$ ano é semelhante ao entalhamento medido na região centro norte da Inglaterra (tab 4.9), região tectonicamente estável durante o Pleistoceno, tendo sofrido movimentos verticais neste periodo, principalmente devido à compensações isostáticas, controladas pelas fases glaciais. Em contraste, a taxa de entalhamento máximo medida para a ilha sul da Nova Zelândia e Montanhas Rochosas do Canadá (Crowsnest Pass), chega a suplantar o dobro do entalhamento proposto para o Alto Ribeira (tab 4.9). Estas taxas superiores de entalhamento subterrâneo são correlacionadas a um regime mais intenso de soerguimento da região, em função do ambiente tectônico ativo (zonas próximas ou sobre cadeias de montanhas em desenvolvimento) destas áreas (Williams, 1982 e Ford, et al., 1981). 


\begin{tabular}{|c|c|c|c|}
\hline Local & $\begin{array}{c}\text { Taxas máximas } \\
\text { de entalhamento } \\
\text { subterrâneo } \\
\text { cm / ano }\end{array}$ & $\begin{array}{c}\text { Tempo envolvido } \\
\text { (antes do presente) } \\
\times 10^{3} \text { anos }\end{array}$ & Fonte \\
\hline $\begin{array}{c}\text { Yorkshire Dales, } \\
\text { centro-norte da Inglaterra }\end{array}$ & 0,002 a 0,005 & 350 & $\begin{array}{c}\text { Gascoyne, } 1981 \\
\text { Gascoyne,Ford e Schwarcz, } 1983\end{array}$ \\
\hline $\begin{array}{l}\text { Bearjaw Valley, } \\
\text { Rochosas, Canadá }\end{array}$ & 0,005 a 0,013 & 350 a 700 & Ford, et. al., 1981 \\
\hline $\begin{array}{c}\text { Crowsnest Pass, } \\
\text { Rochosas, Canadá }\end{array}$ & 0,011 a 0,013 & 700 a 100 & Ford, et. al., 1981 \\
\hline $\begin{array}{c}\text { Nova Zelândia, } \\
\text { noroeste da Ilha Sul }\end{array}$ & 0,014 a 0,027 & 400 & Williams, 1982 \\
\hline Jamaica & 0,013 a 0,020 & 200 & Gascoyne, 1981 \\
\hline Sul da Tasmânia & $\begin{array}{c}0,0106 \text { a } 0,0212 \\
\text { e } \\
0,0063\end{array}$ & 190 & Goede e Harmon, 1983 \\
\hline $\begin{array}{c}\text { Alto Ribeira } \\
\text { Iporanga, São Paulo }\end{array}$ & 0,0029 a 0,0052 & 240 & Este trabalho \\
\hline
\end{tabular}

Tabela 4.9 - Quadro comparativo entre taxas de entalhamento fluvial subterrâneo de diferentes regiōes cársticas.

Baseado neste quadro comparativo de taxas de entalhamento fluvial subterrâneo, conclui-se que o Alto Ribeira enquadra-se num regime de taxas médias de entalhamento, interpretado como sendo conseqüência de um regime de soerguimento tectônico moderado durante o período datado ( 240.000 anos), o que coincide também, com a interpretação morfológica do padrão vertical de condutos, apresentada anteriormente.

Finalmente deve-se frisar ainda, que a taxa de entalhamento vertical determinada acima, representa uma média das taxas correspondentes a um longo prazo, ou seja, é o resultado final de um processo de soerguimento, que não necessariamente foi constante durante o intervalo temporal considerado. Este período, provavelmente inclui fases de maior e menor soerguimento, ou até, pulsos de subsidência (ou subidas glácio-eustáticas do nível de base) acompanhadảs de agradação dos canais fluviais subterrâneos e externos.

A detecção de registros desta yariação do processo de rabaixamento do nível de base, depende de um estudo específico, para obtenção de um número maior de idades radiométricas de depósitos calcíticos, relacionados ao entalhamento fluvial subterrâneo.

\section{Estimativa da idade de condutos e dos vales externos adjacentes ao sistema de cavernas Pérolas-Santana}

Considerando que o entalhamneto fluvial vertical ao longo do sistema de cavernas Pérolas-Santana foi aproximadamente constante ao longo do tempo, ou seja, períodos de entalhamento vadoso mais intenso, sendo compensados, por fases de rebaixamento mais lento do leito fluvial, propõe-se utilizar a taxa de entalhamento obtida no item anterior, para calcular uma estimativa da idade deste sistema de cavernas.

A profundidade máxima de canyons vadosos observada nas cavernas Pérolas e Santana varia entre 40 e $50 \mathrm{~m}$. Com a taxa de entalhamento vadoso entre 0,0029 e 0,0052 $\mathrm{cm} / \mathrm{ano}$ aplicada sobre $50 \mathrm{~m}$ de profundidade, obtém-se $961,5 \mathrm{Ka}(\mathrm{Ka}=1000$ anos $)$ como uma idade mínima, $1724,1 \mathrm{Ka}$ como máxima e 1190,5 Ka como uma idade média Deve-se 
lembrar aqui, que estas idades são mínimas, pois a velocidade de entalhamento determinada acima corresponde à valores máximos.

Conclui-se, portanto, que no mínimo por aproximadamente 1,2 a 1,7 milhões de anos, até o presente, o sistema cárstico subterrâneo, em questão, se encontră em fase de desenvolvimento, com entalhamento vadoso.

Esta idade mínima proposta para o sistema Pérolas-Santana, é compatível com idades determinadas para outros sistemas cársticos. Rowe (1985), com base em taxas de entalhamento subterrâneo, datadas pelo método ${ }^{230} \mathrm{Th} /{ }^{234} \mathrm{U}$ e paleomagnetismo em espeleotemas, reconheceu que desde $1,5 \mathrm{Ma}$ o entalhamento subterrâneo e a dissecação do platô do sul das montanhas Pennines (centro sul da Inglaterra) está em franco desenvolvimento. Villinger (1987) e Vogelsang e Villinger (1987), utilizando a taxa de erosão química e o volume de cavernamento, estimaram a idade do sistema cárstico DonauAach (Alemanha) entre $500 \mathrm{Ka} \mathrm{e} 1 \mathrm{Ma}$. Este mesmo sistema de cavernas, foi reavaliado por Dreybrodt (1990), com base no cálculo da idade através de seu modelo cinético de dissolução de calcita, como tendo em torno de 1,3 Ma. Conforme já citado na introdução (4.4.1), Gascoyne, et. al. (1983), obtiveram uma idade mínima entre $700 \mathrm{Ka}$ e 1 Ma para a fase de desenvolvimento do sistema de cavernas Castleguard, Canadá.

A taxa de entalhamento subterrâneo obtida para a região estudada, também pode ser utilizada, para avaliar uma idade mínima dos vales fluviais externos, sobre metacalcários e adjacentes aos sistemas de cavernas, seguindo a metodologia de Ford et. al. (1981).

O princípio desta avaliação de idade da paisagem externa, é a correlação entre o entalhamento vertical subterrâneo e a velocidade de rebaixamento dos fundos de vales fluviais, sobre a rocha encaixante da caverna. No exemplo em análise, correlaciona-se o entalhamento vadoso da caverna Santana com o rebaixamento do vale do rio Betari. $O$ vale do rio Betari é transversal ao alinhamento do sistema de cavernas Pérolas Santana, interceptando este, representando o nível de base local, em relação ao entalhamento da drenagem subterrânea.

Esta correlação segue a premissa de que o entalhamento subterrâneo possui praticamente a mesma velocidade do rebaixamento do canal fluvial externo. Considerando esta premissa, aplica-se a taxa de entalhamento do canyon subterrâneo ao entalhamento do desnivel entre as cristas e fundos de vales do calcário.

Para o vale do Betari, junto à ressurgência da caverna Santana, obteve-se um desnivel de $460 \mathrm{~m}$, entre a crista sobre os calcários (cota 700 m.s.n.m) e o leito do rio (cota 240), medido sobre a carta topográfica 1:10.000 (folha U-12, DAEE, 1957). Este é o entalhamento fluvial mais profundo adjacente ao sistema Pérolas-Santana, sobre metacalcários.

A taxa média de entalhamento subterrâneo $(0,0042 \mathrm{~cm} /$ ano $)$ aplicada neste desnível, resulta numa idade aproximada de 10,9 Ma para este entalhamento fluvial. Transferindo o erro da taxa de entalhamento para este cálculo, obtêm-se a idade mínima de $8,9 \mathrm{Ma}, \mathrm{e}$ máxima de $15,8 \mathrm{Ma}$, para o vale do rio Betari, transversal ao calcário encaixante da caverna Santana. 
Este cálculo da idade mínima do relevo, deve sofrer uma correção em decorrência do fato das cristas calcárias não permanecerem estáticas em relação ao rebaixamento erosivo dos talvegues fluviais. $\mathrm{Na}$ realidade estas também são rebaixadas com o tempo, mas com taxas muito inferiores que o talvegue. Este rebaixamento das cristas calcárias é evidenciado pelo desnível de 150 a $230 \mathrm{~m}$ dos topos calcários em relação às cristas quartzíticas e metapelíticas adjacentes.

No caso da medida de desnível utilizada no cálculo da idade, a diferença de cota entre a crista de calcário e o cume quartzítico (crista da Serra da Boa Vista) mais próximo é de $230 \mathrm{~m}$. Isto significa que o desnível total entalhado pelo rio Betari, sobre os metacalcários Furnas Santana, foi de no mínimo 690m.

Considerando este desnível total entalhado pelo rio Betari, com uma taxa máxima média de $0,0042 \mathrm{~cm} /$ ano, extrapola-se a idade mínima média deste vale para $16,4 \mathrm{Ma}$ (ou entre 23,8 e 13,3 Ma, utilizando-se a faixa de variação da taxa de entalhamento).

Finalmente, convém frisar mais uma vez, o caráter preliminar desta idade, ressaltando tratarem-se de idades mínimas, devido à utilização de taxas máximas de entalhamento subterrâneo.

\subsection{Evolução do sistema cárstico no quadro geomorfológico regional}

Seguindo a compartimentação geomorfológica do Estado de São Paulo de Almeida (1964), a região do Alto Ribeira, insere-se na sub-zona de Paranapiacaba, a qual "constitui o setor recuado para o interior, da zona da Serrania Costeira" (Serra do Mar). Esta pertence ao "rebordo do Planalto Atlântico, diretamente drenado para o mar", e denominado por Almeida (op. cit.), de Província Geomorfológica Costeira, denominação esta, mantida posteriormente no zoneamento geomorfológico de São Paulo, apresentado em IPT (1981a), conforme foi detalhado no capítulo 2 .

A paisagem serrana do Alto Ribeira, é uma herança da movimentação tectônica da crosta, principalmente no sentido vertical, do Arco de Ponta Grossa, após a consolidaçâo da faixa de dobramentos Ribeira (Hasui e Oliveira, 1984) no Proterozóico Superior.

Asmus (1981), com base nos trabalhos de Fúlfaro (1971), Gama Jr. (1979) e Barberena, Correia e Aumond (1980), concluiu que o Arco de Ponta Grossa não existia até o final do Permiano, sendo que sua formação iniciou-se no Triássico - Jurássico, com o soerguimento da crosta e subdivisão da Bacia do Paraná em duas sub-bacias. Até então, esta região era coberta pelos sedimentos permianos da Bacia do Paraná.

Com o contínuo soerguimento do arco, em paralelo ao inicio da fragmentação do paleo-continente Gondwana no sudeste do Brasil, a cobertura sedimentar do arco foi totalmente erodida, e a partir do Turoniano, iniciou a constituir um importante alto estrutural em relação à bacia do Paraná (Zalán, et. al., 1990).

Conclui-se, portanto, que no contexto regional, a área de estudo iniciou sua história de soerguimento tectônico no Cretáceo Médio. Este processo envolveu a remoção da cobertura da Bacia do Paraná e parte das rochas supracrustais do Grupo Açungui, atingindo o quadro atual da Serra de Paranapiacaba. Na área estudada (anticlinal da Biquinha e 
sinclinal do Lageado), foram removidos, no mínimo, $3300 \mathrm{~m}$ de metassedimentos supracrustais, conforme medida obtida sobre o perfil estrutural apresentado por Campanha (1991).

$\mathrm{Na}$ paisagem serrana atual da região estudada, observa-se o ñvelamento aproximado dos topos de cristas quartzíticas e metapelíticas, formando uma superficie que oscila nas cotas de 900 a $1100 \mathrm{~m}$ (foto 4.6). Neste quadro, ressalta-se a crista de quartzito da serra da Boa Vista, com cotas máximas entre 940 e 1000m.

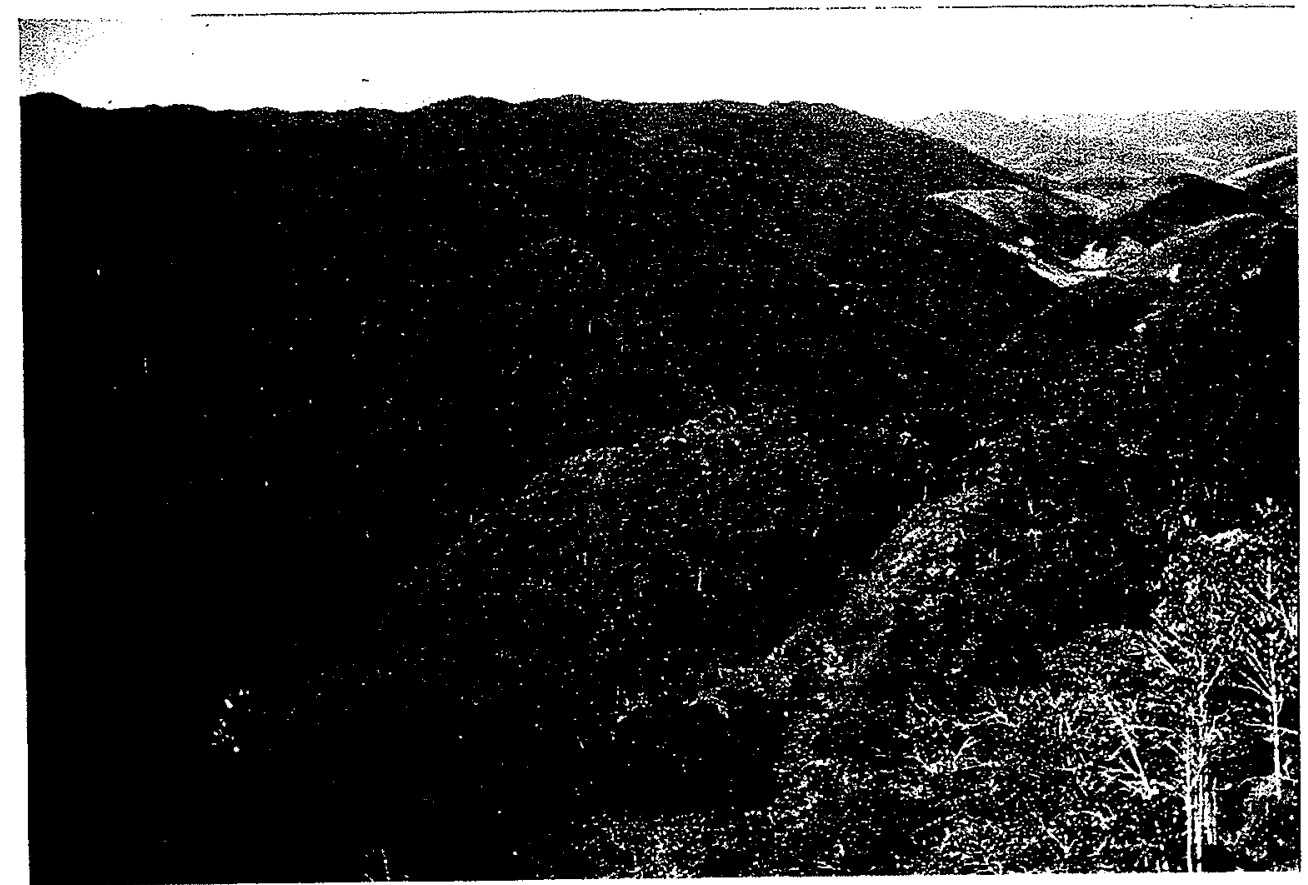

Foto 4.5 - Aspecto do nivelamento de cristas na área estudada, correlacionado à superfície Japi. Vista do vale do rio Betari do mirante da Serra da Boa Vista, estrada Apiá - Iporanga.

Este nivelamento característico de cristas observado na área, foi correlacionado por Almeida (1964) à superficie de aplainamento Japi, por ele definida como sendo um subnivelamento de testemunhos de uma superfície erosiva, embutida no Planalto Atlântico, hoje na cota em torno de $1000 \mathrm{~m}$. Almeida (1964) ressalta a dificuldade de datação desta superficie de aplainamento, sugerindo idade mínima pliocênica. Posteriormente, com o reconhecimento desta superficie erosiva cortando intrusões alcalinas senonianas (Cretáceo Superior) situando-se antes do início da subsidência do gráben do Paraíba do Sul, Almeida (1976) redifiniu sua idade, atribuindo seu desenvolvimento principal ao Eoceno. Melo, et. al. (1985) propuseram idade mínima eocênica superior ao preenchimento sedimentar da bacia do Paraíba do Sul.

A idade mínima do vale do Betari, obtida neste trabalho, contribui no refinamento da datação da superfície de aplainamento Japi, no conceito de Almeida (1964). Propõe-se, que o entalhamento desta superfície, na área da sub-zona serrana Paranapiacaba, iniciou-se no mínimo, durante o Mioceno Inferior ( $24 \mathrm{Ma}$ ) a Médio (13,3 Ma.), com base no tempo envolvido no esculpimento do vale do Betari. 
Portanto, o aplainamento da superficie Japi, deve ter ocorrido no período máximo entre o Eoceno (idade máxima atribuída por Almeida, 1976) e o Mioceno Inferior a Médio, idade mínima obtida para a superficie Japi neste trabalho (fig 4.36).

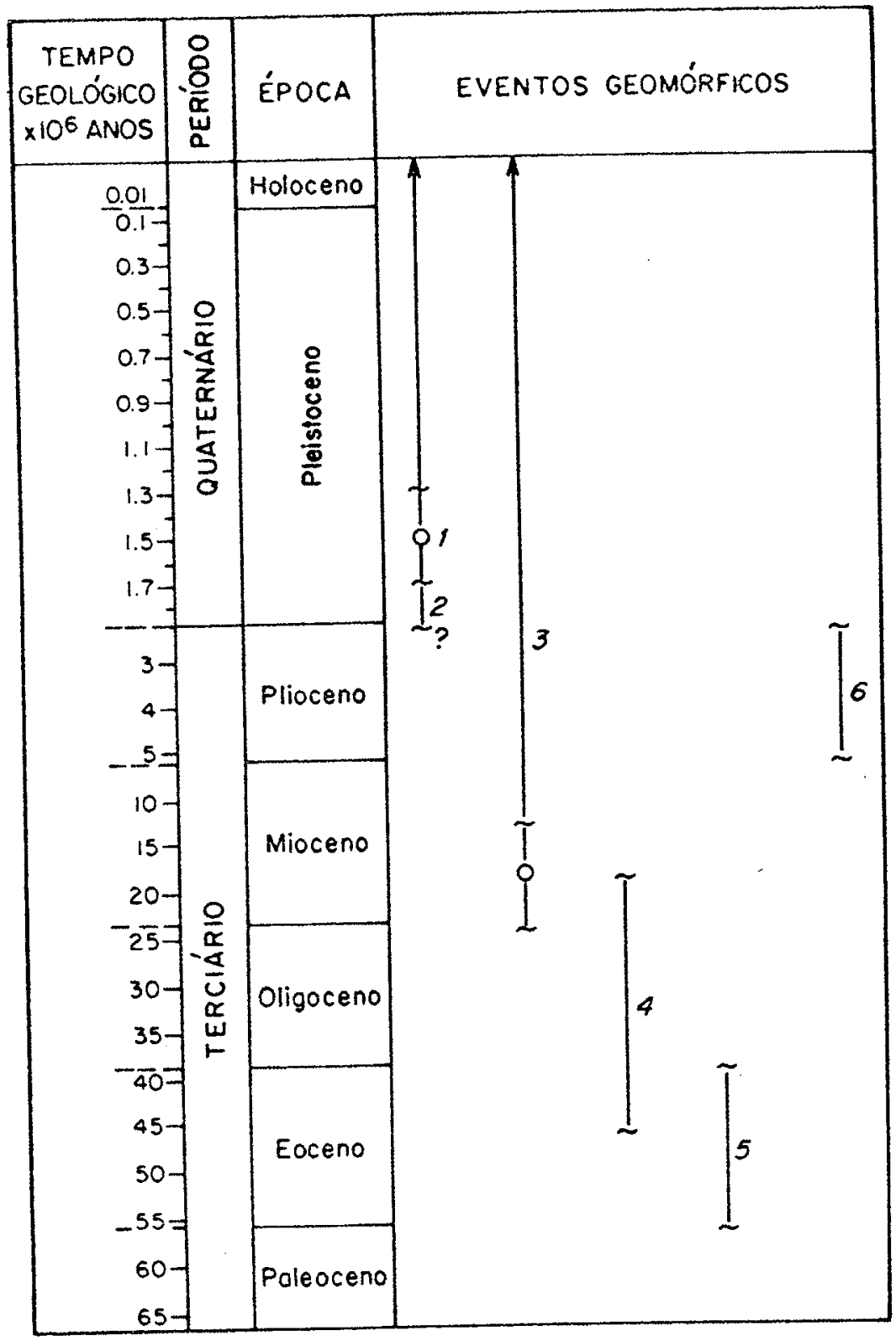

Figura 4.36 - Quadro demonstrativo da cronologia de eventos geomórficos cenozóicos na região do Alto Ribeira. Subdivisão do Cenozóico adaptada de Van Eysinga (1975). 1-Entalhamento vadoso de sistemas de cavernas.

2- Fase de iniciação de condutos freáticos.

3- Dissecação da superficie de aplainamento Japi (entalhamento do vale do rio Betari).

4- Desenvolvimento da superficie Japi, segundo proposta deste trabalho.

5- Desenvolvimento da superficie Japi, segundo Almeida (1976).

6- Desenvolvimento da superficie Japi, segundo Almeida (1964).

Indicação da idade máxima e mínima em relação à média.

A fase de desenvolvimento de sistemas de cavernas envolveu no mínimo os últimos 1,2 a 1,7 Ma., conforme estimativa da idade do entalhamento vadoso obtida para a caverna 
Santana. Isto implica que, durante este periodo, os metacalcários já possuíam permeabilidade secundária avançada, capaz de absorver grande parte do escoamento superficial. Isto, por sua vez, significa que neste intervalo de tempo, o sistema de drenagem superficial estava em fase adiantada de segmentação, com insurgências e ressurgências estabelecidas, ou seja, a paisagem cárstica superficial (com bacias poligonais) estava em desenvolvimento e, provavelmente, em grande parte já implantada.

Desta maneira interpreta-se que, no processo de dissecação do relevo na área de estudo, a paisagem fluvial sobre os metacalcários, deu lugar à topografia de bacias poligonais, no mínimo, em tôrno de $2 \mathrm{Ma}$. antes do presente. Inclui-se nestes $2 \mathrm{Ma}$., cerca de $300 \mathrm{Ka}$ para a fase de iniciação da espeleogênese, baseado na taxa média de abertura longitudinal de condutos freáticos de $5 \times 10^{4}$ anos $/ \mathrm{km}$, de Ford $(1980,1988)$, conforme comentado no inicio do item 4.4.1.

Por último, deve-se comentar ainda, que a história geomórfica mais recente da região estudada provavelmente foi influenciada pelas variações do nivel de base, controladas pelas oscilações do nível médio do mar durante as fases glaciais pleistocênicas, como também, por variações nas taxas e sentido de movimentos tectônicos verticais. Estes últimos, foram identificados na região do baixo vale do Ribeira, por Melo (1990) e Melo, Fernandes e Coimbra (1990), através de falhamentos em sedimentos de terraços fluviais suspensos, da Formação Sete Barras e Pariqüera Açu, atribuídas ao Terciário Superior a Pleistoceno.

A hipótese de influência eustática na dinâmica de entalhamento e agradação de vales fluviais e condutos subterrâneos, é levantada aqui, devido ao fato, de que durante o último máximo glacial (em tôrno de $15 \mathrm{ka}$ ), o nível do mar recuou, atingindo a cota batimétrica atual de $130 \mathrm{~m}$, conforme Kowsmann e Ataide Costa (1979).

Desta observação, surge a questão, de qual teria sido o impacto geomórfico de um incremento do potencial hidráulico na área cárstica, em função da oscilação de até $130 \mathrm{~m}$ do nivel de base marinho, durante um período de cerca de $10 \mathrm{ka}$, duração mínima do nível marinho recuado, segundo Kowsmann e Ataide Costa (op. cit.).

Um dos efeitos deste incremento do potencial hidráulico sobre a área cárstica, poderia ter sido, um período de aumento na capacidade erosiva do sistema fluvial e rebaixamento dos fundos de vales, aliado ao incremento do gradiente hidráulico de sistemas de circulação cársticos e conseqüente aceleração no entalhamento subterrâneo. Após o término da fase glacial e volta às condições normais de nível de base, com redução do potencial hidráulico na área, a capacidade de erosão e transporte do sistema de drenagem diminuiu, condicionando o assoreamento de fundos de vales e segmentos de condutos subterrâneos, previamente entalhados.

Na planicie aluvial do rio Betari, junto ao bairro da Serra (trecho do rio sobre a área carbonática Lageado-Bombas), observou-se que abaixo do nível atual do rio, existe um preenchimento de sedimentos grosseiros gradando para finos no topo, com uma espessura mínima de 3 a $5 \mathrm{~m}$, observados em poços caseiros para abastecimento de água. Isto 
evidencia que o rio Betari, atualmente está entalhando seus próprios sedimentos, depositados anteriormente.

Em várias cavernas como, por exemplo, Areias e Ouro Grosso (localizadas na área carbonática Lageado-Bombas), notou-se a ocorrência de estalagmites e escorrimentos calcíticos sobre depósitos fluviais ou sobre o fundo rochososo do canal subterrâneo, nas proximidades do leito fluvial atual, cerca de $0,5 \mathrm{~m}$ acima do nivel normal do rio atual e com evidências de intensa re-dissolução. Esta re-dissolução é causada pela exposição do espeleotema ao fluxo de água corrosivo, o qual erode a calcita, entalhando-a ou afinando a estalagmite, expondo suas linhas de crescimento. Estas estalagmites observadas tiveram, portanto, uma fase de crescimento acima do nível de variação do rio, seguida de uma fase de erosão intensa, ou seja, abaixo do nivel de variação do rio e, uma fase atual, cerca de $0,5 \mathrm{~m}$ acima do nível do rio (fig 4.37), sendo atingidas por este, somente com vazões altas de enchentes. Deve-se frizar aqui, que estalagmites bem formadas, como é o caso das observadas, somente se desenvolvem, sem a ação de fluxos freqüentes de enchentes.

Vale do Betari
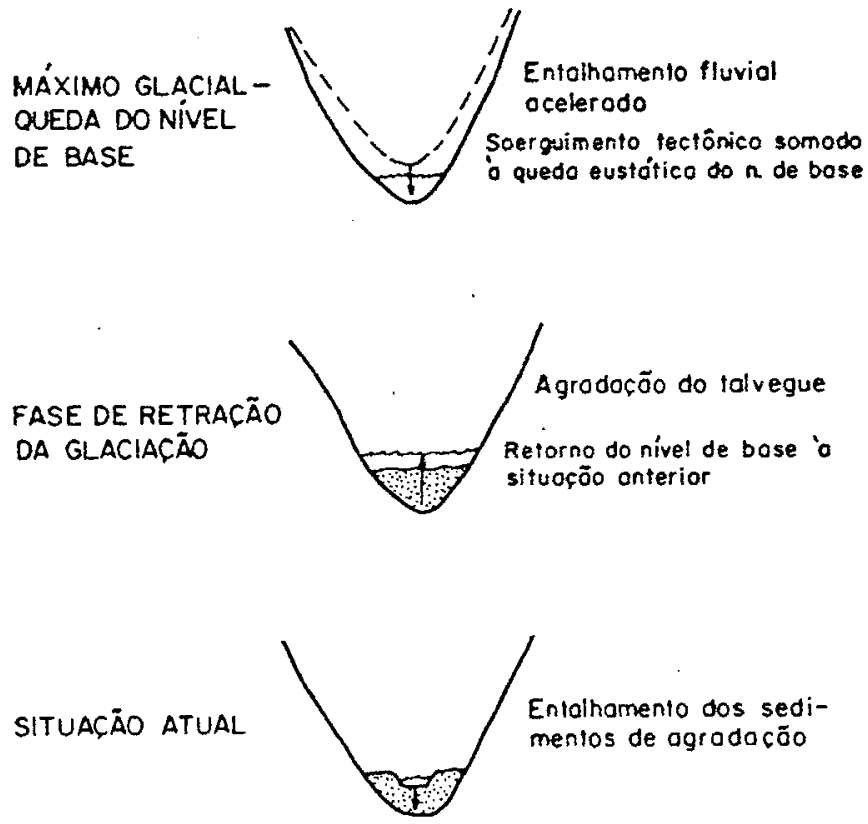

Afluente subterrôneo

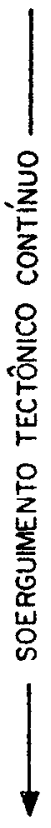

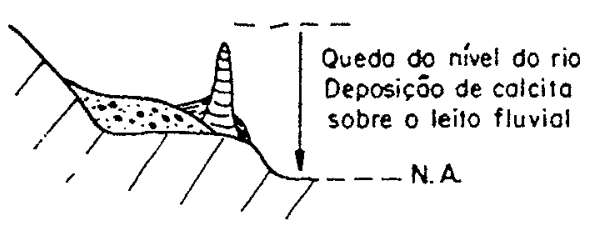
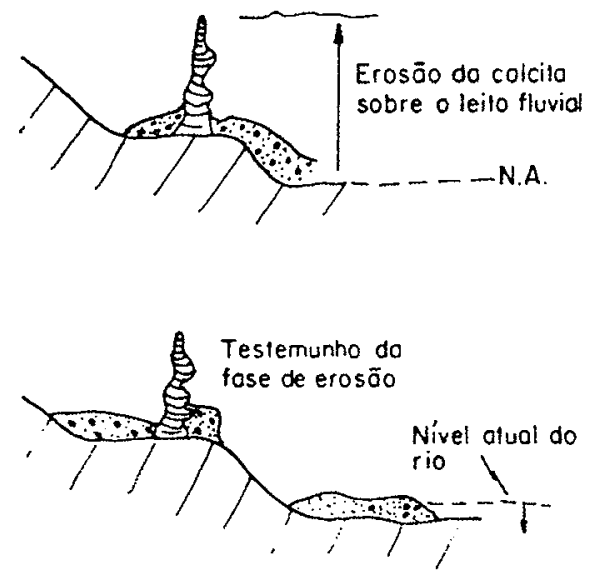

Figura 4.37 - Representação esquemática da agradação do vale do rio Betari (no Bairro da Serra) e re-dissolução de estalagmites formadas sobre o leito fluvial de afluentes subterrâneos do rio Betari, interpretados como sendo produto da variação eustática do nível de base na área, durante a última fase glacial.

Estes canais fluviais subterrâneos e a planície aluvial do bairro da Serra, estão atualmente, respectivamente, a 200 e $170 \mathrm{~m}$ acima do nivel do mar, distando deste em linha reta cerca de $90 \mathrm{~km}$.

Retomando a discussão hipotética acima iniciada, duas hipóteses poderiam ser consideradas, para explicar, tanto o re-entalhamento de sedimentos do próprio rio Betari, como também, a fase de re-dissolução de espeleotemas próximos ao leito dos rios 
subterrâneos. Ambas requerem uma fase de rebaixamento do nivel de base local, seguida da subida do mesmo,

A primeira hipótese baseia-se na variação eustática do nivel de base. Nesta, associase o entalhamento da planície do rio Betari, no bairro da Serra, abaixo do nível atual, assim como, a deposição de calcita secundária sobre o leito exposto acima do nível de água de canais subterrâneos, ao período de nível de base local rebaixado em função da queda do nível do mar durante a última fase glacial ( entre 20 e 10ka atrás). Com a retração da glaciação e subida do nível médio do mar, o nível de base local teria retornado aos níveis anteriores, diminuindo o gradiente hidráulico do sistema de drenagem, causando a agradação da planície aluvial do rio Betari, assim como, o afogamento e re-dissolução de espeleotemas formados sobre os leitos fluviais subterrâneos.

A segunda hipótese, mais ousada, é baseada em movimentos isostáticos na região, em função de tectônica vertical de blocos crustais, através da reativação de falhamentos antigos, refletindo a atividade tectônica pleistocênica, definida por Melo (1990) no baixo vale do Ribeira, ao longo do lineamento Guapiara. Nesta hipótese, o entalhamento do rio Betari, assim como, a deposição de espeleotemas em trechos do leito fluvial, estariam relacionados ao soerguimento tectônico da área, seguido por um período de subsidência da mesma, responsável pela agradação do vale fluvial e erosão dos espeleotemas, novamente substituído por uma retomada do soerguimento, atuante até o presente, re-entalhando os sedimentos de agradação e os canais subterrâneos, expondo os espeleotemas erodidos acima do nível do rio.

De uma forma preliminar, favorece-se a primeira hipótese, devido à dificuldade de demonstrar, qual o mecanismo geodinâmico atuante na área, responsável pela oscilação vertical de blocos crustais, considerando o nível de base praticamente estável durante o Pleistoceno, o que também, incorre numa simplificação, provavelmente incorreta.

Para verificar qual dos mecanismos hipotéticos acima esboçados é mais provável, para explicar a oscilação pleistocênica do nível de base na área cárstica estudada, existe a necessidade de um estudo específico da distribuição e cronologia dos espeleotemas com redissolução, assim como, dos depósitos fluviais ao longo do rio Betari e seus afluentes subterrâneos. Em paralelo, necessita-se investigar qual foi a real variação de gradiente hidráulico e incremento da capacidade de erosão fluvial na área, em resposta ao recuo do nível do mar sobre a plataforma continental, até a cota de $-130 \mathrm{~m}$.

O estudo deste problema foge do escopo desta tese, tendo sido reconhecido durante o desenvolvimeno dos trabalhos relativos a esta tese, e discutidos aqui preliminarmente, com o objetivo de evidenciar o potencial de contribuição do estudo geológico e paleohidrológico de sistemas cársticos no entendimento da evolução geomórfica cenozóica do alto vale do Ribeira.

\subsection{Conclusões}

Nas áreas carbonáticas Furnas-Santana e Lageado-Bombas, os sistemas de cavernas são do tipo misto e ocorrem preferencialmente nas proximidades dos contatos $\mathrm{SE}$, em 
função da concentração das linhas de fluxo da água subterrânea nesta zona de permeabilidade contrastante, representada pelo contato entre metapelitos e metacalcários. Esta concentração de linhas de fluxo, é condicionada pela resultante entre o gradiente hidráulico dirigido para o nível de base local (rio Betari) e aquele com sentidó geral para o no Ribeira, nivel de base regional relativo aos metacalcários.

A morfologia planimétrica dos sistemas de cavernas, reflete o estilo estrutural do metacalcário encaixante. $\mathrm{O}$ padrão planimétrico retilíneo e anguloso $(\mathrm{S} \sim 1,01$ a 1,09), típico do sistema Pérolas-Santana, está associado a mergulhos altos do acamamento, enquanto que o padrão sinuoso e curvilíneo $(S \sim 1,24$ a 1,49) desenvolve-se sobre mergulhos moderados a baixos da estratificação, como é o caso da caverna Areias.

O grau de sinuosidade dos condutos subterrrâneos depende do ângulo agudo entre o gradiente hidráulico e a rede de descontinuidades presente na rocha encaixante. Quanto maior for este ângulo, tanto mais sinuosa será a rota de condutos da água subterrânea. Entre as descontinuidaddes presentes, os planos de estratificação, fraturas simples longas e falhas constituem as estruturas mais favoráveis para instalação de condutos.

A iniciação de proto-cavernas, acompanha linhas de intersecção, entre o acamamento e fraturas simples longas e falhas (incluindo fraturas de cisalhamento). A profundidade de iniciação de condutos freáticos, abaixo do lençol freático, segue uma função exponencial, onde a base da função é o produto entre o seno do ângulo de mergulho da estratificação e a distância entre o ponto de insurgência e ressurgência da rota de condutos em iniciação, seguindo o modelo espeleogenético de Worthington (1991), conforme testado para o sistema Pérolas-Santana. Com a confirmação deste modelo, é possível prever estimativas da profundidade de condutos cársticos inacessiveis, com base no conhecimento da estrutura da rocha carbonática e da localização de sumidouros e ressurgências.

A fase de desenvolvimento da espeleogênese, na área estudada, caracteriza-se principalmente pelo entalhamento vadoso ao longo dos condutos principais dos sistemas de cavernas, produzindo canyons subterrâneos com até $50 \mathrm{~m}$ de entalhamento vertical, sob condições de rebaixamento moderado do nível de base destes sistemas, interpretado como sendo produto de soerguimento tectônico moderado da área.

As ıdades ${ }^{230} \mathrm{Th} /{ }^{234} \mathrm{U}$ de calcita secundária depositada diretamente sobre testemunhos de sedimentos fluviais subterrâneos, permitiu estimar a taxa média máxima de entalhamento vadoso subterrâneo, atuante na área, durante os últimos 240.000 anos. Obteve-se um valor entre 0,0029 e $0,0052 \mathrm{~cm} / \mathrm{ano}$, sendo que a taxa máxima de entalhamento subterrâneo, mais provável, é em torno de $0,0042 \mathrm{~cm} /$ ano $(42 \mathrm{~mm} / \mathrm{ka})$.

Aplicando o resultado acima, sobre o entalhamento vadoso observado na área, concluiu-se que o sistema cárstico do Alto Ribeira, encontra-se na fase de desenvolvimento, por aproximadamente 1,7 milhões de anos e que a idade mínima do sistema de cavernas Pérolas-Santana, é muito próxima de 2 milhões de anos. 
Correlacionando o entalhamento fluvial subterrâneo ao rebaixamento do vale do rio Betari sobre metacalcários, propõe-se idade mínima de $16,4_{-3,1}^{+7,4}$ milhões de anos para to esculpimento deste vale.

Num contexto regional de evolução do relevo, concluiu-se que a superficie de aplainamento Japi (Almeida, 1964), instalou-se na região do Alto Ribeira, entre o Eoceno Superior e o Mioceno Inferior a Médio, e que a dissecação desta iniciou-se no mínimo a cerca de 23,8 Ma. (Mioceno Inf.). Neste quadro cronológico de evolução do relevo, os sistemas fluviais sobre os metacarbonatos foram substituídos pela topografia de bacias poligonais de drenagem centrípeta, em torno de 2 milhões de anos.

As idades obtidas neste trabalho são preliminares, devendo sofrer detalhamento com pesquisas futuras. 


\section{CAPÍTULO 5 \\ DINÂMICA MODERNA DO SISTEMA CÁRSTICO DO ALTO RIBEIRA}

\subsection{Introdução}

A água subterrânea constitui o agente geomórfico primário em terrenos cársticos. Devido ao fato da interação água - rocha representar o processo fundamental da dinâmica de sistemas cársticos, o impacto geomórfico da água subterrânea sobre áreas carbonáticas, tem sido um dos temas centrais das pesquisas mais detalhadas e abrangentes desenvolvidas sobre paisagens cársticas do nosso planeta (Drake, 1984), com o objetivo de quantificar taxas de erosão sobre rochas carbonáticas.

Para estabelecer parâmetros quantitativos do processo de erosão química atuante num sistema cárstico, necessita-se medir o volume de solvente (água) transmitido pelo sistema durante um ano hidrológico ou mais (monitoramento hidrológico), assim como, avaliar o impacto deste solvente sobre a rocha carbonática encaixante do mesmo (monitoramento hidroquímico), segundo Smith e Newson (1974).

Neste trabalho selecionou-se o sistema de drenagem cárstica Pérolas-Santana (anexo 4.2) para a análise do seu balanço hídrico e de sua dinâmica erosiva atual. O critério norteador desta escolha foi o fato deste sistema apresentar, a princípio, somente uma ressurgência da água coletada sobre sua área de captação (o que se mostrou mais complexo após a realização do estudo), assim como, pelo maior grau de conhecimento disponível, em relação à distribuição de cavernas cartografadas e das rotas de fluxo da água subterrânea deste sistema.

\subsection{Hidrologia do sistema de cavernas Pérolas-Santana}

\subsubsection{Medição de vazão}

\section{Métodos utilizados}

Com o objetivo de medir o'volume de água escoado pelo sistema Pérolas Santana durante um ano hidrológico, monitorou-se a vazão do córrego Roncador na ressurgência da caverna Santana (anexo 4.3). Para se obter uma estimativa do volume de água injetada na área do sumidouro principal deste sistema, executou-se o monitoramento da vazão nas proximidades do sumidouro da caverna Pérolas (anexo 4.3).

Este monitoramento hidrológico envolveu a instalação de limnógrafos. Na caverna Santana o limnógrafo foi instalado a cerca de $100 \mathrm{~m}$ da entrada da caverna (foto 51 ). Outro limnógrafo foi instalado na margem do rio subterrâneo na caverna Pérolas, cerca de $300 \mathrm{~m} \mathrm{a}$ jusante do sumidouro principal do rio Roncador. Este ponto representa a água coletada pela planície cárstica do polje de contato junto ao sumidouro desta caverna, assim como, o escoamento superficial coletado sobre metapelitos e granitos na área de captação alogênica deste rio (anexo 3.3 e fig 5.1), antes de atingir o sumidouro.

Utilizou-se limnógrafos da marca Stevens (modelo 68-F), de tambor registrador horizontal e registro mensal na escala 1:1. Este equipamento é de propriedade do 


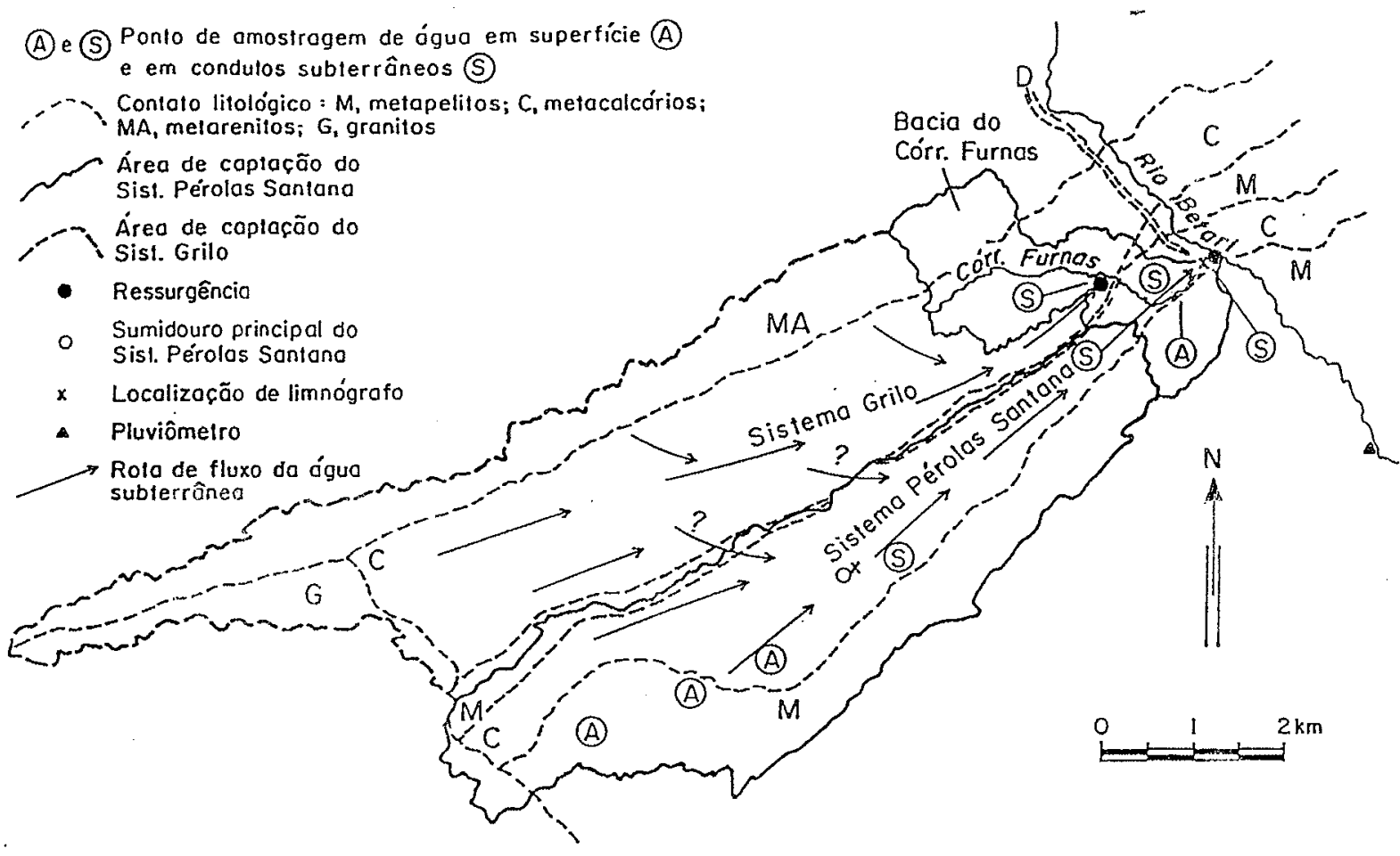

Figura 5.1 - Demarcação pelos divisores topográficos das áreas de captação referentes às bacias hidrográficas dos sistemas cársticos Pérolas-Santana e Grilo, com localização dos pontos de amostragem hidroquímica e de instalação dos limnógrafos.

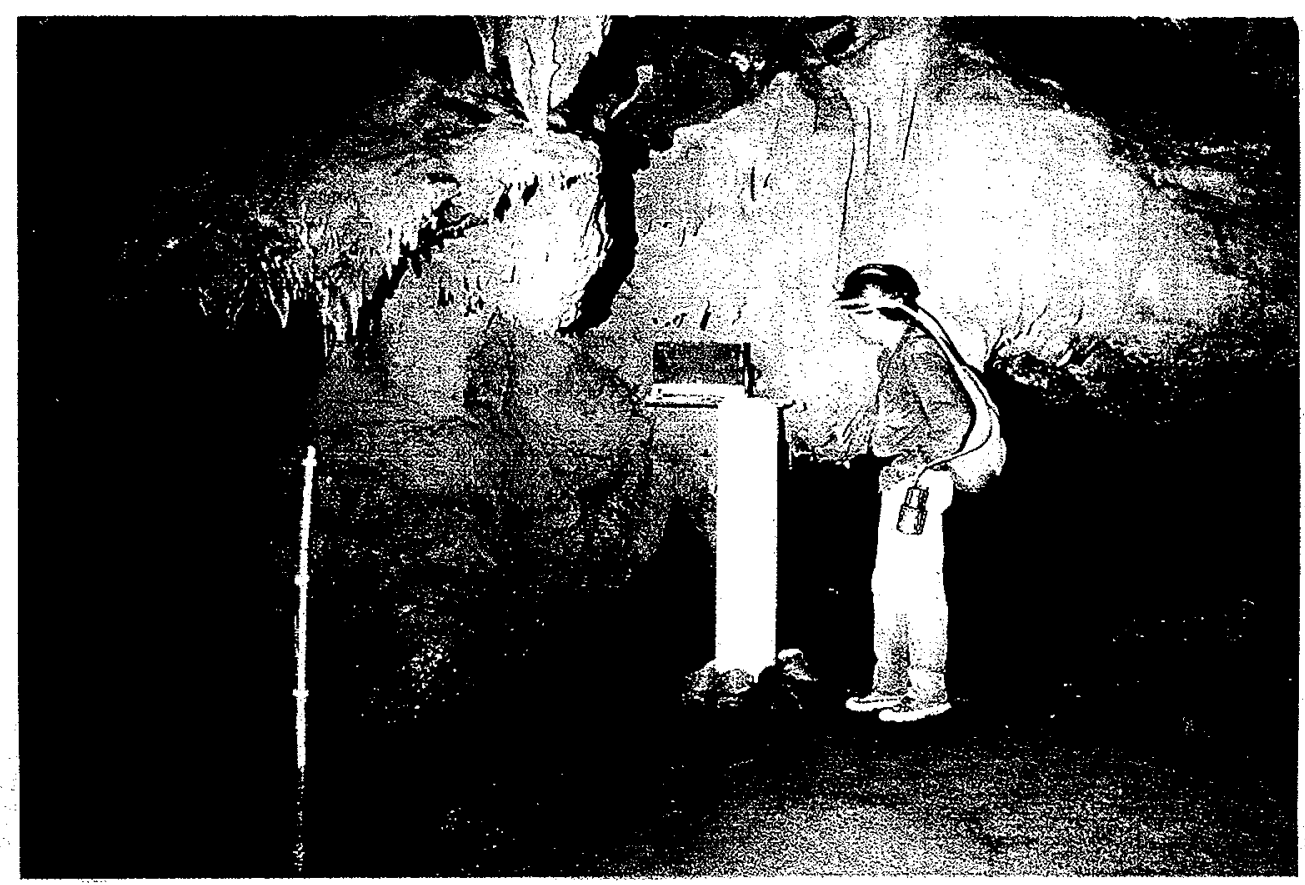

Foto 5.1 - Vista do limnógrafo instalado na ressurgência do sistema Pérolas-Santana, a cerca de $100 \mathrm{~m}$ da entrada da caverna Santana. A esquerda do limnógrafo oberva-se a régua de referência. 
Departamento de Geografia da McMaster University, obtido para este trabalho por empréstimo, através do Prof. Derek Ford.

Os limnógrafos foram colocados sobre tubos de PVC de $2 \mathrm{~m}$ de altura e $30 \mathrm{~cm}$ de diâmetro. A base destes tubos estabilizadores foi perfurada e revestida com uma tela de malha fina (filtro) e enterrada nas margens dos rios monitorados, a uma profundidade de $40 \mathrm{~cm}$ abaixo do nível de água da época de estiagem (foto 5.1), seguindo as recomendações de Church e Kellerhals (1970). Como referência para o registro da variação de altura da lâmina de água nos pontos monitorados instalou-se no leito do rio junto a cada limnógrafo uma régua vertical graduada em milímetros.

O registro da variação do nível do rio na ressurgência do sistema para o período entre junho de 1990 e fevereiro de 1992 foi obtido através da montagem e digitalização das folhas de registro mensais, conforme o exemplo do anexo 5.1

A transformação da curva de variação do nivel do rio na curva de vazão instantânea requer a construção de uma curva chave, a qual relaciona a altura do rio com a descarga fluvial correspondente (Gupta, 1989). Para tal, mediu-se a vazão nos pontos monitorados em diferentes alturas do rio.

Dois métodos foram utilizados para medir vazões: o método área-velocidade e o de diluição de sal $(\mathrm{NaCl})$.

Para aplicação do método área - velocidade selecionou-se uma seção transversal ao rio Roncador, o menos irregular possível, de baixa energia e o mais próxima da ressurgência, no caso da caverna Santana. Este método baseia-se na medição da velocidade do fluxo de água com molinete fluviométrico em vários pontos ao longo da seção transversal do rio e nas profundidades de $1 / 3$ e $2 / 3$ em cada um destes pontos. Estas velocidades sâo posteriormente multiplicadas pelas áreas de influência dos pontos de medição de fluxo (Gupta, 1989). A vazão total corresponde à somatória das vazões obtidas nos vários setores ao longo da seção transversal, a qual foi medida minuciosamente com trena. Na caverna Santana, a título de exemplo, subdividiu-se a seção com 3,5m de comprimento em 15 setores, nos quais mediu-se a velociade do fluxo nas profundidades de $1 / 3$ e $2 / 3$, quando a lâmina de água do setor era superior a $30 \mathrm{~cm}$ (a profundidade máxima em vazões baixas era de $75 \mathrm{~cm}$, chegando a $1,4 \mathrm{~m}$ em vazões elevadas).

Este método é indicado para fluxos fluviais de comportamento quase laminar (pouco turbulento). No caso da caverna Santana, o trecho escolhido para medição de vazão apresentava leve turbulência em níveis baixos de descarga. Durante vazões altas, notou-se alta turbulência e turbidez da água, o que praticamente impediu a aplicação desta técnica. No segmento monitorado do córrego Roncador na caverna Pérolas, a pequena espessura da lâmina de água (entre 10 a $20 \mathrm{~cm}$ ) e a forma altamente irregular do leito fluvial, tornaram a aplicação do método área-velocidade pouco viável.

Em função dos problemas acima apontados, aplicou-se o método de diluição de sal para medir a vazão na caverna Pérolas e nas alturas altas do rio na caverna Santana, pois esta técnica é especialmente apropriada para fluxos altamente turbulentos (Church e Kellerhals, 1970). Baseia-se na injeção instantânea no rio de um volume previamente 
medido (S) de solução de sal $(\mathrm{NaCl})$, sendo que num ponto a jusante da injeção, após sua completa homogenização, mede-se a variação de concentração, $c(t)$, do sal, conforme a passagem da "onda" de solução de sal. Esta concentração $c(t)$ varia de zero até um máximo, caindo novamente a zero, após a passagem da solução (S). A cada instante ( $t$ ), durante a passagem da onda de sal, a água do rio irá conter uma fração (s) do volume (S) inicialmente injetado. Portanto, a concentração média da solução no rio será dada pela expressão:

$$
c(t)=\frac{S}{Q}, \text { ou } S=Q c(t)
$$

onde $\mathrm{Q}$ é a vazão do rio a ser determinada.

Após a passagem da onda de solução de sal pelo ponto de medição, teremos:

$$
S=Q \int_{t i}^{t f} c(t) d t
$$

onde $\mathrm{S}$ equivale ao volume de solução de sal injetada no rio e $t i$ e $t f$ são os tempos de início e fim da passagem da "onda de sal". Através de um rearranjo desta equação, obtém-se a vazão $Q$ do rio:

$$
Q=\frac{S}{\int_{t i}^{t f} c(t) d t}
$$

Os valores de concentração de sal no rio durante o intervalo ti e tf são lidos através de medidas de condutividade elétrica no rio. Estas leituras de condutividade são posteriormente transformadas em concentrações relativas ao volume (S) inicialmente conhecido, com concentração padrão 1 , através de uma curva de calibração, a qual deve ser obtida no local, logo após a injeção.

Para efetuar o cálculo das concentrações de diluição (calibração entre condutividade e concentração), assim como a integral da curva de concentração de sal no rio versus tempo, o que fornece a vazão $(\mathrm{Q})$, utilizou-se uma rotina de computador desenvolvida por Karmann (1989), conforme exemplo do anexo 5.2

\section{Resultados obtidos}

Os resultados das medidas de vazão são apresentados na tabela 5.1. A precisão destas medidas foi testada através da medição da mesma vazão pelos dois métodos diferentes em várias alturas. Os resultados obtidos mostraram diferenças de até $12 \%$ entre vazões obtidas com os dois métodos, sendo que a diferença maior foi observada com vazões maiores. Repetindo a mesma medida por três vezes com o método de diluição de sal, obteve-se erros entre 6 e 10\% em relação ao valor médio das três medidas. Considerase, portanto, que as vazões medidas no sistema Pérolas-Santana envolvem um erro máximo de $12 \%$, o que é bastante aceitável em medidas de vazão. executadas em canais irregulares (Gupta, 1989). No total realizou-se 58 medidas de vazão para este trabalho.

As curvas-chave (fig 5.2) foram determinadas para os dois pontos monitorados considerando que a relação entre a altura do rio e a vazão correspondente segue uma função exponencial do tipo $Q=a A^{b}$, onde $Q$ é a vazão $\mathrm{em} \mathrm{m} 3 / \mathrm{s}$ e $A$ a altura em metros da lâmina d'água do rio em relação a um datum arbitrário marcado na régua graduada de referência instalada junto aos limnógrafos. 

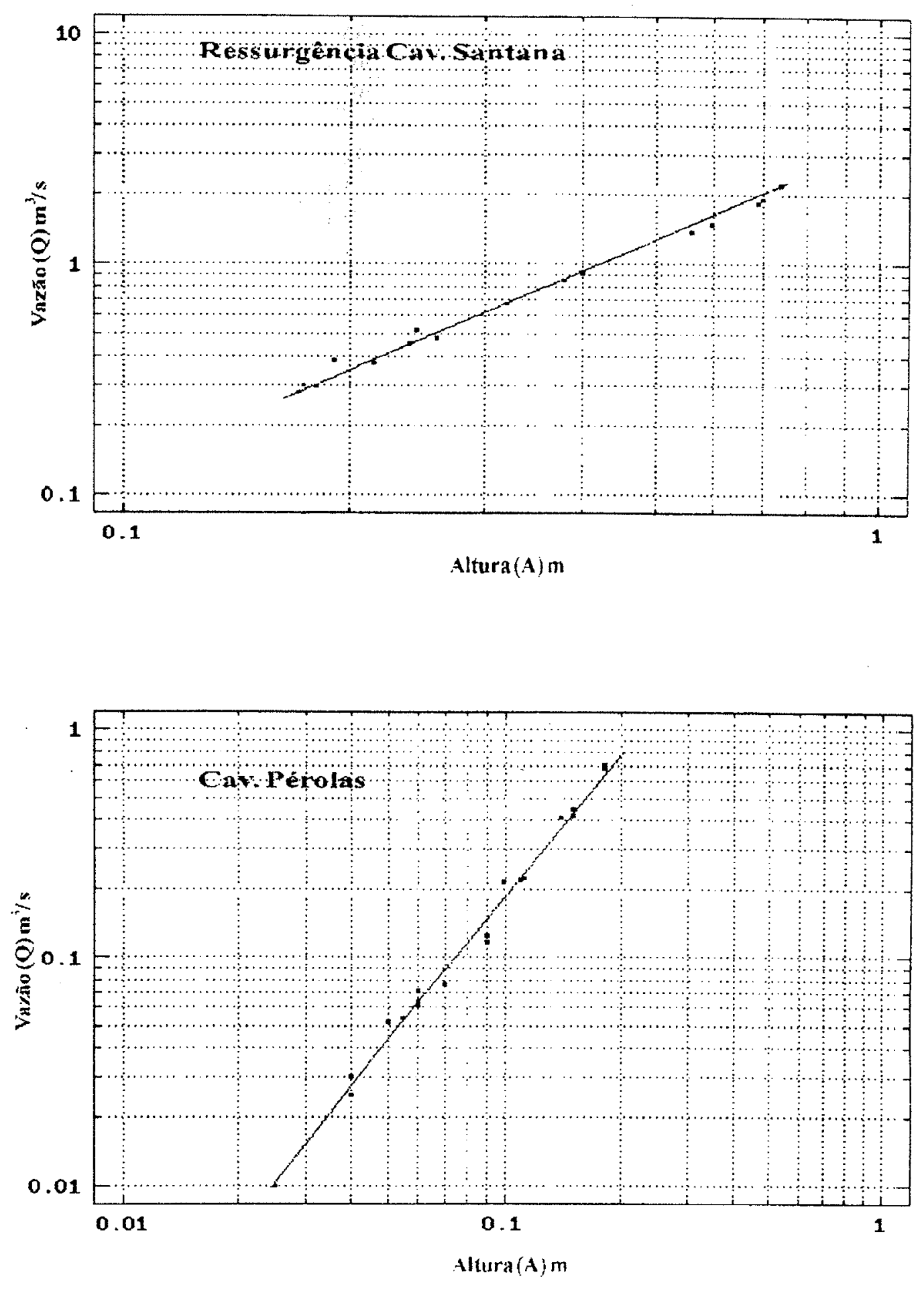

Figura 5.2 - Relação entre altura do rio e vazão para a ressurgência do sistema PérolasSantana e sumidouro principal do sistema, caverna Pérolas. 


\begin{tabular}{|c|c|c|c|}
\hline \multicolumn{2}{|c|}{ 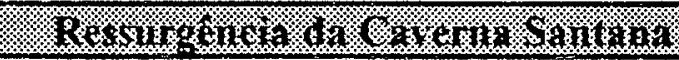 } & \multicolumn{2}{|c|}{ 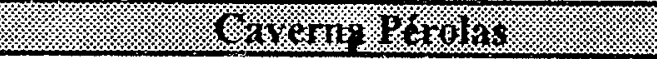 } \\
\hline Altura do rio (metros) & $\operatorname{Vazão}\left(\mathrm{m}^{3} / \mathrm{s}\right)$ & Altura do rio (metros) & Vazão $\left(\mathrm{m}^{3} / \mathrm{s}\right)$ \\
\hline 0,17 & 0,277 & 0,025 & 0,01 \\
\hline 0,173 & 0,300 & 0,04 & 0,0275 \\
\hline 0,18 & 0,296 & 0,05 & 0,052 \\
\hline 0,19 & 0,384 & 0,055 & 0,054 \\
\hline 0,215 & 0,375 & 0,06 & 0,065 \\
\hline 0,240 & 0,452 & 0,07 & 0,076 \\
\hline 0,245 & 0,520 & 0,09 & 0,122 \\
\hline 0,26 & $0,480^{*}$ & 0,10 & $0,215^{*}$ \\
\hline 0,32 & $0,670^{*}$ & 0,11 & $0,222 *$ \\
\hline 0,38 & $0,840^{*}$ & 0,112 & $0,225^{*}$ \\
\hline 0,40 & $0,920^{*}$ & 0,14 & $0,410^{*}$ \\
\hline 0,56 & $1,390^{*}$ & 0,15 & $0,435^{*}$ \\
\hline 0,595 & $1,500^{*}$ & 0,18 & $0,695^{*}$ \\
\hline 0,69 & $1,860^{*}$ & & \\
\hline 0,70 & $1,940^{*}$ & & \\
\hline 0,74 & $2,202^{*}$ & & \\
\hline
\end{tabular}

Tabela 5.1 - Vazões medidas na ressurgência da caverna Santana e na caverna Pérolas (respectivamente, ressurgência e sumidouro principal do sistema de cavernas Pérolas Santana). * vazões medidas somente com o método de diluição de sal. Altura do rio medida sobre a régua de referência instalada para cada limnógrafo.

Para a ressurgência do sistema Pérolas-Santana (cav. Santana) obteve-se a equação:

$$
Q=1.135 A^{1.34} \text {, ou } \ln Q=\ln 1,135+1,34 \ln A,
$$

com coeficiente de correlação de 0,99 e $\mathrm{R}^{2}$ igual a $99,43 \%$.

Para o sumidouro principal do sistema (cav. Pérolas) a equação chave equivale a:

$$
Q=3,177 A^{2,109} \text {, ou } \ln Q=\ln 3,177+2,109 \ln A,
$$

com coeficiente de correlação de 0,99 e $\mathrm{R}^{2}=99,14 \%$.

Com base na equação chave para a ressurgência do sistema de cavernas PérolasSantana, transformou-se a curva de variação do nível do rio versus tempo (anexo 51 ) na curva de vazão instantânea em função do tempo (fluviograma), representada na figura 5.3

\subsubsection{Análise do fluviograma da ressurgência do sistema Pérolas-Santana}

O fluviograma de nascentes cársticas representa uma espécie de "assinatura" das características fisicas do aqüífero associado ao sistema de cavernas e sua área de captação, fornecendo uma série de parâmetros hidrológicos fundamentais para uma análise quantitativa deste aqüífero (Milanovic, 1981 e Mangin, 1984)

$\mathrm{Na}$ tabela 5.2 apresenta-se alguns destes parâmetros obtidos para a ressurgência da caverna Santana. As vazões máxima (Qx), mínima (Qn) e média (Qm) correspondem ao período total monitorado (22 meses, junho de 90 a fevereiro de 92), incluindo duas épocas chuvosas. Os volumes de escoamento total $(\mathrm{Vt})$, escoamento direto $(\mathrm{Vd})$ e de escoamento básico $(\mathrm{Vb})$ correspondem a um ano hidrológico (entre dois períodos de estiagem, conforme a definição de Linsley e Franzini, 1978), compreendido de junho de 90 a setembro 


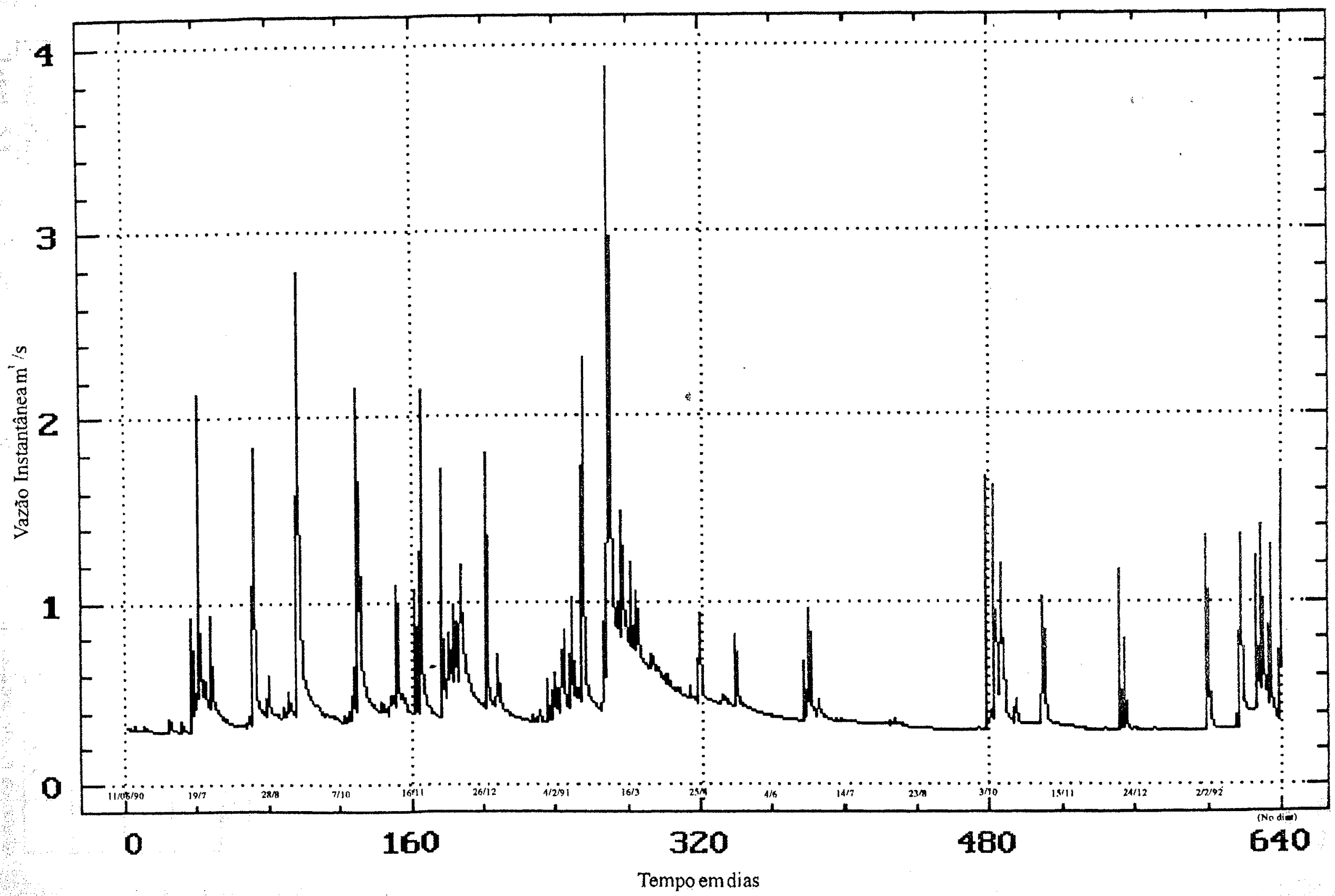

Figura 5.3 - Hidrograma da ressurgência dosistema de cavernas Pérolas-Santana para o perlodo de 11 dejunho de 1990 a 16 de março de 1992. 
de 91. O volume de escoamento total foi obtido através do cálculo da área sob os fluviogramas mensais deste periodo. Sobre os hidrogramas mensais ampliados separou-se graficamente o escoamento direto do básico, utilizando o método de Gupta (1989) 0 escoamento básico representa a diferença entre Vt e V.d

\begin{tabular}{|l|l|}
\hline Vazão máxima anual $\left(Q_{x}\right)$ & $3,876 \mathrm{~m}^{3} / \mathrm{s}$ \\
\hline Vazão mínima anual $\left(Q_{n}\right)$ & $0,196 \mathrm{~m}^{3} / \mathrm{s}$ \\
\hline Vazão média anual $\left(Q_{m}\right)$ & $0,504 \mathrm{~m}^{3} / \mathrm{s}$ \\
\hline $\begin{array}{c}\text { Razão entre vazão máxima e vazão mínima } \\
\left(Q_{x} / Q_{n}\right)\end{array}$ & 19,7 \\
\hline Volume total escoado $(16$ meses $), V t$ & $20.032 .197,24 \mathrm{~m}^{3}$ \\
\hline Volume de escoamento direto, $V d$ & $3.575 .696,9 \mathrm{~m}^{3}(17,9 \%)$ \\
\hline Volume de escoamento básico, $V b$ & $16.456 .500,34 \mathrm{~m}^{3}(82,1 \%)$ \\
\hline
\end{tabular}

Tabela 5.2 - Parâmetros hidrológicos de vazão do sistema Pérolas-Santana. As vazões e volumes calculados envolvem um erro de até $12 \%$ devido à incerteza desta ordem de grandeza nas medições de vazão.

Segundo Worthington (1991), a razão $Q x / Q n$ aliada ao tempo em que $Q>0$ constitui um dos critérios mais simples e úteis para diferenciar o regime de fluxo de nascentes cársticas, conforme é sintetizado na tabela 5.3. Worthington (op. cit) diferencia os seguintes tipos de nascentes:

- nascente do tipo fluxo total permanente (full flow) possui Qx/Qn alto, é perene e representa o escoamento total de uma área e seu aquífero associado.

- nascente tipo fluxo básico (underflow) ocorre em sistemas de drenagem subterrânea com três ou mais nascentes em diferentes cotas representando ramos distributários do sistema. A nascente na cota mais baixa irá drenar principalmente o escoamento básico do sistema, constituíndo a nascente do tipo fluxo basal. Caracteriza-se por $\mathrm{Qx} / \mathrm{Qn}$ muito inferior ao tipo anterior.

- nascente tipo fluxo de transbordamento (overflow) representa a nascente em cota mais alta em sistemas distributários acima descritos. Irá drenar principalmente o escoamento direto associado à enchentes do sistema, sendo portanto, intermitente.

- nascente tipo fluxo básico e transbordante (underflow-overflow) é aquela situada em cotas intermediárias entre a nascente mais baixa e a mais alta em sistemas distributários. Pode apresentar fluxo tanto perene como intermitente $(\mathrm{Qn}=0)$.

\begin{tabular}{|l|c|c|}
\hline $\begin{array}{c}\text { Fluxo total permanente } \\
\text { (full flow) }\end{array}$ & alta & todos \\
\hline $\begin{array}{l}\text { Fluxo Básico } \\
\text { (underflow) }\end{array}$ & baixa & todos \\
\hline $\begin{array}{c}\text { Fluxo de transbordamento } \\
\text { (overflow) }\end{array}$ & $\infty\left(Q_{n}=0\right)$ & alguns a todos \\
\hline $\begin{array}{c}\text { Fluxo básico e transbordante } \\
\text { (underflow - overflow) }\end{array}$ & baixa a $\infty$ & alguns a todos \\
\hline
\end{tabular}

Tabela 5.3 - Classificação de nascentes cársticas em função das características da vazão (adaptado de Worthington, 1991 ). 
Conforme a classificação acima, a nascente do sistema Pérolas - Santana é do tipo fluxo total permanente (full flow), pois apresenta valor alto de $\mathrm{Qx} / \mathrm{Qn}$ com fluxo formado tanto por escoamento básico ( $82 \%$ da vazão total anual) como por direto $(17,9 \%)$, não apresentando nascentes em cotas superiores (sistema convergente em uma ressurgência).

Ainda segundo Worthington (1991), a caracterização hidrológica de nascentes cársticas pode ser refinada com base na análise da forma do hidrograma de deflúvio e seu coeficiente de recessão $(\alpha)$, o que permite inferir características sobre a geometria e estrutura do aqǘfero associado à nascente.

As curvas de recessão são subdivididas em dois ou tres segmentos, um ou dois superiores relacionados ao escoamento direto, onde a vazão diminui rapidamente com o tempo, seguidos de uma recessão lenta da vazão, equivalente ao escoamento essencialmente básico (Milanovic, 1981). Conforme definido por Barnes (1939, apud Anderson e Burt, 1980) as curvas de recessão seguem uma função exponencial do tipo:

$$
Q t=Q_{0} e^{-\alpha t} \text {, ou } Q t=Q_{0} e^{-\alpha\left(t-t_{0}\right)}
$$

onde $\mathrm{Qt}$ é a vazão total $\mathrm{em} \mathrm{m} \mathrm{m}^{3} / \mathrm{s}$ durante o inter alo de tempo considerado ( $\mathrm{t}-\mathrm{t}_{0}$, em dias), $\mathrm{Q}_{0}$ a vazão no início da recessão $\left(\mathrm{t}_{0}\right)$, e $\alpha$ o coeficiente de recessão. As recessões do escoamento básico normalmente se ajustam a um único valor de $\alpha$, embora com variações sazonais (Worthington, op cit).

Os hidrogramas de recessão dos principais eventos de subida do nível do rio na ressurgência da caverna Santana foram obtidos através da ampliação dos trechos correspondentes do fluviograma geral da figura 5.3, conforme é exemplificado pela figura 5.4. Plotando a vazão média diária destes hidrogramas em escala logarítmica contra o tempo em dias, nota-se que a curva geral de cada hidrograma se ajusta a segmentos aproximadamente retilíneos (fig 5.4). Cada segmento destes corresponde a um período com $\alpha$ constante. Este é calculado pela expressão:

$$
\alpha=\frac{\ln Q_{1}-\ln Q_{2}}{t_{1-t_{2}}}
$$

(segundo Mangin, 1984) onde $Q_{1}$ é a vazão no início da recessão retilínea (em $\left.t_{l}\right)$ e $Q_{2}$ a vazão no final desta, em $t_{2}$. Os valores de $\alpha$ obtidos desta maneira para a caverna Santana são apresentados na tabela 5.4. O coeficiente $\alpha$ da vazão reflete a capacidade do aqǘfero em suprir água. É uma função da porosidade efetiva e da transmissividade do meio permeável que contém água.

No conjunto de coeficientes de recessão calculados distingue-se valores de três ordens de grandeza distintas, refletindo sazonalidade de $\alpha$. Os coeficientes entre 0,0026 e 0,007 caracterizam o período de baixa recarga do aqǘfero (período de estiagem). A época do ano com alta recarga do aqǘfero (entre os meses de outubro a abril) é marcada por recessões do escoamento básico com $\alpha$ entre 0,014 e 0,010. O deflúvio rápido do escoamento direto é caracterizado por coeficientes de recessão em torno de 0,24 . 

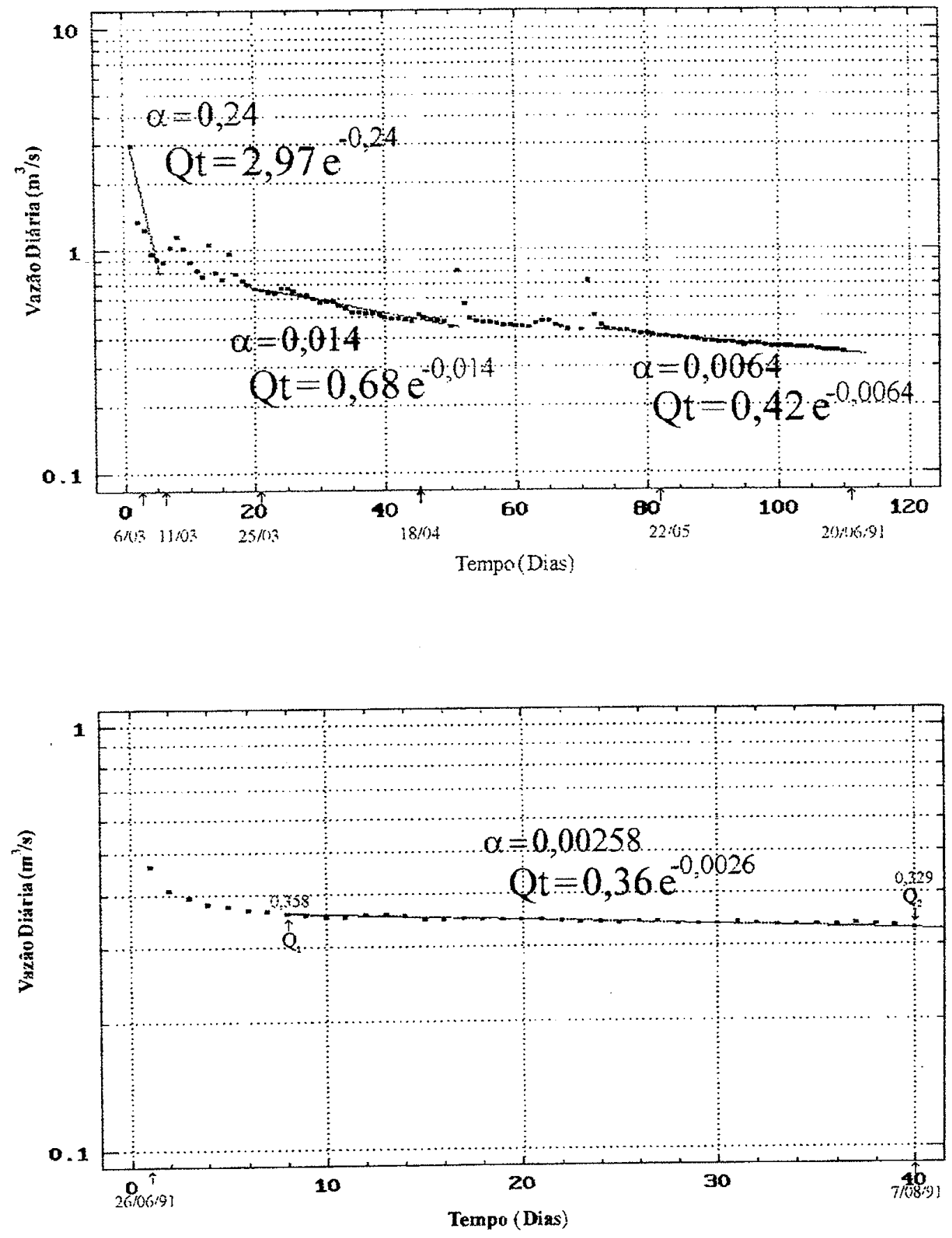

Figura 5.4 - Hidrogramas de deflúvio com indicação dos coeficientes de recessão $(\alpha)$ da ressurgência da caverna Santana para os períodos de março a junho de 1991 e junho a agosto de 1991. 


\begin{tabular}{|c|c|c|c|}
\hline Período do ano & Tempo (dias) & $\begin{array}{l}Q_{1} \\
Q_{2}\end{array} m^{3} / s$ & $\alpha\left(\mathrm{dia}^{-1}\right)$ \\
\hline $22 / 06$ a $03 / 07 / 90$ & 12 & $\begin{array}{l}0.31786 \\
0.30158 \\
\end{array}$ & $\overline{0} .00438$ \\
\hline $07 / 08$ a $13 / 08 / 90$ & 8 & $\begin{array}{l}0.348675 \\
0.328628 \\
\end{array}$ & 0.00702 \\
\hline $28 / 09$ a $10 / 10 / 90$ & 13 & $\begin{array}{c}0.3987 \\
0.34867 \\
\end{array}$ & 0.0103 \\
\hline $06 / 03$ a $11 / 03 / 91$ & 5 & $\begin{array}{c}2.97167 \\
0.895404\end{array}$ & 0.239 \\
\hline $25 / 03$ a $18 / 04 / 91$ & 25 & $\begin{array}{c}0.675154 \\
0.4788296 \\
\end{array}$ & 0.0137 \\
\hline $22 / 05$ a $20 / 06 / 91$ & 29 & $\begin{array}{l}0.41744 \\
0.34668 \\
\end{array}$ & 0.00640 \\
\hline 06/07 a 07/08/91 & 32 & $\begin{array}{c}0.35830 \\
0.3296 \\
\end{array}$ & 0.00258 \\
\hline
\end{tabular}

Tabela 5.4 - Coeficientes de recessão calculados para a ressurgência da caverna Santana.

Os valores de $\alpha$ determinados para o sistema Pérolas-Santana enquadram-se nas ordens de grandeza típicas de curvas de recessão de aqüíferos cársticos bem desenvolvidos, como é o caso do sistema Ombla, na Yugoslávia, cuja hidrologia foi detalhadamente estudada por Milanovic (1976), o qual interpreta as tres ordens de grandeza detectadas para $\alpha$ da seguinte maneira:

- O valor alto de $\alpha(0,24$ para o sistema Pérolas-Santana) corresponde ao deflúvio rápido de água de escoamento direto acumulada em cavernas freáticas amplas e condutos vadosos. No caso do sistema Pérolas-Santana, este escoamento direto perdura entre 2 (período de nível baixo do rio) a 5 dias (época de nível alto do rio subterrâneo). No sistema Ombla, com vazão máxima e mínima respectivamente de 165 e $4,1 \mathrm{~m}^{3} / \mathrm{s}$, o esvaziamento do escoamento direto em níveis altos do rio perdura no máximo por 7 dias, com $\alpha$ em torno de 0,13 .

- O coeficiente de recessão em torno de 0,01 caracteriza o escoamento básico alimentado por água acumulada no sistema interconectado de juntas localmente carstificadas e fissuras maiores. No sistema Ombla este escoamento ocorre por até 13 dias, enquanto que no sistema Pérolas-Santana o fluviograma indicou períodos de até 25 dias para este escoamento, o que é interpretado como sendo causado por um alto grau de fissuramento cárstico interconectado presente no aqüífero.

- O índice $\alpha$ da ordem de 0,003 a 0,007 (em períodos de baixa ou nenhuma recarga do aqüífero) caracteriza o escoamento básico proveniente da drenagem lenta da agua subterrânea acumulada na porosidade de fraturas pouco alargadas por dissolução e distribúidas ao longo de todo maciço carbonático, assim como, da água retida na porosidade do solo de cobertura do carst e nos depósitos arenosos e argilosos acumulados em segmentos de cavernas. O tempo medido deste escoamento básico sem recarga significativa do aqǘfero foi de 32 dias para o sistema Pérolas-Santana:

Em sintese, numa interpretação qualitativa seguindo Milanovic (1976), os valores baixos de $\alpha$ das recessões do escoamento básico indicam que o aquífero associado ao 
sistema Pérolas-Santana possui extensiva rede de fissuramento, possibilitando uma grande capacidade de armazenamento de água subterrânea, a qual é drenada por períodos longos ( $\sim 30$ dias) com vazão lentamente decrescente nas épocas de estiagem.

Uma interpretação alternativa do comportamento de $\alpha$ do sistema Pérolas-Santana pode ser obtida com base nos padrões de fluviogramas definidos por Worthington (1991) para nascentes cársticas. Segundo estes padrões, o fluviograma do sistema em questão reflete uma nascente do tipo fluxo total permanente com adição de fluxo basal (gaining underflow). Esta caracteriza-se pela subdivisão do fluviograma do escoamento básico (plotado em escala log-normal) em segmentos retilíneos de $\alpha$ decrescente, em contraste com o fluviograma de nascentes estritamente do tipo fluxo total permanente, onde $\alpha$ é constante após o escoamento direto. $\mathrm{O}$ decréscimo gradativo de $\alpha$ nas nascentes do tipo gaining underflow é atribuído por Worthington (op. cit.) a uma suplementação de água ao escoamento do tipo fluxo total permanente. Esta suplementação pode ser de origem externa ou interna. Como exemplo de contribuição externa, o autor acima cita um rio superficial que perde vazão para o sistema subterrâneo. A suplementação interna é exemplificada através do vazamento de um sistema de drenagem subterrânea vizinho ao primeiro.

No caso do sistema Pérolas-Santana, as duas hipóteses de suplemantação de água podem estar ocorrendo. Conforme será demonstrado no item seguinte, o balanço hídrico mostrou que há um excesso de água na ressurgência em relação ao volume coletado pela área de captação do sistema delimitada pelos divisores topográficos. Este fato sugere que há uma contribuição de água no sistema Pérolas-Santana proveniente do sistema cárstico vizinho (sistema Grilo, anexo 4.3), ou por perda de água superficial do córrego Furnas, o qual cruza o sistema Pérolas-Santana em superficie.

Com base na interpretação acima conclui-se que a nascente do sistema PérolasSantana é do tipo fluxo total permanente com adição de fluxo basal, com características gerais de uma nascente tipo fluxo total permanente, refletindo um aqüífero altamente carstificado.

\subsubsection{Balanço hídrico e área de captação do sistema Pérolas-Santana}

Com o objetivo de testar a validade da área de captação definida pelos divisores topográficos da bacia do sistema Pérolas-Santana, obteve-se abaixo a estimativa do balanço hídrico da bacia associada ao sistema cárstico. Segundo Atkinson e Drew (1974), o cálculo do balanço hídrico de bacias cársticas constitui um dos métodos mais seguros em avaliar a validade de suas áreas de captação de água.

$\mathrm{O}$ balanço hídrico de bacias hidrográficas e aqüíferos é calculado pela expressão

$$
P=Q+E \pm \Delta S
$$

onde $P$ é o volume de precipitação sobre a bacia (recarga do aqüifero), $Q$ é o volume total escoado pela bacia, $E$ é o volume retornado à atmosfera por evapotranspiração e $\Delta S$ o volume de água retirado ou renovado ao estoque de água armazenada pelo aquífero. No cálculo do balanço hídrico para períodos longos $\Delta S$ tende a se autocompensar o que elimina este termo da expressão acima (Gupta, 1989). No presente estudo considerou-se um ano 
hidrológico (junho de 1990 a setembro de 1991) para o cálculo do balanço hídrico, tempo suficiente para tornar $\Delta \mathrm{S}$ pouco expressivo.

\section{Volume de precipitação $(P)$}

Os dados pluviométricos utilizados (fig 5.5) foram obtidos pelo posto pluviométrico Serra dos Motas (DAEE, 1992), localizado no Bairro da Serra, a cerca de $3 \mathrm{~km}$ da ressurgência da caverna Santana (fig 5.1).

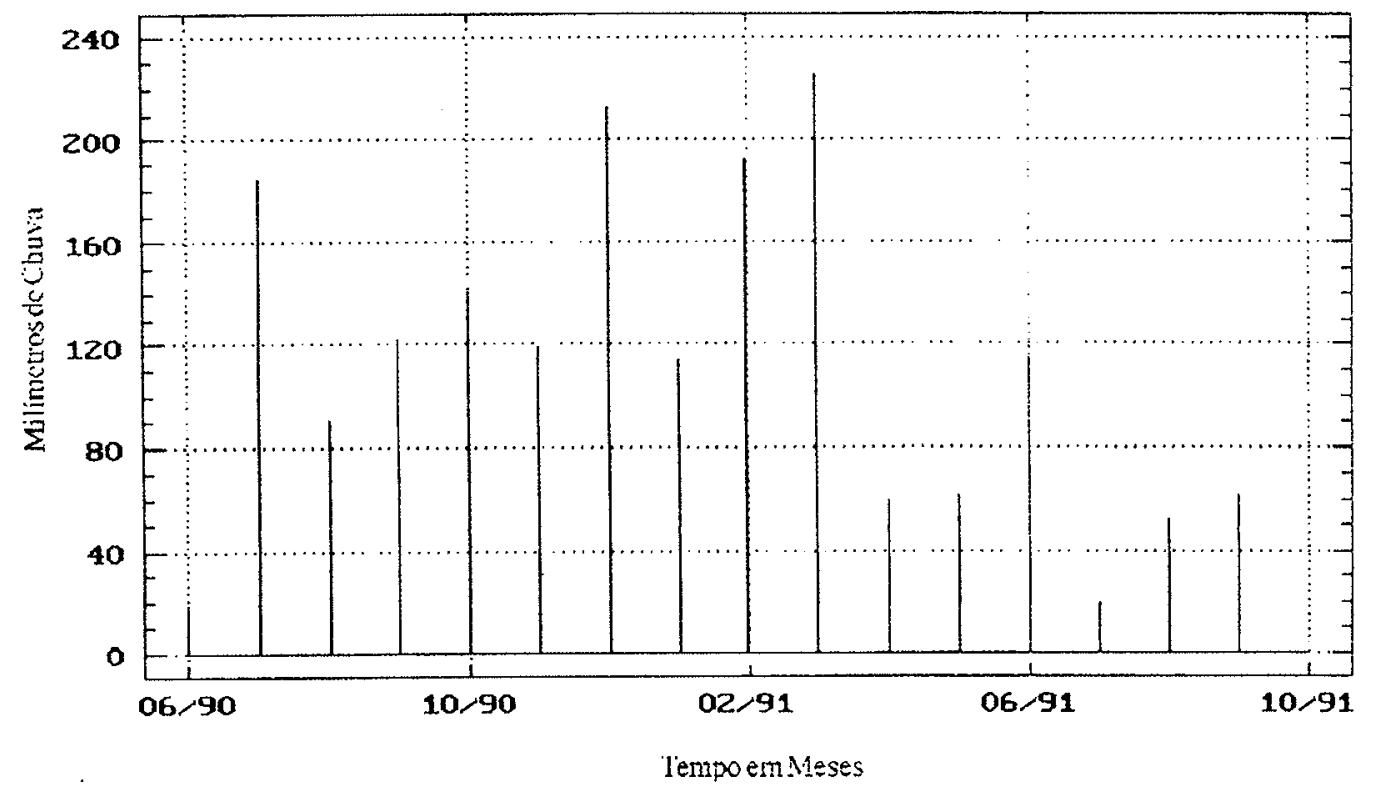

Figura 5.5 - Totais mensais de chuva medidos no posto pluviométrico Serra dos Motas (bairro da Serra, Iporanga).

Considera-se estas medidas aceitáveis, mas não ideais, visto que em função da distância do posto pluviométrico em relação à bacia monitorada, parte da chuva medida no Bairro da Serra não necessariamente ocorreu sobre a bacia e vice-versa, principalmente devido à topografia acidentada e chuvas de verão localizadas.

O total de precipitação para o período de 11 de junho de 90 a 28 de setembro de 1991 (ano hidrológico considerado) foi de $1789,6 \mathrm{~mm}$.

\section{Volume de água escoada $(Q)$ pelo sistema e sua área de captação}

O volume total de água escoada pelo sistema Pérolas-Santana durante o ano hidrológico de 1990-91 (16 meses) foi de 20.032.187,24 $\mathrm{m}^{3}$. Esta medida foi obtida através da integração do fluviograma da ressurgência do sistema para o período considerado. Este volume inclui um erro de cerca de $12 \%$, conforme comentado anteriormente.

A área de captação do sistema foi demarcada pelos divisores topográficos sobre fotografias aereas 1:25.000 (mapa morfológico da área Furnas-Santana, anexo 3.3) e base topografica 150000 (Folha Iporanga, IBGE, 1987). Excluiu-se desta área o trecho da 
bacia de escoamento superficial do rio Furnas o qual cruza o sistema Pérolas-Santana em superficie nas proximidades da ressurgência do sistema (fig 5.1). A área de captação total (área alogênica e autogênica) perfaz 14,5805 km² sobre a base $1: 25.000$ e $14,9907 \mathrm{~km}^{2} \mathrm{em}$ escala 1:50.000. Adotou-se a média destas medidas, $14,7856 \mathrm{~km}^{2}$. A superficie de captação autogênica deste sistema é de $7,349 \mathrm{~km}^{2}$ ( $49,7 \%$ do total).

O volume total escoado sobre a área total de captação fornece o escoamento total em milímetros de $1354,84 \mathrm{~mm}(\approx 1355 \mathrm{~mm})$.

\section{Evapotranspiração $(E)$}

Devido à presença de Mata Atlântica preservada e temperatura média anual alta $\left(\sim 20^{\circ} \mathrm{C}\right)$ a evapotranspiração é um importante fator no balanço hídrico da região, podendo ser estimada entre 50 a $60 \%$ da precipitação total da área (Uehara, 1994), o que resulta em 895 a $1074 \mathrm{~mm}$ para o período monitorado.

Segundo o levantamento hidrológico da bacia do rio Ribeira (DAEE, 1990), a evapotranspiração anual média da bacia do Ribeira é de $844 \mathrm{~mm} /$ ano, o que para o período de 16 meses corresponde a cerca de $1125 \mathrm{~mm}$.

Considerando as medidas de evapotranspiração obtidas pelo método de Thornthwaite e apresentadas no relatório CBA/CNEC (1983), a bacia monitorada encontrase entre as curvas de 830 e $1000 \mathrm{~mm} /$ ano de evapotranspiração potencial.

No presente estudo adotou-se $1000 \mathrm{~mm}$ de evapotranspiração para o ano hidrológico 90/91, o que representa uma média aproximada dos valores acima apresentados.

\section{Balanço hídrico da bacia do sistema Pérolas-Santana}

Aplicando a expressão $P=Q+E$ para um ano hidrológico com os valores acima: expostos, obtém-se:

$$
1790 \mathrm{~mm}<(1355+1000) \mathrm{mm} \text { ou } 1790 \mathrm{~mm}=(2355-565) \mathrm{mm}
$$

o que evidencia um forte desbalanceamento hídrico, ou seja, há um excesso de $565 \mathrm{~mm}$ $(31,6 \%)$ de água escoada pelo sistema de cavernas em relação à recarga pluviométrica coletada somente pela área de captação da bacia demarcada pelos seus divisores topográficos (fig 5.1).

O desbalanceamento hídrico obtido acima leva a concluir que a área de recarga admitada inicialmente $\left(14,79 \mathrm{~km}^{2}\right)$ é insuficiente para coletar o volume escoado durante 0 período considerado. No sentido de compensar o excesso de $565 \mathrm{~mm}$ do escoamento total (1355), a área de captação inicialmente admitida deve ser incrementada em $10,57 \mathrm{~km}^{2}$ para resultar no escoamento sobre a área $(Q)$ de $790 \mathrm{~mm}$, balanceando a expressão $\mathrm{P}=\mathrm{Q}+\mathrm{E}$.

Em função deste balanceamento deve-se admitir uma área mínima de captação de recarga superficial do sistema Pérolas-Santana de $25,4 \mathrm{~km}^{2}$, sendo que a área de captação definida somente pelos divisores topográficos não é valida para este sistema. Convém ressaltar que este valor de área possui uma incerteza mínima de $12 \%$ propagada a partir do erro detectado nas medidas de vazão. 


\section{Área de captação e recarga do aqüífero}

A conclusão obtida acima permite redifinir a área de captação e discutir o mecanismo de recarga do aqǘfero associado ao sistema Pérolas-Santana.

Observando a distribuição de sistemas de cavernas (anexo 4.3), a drenagem superficial (anexo 3.3) e as nascentes cársticas no setor a SW do rio Betari na área carbonática Furnas-Santana, surgem duas possibilidades em aumentar a área de captação do referido sistema. A primeira baseia-se na contribuição da bacia do córrego Furnas na vazão da caverna Santana. A segunda requer a bacia do sistema cárstico do Grilo fornecendo parte do excesso de vazão detectada na ressurgência do sistema Pérolas-Santana.

A bacia do córrego Furnas, conforme descrito no capítulo 3, não é puramente fluvial. Praticamente toda água deste córrego origina-se do sistema de drenagem subterrânea do Grilo, cuja nascente é o principal tributário do córrego Furnas (fig 5.1 e anexo 4.3). A partir da ressurgência da caverna do Grilo, a bacia do Furnas apresenta características fluviais, com seu talvegue encaixado cruzando a caverna Santana, a qual está a cerca de $150 \mathrm{~m}$ de profundidade abaixo do canal fluvial (fig 4.21). Na caverna Santana, nas proximidades do córrego em superficie, nota-se gotejamentos rápidos no topo do canyon subterrâneo, os quais provavelmente representam infiltrações do córrego em superficie. Além disto, parte do trecho final do córrego Furnas desenvolve-se sobre o contato litológico, onde há situação favorável para infiltraçào. É provável, portanto, que haja perda de água do leito do córrego Furnas alimentando a nascente da caverna Santana, mas não em volume suficiente para explicar o excesso de vazão nesta.

A segunda possibilidade fundamenta-se no fato de que a vazão da nascente da caverna do Grilo representa somente cerca de $2 / 3$ da vazão medida na caverna Santana, apesar da área de captação do sistema do Grilo, demarcada pelos divisores topográficos ser superior à do sistema Pérolas-Santana (fig 5.1). Isto mostra que a vazão do sistema do Grilo é insuficiente em relação a sua área de captação superficial. Esta fração de água que deixa de ressurgir na caverna do Grilo, somente pode estar sendo desviada para o sistema Pérolas-Santana, contribuindo no excesso de vazão deste. Confirma-se, portanto, a hipótese de conexão entre as rotas de fluxo dos sistemas de drenagem subterrânea do Grilo e Pérolas-Santana (fig 5.6).

Embora seja possível afirmar que a área total de captação superficial do sistema Pérolas-Santana é de $25,4 \mathrm{~km}^{2}$, a demarcação exata desta área somente poderá ser definida com a futura aplicação de traçadores do fluxo de água subterrânea sobre a porção da área carbonática Furnas Santana a SW do rio Betari. Sem esta definição, a delimitação da área de recarga é apenas aproximada.

A área de captação total do sistema Pérolas-Santana demarcada pelos divisores topográficos foi de $14,8 \mathrm{Km}^{2}$, onde $7,4 \mathrm{Km}^{2}$ compõem a superficie de recarga autogênica (fig 5.1) e os $7,4 \mathrm{Km}^{2}$ restantes coletam escoamento alogênico injetado nos metacalcários na zona de contato através de sumidouros em vales cegos. Além deste total inicial, faltam $9,6 \mathrm{Km}^{2}$ para completar os $25,4 \mathrm{Km}^{2}$ necessários para alimentar a vazão deste sistema 


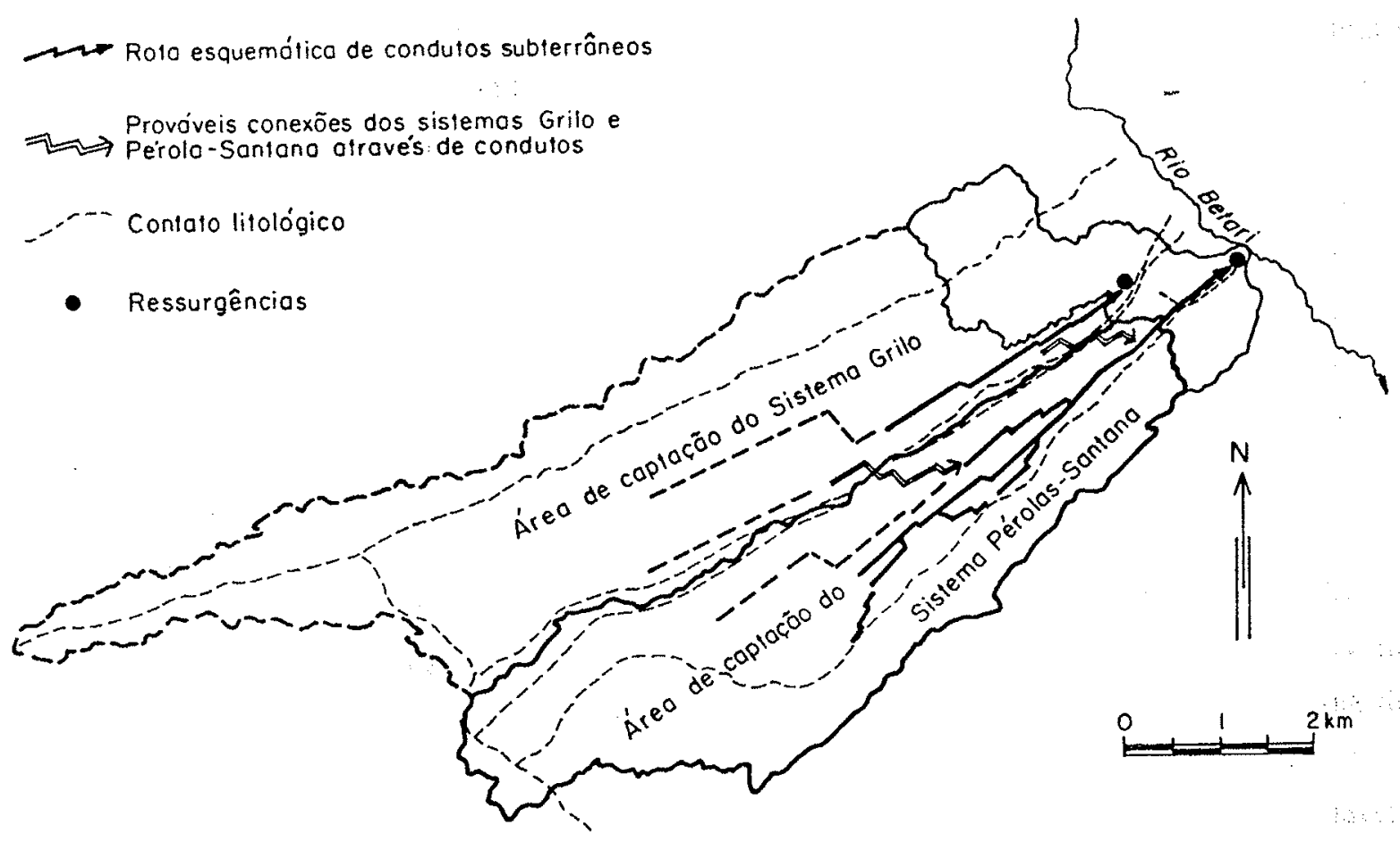

Figura 5.6 - Geometria da conexão subterrânea entre os sistemas Pérolas-Santana e Grilo interpretada em função do balanço hídrico da bacia Pérolas-Santana e o padrão de condutos da área.

O sistema do Grilo possui área de recarga autogênica demarcada por divisores topográficos de $10,7 \mathrm{Km}^{2}$ e $7,6 \mathrm{Km}^{2}$ de coleta de escoamento superficial alogênico, perfazendo um total de $18,3 \mathrm{Km}^{2}$.

Desconsiderando a bacia do córrego Furnas e em função da provável alimentação parcial do aquúfero associado ao sistema Pérolas-Santana pelo sistema do Grilo, admite-se que cerca de $50 \%\left(9,6 \mathrm{Km}^{2}\right)$ da área de captação e recarga do sistema do Grilo são necessários para completar a vazão do sistema Pérolas-Santana.

O caminho exato do fluxo subterrâneo e a delimitação desta área, conforme citado acima, deverão ser definidos em trabalhos futuros com aplicação de traçadores como corantes fluorescentes.

\subsection{Hidroquímica do carste do Alto Ribeira}

Com o objetivo de caracterizar a interação entre água meteórica e rocha carbonática em ambiente sub-tropical úmido e assim comparar esta interação com aquela atuante em outras situações geográficas sob regimes climáticos distintos, executou-se um conjunto de análises físicas e químicas da água superficial e subterrânea do carste estudado. Estes resultados também permitem estabelecer a relação entre a vazão de uma bacia de drenagem e a quantidade de soluto no volume escoado, dado essencial para o cálculo da denudação química do sistema cárstico monitorado. 


\subsubsection{Amostragem e parâmetros hidroquímicos medidos}

A caracterização química do fluxo de água através do sistema Pérolas-Santana exigiu a amostragem das diferentes classes hidroquímicas deste sistema, seguindo o método de Drake e Harmon (1973).

O escoamento superficial foi amostrado em vários pontos antes e após este atingir o corpo carbonático encaixante do sistema (água alogênica), como também, coletram-se amostras do escoamento superficial captado diretamente sobre calcários (água autogênica).

A água subterrânea do aqüífero cárstico foi amostrada em nascentes cársticas (ressurgências de sistemas de cavernas), nos pontos de gotejamento ao longo de cavernas e no poço de abastecimento de água do bairro da Serra (ver localização no anexo 4.2) perfurado em metacalcários.

A localização dos pontos amostrados na área carbonática Furnas-Santana é apresentada na figura 5.1. No sentido de obter um conjunto de amostras representativo da faixa carbonática do Lageado (descrita na introdução), amostrou-se também o sistema de drenagem cárstica Temimina-Pescaria, localizado a nordeste da área Furnas-Santana.

Um dos objetivos destas coletas foi o de possibilitar o cálculo de variáveis geoquímicas como o índice de saturação em calcita e dolomita e a pressão parcial de $\mathrm{CO}_{2}$ em equilíbrio na solução. O cálculo destas variáveis, segundo Langmuir (1971), exige a determinação da concentração dos principais cátions e ânions dissolvidos, assim como, da temperatura e do $\mathrm{pH}$ da água amostrada.

Para posterior determinação em laboratório dos principais cátions e ânions, coletouse três amostras em cada ponto amostrado, utilizando frascos de polietileno com $100 \mathrm{ml}$ de volume, respeitando as normas de coleta recomendadas por Ford e Williams (1989).

As amostras para análise de $\mathrm{Ca}^{++}$e $\mathrm{Mg}^{++}$foram acidificadas no ato da coleta (três gotas de ácido nítrico concentrado) e acondicionadas sob refrigeração até a chegada ao laboratório para análise através de absorção atômica. Os trabalhos de campo para amostragem sempre foram organizados no sentido de não ultrapassar o máximo de quatro dias entre a coleta e a análise por absorção atômica. Utilizou-se o equipamento de absorção atômica da Divisão de Engenharia de Materiais do Instituto de Pesquisas Tecnológicas do Estado de São Paulo (IPT).

Os frascos para análise de alcalinidade $\left(\mathrm{HCO}_{3}{ }^{-}\right)$também foram transportados sob refrigeração até a base de campo, onde após algumas horas da coleta realizou-se sua análise através de titulação acidimétrica (indicador misto de verde de bromocresol e vermelho de metila titulados com ácido sulfúrico $0,05 \mathrm{~N}$ ). Como as águas analisadas apresentaram $\mathrm{pH}$ entre 7,5 e 8,3 o ânion predominante do sistema $\mathrm{H}_{2} \mathrm{CO}_{3}, \mathrm{HCO}_{3}{ }^{-e} \mathrm{CO}_{3}$ - é o segundo (Freeze e Cherry, 1979), o que foi testado através da titulação do ânion $\mathrm{CO}_{3}{ }^{-}$, o qual não se mostrou presente.

O terceiro frasco de cada coleta destinou-se para a análise dos ânions sulfato, cloreto e nitrato, realizada através de cromatografia de íons (cromatógrafo Dionex, do Centro de Pesquisas de Águas Subterrâneas, CEPAS - IGcUSP) e dos cátions sódio e 
potássio, efetuada através de espectrofotometria de chama, junto ao laboratório de química do Departamento de Mineralogia e Petrologia do Instituto de Geociências da USP.

Especial atenção foi prestada nas medidas de $\mathrm{pH}$, pois este é um dos parâmetros mais sensíveis para medição e fundamental para o cálculo dos índices de saturação em cálcio e magnésio (Ford e Williams, 1989). As medidas foram realizadas nos pontos de coleta, utilizando-se um medidor de $\mathrm{pH}$ digital portátil (Digisense modelo 5985-80) com precisão de 0,05. Antes de cada etapa de campo e quando necessário, antes de cada coleta, calibrou-se o medidor de pH com soluções padrão de pH 7 e 10 . Estas medidas de pH são automaticamente compensadas para a temperatura da amostra através de um sensor térmico imerso juntamente com o eletrôdo para $\mathrm{pH}$ no frasco de medida em equlíbrio com a temperatura da água amostrada. Desta maneira obteve-se a temperatura da amostra em paralelo à leitura de $\mathrm{pH}$.

Por último, em cada estação de coleta mediu-se também a condutividade elétrica da água com um condutivímetro portátil YSI (Yellow Springs Instruments) modelo 33M. Este parâmetro mostrou-se útil devido à relação linear obtida entre a condutividade específica e a dureza total da água, o que permite estimar o conteúdo em cálcio e magnésio de águas da área somente através de uma leitura de condutividade.

As coletas e medidas dos parâmetros acima especificados foram sistematicamente distribuídas ao longo de um ano hidrológico no sentido de obter, além da diferenciação de classes hidroquímicas, a sazonalidade composicional destas classes.

Os resultados analíticos e parâmetros medidos da amostragem hidroquímica realizada são apresentados na listagem do anexo 5.3 .

\subsubsection{Parâmetros hidroquímicos derivados Dureza total $(D T)$}

A dureza total de águas naturais é definida pela soma das suas concentrações de $\mathrm{Ca}^{++}$e $\mathrm{Mg}^{++}$. A maioria dos estudos geoquímicos de águas cársticas expressa a dureza total em $\mathrm{mg} / \mathrm{l}$ equivalentes a $\mathrm{CaCO}_{3}$, ou seja, a quantos $\mathrm{mg} / \mathrm{l}$ de calcita corresponde a soma das concentrações de cálcio e magnésio medidas na amostra (White, 1988). A dureza total é obtida pela expressão

$$
D T=\left[\mathrm{Ca}^{++}\right] 2,49+\left[\mathrm{Mg}^{++}\right] 4,12
$$

onde $\left[\mathrm{Ca}^{++}\right]$e $\left[\mathrm{Mg}^{++}\right]$são as concentrações em mg/l medidas nas amostras e os coeficientes 2,49 e 4,12 correspondem aos fatôres de conversão das concentrações em equivalentes de $\mathrm{CaCO}_{3} \mathrm{em} \mathrm{mg} / \mathrm{l}$.

Os valores de dureza total das amostras coletadas estão listados no anexo 5.4.

\section{Condutividade especifica corrigida para $20^{\circ} \mathrm{C}$}

Devido ao fato da condutividade elétrica de águas naturais ser fortemente dependente da temperatura (Albutt, 1977 e Calles e Calles, 1990), as medidas obtidas em campo, a diferentes temperaturas, foram corrigidas para uma referencia comum Somente 
após esta correção as medidas são passiveis de comparação entre si, podendo ser utilizadas para testar sua dependência da dureza total da água.

Utilizou-se a equação empírica desenvolvida por Albutt (1977) para correção da condutividade de águas ricas em carbonatos para o datum de $20^{\circ} \mathrm{C}$, conforme segue abaixo:

$$
C_{20}=C_{T}\left(\frac{1,7728}{1+\alpha T+\beta T^{2}}\right)
$$

onde $C_{20}$ corresponde à condutividade, em $\mu \mathrm{mhos} / \mathrm{cm}$, corrigida para $20^{\circ} \mathrm{C}, C_{T}$ é a condutividade medida na temperatura $\mathrm{T}$ e $\alpha$ e $\beta$ são constantes determinadas empiricamente para a temperatura de $20^{\circ} \mathrm{C}$, valendo 0,0361 e 0,000127 , respectivamente.

Os valores de condutividade corrigida para $20^{\circ} \mathrm{C}$ estão listados no anexo 5.4 .

\section{Condutividade específica e dureza total}

Plotando a condutividade corrigida $\left(\mathrm{C}_{20} \mathrm{em} \mu \mathrm{mhos} / \mathrm{cm}\right)$ em função da dureza total (DT em mg/l equivalente a $\mathrm{CaCO}_{3}$ ) do conjunto de águas analisadas (fig 5.7) obteve-se a função linear

$$
C_{20}=21,248+1,501 D T
$$

com coeficiente de correlação de 0,97 e $\mathrm{R}^{2}$ de $93,1 \%$.

Esta relação mostrou-se muito útil em avaliar o teor de carbonato dissolvido e conseqüentemente o grau de saturação de águas em pontos remotos, principalmente nos trechos de dificil acesso em cavernas.

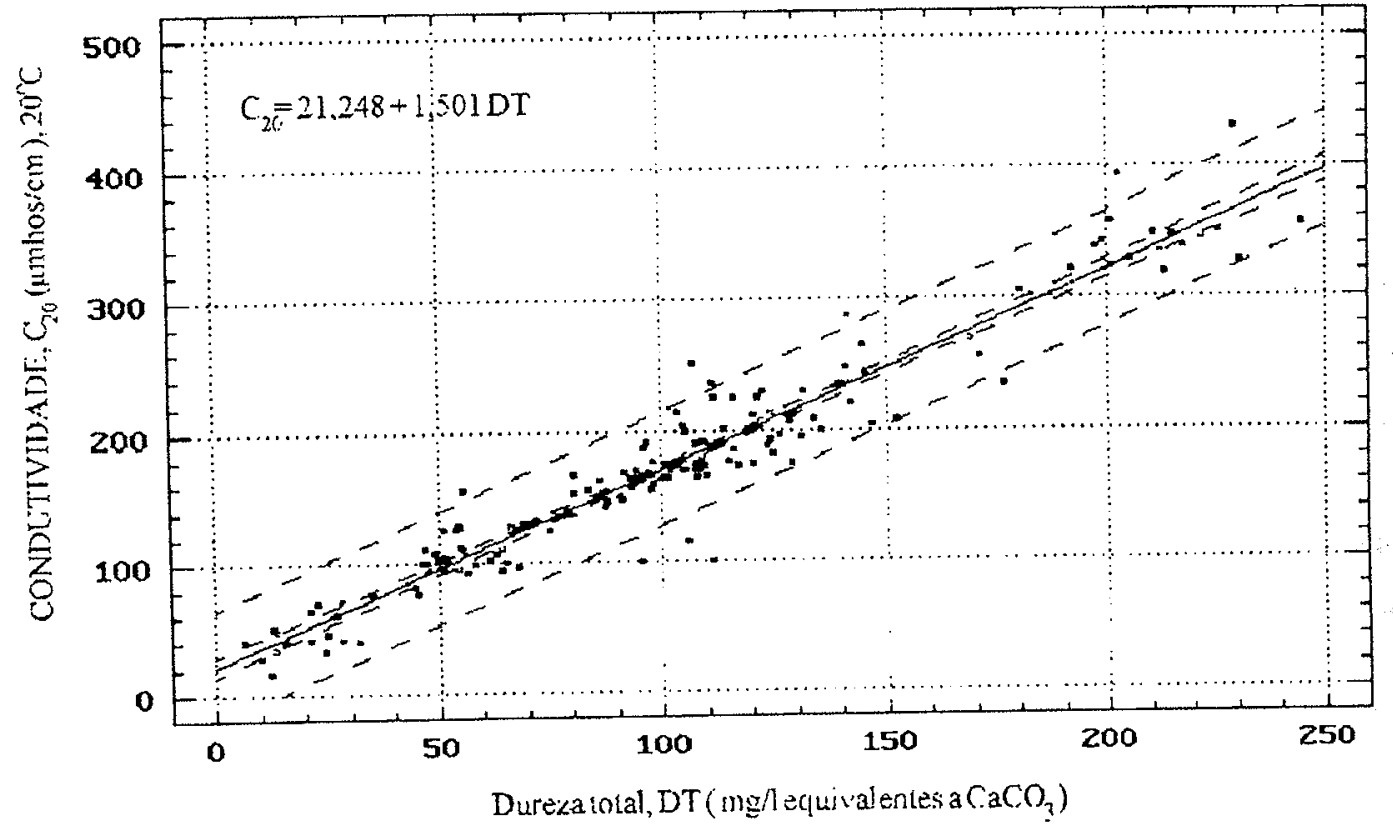

Figura 5.7- Condutividade específica em função da dureza total das águas coletadas 


\section{Razão molar Cálcio/Magnésio}

Seguindo a convenção adotada na maioria das publicações sobre geoquímica de águas cársticas (Langmuir, 1971), converteu-se as concentrações em mg/l de $\mathrm{Ca}^{++} \mathrm{e} \mathrm{Mg}^{++}$ no número de moles correspondentes, para calcular a razão $\mathrm{Ca}^{++} / \mathrm{Mg}^{++}$molar.

A razão $\mathrm{Ca}^{++} / \mathrm{Mg}^{++}$em peso das amostras analisadas é listada no anexo 5.3 enquanto a razão correspondente em moles é apresentada no anexo 5.4.

\section{Índice de saturação em calcita $\left(S I_{c}\right)$ e dolomita $\left(S I_{d}\right)$}

$\mathrm{O}$ índice de saturação expressa o quanto uma água natural desvia do estado de equilíbrio (White, 1988). O índice de saturação em calcita $\left(S I_{C}\right)$, segundo Langmuir (1971), é definido pela relação

$$
S I_{c}=\log \frac{I A P_{c}}{K_{c}}
$$

onde $I A P_{\mathcal{C}}$ é o produto de atividade iônica $\left[\mathrm{Ca}^{++}\right]\left[\mathrm{CO}_{3}^{--}\right]$em solução. De forma similar, o indice de saturação em dolomita $\left(S I_{d}\right)$ é obtido pela equação

$$
S I_{d}=\log \left(\frac{I A P_{d}}{K_{d}}\right)^{2}
$$

onde $I A P d$ é o produto de atividade iônica $\left[\mathrm{Ca}^{++}\right]\left[\mathrm{Mg}^{++}\right]\left[\mathrm{CO}_{3}^{--}\right]^{2}$ em solução. Os índices $K_{C}$ e $K_{d}$ correspondem aos produtos de solubilidade da calcita e dolomita (atividade iônica padrão de calcita e dolomita em solução em equlíbrio), respectivamente.

Nestas expressões, quando $I A P=K, S I=0$, significando que a água está em perfeito equilíbrio com o mineral carbonático em solução, ou seja, a solução está saturada e não ocorre dissolução nem precipitação deste carbonato. Valores positivos de $S I$ indicam soluções supersaturadas e valores negativos representam águas insaturadas (agressivas) em relação aos minerais carbonáticos.

Um aspecto importante no cálculo do índice de saturação é a influência do $\mathrm{pH}$ medido em campo, pois este valor é usado no cálculo da atividade iônica $\left[\mathrm{CO}_{3}^{--}\right]$. Este fato torna a precisão do índice de saturação totalmente dependente da qualidade da determinação do $\mathrm{pH}$. Ótimas medidas de $\mathrm{pH}$ normalmente possuem uma incerteza de no mínimo $\pm 0,05$ o que induz um erro de 0,1 no índice de saturação (Langmuir, 1971).

No presente trabalho utilizou-se o programa WCHEM3, desenvolvido pelo Departamento de Geologia da McMaster University, para calcular os índices de saturação em calcita e dolomita das águas amostradas, conforme expresso no anexo 5.3.

\section{Pressão parcial de $\mathrm{CO}_{2}$}

A pressão parcial de $\mathrm{CO}_{2}$ é um imporatnte parâmetro hidroquímico pois reflete a proveniência e história de águas cársticas (Ford e Williams, 1989). Representa a pressão de 
uma fase gasosa de $\mathrm{CO}_{2}$ coexistente e em perfeito equilibrio com a água analisada (White, 1988). Este parâmetro é obtido pela expressão

$$
\mathrm{PCO}_{2}=\frac{\left[\mathrm{HCO}_{3}^{-}\right]\left[\mathrm{H}^{+}\right]}{K_{1} \mathrm{~K}_{\mathrm{CO}_{2}}}
$$

onde $\left[\mathrm{HCO}_{3}^{-}\right]$é a atividade iônica da concentração do ânion $\mathrm{HCO}_{3}{ }^{-}$obtida por titulação da amostra de água, $\left[\mathrm{H}^{+}\right]$o valor negativo do $\mathrm{pH}, \mathrm{K}_{1}$ a constante de dissociação do ácido carbônico e $\mathrm{K}_{\mathrm{CO}_{2}}$ a constante de hidratação do $\mathrm{CO}_{2}$. (valores obtidos em tabelas de constantes termodinâmicas).

A pressão parcial de $\mathrm{CO}_{2}$ é expressa em atmosferas ou porcentagem. É usual na literatura específica apresentar os valôres de $\mathrm{PCO}_{2}$ na forma de seu logaritmo negativo. $\mathrm{O}$ símbolo para tal é $\mathrm{pPCO}_{2}$, onde $\mathrm{p}$ representa o sinal negativo do logaritmo de $\mathrm{PCO}_{2}$. Por exemplo, com $\mathrm{PCO}_{2}=0,0025$ atm, $\mathrm{pPCO}_{2}=2,60$ ou seja, $10^{-2.60}=0,0025$

Os valores de $\mathrm{pCO}_{2}$ obtidos neste estudo foram calculados através do programa WCHEM3 (acima citado), conforme listagem no anexo 5.3

\section{Erro de balanço iônico (IBE)}

Erros nas determinações de concentração de cátions e ânions e a eventual falta de alguma espécie iônica não analisada numa análise química de àgua, a princípio completa, podem ser estimados através do cálculo do balaço iônico (Ford e Williams, 1989), dado pela expressão

$$
I B E=\frac{\sum m_{i} z_{i_{\text {cations }}}-\sum m_{i} z_{i_{\text {duons }}}}{\sum m_{i} z_{i_{\text {catrons }}}+\sum m_{i} z_{i_{\text {tuions }}}} \times 100
$$

onde $m_{\mathrm{i}}$ é a molaridade dos íons analisados e $z_{j}$ a valência destes. O erro de balanço iônico é expresso em porcentagem.

No caso de análises de água envolvendo determinações de campo, como no presente estudo, aceita-se um erro de até 5\% (Ford e Williams, op cit).

No conjunto de análises apresentado no anexo 5.3, nota-se que o IBE varia em torno de 2 a 5\%, com algumas análises atingindo 14\% de erro. Estas últimas foram descartadas. Atribui-se este erro à determinação imprecisa de ânions, principalmente de $\mathrm{SO}_{4}{ }^{--}$, devido a falhas no equipamento utilizado, as quais não puderam ser eliminadas até o fechamento dos trabalhos.

\subsubsection{Fácies hidroquímicas do carste estudado}

O conjunto de parâmetros hidroquímicos medidos e derivados permitiram relacionar as características fisico-químicas das águas do sistema cárstico estudado com a origem destas águas (águas alogênicas, autogênicas ou mistas) e seu ambiente de fluxo (fluvial ou subterrâneo ao longo de fissuras ou condutos maiores). Desta união entre uma classificação hidrológica e química de águas surge a definição da fácies hidroquímica como sendo um tipo de recarga ou fluxo de água no sistema cárstico o qual possui um conjunto de parâmetros químicos característicos, conforme proposto previamente por Back (1960), Harmon et al. (1972), Drake e Harmon (1973) e Gunn (1983). 


\begin{tabular}{|c|c|c|c|c|c|c|c|}
\hline \multirow{3}{*}{$\begin{array}{l}\text { PARAMETROS } \\
\bar{X}{ }_{\text {min. }}^{\text {máx. }} \\
\text { CV\% } \Delta\end{array}$} & \multicolumn{7}{|c|}{ Fácies Hidroquímicas } \\
\hline & \multicolumn{3}{|c|}{ Escoamento Superficial' } & \multicolumn{2}{|c|}{ Percolação Autogênica } & \multirow[b]{2}{*}{$\begin{array}{l}\text { Circulação } \\
\text { Freática } \\
\text { profunda }\end{array}$} & \multirow[b]{2}{*}{$\begin{array}{l}\text { Ressurgências } \\
\text { Cársticas }\end{array}$} \\
\hline & Alogêtrico & Autogênico & Fluviocarstico & $\begin{array}{c}\text { Percolação } \\
\text { vadosa } \\
\mathrm{em} \\
\text { fissuras }\end{array}$ & $\begin{array}{c}\text { Percolação } \\
\text { vadosa } \\
\text { em } \\
\text { condutos }\end{array}$ & & \\
\hline$N^{2}$ de Amostras & 8 & 12 & 26 & 18 & 18 & 4 & 43 \\
\hline $\begin{array}{l}\text { Temperatura } \\
{ }^{\circ} \mathrm{C}\end{array}$ & $\begin{array}{c}20 \\
18,2^{15} \\
9.8 \% \quad 5 \\
\end{array}$ & $\begin{array}{c}19,9 \\
19,4 \\
18,7 \\
3,3 \% \quad 1,2 \\
\end{array}$ & $\begin{array}{c}18,1^{20,2} \\
13,4 \\
9,9 \% \quad 6,8 \\
\end{array}$ & $\begin{array}{c}19,6 \\
18,9 \\
18,1 \\
2,6 \% \quad 1,5 \\
\end{array}$ & $\begin{array}{c}17,6^{22} \\
13,5 \\
13,2 \% \quad 8,5 \\
\end{array}$ & $\begin{array}{c}21,2 \\
20,8 \\
20,1 \\
0,3 \% \quad 1,1 \\
\end{array}$ & $\begin{array}{c}18,9 \\
17,9 \\
3,1 \% \quad 2,1 \\
\end{array}$ \\
\hline $\begin{array}{l}\mathrm{Ca}+4 \\
\mathrm{mg} / \mathrm{l}\end{array}$ & $\begin{array}{lll} & & 7 \\
3,1 & & \\
& 1 & \\
68 \% & 6\end{array}$ & $\begin{array}{c}58,6 \\
43,7 \\
32 \\
32 \% \quad 27\end{array}$ & $\begin{array}{cc} & 29,4 \\
14,1 & 5,5 \\
47 \% & 23,9\end{array}$ & $\begin{array}{c}90 \\
76,8 \\
68 \\
7,5 \% \quad 22\end{array}$ & $\begin{array}{c}37,8^{47,2} \\
27,6 \\
15 \% \quad 19,6\end{array}$ & $\begin{array}{cc}38,7^{43} & 36 \\
1 \% & 7\end{array}$ & $\begin{array}{ll}32,1 & 48 \\
& 21 \\
19 \% & 27\end{array}$ \\
\hline $\begin{array}{l}\mathrm{Mg}+4 \\
\mathrm{mg} / \mathrm{l}\end{array}$ & $\begin{array}{c}1,3^{2,1} \\
0.8 \\
39 \% \quad 1,3 \\
\end{array}$ & $\begin{array}{c}7,3^{8,2} \\
6,5 \\
12 \% \quad 1,7 \\
\end{array}$ & $\begin{array}{cc} & 5,7 \\
3,4 & \\
& 1,4 \\
35 \% & 4.3 \\
\end{array}$ & $\begin{array}{c}4,9.3 \\
4,6 \\
14 \% \quad 2,7 \\
\end{array}$ & \begin{tabular}{ll} 
& \multicolumn{1}{c}{18,5} \\
& \\
& 2,4 \\
$63 \%$ & 16,1 \\
\end{tabular} & $\begin{array}{ll}11,4 \\
10 \\
16 \% & 8,3 \\
\end{array}$ & $\begin{array}{cc} & 8,2 \\
5,3 & \\
& 3.5 \\
21 \% & 4,7 \\
\end{array}$ \\
\hline $\begin{array}{l}\mathrm{CaMg} \\
\text { (molar) }\end{array}$ & 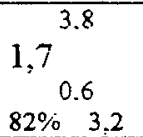 & $\begin{array}{c}3,6{ }^{4,3} \\
3,0 \\
20 \% \quad 1,3\end{array}$ & $\begin{array}{ll} & 5,1 \\
& \\
35 \% & 1,0 \\
4,1\end{array}$ & $\begin{array}{c}9,6^{13,5} \\
17 \% \quad 6,3\end{array}$ & $\begin{array}{cc} & 9,9 \\
4,4 & \\
49 \% & 8,3 \\
4,5\end{array}$ & $\begin{array}{c}2,4^{3,2} \\
26 \% \quad 1,2\end{array}$ & $\begin{array}{cc} & 5,3 \\
3,8 & \\
& 2,7 \\
17 \% & 2,6\end{array}$ \\
\hline $\begin{array}{l}\text { Alcalinidade } \\
\mathrm{mg} /, \mathrm{HCO}_{3}^{-}\end{array}$ & $22,3^{30}{ }_{15}$ & $\begin{array}{c}195 \\
151 \\
118 \\
26 \% \quad 77\end{array}$ & $\begin{array}{cc} & 110 \\
60 & \\
& 28 \\
35 \% & 82 \\
\end{array}$ & $\begin{array}{c}261 \\
240 \\
201 \\
6 \% \quad 60 \\
\end{array}$ & $\begin{array}{ll} & 200 \\
143 & 114 \\
18 \% \quad 86 \\
\end{array}$ & $\begin{array}{c}148^{155} \\
135 \\
0,8 \% \quad 20\end{array}$ & $\begin{array}{ll}116 & \\
& 88 \\
14 \% & 64 \\
\end{array}$ \\
\hline $\begin{array}{c}\text { Dureza Total } \\
\text { mg/l } \\
\text { equivalente } \\
\text { a } \mathrm{CaCO}_{3}\end{array}$ & $\begin{array}{l}13{ }^{22.4} \\
40 \% \quad 6.2 \\
\end{array}$ & $\begin{array}{c}180 \\
139 \\
107 \\
27 \% \quad 73 \\
\end{array}$ & $\begin{array}{l}49 \\
43,4 \\
41 \% \quad 72.6 \\
\end{array}$ & $\begin{array}{c}244,7 \\
212^{192} \\
70 \quad 52,7 \\
\end{array}$ & $\begin{array}{c}122^{177} \\
96,2 \\
18 \% \quad 80,8 \\
\end{array}$ & $\begin{array}{c}141,6 \\
139^{135} \\
135 \\
2 \% \quad 6,6 \\
\end{array}$ & $\begin{array}{cc}102^{152,1} \\
& 69 \\
18 \% & 83,1 \\
\end{array}$ \\
\hline $\mathrm{pH}$ & $\begin{array}{c}7,25 \\
6,97 \\
6,53 \\
4 \% \quad 0.72\end{array}$ & $\begin{array}{c}8,13 \\
8,09 \\
8,06 \\
0,4 \% \quad 0,07\end{array}$ & $\begin{array}{c}, 0,05 \\
7,54 \\
3 \% \quad 7,00 \\
3 \% \quad 1,05 \\
\end{array}$ & $\begin{array}{c}7,80 \\
7,49 \\
7,30 \\
2 \% \quad 1,50 \\
\end{array}$ & $\begin{array}{cc}8,28 \\
8,02 \\
7,54 \\
3 \% & 0,74 \\
\end{array}$ & $\begin{array}{c}8,04 \\
7,87 \\
7,76 \\
2 \% \quad 0,28 \\
\end{array}$ & $\begin{array}{c}7,92 \\
7,29 \\
\\
3 \% \quad 0,48 \\
3 \%\end{array}$ \\
\hline $\begin{array}{l}\mathrm{pPCO}_{2} \\
\text { atm.. }\end{array}$ & $\begin{array}{l}2.9 \\
2,65 \\
2.2 \\
9 \% \quad 0.7\end{array}$ & $\begin{array}{c}3,09 \\
2,96 \\
2,83 \\
4 \% \quad 0,26\end{array}$ & $\begin{array}{cc} & 3,24 \\
2,82 & 2,26 \\
& 2 \% \quad 0,98\end{array}$ & $\begin{array}{c}2,44 \\
2,15 \\
1,94 \\
60^{\circ} \quad 0,5\end{array}$ & $\begin{array}{cc} & 3,25 \\
2,92 & \\
& 2,35 \\
9 \% & 0,9\end{array}$ & 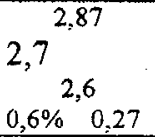 & $\begin{array}{cc} & 3,33 \\
2,89 & 2,49 \\
7 \% & 0,84\end{array}$ \\
\hline $\begin{array}{l}\text { Indice de } \\
\text { saturação em } \\
\text { calcita, } \\
\text { SIc }\end{array}$ & $\begin{array}{c}-2.14 \\
-2,76 \\
-3,6 \leq \\
19 \% \quad 1.51\end{array}$ & $\begin{array}{c}0,55 \\
+0,33 \\
0,18 \\
60 \% \quad 0,37 \\
\end{array}$ & $\begin{array}{c}-0,31 \\
-1,10 \\
-1,94 \\
45 \% \quad 1,63 \\
\end{array}$ & $\begin{array}{c}0,5 \\
-0,19 \\
-0,01 \\
-\quad 0,51 \\
\end{array}$ & $\begin{array}{c}0,51 \\
+0,18 \\
-0,37 \\
+\quad 0,88 \\
\end{array}$ & $\begin{array}{cc} & 0,34 \\
+ & 0,08 \\
& -0,14 \\
* & 0,48 \\
\end{array}$ & $\begin{array}{cc} & 0,43 \\
-0,06 \\
* \quad-0,61 \\
+1,04 \\
\end{array}$ \\
\hline $\begin{array}{l}\text { Indice de } \\
\text { saturação em } \\
\text { dolomita, } \\
\text { SId }\end{array}$ & $\begin{array}{c}4.59 \\
-5,52 \\
-7.0 \\
* \quad 2.41 \\
\end{array}$ & $\begin{array}{r}0,57 \\
+0,23 \\
0,01 \\
* \quad 0,56 \\
\end{array}$ & $\begin{array}{c}-1,05 \\
-2,49 \\
-4,18 \\
* \quad 3,13 \\
\end{array}$ & $\begin{array}{c}0,2 \\
-0,51 \\
-0,92 \\
-\quad 1,12 \\
\end{array}$ & $\begin{array}{cc} & -0,84 \\
-0,18 & -1,2 \\
* \quad 2,04 \\
\end{array}$ & $\begin{array}{c}0,31 \\
-0,09 \\
-0,49 \\
+\quad 0,80 \\
\end{array}$ & $\begin{array}{c}0.39 \\
-0.57 \\
-1.77 \\
* \quad 2.16 \\
\end{array}$ \\
\hline $\begin{array}{l}\text { Condutividade } \\
\mu \mathrm{mhos} / \mathrm{cm}\end{array}$ & $43{ }_{37 \%}^{70} 15$ & $\begin{array}{c}295 \\
252 \\
211 \\
17 \% \quad 84\end{array}$ & $\begin{array}{ll} & 155 \\
90 & \\
& 29 \\
39 \% & 126\end{array}$ & $\begin{array}{c}342^{420} \\
308 \\
80 \% \quad 112\end{array}$ & $\begin{array}{l}250 \\
189^{142} \\
17 \% \quad 108\end{array}$ & $\begin{array}{c}436 \\
320^{231} \\
33 \% \quad 205\end{array}$ & $\begin{array}{ll} & 260 \\
170 & \\
& 100 \\
17 \% & 160 \\
\end{array}$ \\
\hline
\end{tabular}

Tabela 5.5 - Parâmetros físico-químicos medidos e calculados para as fácies hidroquímica identificadas no sistema cárstico estudado. * - valores do coeficiente de variação não calculados

Separando as análises químicas (anexo 5.3) de acordo com seu ambiente hidráulico (tabela 5.5), diferenciou-se as seguintes fácies hidroquímicas para o carste estudado:

\section{Escoamento superficial alogênico}

Esta fácies hidroquímica é representada pela água de escoamento em regime fluvial sobre metapelitos e rochas graníticas que contornam os metacalcarios, constituindo a 
recarga alogênica do aqǘfero cárstico. Suas características fisico-químicas apresentadas na tabela 5.5 correspondem ao estado dá água antes de atingir a faixa carbonática. Com índice médio de saturação em calcita e dolomita respectivamente de $-2,76$ e $-5,52(0,1$ ] e $0,0006 \%$ de saturação), pH médio de 6,97 e dureza total de $13 \mathrm{mg} / 1$ equiv. a $\mathrm{CaCO}_{3}$, exprime-se a alta agressividade desta fácies aquática em relação aos metacalcários da área. Na figura 5.8 nota-se visualmente o contraste dos parâmetros fisico-químicos desta fácies hidroquímica em relação às demais.

\section{Escoamento superficial autogênico}

Corresponde a água captada diretamente pela superficie metacarbonática alimentando a recarga autogênica do aqüífero cárstico (fig 5.9). Em quase sua totalidade este escoamento superficial é injetado no maciço carbonático através de sumidouros em fundos de bacias poligonais fechadas com drenagem centrípeta, formando pontos concentrados de recarga. A fração de água restante nesta superficie é absorvida pelo maciço carbonático através de percolação difusa ao longo de descontinuidades como juntas e planos de acamamento.

Coletou-se amostras desta fácies hidroquímica ao longo de pequenos córregos perenes (raros sobre a superficie calcária da área) e filetes de água nas proximidades de fundos de depressões poligonais.

Caracteriza-se por uma alto teor de sólidos dissolvidos, com dureza total e alcalinidade entre os valores mais altos do conjunto amostrado $\left(\mathrm{DT}=139 \mathrm{mg} / \mathrm{lde} \mathrm{CaCO}_{3} \mathrm{e}\right.$ Alcalinidade $=151 \mathrm{mg} / \mathrm{l}$ ), somente suplantados pelos teores da percolação vadosa em fissuras. Este alto teor de sólidos dissolvidos é acompanhado pelo $\mathrm{pH}$ mais alcalino $(8,09) \mathrm{e}$ maior índice de saturação em calcita $(0,33$ o que equivale a $210 \%$ de saturação em calcita) entre as demais fácies hidroquímicas evidenciadas.

\section{Escoamento superficial fluviocárstico}

A água superficial de origem alogênica e que continua sobre os metacalcários em canais fluviais representa esta fácies hidroquímica (fig 5.9). Amostrou-se esta em vários pontos no polje de contato adjacente ao sumidouro principal do sistema de cavernas Pérolas-Santana (anexo 4.3) e na zona morfológica fluviocárstica circundante a este polje. Os pontos de coleta situam-se em canais fluviais sobre metacalcários entre 300 e $800 \mathrm{~m}$ de distância do contato com metapelitos.

Quimicamente esta água é marcada por uma gradativa atenuação da sua agressividade em relação aos metacarbonatos, conforme aumenta sua distância de escoamento sobre estes, até ser absorvida em sumidouros, o que é evidenciado pelos altos valores do $\mathrm{CV}$ dos seus parâmetros medidos e derivados (tab 5.5 e fig 5.8). A amostragem mostrou uma transição do índice de saturação em calcita de -2 nos primeiros metros de percolação sobre carbonato até $-0,3$ após cerca de $800 \mathrm{~m}$ sobre este, o que representa uma água praticamente $50 \%$ saturada em calcita após este percurso superficial. Na figura 58 
visualiza-se como os parâmetros fisico-químicos desta fácies representam uma transição entre aqueles das águas alogênicas e os da fácies de escoamento autogênico.

\section{Percolação autogênica vadosa em fissuras}

$\mathrm{O}$ ambiente de fluxo desta fácies hidroquímica é formado por capilares e protocondutos desenvolvidos sobre planos de acamamento, fraturas e na intersecção destes. Corresponde a água de origem autogênica e de percolação difusa no maciço carbonático entre a superficie e o nível de condutos do rio subterrâneo (fig 5.9) onde foi coletada em pontos de gotejamento. Estes apresentam vazão desde gotejamentos lentos até filetes de vazão contínua, quase sempre associados à precipitação de carbonato de cálcio secundário (espeleotemas).

Apresenta os valores médios de dureza total $\left(212 \mathrm{mg} / \mathrm{l}\right.$ de $\left.\mathrm{CaCO}_{3}\right)$ e alcalinidade (239 mg/l) mais elevados entre as águas amostradas, com pequena variabilidade (CV 5,9 e 6,6 tab 5.5), associados a um índice de saturação médio em calcita e dolomita de $+0,19 \mathrm{e}-$ $0,51 \mathrm{com} \mathrm{pH}$ médio de 7,49. Um fato que se ressalta neste quadro químico é o alto teor em sólidos dissolvidos ( $212 \mathrm{mg} / \mathrm{l} \operatorname{com} 155 \%$ de saturação em calcita e $31 \%$ de saturação em dolomita) com um $\mathrm{pH}$ de somente 7,5 , ponto a ser discutido na evolução das águas cársticas. Caracteriza-se também por uma baixa variabilidade dos parâmentros químicos ( $C V$ baixo), somente superior à fácies de circulação freática profunda (tab 5.5 e fig 5.8).

\section{Percolação autogênica vadosa em condutos}

Esta é a fácies aquática que circula em condutos vadosos menores (ramos da caverna principal, freqüentemente impenetráveis devido as suas seções decimétricas), ou cavernas vadosas conectadas à fundos de depressões poligonais, representando pequenos afluentes (fig 5.9), quase sempre associados à deposição de calcita secundária na forma de escorrimentos calcíticos com represas de travertino.

Atribui-se origem autogênica a esta fácies hidroquímica devido ao seu alto conteúdo médio em sólidos dissolvidos (DT $=122 \mathrm{mg} / \mathrm{l}$ de $\mathrm{CaCO}_{3}$ e alcalinidade $=143 \mathrm{mg} / 1 \mathrm{de} \mathrm{HCO}_{3}{ }^{-}$ ), além do $\mathrm{pH}(8,02)$ semelhante ao da água superficial autogênica (tab 5.5 e fig 5.8), apesar de existir a possibilidade de parte desta água representar contribuições de origem alogênica, as quais penetram no maciço calcário após um percurso considerável sobre a superficie carbonática.

\section{Circulação freática em condutos profundos}

Esta é a água de circulação mais profunda no sistema cárstico (fig 5.9). Seu fluxo ocorre principalmente através da rede de proto-cavernas e condutos freáticos em fase inicial de desenvolvimento localizados abaixo da rota principal de condutos em fase avançada de desenvolvimento. $\mathrm{Na}$ área estudada estes condutos profundos foram evidenciados através da perfuração do poço para abastecimento de água do Bairro da Serra. Este poço atingiu condutos na profundidade entre 77 e 147 metros abaixo do lençol freático (Politi, 1988) A amostragem hidroquímica fol obtida diretamente deste poço. 


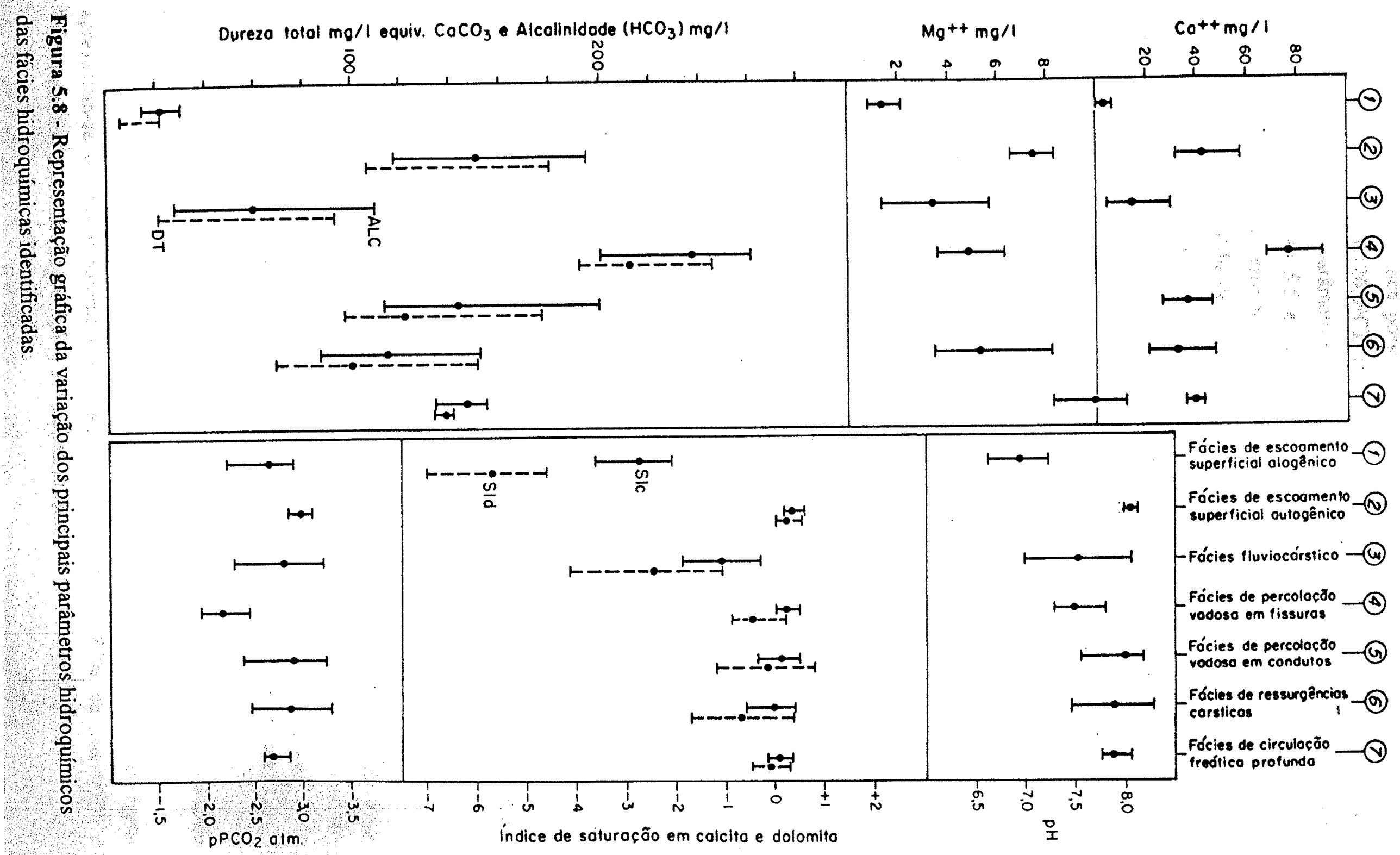


Esta fácies hidroquímica possui como assinatura fisico-química uma temperatura média anual mais elevada $\left(20,8^{\circ} \mathrm{C}\right.$ ), associada a uma variabilidade sazonal (CV) muito inferior dos principais parâmetros físico-químicos, em relação às demais fácies hidroquímicas da área (tab 5.5 e fig 5.8). Oscila em torno da saturação em calcita e dolomita (considerando um erro de 0,1 nos índices de saturação) ${ }_{2}$ com SIc $=+0,08$ e SId $=$ $-0,09$. Sua dureza total média de $139 \mathrm{mg} / \mathrm{l}$ de $\mathrm{CaCO}_{3}$ e alcalinidade de $148 \mathrm{mg} / \mathrm{lde} \mathrm{HCO}_{3}^{-}$ são muito semelhantes às do escoamento superficial autogênico (tab 5.5), distinguindo-se deste pelo valor inferior do $\mathrm{pH}(7,87)$ e pressão parcial de $\mathrm{CO}_{2}$ superior $\left(10^{-2,7} \mathrm{~atm}\right)$, não considerando o teor de magnésio.

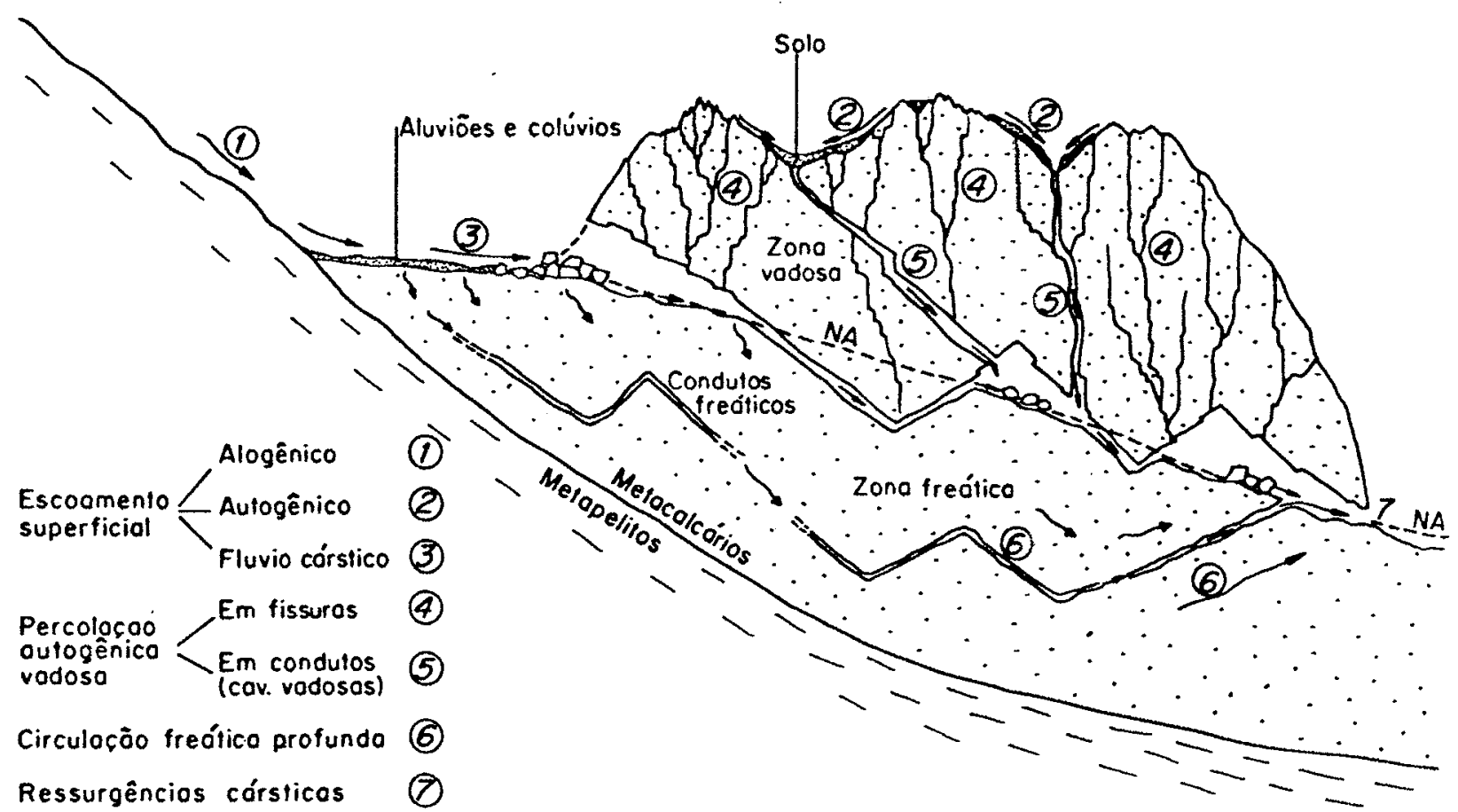

Figura 5.9 - Perfil esquemático de um sistema cárstico com a localização das fácies hidroquímicas identificadas na área de estudo.

\section{Ressurgências cársticas}

Esta fácies hidroquímica corresponde à mistura das demais classes de água identificadas, pois representa o escoamento de praticamente todo volume de água coletado e transmitido pelo sistema cárstico e sua bacia de captação, incluindo a água freática de circulação profunda abaixo do nível principal de condutos do rio subterrâneo do sistema (fíg 5.9).

Amostrou-se as ressurgências dos sistemas Pérolas-Santana, Grilo e Córrego Fundo (lagoa do Bairro da Serra, anexo 4.3).

$\mathrm{Na}$ média dos diferentes regimes de vazão das ressurgências, estas águas apresentam-se levemente saturadas em calcita $\left(\mathrm{SI}_{\mathrm{c}}=-0,06,87 \%\right.$ de saturação) e insaturadas em dolomita $\left(\mathrm{SI}_{\mathrm{d}}=-0,57,27 \%\right.$ de saturação). 
Sua dureza total média de $102 \mathrm{mg} / \mathrm{l}$ equivalentes $\mathrm{CaCO}_{3}$ e alcalinidade de $116 \mathrm{mg} / \mathrm{l}$ de $\mathrm{HCO}_{3}{ }^{-}$apresentam valores distintos das demais fácies hidroquímicas, aproximando-se mais das águas de percolação vadosa em condutos (tab 5.5 e fig 5.8). São semelhantes também à media dos valores médios de DT $\left(112 \mathrm{mg} /\right.$ equiv. a $\left.\mathrm{CaCO}_{3}\right)$ e alcalinidade $(126$ $\mathrm{mg} / \mathrm{l}$ de $\mathrm{HCO}_{3}{ }^{-}$) das demais fácies hidroquímicas, refletindo a mistura destas. O pequeno desvio é atribuído à mistura de diferentes volumes de cada fácies, conforme o regime de vazão e recarga do sistema.

\subsubsection{Evolução geoquímica das águas do sistema cárstico estudado}

O fluxo de água através de terrenos cársticos e seu aqüifero possui dois tipos de recarga: injeções alogênicas coletadas nas áreas de captação não carbonáticas que circundam o terreno carbonático e recarga autogênica derivada somente da precipitação captada diretamente pela superficie cárstica.

A análise da evolução química das águas no sistema cárstico, deve partir portanto, da interação entre o tipo de recarga (precipitação ou recarga alogênica) e a rocha carbonática.

\begin{tabular}{|c|c|c|c|c|c|}
\hline $\begin{array}{c}\text { Tipo } \\
\text { de } \\
\text { rocha }\end{array}$ & $\begin{array}{l}\bar{x}_{\operatorname{mix}}^{\max } \\
\text { cV\% } \Delta\end{array}$ & $\mathrm{CaO}$ & $\mathrm{MgO}$ & $\mathrm{CaO} / \mathrm{MgO}$ & Mineralogia \\
\hline \multicolumn{2}{|c|}{$\begin{array}{l}\text { Metacalcário } \\
\text { Calcítico (6) }\end{array}$} & $\begin{array}{c}54,4 \\
49,6 \\
43,1 \\
10 \% 11,3 \\
\end{array}$ & $\begin{array}{c}0,9 \\
0,6 \\
0,4 \\
44 \% 0,5 \\
\end{array}$ & $\begin{array}{c}123,3 \\
90,4 \\
58,6 \\
36 \% 64,7 \\
\end{array}$ & $\begin{array}{l}\text { Calcita, quartzo, } \\
\text { moscorita, clorita }\end{array}$ \\
\hline \multicolumn{2}{|c|}{$\begin{array}{c}\text { Metacalcário } \\
\text { Magnesiano } \\
(6) \\
\end{array}$} & $\begin{array}{c}55,5 \\
44,9 \\
31,2 \\
23 \% 24,3\end{array}$ & $\begin{array}{c}2,0 \\
1,2 \\
0,5 \\
42 \% 1,5\end{array}$ & $\begin{array}{c}62,4 \\
41,4 \\
24,5 \\
33 \% 37,9 \\
\end{array}$ & $\begin{array}{c}\text { Calcita, quartzo, } \\
\text { dolomita, } \\
\text { moscovita }\end{array}$ \\
\hline \multicolumn{2}{|c|}{$\begin{array}{l}\text { Metacalcário } \\
\text { Dolomítico } \\
(10)\end{array}$} & $\begin{array}{c}\frac{52,7,5}{32,6} \\
43,4 \\
52,2 \\
14 \% 19,6\end{array}$ & $\begin{array}{c}8,0 \\
3,9 \\
2,6 \\
41 \% 5,4\end{array}$ & $\begin{array}{c}17,5 \\
12,2 \\
5,1 \\
29 \% 12,4 \\
\end{array}$ & $\begin{array}{l}\text { Calcita, dolomita, } \\
\text { quartzo, moscovita } \\
\text { (clorita) }\end{array}$ \\
\hline \multicolumn{2}{|c|}{$\begin{array}{l}\text { Metadolomito } \\
\text { Calcítico (1) }\end{array}$} & 34,7 & 13 & 2,7 & $\begin{array}{l}\text { Calcita, dolomita, } \\
\text { quartzo, moscovita, } \\
\text { clorita }\end{array}$ \\
\hline \multicolumn{2}{|c|}{$\begin{array}{c}\text { Filito } \\
\text { Carbonático * }\end{array}$} & 20,4 & 5,2 & 3,9 & $\begin{array}{c}\text { Quartzo, } \\
\text { moscorita, calcita, } \\
\text { clorita, dolomita }\end{array}$ \\
\hline \multicolumn{2}{|c|}{$\begin{array}{c}\text { Filito } \\
\text { Carbonático } \\
\text { Dolomítico * }\end{array}$} & 19,2 & 6,7 & 2.9 & $\begin{array}{l}\text { Quartzo, } \\
\text { moscovita, } \\
\text { dolomita, clorita }\end{array}$ \\
\hline
\end{tabular}

Tabela 5.6 - Classificação química das rochas carbonáticas da área carbonática Furna-Santana. Análises químicas extraída de Barbieri (1993). * Composição média de 3 análises. $\bar{x}=$ valor médio, $\mathrm{CV}=$ coeficiente de variação, $\Delta=$ variação. ( ) número de análises. $\mathrm{CaO}$ e $\mathrm{MgO} \mathrm{em} \% \mathrm{em}$ peso na rocha.

$\mathrm{Na}$ área de estudo predominam metacalcários dolomíticos, seguidos de metacalcários magnesianos e calcíticos (tabela 5.6 e figura 2.4), classificados em função do seu teor em $\mathrm{CaO}$ e $\mathrm{MgO}$ (porcentagem em peso), seguindo a classificação de Martinet e 
Sougy (1961). Localmente ocorrem niveis de metadolomito calcítico (com até $60 \% \mathrm{em}$ dolomita e cerca de $25 \%$ em calcita, segundo Barbieri, 1993). Intercalações de filito carbonático e dolomítico são muito freqüentes. Nestes, a dolomita constitue o principal mineral carbonático (Barbieri, op. cit.).

A chuva na região de estudo apresenta $\mathrm{pH}$ medido entre 6,2 e $6,64 \mathrm{com}$ teor em $\mathrm{Ca}^{++}$e $\mathrm{Mg}^{++}$de 0,5 e $0,3 \mathrm{mg} / \mathrm{l}$, respectivamente $\left(\mathrm{DT}=2,5 \mathrm{mg} / \mathrm{l}\right.$ equiv. a $\mathrm{CaCO}_{3}$ ) e $\mathrm{PCO}_{2}$ de $10^{-3,5}$ ou 0,000318 atm. (atmosfera global média, segundo Drake e Harmon, 1973).

Esta água pluvial, coletada pela superficie de rochas metapeliticas (metassiltitos e filitos) e graníticas que circundam a área carbonática Furnas Santana, passa para um $\mathrm{pH}$ médio de 6,97 , com 3,1 e $1,3 \mathrm{mg} / 1$ de $\mathrm{Ca}^{++}$e $\mathrm{Mg}^{++}$(DT $=13 \mathrm{mg} / \mathrm{l}$ equiv. $\mathrm{CaCO}_{3}$ ) e $\mathrm{PCO}_{2}$ médio de $10^{-2,65} \mathrm{~atm}$. Este aumento da ordem de 7 vezes a pressão parcial de $\mathrm{CO}_{2}$ da atmosfera, evidencia que esta água alogênica percolou o horizonte superior do solo, tendendo a equlibrar-se com a atmosfera deste, rica em $\mathrm{CO}_{2}$ devido à grande quantidade de matéria orgânica em decomposição e respiração de raízes. A pressão parcial de $\mathrm{CO}_{2}$ no solo pode ser estimada através da equação de Brook et. al. (1983):

$$
\log P C O_{2}=-3,47+2,09\left(1-e^{-0,00172 E}\right)
$$

onde E corresponde à evapotranspiração média anual da área. Considerando $1000 \mathrm{~mm}$ como sendo a evapotranspiração média anual da área (conforme concluído no item 5.2.3), obtémse uma pressão parcial de $\mathrm{CO}_{2}$ de $10^{-1,754} \mathrm{~atm}$. para o solo da área estudada, o que corresponde a cerca de 55 vezes a pressão parcial de $\mathrm{CO}_{2}$ da atmosfera global média.

O aumento do teor em cálcio e magnésio na água alogênica, em relação à pluvial, é atribuído ao contato deste escoamento superficial com filitos e metassiltitos carbonáticos, os quais formam intercalações de espessura métrica na sequeência metapelítica da Formação Bairro da Serra.

A transição da fácies hidroquímica de escoamento alogênico para a de escoamento fluviocárstico é marcada pelo aumento brusco dos índices de saturação em calcita e dolomita (fig 5.10), os quais saltam de $-2,76$ e $-5,72$ para $-1,10$ e $-2,49$, com dureza total média de $49 \mathrm{mg} / \mathrm{l}$ equiv. a $\mathrm{CaCO}_{3}$. Este incremento na saturação em minerais carbonáticos é acompanhado pela diminuição da pressão parcial de $\mathrm{CO}_{2}$ e aumento do $\mathrm{pH}$ desta fácies em relação as águas alogênicas (fig 5.10, 5.11 e 5.12). O incremento do pH é conseqüência da diminuição da concentração de íons $\mathrm{H}^{+}$, os quais são consumidos pela formação de íons bicarbonato $\left(\mathrm{H}^{+}+\mathrm{CO}_{3}{ }^{--} \rightarrow \mathrm{HCO}_{3}^{-}\right)$. Os íons carbonato, por sua vez, são produzidos pela solubilização de $\mathrm{CaCO}_{3}$ e $\mathrm{CaMg}\left(\mathrm{CO}_{3}\right)_{2}$ presentes nos metacalcários. Esta dissolução consome $\mathrm{CO}_{2}$ na produção de $\mathrm{H}_{2} \mathrm{CO}_{3}$ tendendo a repor $\mathrm{H}^{+}\left(\mathrm{H}_{2} \mathrm{O}+\mathrm{CO}_{2} \rightarrow \mathrm{H}_{2} \mathrm{CO}_{3} \rightarrow \mathrm{H}^{+}\right.$ $+\mathrm{HCO}_{3}{ }^{-}$), o que é refletido pela queda da pressão parcial de $\mathrm{CO}_{2}$ nesta fácies bidroquímica.

A água de precipitação com $\mathrm{pH}$ médio de 6,42 dá origem a fácies de escoamemto autogênico, com pH médio de 8,09 e alto índice de saturação em carbonatos, após sua interação com a superficie carbonática de bacias poligonais fechadas. $\mathrm{O}$ aumento do $\mathrm{pH}$ 


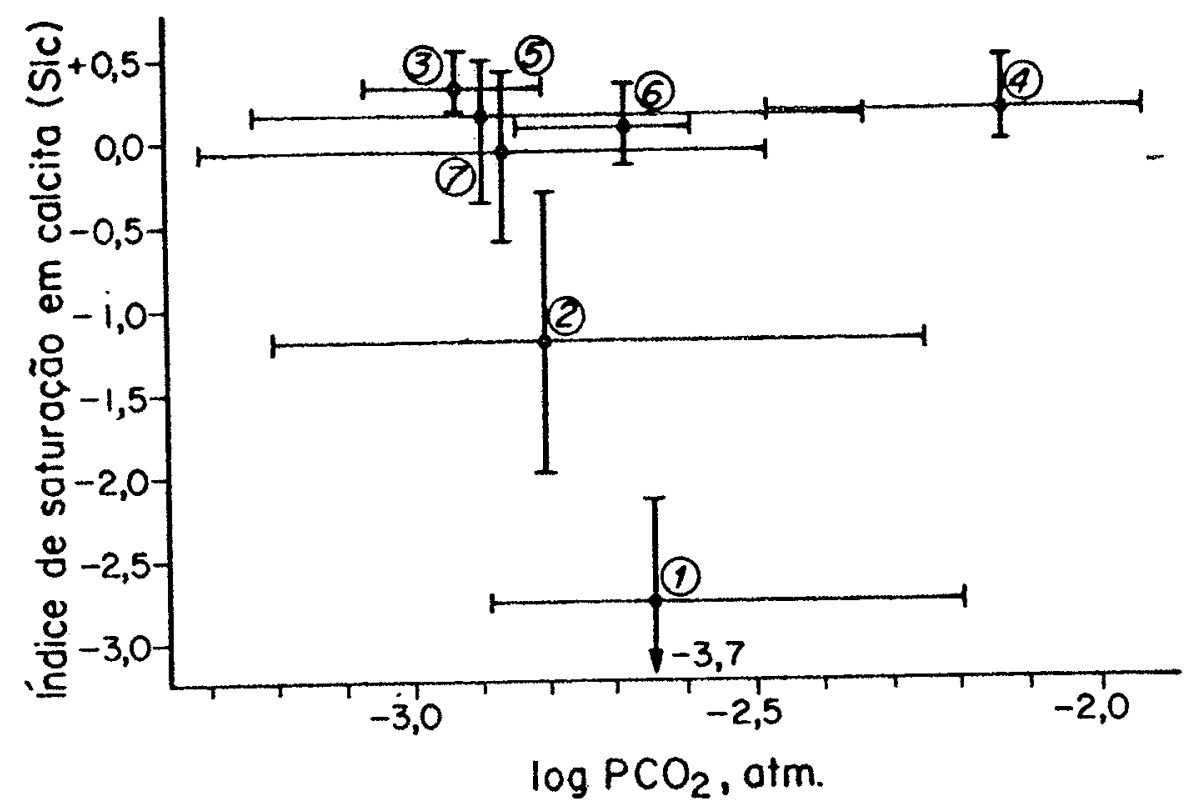

Figura 5.10 - Variação do índice de saturação em calcita em relação à pressão parcial de $\mathrm{CO}_{2}$ nas fácies hidroquímicas identificadas. 1- Fácies de escoamento alogênioo, 2-Fácies de escoamento fluviocárstico, 3Fácies de escoamento autogênico, 4- Fácies de percolaçăo vadosa em fissuras, 5- Fácies de percoalção vadosa em condutos, 6- Fácies de circulação freática profunda e 7- Fácies de ressurgência cárstica.

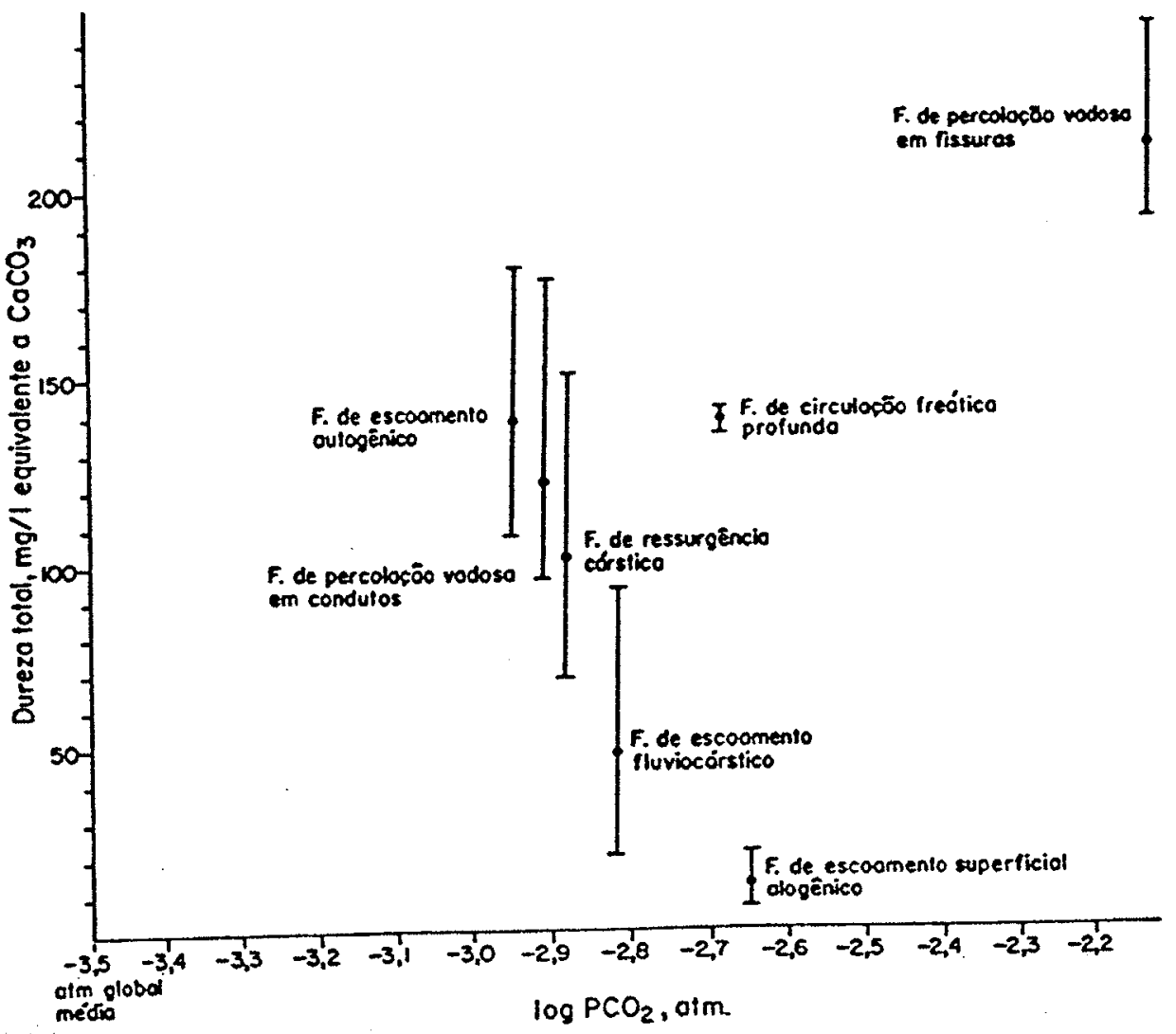

Figura 5.11 - Variação da dureza total em relação à pressão parcial de $\mathrm{CO}_{2}$ nas fácies hidroquímicas identificadas. 


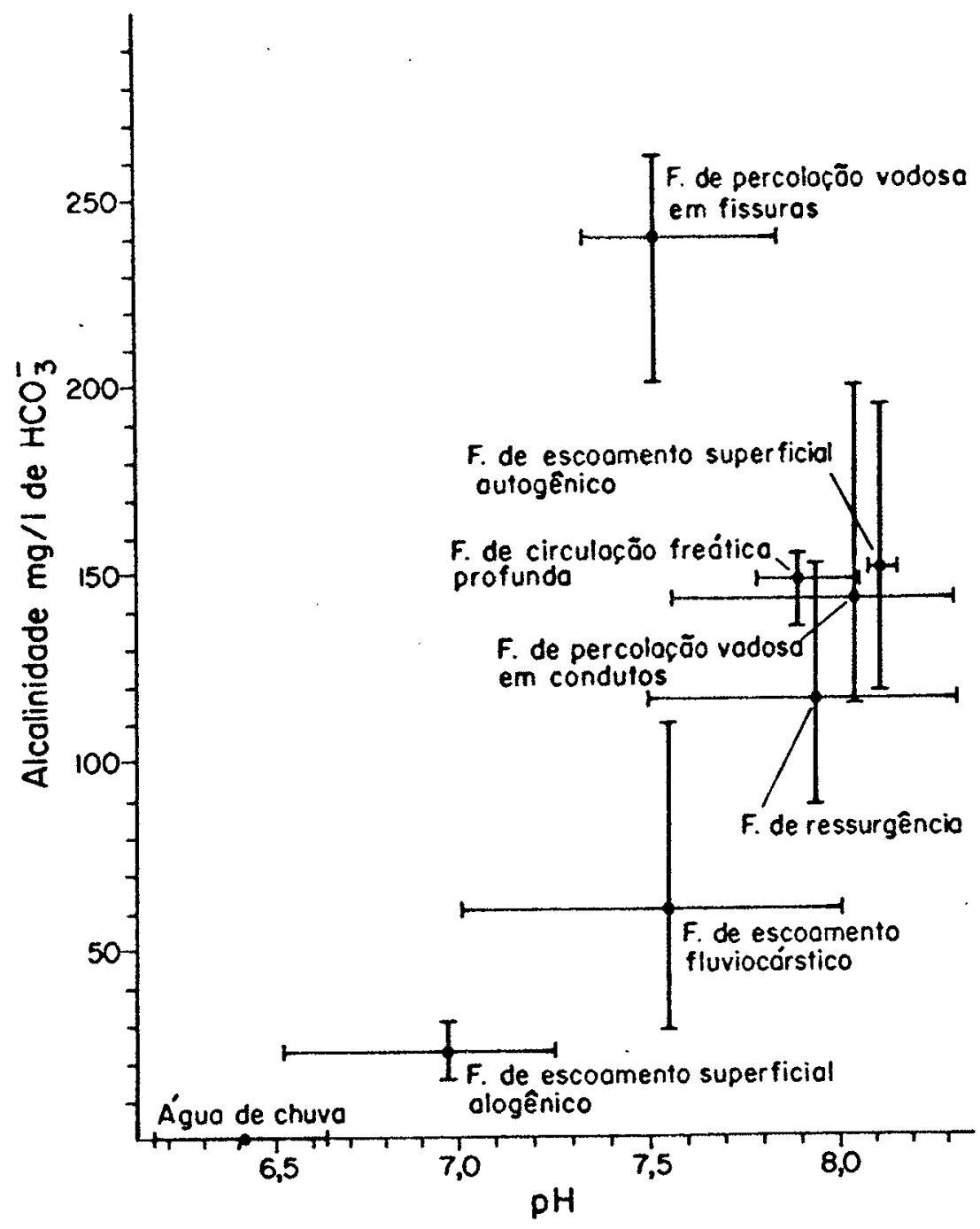

Figura 5.12 - Variação da alcalinidade em relação ao pH nas fácies hidroquímicas identificadas na área de estudo.

desta fácies, assim como do escoamento fluviocárstico e de ressurgências cársticas, mostra uma tendência diretamente proporcional ao incremento do teor em $\mathrm{HCO}_{3}{ }^{-}$(fig 5.12), apesar da grande dispersão dos pontos nesta relação (fig 5.13). Enquanto o índice de saturação em carbonato da água de escoamento autogênico é alto, a pressão parcial de $\mathrm{CO}_{2}$ nesta fácies é quase a metade de $\mathrm{PCO}_{2}$ da água alogênica e também inferior em relação a fácies fluviocárstica (fig 5.11). Esta evolução química da água é decorrente do ambiente de dissolução da rocha carbonática e do tempo de residência da água na zona enriquecida em gás carbônico.

A correlação positiva entre $\mathrm{pH} \mathrm{e} \mathrm{HCO}_{3}{ }^{-}$indica que conforme progride o consumo de $\mathrm{CO}_{2}$ pela dissolução de calcita e dolomita, este é continuamente suprido pela atmosfera do solo, e a reação geral de dissolução de calcita:

$$
\mathrm{CaCO}_{3}+\mathrm{CO}_{2}+\mathrm{H}_{2} \mathrm{O}=\mathrm{Ca}^{++}+2 \mathrm{HCO}_{3}^{-}
$$

(similar à de dissolução de dolomita), tende a atingir o equilíbrio, tornando a água saturada a supersaturada em calcita, situação típica de sistemas abertos de dissolução (sistemas coincidentes), conforme os modelos de dissolução de calcita e dolomita de Langmuir (1971), Harmon (1973) e Drake (1983). 


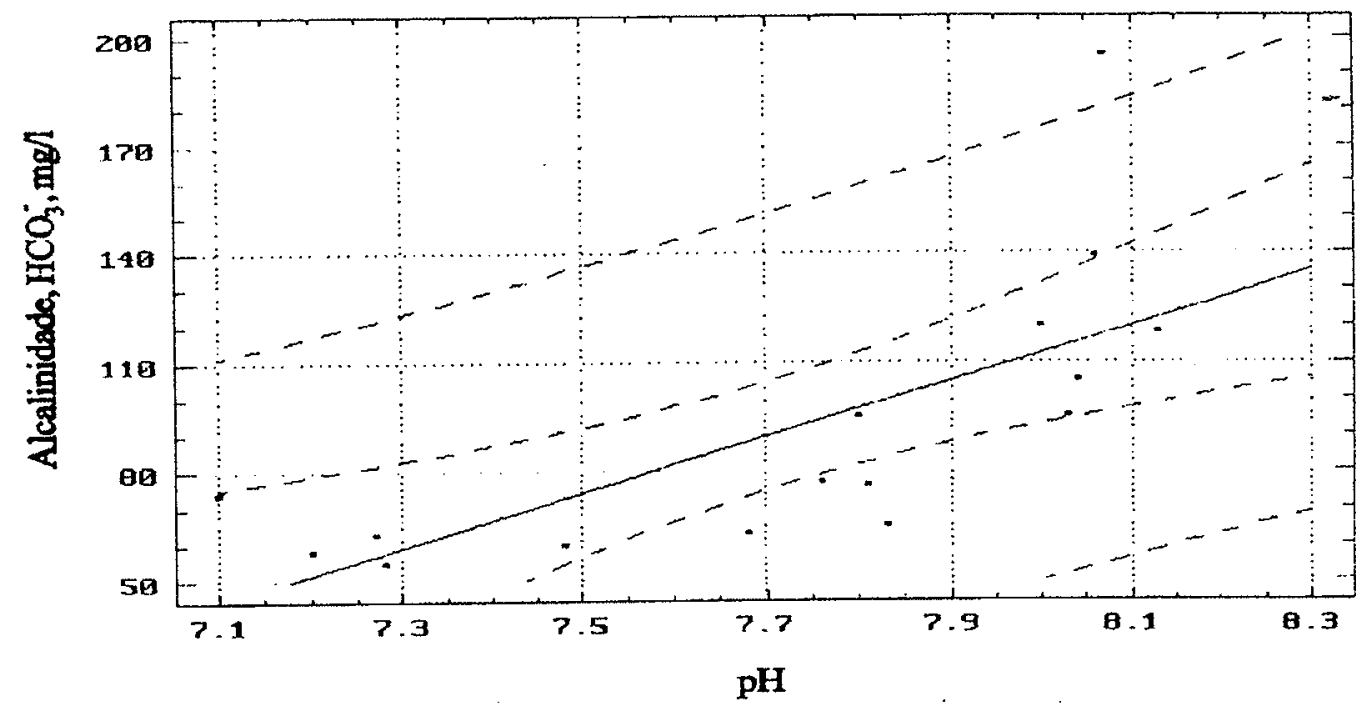

A
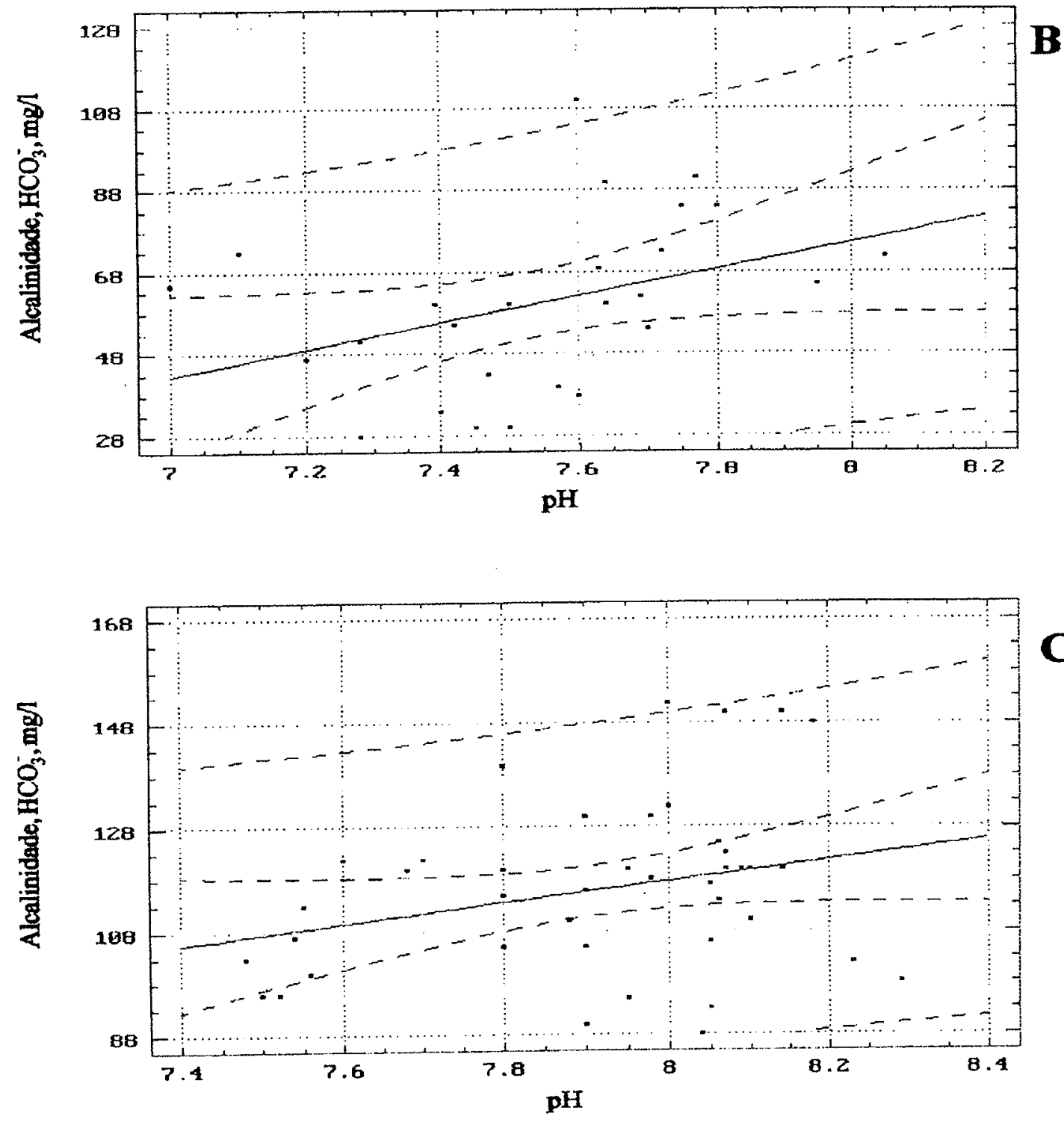

C

Fig 5.13 - Alcalinidade em função do pH das amostras do rio Roncador na caverna Pérolas (A), do escoamento fluviocárstico na planície do polje junto ao sumidouro da cav. Pérolas (B) e da ressurgência na cav Santana. 
A variação da pressão parcial de $\mathrm{CO}_{2}$ entre fácies hidroquímicas é atribuida principalmente a tempos diferentes de residência da água na zona do solo enriquecida em $\mathrm{CO}_{2}$ e à presença ou não de calcita elou dolomita. A fácies alogênica, além de percolar em ambiente quase que desprovido de calcita e dolomita (o que anula o processo de consumo de $\mathrm{CO}_{2}$, conforme comentado acima), representa água coletada em redes de drenagem superficiais continuas e muito maiores em área do que as bacias poligonais de captação autogênica. Esta área maior de coleta do escoamento superficial condiciona um contato mais prolongado da água de percolação com o horizonte superior do solo e conseqüentemente uma $\mathrm{PCO}_{2}$ mais elevada nesta água de escoamento alogênico em relação a água de escoamento superficial autogênico, a qual com $\mathrm{PCO}_{2}$ inferior, reflete tempo de residência menor no solo, em função das bacias de captação menores.

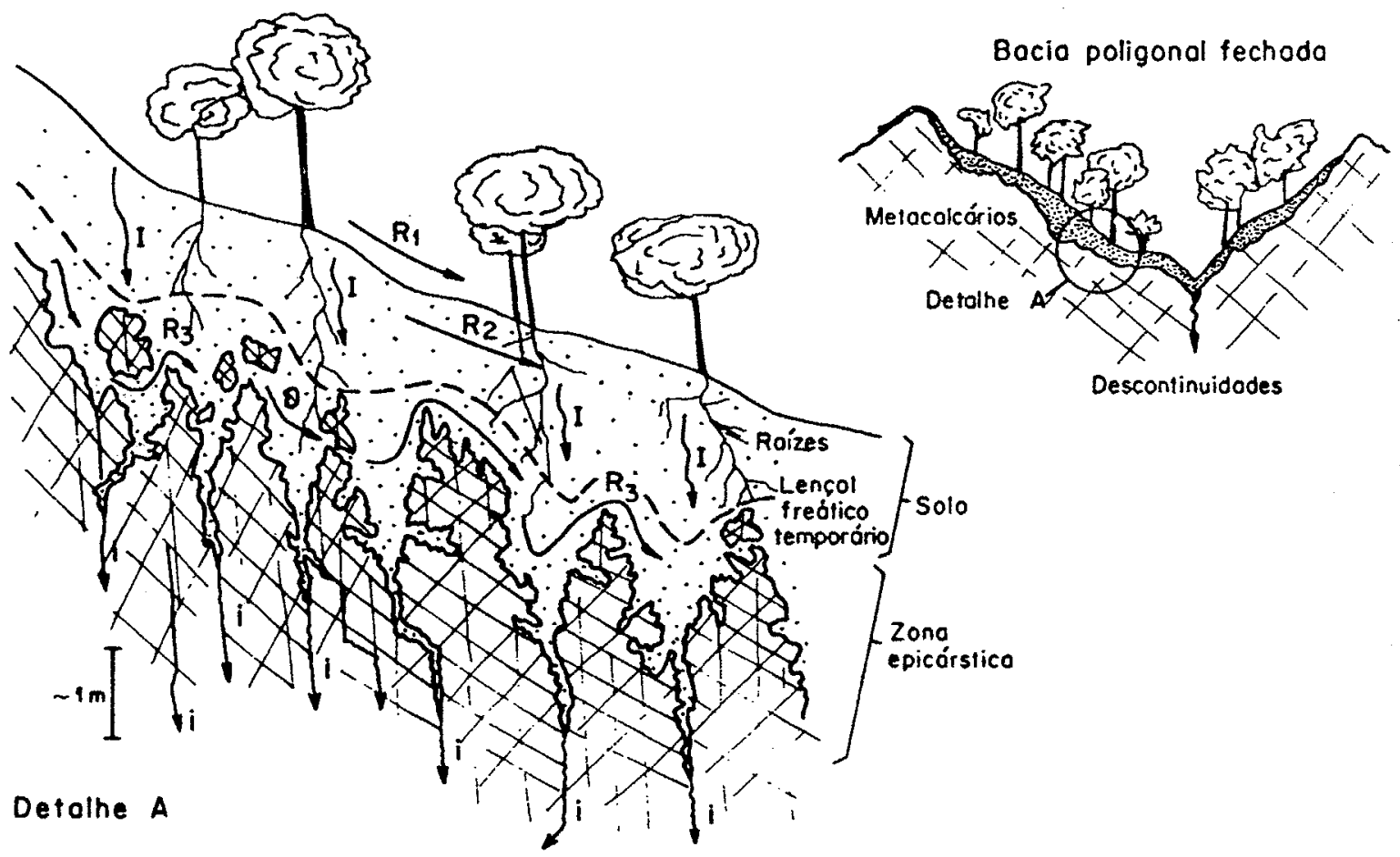

Figura 5.14 - Seção esquemática da superficie dos metacalcários nas encostas de bacias poligonais fechadas mostrando a morfologia da zona epicárstica (segundo definicão de Williams, 1985). R1- escoamento superficial direto, R2-escoamento lateral na porosidade do solo, R3- escoamento lateral na zona epicárstica. Velocidade de R1>R1>R3. Iinfiltração vertical, $1>i$, condicionando lençol freático temporário.

Parte do escoamento superficial autogênico alimenta a fácies de percolação vadosa em fissuras, onde atinge os valores máximos de dureza total, alcalinidade e $\mathrm{PCO}_{2}$ em relação às demais fácies hidroquímicas (fig 5.11 e 5.12). A água de percolação vadosa em fissuras corresponde à fração da recarga autogênica coletada por bacias poligonais fechadas e concentrada na zona epicárstica (seg Williams, 1985) ou subcutânea (seg. Gunn, 1983), a 
qual corresponde ao nível superior da rocha carbonática parcialmente intemperizada, predominantemente coberta por solo e entalhada por sulcos e fendas (karren ou lapiás cobertos) de dissolução (figura 5.14). Devido a alta rugosidade da superficie epicárstica, o fluxo lateral de água do escoamento subcutâneo (nas encostas de depressões poligonais e abaixo do solo) será lento, o que condiciona um tempo maior de interação, tanto entre água e rocha carbonática, como também, entre água e o ambiente do solo com alta $\mathrm{PCO}_{2}$, o que resulta no mais elevado teor em sólidos dissolvidos e maior $\mathrm{PCO}_{2}$ desta fácies hidroquímica (figs 5.10 e 5.11).

Plotando a alcalinidade em função do $\mathrm{pH}$ da fácies hidroquímica de percolação vadosa em fissuras, obtém-se uma relação onde o teor em $\mathrm{HCO}_{3}^{-}$é inversamente proporcional ao $\mathrm{pH}$ (fig 5.15). Esta relação corresponde à evolução do sistema $\mathrm{CaCO}_{3}+$ $\mathrm{H}_{2} \mathrm{O}+\mathrm{CO}_{2}$ em condições fechadas em relação ào $\mathrm{CO}_{2}$ (sistema seqüencial, Langmuir, 1971), onde a água com alta $\mathrm{PCO}_{2}$ inicial continua seu caminho de percolação pelo maciço carbonático através de juntas alargadas, mas isolada da fonte de $\mathrm{CO}_{2}$. Desta forma, a diminuição de $\mathrm{CO}_{2}$ na solução, será acompanhada, com o tempo, de um incremento de $\mathrm{HCO}_{3}{ }^{-}$. A diminuição do $\mathrm{pH}$ com o aumento da concentração do íon hidrogenocarbonato é reflexo do aumento da concentração de $\mathrm{H}^{+}$na solução, onde $\circ \mathrm{CO}_{2}$ é gradativamente consumido (diminuindo a $\mathrm{PCO}_{2}$ da solução) para gerar $\mathrm{H}_{2} \mathrm{CO}_{3}$ e este, por sua vez, consumido para formar $\mathrm{H}^{+}$e $\mathrm{HCO}_{3}^{-}$, segundo o equilíbrio:

$$
\mathrm{H}_{2} \mathrm{O}+\mathrm{CO}_{2} \leftrightarrows \mathrm{H}_{2} \mathrm{CO}_{3} \leftrightarrows \mathrm{H}^{+}+\mathrm{HCO}_{3}^{-} \text {, }
$$

tornando a solução saturada a supersaturada em calcita, com índices de saturação em calcita de até 0,5 (tabela 5.5).

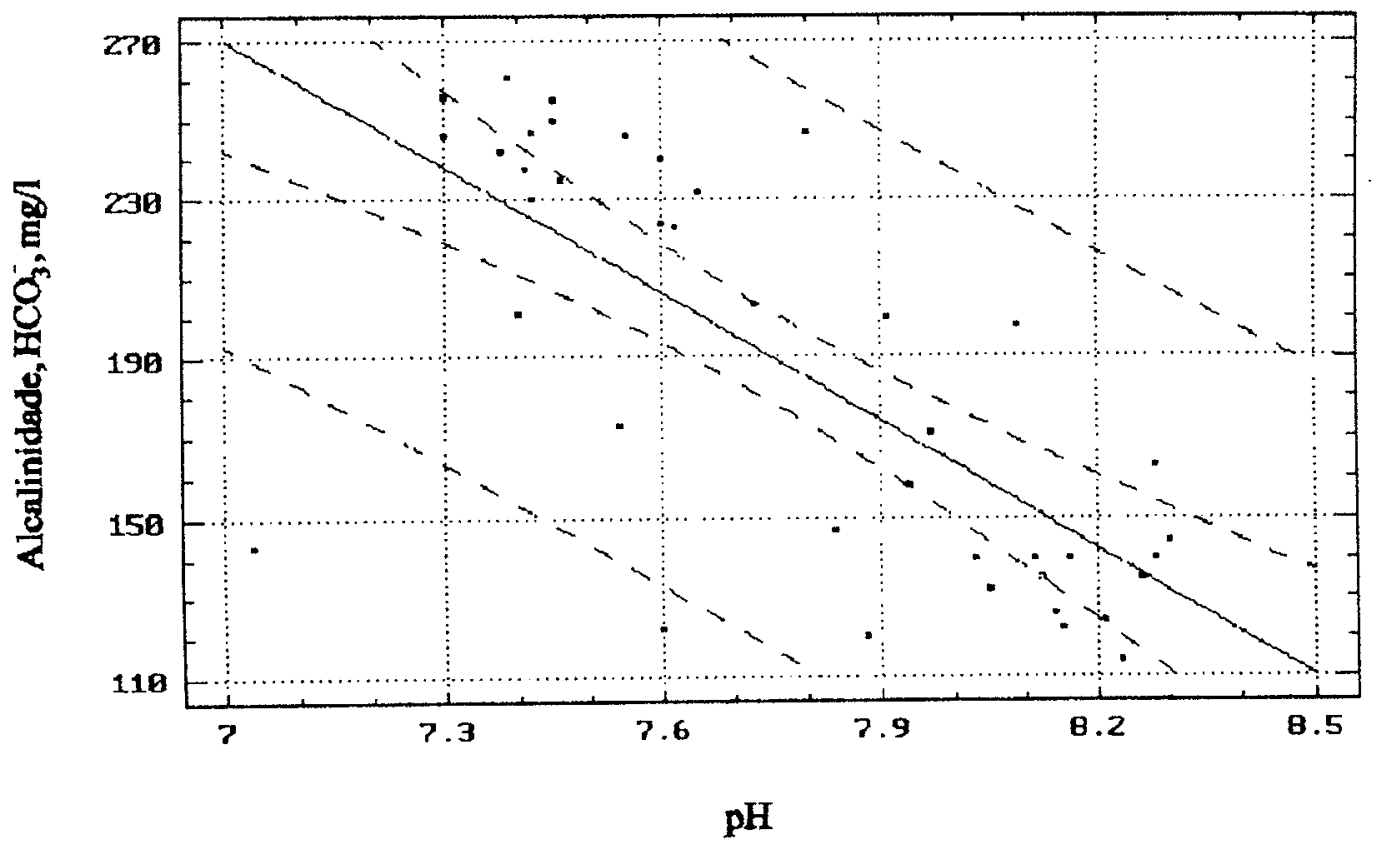

Figura 5.15 - Alcalinidade em função do pH das águas de percolação vadosa em fissuras. 
Esta fácies hidroquímica de percolação vadosa em fissuras é a principal fonte de calcita secundária precipitąda em cavidades no interior do maciço carbonático (Bull, 1983). A precipitação de carbonatos (principalmente calcita e/ou aragonita) é condicionada pelo caráter saturado destas águas, as quais, em equilíbrio com elevada $\mathrm{PCO}_{2}$, ao atingirem cavernas, sofrem uma degaseificação, pois a solução tendendo a equilibrar-se com a pressão de $\mathrm{CO}_{2}$ da cavidade (normalmente próxima da $\mathrm{PCO}_{2}$ da atmosfera), perde $\mathrm{CO}_{2}$ para a atmosfera da cavidade, tornando-se supersaturada em relação aos carbonatos citados, o que causa a precipitação destes.

Um aspecto importante na evolução geoquímica das águas de percolação vadosa em fissuras é o controle da precipitação de calcita ou aragonita pelo teor em $\mathrm{Mg}^{++}$nestas águas. Notou-se que os pontos de gotejamento com razão molar $\mathrm{Ca}^{++} / \mathrm{Mg}^{++}$entre 1,6 e 0,6 (amostras 170 a 172, anexo 5.4) em contraste com aqueles de relação alta entre 11 e 1.8 , precipitam aragonita no lugar de calcita, comprovando o controle da precipitação de aragonita por soluções ricas em magnésio, conforme proposto por Lippman (1960), evidenciado por Gonzales e Lohmann (1988) nas cavernas do Novo México (EUA) e por Barbieri (1993) nas cavernas da região estudada. A produção de soluções percolantes com razões baixas de cálcio e magnésio está associada à lixiviação de estratos de filito carbonático, onde dolomita perfaz quase que $100 \%$ dos minerais carbonáticos e dolomitos calcíticos, os quais formam intercalações centimétricas a métricas nos metacalcários calcíticos dominantes (Barbieri, 1993).

A percolação vadosa em condutos pode ser sub-classificada em dois tipos de águas com agressividades distintas em relação aos minerais carbonáticos. Aquela saturada em calcita é alimentada principalmente pela somatória de infiltrações lentas ao longo de fissuras, apresentando volumes reduzidos e dando origem à depositos calcíticos secundários em cavernas, através da exsolução de $\mathrm{CO}_{2}$. O segundo tipo representa a água de captação superficial autogênica, de escoamento rápido em superficie e que é absorvida por fundos de depressões diretamente conectados a condutos vadosos (invasões vadosas). Sua insaturação em calcita e dolomita é conseqüência do escoamento inicial em superficie sobre o solo residual argiloso que cobre o metacalcário, absorção rápida por condutos e, portanto, pouco tempo de interação com a rocha carbonática.

A fácies de percolação freática profunda representa a mistura de todas as fácies hidroquímicas acima caracterizadas, o que é evidenciado pela posição mediana de sua dureza total (fig 5.11), índice de saturação em calcita (fig 5.10) e alcalinidade desta fácies em relação às demais. $O$ baixo coeficiente de variação dos seus principais parâmetros fisicoquímicos (tabela 5.5) reflete o tempo maior de residência desta fácies no maciço carbonático, em relação às demais, o que acaba reduzindo ao máximo a influência sazonal sobre o quimismo desta fácies aquática. Apesar da alta dureza total e alacalinidade, semelhantes às da água de escoamento epicárstico subcutâneo, seu pH é bem inferior, sugerindo evolução do sistema $\mathrm{CaCO}_{3}, \mathrm{H}_{2} \mathrm{O}$ e $\mathrm{CO}_{2}$ em ambiente seqüencial com relação ao $\mathrm{CO}_{2}$ 
A temperatura média superior da fácies freática profunda (tab 5.5) é interpretada como sendo influência do grau geotérmico sobre esta água (associado ao tempo maior de residência desta no maciço carbonático) em função da elevada profundidade de çirculação desta, a qual deve atingir entre 200 a $350 \mathrm{~m}$ abaixo do N.A., segundo o modelo de profundidades de condutos e proto-condutos esboçado no item 4.3.3.2.

Observando as análises químicas da fácies de circulação freática profunda (amostras $90,98,104,105$ e 167, anexo 5.3), nota-se que estas, em comparação com as demais fácies hidroquímicas, possuem teores mais elevados (entre 4 e $8 \mathrm{mg} / \mathrm{l}$ ) de sulfato. Associa-se a origem do ânion $\mathrm{SO}_{4}^{--}$à oxidação do enxôfre reduzido de sulfetos, principalmente pirita, no ambiente freático com oxigênio dissolvido, segundo a reação (Bottrell et. al., 1991):

$$
\mathrm{FeS}_{2}+\mathrm{H}_{2} \mathrm{O}+7 / 2 \mathrm{O}_{2}=\mathrm{Fe}^{++}+2 \mathrm{SO}_{4}^{--}+2 \mathrm{H}^{+}
$$

A pirita ocorre na forma de cristais milimétricos disseminados em alguns estratos de metacalcário e mais freqüentemente em camadas carbonático-pelíticas intercaladas na seqüência metacarbonática.

A presença de sulfato também nas águas cársticas vadosas da área de estudo, apesar de quase não detectada pela amostragem realizada, é evidenciada pela presença de gipsita secundária depositada pelas águas de percolação vadosa em fissuras ao atingir certos trechos de cavernas na zona vadosa.

$\mathrm{O}$ ânion $\mathrm{SO}_{4}^{--}$detectado nas águas freáticas profundas possui uma importante implicação espeleogenética, conforme Ball e Jones (1990), pois além de constituir uma fonte de íons $\mathrm{H}^{+}$para aumentar a dissolução no sistema $\mathrm{CaCO}_{3}, \mathrm{H}_{2} \mathrm{O}$ e $\mathrm{CO}_{2}, o$ ácido sulfúrico gerado na oxidação de pirita pode representar uma reativação da agressividade da água em ambientes profundos do aqǘfero carbonático, onde a água de percolação ao longo de descontinuidades após um tempo de residência maior e isolado de fontes de $\mathrm{CO}_{2}$, a princípio, já estaria saturada em calcita, considerando-se somente a corrosão pelo ácido carbônico.

A fácies hidroquímica de ressurgências cársticas, conforme citado anteriormente, representa o retorno para a superficie, de praticamente todo volume de água absorvido e transmitido pelo maciço carbonático. A grande variabilidade com o tempo do índice de saturação em calcita e dolomita desta fácies $\left(\Delta \mathrm{SI}_{\mathrm{c}}=1,04\right.$ e $\left.\Delta \mathrm{SI}_{\mathrm{d}}=2,16\right)$ expressa a influência do regime de recarga do aqüífero sobre o quimismo do sistema cárstico. Períodos de alta recarga (recorrência de eventos de chuva) estão associados a níveis maiores de vazão da ressurgência com água insaturada em calcita e dolomita ( $\mathrm{SI}_{c}$ e $\mathrm{SI}_{d}$ negativos). Ao contrário, períodos de baixa recarga, com niveis menores de vazão associam-se a água saturada em calcita e dolomita (índices de saturação positivos, fig 5.10 e tab 5.5). 0 índice de saturação dos períodos de baixa vazão é semelhante ao da água de circulação freática profunda e ligeiramente inferior ao da fácies de percolação vadosa em fissuras, o que indica que o escoamento basal da ressurgência é alimentado principalmente por estas fácies hidroquímicas, com mistura de uma fração pequena de água insaturada, provavelmente de origem fluviocárstica ou até de contribuições alogênicas injetadas ao longo do contato litológico e transmitidas diretamente para a rede principal de condutos. Por outro lado, o 
escoamento direto, responsável por eventos de vazões elevadas, apresenta índice de saturação em calcita semelhante ao da fácies fluviocárstica com niveis de saturação mais altos (fig 5.10). Isto é interpretado como sendo reflexo do curto tempo de residência no maciço carbonático da água de escoamento direto, cuja fonte principal de sólidos dissolvidos é a parte da água armazenada em condutos e fissuras (tanto freáticos como vadosos), a qual gradativamente é expulsa e substituída nos eventos de recarga do aqüífero, somando-se ao escoamento direto.

A sazonalidade química de ressurgências cársticas será detalhada no próximo item.

\subsection{Dinâmica corrosiva do sistema cárstico Pérolas-Santana}

A dinâmica corrosiva de sistemas cársticos pode ser expressada quantitativamente pelos seguintes parâmetros derivados: taxa de saturação em calcita e dolomita de águas alogênicas ao invadirem o terreno cárstico, variação sazonal do índice de saturação em calcita e dolomita das águas que circulam pelo sistema (principalmente da sua ressurgencia e a relação entre a discarga desta e a dureza total da água) e a taxa de denudação química da bacia hidrográfica associada ao sistema.

\subsubsection{Taxa de saturação de águas alogênicas (TS)}

A taxa de saturação em calcita e dolomita de córregos alogênicos, ao adentrarem terrenos cársticos, revela a distância necessária para que o escoamento superficial sobre rochas carbonáticas atinja a saturação nestes minerais. É definida aqui pela razão entre a variação do índice de saturação $\left(\Delta S I_{\mathcal{C}}\right.$ ou $\Delta S I_{d}$, expressos em unidades de saturação, US) e a distância $(d \mathrm{em} \mathrm{km})$ percorrida pela água sobre o terreno cárstico, até atingir o estado saturado:

$$
T S=\frac{\Delta S I_{c}}{d}
$$

Para o córrego Pérolas localizado sobre o polje de contato da extremidade SW da área carbonática Furnas-Santana obteve-se uma taxa de saturação em calcita entre 1,4 e 1,5 unidades de saturação $/ \mathrm{km}$. Isto significa que o córrego alogênico aumenta 1,4 a 1,5 unidades de saturação em calcita por quilômetro de fluxo sobre o terreno carbonático, desde o contato litológico (P1), até atingir a saturação em calcita (fig 5.16). Entre o contato e o sumidouro, o córrego Pérolas meandra na planície associada ao polje, coberta em grande parte por aluviões alóctones que contornam colinas de substrato calcário. A taxa de $1,4 \mathrm{US} / \mathrm{km}$ corresponde a uma vazão aproximada de $0,01 \mathrm{~m}^{3} / \mathrm{s}$ do córrego, enquanto a taxa de $1,5 \mathrm{US} / \mathrm{km}$ associa-se a $0,03 \mathrm{~m}^{3} / \mathrm{s}$. Após cerca de $2,34 \mathrm{~km}$ de escoamento sobre o terreno cárstico, o córrego Pérolas atinge o estado saturado em calcita, o qual é mantido praticamente constante até a ressurgência do sistema (fig 5.16), no regime de vazão entre eventos de chuva. A taxa acima calculada não é válida para periodos de chuvas.

Com relação à dolomita, apesar do rápido incremento da saturação da água neste mineral desde o contato litológico (fig 5.16), não se obteve $T S_{d}$ pelo fato desta drenagem não atingir o estado saturado em dolomita ao longo de todo seu percurso sobre rochas carbonáticas. 
Troester e White (1986) obtiveram taxas de saturação em calcita entre 0,2 e 0,5 US/ $\mathrm{km}$ para rios alogênicos que circulam sobre terrenos cársticos (com vazões médias entre 0,4 e $3,3 \mathrm{~m}^{3} / \mathrm{s}$ ) na região nordeste da itha de Porto Rico.

A interpretação deste parâmetro e sua comparação com o de outras áreas cársticas, deve considerar os seguintes aspectos, dos quais depende diretamente: regime de vazão da drenagem fluviocárstica, tipo de alimentação desta drenagem sobre o terreno cárstico (escoamento da zona epicárstica e/ou superficial), tipo de cobertura associada ao vale e planície do rio (cobertura não carbonática, alóctone ou autóctone), natureza do leito fluvial (com depósitos aluvionares e/ou rocha expoxta), tipo de rocha carbonática e gradiente hidráulico da drenagem.

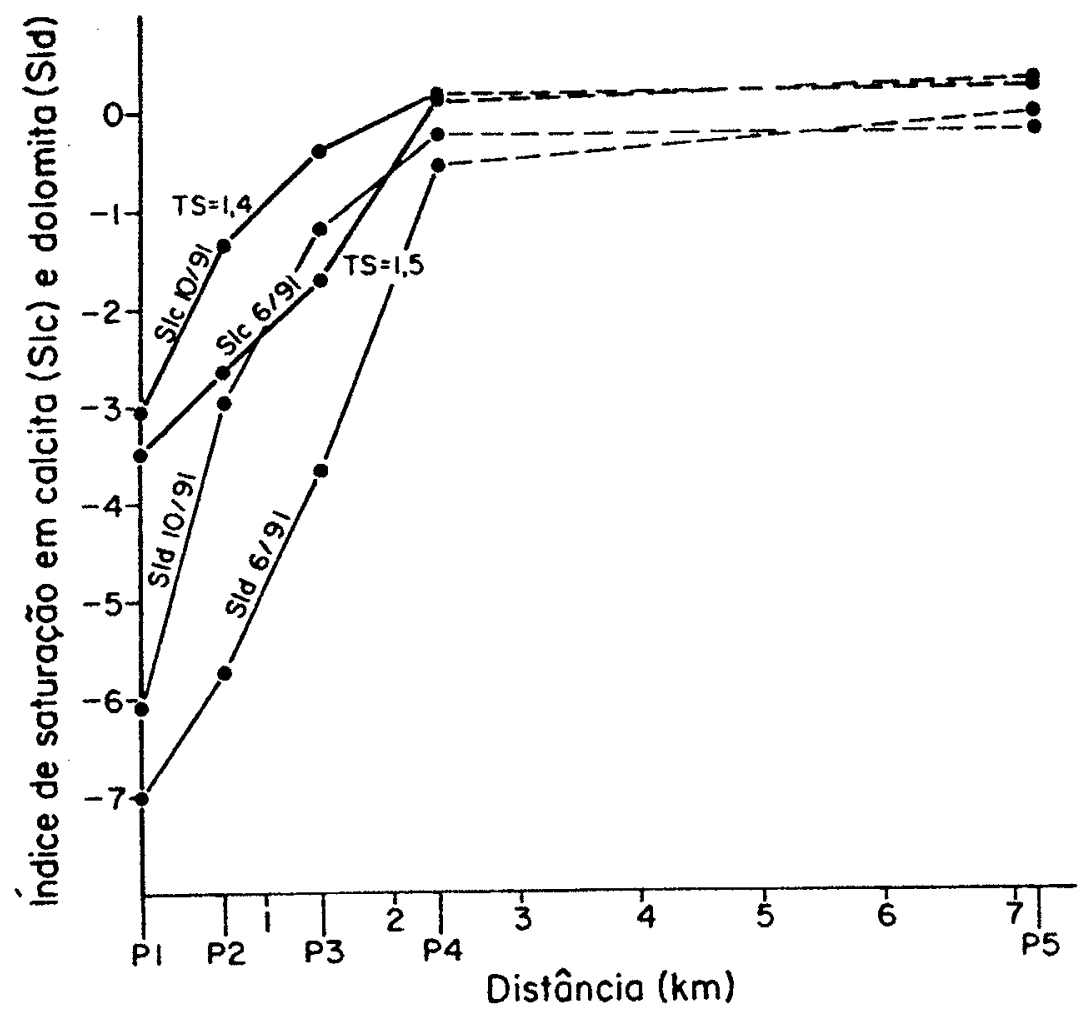

Figura 5.16 - Variação dos índices de saturação em calcita e dolomita ao longo da drenagem do sistema Pérolas-Santana, entre o contato com metapelitos e a ressurgência do sistema. P1- sobre o contato, P2 e P3 - sobre a planície do polje de contato, P4- no início da caverna Pérolas e P5- na ressurgência do sistema, proximidades da entrada da caverna Santana.

No presente estágio deste trabalho, não se dispõe de medidas do parâmetro acima, para um conjunto de drenagens alogênicas sobre metacalcários, em situações geológicas e geomórficas variadas, o que impede uma análise interpretativa da taxa de saturação obtida para o córrego Pérolas. Este dado deverá ser aliado à futuras medidas, permitindo então, uma interpretação significativa. 


\subsubsection{Variação sazonal do índice de saturação em calcita e dolomita de águas cársticas}

Com base na variação do índice de saturação em calcita e dolomita de um conjunto de análises de água distribuídas regularmente ao longo de um ano, define-se a amplitude de variação sazonal da saturação, parâmetro útil para quantificar a duração da agressividade de águas cársticas em relação a calcita e dolomita. Como exemplos deste parâmetro selecionou-se a variação sazonal do índice de saturação das águas da ressurgência em contraste com as de percolação vadosa em fissuras do sistema Pérolas-Santana (fig 5.17a e $5.17 \mathrm{c}$ ).

A ressurgência do sistema Pérolas-Santana apresentou índice máximo de saturação em calcita de $+0,25$ e mínimo de $-0,61$, o que resulta numa variação de 0,86 para o período de junho de 1990 a fevereiro de 1991 (20 meses, fig 5.17a). Com relação ao período de junho de 90 a maio de 91 , a ressurgência apresentou vazão insaturada por cerca de 9 meses (setembro de 90 a maio de 91) e saturada por 3 meses (junho a agosto). Com este resultado, afirma-se que por aproximadamente 9 meses, por ano hidrológico, o fluxo de água subterrânea deste sistema se comporta, de modo geral, agressivo em relação à calcita, causando portanto, abrasão química dos metacalcários ao longo da rota de fluxo da água subterrânea deste sistema neste período, o qual é alternado por periodos de cerca de 3 meses de fluxo quimicamente inerte em relação à calcita dos metacalcàrios.

Com relação à dolomita, o escoamento da ressurgência do sisiema Pérolas-Santana apresenta índice de saturação entre $-1,77$ e $-0,11$, o que resulta numa variação sazonal de 1,66, permanecendo agressiva ao longo de todo ano hidrológico monitorado (fig 5.17a).

A variação do índice de saturação em calcita e dolomita do escoamento da ressurgência do sistema Pérolas-Santana e, conseqüentemente, da concentração em sólidos dissolvidos, é inversamente proporcional a vazão do sistema carstico, conforme é visualizado pela combinação das curvas das figuras 5.17 a e 5.17 b e pela relação obtida entre a dureza total deste escoamento e sua vazão (fig 5.18).

A vazão, por sua vez, é controlada pela recarga do aqüífero com precipitação de água meteórica. Períodos com chuvas intensas freqüentes determinam elevação dos níveis de vazão do sistema. Portanto, quanto mais prolongado for o periodo de chuvas, tanto maior será o período de vazões altas, causando períodos mais lorgos de escoamento corrosivo (insaturado) em relação aos minerais carbonáticos. A diminuição da concentração de sólidos dissolvidos (aumento da agressividade) com o aumento da vazão é resposta direta do tempo menor de residência das águas de vazões altas, devido ao aumento da velocidade de fluxo destas, ao longo dos condutos subterrâneos $(Q=\vee \times A, \vee=$ velocidade, $\mathrm{A}=$ seção média dos condutos).

Devido a recorrência de anos mais úmidos entre períodos mais secos, como o ano de 1990, com um total anual de $1792 \mathrm{~mm}$ de chuva, seguidos por $1320 \mathrm{~mm}$ no ano de 91 , o período de agressividade do fluxo de água subterrânea para o ano de 91 foi menor que 9 meses. Mas, por outro lado, anos muito úmidos, como foi o de 1983 , com $2400 \mathrm{~mm}$ de chuva anuais (DAEE, 1992), devem refletir periodos anuais mais prolongados de agressividade do fluxo. O período de 9 meses de agressividade em relafão a calcita por ano 


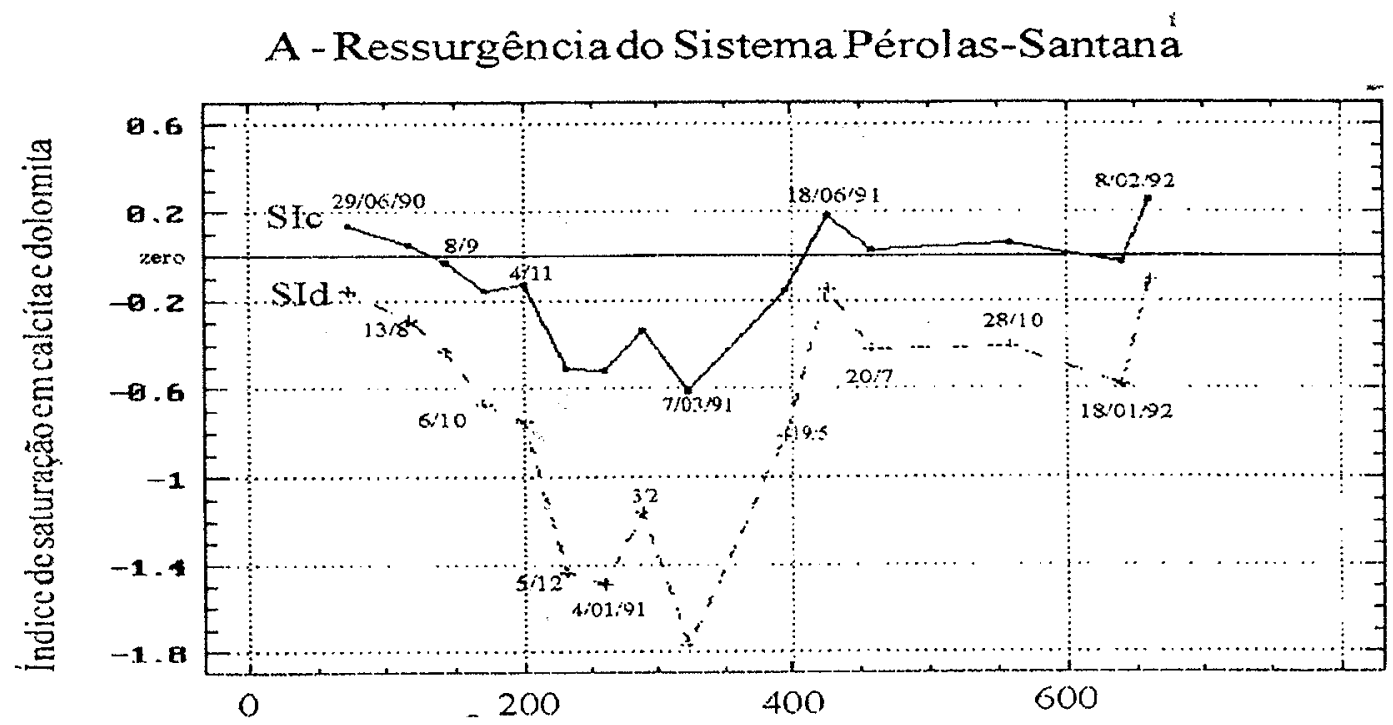

B - Ressurgência do Sistema Pérolas-Santana

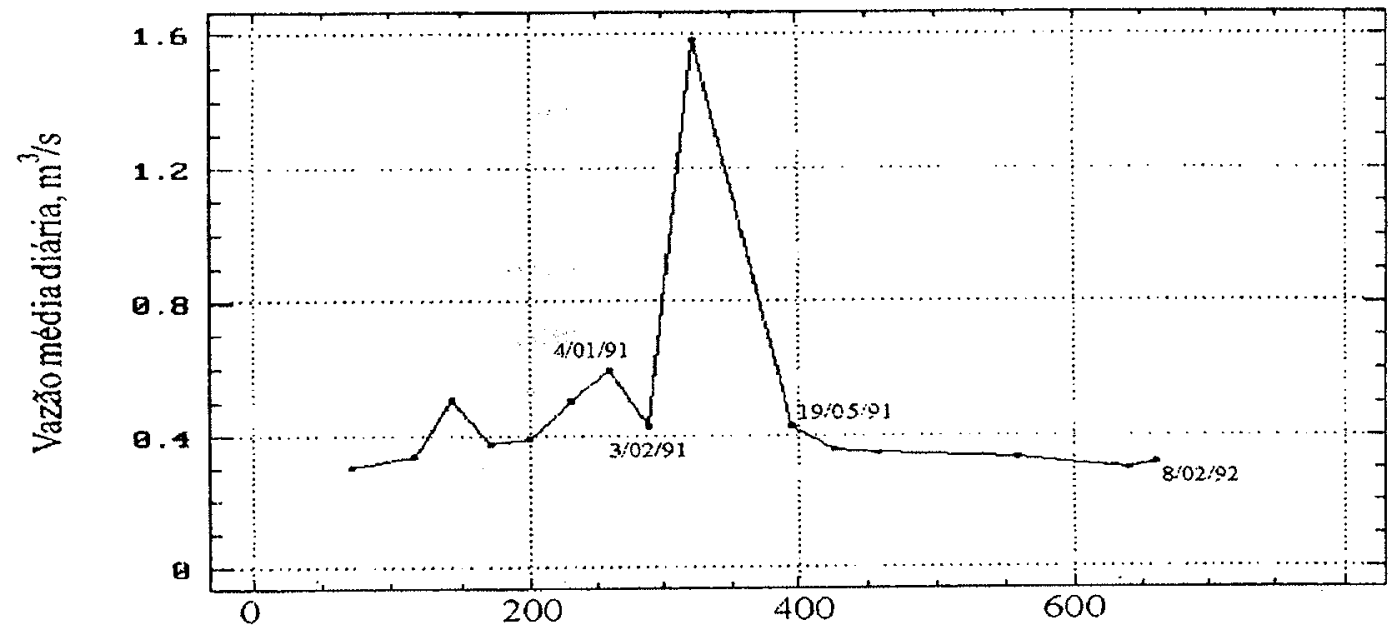

C - Percolação vadosa em fissuras

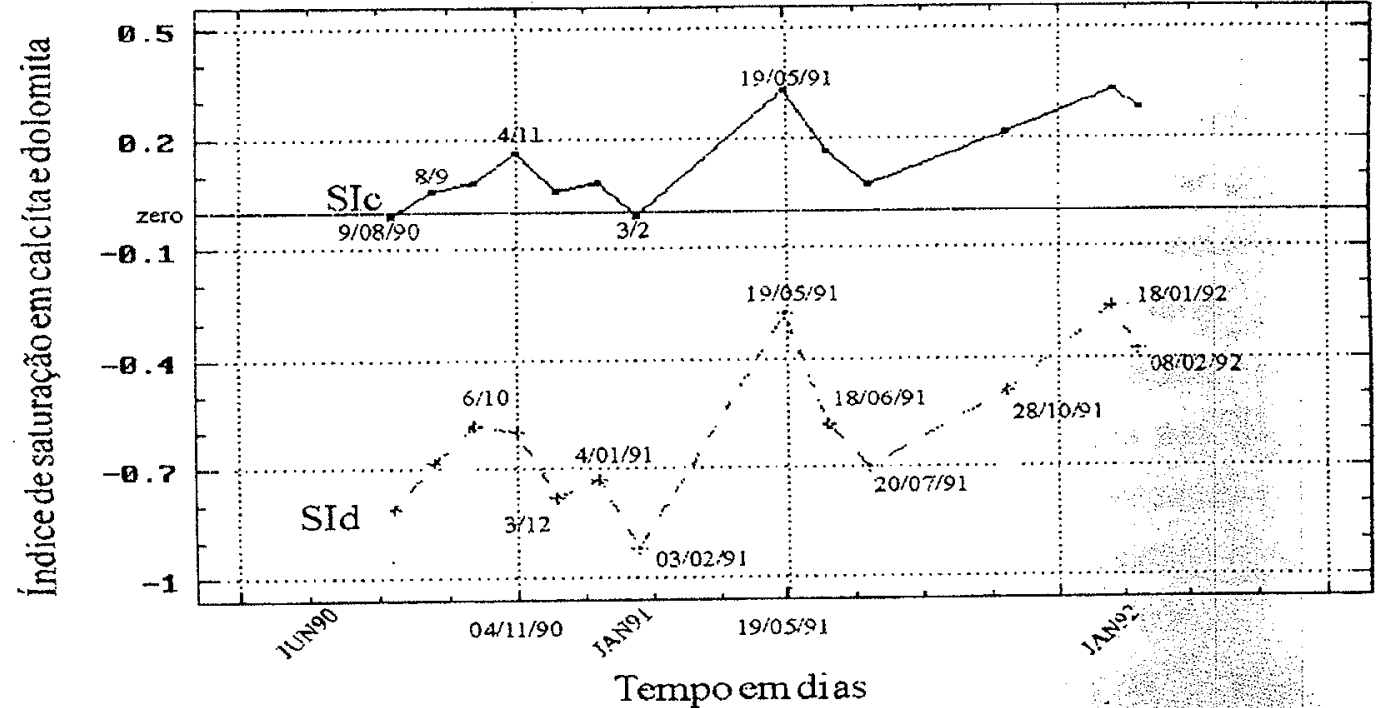

Figura 5.17 - Variaçã̃o sazonal do indice de saturação em calcita das águas da ressurgência da caverna de Santana e de percolação vadosa em fissuras em função da vazão do sistema de cavernas Pérolas-Santana. 


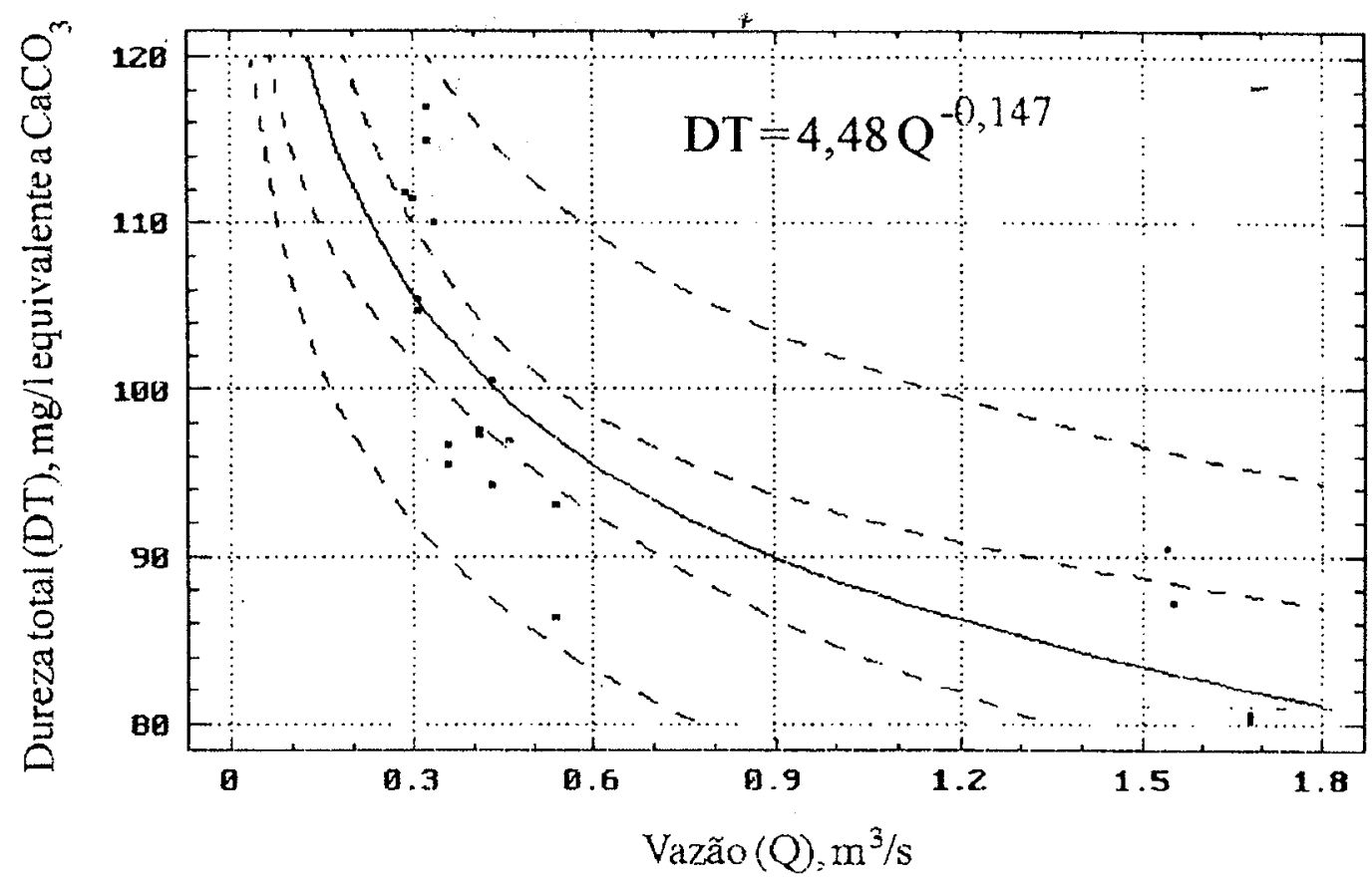

Figura 5.18 - Relação entre dureza total e vazão da ressurgência do sistema Pérolas-Santana. Coeficiente de correlação -0,83. Envoltórias de 90 e $95 \%$ de probabilidade.

hidrológico, é portanto, uma primeira aproximação da duração do caráter corrosivo da água associada à ressurgência do sistema Pérolas-Santana. A representatividade estatística desta duração somente poderá ser testada através de vários anos seguidos de monitoramento da ressurgência.

A fácies de percolação vadosa lenta ao longo de fissuras (descontinuidades em parte alargadas por dissolução) do maciço carbonático encaixante da caverna Santana apresenta variação sazonal dos índices de saturação em calcita e dolomita respectivamente de $0,34 \mathrm{e}$ 0,66. Estes valores são praticamente a metade da amplitude sazonal de SIc e SId da percolação rápida em condutos acima descrita.

A percolação vadosa lenta em fissuras apresentou-se saturada a super-saturada em relação a calcita durante todo período monitorado e, insaturada em relação a dolomita (fig $5.17 \mathrm{c}$ ), o que evidencia o potencial constante desta água em precipitar calcita, sendo que sua capacidade corrosiva está limitada aos horizontes superiores do maciço carbonático. $\mathrm{Na}$ curva de variação dos índices de saturação com o tempo, nota-se que no período compreendido entre agosto de 90 e fevereiro de 91 esta água apresentou saturação inferior ao período de maio de 91 a janeiro de 92 (fig 5.17c). Estes dois periodos de saturação contrastante correspondem também a fases com distintas intensidades de recarga pluviométrica (fig 5.5). O primeiro período corresponde à pluviosidade maior e saturação menor, enquanto o segundo, reflete pluviosidade menor e saturação maior.

Comparando a curva de variação com o tempo do índice de saturação da água de percolação vadosa em fissuras com aquela da vazão da ressurgência versus tempo (figs $5.17 \mathrm{~b}$ e $5.17 \mathrm{c}$ ), nota-se que a partir do dia $3 / 2 / 91$ iniciou-se uma fase de intensa recarga do aqüífero (aumento da vazão) que perdurou até meados de março (fig $517 \mathrm{~b}$ ), caindo 
rapidamente em seguida até 19/5/91. Esta fase de recarga do sistema foi acompanhada pelo incremento constante da saturação em calcita e dolomita da água de percolação lenta que ressurge em gotejamentos na caverna, até o ponto de amostragem do dia. 19/5/91 (fig $5.17 \mathrm{c}$ ), a partir do qual, ocorreu o decréscimo da concentração de sólidos dissolvidos nestes gotejamentos até julho de 91 .

A variação acima descrita representa um exemplo didático de como o mecanismo de recarga do aqǘfero condiciona a variação do quimismo da água de percolação lenta no maciço rochoso carbonático. Interpreta-se que o crescimento da vazão do sistema (fase de chuvas intensas) em paralelo à concentração em $\mathrm{Ca}$ e $\mathrm{Mg}$ do gotejamento na caverna é causado pela expulsão da água de percolação vadosa lenta que tinha sido acumulada na rede de fissuras e capilares durante a fase de recarga anterior. Com o início das chuvas intensas, uma nova frente de água é injetada no maciço rochoso, aumentando a pressão sobre a água retida no fissuramento menor, o què causa a expulsão desta água mais antiga e- a substituição desta pela nova frente de infiltração. Esta água em expulsão possui alta concentração (saturação em carbonatos) de sólidos dissolvidos devido ao tempo maior de residência no maciço carbonático. A substituição da água acumulada anteriormente perdura por cerca de 2 meses ( $3 / 2$ a 19/5/91, fig 5.17c). Logo após o escoamento desta água mais saturada, o índice de saturação do gotejamento decresce rapidamente. Atribui-se esta queda da concentração em $\mathrm{Ca}$ e $\mathrm{Mg}$ à chegada no nível da caverna da frente do novo pulso de água injetada pelo último evento de recarga do maciço fissurado. Com a interrupção da recarga pluviométrica (em 7/3/91) e escoamento da parte inicial do pulso de recarga através do fissuramento mais aberto e bem interconectado (fase de queda do índice de saturação entre $19 / 5$ e $20 / 7 / 91$, fig 5.17c), os gotejamentos começam a ser alimentados pelo escoamento relativamente mais lento a partir das fissuras menores e capilares, nos quais, a água tem residencia mais prolongada, causando uma nova fase ascendente da saturação em calcita e dolomita do gotejamento na caverna (a partir do dia 20/7/91, fig 5.17c)

Conforme citado anteriormente, a infiltração vadosa em fissuras perde sua capacidade corrosiva de minerais carbonáticos no horizonte superior do maciço calcário (alguns metros abaixo da zona epicárstica onde evolui em sistema fechado com relação ao $\mathrm{CO}_{2}$, segundo Williams, 1985). Esta água de infiltração é responsável pelo rebaixamento geral da superficie de bacias poligonais fechadas através da dissolução de calcita e dolomita principalmente na zona epicárstica. Após percolar na vertical pelo maciço rochoso (no caso da cav. Santana, entre 100 e $250 \mathrm{~m}$ ) com quase desprezível e localizada atividade de dissolução (p. ex. reativação da agressividade da água em relação a calcita através da corrosão de mistura), esta fácies hidroquímica é responsável pela atividade construtiva de depósitos secundários de calcita (e secundariamente de aragonita) em espaços vazios no interior do maciço, principalmente ao atingir a rede de condutos de origem freática ou vadosa, expostos acima do nível d'água.

Esta infiltração supersaturada em equilíbrio com alta $\mathrm{PCO}_{2}$, ao encontrar a fácies de percolação profunda em condutos, também saturada, mas com $\mathrm{PCO}_{2}$ inferior, fornece 
condições localizadas para o fenômeno da corrosão de mistura (conforme analisado no item 4.3.3.2), contribuindo assim na iniciação e ampliação de condutos freáticos.

\subsubsection{Taxa de denudação química da bacia do sistema Pérolas-Santana}

A taxa de denudação de terrenos cársticos por dissolução (ou simplesmente taxa de denudação cárstica) é definida como a perda média de massa em solução de bacias de drenagem sobre rochas carbonáticas (White, 1984), representando a taxa de rebaixamento da superficie do relevo cárstico em função do intemperismo e erosão.

Embora a erosão química de terrenos carbonáticos ocorre tanto em superficie como em subsuperficie, as taxas de denudação são expressas, por convenção, pelo equivalente em espessura de rocha removida por unidade de tempo ao longo de uma superficie horizontal. As unidades mais freqüentemente utilizadas são milímetros removidos por mil anos $(\mathrm{mm} / \mathrm{ka}$, onde $\mathrm{ka}=1000$ anos), o que equivale também a $\mathrm{m}^{3} / \mathrm{km}^{2} \times$ ano (Ford e Williams, 1989).

As primeiras estimativas quantitativas da denudação química de terrenos cársticos foram obtidas por Corbel (1959), através de sua clássica expressão:

$$
X=\frac{4 E T}{100}
$$

onde $X$ é a taxa de erosão química ( $\mathrm{mm} / \mathrm{ka}$ ), $E$ é a pluviosidade anual em decímetros na área cárstica (dm/ano) e $T$ corresponde a média anual da dureza total (em $\mathrm{mg} / \mathrm{l}$ equivalentes a $\mathrm{CaCO}_{3}$ ) do escoamento da bacia.

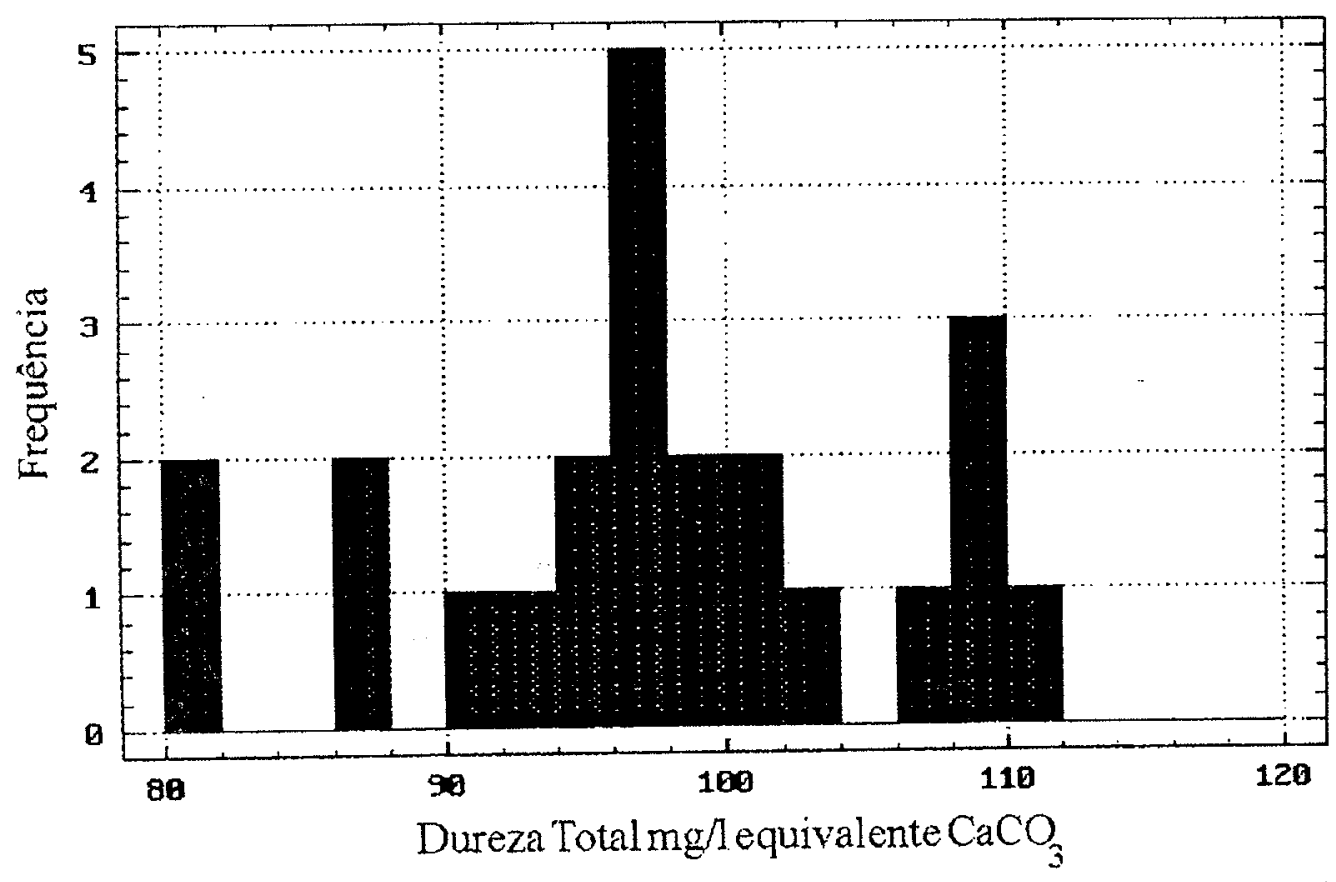

Figura 5.19 - Distribuição de frequêencia das análises de dureza total (mg/l equivalentes a $\mathrm{CaCO}_{3}$ ) da ressurgência da caverna Santana para o período de junho de 1990 a julho de 1991. Total de 23 amostras, média $=97,34 \mathrm{mg} /$, coeficiente de variação $=8,8 \%$. Os três grupos de frequência correspondem aos regimes de vazão alta, média e baixa, respectivamente, da esquerda para direita. 
Considerando uma pluviosidade de $1600 \mathrm{~mm}$ (16 dm) sobre a bacia do sistema Pérolas-Santana (média dos últimos 17 anos da pluviosidade medida no pluviomêtro do bairro da Serra, DAEE, 1992) e dureza total média anual da ressurgência do sistema de $97,34 \mathrm{mg} / \mathrm{l}$ equiv. a $\mathrm{CaCO}_{3}$ (fig 5.19 ), obtém-se uma taxa de denudação $X=62,3 \mathrm{~mm} / \mathrm{ka}$, através da equação de Corbel (1959).

Trabalhos posteriores, como os de Williams (1963), Pulina (1972) e Drake e Ford (1973), consideraram a equação de Corbel demasiadamente simplificada, sendo que as taxas de denudação cárstica obtidas através desta, seriam superestimadas. $\mathrm{O}$ caráter simplificado seria decorrente do fato da equação de Corbel não considerar a fração da dureza total gerada pela porção da bacia sobre rochas não carbonáticas e, introduzida no escoamento final da bacia, além da perda de parte da precipitação sobre a bacia, através da evapotranspiração, o que acaba reduzindo o volume escoado pela bacia, em relação ao volume total de precipitação (White, 1984).

Examinando os fatores acima apontados, Pulina (1972) propôs a equação:

$$
D m=12,6 \frac{(T-T a) Q}{P}
$$

onde $D m$ é a taxa de denudação média da bacia cárstica $(\mathrm{mm} / \mathrm{ka}), T$ é a média anual da dureza total do escoamento da bacia ( $\mathrm{mg} / \mathrm{l}$ equiv. a $\mathrm{CaCO}_{3}$ ), Ta é a dureza total do escoamento alogênico introduzido no sistema cárstico mas captado sobre a porção não carbonática da bacia, $Q$ é a vazão média anual do sistema $\left(\mathrm{m}^{3} / \mathrm{s}\right)$ e $P$ a área total da bacia de captação do sistema $\left(\mathrm{km}^{2}\right)$.

Através da equação de Pulina (1972) obteve-se uma taxa de denudação média $\mathrm{Dm}=$ $21,1 \mathrm{~mm} / \mathrm{ka}$ para a bacia do sistema Pérolas-Santana, com $T=97,34 \mathrm{mg} / \mathrm{l}$ equiv. a $\mathrm{CaCO}_{3}$, $T a=13 \mathrm{mg} / 1$ equiv. a $\mathrm{CaCO}_{3}$ (valor médio da dureza total de córregos alogênicos, tabela 5.5), $Q=0,504 \mathrm{~m}^{3} / \mathrm{s}$ (tabela 5.2) e $P=25,4 \mathrm{~km}^{2}$ (área total de captação da bacia obtida pelo balanço hídrico do sistema, item 5.2.3).

Smith e Atkinson (1976) apresentaram uma análise crítica dos resultados publicados até 1975 sobre a relação entre as taxas de denudação química de terrenos cársticos em diferentes condições climáticas. Concluíram que o volume de escoamento (ou precipitação) é o fator que mais influencia as taxas de denudação, em detrimento da temperatura, conforme postulado anteriormente por Corbel (1959) e outros. Com relação ao clima, mostraram que a denudação cárstica de zonas árticas a sub-árticas é inferior e facilmente distinguivel da taxa de denudação de áreas cársticas temperadas e tropicais, enquanto que entre estas duas últimas zonas climáticas, as taxas de denudação química sâo dificilmente diferenciadas.

Smith e Atkinson (1976) propuseram calcular a taxa de denudação cárstica $(X)$ através da expressão:

$$
X=\frac{\bar{Q}}{A} \cdot \frac{T}{10^{6} r} \cdot \frac{1}{n}
$$

onde $\bar{Q}$ é o volume médio anual de água escoada pela bacia, $\mathrm{em}^{3} /$ ano, $T$ é a dureza total média deste escoamento ( $\mathrm{mg} / \mathrm{l}$ equiv. a $\mathrm{CaCO}_{3}$ ), $r$ é a densidade média da rocha carbonática 
em $\mathrm{g} / \mathrm{cm}^{3}, A$ é área total em $\mathrm{km}^{2}$ da bacia e $n$ a fração desta área ocupada por rochas carbonáticas.

Aplicando a equação de Smith e Atkinson (1976) aos dados da bacia PérolasSantana, obteve-se uma taxa de denudação de $35,3 \mathrm{~mm} / \mathrm{ka}$ ou $\mathrm{m}^{3} / \mathrm{km}^{2} \times$ ano, através dos valores de $\bar{Q}=16.997 .796,02 \mathrm{~m}^{3}$ /ano, volume escoado pela ressurgência do sistema para 0 período de jun. de 90 a jun. de 91 (tabela 5.8), $T=97,34 \mathrm{mg} /$ equiv. a $\mathrm{CaCO}_{3}, r=2,60$ $\mathrm{g} / \mathrm{cm}^{3}$, densidade média adotada para os metacalcários da área de estudo, $A=25,4 \mathrm{~km}^{2}$ e $n$ $=0,71$, considerando que do total da área de captação da bacia, no mínimo $7,4 \mathrm{~km}^{2}$ são de captação alogênica, o que resulta em no máximo $18 \mathrm{~km}^{2}$ de captação autogênica e portanto, $\mathbf{n}=18 / 25,4$.

White (1984) confirma a dependência direta da taxa de denudação cárstica do volume de precipitação e, conseqüentemente, do escoamento transmitido pelo sistema. Plotando as taxas de denudação de diversas áreas do mundo versus o escoamento efetivo $(P$ - Ev) destas bacias cársticas (fig 5.20), obteve um melhor ajuste dos pontos através de uma regressão linear com $\mathrm{r}^{2}=0,92$, cuja expressão é:

$$
D=0,049(P-E v)+6,3
$$

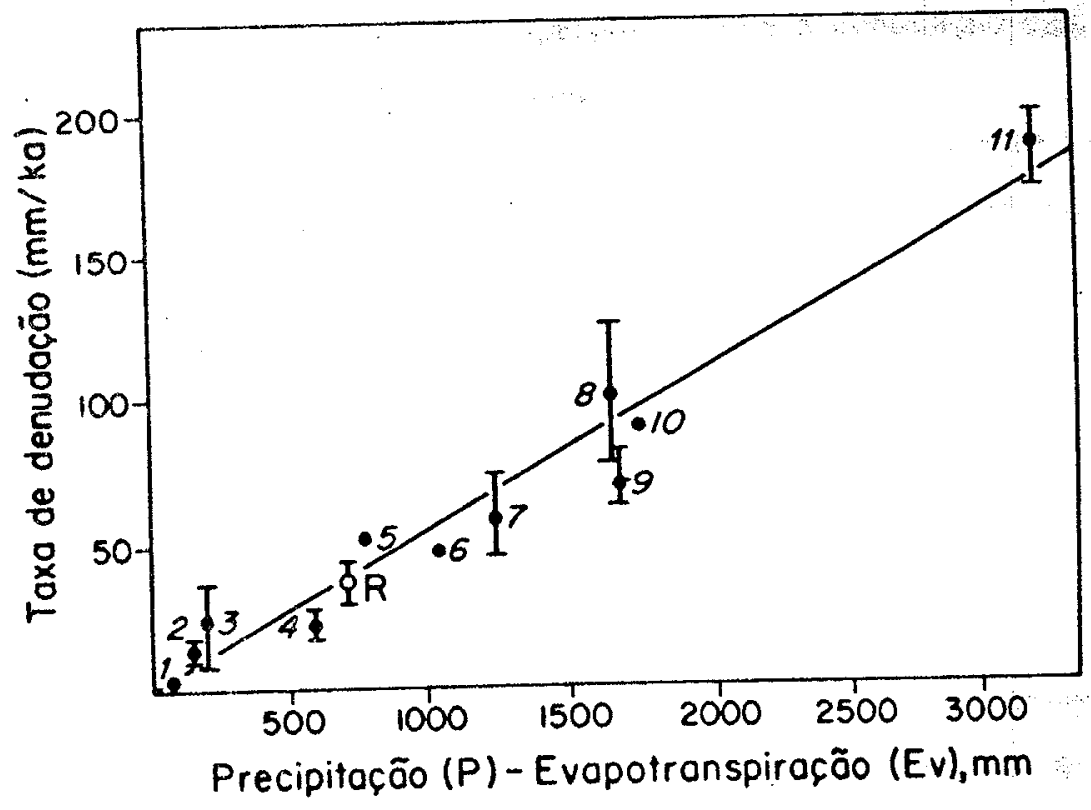

Figura 5.20 - Taxas de denudação cárstica $(D)$ em função da precipitação efetiva ou escoamento da bacia $(P-E v)$, segundo White (1984). Os pontos plotados foram extraídos de 1- Ártico canadense, Smith (1962); 2 e 3- Polônia, Glazek e Markovicz-Lohinovicz (1973); 4- West Virginia, EUA, Ogden (1982); 5- Irlanda, Williams (1963), 6- Bulgaria, Markovicz, et. al. (1972); 7- Montanhas Tatra, Polonia, Glazek e Markovicz-Lohinivicz (1973); 8- Nova Zelândia, Williams e Dowling (1979), 9- Nova Zelândia, Gunn (1981b); 10- Belize, Miller (1982); 11-Gunung Mulu, Malásia, Sweeting (1979) e R-Alto Ribeira, Brasil, ponto calculado no presente trabalho.

A bacia Pérolas-Santana, com $(P-E v)$ anual médio de $700 \mathrm{~mm}$, insere-se perfeitamente neste alinhamento, com uma taxa de denudação $D=40,6 \mathrm{~mm} / \mathrm{ka}($ fig 5.20$)$ A 
pluviosidade $(P)$ baseia-se na média dos últimos 17 anos $(1600 \mathrm{~mm})$ medida no pluviômetro do bairro da Serra (DAEE, 1992). A evapotranspiração $(E v)$ utilizada no cálculo açima $(900 \mathrm{~mm})$ corresponde à média dos valores da área de estudo, que variam entre 800 e 1000 $\mathrm{mm}$.

White (op. cit.), aprofundou a análise da questão clássica sobre a dependência climática da taxa de evolução de relevos cársticos. Partindo da premissa de que a água injetada no maciço carbonático, tanto através de infiltração difusa após percolar o solo, como por infiltração concentrada em fundos de dolinas ou, através de sumidouros em vales cegos, atinge o equilíbriio com a rocha carbonática, White propôs o cálculo de uma taxa de denudação teórica, através de uma equação que envolve as três variáveis climáticas fundamentais: temperatura, pressão de $\mathrm{CO}_{2}$ no solo e precipitação, conforme segue abaixo:

$$
\text { Dmáx. }=\frac{100}{\rho \sqrt[3]{4}}\left(\frac{K_{c} K_{1} K_{C O_{2}}}{K_{2}}\right)^{1 / 3} P C O_{2}{ }^{1 / 3}(P-E v)
$$

Esta taxa de denudação teórica é máxima (Dmáx) pois representa o limite superior do equilíbrio químico entre minerais carbonáticos e a água, onde o escoamento total da bacia $(P-E v)$ está saturado e equilibrado com a temperatura local e a pressão de $\mathrm{CO}_{2}$ do ambiente de dissolução. A influência da temperatura sobre a denudação está embutida na dependência das constantes de equilíbrio da temperatura.

Com a equação acima obteve-se uma previsão teórica de $D m a ́ x=49,1 \mathrm{~mm} / \mathrm{ka}$ para a bacia Pérolas-Santana. Para tal, adotaram-se as constantes de equilíbrio das reações principais envolvidas na dissolução de calcita, tabeladas por Plummer e Busenberg (1982) para $20^{\circ} \mathrm{C}$, conforme especificado abaixo:

$$
\begin{gathered}
\mathrm{CaCO}_{3(s o l)} \leftrightarrows \mathrm{Ca}_{(a q)}^{++}+\mathrm{CO}_{(a q)}^{--} \quad \mathrm{K}_{\mathrm{c}}=10^{-8,45} \\
\mathrm{H}_{2} \mathrm{O}+\mathrm{CO}_{2(a q)} \leftrightarrows \mathrm{H}_{2} \mathrm{CO}_{3} \quad \mathrm{~K}_{\mathrm{CO}_{2}}=10^{-1,41} \\
\mathrm{H}_{2} \mathrm{CO}_{3} \leftrightarrows \mathrm{HCO}_{3}^{-}+\mathrm{H}^{+} \mathrm{K}_{1}=10^{-6,38} \mathrm{e} \\
\mathrm{HCO}_{3}^{-} \leftrightarrows \mathrm{CO}_{3}^{--}+H^{+} \mathrm{K}_{2}=10^{-10,38}
\end{gathered}
$$

Como densidade do metacalcário $(\rho)$ utilizou-se $2,6 \mathrm{~g} / \mathrm{cm}^{3}$. Quanto à pressão parcial de $\mathrm{CO}_{2}$ do solo seguiu-se o valor calculado de $10^{-1,754}$ atm. pela expressão de Brook et. al. (1983), conforme descrito no item 5.3.4.

Por último, determinou-se um valor da taxa de denudação da bacia do sistema Pérolas-Santana através do cálculo do total de massa equivalente a $\mathrm{CaCO}_{3}$ removida pelo sistema de drenagem em um ano hidrológico, ao longo do qual, monitorou-se o volume escoado e sua dureza total. O método proposto aqui fundamenta-se nos trabalhos de Drake e Ford (1973) e Ogden (1982). Diferencia-se destes, pelo fato de ser aplicável a bacias com captação mista alogênica e autogênica, devido à inclusão de um termo na fórmula de cálculo da taxa, que subtrai a contribuição em massa de carbonatos de origem alogênica.

Propõe-se a seguinte equação para calcular a taxa de denudação química $(D q)$ da bacia de drenagem do sistema Pérolas-Santana: 


$$
D q=\frac{\left(\sum_{1}^{n} V_{n} \cdot T\right)-\left(P \cdot T_{a}\right)}{d} \cdot 10^{-6} \cdot \frac{1}{A} \cdot \frac{1}{C}, \text { onde }{ }_{n}=\int_{t}^{t_{n}} \frac{d Q}{d t} \text { e } P=\bar{p} \cdot A_{a}
$$

Devido ao fato da dureza total ( $T$ em $\mathrm{mg} / \mathrm{l}$ equiv. a $\mathrm{CaCO}_{3}$ ) do escoamento da bacia na ressurgência do sistema variar na razão exponencial inversamente proporcional à vazão $\left(Q \mathrm{em} \mathrm{m}^{3} / \mathrm{s}\right)$, conforme é visualizado pela tabela 5.7 e figura 5.20 , mas, por outro lado, o fluxo instantâneo de sólidos dissolvidos ( $Q \cdot T \mathrm{em} \mathrm{g} / \mathrm{s}$, tabela 5.7$)$ variar na razão linear diretamente proporcional à vazão $(Q)$ deste sistema (fig 5.21), subdividiu-se a curva geral da vazão do sistema versus o tempo em períodos de vazão alta, média e baixa, nos quais se dispunha de análises de dureza total. Esta subdivisão teve como objetivo relacionar cada período de regime de vazão com sua dureza total média $(T)$, em função da variação acima apontada (tabela 5.8). Cada um destes segmentos da curva de vazão instantânea ( $Q$ versus tempo, fig 5.3) foi integrado graficamente para obter o volume $\left(V_{n}, \mathrm{~m}^{3}\right)$ total de água escoada em cada período $n$ (tabela 5.8). Através do produto entre $V_{n}$ e $T$ de cada período e a somatória destes, obteve-se a massa total equivalente a $\mathrm{CaCO}_{3}$ removida em solução da bacia (termo $\Sigma V_{n} \cdot T$ da equação acima, em g/ano). Deste total de sólidos dissolvidos escoados pela ressurgência deve-se subtrair a massa equivalente a $\mathrm{CaCO}_{3}$ de origem alogênica e introduzida no sistema cárstico através do volume de água coletada sobre a área de captação alogênica do sistema (termo $P \cdot T_{a}$ da equação acima). A quantificação exata deste termo depende da demarcação precisa da área de captação alogênica, pois a variável $P$ da equação acima é obtida pelo produto entre a pluviosidade $(p)$ e a área de captação alogênica $\left(A_{a}\right)$ do sistema. No caso da bacia do sistema estudado, a demarcação exata de $A_{a}$ não foi possível, sabendo-se até o estágio atual deste trabalho, que esta area corresponde no mínimo a $7,4 \mathrm{~km}^{2}$ (ver discussão do balanço hídrico e área de captação do sistema, item 5.2.3). A precipitação ( $p$ ) na área durante o período considerado (11/6/90 a $18 / 6 / 91$ ) foi de $1583,9 \mathrm{~mm}$, o que sobre a área de $7,4 \mathrm{~km}^{2}$ perfaz $11.721 .600 \mathrm{~m}^{3}$. A dureza total média deste escoamento alogênico $\left(T_{a}\right)$ injetado no sistema cárstico é de $13 \mathrm{mg} / 1$ equiv. a $\mathrm{CaCO}_{3}$ (tabela 5.5), o que resulta em $152.380 .800 \mathrm{~g}$ equivalentes a $\mathrm{CaCO}_{3}$ os quais foram subtraídos do total de sólidos dissolvidos escoados (tabela 5.8) para obtenção do fluxo de massa (1.455.858.331g equivalentes a $\mathrm{CaCO}_{3}$ ) efetivamente originado no maciço carbonático. Devido à impossibilidade de demarcação total da área alogênica, este valor do fluxo de massa no período considerado deve ser ligeiramente inferior ao utilizado no presente cálculo da denudação. A massa total equivalente a $\mathrm{CaCO}_{3}$ escoada pela bacia sobre a densidade $(d)$ de $2,6 \mathrm{~g} / \mathrm{cm}^{3}$ considerada para os metacalcários da área, resulta no volume de $559,946 \mathrm{~m}^{3} /$ ano de rocha carbonática removida em solução. Distribuindo este volume sobre a área total de captação da bacia $\left(A=25,4 \mathrm{~km}^{2}\right)$ obteve-se a taxa de denudação aparente do sistema cárstico $(D=22,1 \mathrm{~mm} / \mathrm{ka})$, pois esta representa a remoção de carbonatos por dissolução inclusive sobre a área alogênica. Esta taxa aparente deve ser corrigida pelo fator $1 / C$ (semelhante ao fator $1 / \mathrm{n}$ de Smith e Atkinson, 1976) para obtenção 
da taxa real de denudação química $(D q)$. C é a razão entre a área de captação autogênica (no caso $18 \mathrm{~km}^{2}$ ) e a área total da bacia $(A)$. Desta maneira restringe-se a denudação química à fração da bacia ocupada por rochas carbonáticas. Obteve-se assim, um valor final de $D q=31,1 \mathrm{~mm} / \mathrm{ka}$ para o sistema cárstico Pérolas-Santana.

\begin{tabular}{|c|c|c|c|}
\hline $\begin{array}{c}\text { Data de } \\
\text { amostragem }\end{array}$ & $\begin{array}{c}\text { Dureza } \\
\text { total } T, \\
\mathrm{mg} / 1\end{array}$ & $\begin{array}{c}\text { Vazão, } \\
Q \mathbf{m}^{\mathbf{3}} / \mathbf{s}\end{array}$ & $\begin{array}{c}\text { Fluxo de } \\
\text { sólidos } \\
\text { dissolvidos, } T . \boldsymbol{Q} \\
\mathbf{g} / \mathbf{s}\end{array}$ \\
\hline $29 / 06 / 90$ & 106,1 & 0,305 & 32,36 \\
\hline $13 / 08 / 90$ & 99,3 & 0,337 & 33,46 \\
\hline $08 / 09 / 90$ & 97,2 & 0,510 & 49,6 \\
\hline $06 / 10 / 90$ & 96,2 & 0,373 & 35,9 \\
\hline $04 / 11 / 90$ & 101,8 & 0,389 & 39,6 \\
\hline $05 / 12 / 90$ & 88,9 & 0,506 & 45,0 \\
\hline $04 / 01 / 91$ & 89,8 & 0,597 & 53,6 \\
\hline $03 / 02 / 91$ & 97,5 & 0,429 & 41,8 \\
\hline $07 / 03 / 91$ & 80,5 & 1,581 & 127,3 \\
\hline $19 / 05 / 91$ & 100,5 & 0,430 & 43,24 \\
\hline $18 / 06 / 91$ & 109,9 & 0,354 & 38,9 \\
\hline
\end{tabular}

Tabela 5.7 - Relação do fluxo de sólidos dissolvidos ( $\mathrm{g} / \mathrm{s}$ equivalente a $\mathrm{CaCO}_{3}$ ) em função do regime de vazão da ressurgência do sistema Pérolas-Santana.

\begin{tabular}{|c|c|c|c|c|}
\hline \multicolumn{2}{|c|}{ Período } & \multirow{2}{*}{ Volume escoado $\mathrm{V} n, \mathbf{m}^{\mathbf{3}}$} & \multirow{2}{*}{$\begin{array}{c}\text { Dureza total } \\
\text { média } T, \mathrm{mg} / 1 \\
\text { equivalente a } \\
\mathrm{CaCO}_{3} \\
106,1 \\
\end{array}$} & \multirow{2}{*}{$\begin{array}{c}\mathrm{CaCO}_{3} \\
\text { removido em solução, } \\
\text { V.T, } \mathrm{g} \\
100606090 \\
\end{array}$} \\
\hline $11 / 06 / 90$ & $16 / 07 / 90$ & & & \\
\hline $16 / 07 / 90$ & a $19 / 08 / 90$ & 1421540,78 & 99,3 & 141158999,5 \\
\hline $19 / 08 / 90$ & a $12 / 09 / 90$ & 989003,7 & 97,2 & 96131159,64 \\
\hline $12 / 09 / 90$ & a $13 / 10 / 90$ & 1462625,43 & 96,2 & 140704566,4 \\
\hline $13 / 10 / 90$ & a $17 / 11 / 90$ & 1675014,84 & 101,8 & 170516510,7 \\
\hline $17 / 11 / 90$ & a $27 / 12 / 90$ & 2043012,77 & 88,95 & 181725985,9 \\
\hline $27 / 12 / 90$ & a $29 / 01 / 91$ & 1252906,23 & 89,8 & 112510979,5 \\
\hline $29 / 01 / 91$ & a $02 / 03 / 91$ & 1538578,56 & 97,5 & 150011409,6 \\
\hline $02 / 03 / 91$ & a $03 / 04 / 91$ & 2657230,28 & 80,5 & 213907037,5 \\
\hline $03 / 04 / 91$ & a $05 / 05 / 91$ & 1003221,31 & 90 & 90289917,59 \\
\hline $05 / 05 / 91$ & a $15 / 05 / 91$ & 1003221,31 & 100 & 100322130,7 \\
\hline $15 / 05 / 91$ & a $18 / 06 / 91$ & 1003221,31 & 110 & 110354343,7 \\
\hline & & $6997796,02 \mathrm{~m}^{3} /$ ano & & $\sum=1608239131 \mathrm{~g} / \mathrm{ano}$ \\
\hline
\end{tabular}

Tabela 5.8 - Relação dos períodos com vazão alta, média e baixa e os totais correspondentes em volume escoado $(V)$ e massa equivalente a $\mathrm{CaCO}_{3}$ removida em soluçâo $(V \cdot T)$ pelo sistema Pérolas-Santana durante o período monitorado.

Após calcular a taxa de denudação cárstica por diferentes métodos, obtendo resultados que oscilam entre 21 e $62 \mathrm{~mm} / \mathrm{ka}$ (tabela 5.9), surge a questão, de qual resultado é mais significativo. 


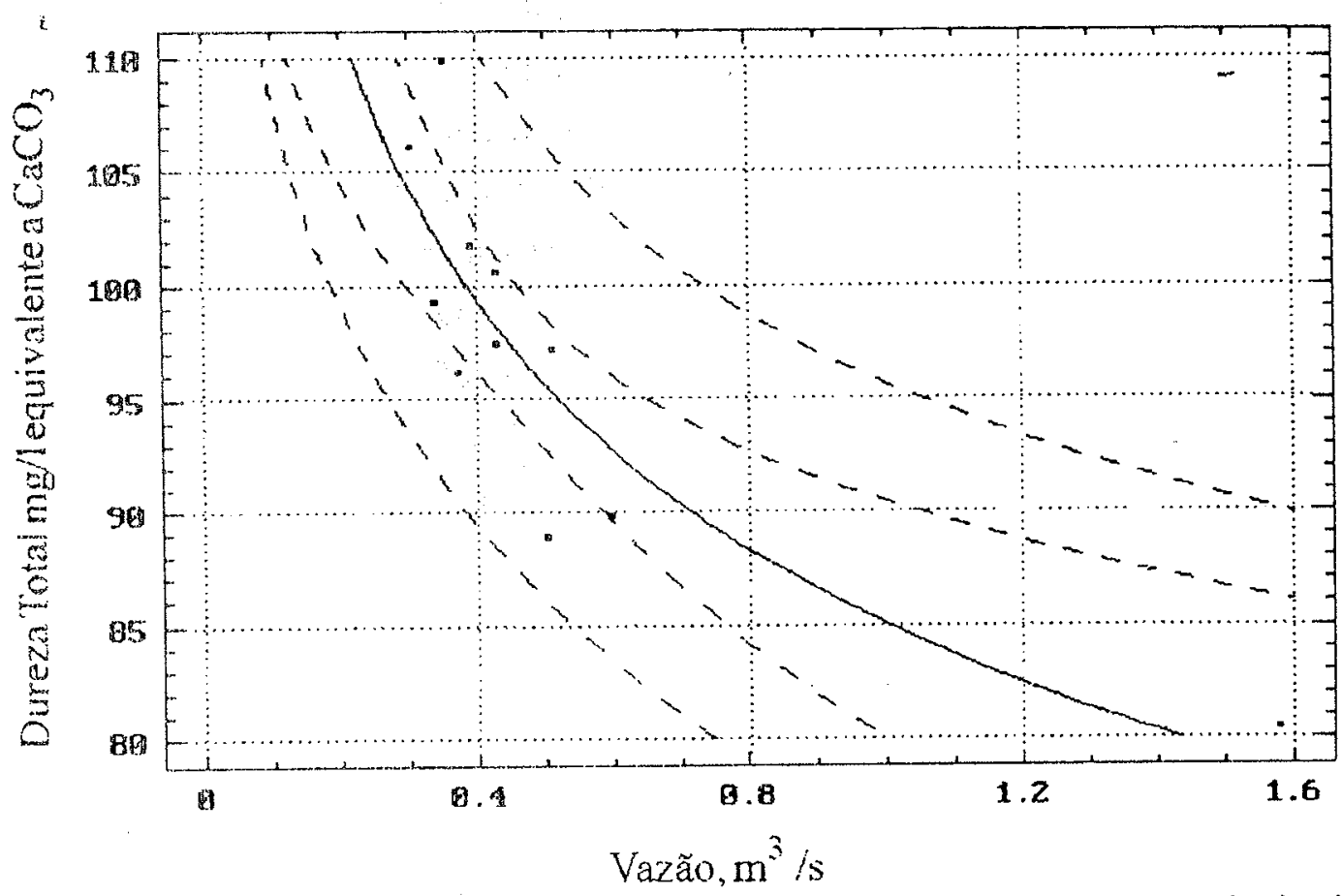

Figura 5.21 - Variação da dureza total em função da vazão na ressurgência da caverna Santana para o periodo de $29 / 6 / 90$ a $18 / 6 / 91$. Coeficiente de correlação de $-0,88$ e $\mathrm{R}^{2}=$ $76,8 \%$.

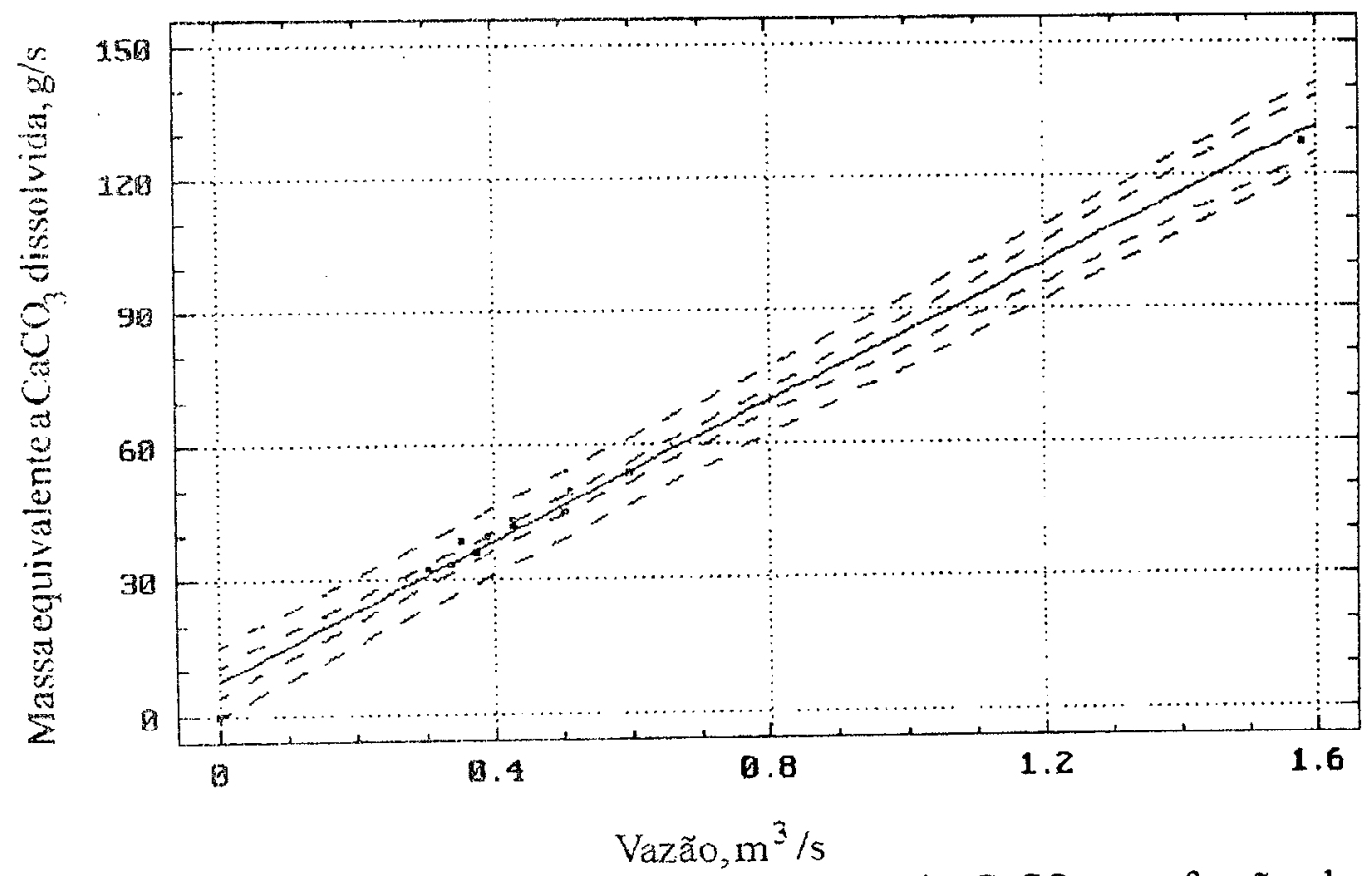

Figura 5.22 - Fluxo de massa equivalente a $\mathrm{g} / \mathrm{s}$ de $\mathrm{CaCO}_{3}$ em função da vazão na ressurgência da caverna Santana. Coeficiente de correlação de 0,99 e $\mathrm{R}^{2}=98,9 \%$.

A equação de Corbel (1959) não considera a perda de água por evapotranspiração, o que resulta num excesso do volume de escoada pela ressurgencia, induzindo assim, uma taxa de denudação super-estimada em relação à realidade. Este exagero é reforçado pelo 
fato deste cálculo não subtrair o volume equivalente a $\mathrm{CaCO}_{3}$ introduzido no sistema no caso de bacias com parte da captação alogênica.

No cálculo segundo Pulina (1972), onde a dureza total média do escoamento alogênico é deduzida da concentração média equivalente a $\mathrm{CaCO}_{3}$ da ressurgência, a taxa de denudação cárstica é subestimada. Isto ocorre porque a subtração direta entre estas concentraçôes desconsidera a diminuição da concentração em $\mathrm{CaCO}_{3}$ da água alogênica ao esta atravessar o sistema cárstico, devido à adição contínua de água ao sistema captada sobre o terreno cárstico. Por exemplo, a dureza total de $13 \mathrm{mg} / \mathrm{l}$ medida no escoamento alogênico do sistema Pérolas-Santana, será drasticamente diluída até a ressurgência, em função do aumento do volume de água nesta travessia. A subtração de $13 \mathrm{mg} / \mathrm{l}$ da concentração equivalente a $\mathrm{CaCO}_{3}$ na ressurgência, acarreta portanto, uma correção excessiva, reduzindo a dureza total da ressurgência abaixo do valor real, subestimando assim, a taxa de denudaçăo química.

\begin{tabular}{|c|c|c|}
\hline $\begin{array}{l}\text { Método de } \\
\text { cálculo utilizado }\end{array}$ & $\begin{array}{l}\text { Taxa de } \\
\text { denudą̧äo } \\
\text { cárstica, } \\
\text { murn/Ka }\end{array}$ & Deficiência do método \\
\hline Corbel $(1959)$ & 62.3 & $\begin{array}{l}\text { - Desconsidera a perda por Ev no escoamento da bacia } \\
\text { - Desconsidera adição alogênica de } \mathrm{CaCO}_{3} \\
\text { - Desconsidera variação de } \mathrm{T} \text { com } \mathrm{Q} \text { da ressurgência } \\
\end{array}$ \\
\hline Puina (1972) & 21,1 & $\begin{array}{l}\text { - Considera a adição alogênica de } \mathrm{CaCO}_{3} \text { mas não a diluição desta } \\
\text { até a ressurgência }\end{array}$ \\
\hline $\begin{array}{c}\text { Smith e Atkinson } \\
(1976)\end{array}$ & 35,3 & $\begin{array}{l}\text { - Desconsidera variação de } \mathrm{T} \text { com } \mathrm{Q} \text { da ressurgência } \\
\text { - Desconsidera, em parte, a adição alogênica de } \mathrm{CaCO}_{3}\end{array}$ \\
\hline $\begin{array}{l}\text { White (1984) } \\
\text { relação entre (P-Ev) } \\
\text { e denudacão }\end{array}$ & 40,6 & $\begin{array}{l}\text { - Relação empírica entre o escoamento da bacia e a denudação. } \\
\text { - Acaba superestimando a denudação }\end{array}$ \\
\hline $\begin{array}{c}\text { White (1984) } \\
\text { Denudação máxima } \\
\text { teórica }\end{array}$ & 49,1 & $\begin{array}{l}\text { - Cálculo teórico que considera } \mathrm{PCO}_{2} \text { do solo constante } \\
\text { - Desconsidera variação de } \mathrm{T} \text { com } \mathrm{Q} \\
\text { - Considera o escoamento saturado em } \mathrm{CaCO}_{3} \text { durante o ano } \\
\text { hidrológico }\end{array}$ \\
\hline Este trabalho & 31,1 & $\begin{array}{l}\text { - No presente cálculo não foi possível determinar a área total de } \\
\text { captação alogênica }\end{array}$ \\
\hline
\end{tabular}

Tabela 5.9 - Quadro resumido das taxas de denudação química calculadas segundo métodos diferentes para a bacia do sistema Pérolas-Santana

O método de Smith e Atkinson (1976) reresenta um avanço no cálculo da denudação cárstica, pois no caso de bacias mistas (alogênicas e autogênicas), corrige a denudação, distribuindo o volume de $\mathrm{CaCO}_{3}$ removido somente sobre a área carbonática da bacia, deduzindo a fração de área alogênica desta bacia. Por outro lado, este cálculo incorre em erro, pelo fato de não considerar a variação da dureza total nos diferentes regimes de vazão do sistema, simplificando esta variação ao utilizar somente o valor médio da dureza total em relação ao volume total de água escoada. 
O cálculo da denudação máxima teórica segundo White (1984), conforme ressaltado pelo próprio autor, representa um valor relativamente superestimado da denudação, pelo fato de envolver a premissa de que o escoamento do sistema se mantém saturado em relação a calcita durante o ano de precipitação considerado, o que não ocorre na realidade, conforme foi demonstrado na análise da sazonalidade do $\mathrm{SI}_{\mathrm{c}}$ da vazão do sistema PérolasSantana (item 5.4.2). Fato semelhante ocorre com a pressão de $\mathrm{CO}_{2}$, a qual também varia em função de períodos com maior e menor recarga de água no solo.

A denudação química obtida através do cálculo proposto neste trabalho (adaptando o método de Ogden, 1982), onde respeita-se a diminuição da dureza total do escoamento em função do aumento da vazão, subtrai-se o volume de carbonato de origem alogenica, além de abstrair-se a área de captação alogênica na distribuição do volume de carbonato lixiviado da bacia, deve representar o valor mais próximo da realidade, apesar de ser ligeiramente superestimado, no caso do sistema Pérolas-Santana, pelo fato do cálculo ter considerado somente a área mínima de captação alogênica da bacia.

Neste quadro geral de resultados obtidos para o sistema Pérolas-Santana (tabela 5.9), conclui-se que os valores de denudação entre 40 e $62 \mathrm{~mm} / \mathrm{ka}$ são superestimados, enquanto que $21 \mathrm{~mm} / \mathrm{ka}$ é subestimado. A denudação em torno de $30 \mathrm{~mm} / \mathrm{ka}$, além de representar a média dos extremos calculados, é considerada também, como a mais precisa, devido ao método de cálculo utilizado. Deve-se lembrar ainda, que o valor de $D q=31,1$ $\mathrm{mm} / \mathrm{ka}$ insere um erro de até $20 \%(D q=31,1 \pm 6 \mathrm{~mm} / \mathrm{ka})$, em função dos erros acumulados nas medições de vazão $(\sim 10 \%)$, nas análises químicas $(\sim 5 \%)$ e na medição das áreas de captação da bacia $(\sim 5 \%)$.

Comparando a taxa de denudação cárstica obtida através do balanço de massa de rocha carbonática removida em solução (entre 21 e $62 \mathrm{~mm} / \mathrm{ka}$ e media de $31,1 \mathrm{~mm} / \mathrm{ka}$ ) com a taxa máxima de entalhamento vertical de condutos vadosos calculada através da datacão de níveis fluviais subterrâneos (entre 29 e $54 \mathrm{~mm} / \mathrm{ka}$, com o valor médio de $42 \mathrm{~mm} / \mathrm{ka}$, tabela 4.8), nota-se que ambos resultados variam na mesma ordem de grandeza.

Esta semelhança representa uma confirmação do resultado, pois o mesmo fol obtido através de métodos completamente distintos.

Suporta também, o ponto de vista expresso em Gascoyne, Ford e Schwarcz (1983) de que a região de máxima dissolução de rocha carbonática é a base do solo, sendo que a taxa de rebaixamento por dissolução da superficie epicárstica procede aproximadamente na mesma velocidade com que a dissolução entalha os condutos vadosos principais que drenam tanto a água de sumidouros alogênicos como a água coletada pela superficie epicarstica.

\subsection{Conclusões}

A ressurgência cárstica do sistema de drenagem subterrânea Pérolas-Santana é do tipo fluxo total permanente (full flow, classificação de Worthington, 1991 ), onde $82,1 \%$ da vazão total anual corresponde a escoamento básico e $17,9 \%$ ao escoamento direto, com Qx(vazão máxima) $/ Q n($ vazão mínima $)=19,7$ para o ano hidrológico de 1990-1991. 
A análise dos coeficientes de recessão do escoamento básico (sobre períodos de até 32 dias sem recarga) do sistema Pérolas-Santana, permitiu classificar sua ressurgência (classificação de Milanovic, 1976) como sendo associada a um aqüífero cárstico com alto grau de fissuramento interconectado, responsável pelo acumulo de um grande volume de água freática, a qual é lentamente drenada em épocas de estiagem.

Ainda segundo a classificação de Worthington (1991), o monitoramento hidrológico permitiu confirmar o caráter altamente carstificado do aqüifero, classificando-se a ressurgência como do sub-tipo gaining-underflow (sistema com suplementação de água por um sistema vizinho de drenagem subterrânea), com base nas características de deflúvio do sistema.

Através do balanço hídrico do sistema Pérolas-Santana concluiu-se que a área de captação da bacia do sistema definida pelos divisores topográficos $\left(14,8 \mathrm{~km}^{2}\right)$ é insuficiente para alimentar a vazão medida na ressurgência. Estabeleceu-se uma área de captação de $25,4 \mathrm{~km}^{2}$, dos quais $9,6 \mathrm{~km}^{2}$ pertencem a área de captação do sistema vizinho (sistema Grilo). Comprovou-se assim, uma conexão subterrânea entre sistemas cársticos vizinhos, os quais, através de uma análise da drenagem superficial, seriam independentes.

Os resultados das análises químicas e dos parâmetros hidroquímicos calculados associados aos diferentes ambientes hidráulicos de circulação das águas coletadas ao longo dos sistemas cársticos Pérolas-Santana e Temimina-Pescaria, permitiram diferenciar as seguintes fácies hidroquímicas: escoamento superficial alogênico, escoamento superficial fluviocárstico, percolação autogênica vadosa em fissuras, percolação autogênica vadosa em condutos, circulação freática em condutos profundos e escoamento de ressurgências cársticas, cada uma caracterizada pela sua dureza total (em $\mathrm{mg} / 1$ equivalentes a $\mathrm{CaCO}_{3}$ ), alcalinidade ( $\mathrm{mg} / \mathrm{l}$ de $\left.\mathrm{HCO}_{3}{ }^{-}\right), \mathrm{pH}$, pressão parcial de $\mathrm{CO}_{2}$ e índices de saturação em calcita e dolomita.

Em função desta diferenciação de fácies hidroquímicas foi possível traçar uma evolução geoquímica das águas ao longo das rotas de fluxo da água no sistema cárstico em ambiente subtropical úmido.

Com base nas características hidroquímicas, concluiu-se que o sistema cárstico Pérolas-santana, amostra representativa do carste do Alto Ribeira, tem sua evolução controlada pela ação de água meteórica enriquecida em ácido carbônico no solo e horizonte epicárstico, onde as reações do sistema $\mathrm{CaCO}_{3}+\mathrm{H}_{2} \mathrm{O}+\mathrm{CO}_{2}$ controlam essencialmente a carstificação. Localmente na zona vadosa, e principalmente em rotas de circulação mais profundas, a carstificação pelo ácido carbônico é reduzida e provavelmente acompanhada por um incremento da capacidade corrosiva da água pela ação de ácido sulfúrico produzido pela oxidação de sulfetos (pirita) disseminados em certos estratos da rocha metacalcária. Esta ação é evidenciada pela presença de $\mathrm{SO}_{4}$ na água profunda e sulfatos como gipsita em cavernas vadosas.

A identificação da fácies de circulação freática profunda, com temperatura média anual de $20,8^{\circ} \mathrm{C}$ em contraste com $18^{\circ} \mathrm{C}$ da água superficial, confirmou a previsão do modelo de profundidades de condutos, segundo o qual, estima-se que os condutos 
associados à rota de fluxo da água subterrânea atingem máximos de 200 a $350 \mathrm{~m}$ de profundidade abaixo do pível d água.

Com relação à dinâmica atual do sistema cárstico, concluiu-șe que a fácies hidroquímica de ressurgência apresenta-se corrosiva em relação à calcita por cerca de 9 meses por ano hidrológico, confirmando um comportamento sazonal semelhante às nascentes cársticas importantes de outras áreas, em climas desde tropicais à subárticos, conforme Ford e Williams (1989). A percolação vadosa lenta em fissuras, por outro lado, apresenta-se saturada em calcita ao longo de todo ano hidrológico. A partir da sazonalidade química do gotejamento em cavernas vadosas, determinou-se que a substituição da infiltração lenta em fissuras na zona vadosa, em função de eventos de recarga do aquífero envolve cerca de 2 meses no sistema Pérolas-Santana.

A dinâmica atual do sistema cárstico Pérolas-Santana é expressa sintéticamente através da taxa de rebaixamento da superficie epicárstica em torno de $31,1 \pm 6 \mathrm{~mm} / \mathrm{ka}$, a qual, é semelhante a taxa de entalhamento fluvial do leito de condutos vadosos, também determinada neste trabalho.

A taxa de denudação cárstica determinada para a bacia do sistema Pérolas-Santana, amostra representativa de um sistema cárstico de clima subtropical úmido, confirma as conclusões de Smith e Atkinson (1976), Ogden (1982) e White (1984), de que as taxas de evolução entre terrenos cársticos temperados e tropicais (com algumas excessões como o carste de Gunong Mulu, Malásia) são dificilmente distinguíveis, sendo consideradas semelhantes, dependendo essencialmente da taxa pluviométrica das áreas. 


\section{CAPÍTULO 6 ¿ CONSIDERAÇÕES FINAIS}

Os trabalhos aqui desenvolvidos, sobre uma área de amostragem do alto vale do rio Ribeira de Iguape, permitiram ao autor, obter uma visão ampla sob o ponto de vista geocientífico, do carste como sistema de relevo e dos principais processos envolvidos na evolução geomórfica e hidrogeológica desta categoria de paisagem natural.

Através da cartografia e análise morfométrica das formas de relevo, foi possível distinguir diversas unidades morfológicas de relevo, cada qual, associada a um estágio evolutivo distinto da superficie cárstica. Esta evolução da paisagem cárstica é marcada pela transição entre a paisagem fluvial para a de carste poligonal, em função do aumento gradativo da permeabilidade secundária nas rochas carbonáticas, através da instalação de sistemas de cavernas.

A integração entre a análise de relevo e os estudos geoespeleológicos, mostrou que a zona de carste poligonal mais desenvolvida reflete a presença preferencial de condutos associados à sistemas de cavernas em profundidades de até $200 \mathrm{~m}$ abaixo da superficie. Um dos resultados mais significativos obtido através da integração do estudo do relevo e da evolução de sistemas de cavernas é a estimativa da idade de vales fluviais adjacentes a canyons subterâneos Esta idade foi obtida através da geocronologia (pelo método $\mathrm{Th} / \mathrm{U}$ ) de calcita secundária depositada sobre níveis fluviais antigos ao longo de canyons vadosos subterrâneos e da posterior correlação entre a taxa de entalhamento fluvial subterrâneo e a taxa de rebaixamento erosivo de leitos fluviais externos. Desta maneira, propõe-se neste trabalho, uma idade mínima de $6_{-3,4}^{-1.4}$ Ma para o vale do rio Betari, junto a área carbonática encaixante do sistema de cavernas Pérolas-Santana. Este resultado, além de quantificar a velocidade de entalhamento do relevo, contribui para o esclarecimento da evolução geomorfológica regional, através da obtenção de uma idade mínima entre 24 e 13 Ma para o início do entalhamento da superficie de erosão Japi (definida originalmente por Almeida, 1964), caracterizada na área de estudo, pelo nivelamento das cristas entre as cotas de 900 a $1100 \mathrm{~m}$.

O mapeamento morfológico e geológico de fragmentos acessíveis de sistemas de cavernas, revelou ser uma ferramenta valiosa para decifrar a história espeleogenética de aqüíferos cársticos. Através deste mapeamento foi possível relacionar os padrões morfológicos definidos em planta, em seções longitudinais e transversais, com a estrutura (padrão de fraturamento superposto ao ângulo de mergulho do acamamento e variabilidade da direção deste) da rocha carbonática hospedeira das cavernas. Forneceu também, os elementos fundamentais para definir os fatores condicionantes da iniciação de protocavernas no carste estudado (proto-condutos guiados principalmente pela intersecção de fraturas longas sobre planos de estratificação do metacalcário).

Adaptando os modelos atuais de espeleogênese (sintetizados em Ford e Williams, 1989 e Worthington, 1991) aos dados obtidos neste trabalho, elaborou-se uma sequência evolutiva da espeleogênese do sistema de cavernas Pérolas-Santana, desde a fase de pré- 
iniciação até a fase de desenvolvimento avançado, atualmente observada. Neste quadro evolutivo, foi possível apresentar idades (apesar de preliminares) das etapas do processo. Este procedimento poderá servir de base metodológica para ser aplicada em outros sistemas de cavernas do Alto Ribeira e, principalmente, em outras áreas cársticas brasileiras, com situações geomorfológicas e tectônicas diferentes, detalhando e/ou reformulando os conceitos e o modelo evolutivo de aqüíferos cársticos, proposto neste trabalho. Especialmente com relação à geocronologia de calcita, método neste trabalho apenas iniciado de forma preliminar, muito campo de pesquisa é previsto, com o objetivo de integrar os dados de evolução de cavernas com estudos da dinâmica erosiva externa. Espera-se contribuir assim, na cronologia de eventos e processos tectônicos quaternários (e por extrapolação, até terciários) envolvidos na modelagem das paisagens cársticas e, por correlação, de terrenos não cársticos adjacentes.

Um dos produtos mais importantes obtidos com a análise morfológica dos condutos, aliada ao levantamento da geologia estrutural da rocha encaixante e da distância entre sumidouros e ressurgências, foi a confirmação e adaptação, para a área de estudo, do método de Worthington (1991), no sentido de contribuir na previsibilidade do local de ocorrência e da provável profundidade de condutos cársticos em rochas carbonáticas. Desta maneira, este trabalho representa o início do estudo geológico sistemático de sistemas de cavernas no Brasil, com o objetivo geral de contribuir na aplicação no Brasil, a médio prazo, da questão clássica da geoespeleologia e geomorfologia de terrenos cársticos, que é a de prever a ocorrência de fenômenos como cavernas (não evidentes através da observação da drenagem superficial) e zonas potenciais de subsidência catastrófica. Esta possibilidade de previsão deverá contribuir no planejamento do uso e ocupação de áreas cársticas, assim como, na orientação da exploração de aquuíferos cársticos.

O monitoramento hidrológico e hidroquímico do sistema cárstico Pérolas-Santana, típico da região do alto vale do rio Ribeira de Iguape, teve como resultado principal, o cálculo da taxa de denudação química da bacia de drenagem cárstica associada ao sistema de cavernas. $O$ valor obtido de $31,1 \pm 6 \mathrm{~mm} / 1000$ anos representa o primeiro exemplo quantitativo da dinâmica de rebaixamento da superficie carbonática em ambiente subtropical úmido da América do Sul. Este resultado é uma importante contribuição para o quadro comparativo da dinâmica erosiva de sistemas cársticos, em ambientes distintos, a nível mundial.

O presente trabalho representa apenas o primeiro passo para a abertura de um vasto campo de pesquisas, tanto acadêmicas, como com potencial de aplicação prática no manejo de áreas cársticas e seus aqüíferos. $\mathrm{Na}$ área da geoespeleologia, por exemplo, pesquisas futuras deverão ser concentradas no tema relativo aos fatores geológicos, estruturais e hidrológicos, condicionantes de sistemas de cavernas, com o objetivo de refinar o modelo de previsão de ocorrência de condutos. No campo da hidrologia e hidrogeologia de aqǘferos cársticos, um número mais significativo de bacias deverão ser monitoradas (tanto no carste do vale do Ribeira como em outras áreas cársticas brasileiras), no sentido de aprimorar as técnicas de demarcação dos sistemas de drenagem subterrânea e de avaliação 
dos volumes de água armazenada e transmitida por aqǘferos cársticos. O monitoramento hidrológico e hidroquímico de nascentes e ressurgências cársticas deverá ser aliado à ensaios com traçadores (por exemplo, corantes), o que desenvolverá a capacidade de interpretação hidrodinâmica e hidrogeológica dos aqǘíferos cársticos associados. Com relação à geoquímica dos processos de dissolução e precipitação de minerais carbonáticos em ambiente cárstico, investigações deverão ser dirigidas na definição dos controles fisicoquímicos da deposição de minerais secundários e de suas transformações diagenéticas em cavernas. Inclusive com estudos da sua composição isotópica (aspecto não abordado nesta tese) associados à geocronologia de calcita secundária, visando a aplicação destes resultados, no estudo de flutuações paleoclimáticas recentes e da geologia quaternária de terrenos cársticos, seguindo as tendências internacionais das pequisas geológicas em áreas cársticas. 


\section{REFERÊNCLAS}

AB' SABER, A.N.-1977-Espaços ocupados pela expansão dos climas secos na América do Sul, por ocasião dos períodos glaciais quaternários. Paleoclimas, (3).1-19.

AFONSO de SOUZA, M.-1993- Mapeamento geoespeleológico do sistema de cavernas Areias, Iporanga, SP. In: SIMPÓSIO DE INICIAÇÃO CIENTÍfICA, 1., São Paulo, 1993. Resumos. São Paulo, USP/CNPQ. p. PB04.

ALLBUT, M.-1977- An appraisal of the conductance method for the in situ measurement of total hardness and aggressivity. Transactions British Cave Research Association, 4(4): $431-439$.

ALMEIDA, F.F.M.-1964- Os fundamentos geológicos do relevo paulista. Boletim I.G.G., (41):169-263, São Paulo.

ALMEIDA, F.F.M-1976- The system of continental rifts bordering the Santos basin, Brazil. Anais da Academia brasileira de Ciências, 48 (suplemento): 15-26.

ANDERSON, M.G. \& BURT, T.P.-1980- Interpretation of recession flow. Journal of Hydrology, 46(1-2): 89-101.

ASMUS, H.E.-1981- Relacionamento genético de feições geológicas da margem continental sudeste brasileira e da área continental emersa adjacente. In: SIMPÓSIO REGIONAL DE GEOLOGIA, 3., Curitiba, 1981. Atas, São Paulo, SBG. v.1, p. 262273.

ATKINSON, T.C. \& DREW, D.P.-1974- Underground drainage of limestone catchments in the Mendip Hills. In: GREGORY, K.J. \& WALLING, D.E. (eds.) Fluvial Processes in Instrumented Watersheeds. London, Institute of British Geographers (Special Publication 6), p. 87-106.

AULER, A. \& RUBBIOLI, E.-1993- A toca da Boa Vista. In Grupo Bambuí de Pesquisas Espeleológicas - Uma década revelando o Brasil subterrâneo. Belo Horizonte, Grupo Bambuí de Pesquisas Espeleológicas (GBPE) e Laboratório de Pesquisas Históricas (LAPHIS), p. 14-15.

BACK, W.-1960- Origin of hydrochemical facies of ground water in the Atlantic Coastal Plain. In: INTERNATIONAL GEOLOGICAL CONGRESS, 21., Copenhagen, 1960. Proceedings. Copenhagen, Det Berlingske. p. 87-95.

BACK, W. \& ARENAS, A.D.-1989- Karst terrains: resources and problems. Nature \& Resources, Special Issue, Unesco, p. 19-26.

BADGLEY, P.C.-1965-Structural and tectonic principles. New York, Harper and Row, $521 \mathrm{p}$.

BALL, T.K. \& JONES, J.C.-1990- Speleogenesis in the limestone outcrop north of the South Wales Coalfield: the role of micro-organisms in the oxidation of sulphides and hydrocarbons. Cave Science, 17(1): 3-8.

BARBERENA, M.C.; CORREIA, N.R. \& AUMOUND, J.J.-1980- Contribuição à estratigrafia e bioestratigrafia do Grupo Passa Dois na Serra do Cadeado (NE do Paraná, Brasil). Revista Brasileira de Geociências 10(4): 268-275.

BARBIERI, A.J.-1993- Depósitos minerais secundários das cavernas Santana, Pérolas e Lage Branca, município de Iporanga, São Paulo. São Paulo, 96 p. (Dissertação de Mestrado - Instituto de Geociências/USP).

BARNES, B S -1939- The structure of discharge-recession curves Transactions American Geophysical Union, 20: 721-725. 
BARROS BARRETO, C.N G, DE BLASIS, P.D; DIAS NETO, C.M; KARMANN, I; LINO, C.F. \& ROBRAHN, EM-1982- Abismo Ponta de Flecha: um projeto arqueológico, paleontológico e geológico no médio Ribeira de Iguape, São Paulo. Revista de Pré-História, 3(4) 195-215, São Paulo.

BATISTUCCI, N.L.N.-1988- Mapeamento geoespeleológico da caverna Água Suja: desenvolvimento de métodos. FAPESP, 45 p. (Relatório de Iniciação Científica no 87/2104-1).

BLÉS, J.L. \& FEUGA, B-1986-The fracture of rocks. New York, Elsevier, 131 p.

BÖGLI, A.-1964- Mischungskorrosion, ein Beitrag zum Verkarstungsproblem. Erdkunde, 18(2): 83-92.

BÖGLI, A-1969- Neue Anschauungen über die Rolle von Schichtfugen und Klüften in der karsthydrographischen Entwicklung. Geologische Rundschau, 58(2): 395-408.

BÖGLI, A.-1978- Karsthydrogrphie und physische Speläologie. Berlin, Springer Verlag; $292 \mathrm{p}$.

BOTTREL, S.H.; SMART, P.L.; WHITACKER, F. \& RAISWELL, R.-1991Geochemistry and isotope systematics of sulphur in the mixing zone of Bahamian blue holes Applied Geochemistry, 6: 97-103.

BRAUN, O.P.G.-1971- Contribuição à geomorfologia do Brasil Central. Revista Brasileira de Geografia, 32(3): 3-39.

BRETZ, J.H.-1942- Vadose and phreatic features of limestone caverns. Joumal of Geology, 50(6): 675-811.

BROOK, G.A.; FOLKOFF, M.E. \& BOX, E.O.-1983- A world model of soil carbon dioxide. Earth-Surface Processes and Landforms, 8(1): 79-88.

BROWN, K.S. \& AB' SABER, A.N.-1979- Ice age forest refuges and evolution in the neotropics: correlation of paleoclimatological, geomorphological and pedological data with modern biological endemism. Paleoclimas, (5): 1-30.

BRUCKER, R.W.; HESS, J.W. \& WHITE, W.B.-1972- Role of vertical shafts in the movement of ground water in carbonate aquifers. Ground Water, 10(6): 5-13.

BULL, P.A.-1980- The antiquity of caves and dolines in the British Isles. Zeitschrift für Gemorphologie, Supplement Band 36: 217-232.

BULL, P.A.-1983- Chemical sedimentation in caves. In: GOUDIE, A.S. \& PYE, K. (eds) Chemical sediments and geomorphology: precipitates and residua in the nearsurface environment. London, Academic Press, p. 301-319.

CBA (COMPANHIA BRASILEIRA DE ALUMÍNIO) e CNEC (CONSÓRCIO NACIONAL DE ENGENHEIROS CONSULTORES)-1983- Aproveitamento hidrelétrico Descalvado- Pedido de Concessão. São Paulo, CBA/CNEC, 116 p. (Relatório).

CALLES, B. \& CALLES, U.M.-1990- Temperature correction of electrical conductivity values. Earth-Surface Processes and Landforms, 15(7): 673-678.

CAMPANHA, G.-1991- Tectônica proterozóica no Alto e Médio Vale do Ribeira, Estados de São Paulo e Paraná. São Paulo, 296p. (Tese de Doutoramento - Instituto de Geociências/ USP).

CAMPANHA, G.; BISTRICHI, C.A. \& ALMEIDA, M.A.-1987- Considerações sobre a organização litoestratigráfica e evolução tectônica da faixa de dobramento Apiá. In: SIMPÓSIO SUL-BRASILEIRO DE GEOLOGIA, 3., Curitiba, 1987. Atas Curitiba, SBG v 2 p 725-742. 
CAMPANHA, G.A.; GIMENES FILHO,A; VIEIRA CAETANO, S.L.; ALVES PIRES, F.; LUCAS DANTAS, A.S TEIXEIRA, A.L: DEHIRA, L.K.; HACHIRO, J.; STEFANI, F.L.-1985- Geologia das folhas Iporanga (SG.22-X-B-V-2) e Grtita do Diabo (SG.22-X-B-VI-1), Estado de São Paulo. São Paulo, IPT/Pró-Minério. (Relatório $\mathrm{n}^{\circ} 22.352$ )

CHABERT, C. \& WATSON, R.A-1981- Mapping and measuring caves. A conceptual analysis. National Speleological Society Bulletin, 43(1): 3-1 1

CHURCH, M. \& KELLERHALS, R-1970- Stream gauging techniques for remote areas using portable equipment. Ottawa, 89 p. (Technical Bulletin, 25) Inland Waters Branch, Dep. of Energy, Mines and Resources.

COLLET, G.C.; LeBRET, M.; MARTIM, P.; \& GOUPHON, P.-1970-Esboço topográfico do Abismo dos Caramujos. São Paulo, Sociedade Brasileira de Espeleologia (mapa).

CORDANI, U.G. \& BRITO NEVES, B.B.-1982- The geologic evolution of South America during the Archean and Early Proterozoic. Revista Brasileira de Geociências 12(13): $78-88$

CORBEL, J -1959- Erosion en terrain calcaire. Annales Geographie, 68: 97-120.

COURBON, P.; CHABERT, C.; BOSTED, P. \& LINDSLEY, K.-1989-Atlas of the great caves of the world. St. Louis, Cave Books, $369 \mathrm{p}$.

COUTARD, J.; KOHLER, H.C. \& JOURNAUX, A.-1978- Mapa do carst. Região de Pedro Leolpoldo - Lagoa santa, Minas Gerais Brasil (esc. 1:50.000). Caen, Université de Caen e Centre de Geomorphologie/CNRS (mapa).

CRAMER, H.-1941- Die Systematik der Karstdolinen. Neues Jahrbuch für Mineralogie, Geologie und Paläontologie, Beilage Band, Abt. B, 85(2): 293-382.

DAEE - DEPARTAMENTO DE ÁGUAS E ENERGIA ELÉTRICA-1990- Plano Estadual de Recursos Hidricos: primeiro plano do Estado de São Paulo-Síntese. São Paulo, CRH/DAEE, 120 p.

DAEE - DEPARTAMENTO DE ÁGUAS e ENERGIA ELÉTRICA-1991- Dados hidrometeorológicos - Posto Apiai (Município de Apiaí), periodo de 1962 a 1991. São Paulo, Sistema Banco de Dados Hidrometeorológicos, DAEE.

DAEE - DEPARTAMENTO DE ÁGUAS e ENERGIA ELÉTRICA-1992- Dados hidrometeorológicos - Posto Serra dos Motas (Município de Iporanga), período de 1972 a1992. São Paulo, Sistema Banco de Dados Hidrometeorológicos, DAEE.

DAVIS, G.H.-1984- Structural geology of rocks and regions. Toronto, John Wiley \& Sons, $492 \mathrm{p}$.

DAVIS, W.M.-1930- Origin of limestone caverns. Geological Society of America Bulletin, 41: 475-628.

DAY, M.-1976- The morphology and hydrology of some Jamaican karst depressions. Earth-Surface Processes 1(2): 111-129.

DEIKE, R.G.-1969- Relations of jointing to orientation of solution cavities in limestones of central Pennsylvania. American Journal of Science, 267: 1230-1248.

DEIKE, R.G.-1989- Fracture controls on conduit development. In: WHITE, W.B. \& WHITE, E.L. (eds.) Karst hydrology, concepts from the Mammoth Cave area. New York, Van Nostrand Reinhold, p. 259-291

DEIKE, G.H. \& WHITE, W.B.-1969- Sinuosity in limestone solution conduits. American Journal of Science, 267(2): 230-241.

DRAKE, J.J. 1983- The effects of geomorphology and seasonality on the chemistry of carbonate groundwater Journal of Hydrology, 61(1-3) 223-236 
DRAKE, J.J.-1984- Theory and model for global carbonate solution by groundwater. In: LaFLEUR, R.G. (ed.) Groundwater as a geomorphic agent. Boston, Allen \& Unwin, p. 211-226.

DRAKE, J.J. \& FORD, D.C.-1972- The analysis of growth patterns of two generation populations: The examples of karst sinkholes. Canadian Geographer, 16: 381-384.

DRAKE, J.J. \& FORD, D.C.-1973- The dissolved solids regime and hydrology of two mountain rivers. In . INTERNATIONAL CONGRESS OF SPELEOLOGY, 6. Oloumuc, 1973, Proceedings Oloumuc, v. 3 p. 53-61

DRAKE, J.J. \& HARMON, R.S.-1973- Hydrochemical environments of carbonate terrains. Water Resources Research, 9(4): 949-957.

DREYBRODT, W.-1981a- Kinetics of dissolution of calcite and its application to karstification. Chemical Geology, 31(3): 245-269.

DREYBRODT, W. $-1981 \mathrm{~b}$ - Mixing corrosion in $\mathrm{CaCO}_{3}-\mathrm{CO}_{2}-\mathrm{H}_{2} \mathrm{O}$ systems and its role in the karstification of limestone areas. Chemical Geology, 32(3-4): 221-236

DREYBRODT, W.-1987- The kinetics of calcite dissolution and its consequences to karst evolution from the initial to the mature state. National Speleological Society Bulletin, 49(2): $31-49$.

DREYBRODT, W.-1988- Processes in karst systems - Physics, Chemistry and Geology (Springer series in physical environments 4). Berlin, Springer Verlag, $288 \mathrm{p}$

DREYBRODT, W.-1990- The role of dissolution kinetics in the development of karst aquifers in limestone: a model simulation of karst evolution. Journal of Geology, 98(5): 639-655.

EWERS, R.0.-1972- $A$ model for the development of subsurface drainnage routes along bedding planes. Cincinnati, 230p. (M.sc. thesis, Department of Geology - University of Cincinnati)

EWERS, R.O.-1982- Cavern development in the dimensions of length and breadth. Hamilton, 398p., (PhD thesis, Department of Geology - McMaster University).

FERREIRA, F.J.F.; MORAES, R.A.V.; FERRARI, M.P. \& VIANNA, R.B.-1981Contribuição ao estudo do Alinhamento Estrutural de Guapiara. In: SIMPOSIO REGIONAL DE GEOLOGIA, 3., Curitiba, 1981. Anais Curitiba, SBG. v1, p 226240.

FORD, D.C.-1964- Origin of closed depressions in the central Mendip Hills. In: INTERNATIONAL GEOGRAPHICAL CONGRESS, 20., London, 1964, Abstract Papers London, p. 105-106.

FORD, D.C.-1965- The origin of limestone caverns: a model from the central Mendip Hills, England. Bulletin of the National Speleological Society, 27(4): 109-132

FORD, D.C.-1971a- Characteristics of limestone solution in the southern Rocky Mountains and Selkirk Mountains, Alberta and British Columbia. Canadian Joumal of Earth Sciences, 8(6): 585-609.

FORD, D.C.-1971b- Geologic structure and a new explanation of limestone cavern genesis Cave Research Group of great Britain Transactions, 13(2):81-94

FORD, D.C.-1973- Development of the canyons of the South Nahanni River, N W. T. Canadian Journal of Earth Sciences, 10(3): 366-378.

FORD, D.C.-1980- Threshold and limit effects in karst geomorphology In COATES, DL \& VITEK, J.D. (Eds.) Thresholds in Geomorphology, London, George Allen \& Unwin, p 345-362. 
FORD, D.C.-1988- Characteristics of dissolutional cave systems in carbonate rocks. In: JAMES, N.P. \& CHOQUETTE, P.W. (eds) Paleokarst. New York, Springer Verlag, p. 25-57.

FORD, D.C. \& EWERS, R.0.-1978- The development of limestone cave systems in the dimensions of length and depth. Canadian Journal of Earth Sciences, 15(11): 17831798.

FORD, D.C.; PALMER, A.N. \& WHITE, W.B.-1988- Landform development, Karst. In: BACK, W.; ROSENHEIN, J.S. \& SEABER, P.R. (eds) The Geology of North America. Boulder, Geological Society of America, v. O-2 (Hydrogeology), p. 401412.

FORD, D.C.; SCHWARCZ; H.P.; DRAKE, J.J; GASCOYNE, M. HARMON, R.S. \& LATHAM, A.G.-1981- Estimates of the age of the existing relief within the southern Rocky Mountains of Canada. Artic and Alpine Research, 13(1): 1-10.

FORD, D.C. \& WILLIAMS, P.W.-1989- Karst geomorphology and hydrology. London, Unwin Hyman, 601p.

FORD, T.D. \& WORLEY, N.E.-1977- Phreatic caves and sediments at Mallock, Derbyshire. In: INTERNATIONAL CONGRESS OF SPELEOLOGY, 7., Sheffield, 1977. Proceedings Sheffield, IUS, 1977. p. 194-196.

FORTI, P.-1989- The role of sulfide-sulfate reactions in speleogenesis. In: INTERNATIONAL CONGRESS OF SPELEOLOGY, 10., Budapest, 1989 Proceedings Budapest IUS, 1989. v.1 p. 71-73.

FREEZE, R.A. \& CHERRY, J.A.-1979-Groundwater. New Jersey; Prentice-Hall, 604 p.

FULFARO, V.J.-1971- A evolução tectônica e paleogeográfica da bacia sedimentar do Paraná pelo trend surface analysis. Geologia, Escola de Engenharia de São Carlos, 14: 14-112.

GALE, S.J.-1984- The hydraulics of conduit flow in carbonate aquifers. Journal of Hydrology, 70(1-4): 309-327.

GAMA Jr., E.-1979- A sedimentação do grupo Passa Dois (exclusive Formação Irati): um modelo geomórfico. Revista Brasileira de Geociências, 9(1): 1-16.

GAMS, I.-1978- The polje: The problem of definition. Zeitschrift für Geomorphologie, Neue Folge, 22(2): 170-181.

GASCOYNE, M.-1977- Uranium series dating of speleothems: an investigation of technique, data prcessing and precision. Hamilton, 82 p., Department of Geology, McMaster University (Technical Memo. 77-4).

GASCOYNE, M-1980- Pleistocene climates determined from stable isotope and geochronologic studies of speleothem. Hamilton, $467 \mathrm{p}$., $(\mathrm{PhD}$ thesis, Department of Geology - McMaster University).

GASCOYNE, M.-1981- Rates of cave passage entrenchment and valley lowering determined from speleothem age measurements. In: INTERNATIONAL CONGRESS OF SPELEOLOGY, 8., Bowling Green, 1981, Proceedings Bowling Green, 1981. v.1, p. 99-100.

GASCOYNE, M.; FORD, D.C. \& SCHWARCZ, H.P.-1983- Rates of cave and landform development in the Yorkshire Dales from speleothem age data. Earth-Surface Processes and Landforms, 8(6): 557-568.

GASCOYNE, M:; LATHAM, A.G.; HARMON, R.S. \& FORD, D.C.-1983- The antiquity of Castleguard cave, Columbia Icefields, Alberta, Canada Artic and Alpine Research, $15(4)$. $463-470$ 
GASCOYNE, M.; SCHWARCZ, HP \& FORD, D.C.-1978- Uranium series dating and stable isotope studies of speleothems. Part I. Theory and techniques. Transactions of

- the British Cave Research Association, 5(2): 91-111.

GILLI, E.-1986- Les grandes cavites souterraines: études et applications. Karstologia, 8: 311 .

GLAZEK, J. \& MARKOWICZ-LOHINOWICZ, M.-1973- Remarks to the use of quantitative methods to karst denudation velocity. In: INTERNATIONAL CONGRESS OD SPELEOLOGY, 6., Oloumuc, 1973. Proceedings Oloumuc, 1973. v.3, p. 225-230.

GOEDE, A \& HARMON, R.S-1983-Radiometric dating of Tasmanian speleothems evidence of cave evolution and climatic change. Journal Geological Society of Australia, 30(1-2): 89-100.

GONZALES, L.A. \& LOHMANN, K C.-1988- Controls on mineralogy and composition of spelean carbonates Carlsbad Caverns, New Mexico. In: JAMES, N.P. \& CHOQUETTE, P.W. (eds) Paleokarst, Berlin, Springer Verlag, p. 81-101.

GRUND, A.1914- Der Geographische Zyklus im Karst. Zeitschrift der Gesellschaft für Erdkunde, 52: 621-640.

GUERRA, A.M.-1986- Processos de carstificação e hidrogeologia do Grupo Bambuí na região de Irecê, Bahia. São Paulo, 132 p. (Tese de doutoramento - Instituto de Geociências/USP).

GUNN, J.-1978- Karst hydrology and solution in the Waitomo district, New Zeland. Auckland, 240 p. (PhD thesis, Auckland University).

GUNN, J.-1981a- Hydrological processes in karst depressions. Zeitschrift für Geomorphologie Neue Folge 25(3): 313-331.

GUNN, J.-1981b-Limestone solution rates and processes in the Waitomo District, New Zealand. Earth-Surface Processes and Landforms, 6(5): 427-455.

GUNN, J.-1983- Point-recharge of limestone aquifers- a model from New Zealand Karst. Journal of Hydrology, 61(1-3): 19-29.

GUNN, J.-1986-Solute processes and karst landforms. In: TRUDGILL, S.T. (ed) Solute Processes. Chichester, John Wiley \& Sons, p. 363-437.

GUPTA, R.S.-1989- Hydrology and hydraulic systems. Englewood Cliffs, Prentice Hall, $739 \mathrm{p}$.

GUSSO, G.L.N.; DIAS NETO, C.M.; TRAJANO, E.; KARMANN, I; ROGRIGUES, R. \& LINO, C.-1979- Paleontologia das cavernas do vale do Ribeira-exploração 1Abismo do Fóssil (SP145). Resultados parciais. In: SIMPÓSIO REGIONAL DE GEOLOGIA, 2., Rio Claro, 1979. Atas SBG, Rio Claro, 1979. v.1, p. 257-268.

GUTJAHR, M.R.-1993-Critérios relacionados à compartimentação climática de bacias hidrográficas: a bacia do Rio Ribeira de Iguape. São Paulo, 90p. (Dissertação de Mestrado, Departamento de Geografia - FFLCH/USP).

HACK, J. T.-1973- Stream profile analysis and stream gradient index. Journal Research $U$. S. Geological Survey, 1(4): 421-429.

HARMON, R.S.-1973- The chemical history of some carbonate ground waters - central Appalachians. In: INTERNATIONAL CONGRESS OF SPELEOLOGY, 6, Oloumuc, 1973, Proceedings Oloumuc, 1973. v.1, p. 95-101.

HARMON, R.S.; HESS, J.W; JACOBSON, R.W.; SHUSTER, E.T; HAYWOOD, C \& WHITE, W.B.-1972- Chemistry of carbonate denudation in North America. Transactions Cave Research Group of Great Britain, 14. 96-103. 
HARMON, R.S.; THOMPSON, P.; SCHWARCZ, H.P. \& FORD, D.C.-1975- Uranium series dating of speleothems. National Speleological Society: Bulletin, 37(2): 21-33.

HASUI, Y.; CREMONINI, O.A. \& BORN, H.-1984- $O$ "Granito Três Córregos" revisado e o Maciço Catas Altas. In: CONGRESSO BRASILEIRO DE GEOLOGIA, 33., Rio de Janeiro, 1984. Anais Rio de Janeiro, SBG, 1984. v.7, p. 3023-3031.

HASUI, Y. \& OLIVEIRA, M.A.F.-1984- Província Mantiqueira- setor central. In: ALMEIDA, F.F.M \& HASUI, Y. (coords.) O Pré-Cambriano do Brasil. São Paulo, Editora Edgard Blücher, p. 308-344.

HESS, J.W. \& HARMON, R.S.-1981- Geochronology of speleothems from the Flint Ridge - Mammoth Cave system, Kentucky, USA. In: INTERNATIONAL CONGRESS OF SPELEOLOGY, 8., Bowling Green, 1981, Proceedings Bowling Green, 1981. v.1, p 433-436.

HUNTOON, P.W.-1985- Gradient controlled caves, Trapper-Medicine Lodge area, Bighorn basin, Wyoming. Ground Water, 23(4): 443-448.

INSTITUTO DE PESQUISAS TECNOLÓGICAS DO ESTADO DE SÃO PAULO- IPT. 1981a- Mapa geomorfológico do Estado de São Paulo, escala 1:1.000.000. São Paulo, Secretaria da Indústria, Comércio, Ciência e Tecnologia do Estado de São Paulo e IPT (Publicação IPT no 1183).

NSTITUTO DE PESQUISAS TECNOLÓGICAS DO ESTADO DE SÃO PAULO- IPT$198 \mathrm{lb}-$ Mapa geológico do Estado de São Paulo, escala 1:500.000. São Paulo, Secretaria da Indústria, Comércio, Ciência e Tecnologia do Estado de São Paulo e IPT (Publicação IPT no 1184).

JAKUCS, L.-1977- Morphogenetics of karst regions. New York, John Wiley \& Sons, $129 \mathrm{p}$.

JAMESON, R.A.-1981- Development of flow paths and cave passages from fault segments in West Virginia caves. In: INTERNATIONAL CONGRESS OF SPELEOLOGY, 8., Bowling Green, 1981. Proceedings Bowling Green, 1981. v.2, p. 717-719

JAMESON, R.A.1985-Structural segments and the analysis of flow paths in the North Canyon of Snedegar cave, Friars Hole cave system, West Virginia 421p. (MSc thesis, College of Arts and Sciences - West Virginia University).

JENNINGS, J.N.-1985-Karst Geomorphology. Oxford, Basil Blackwell, 293 p.

KARMANN, B.-1989- Programa de cálculo de vazão pelo método de diluição de sal (Turbo Pascal 6.0), São Paulo, inédito.

KARMANN, I.-1982- Paleontologia do vale do Ribeira Exploração II Geologia, arqueologia e paleontologia do abismo Ponta de Flecha (SP-175), Iporanga, SP. FAPESP, 37 p. (Relatório de Iniciação Científica n ${ }^{\circ}$ 81/1161-5)

KARMANN, I.-1983- Província Espeleológica do Vale do Ribeira aspectos fisicos e necessidade de sua preservação. In: SIMPÓSIO SOBRE A OCUPACÁO DO VALE DO RIBEIRA, 1., São Paulo, 1983 Atas São Paulo, ABGE/SBE, 1983 p 34-37.

KARMANN, I. \& SANCHEZ, L.E-1986- Speleological Provinces in Brazil In CONGRESO INTERNACIONAL DE ESPELEOLOGIA, 9, Barcelona, 1986 Anales Barcelona, IUS, 1986. v.1, p. 151-153.

KASTNING, E.H.-1983- Relict caves as evidence of landscape and aquifer evolution in a deeply dissected carbonate terrain: Southwest Edwards plateau, Texas, USA. Journal of Hydrology, 61(1-3). 89-112. 
KASTNING, E.H.-1984- Hydrogeomorphic evolution of karsted plateaus in response to regional tectonism. In: LaFLEUR, R.G. (ed.) Groundwater as a geomorphic agent. Boston, Allen \& Unwin, p. 351-382.

KEMMERLY, P.R.-1982- Spatial analysis of a karst depression population: Clues to genesis. Geological Society of America Bulletin, 93(11): 1078-1086

KIRALY, L; MATHEY, B. \& TRIPET, J.P.-1971- Fissuration et orientation des cavites souterraines. Bulletin Societé Neuchatel de Sciences de la Nature, 94: 99-114.

KOHLER, H.C.-1989- A geomorfologia cárstica na região de Lagoa Santa, MG. São Paulo, 113 p. (Tese de doutoramento, Instituto de Geografia - FFLCH/USP).

KOWSMANN, R.O. \& ATAIDE COSTA, M.P.-1979- Sedimentação quaternária da margem continental brasileira e das áreas oceânicas adjacentes. Rio de Janeiro, Petrobrás, 55 p. (Projeto Remac, $n^{\circ} 8$ ).

KRONE, R-1914- Informações ethnographicas do valle do rio Ribeira de Iguape. In: COMMISSÃO GEOGRAPHICA E GEOLÓGICA DO ESTADO DE SÃO PAULO (ed.) Exploração do Rio Ribeira de Iguape. $2^{\text {a }}$ edição, São Paulo, p. 24-34.

KRONE, R-1950- As grutas calcárias do vale do rio Ribeira de Iguape. O I.G.G., 8(3): 248-297 (transcrição do vol. VX, Arquivos do Museu Nacional, 1909, Rio de Janeiro).

LANGMUIR, D.-1971- The geochemistry of some carbonate ground waters in central Pennsylvania. Geochimica Cosmochimica Acta, 35(10): 1023-1045.

LATTMAN, L.H. \& PARIZEK, R.R.-1964- Relationship between fracture traces and the occurence of ground water in carbonate rocks. Journal of Hydrology, 2(2): 73-91

LAURITZEN, S.E.-1989- Shear, tension or both- a critical view on the prediction potential for caves. Proc. 10th International Congress of Speleology, vol. 1:118-120, Budapest.

LAURITZEN, S.E.; ABBOT, J.; ARNESEN, R.; CROSSLEY, G.; GREPERRUD, D.; IVE, A. \& JOHNSON, S.-1985- Morphology and hydraulics of an active phreatic conduit. Cave Science, 12(3): 139-146.

LAVALLE, P.-1967-Some aspects of linear karst depression development in south-central Kentucky. Assoc. American Geographers, Annals, 57: 49-71.

Le BRET, M.-1966- Estudos espeleológicos no vale do Alto Ribeira. Boletim I.G.G., 47: 71-123, São Paulo.

LEHMANN, H.-1936- Morphologische studien auf Java. Geographische Abhandlungen, 3(9): $114 \mathrm{p}$.

LEPINE, R.D.-1993- Mapeamento e estudo geoespeleológico da caverna de Santana, Iporanga, São Paulo. FAPESP, 24p. (Relatório de Iniciação Científica no 91/2314-1).

LINSLEY, R.K. \& FRANZINI, J.B.-1978- Engenharia de recursos hídricos. São Paulo, Edusp e McGrawHill, 798 p.

LIPPMANN, F.-1960- Versuche zur Aufklärung der Bildungsbedingungèn von Calcit und Aragonit. Fortschritte in Mineralogie, 38: 156-161.

LOWE, D.J.-1992- A historical review of concepts of speleogenesis. Cave Science, 19(3): 63-90.

MANDELBROT, B.B.-1983- The fractal geometry of nature. New York, Freeman, 468 p.

MANGIN, A.-1984- Pour une meilleure connaissance des systemes hidrologiques à partir des analyses correlatoire et spectrale. Journal of Hydrology, $67(1-4) \cdot 25-43$. 
MARINHO, M. de A-1989-Estudo morfológico preliminar do sistema cárstico Pérolas Santana, Iporanga, SP CNPQ, 38p. (Relatório de Iniciação Científica no 804393/885).

MARKOWICZ, MV, POPOV, V \& PULINA, M-1972-Comments on-karst denudation in Bulgaria. Geographica Polonica, 23: 111-139.

MARTMM, P.; CHRYSOSTOMO, R.S. \& RODRIGUES, R.-1989-Cadastro nacional de cavidades naturais Indice de dados sobre as cavernas do Brasil. São Paulo, Sociedade Brasileira de Espeleologia, 222 p.

MARTINET, B. \& SOUGY, J.-1961- Utilization pratique des classifications chimiques des roches carbonatées. Annales de la Faculté des Sciences de L'Université de Dakar, 6:81-92.

McCONNELL, H. \& HORN, J.M.-1972- Probabilities of surface karst. In: CHORLEY, R.J. (Ed.) Spatial analysis in geomorphology. New York, Harper and Row, p.111133.

MELO, M.S. de-1990- A Formação Pariqüera-Açu e depósitos relacionados: sedimentação, tectônica e geomorfogênese. São Paulo, 211p. (Dissertaçâo de Mestrado - Instituto de Geociências/USP)

MELO, M.S.; FERNANDES, L.A. \& COIMBRA, A.M.-1990- Evolução tectonosedimentar cenozóica do baixo vale do rio Ribeira do Iguape. SP. In: CONGRESSSO BRASILEIRO DE GEOLOGIA, 36., Natal 1990, Anais SBG, Núcleo Nordeste 1990, v. 5 , p. $2250-2260$.

MELO, M.S.; RICCOMINI, C.; HASUI, Y.; ALMEIDA, F.F.M. \& COIMBRA, A.M.1985- Geologia e evolução do sistema de bacias tafrogênicas continentais do Sudeste do Brasil. Revista Brasileira de Geociências, 15(3): 193-201.

MILANOVIC, P.T.-1976- Water regime in deep karst. Case study of the Ombla spring drainage area. In: YEVJEVICH, V. (ed.) Karst hydrology and water resources, vol. 1. Karst hydrology. Fort Collins, Water Resources Publications, p.165-191.

MILANOVIC, P.T.-1981- Karst hydrogeology. Littleton, Water Resources Publication, $434 \mathrm{p}$.

MILLER, T.E.-1982-Hydrochemistry, hydrology and morphology of the Caves Branch karst, Belize. Hamilton, 281p. (PhD thesis - Department of Geology - McMaster University).

MILLS, P.-1981- Karst drainage patterns in the Quatsino Limestone, Northern Vancouver Island, Canada. INTERNATIONAL CONGRESS OF SPELEOLOGY, 8., Bowling Green, 1981. Proceedings, Bowling Green IUS, 1981. v.1, p. 117-119.

MOTKE, F.D. \& PALMER, A.N.-1972- Genetic relationship between caves and landforms in the Mammoth Cave National Park area. Würtzburg, Böhler Verlag, $69 \mathrm{p}$.

MMAJ/JCA - METAL MINING AGENCY OF JAPAN/JAPAN INTERNATIONAL COOPERATION AGENCY-1983-Report on Geological Survey of Anta Gorda, phase 3. São Paulo, Convênio DNPM/MMAJ/JICA, 220p.

MONROE, W.H.-1974- Dendritic dry valleys in the cone karst of Puerto Rico. Joumal of Research U. S. Geological Survey, 2(2): 159-163.

MONTEIRO, C.A.-1969- A frente polar Atlantica e as chuvas de inverno na fachada sul oriental do Brasil. In: Instituto de Geografia (ed.) A contribuição metodológica à análise rítmica dos tempos no Brasil, Série de monografias, FFLCH/USP, $1,1-62$ 
MOTYKA, I. \& WILK, Z-1984-Hydraulic structure of karst-fissured Triassic rocks in the vicinity of Olkusz (Poland). Kras i Speleologia, 14(5): 11-24

MYLROIE, J.E. \& CAREW, J.L.-1986- Minimum duration of speleogenesis. INTERNATIONAL CONGRESS OF SPELEOLOGY, 9., Barcelona 1986, Proceedings, Barcelona IUS, 1986, v.1, p. 249-251.

NEWSON, M.D:-1971- A model of subterranean erosion in the British Isles based on hydrology. Transactions of the Institute of British Geographers, 54: 55-70.

OGDEN, A.E-1982- Karst denudation rates for selected spring basins in West Virginia. National Speleological Society Bulletin, 44: 6-10.

PALMER, A.N.-1981- Hydrochemical factors in the origin of limestone caves. INTERNATIONAL CONGRESS OF SPELEOLOGY, 8., Bowling Green 1981, Proceedings Bowling Green IUS, 1981. v.1, p. 120-122.

PALMER, A.N.-1984- Geomorphic interpretation of karst features. In: LaFLEUR RG (ed) Groundwater as a geomorphic agent. Boston, Allen \& Unwin, p. 174-209.

PALMER, A N.-1987- Cave levels and their interpretation. National Speleological Society Bulletin, 49(2): 50-66.

PALMER, A.N.-1991- Origin and morphology of limestone caves. Geological Saciety of America Bulletin, 103: 1-21.

PALMQUIST, R-1979- Geologic controls on doline characteristics in mantled karst. Zeitschrift für Geomorphologie, Supplement Band, 32: 90-106.

PARIZEK, R.P.-1976- On the nature and significance of fracture traces and lineaments in carbonate and other terranes. In: YEVJEVICH, V. (ed.) Karst Hydrology. Fort Collins, Water Research Publications, v. 1, p. 47-108.

PENCK, A-1900- Geomorphologische Studien aus der Hercegovina. Zeitschrift Deut. Osterreich Alpenverein, 31:25-41.

PHILADELPHI, M.A -1990-Mapeamento e estudo geoespeleológico das cavernas do sistema Temimina Pescaria, Iporanga, SP. FAPESP, 38 p. (Relatório de Iniciação Científica no 89/1700-5).

PIRES, F.A.-1988- Uma nova concepção para os ambientes do Grupo Açungui, na região de Iporanga e Apiaí, sul de São Paulo. In: CONGRESSO BRASILEIRO DE GEOLOGIA, 35., Belém 1988, Anais Belém, SBG 1988. v.2, p. 606-616.

PIRES, F.A.-1989- Análise paleoambiental e estratigráfica de sequiencias metassedimentares (Grupo Açungui) na região de Iporanga e Apiaí - São Paulo. São Paulo, 151p. (Dissertação de Mestrado - Instituto de Geociências/USP).

PLUMMER, L.N. \& BUSENBERG, E.-1982- The solubilities of calcite, aragonite and vaterite in $\mathrm{CO}_{2}-\mathrm{H}_{2} \mathrm{O}$ solutions between 0 and $90^{\circ} \mathrm{C}$ and an evaluation of the aqueous model for the system $\mathrm{CaCO}_{3}-\mathrm{CO}_{2}-\mathrm{H}_{2} \mathrm{O}$. Geochimica Cosmochimica Acta, 46(6), 1011-1040.

PLUMMER, L.N. \& WIGLEY, T.M.L.-1976- The dissolution of calcite in $\mathrm{CO}_{2}$ saturated solutions at $25^{\circ} \mathrm{C}$ and 1 atmosphere total pressure. Geochimica Cosmochimica Acta, 40(2): 191-202.

PLUMMER, L.N.; WIGLEY, T.M.L. \& PARKHURST, D.L.-1978- The kinetics of calcite dissolution in $\mathrm{CO}_{2}$-water systems at 5 to $60^{\circ} \mathrm{C}$ and 0.0 yo $1.0 \mathrm{~atm} . \mathrm{CO}_{2}$. American Journal of Science, 278: 179-216.

PLUMMER, L.N, WIGLEY, TML \& PARKHURST, DL.-1979-Critical review of the kinetics of calcite dissolution and precipitation. In: JENNE, E A (ed) Chemical 
modelling in aqueous systems. American Chemistry Society Symposium Series, 93 537-573.

POLITI ENGENHARIA e CONSTRUÇÕES LTDA-1988- Relatório de perfuração de poço, obra n० 611/88, Bairro da Serra, Iporanga, São Paulo.

POWELL, RL-1976. Some geomorphic and hydrologic implications of jointing in carbonate strata of Mississipian age in south-central Indiana. Lafayette, 169 p. (PhD thesis - Purdue University).

PRZYBYLOWICZ, W, SCHWARCZ, H.P. \& LATHAM, A-1991- Dirty calcites 2. Uranium series dating of artificial calcite-detritus mixtures. Chemical Geology, Isotope Geoscience Section, 86(2): 161-178.

PULINA, M.-1972-A comment on present day chemical denudation in Poland. Geographica Polonica, 23: 45-62.

RAMSAY, J.G. \& HUBER, M.I.-1987- The techniques of modern structural geology: Folds and Fractures. London, Academic Press, 700 p.

REAMS, M.W.-1992- Fractal dimensions of sinkholes. Geomorphology, 5: 159-165.

RHOADES, R. \& SINACORI, N.M.-1941- Patterns of groundwater flow and solution. Jornal of Geology, 49: 785-794

RIEDEL, W.-1929- Zur Mechanik geologischer Brucherscheinungen. Centralblatt für Mineralogie, Geologie und Paläontologie, Abt. B: 354-368.

ROGLIC, J.Z.-1960- Das verhältnis der Flusserosion zum Karstprozess. Zeitschrift für Geomorphologie, 4(2): 116-117.

ROWE, P.-1985- Rates of valley incision in the carboniferous limestone of the southern Pennines. Cave Science, 12(3): 30-31.

RUST, B.R.-1979- Coarse alluvial deposits. In: WALKER, RG. (ed) Facies Models Toronto, GAC (Geoscience Canada Reprint Series 1) p. 9-21

SÁNCHEZ, L.E.-1984- Cavernas e paisagem cárstica do Alto Vale do Ribeira/SP: uma proposta de tombamento. Espeleo-Tema, 14:9-21.

SÁNCHEZ, L.E.-1986- Bibliografia espeleológica brasileira - 1836/1980. Ciência e Cultura, 38(5): 927-932.

SCHMIDT, V.A.-1982- Magnetostratigraphy of sediments in Mammoth Cave, Kentucky. Science, 271: 827-829.

SCHWARCZ, H.P. \& BLACKWELL, B.-1985- Dating methods of Pleistocene deposits and their problems: II Uranium-series disequilibrium dating. In: RUTTER, N.W. (ed) Dating methods of Pleistocene deposits and their problems. Toronto, GAC (Geoscience Canada Reprint Series 2) p. 9-18

SHULITS, S.-1941- Rational equation of river bed profile. Transactions American Gephysical Union, 22: 622-630.

SILVA, A.B.-1973- Contribuição à hidrogeologia dos Carstes da região da Bahia, Agua Subterrânea, 1(3): 11-16.

SILVA, A.B.-1984- Análise morfoestrtural, hidrogeológica e hidroquímica no estudo do aqüífero cárstico do Jaíba, norte de Minas Gerais. São Paulo, 189p (Tese de Doutoramento - Instituto de Geociências/USP).

SMITH, D I.-1962- The solution of limestone in an Artic environment London, Institute of British Geographers, Special Publication 4, p. 187-200. 
SMITH, D.I. \& ATKINSON, T.C.-1976- Process, landforms and climate in limestone regions. In: DERYSHIRE, E. (ed.) Geomorphology and Climate. London, John Wiley, p. 369-409.

SMITH, D.I. \& NEWSON, MD.-1974- The dynamics of solutional and mechanical erosion in limestone catchments on the Mendip Hills, Somerset. In: GREGORY, K.J. \& WALLING, D.E. (eds.) Flivial Processes in Instrumented Watersheeds. London, Institute of British Geographers, Special Publication 6, p. 155-167.

SOUZA, A.P.-1990-Mapa geológico na escala 1:50.000 e esboço da evolução tectônica e sedimentar do Grupo Itaiacoca, nas folhas Barra do Chapéu e Ouro Verde - SP/PR. São Paulo, 200 p. (Dissertação de Mestrado - Instituto de Geociências/USP).

STRAHLER, A.N.-1964- Quantitative geomorphology of drainage basins and channel networks. In: CHOW, V.T. (ed) Handbook of a Applied Hydrology. New York, McGraw Hill, section 4, p.39-76.

SUSTERIC, F.-1979- Some principles of cave profile simulation. In: SYMPOSTUM INTERNACIONAL SUR L'EROSION KARST. Aix-en-Provence, Actes p. 125-131

SWEETING, M.M.-1958- The karstlands of Jamaica. Geography Journal, 124: 184-199.

SWEETING, M.M.-1972-Karst landforms. New York, Mcmillan, 362p.

SWEETING, M.M.-1979- Weathering and solution of the Melinau limestones in the Mulu National Park, Sarawak, Malaysia. Annales Societé Geologique Belgique, 102: 53-57.

TERZAGHI, K-1958- Landforms and subsurface drainage in the Gacka region in Yugoslavia. Zeitschrift für Geomorphologie, 2(1-2): 76-100.

THOMPSON, P.-1974- Extraction and isotopic analysis of trace amounts of $U$ and Th from speleothems. Hamilton, 20 p. (Department of Geology, McMaster University (Technical Memo. 73-9).

THOMSON, K.C. \& TAYLOR, R.L.-1991- The art of cave mapping. Quarterly Journal of the Missouri Speleological Survey, 31(1-4): 1-183.

THORNBURY, W.D.-1969- Principles of geomorphology. New York, John Wiley \& Sons, second edition, $594 \mathrm{p}$.

THRAILKILL, J.-1968- Chemical and hydrologic factors in the excavation of limestone caves. Geological Society of America Bulletin, 79: 19-46.

TROESTER, J.W.; WHITE, E.I. \& WHITE, W.B.-1984- A comparison of sinkhole depth frequency distributions in temperate and tropical karst regions. In: BECK, BF. (ed) Sinkholes: Their Geology, Engineering and Environmental Impact. Rotterdam, Balkema, p. 65-74.

TROESTER, J.W. \& WHITE, W.B.-1986- Geochemical investigations of three tropical karst drainage basins in Puerto Rico. Ground Water, 24(4): 475-482

TRUDGILL, S.T.-1985-Limestone geomorphology. London, Longman, 210 p.

UEHARA, K.-1994- Comunicação pessoal.

VAN EYSINGA, F.W.B.-1975- Geological time table. 3th ed., Amsterdam, Elsevier

VILLINGER, E.-1987- Die Blautopfhöhle bei Blaubeuren als Beispiel für die Entwicklung des Karstsystems im schwäbischen Malm. Geologisches Jahrbuch., C(49): 71-103

VOGELSANG, D. \& VILLINGER, E.-1987- Elektromagnetische und hydrogeologische Erkundung des Donau-Aach-Karstsystems (Schwäbische Alb) Geologisches Jahrbuch C(49): 3-33.

WADGE, G. \& DIXON, TH-1984-A geological interpretation of Seasat-Sar imagery of Jamaica. Joumal of Geology, 92(5) : 561-581. 
WALTHAM, A.C.-1981- Origin and development of limestone caves. Progress in Physical: Geography, 5(2): 242-256.

WATSON, R.A. \& WHITE, W.B.-1985- The history of American theories of cave origin. In: DRAKE, E.J. \& JORDAN, W.M: (eds.) Geologists and ideas; a history of North American Geology. Boulder, Geological Society of America, v. 1, p. 109-123.

WEYL, P.K.-1958- Solution kinetics of calcite. Journal of Geology, 66: 163-176.

WHITE, E.L., \& WHITE, WB-1979- Quantitative morphology of landforms in carbonate rock basins in the Appalachian Highlands. Geological Society of America Bulletin, 90(4):385-396.

WHITE, E.L \& WHITE, W B.-1983- Karst landforms and drainage basin evolution in the Obey River Basin, North-Central Tennesse, U.S.A. Journal of Hydrology, 61(1-3): 69-82.

WHITE, W.B.-1966- The preparation of geographical cave reports. National Speleological Society News, 24: 85-92.

WHITE, W.B.-1977- Role of solution kinetics in the development of karst aquifers. In: TOLSON, J.S. \& DOYLE, F.L (eds.) Karst hydrogeology. Huntsville, University of Alabama (International Association of Hydrogeologists, Mem. 12) p. 120-132.

WHITE, W.B.-1984- Rate processes: chemical kinetics and karst landform development. In: LaFLLEUR, R.G. (ed) Groundwater as a geomorphic agent. Boston, Allen \& Unwin, p. 227-248.

WHITE, W.B.-1988- Geomorphology and hydrology of karst terrains. Oxford, Oxford University Press, 464p.

WHITE, W.B. \& DEIKE, G.H.-1989- Hydraulic geometry of cave passages. In: WHITE, W.B. \& WHTTE, E.L. (eds.) Karst hydrology, concepts from the Mammoth Cove area New York, Van Nostrand Reinhold, p. 223-257.

WHITE, W.B. \& LONGYEAR, J.-1962- Some limitations on spelleogenetic speculation imposed by the hydraulics of groundwater flow in limestone. Nittany Grotto Newsletter, 10: 155-167.

WHITE, W.B. \& WHITE, E.I.-1987- Ordered and stochastic arrangements within regional sinkhole populations. In: BECK, B.F. \& WILSON, W.L. (eds.) Multidisciplinary Conference on Sinkholes and the Environmental Impacts of Karst, 2. Orlando, Florida Sinkhole Research Institute, University of Central Florida, p. 85-90.

WIGLEY, T.M.L. \& PLUMMER, L.N.-1976- Mixing of carbonate waters. Geochimica Cosmochimica Acta, 40(9): 989-995.

WILLIAMS, P.W.-1963- An initial estimate of the speed of limestone solution in County Clare. Irish Geographer, 4: 432-441.

WILLIAMS, P.W.-1971- Illustrating morphometric analysis of karst with examples from New Guinea. Zeitschrift für Geomorphologie Neue Folge, 15: 40-61.

WILLIAMS, P.W.-1972a- The analysis of spatial characteristics of karst terrains In: CHORLEY, R.J. (ed.) Spatial analysis in geomorphology. New York, Harper and Row, p.136-166.

WILLIAMS, P.W.-1972b- Morphometric analysis of polygonal karst in New Guinea. Geological Society of America Bulletin, 83: 761-796.

WILLIAMS, P.W.-1982- Speleothem dates, Quaternary terraces and uplift rates in New Zealand. Nature, 298: 257-260.

WLLLAMS, PW-1985-Subcutaneous hydrology and the development of doline and cockpit karst Zeitschrift für Geomorphologie, Neue Folge, 29(4) 463-482 
WILLIAMS, P.W \& DOWLING, R.K.-1979- Solution of marble in the karst of the Pikikinuna range, northwest Nelson, New Zealand. Earth-Surface Processes and Landforms, 4: 15-36.

WORTHINGTON, S.R H.1991- Karst hydrogeology of the Canadian-Rocky Mountains Hamilton, 227p. (PhD thesis, Department of Geography/McMaster University)

YUAN, D.-1985- On the heterogeneity of karst water. In: Karst Water Resources, Proceedings of the Ankara-Antalya Symposium, I.A.H.S., publ. 161: 281-292.

ZALÁN, P.V.; WOLF, S; CONCEIÇÃO, J.C.; MARQUES, A; ASTOLFI, M.AM; VIEIRA, IS., APPI, V.T. \& ZANOTTO, O.A.-1990- Bacia do Paraná. In RAJA GABAGLIA, G.P. \& MILANI, E.J. (coords.) Origem e evolução de bacias sedimentares. Rio de Janeiro, Petróleo Brasileiro, p. 135-168. 
Anexo 5.2 - Exemplo de cálculo de vazão pelo método de diluição de sal através do programa elaborado por Karmann (1989) em Turbo Pascal 6.0 (profissional).
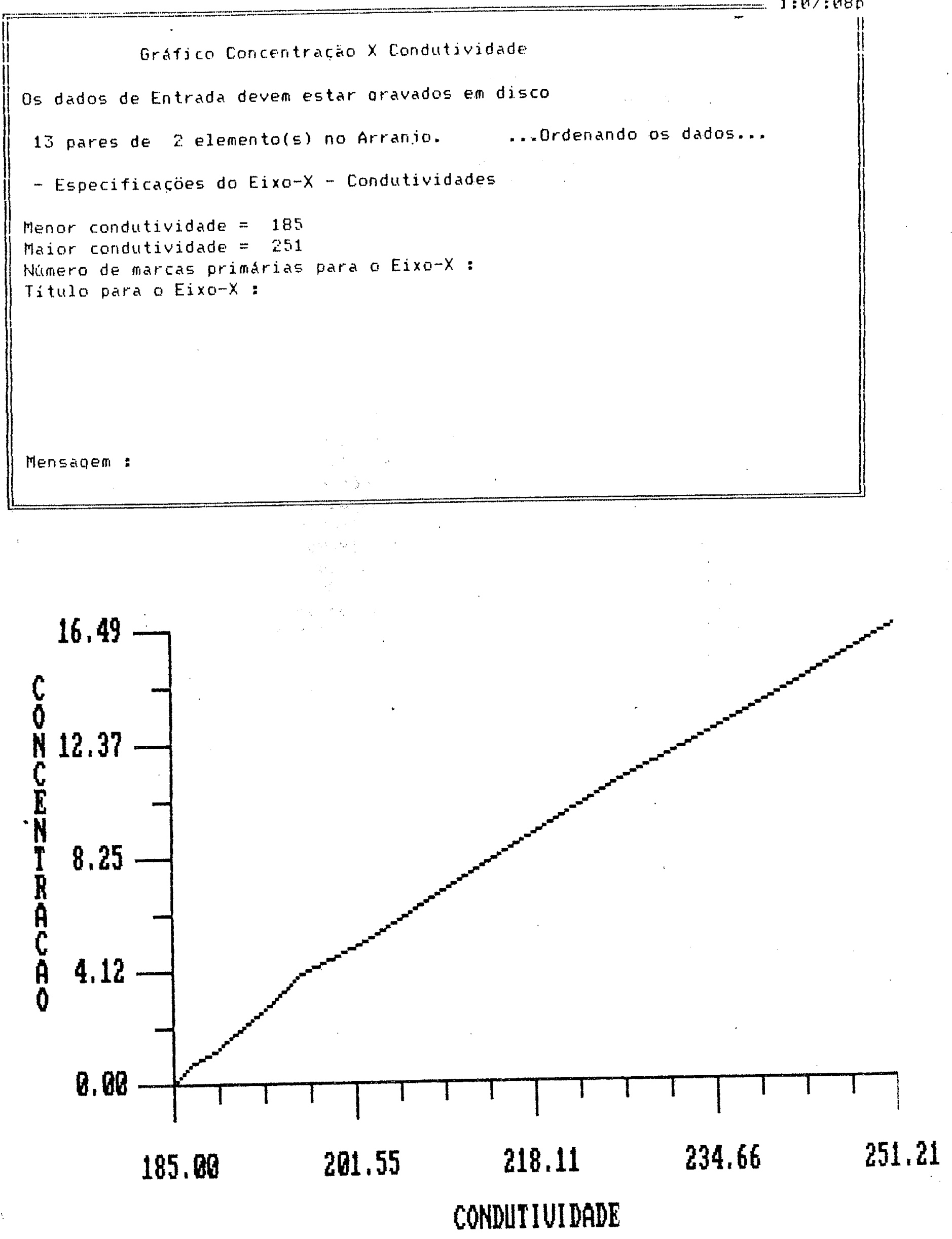


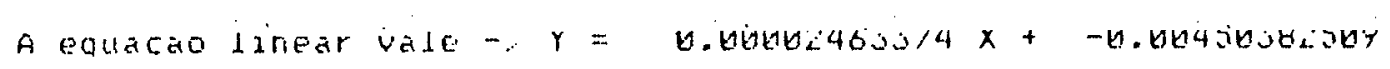

$\begin{array}{ccccc}\text { Orioinal } & \text { Orioinal } & \text { Estimado } & \text { Fesidual } & \text { Yo }-Y m \\ X & \text { Yo } & \text { Ye } & \text { Yo - Ye } & \end{array}$

$\begin{array}{ll}185.00 & 0.00000000006 \\ 186.95 & 0.00007984032 \\ 188.89 & 0.00011964108 \\ 189.87 & 0.00015936255 \\ 193.76 & 0.00027805362 \\ 196.68 & 0.00039603960 \\ 202.53 & 0.00051332675 \\ 216.32 & 0.00070726916 \\ 218.11 & 0.00089931574 \\ 225.89 & 0.00108949416 \\ 234.66 & 0.00127783156 \\ 243.42 & 0.00146435453 \\ 251.21 & 0.00164908917\end{array}$

185.00

189.87

193.76

196.68

202.53

210.32

2.18.11

234.66

251.21
0.00905341712

0. Bด010138899

0. 00014935906

0.00017334455

0.00026928649

0. 00034124295

0.69048515586

0.00067703974

0.09086892363

0.00106080751

0.00127667687

0.00149254624

0.00168443013
$-0.06005341712$

-0.00002154777

$-0.00062971798$

$-0.00601398200$

0. 90060876713

0.00005479665

0. 96962817089

0.00003022942

0. 10003039211

0.00002868665

0. 05000115469

$-0.09002819171$

$-0.00003534096$
$-0.06666412448$

$-0.00058428416$

$-0.00054448340$

$-0.00050476193$

$-0.00638607986$

$-0.00026808488$

$-0.06015079773$

0.06964314468

0.09023519126

0.00042536968

0.00061370708

0.00080023005

0.09698496469 $\begin{array}{cc}\text { Orioinal } & \text { Orioinal } \\ \mathrm{X} & \text { Yo }\end{array}$

185.96

186.95

186.89

189.87

193.76

196.68

202.53

210.32

218.11

225.89

234.66

243.42

251.21
0. 06969986006

G. 96097984032

6. 00011964198

0.06915936255

0. 00627805362

0. 90639603960

Q. 00051332675

0. 04079726916

ה. 94089731574

0. 00108949416

0. 00127783156

0.00146435453

0.00164908917
Estimado

YE

0. 90065341712

0.00616138869

0.00614935906

6. 04017334455

0.09026928649

6. 06034124295

Q. 06448515586

0. 09667763974

D. 06086892363

0.00106089751

0. 00127667687

0.00149254624

0.00168443013
Fiesidual

YO - YE

$-0.00095341712$

- .00902154777

$-0.06062971798$

$-0.09601398200$

0.09000376713

0.06965479665

0. 00002817089

0. 09093022942

0. 00093639211

0. 00002868665

0.00000115469

$-0.06062819171$

$-0.60603534096$
Yo - Ya

$-0.00066412448$

- 0.09658428416

$-0.00654448340$

$-0.00650476193$

$-0.00938607086$

- . 96926868488

$-0.00615679773$

6. 60664314468

0. 60623519126

2. 09042536568

0.00061370708

0. 00636023065

0.09498496469
0.00966412448
0. 06040380263
0.00000001297
0. 00094378966
0. 99829248743

$1: 12: 260$

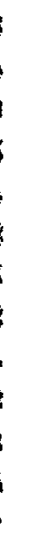

Variaç̆̈o total ......... =

Variặ̈o näo-explicada ... =

Variaç̆̈ explicada ...... = 
Grafico Temoo X Concentraçüo

05 dados de Entrada devem estar oravados em disco

24 pares de 2 elemento(s) no Arranio. ...Ordenando os dados...

- Especificacöes do Eixa-X - Tempo

Menor Teinpo $=0$

Maior Tempo $=115$

Numero de marcas primarias para o Eixo-X:

Titulo para o Eixo-X:

Mensag̣em:

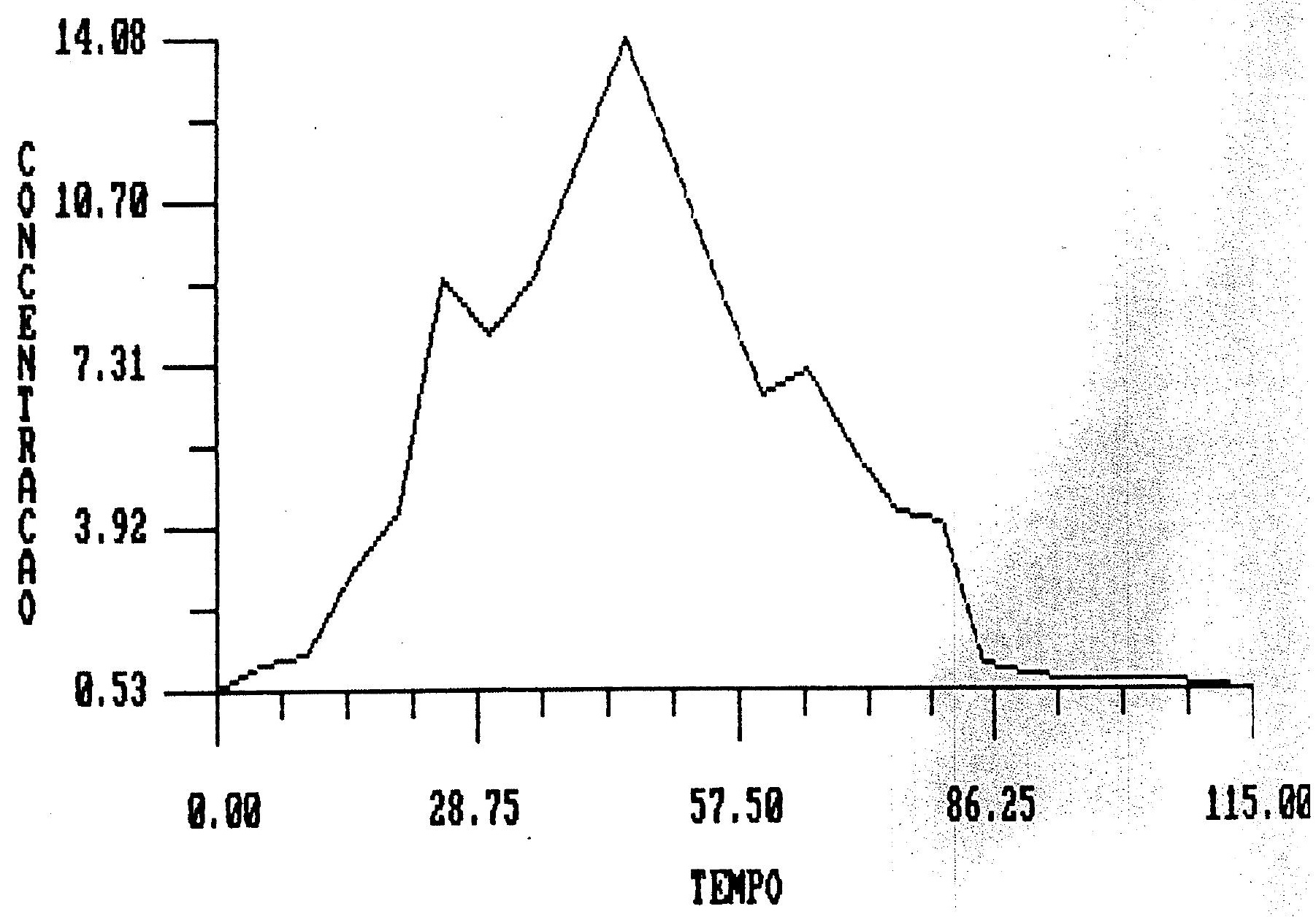




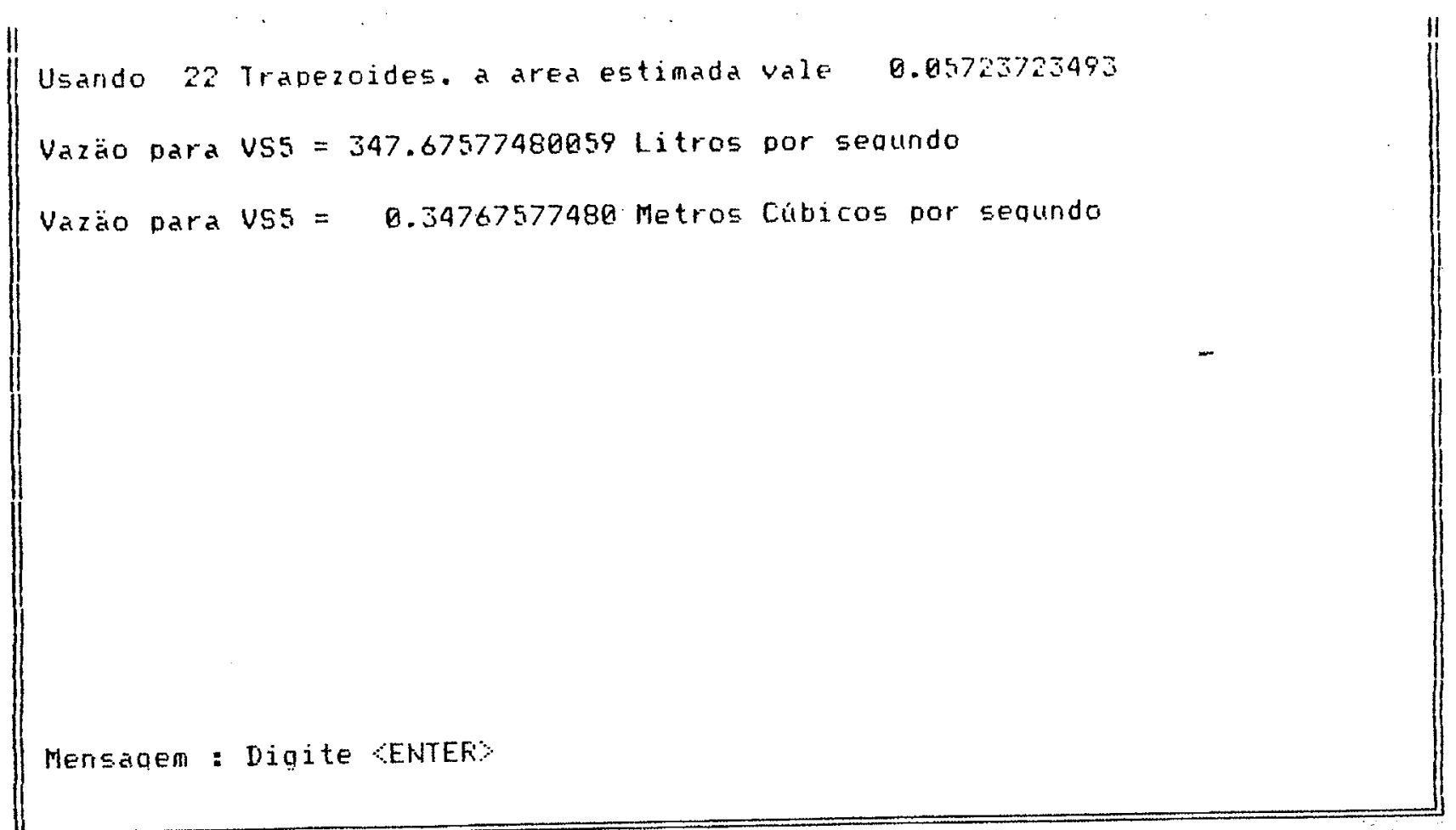


USP / GED - KARST WATER ANALYSIS REPORT - bY TVO RARYANN Listagem das amostras de agua ordenada pelo numero

\section{Cations e anions en ppin ou $\mathrm{mg} / \mathrm{l}$}

cond. [ $-1=\mu \mathrm{NHO} / \mathrm{cm}][-2: \mu \mathrm{S} / \mathrm{C}$
PCO2 entats.

SATC \& SATd ent
Terip ${ }^{\circ} \mathrm{C}$

Pag. :

Data : $12 / 09 / 94$

No. Local de coleta Data pH Temp Cond. Catt $\mathrm{Kg}+\mathrm{Ca} / \mathrm{Mg}$ HCO3- NO3-SO4-- Nat $\mathrm{Kt}$ Cl- SIC SId pPCD2 PCO2 SATC SAMd IBE ObservacaO

1 CAV. SANPANA 2 CAV. SANTAMA 3 CAV. SANPANB

4 CAV, PEROLAS 5 CAV. PEROLAS

6 CORR. FURNAS

7 CAV, PEROLAS

8 COR. PEROLAS

9 CAV. SANPAN

10 SIS, TW, DES

11 SIS, TE, DES

12 SIS. TW. OESH.

14 SIST. PESCARL

15 SIST, PESCARIA

17 CAV C CAPEU

18 CAV. ARANHAS

$19 \mathrm{CAV}$. SANTANA

20 CAV. SANTANA

21 CAV. SANTAM

$22 \mathrm{CAV}$. PRROLAS

$23 \mathrm{CAV}$. PEROLAS

24 CORRECO RURNA

$25 \mathrm{CAV}$, SANTANA

$26 \mathrm{CAV}$, SANTAN

27. CAV, SANTANA

28 CAV. PBROLAS

29 CAV. PEROLAS

$30 \mathrm{CAV}$. PEROLAS

31 COR. PROLA

32 CAV SANTAN

$33 \mathrm{CAV}$, SAMTAN

34 CAV. SANTANA

$35 \mathrm{CAV}$. PEROLAS

36 CAV. PEROLAS

37 CAV, PEROLES

38 COR. PEROLAS $\begin{array}{llllllllllllllllllll}29 / 06 / 90 & 8.06 & 18.2 & 164-1 & 31.5 & 5.7 & 5.5 & 114.0 & 1.4 & 1.3 & 1.5 & 0.5 & 1.7 & 0.07 & -0.28 & 3.05 & 0.00089 & 117.49 & 52.48 & 3.79 \text { ULTMA ESCADA }\end{array}$

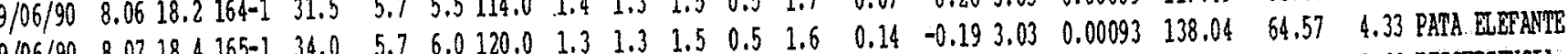

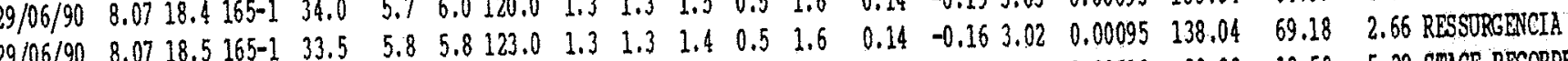

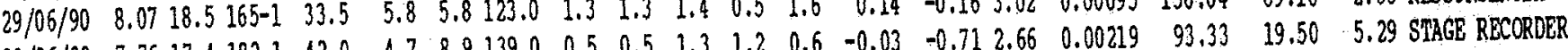

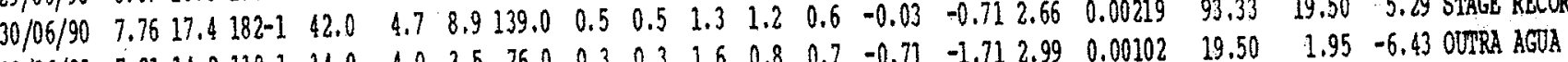

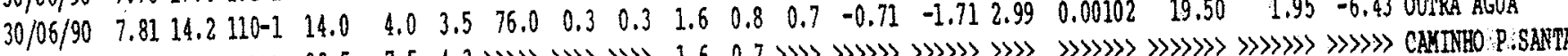

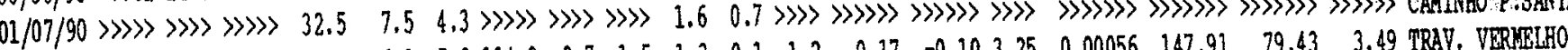

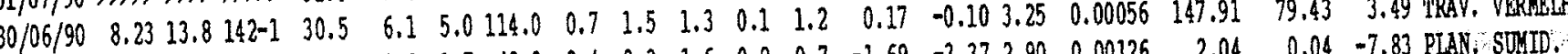

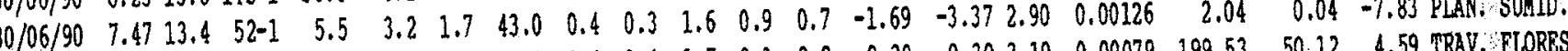
$\begin{array}{lllllllllllllllllll}01 / 07 / 90 & 8.15 & 19.2 & 162-1 & 39.2 & 2.4 & 16.3 & 122.0 & 0.4 & 0.4 & 1.7 & 0.1 & 0.8 & 0.30 & -0.30 & 3.10 & 0.00079 & 199.53\end{array}$ $\begin{array}{llllllllllllllllllll}7 / 07 / 90 & 7.57 & 15.8 & 38-1 & 7.0 & 2.5 & 2.8 & 40.0 & 1.4 & 2.6 & 2.5 & 1.8 & 2.2 & -1.49 & -3.15 & 3.01 & 0.00098 & 3.24 & 0.07 & -5.64 \text { CHEG, NO RTO }\end{array}$

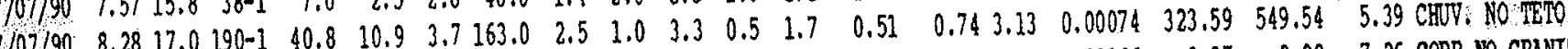

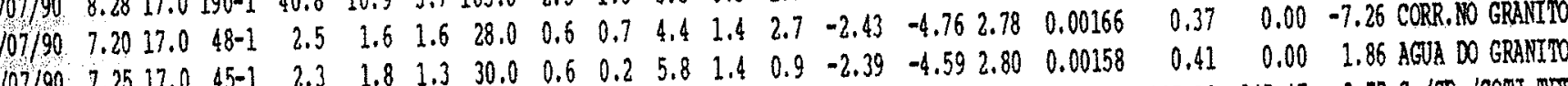

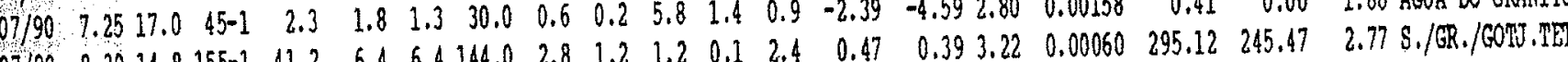

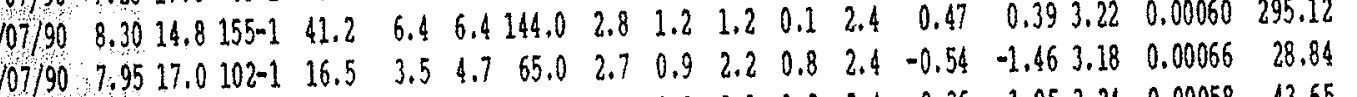

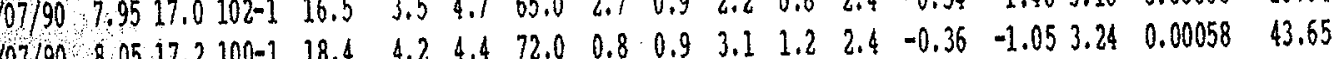
$\begin{array}{llllllllllllllllll} & 0.8 .8 & 0.5 & 5.0 & 1.3 & 2.7 & -1.02 & -2.24 & 2.90 & 0.00126 & 9.55\end{array}$

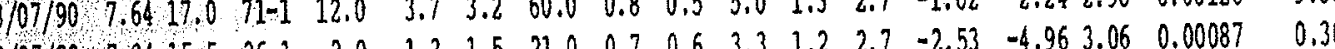

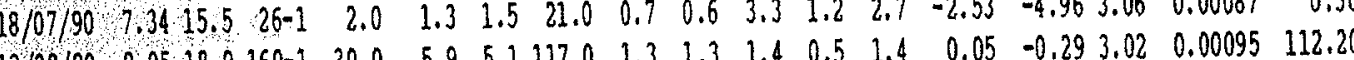

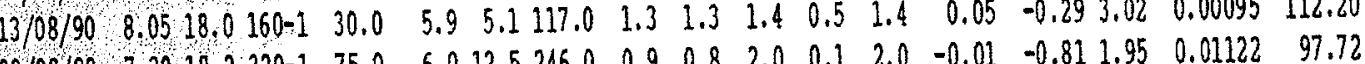

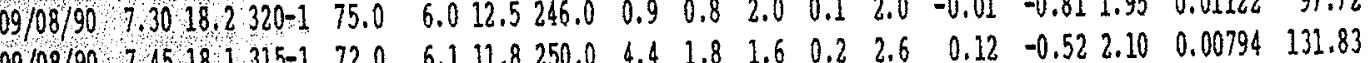
$\begin{array}{lllllllllllllll}0 & 0.0\end{array}$ $.8517 .0120-1,20.0$

$\begin{array}{llllllllllllll}4.0 & 5.0 & 75.0 & 0.7 & 0.6 & 1.6 & 0.6 & 1.6 & -0.50 & -1.40 & 3.02 & 0.00095 & 31.62 \\ 4.7 & 3.0 & 65.0 & 0.6 & 0.6 & 1.8 & 0.6 & 1.4 & -0.75 & -1.71 & 3.07 & 0.00085 & 17.7\end{array}$ $11 / 08 / 90 \quad 7.83 \quad 15.0 \quad 85-1 \quad 14$.

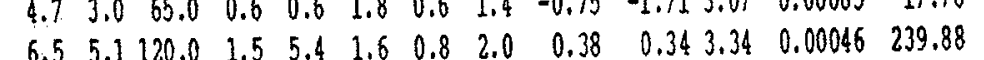
$08.09 / 90 \quad 7.9818 .0161-1$ 2 2

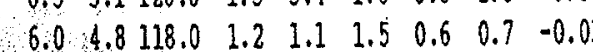

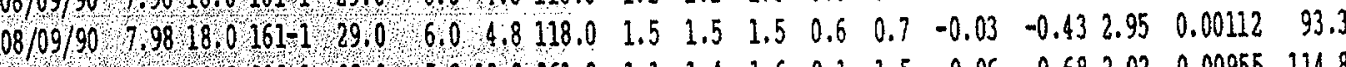

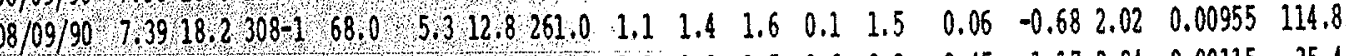

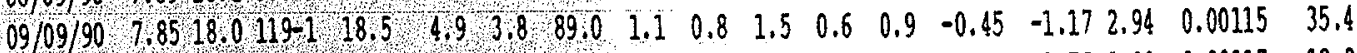

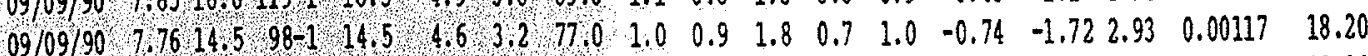
$\begin{array}{lllllllllllllllllll}09 / 09 / 90 & 8.21 & 13.5 & 160-1 & 27.6 & 6.6 & 4.2 & 124.0 & 0.7 & 1.2 & 1.6 & 0.1 & 1.2 & 0.14 & -0.09 & 3.20 & 0.00063 & 138.04\end{array}$

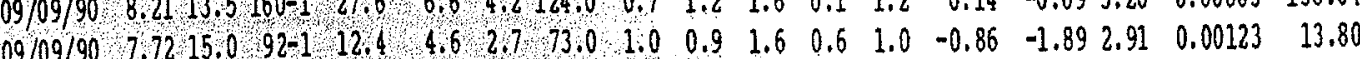

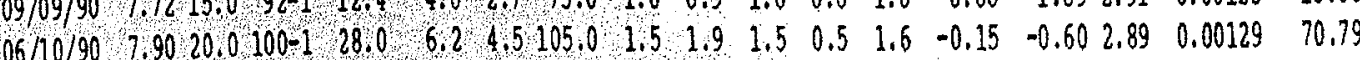

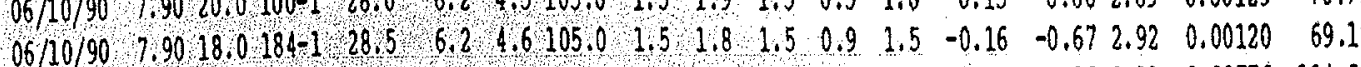

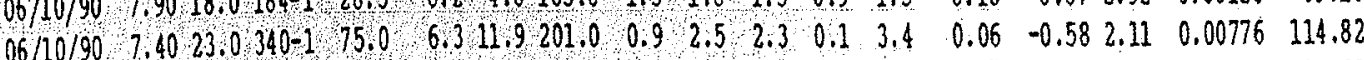

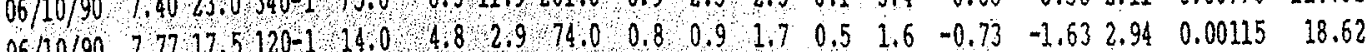

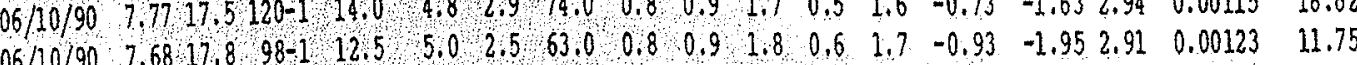

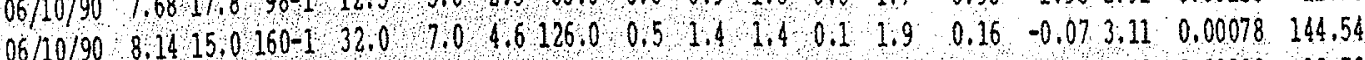
$06 / 10 / 90 \quad 7.7018 .0 \quad 100-1 \quad 12.5 \quad 4.9 \quad 2.6 \quad 54.0 \quad 0.8 \quad 0.9 \quad 1.7 \quad 0.6 \quad 1.7 \quad-0.97 \quad-2.043 .00 \quad 0.00100 \quad 10.72$
8.915 .58 SUM. CAV. PESC. 0.583 .19 200K DA ENTRADA $0.00 \quad-7.65$ RESSURGDNCIA $51.29 \quad 1.28$ RESSURGDCIA 15.492 .46 ESTALAC. MAMG. $30.20-1.30$ ESTALAC. RIO $3.98 \quad 4.23$ STREE RECORDER 1.952 .27 OUIRA AGUA $218.78 \quad 2.59$ CANTHBO SANTAN 3.150 .64 ULTIMA ESCADA $37.15 \quad 0.31$ RESSURERNCIA $20.89-5.60$ BSTALAC. MANG. $6.76-3.84$ STRGE RECORDER $1.91-5.05$ OUTRA AGD $81.28-2.73$ TRAV. VERMELHO $1.29-7.71$ PLAN. SUMID. $21.38 \quad 5.14$ RESSURGENCIA $2.34 \quad 4.10$ STAGE RECORDER 1.120 .90 OUTRA RGUA 85.11 1.86 TRAY. VERVELHO $0.91 \quad 7.32$ PLAN, SOMID
$3.47 \quad 1.34300 \mathrm{~N}$ DO SIMID.

$25.12 \quad 4.54$ ULTIMA ESCADA 26.3011 .69 ESTALAC. MANG. 
No. Local de coleta Data pH Temp Cond. Catt $\mathrm{Mg}+\mathrm{Ca} / \mathrm{Mg}$ HCO3- N03-SO4-- Nat Kt Cl- SIC SId pPCO2 PCO2 SATC SATd IBE ObservacaO

39 CAV. SANPAND 40 CAV. SANTANA

41 CAV. SANTANA

42 CAV, PEROLAS

43 CAV. PEROLAS

44 CAV. PEROLAS

45 COR. PEROLLS

46 CAV SANTANA

47. CAV. SANTANA.

48 CAV. SANTAME

49 CAV. PEROLAS

50 CAV. PEROLLS

51 CAV. PEROLLS

52 COR. PEROLAS

53 TORNBIRA/VANDTR

54 CAV. SANTANA

55 CAV. SANPANE

56 CRV. SANTANA

57 CAV. PEROLAS

58 CAV. PEROLAS

59 CAV. PEROLAS

60 CAV. PRROLAS

61 CAV. SANPANA

62 CAV. SANTANA

63 CAV. SANTANA

64 CAV, SANTAN

65 CAV. SANTAM

66. CORR. FURNAS

67 CAV. PRROLAS

68 CAV. PEROLAS

$69 \mathrm{CAV}$. PEROLAS

70 COR. PEROLAS

71 CAV. SANTANB

72 CAV. SANTANA

73 CAV. SAMTARA

74 CORRESO FURNAS

75 CAV. PEROLAS

76 CAV, PEROLES

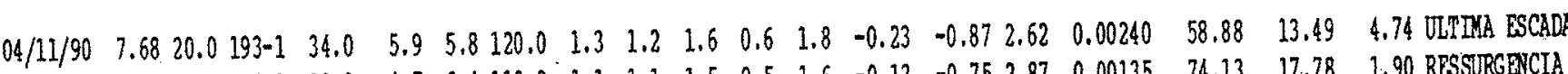

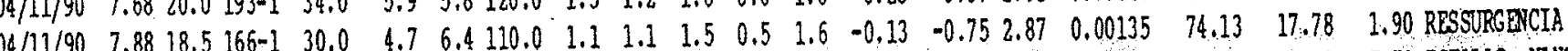

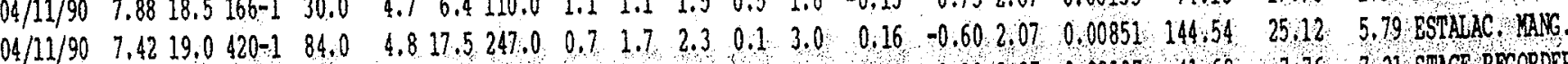

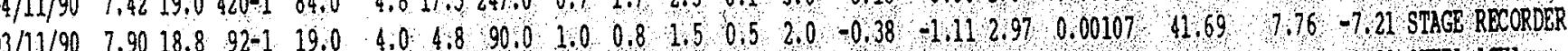

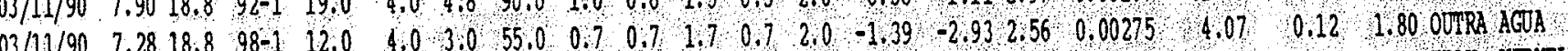

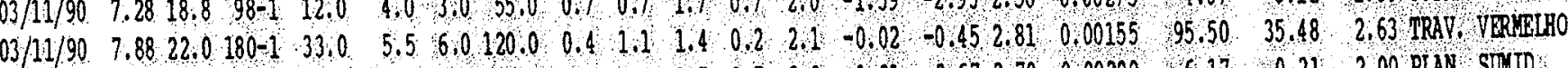

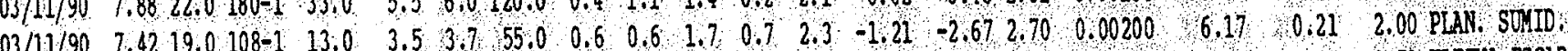

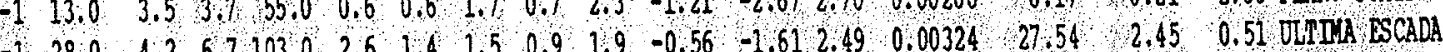

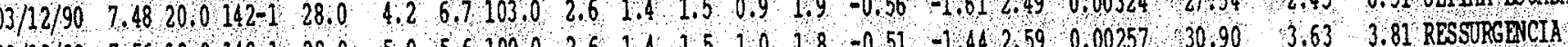

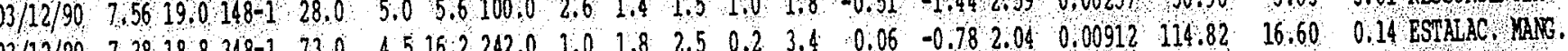

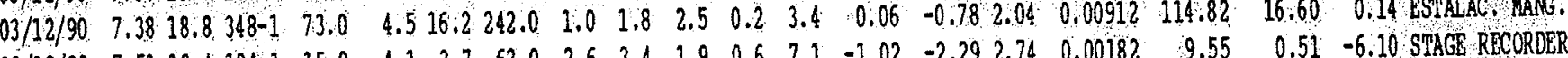

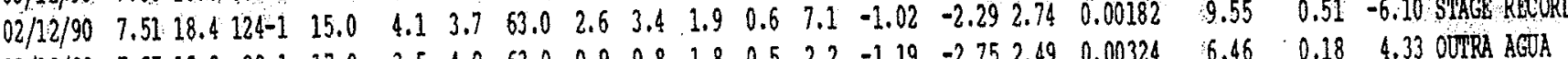
$\begin{array}{llllllllllllllllllll}02 / 12 / 90 & 7.27 & 18.8 & 90-1 & 17.0 & 3.5 & 4.9 & 63.0 & 0.9 & 0.8 & 1.8 & 0.5 & 2.2 & -1.19 & -2.75 & 2.49 & 0.00324 & 6.46 & 0.18 & 4.33 \\ 02 / 12 / 90 & 8.05 & 15.8 & 168-1 & 37.0 & 5.8 & 6.4 & 132.0 & 0.2 & 0.4 & 1.5 & 0.1 & 2.5 & 0.16 & -0.20 & 2.99 & 0.00102 & 144.54 & 63.10 & 3.20 \text { TRAV AGUR VRRELHO }\end{array}$

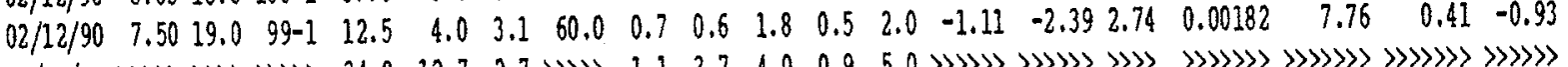

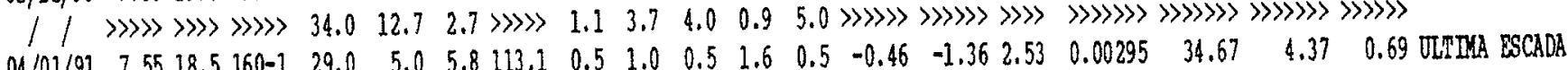

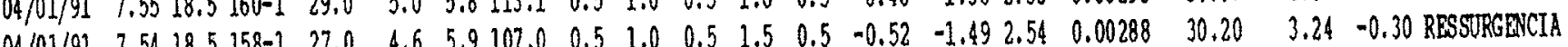

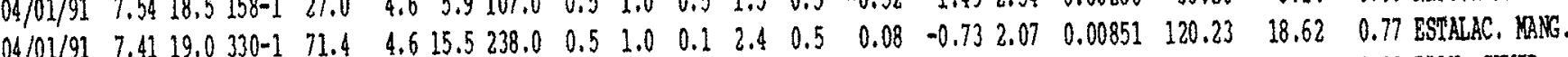

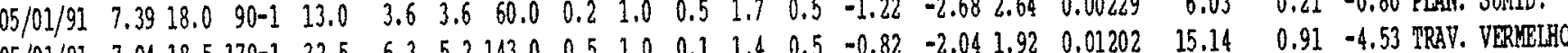

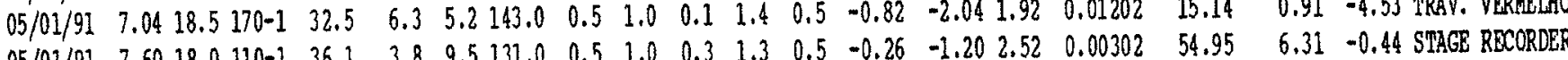

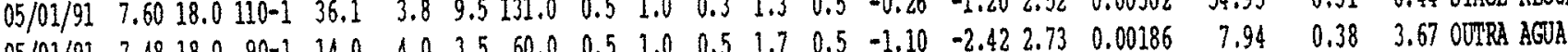

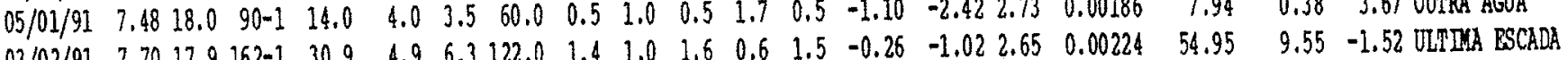

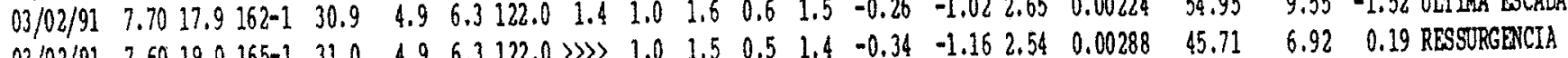

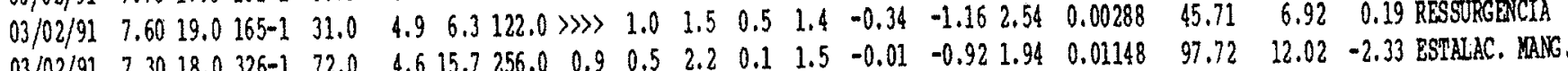

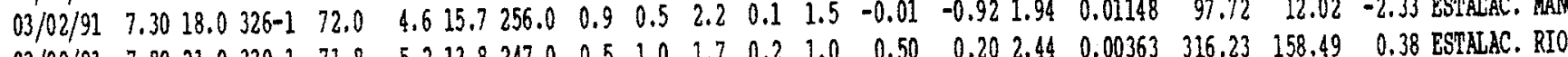

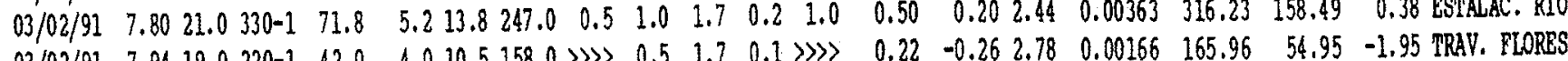

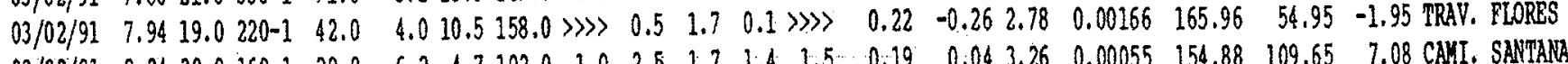

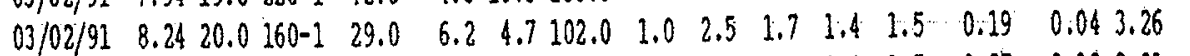
$\begin{array}{lllllllllllllllllllll}04 / 02 / 91 & 8.10 & 19.0 & 99-1 & 38.0 & 3.9 & 9.7 & 134.0 & 0.5 & 0.5 & 1.6 & 0.4 & 1.5 & 0.27 & -0.13 & 3.01 & 0.00098 & 186.21 & 74.13 & 1.07 \text { SPAGE RECORDER }\end{array}$

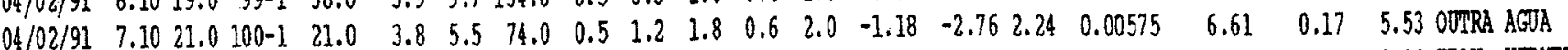

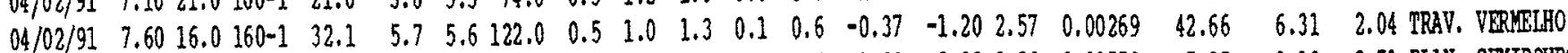

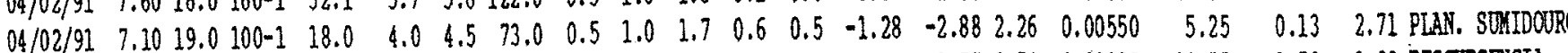

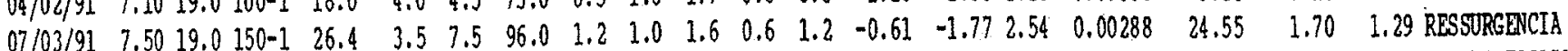

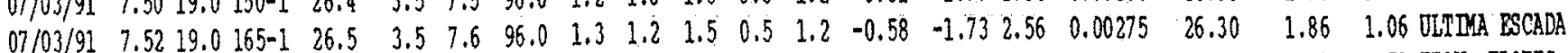

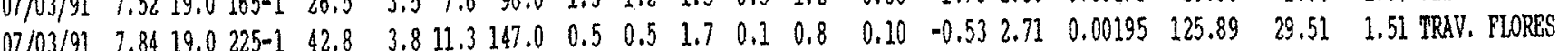

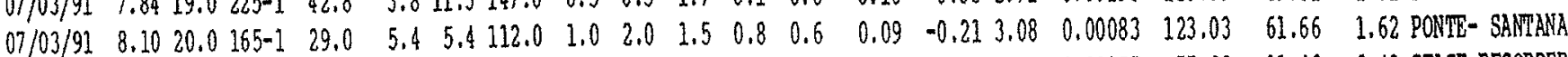

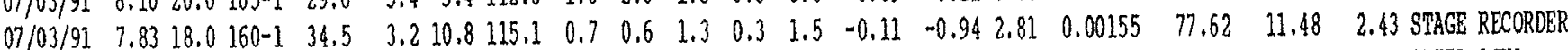
$\begin{array}{lllllllllllllllllllll}07 / 03 / 91 & 7.20 & 19.0 & 105-1 & 14.7 & 3.0 & 4.9 & 58.0 & 1.0 & 0.8 & 1.5 & 0.5 & 1.5 & -1.35 & -3.07 & 2.46 & 0.00347 & 4.47 & 0.09 & 1.58 \text { OUTRR AGJA }\end{array}$ 
USP / GEO - RARST WATER ANALYSIS REPORP - by TVO RARUANN

Listagen das amostras de agua ordenada pelo numero

\section{Cations e anions em ppm ou $\mathrm{mg} / \mathrm{l}$}

Cond. [ $-1=\mu \mathrm{MHO} / \mathrm{cm}][-2: \mu \mathrm{s} / \mathrm{cm}]$

\section{PCO2 en atm.}

SATC \& SATd en :
Tem 'C

Pag. :

Data : $12 / 09 / 94$

No. Local de coleta Data pH Temp Cond. CaH MgH Ca/mg HCO3- NO3- S04-- Nat Rt CI- SIC SId pPCO2 PCO2 SATC SRTd IBE Observacao

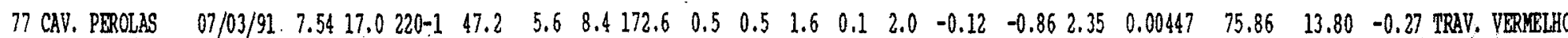

78 COR. PEROLAS

79 CAV. SANTANA

80 CAV. SANTANA

81 CAV. SANPANA

82 CAV. SANTANB

83 CAV. SAHPANA

84 CORRECO FURNAS

85 RIO BETARI

86 CAV. PEROLAS

87 CAV. PEROLAS

88 CAV. PEROLAS

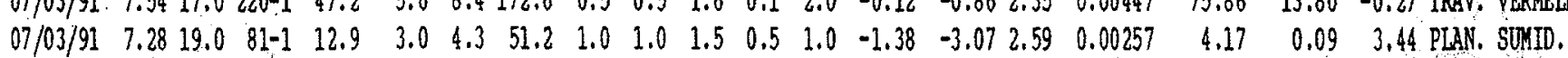

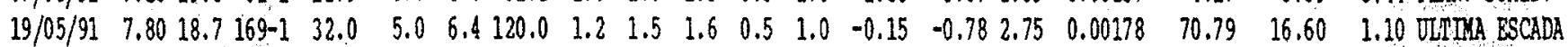

$\begin{array}{lllllllllllllllllllll}19 / 05 / 91 & 7.80 & 18.7 & 170-1 & 32.0 & 5.0 & 6.4 & 115.0 & 0.5 & 1.5 & 1.6 & 0.5 & 1.0 & -0.16 & -0.81 & 2.77 & 0.00170 & 69.18 & 15.49 & 3.45 \text { RESSURGDNCIA }\end{array}$

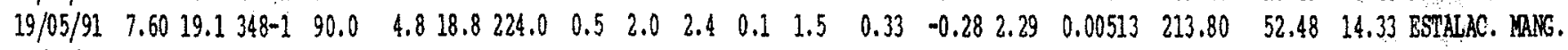

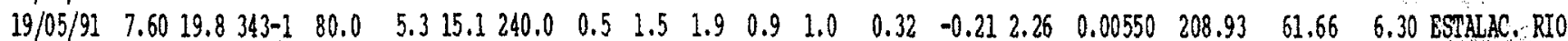

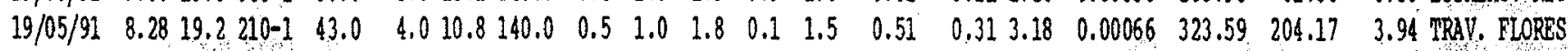

$\begin{array}{lllllllllllllllllllll}19 / 05 / 91 & 8.44 & 19.0 & 210-0 & 30.5 & 6.7 & 4.6 & 104.0 & 1.5 & 4.0 & 1.7 & 0.7 & 2.0 & 0.39 & 0.44 & 3.47 & 0.00034 & 245.47 & 275.42 & 7.33 \text { CAMINHO SANTAMA }\end{array}$

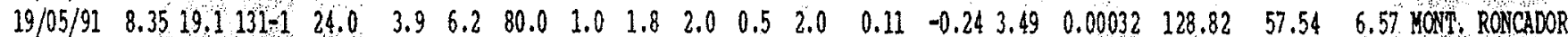

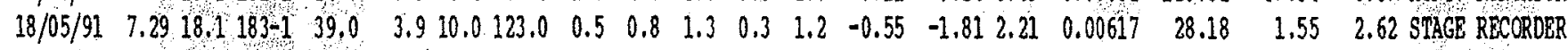
$\begin{array}{llllllllllllllllllll}18 / 05 / 91 & 7.80 & 16.8 & 128-1 & 24.0 & 4.9 & 4.9 & 95.0 & 1.0 & 0.8 & 1.7 & 0.5 & 1.5 & -0.38 & -1.16 & 2.87 & 0.00135 & 41.69 & 6.92 & 1.68 \text { OUTRA AGUA }\end{array}$

$\begin{array}{lllllllllllllllllllllll}89 & & \end{array}$

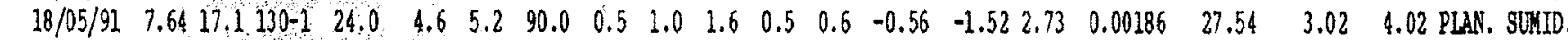

90 BAIRRO DA SERRA 20/05/91 $7.80 \begin{array}{lllllllllllllllllll}21.0 & 436-1 & 37.0 & 11.4 & 3.2 & 155.0 & 1.0 & 6.0 & 2.7 & 0.9 & 1.5 & 0.03 & -0.10 & 2.63 & 0.00234 & 107.15 & 79.43 & 3.62 & \text { POCO SABESP }\end{array}$

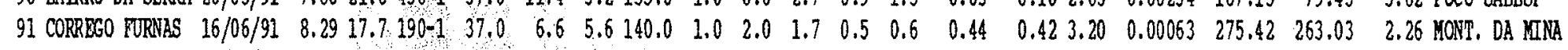

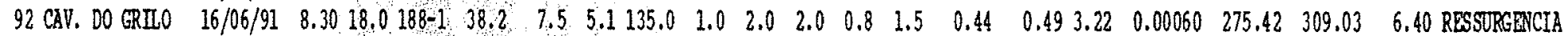

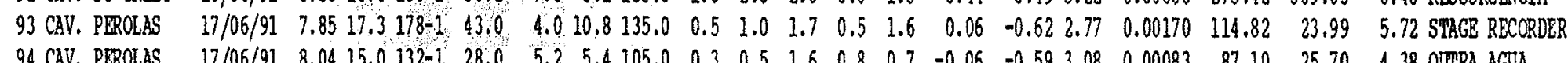
94 CAV. PLROLAS

95 CAV. PRROLAS 96 COR. PEROLAS $\begin{array}{llllllllllllllllllll}17 / 06 / 91 & 8.04 & 15.0 & 132-1 & 28.0 & 5.2 & 5.4 & 105.0 & 0.3 & 0.5 & 1.6 & 0.8 & 0.7 & -0.06 & -0.59 & 3.08 & 0.00083 & 87.10 & 25.70\end{array}$ $\begin{array}{llllllllllllllllllllll}17 / 06 / 91 & 8.00 & 16.0 & 155-1 & 34.1 & 4.8 & 7.1115 .0 & 0.5 & 1.0 & 1.5 & 0.6 & 1.0 & 0.03 & -0.52 & 3.00 & 0.00100 & 107.15 & 30.20 & 5.66 \text { JUZBNTE-STGE.RC }\end{array}$ $\begin{array}{llllllllllllllllllllll}17 / 05 / 91 & 7.50 & 14.3 & 29-1 & 6.2 & 2.1 & 3.0 & 30.0 & 0.4 & 0.3 & 1.5 & 0.8 & 0.7 & -1.75 & -3.70 & 3.08 & 0.00083 & 1.78 & 0.02 & 4.02 \text { PLAN, SOKID. }\end{array}$ $\begin{array}{llllllllllllllllllllllll}97 \text { COR. PEROLAS } & 17 / 06 / 91 & 7.00 & 14.9 & 15-1 & 3.6 & 0.8 & 4.5 & 18.0 & 0.4 & 0.3 & 1.5 & 0.8 & 0.7 & -2.68 & -5.75 & 2.79 & 0.00162 & 0.21 & 0.00 & 0.57 & \text { PLAN, SUMTD. } 2\end{array}$

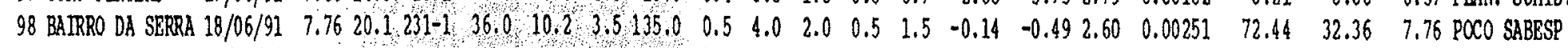

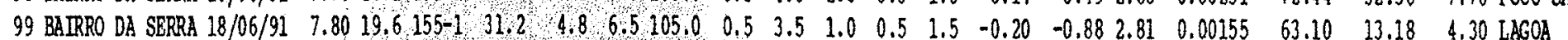

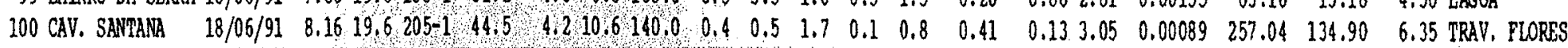

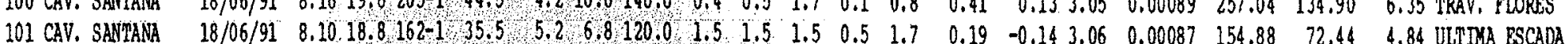
102 CAV. SANT3M

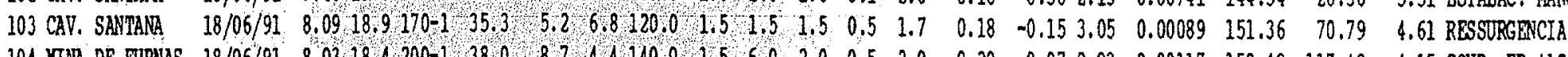

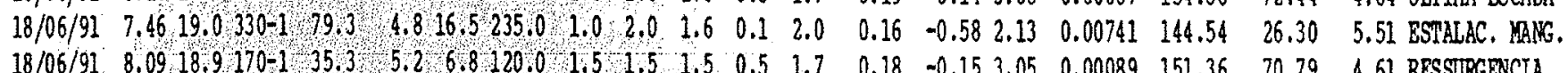

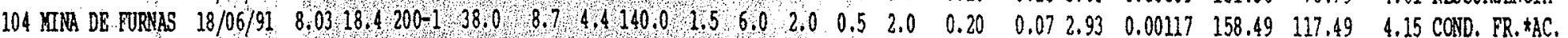

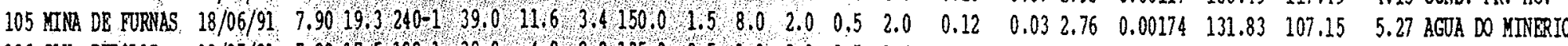

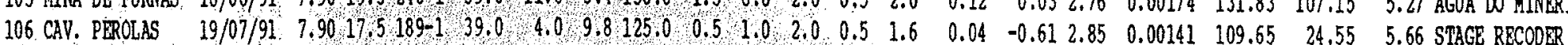
107 CAV. PEROLAS 108 CAV. SANTANA 109 CAV. SANTAM 110 CAV. SAPTANA $111 \mathrm{CAV}$ SNDANE 112 CAV, SANTANA 113 CAV. SANTANA 114 CAV, SANTAMA

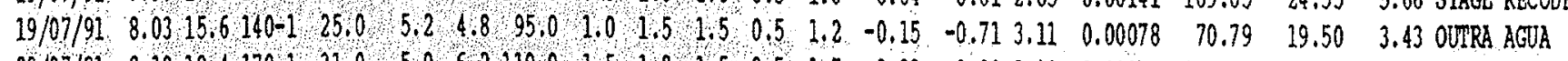

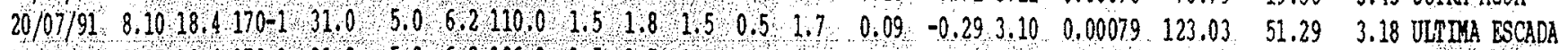

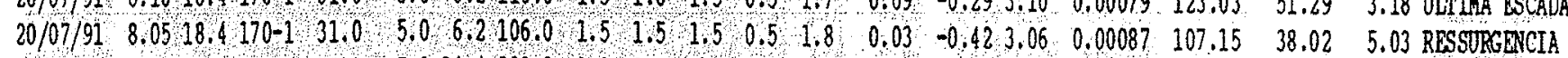

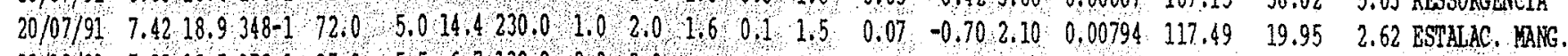

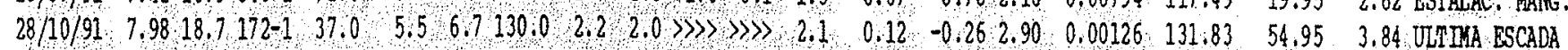
$28 / 10 / 91 \quad 7.9018 .9170-1 \quad 38.0 \quad 5.4 \quad 7.0130 .0 \% 1.9 \quad 1.9 \gg>>>>>2.0 \quad 0,06 \quad-0,412.82 \quad 0.00151 \quad 114.82 \quad 38.90 \quad 4.74$ RESSURGENCIA

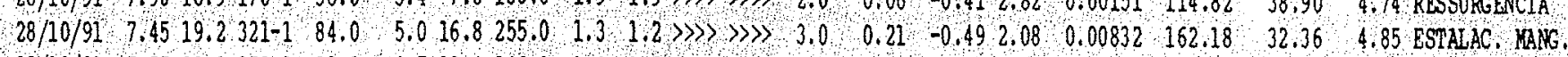

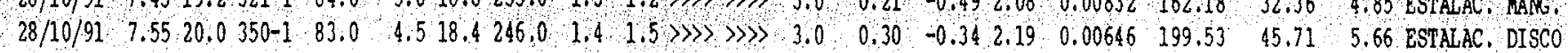




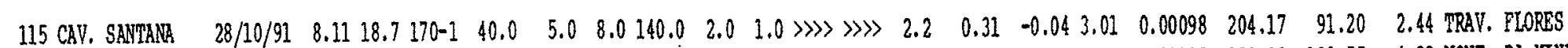

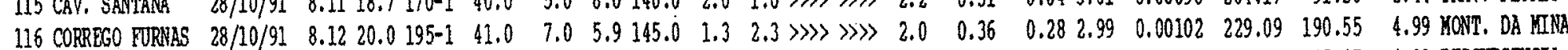

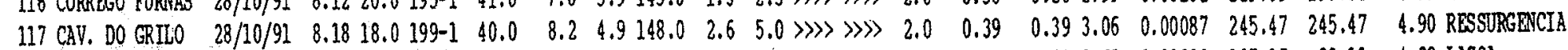

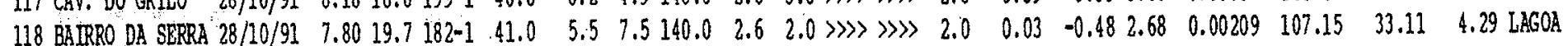

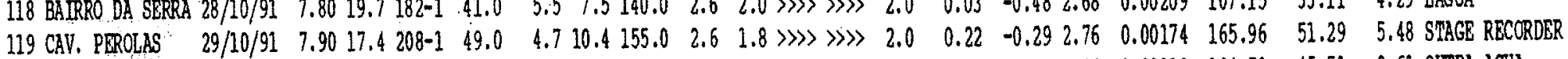

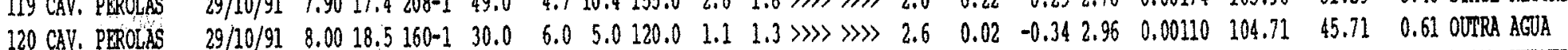

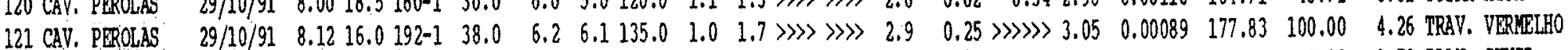

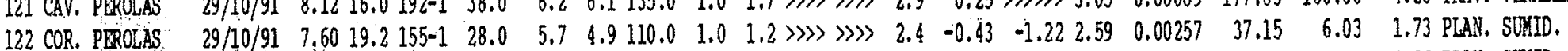

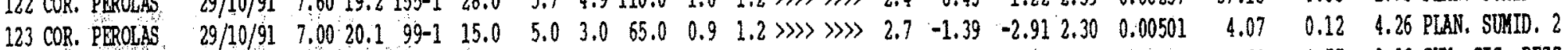

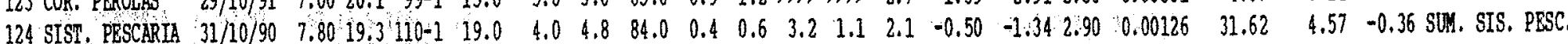

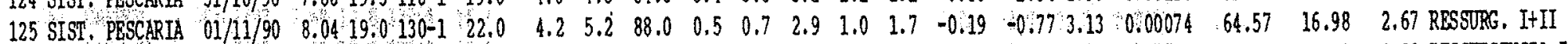

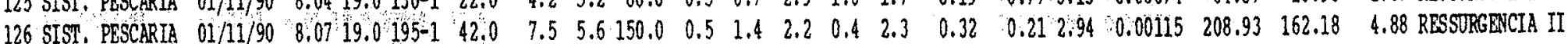

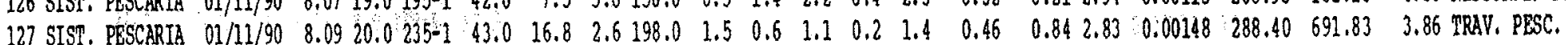

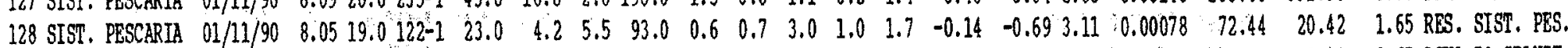

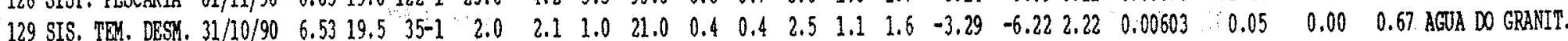

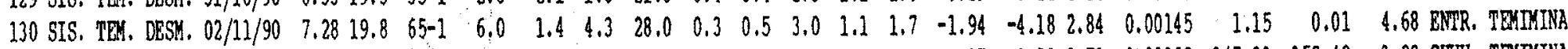

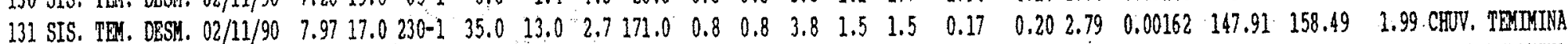

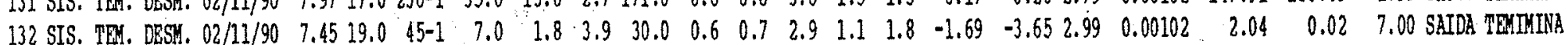

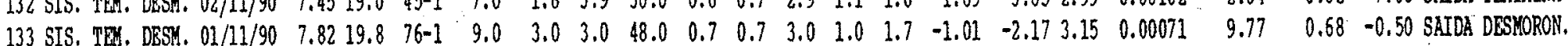

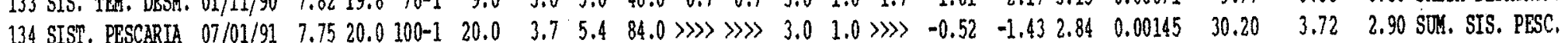

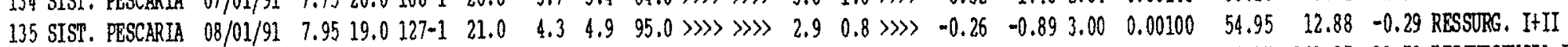

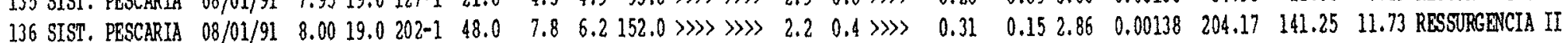

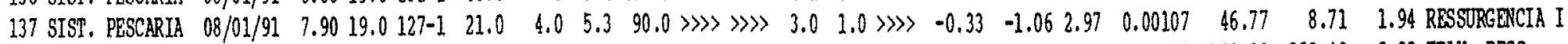

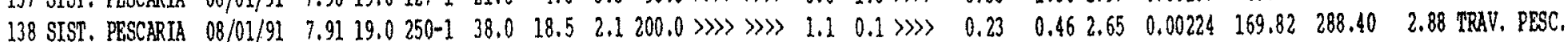

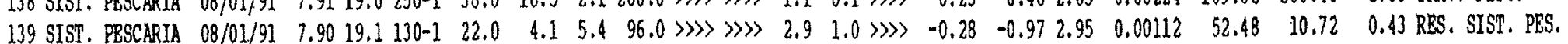

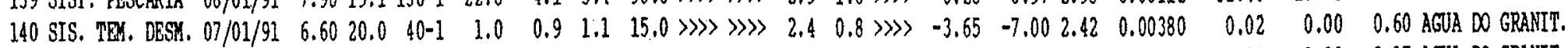

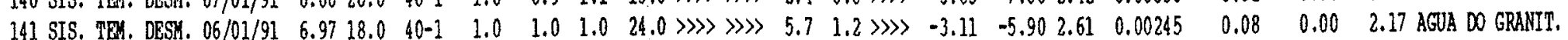

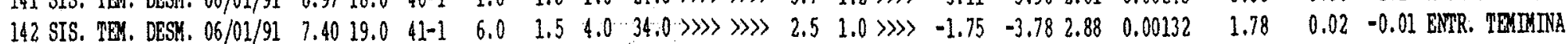

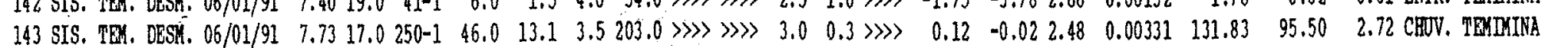

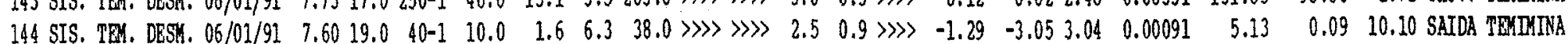

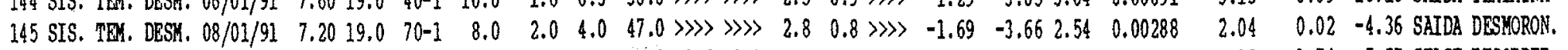

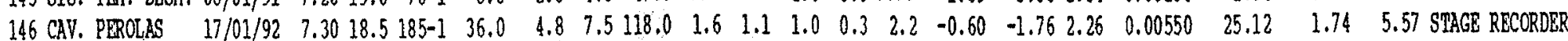

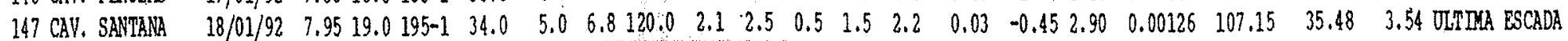

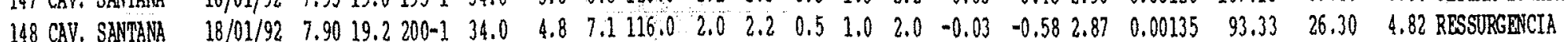

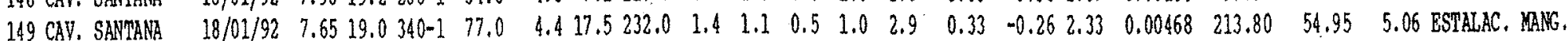

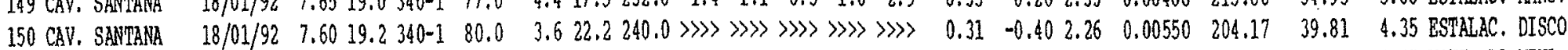

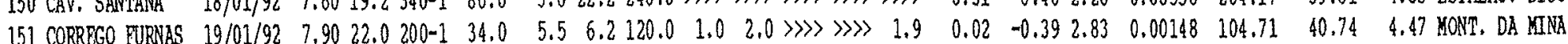

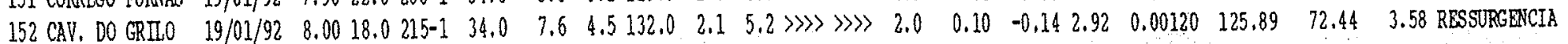




\begin{tabular}{|c|c|c|c|}
\hline $\begin{array}{l}\text { SP / GED - RARST WRTER ANALYSIS REPORT - by TYO RARMANN } \\
\text { istagen das amostras de aqua ordenada pelo numero }\end{array}$ & $\begin{array}{l}\text { Cations e anions en ppm ou mo/l } \\
\text { Cond. }[-1=\mu \mathrm{wH} / \mathrm{cm}][-2: \mu \mathrm{s} / \mathrm{cm}]\end{array}$ & $\begin{array}{l}\mathrm{PCO} \text { em atm. } \\
\mathrm{SATC} \& \text { SaId en }\end{array}$ & $\begin{array}{ll}\text { Pag. : } & 5 \\
\text { Data : } & 12 / 09 / 94\end{array}$ \\
\hline
\end{tabular}

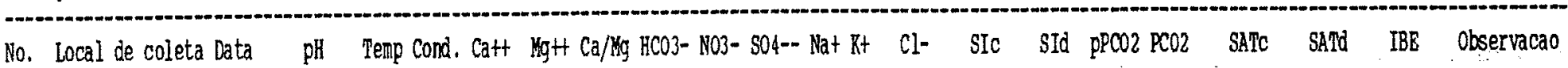

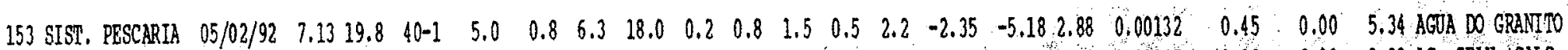

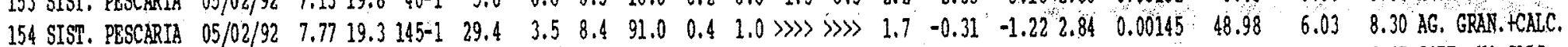

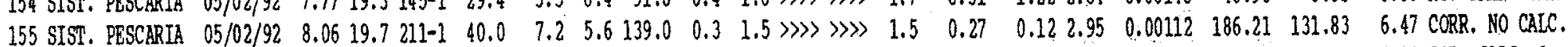

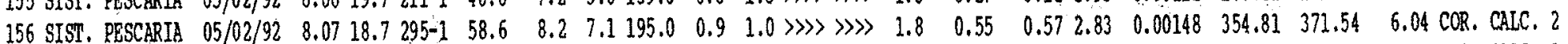

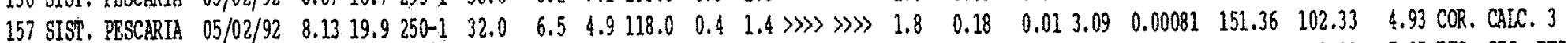

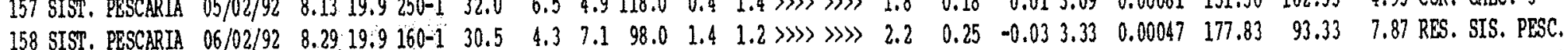

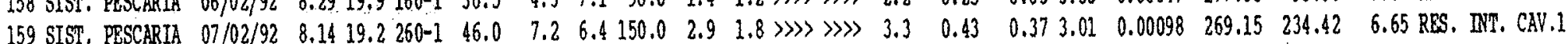

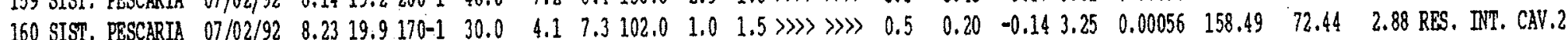

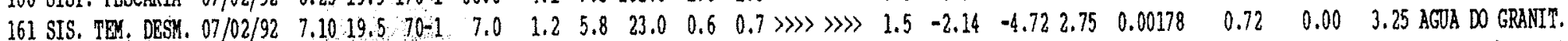

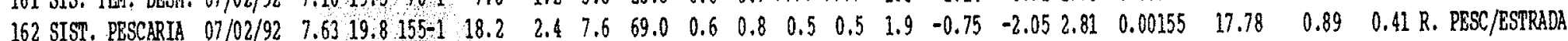

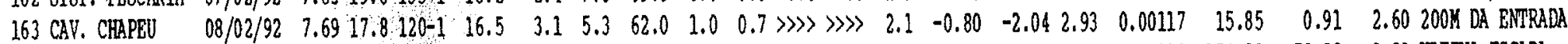

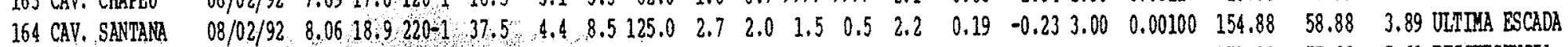

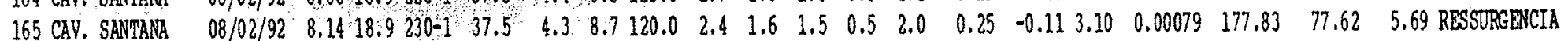

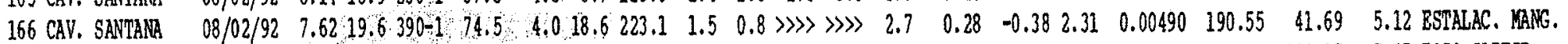

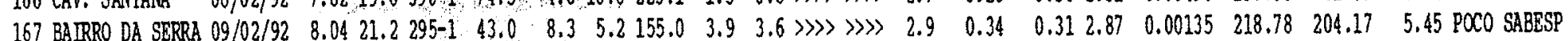

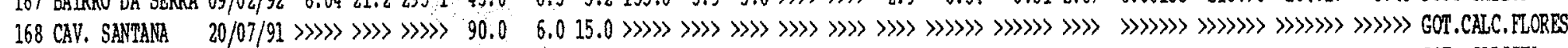

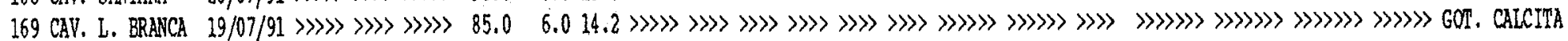

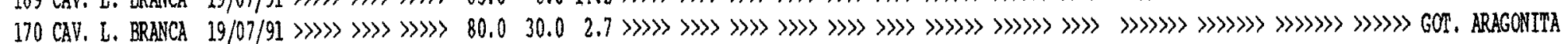

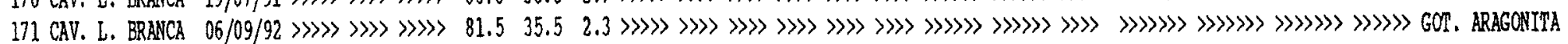

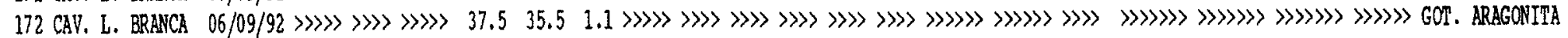
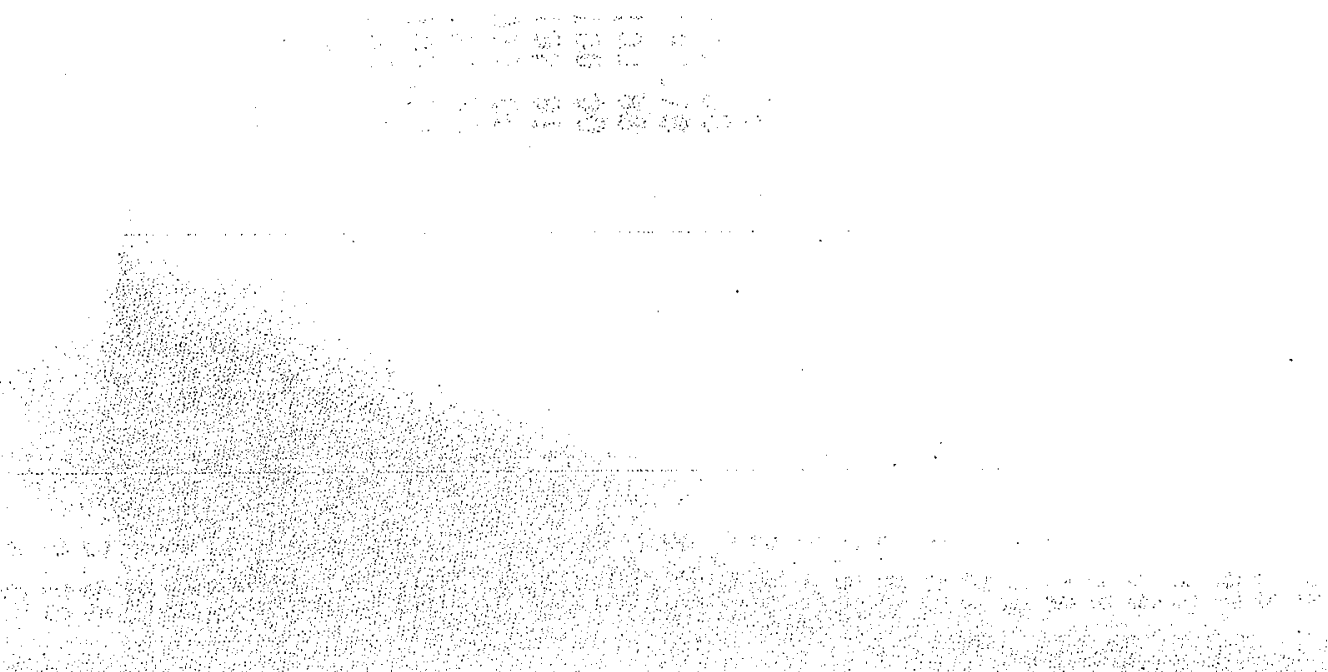
Anexo 5.4 - Listagem da dureza total (mg/ equivalentes a $\mathrm{CaCO}_{3}$ ), condutividade corrigida para $20^{\circ} \mathrm{C}$ e razão molar $\mathrm{Ca} / \mathrm{Mg}$ das amostras de água coletadas.

Universidade de Sao Paulo. Inst. Geociencias

Page :

Total Hardness, Conduct ivity at $20^{\circ} \mathrm{C}$ and Molar Ca/Mg Report Date : 12/09/94

No. Collecting Site Total Hardness Corrected Conductivity Molar Ca/Mg

1 CAV. SANTANA

2 CAV. SANTANA

3 CAV. SANTANA

4 CAV. PEROLAS

5 CAV. PEROLAS

6 CORR. FURNAS

7 CAV. PEROLAS

8 COR. PEROLAS

9 CAV. SANTANA

10 SIS. TEM. DESM.

11 SIS. TEM. DESM.

12 SIS. TEM. DESM.

13 SIS. TEM. DESM.

14 SIST. PESCARIA

15 SIST. PESCARIA

16 SIST. PESCARIA

17 CAV. CHAPEU

18 CAV. ARANHAS

19 CAV. SANTANA

20 CAV. SANTANA

21 CAV. SANTANA

22 CAV. PEROLAS

23 CAV. PEROLAS

24 CORREGO FURNAS

25 CAV. SANTANA

26 CAV. SANTANA

27 CAV. SANTANA

28 CAV. PEROLAS

29. CAV. PEROLAS

30 CAV. PEROLAS

31 COR. PEROLAS

32 CAV. SANTANA

33 CAV. SANTANA

34 CAV. SANTANA

35 CAV. PEROLAS

36 CAV. PEROLAS

37 CAV. PEROLAS

38 COR. PEROLAS

39 CAV. SANTANA

40 CAV. SANTANA

41 CAV. SANTANA

42 CAV. PEROLAS

43 CAV. PEROLAS

44 CAV. PEROLAS

45 COR. PEROLAS

46 CAV. SANTANA

47 CAV. SANTANA

48 CAV. SANTANA

49 CAV. PEROLAS

50 CAV. PEROLAS

51 CAV. PEROLAS

52 COR. PEROLAS

53 TORNEIRA/VANDIR

54 CAV. SANTANA

55 CAV. SANTANA

56 CAV. SANTANA

57 CAV PEROLAS

58 CAV. PEROLAS
102.19

108.43

107.60

124.31

51.45

112.10

101.33

26.92

107.84

27.79

146.83

12.83

13.16

129.31

55.64

63.27

45.22

10.35

99.26

212.13

205.04

66.45

54.34

109.23

97.17

97.17

191.75

66.40

55.17

96.14

49.93

95.50

96.75

213.36

54.75

51.82

108.79

51.41

109.26

94.32

229.68

63.95

46.46

105.11

46.90

87.26

90.56

200.95

54.36

56.89

116.34

47.71

137.25

93.06

86.41

197.37

47.31

107.15
171.11

171.34

170.93

193.60

126.77

>>>>>>

165.36

61.19

165.06

42.05

204.09

51.56

48.34

175.91

109.56

106.89

76.27

28.99

167.74

333.88

329.46

128.90

95.98

174.87

168.79

168.79

321.36

124.76

112.08

187.78

103.88

100.00

192.91

317.66

127.34

103.24

180.66

104.84

193.00

171.96

429.96

94.63

100.80

171.96

110.56

142.00

151.51

357.94

128.76

92.57

185.90

101.35

>>>>>>

165.75

163.68

337.82

94.36

176. 11
3.36

3.62

3.51

5.43

2.13

2.63

3.04

1.04

9.92

1.70

2.27

0.95

0.78

3.91

2.86

2.66

1.97

0.93

3.09

7.59

7.17

3.04

1.81

3.08

2.94

2.94

7.79

2.29

1.91

2.54

1.64

2.74

2.79

7.23

1.77

1.52

2.78

1.55

3.50

3.88

10.63

2.88

1.82

3.64

2.26

4.05

3.40

9.85

2.22

2.95

3.87

1.90

1.63

3.52

3.56

9. 42

2. 19

3.13 
No. Collecting Site. Total Hardness Corrected Conductivity Molar Ca/Mg

59 CAV. PEROLAS

60 CAV. PEROLAS

61 CAV. SANTANA

62 CAV. SANTANA

63 CAV. SANTANA

64 CAV. SANTANA

65 CAV. SANTANA

66 CORR. FURNAS

67 CAV. PEROLAS

68 CAV. PEROLAS

69 CAV. PEROLAS

70 COR. PEROLAS

71 CAV. SANTANA

72 CAV. SANTANA

73 CAV. SANTANA

74 CORREGO FURNAS

75 CAV. PEROLAS

76 CAV. PEROLAS

77 CAV. PEROLAS

78 COR. PEROLAS

79 CAV. SANTANA

80 CAV. SANTANA

81 CAV. SANTANA

82 CAV. SANTANA

83 CAV. SANTANA

84 CORREGO FURNAS

85 RIO BETARI

86 CAV. PEROLAS

87 CAV. PEROLAS

88 CAV. PEROLAS

89 COR. PEROLAS

90 BAIRRO DA SERRA

91 CORREGO FURNAS

92 CAV. DO GRILO

93 CAV. PEROLAS

94 CAV. PEROLAS

95 CAV. PEROLAS

96 COR. PEROLAS

97 COR. PEROLAS

98 BAIRRO DA SERRA

99 BAIRRO DA SERRA

100 CAV. SANTANA

101 CAV. SANTANA

102 CAV. SANTANA

103 CAV. SANTANA

104 MINA DE FURNAS

105 MINA DE FURNAS

106 CAV. PEROLAS

107 CAV. PEROLAS

108 CAV. SANTANA

109 CAV. SANTANA

110 CAV. SANTANA

111 CAV. SANTANA

112 CAV. SANTANA

113 CAV. SANTANA

114 CAV. SANTANA

115 CAV. SANTANA

116 CORREGO FURNAS
105.86

51.45

97.39

97.64

198.87

200.84

121.43

98.00

111.02

68.12

103.68

61.45

80.38

80.63

122.60

94.70

99.39

49.09

141.01

44.59

100.55

100.55

244.67

221.74

123.93

103.80

76.03

113.52

80.15

119.66

78.91

139.40

119.64

126.34

123.93

91.38

104.98

24.14

12.29

131.96

97.7 .3

128.50

110.12

217.93

109.62

130.78

145.22

113.93

83.88

98.05

98.05

200.51

115.11

117.19

230.50

225.94

120.55

131.28
115.32

94.36

170.25

168.91

341.78

322.49

225.22

160.00

101.35

97.72

176.17

102.37

153.56

168.91

230.33

165.00

167.74

107.49

236.32

82.92

174.24

175.27

355.41

344.60

213.97

214.98

133.79

191.40

138.17

199.79

139.30

426.07

200.64

197.10

189.81

149.04

170.66

33.34

16.98

230.46

156.45

206.92

166.63

337.82

174.44

207.68

243.96

200.56

155.70

176.53

176.53

357.09

177.33

174.44

327.06

350.00

175.27

195.00
5.77

2.13

3.83

3.84

9.50

8.38

6.38

2.84

5.92

3.36

3.42

2.73

4.58

4.60

6.84

3.26

6.55

2.98

5.12

2.61

3.89

3.89

11.38

9.16

6.53

2.76

3.74

6.07

2.97

3.85

3.17

1.97

3.40

3.09

6.53

3.27

4.31

1.79

2.73

2.14

3.95

6.43

4.15

10.03

4.12

2.65

2.04

5.92

2.92

3.76

3.76

8.74

4.08

4.27

10.20

11.20

4.86

3.56 
No. Collecting Site Total Hardness Corrected Conductivity

Molar Ca/Mg

\begin{tabular}{|c|c|}
\hline 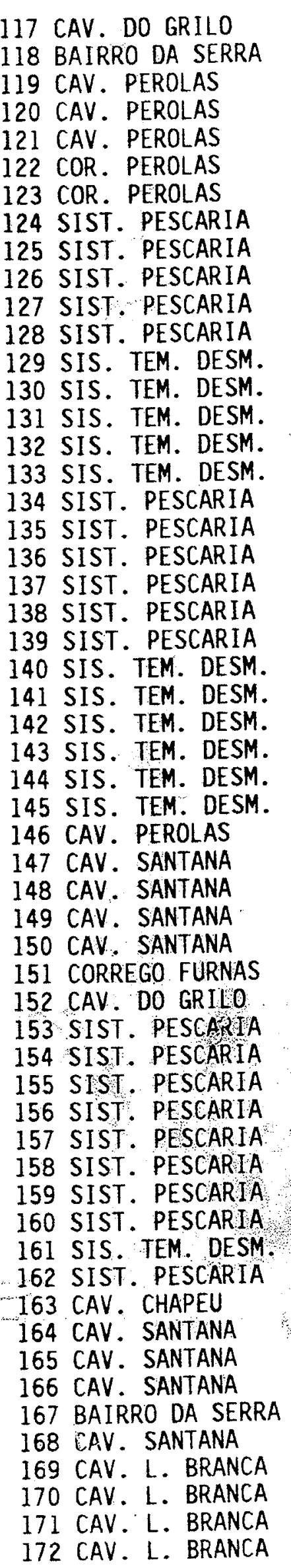 & $\begin{array}{r}133.72 \\
125.10 \\
141.80 \\
99.67 \\
120.49 \\
93.44 \\
58.07 \\
63.95 \\
72.27 \\
135.84 \\
176.62 \\
74.77 \\
13.64 \\
20.76 \\
140.99 \\
24.90 \\
34.84 \\
65.21 \\
70.18 \\
152.06 \\
68.95 \\
171.13 \\
71.86 \\
6.20 \\
6.62 \\
21.17 \\
168.89 \\
31.58 \\
28.23 \\
109.73 \\
105.55 \\
104.73 \\
210.54 \\
214.74 \\
107.61 \\
116.26 \\
15.79 \\
87.88 \\
129.60 \\
180.20 \\
106.73 \\
93.92 \\
144.60 \\
91.85 \\
22.43 \\
55.36 \\
54.00 \\
111.83 \\
111.42 \\
202.64 \\
141.63 \\
239.83 .83\end{array}$ \\
\hline
\end{tabular}

208.63

183.28

221.26

165.75

211.40

157.93

98.77

111.81

133.08

199.62

235.00

124.89

35.41

65.30

247.06

46.07

76.35

100.00

130.01

206.79

130.01

255.93

132.77

40.00

41.94

41.97

268.54

40.95

71.66

191.65

199.62

203.78

348.06

346.42

191.07

225.41

40.19

147.39

212.48

304.15

250.58

160.37

264.91

170.40

70.82

155.72

126.42

225.75

236.01

393.65

286.97

$\gg \gg \gg \gg>$

$\gg \gg \gg \gg \gg$

$\gg>>>>>$

$\gg \gg \gg \gg \gg$

$\gg \gg \gg \gg \gg$
2.96

4.53

6.33

3.04

3.72

2.98

1.82

2.88

3.18

3.40

1.55

3.33

0.58

2.60

1.64

2.36

1.82

3.28

2.97

3.74

3.19

1.25

3.26

0.68

0.61

2.43

2.13

3.80

2.43

4.55

4.13

4.30

10.63

13.49

3.75

2.72

3.80

5.10

3.37

4. 34

2.99

4.31

3.88

4.44

3.54

4.60

3.23

5.18

5.30

11.31

3.15

9.11

8.60

1.62

1.39

0.64 


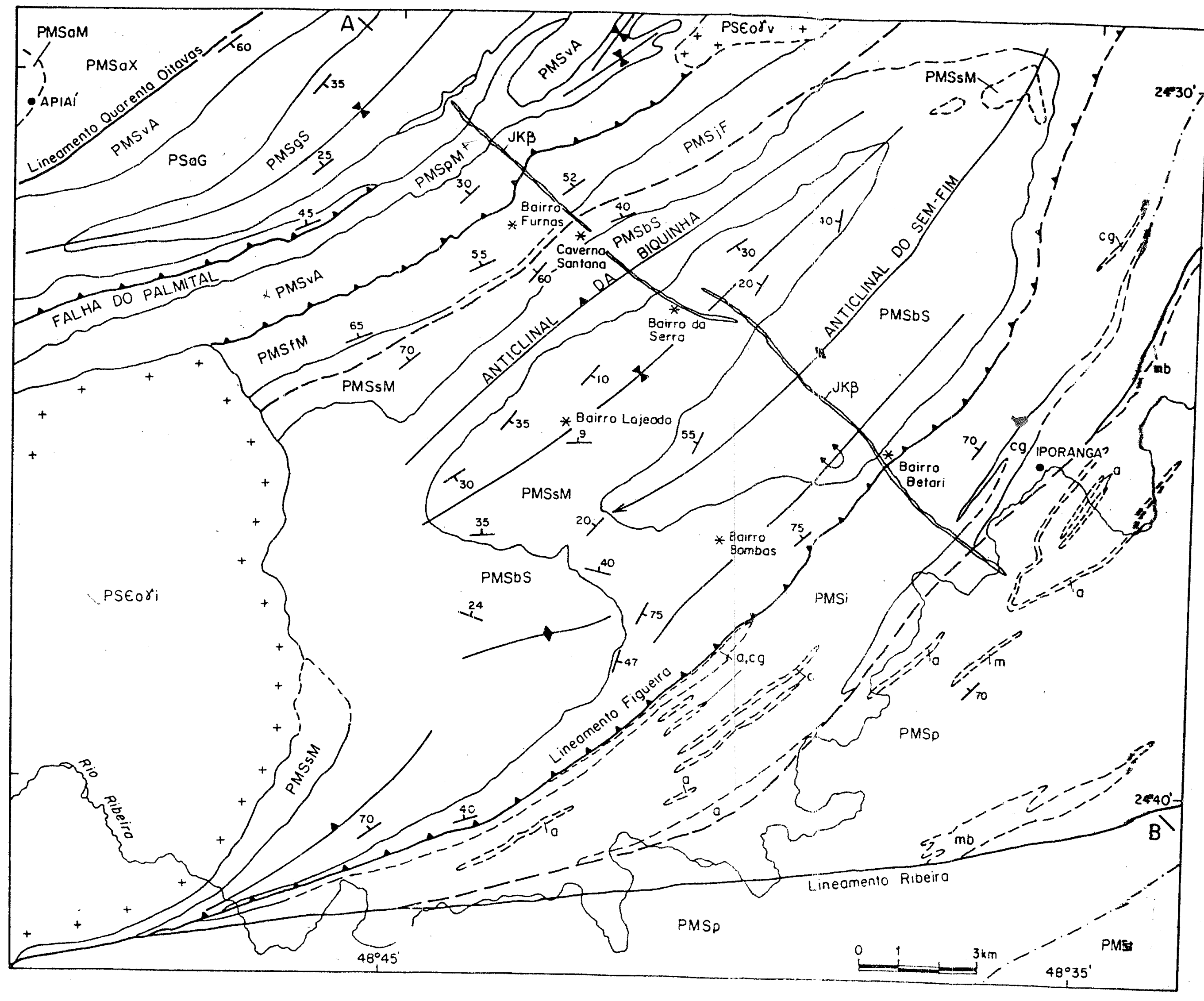

UNIDADES LITOESTRATIGRÁFICAS

(Depósitos de cobertura nõo representados)

JURÁSSICO-CRETÁCEO

JKB Diques bósicos

PROTERCZÓICO SUPERIOR A EOPALEOZÓICO

PSEOr] Granitóides pós-tectônicos i: itaóca v: Vargem Grande

PROTERCZÓICO SUPERIOR

PSOG Gabro de Apiaí

PROTEROZOICO MEDDIO A SUPERIOR

PMSO Xistos ( $X$ ) e Mármores (M) Apiaí

FORMAÇOEES LITOLOGIA

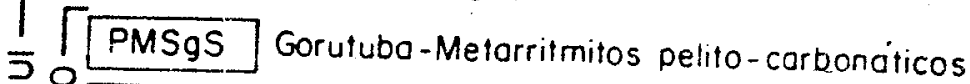

Passo Vinte - Metacalcórios dolomiticos e calcíiticos

\&

PMSfM] Mina de Furnas-Metacalcários calcílicos bandados

胥

[PMSSM Bairro da Serro - Metacalcários colkíiticos

[PMSbS Betari-Metas sititios ef filitos

PMSi I I orongo-Metossitititos, metorgilitos e metarenitos

PMSP Perau-Filitos, xistos verdes, metossiltitos

PMSst Setuva - Xistos, filitos e quartzitos

\section{CONVENGCOEES}

$$
\begin{aligned}
& \text { Anticlinal Anclinal } \\
& \text { Anticlinal com mergulho do plano axial }
\end{aligned}
$$

Adoptodo de Campanto, 1991

\section{Figura 2.2 -}

Contexto geológico local das áreas carbonáticas estudadas. 


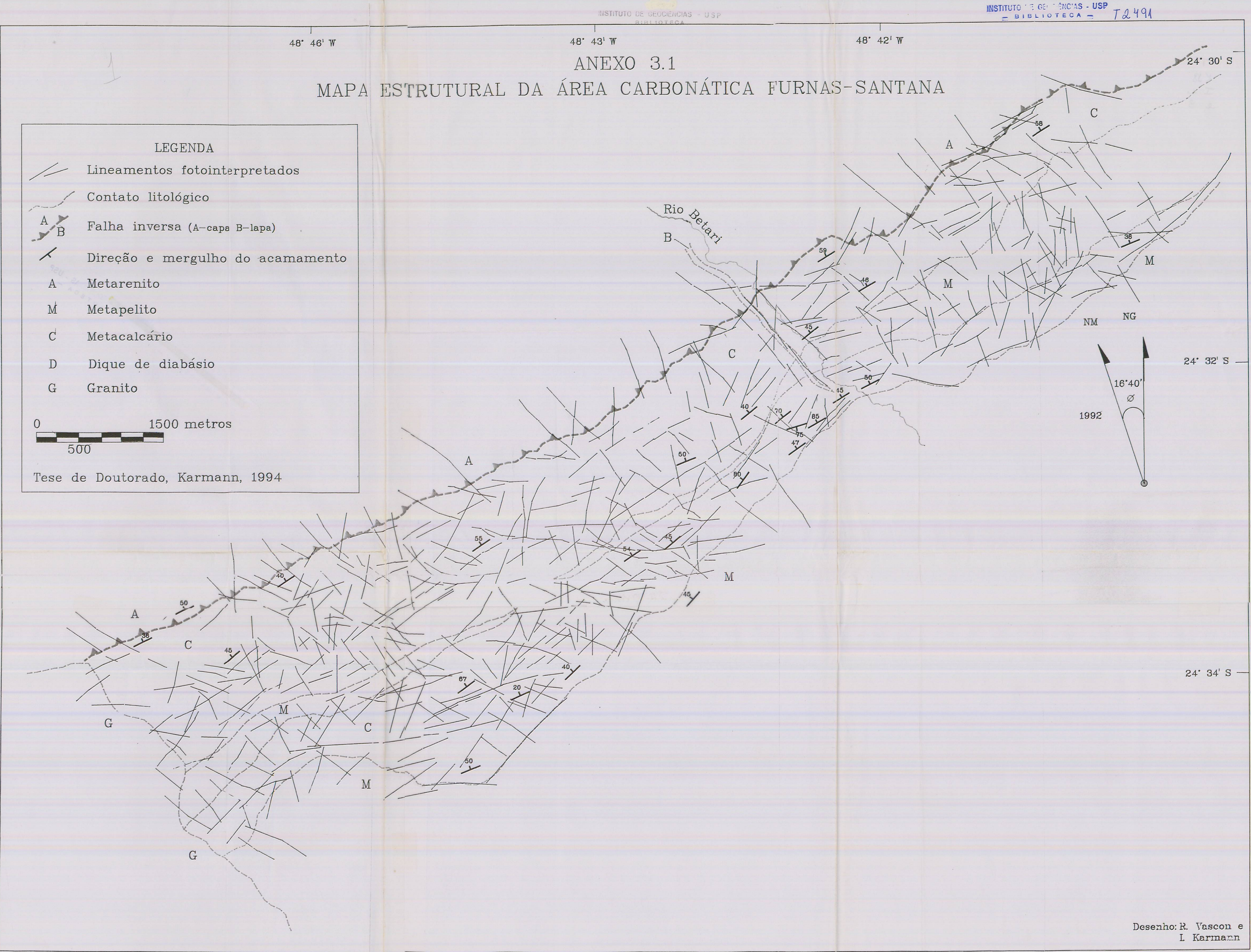




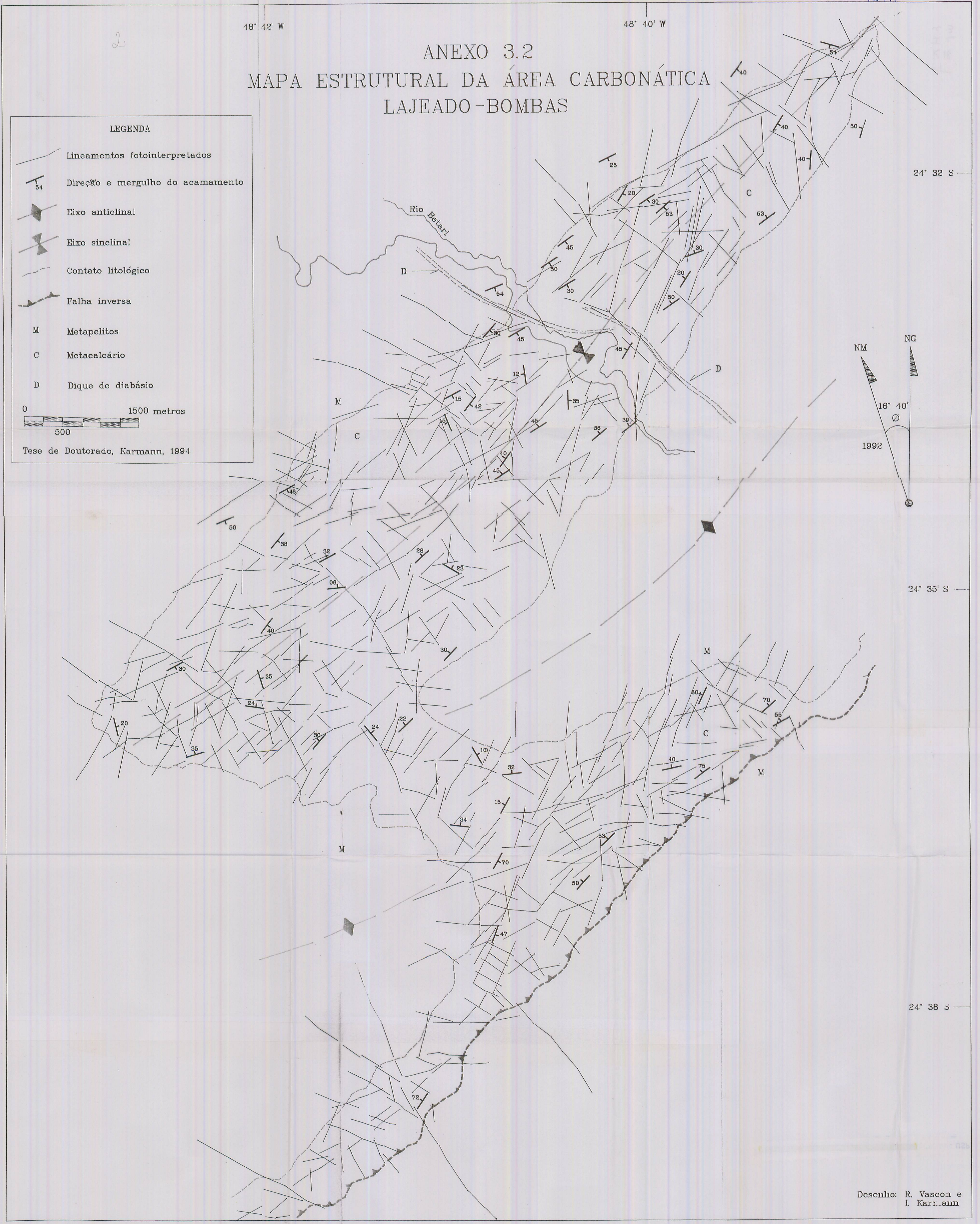




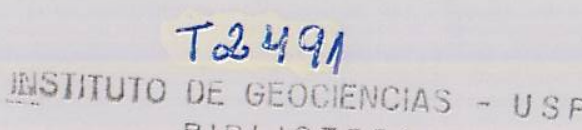




MAPA MORFOLOGICO DA AREA CARBONATTCA LAJEADO BOMBAS

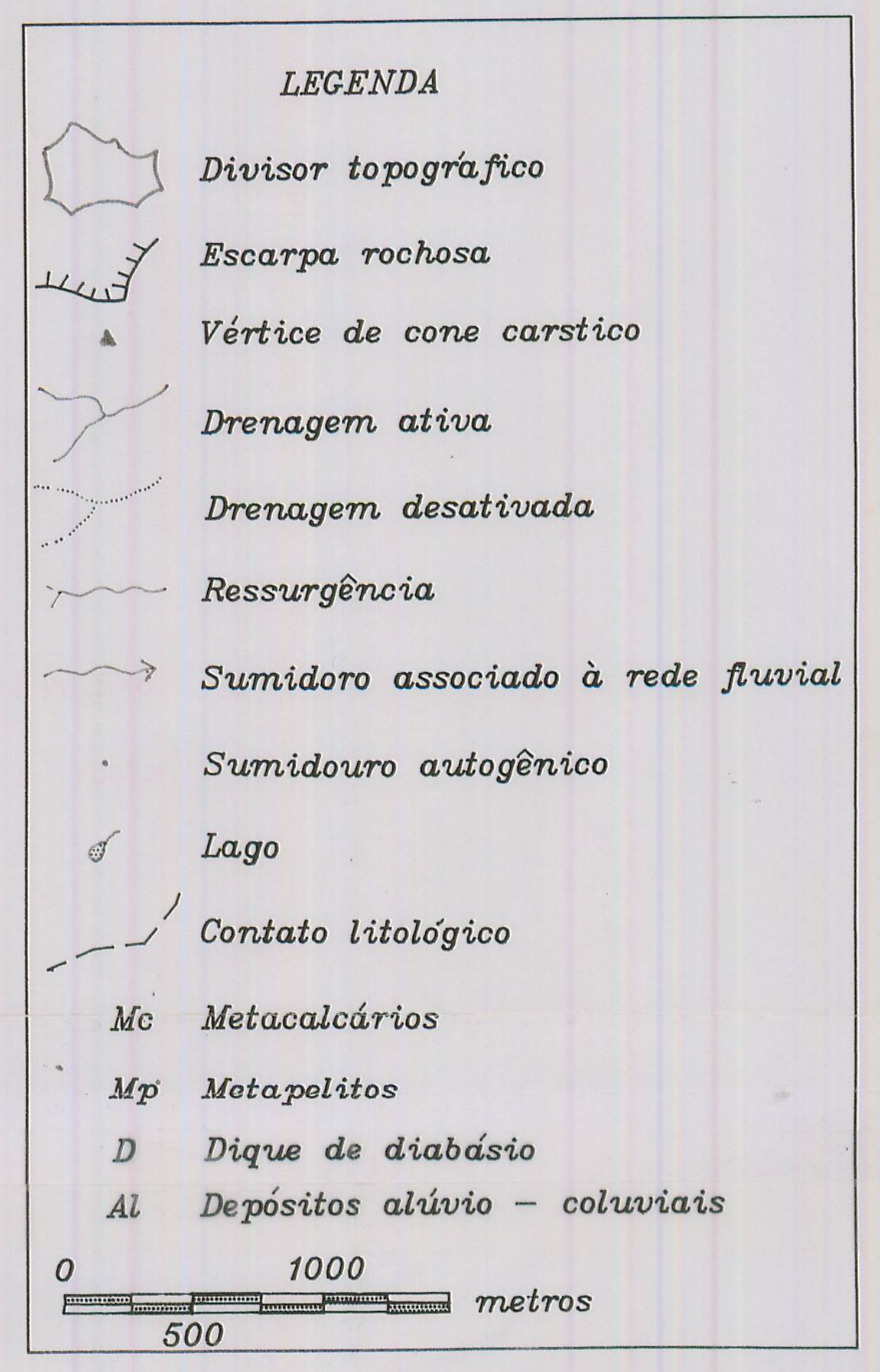

Baseado nas fotografias aéreas 1:25000 No. 47549, 47571-569, 47602-606, 47630-629, Terrafoto, 1972 Fotointerpretacão por I. Karmann, 1992
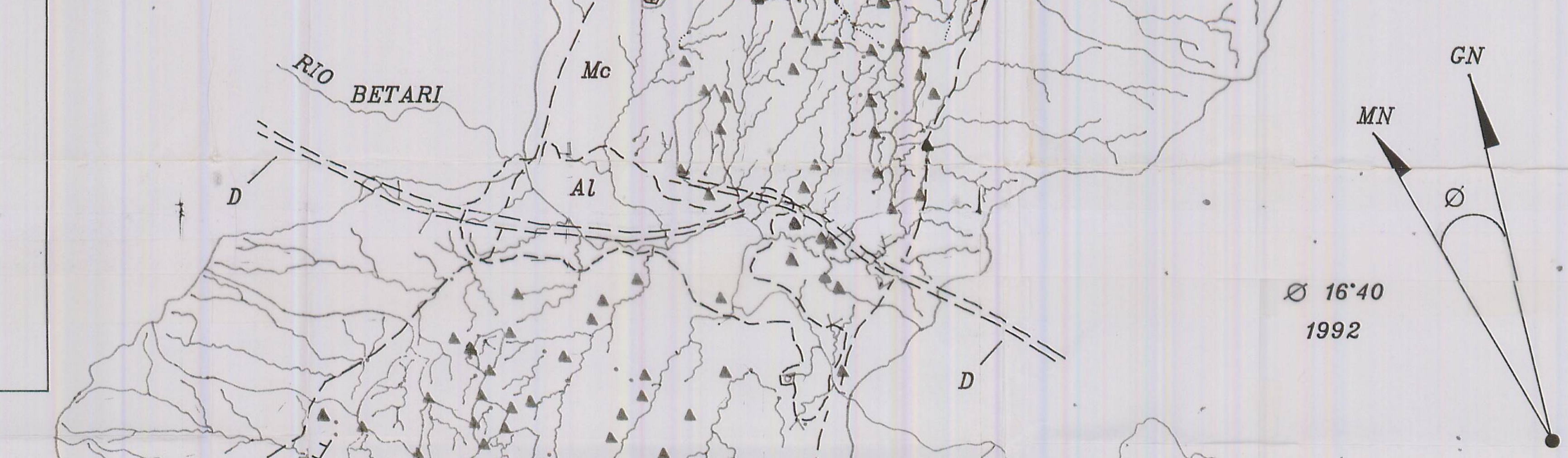
Zoneamento morfológico das áreas carbonáticas

Furnas Santana e Lageado Bombas

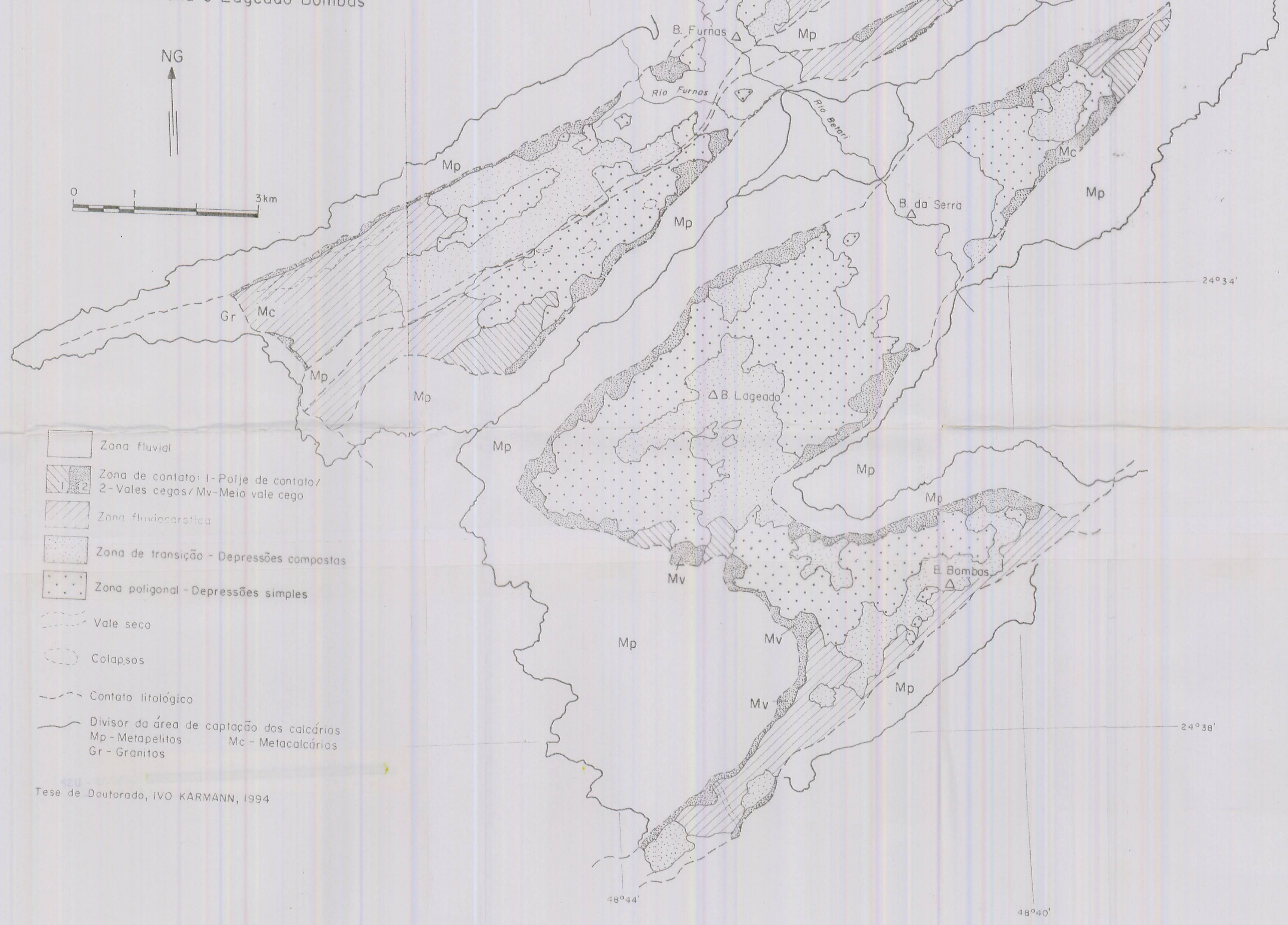




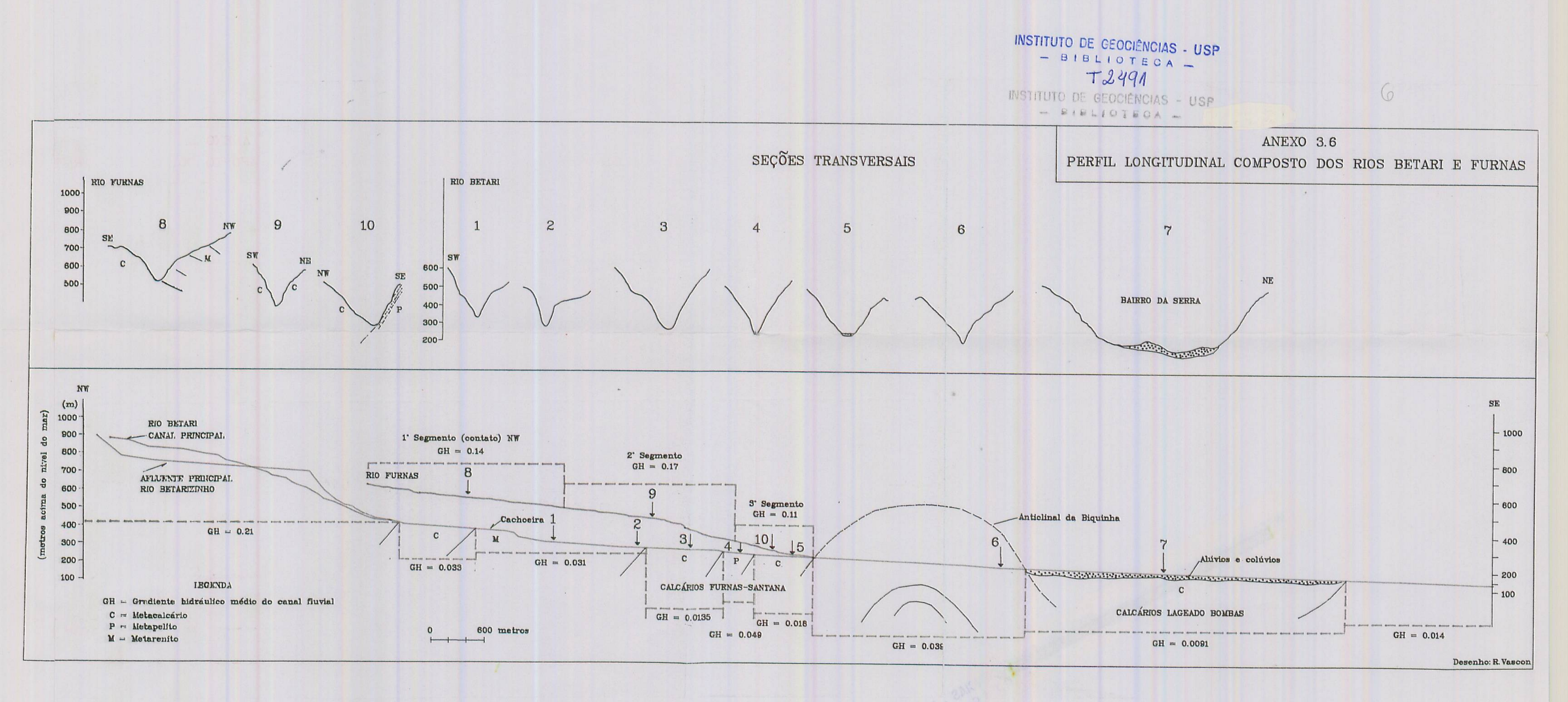




$$
x^{2} x^{2}+y^{3}=
$$


ANEXO 4.2

Distribuição de sistemas de cavernas nas áreas carbonáticas Furnas Santana e Laj:ado Bombas

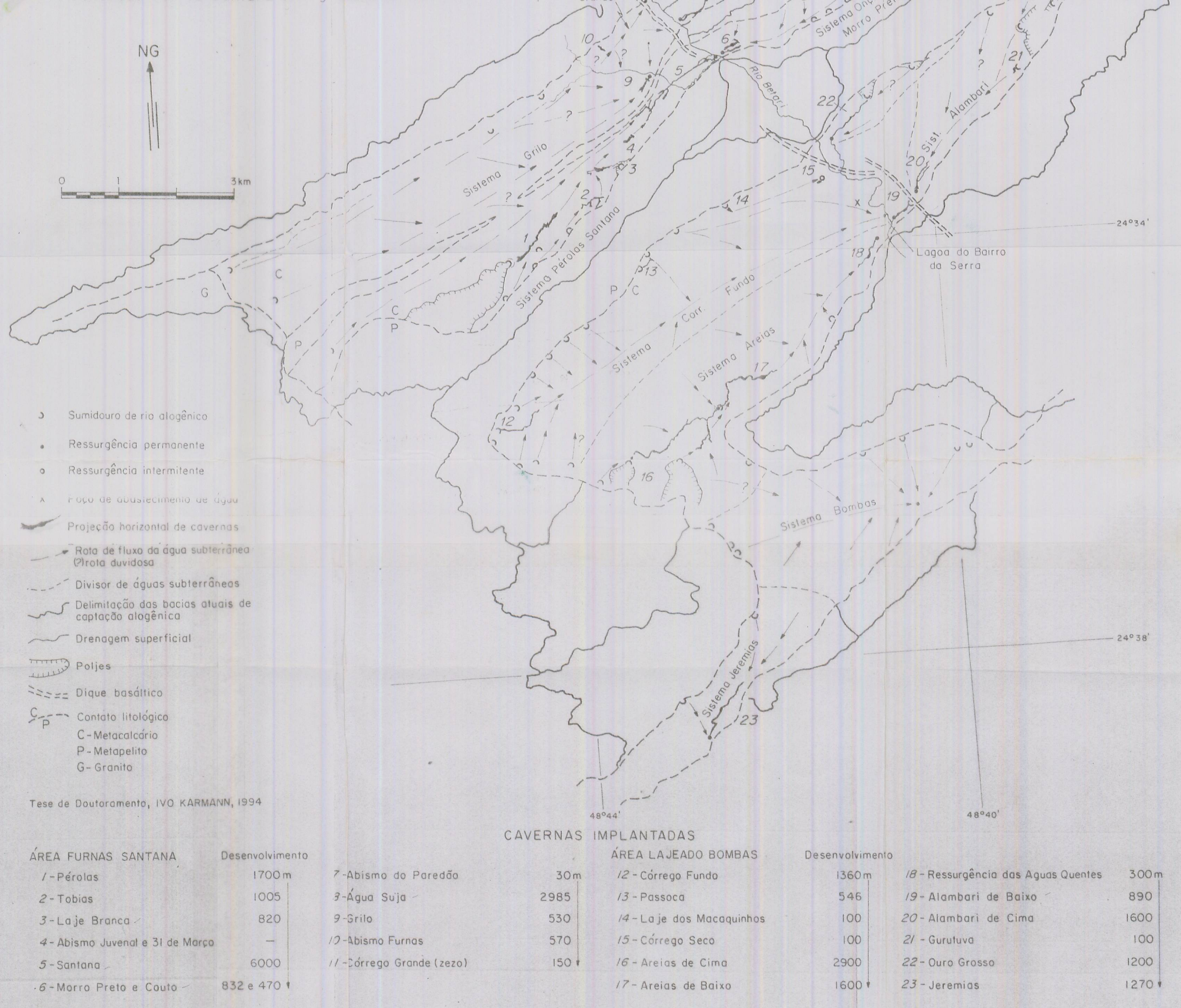




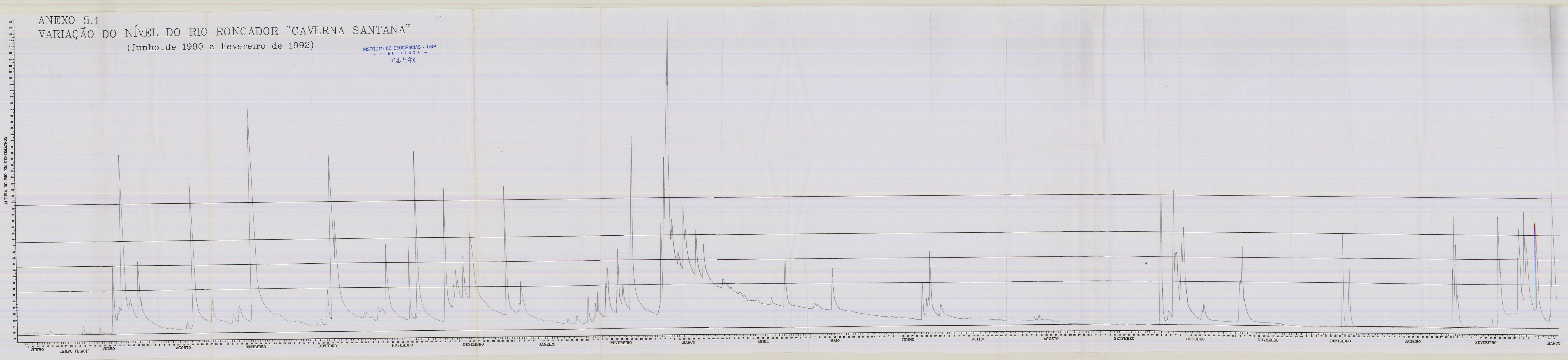

